\title{
SINISTEN MAISEMIEN MIES J. G. Granön tutkijantie 1882-1956
}

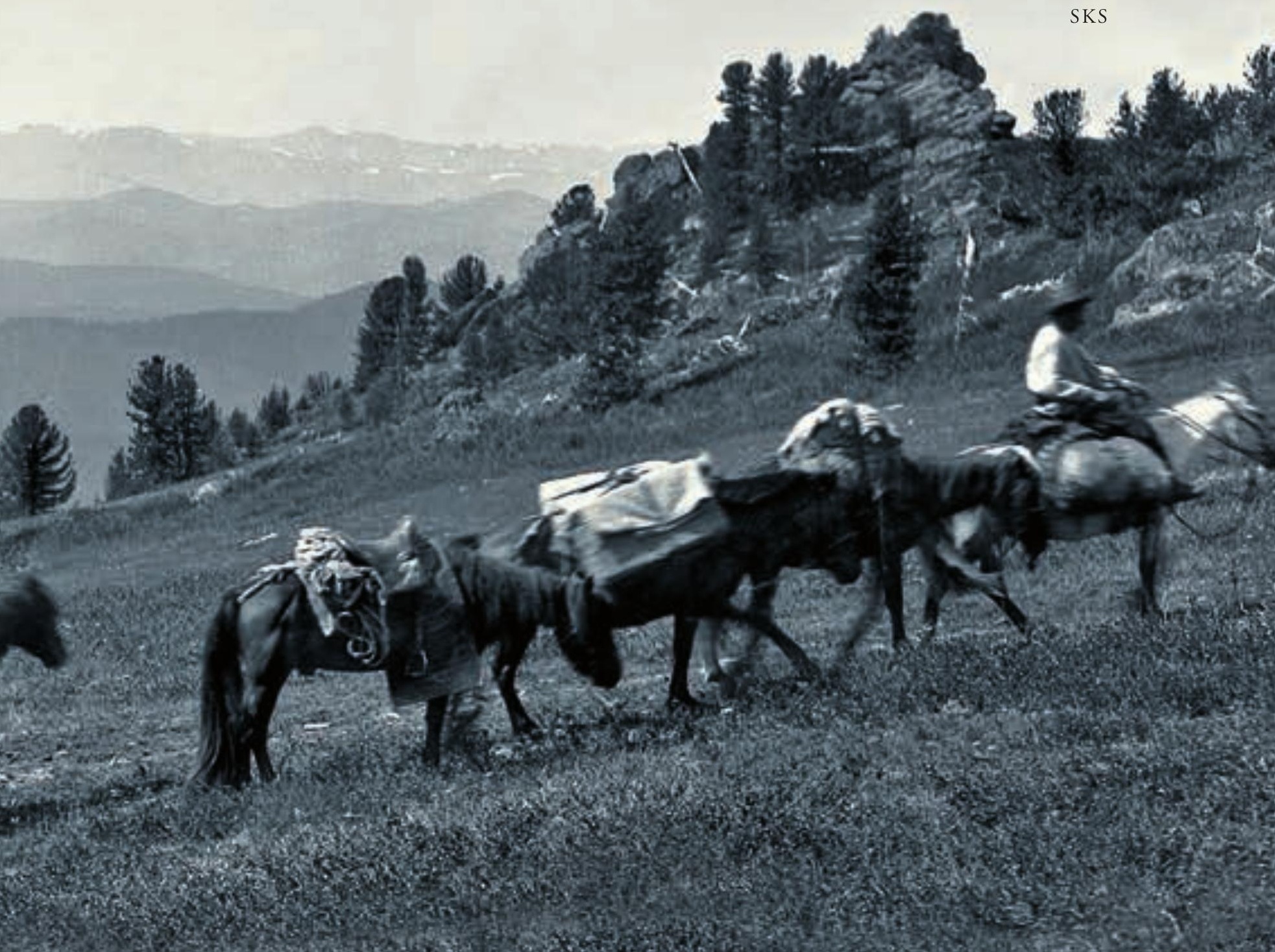




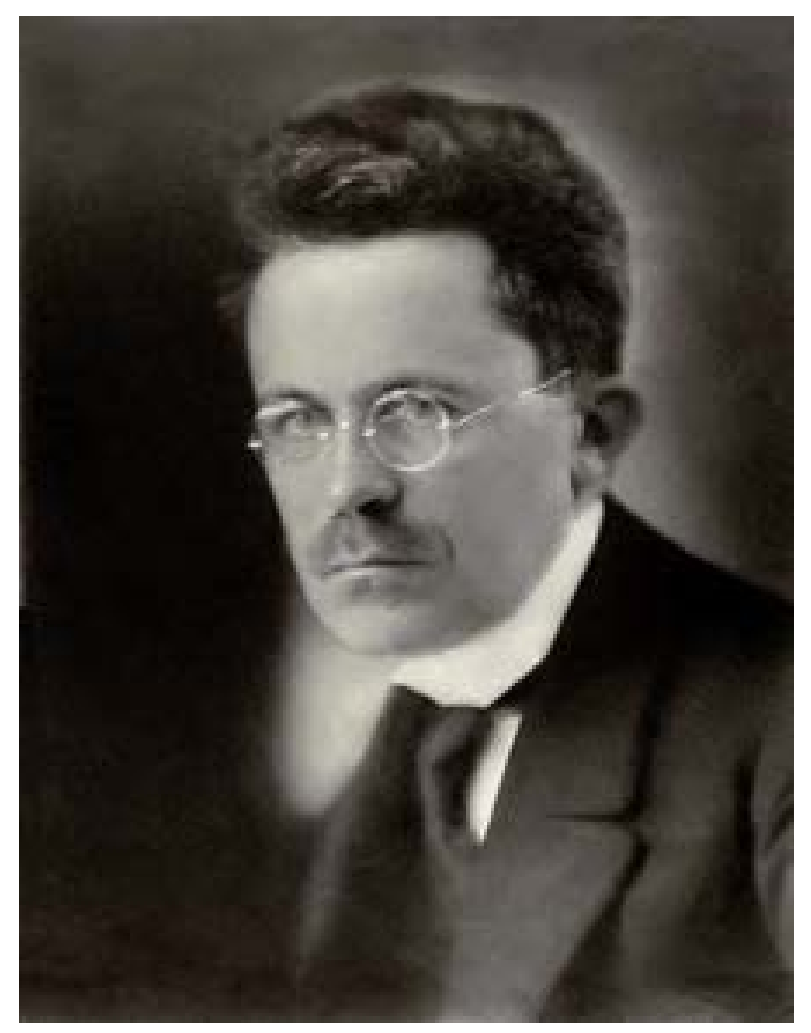


Allan Tiitta

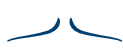

\section{SINISTEN MAISEMIEN MIES}

J. G. Granön tuthiJantie 1882-1956

Suomalaisen Kirjallisuuden Seura | Helsinki 
Historiallisia tutkimuksia 256

Teos on Suomalaisen Kirjallisuuden Seuran nimeämien asiantuntijoiden tarkastama.

VERTAISARVIOITU

KOLLEGIALT GRANSKAD

PEER-REVIEWED

www.tsv.fi/tunnus

Kirjastokonsortio Aleksandria on tukenut teoksen avointa saatavuutta.

(C) 2011 Allan Tiitta, Taneli Eskola ja SKS

Lisenssi CC BY-NC-ND 4.0 International

Digitaalinen versio perustuu Suomalaisen Kirjallisuuden Seuran kustantamaan painettuun teokseen, joka on julkaistu vuonna 2011.

Kannen suunnittelu: Ville Repo

EPUB: Tero Salmén

ISBN 978-952-222-292-3 (sid.)

ISBN 978-952-222-984-7 (PDF)

ISBN 978-952-222-875-8 (EPUB)

ISSN 0073-2559 (Historiallisia tutkimuksia)

DOI: $\underline{\text { http://dx.doi.org/10.21435/ht.256 }}$

Teos on lisensoitu Creative Commons CC BY-NC-ND 4.0 International -lisenssillä. Tutustu lisenssiin englanniksi osoitteessa http://creativecommons.org/licenses/by-nc-nd/4.0/ tai suomeksi osoitteessa https://creativecommons.org/licenses/by-nc-nd/4.0/deed.fi.

Teos on avoimesti saatavissa osoitteessa http://dx.doi.org/10.21435/ht.256 tai lukemalla tämä QR-koodi mobiililaitteella. 


\section{SISÄLLYS}

Lukijalle ................9

SIPERIA OPETTAA . . . . . . . 14

Perheen matkassa................16

Vanhemmat. . . . . . . . . . . . . . 16

Ullavasta Kemiöön . . . . . . . . . . . . . . . . 19

Rohkea päätös . . . . . . . . . . . . . . . 21

Siperian suomalaiset siirtolat . . . . . . 23

Muutto Siperiaan . . . . . . . . . . . . . 26

Kansainvälinen Omsk. . . . . . . . . . . . 27

Sekalainen seurakunta . . . . . . . . . 29

Virkamatkojen antia ............. 31

Alatornion pappila . . . . . . . . . . . 33

Koulunkäynti. . . . . . . . . . . . . 35

Maantieteilijöiden hautomo . . . . . . .37

Poikien valinnat . . . . . . . . . . . . . 38

7. A. Palmén ............... 39

Paluu Siperiaan. . . . . . . . . . . . . . 42

Eetu Isto . . . . . . . . . . . . . . . . . 48

Oman tien alku................52

Vaikea valinta. . . . . . . . . . . . . . 52

7. E. Rosberg................ 54

Maantieteen vaikea itsenäistymiskehitys. . 57

Kukkakimpun kimppuun . . . . . . . . . 60

Henkinen kasvu . . . . . . . . . . . . . . . 63

Ylioppilaan Siperian-kesät . . . . . . . . . . 64
Arkeologiset tutkimusmatkat. . . . . . . . 70

Otto Donner ja Suomalais-ugrilaisen

Seuran tutkimusohjelma . . . . . . . . . . 70

Kohtalokas ensimmäinen tutkimusmatka. . 71

Pyhän kirjakiven tuonti Helsinkiin . . . . . . 81

Pisin Mongolian-matka . . . . . . . . . . . 84

Tieteellisen uran vakiinnuttaminen . . . . 992

Väitöskirja . . . . . . . . . . . . . . . 992

Dosentti, opettaja ja valistaja . . . . . . . . 95

Maantieteen aseman vahvistaja . . . . . . . 99

Uudet tutkimustavoitteet . . . . . . . . . . . 102

Altain tutkimusmatkat $1913-16$. . . . . . . 110

Valtava urakka . . . . . . . . . . . . . . . . 110

Tutkimusmatkailijan telttakoti.... . . 120

Omskin koti. . . . . . . . . . . . . . . . . . . 125

Davisilainen tulkinta Altain

pinnanmuotojen synnystä . . . . . . . . . 128

Katkera paluu. . . . . . . . . . . . . . . . 132

॥ EPÄVARMUUdEN VUODET....136

Vaikea aika ................... 138

Pohjoinen Rautatiekatu 11 . . . . . . . . . 138

Murrosvaihe. . . . . . . . . . . . . . . . . 142

Siirtyminen kustannusalalle . . . . . . . . . 149

Yllättävä ratkaisu . . . . . . . . . . . . . . . 152

Kutsu Tarton yliopiston professoriksi. . . . 152

Hyvät perusteet . . . . . . . . . . . . . . . 154 
III MATKAKIRJALLISUUDEN

KLASSIKKO . . . . . . . . . . . . . . 158

Teoksen synty . . . . . . . . . . . . 160

Kirjalliset lähtökohdat. . . . . . . . . . . . 160

Valokuvauksen kehittäjä . . . . . . . . . . . 164

Tavoitteet ja toteutus . . . . . . . . . . . . 173

Musta, valkoinen ja sininen Altai . . . . . 178

Sanojen ja kuvien liitto . . . . . . . . . . . . 178

Merkitys . . . . . . . . . . . . . . . . . 189

IV VIRON YLIOPISTOMAANTIETEEN

PERUSTAJA . . . . . . . . . . . 196

Asettuminen Tarttoon ............... 198

Uskalias muutto . . . . . . . . . . . . . . . 198

Lepiku 9 . . . . . . . . . . . . . . . 200

Maantieteen laitoksen perustaminen . . . . 202

Paavo Granön kohtalonvuodet . . . . . 205

Muut tehtävät. . . . . . . . . . . . . . . . . 207

Tarton yliopiston professori. . . . . . . . 210

Maantieteen identiteetti tieteenä. . . . . . . 210

Opetuksen tavoitteet. . . . . . . . . . . . 213

Tieteen kaksi kieltä. . . . . . . . . . . . . 214

Käytännön opetustyö . . . . . . . . . . . . . 216

Etevät oppilaat . . . . . . . . . . . . . . 218

Villa Tammekann .............. 221

Aluetutkimuksen kehittäminen . . . . . . . 226
Virolaisen maisematieteen perustaminen . .226

Kotiseuduntutkimuksen käynnistäminen. . 229

Ryhtykäämme kuvaamaan kotimaatamme 233

Kaupunkitutkimuksen aloittaminen . . . . 238

Paluu Suomeen . . . . . . . . . . . . . . . 242

Maantieteellinen uskontunnustus . . . . . . 242

Operaatio "Granö takaisin Suomeen” . . . . 246

Siirtymävaihe. . . . . . . . . . . . . . 250

Jäähyväisluento Tartossa . . . . . . . . . . . 255

V TIETEEN TEKIJÄ JA NÄKIJ Ä . . 260 Helsingin yliopiston professori. . . . . . . . 262

Maantieteen laitoksen työnjako. . . . . . . . 262

Talvet Helsingissä, kesät maalla . . . . . . . 267

Tutkimustyön jatkaminen. . . . . . . . . . 274

Suomen Kartaston toimitustyö . . . . . . . . 274

Maisematieteen perusteiden luominen . . . 277

Ohjelmajulistus . . . . . . . . . . . . . . 284

Iivari Leiviskän vastahyökkäys . . . . . . . . 290

Yllättävä ero . . . . . . . . . . . . . . . . . . 294

Työntö. . . . . . . . . . . . . . . . . . . . . . . 294

Veto . . . . . . . . . . . . . . . . . . . 295

Ratkaisun jälkeen . . . . . . . . . . . . . 300 
VI TURUN SUOMALAISEN

YLIOPISTON PROFESSORI . . . 304

Aurajoen varrella ................306

Kristiinankatu 1 . . . . . . . . . . . . . . . 306

Seurapiirit . . . . . . . . . . . . . . . 310

Maantieteen laitoksen johtaja . . . . . . . 316

Humboldtilainen maantieteen laitos . . . . 316

Opetus . . . . . . . . . . . . . . . . . 320

Oppilaat . . . . . . . . . . . . . . . 327

Puhtaan tieteen aika. . . . . . . . . . . . 334

Syventyminen maisematieteeseen . . . . . . 334

Puhdas maantiede. . . . . . . . . . . . . . . . 338

Ristiriitainen vastaanotto . . . . . . . . . . 350

Suomen maantieteelliset alueet . . . . . . . . 358

Suuri pettymys . . . . . . . . . . . . . . . 367

Formaalisista alueista

toiminnallisiin alueisiin . . . . . . . . . . . . 371

Uusi nousu. . . . . . . . . . . . . . . . . . . 374

Rehtorina eturintamassa . . . . . . . . . . 380

Vaikea ratkaisu . . . . . . . . . . . . . . . . . 380

Puolustustaistelu kansleria vastaan . . . . . 386

Tutkimustyö jatkuu . . . . . . . . . . . . . . . 394

Salaperäinen sairaus . . . . . . . . . . . . . . 394

Paluu Keski-Aasian aineistoihin . . . . . . . 399

Professorin sota . . . . . . . . . . . . .406

Suur-Suomi-kysymys ja tutkijan rooli . . . . 406

Inhimillinen huoli. . . . . . . . . . . . . . . 418

Pako tutkimukseen . . . . . . . . . . . . . . 420
VII VASTUUNKANTAJA . . . . . . . 428

Takaisin pääkaupunkiin ..........440

Maantiede tuuliajolla. . . . . . . . . . . . . 430

Paluu Vihreään taloon. . . . . . . . . . . . . 433

Yliopisto-opetuksen takaaja. . . . . . . . . 436

Professori ja laitoksen esimies . . . . . . . . 4 436

Opetuksen sisältö . . . . . . . . . . . . . . . . 440

Ero yliopistosta. . . . . . . . . . . . . . . . . 442

Akateeminen vaikuttaja. . . . . . . . . . . . 444

Kanslerin monet tehtävät . . . . . . . . . . . . 444

Tärkeät aloitteet . . . . . . . . . . . . . . . . . 449

Kansainväliset suhteet . . . . . . . . . . . . . . 457

Tieteellisen vuorovaikutuksen

monet tiet. . . . . . . . . . . . . . 459

Palkintoja ja kunnianosoituksia. . . . . . . . 464

Kuolema . . . . . . . . . . . . . . . . . . . 468

Vakava sairaus . . . . . . . . . . . . . . . . . 468

Hiljaiset hautajaiset. . . . . . . . . . . . . . 472

VIII EHEÄN IHMISEN ELÄMÄ . . . . 474

Lähdeviitteet . . . . . . . . . . . . . . . . . 482

Lähteet . . . . . . . . . . . . . . . . . . . 502

Kuvaluettelo. . . . . . . . . . . . . . . . . . 505

Henkilöhakemisto. . . . . . . . . . . . . . . 530

Paikkahakemisto . . . . . . . . . . . 536 
"Näkevät ennen pitkää Valkoisen Altain, näyttäytyy valkoinen joki.

Valkoisen Altain vieressä kohoaa Sininen Altai, valkoisen virran

rinnalla vyöryttää vesiään sininen virta. Sinisen Altain edessä nostaa

harjanteensa Musta Altai, sinisten vesien vieressä virtaavat mustat vedet...”

Altai II, 431 


\section{$\mathscr{L u k i j a l l e}$}

Sinisten maisemien mies on kuvaus Suomen kansainvälisesti tunnetuimman maantieteilijän J. G. Granön (1882-1956) mittavasta elämäntyöstä. Hän oli tutkimusmatkailija, tietokirjailija ja valokuvaaja, yliopisto-opettaja, kulttuurivaikuttaja ja monipuolinen tutkija, jonka vaikutus oli suurinta geomorfologina eli maanpinnan muotojen kuvaajana, maisematieteen teorian kehittäjänä sekä maisemien ja ihmisen lähiympäristön hahmottajana.

Granön poikkeuksellisen laajan elämäntyön kartoittaminen olisi ollut luontevinta toteuttaa usean kirjoittajan voimin erillistutkimuksina, joissa hänen toimintansa olisi sijoitettu kunkin alan kontekstiin. Kun tällaisen hankkeen tuottaminen osoittautui ongelmalliseksi, ryhdyin suunnittelemaan kirjoitustyötä yksin 2004. Tehtävä osoittautui hankalaksi, sillä tavoitteena oli yksiosainen henkilöhistoriallinen tietokirja, joka valottaisi Granön toimintaa ja sen merkitystä ja antaisi samalla mahdollisuuden esitellä runsaan kuvituksen avulla hänen panostaan suomalaisen maisema- ja luonnonvalokuvauksen edelläkävijänä. Granön suku oli luovuttanut tutkijan laajan kuvakokoelman Suomalaisen Kirjallisuuden Seuralle toivomuksella, että eri näyttelyissä suuren suosion saaneita kuvia käytettäisiin laajasti elämäkerrassa.

Pitkän pohdinnan jälkeen ymmärsin, että elävää kirjallista asua tavoittelevaa elämäkertaa ei ollut mahdollista toteuttaa perinteisen akateemisen teoksen tavoin. Erillisten teoreettisten ja metodisten johdantolukujen sijasta sijoitin tieteellisen aineksen sekä suoraan tekstiin että runsaisiin alaviitteisiin. Näin kykenin keskittämään kuvauksen Granön toimintaan ja hänen ratkaisuihinsa mutta saatoin samalla tarjota lukijalle kohta kohdalta tarkat tiedot niistä lähteistä, joihin tekstini perustuu ja joista on mahdollista saada lisätietoa kulloinkin käsiteltävistä teemoista. Lisäksi päätin kes- 
kittyä kuvaamaan vain niitä asioita, joista Granön elämä sai ominaisluonteensa ja joilla hänen vaikutuksensa oli tärkein. Tämä merkitsi huomion suuntaamista akateemiseen toimintaan.

Granö koki itsensä nimenomaan yliopistotutkijaksi ja -opettajaksi, mutta hänen osakseen tuli elää ajanjaksona, jolloin tutkijan työt saivat usein väistyä poliittisten muutosten ja sotien tieltä. Pyrin siksi liittämään hänen toimintansa paitsi maantieteen oppihistoriaan myös valtiollisen Suomen dramaattisiin vaiheisiin, 1800-luvun lopun venäläistämiskaudesta ensimmäiseen maailmansotaan, sisällissotaan, talvi- ja jatkosotaan ja lopulta kylmän sodan käänteisiin. Poliittisten jaksojen erillisten tarkastelujen sijasta päätin kuvata runsaan alkuperäisaineiston avulla sitä, miten nämä vaiheet vaikuttivat Granön elämään ja hänen tekemiinsä ratkaisuihin. Tukeuduin myös usein Granön omiin teksteihin, sillä halusin tuoda konkreettisesti esiin hänen taitonsa tietokirjailijana.

Tarina etenee pääosin aikajärjestyksessä ja ongelmakeskeisesti, mutta huomiota suunnataan myös tärkeiden asiakokonaisuuksien systemaattiseen kuvaamiseen ja hänen suhtautumiseensa tiettyihin keskeisiin kysymyksiin, kuten suomen kielen asemaan, Turun Suomalaisen Yliopiston hallinnon ongelmiin ja Suur-Suomiajatteluun. Varsinaisen tekstin ohessa on joitakin lyhyitä erityisartikkeleita, joissa tarkastellaan muun muassa Granön kannalta keskeisiä henkilöitä, tapahtumia tai tilanteita.

Olavi Granö on kuvannut isänsä tieteellistä uraa useissa tutkimuksissa, ja hänen kirjoituksensa muodostavat tukevan perustan teokselleni. Maantieteen 1800- ja 1900-luvun oppihistoriaa on tutkittu Suomessa verraten vähän, joten olen voinut turvautua omien tekstieni lisäksi pääasiassa Stig Jaatisen, Jussi S. Jauhiaisen, Hannu Linkolan, Anssi Paasin, Petri J. Raivon, Kalevi Rikkisen, Oiva Tuomisen, Perttu Vartiaisen ja Pentti Yli-Jokipiin tutkimuksiin. Ulkomaisista tutkijoista Granötä ovat käsitelleet muun muassa Anne Buttimer, Reginald G. Golledge, Torsten Hägerstrand, Michael Jones, Ott Kurs, Vello Paatsi, Hans-Dietrich Schultze ja Eugene Van Cleef. Kuvatessani Granön toimintaa valokuvaajana olen tukeutunut pääosin 
Taneli Eskolan kirjoituksiin. Koska J. G. Granön vaikutus ulottui monelle alalle, työn perustana olevan yleisen tutkimuskirjallisuuden määrä on pakostakin suuri.

Runsaasta kirjallisuudesta huolimatta teos rakentuu suurelta osin alkuperäislähteiden varaan. Keskeisimmän aineiston muodostaa Suomalaisen Kirjallisuuden Seuran kirjallisuusarkistossa säilytettävä J. G. Granön kirjallinen jäämistö, johon on koottu hänen kokonaisena säilynyt laaja kirjeenvaihtonsa sekä kopioina muissa arkistoissa tai yksityiskokoelmissa säilytettäviä asiapapereita ja niin ikään kopioina runsaasti hänen muille henkilöille lähettämiään kirjeitä. Granön vaikutusta Yhdysvalloissa kävin tutkimassa Alfred Kordelinin säätiön myöntämän matka-apurahan turvin Minneapolisissa, Harvardin yliopiston Houghton Libraryssa ja The American Geographical Societyn arkistossa New Yorkissa. Arkistolähteiden antamaa kuvaa on täydennetty painettujen lähteiden sekä eri henkilöiden antamien haastattelujen ja kirjallisten lausuntojen avulla.

Yli puoli vuosikymmentä kestänyt kirjoitustyö tapahtui pääosin Alfred Kordelinin säätiön, Suomen Kulttuurirahaston ja Emil Aaltosen Säätiön 2004-06 myöntämien apurahojen turvin. Kiitän kaikkia näitä säätiöitä ratkaisevan tärkeästä tuesta ja kärsivällisyydestä teoksen valmistumisen viivästyessä. Turun Yliopistosäätiötä kiitän apurahan myöntämisestä teoksen viimeistelemiseen ja mahdollisuudesta asua muutamien päivien ajan Granön oppilaan August Tammekannin entisessä kodissa, nykyisessä Granö-keskuksessa Tartossa. Harvoin humanistitutkija on voinut olla ainoana asukkaana Alvar Aallon suunnittelemassa talossa.

Alkusysäyksen teoksen kirjoittamiseen antoi J. G. Granön poika, akateemikko Olavi Granö, joka on monin tavoin tukenut kirjoitustyötä. Hän on isänsä henkisen perinnön ja kirjallisen jäämistön parhaana tuntijana ja tietopankkina osannut opastaa minut oikeiden kysymysten, teemojen ja aineistojen pariin. Myös Olavi Granön puoliso, filosofian maisteri Eeva Granö, on edistänyt kirjoitustyötä monin tavoin. Ilman heidän kannustustaan tämä teos olisi jäänyt kirjoittamatta.

Professorit Kalevi Rikkinen ja Pentti Yli-Jokipii ovat lukeneet koko käsikirjoituksen ja esittäneet monia tervetulleita vihjeitä sekä korjaus- ja parannusehdotuksia. 
Kiitän heitä molempia suuriarvoisesta avusta, samoin kuin professori Matti Saarnistoa, joka on lukenut ja kommentoinut käsikirjoituksen geologiaan liittyviä osia. Vastuu kirjaan päätyneistä tulkinnoista ja mahdollisista virheistä on tietenkin yksin minun.

Suuressa kiitollisuudenvelassa olen myös virolaisille asiantuntijoille, maantieteen professori Ott Kursille ja filosofian tohtori Vello Paatsille, jotka ovat täydentäneet asiantuntemuksellaan J. G. Granön Viron-aikaa koskevaa osuutta. Kiitän lämpimästi myös kaikkia muita eri alojen asiantuntijoita, jotka ovat antaneet minulle neuvoja tai apua kirjoitustyön aikana, mutta joita en voi erikseen nimetä heidän suuren lukumääränsä vuoksi.

Pätin jo teosta suunnitellessani noudattaa J. G. Granön elämänohjetta "lestissä pysymisessä”. Keskityin kirjoittamiseen ja luovutin teoksen kuvittamisen sen parhaalle mahdolliselle tekijälle, valokuvaajalle ja taiteen tohtori Taneli Eskolalle. Eskola on järjestänyt Suomalaisen Kirjallisuuden Seuraan tallennetun Granön valokuvien kokoelman ja koonnut sen pohjalta laajoja näyttelyjä merkittävine julkaisuineen, jotka ovat nostaneet esiin tutkimusmatkailijan ja tutkijan esteettisen ja taiteellisen puolen.

Sinisten maisemien miehen kuvitus muodostaa oman kokonaisuutensa. Teoksen voi siten nähdä myös J. G. Granön tutkijantien kuvallisena tulkintana, jonka Eskola on luonut tekstini ja omien näkemystensä vuoropuhelun pohjalta. Kiitän Taneli Eskolaa erinomaisen mukavasta ja opettavasta yhteistyöstä, jota tuki Alfred Kordelinin säätiön teoksen kuvitukseen myöntämä apuraha. Eskolan ohella lämpimän kiitoksen ansaitsee Suomalaisen Kirjallisuuden Seuran kuva-arkistonhoitaja Pirjo Mäkilä, joka on pääosin järjestänyt Granön arkiston ja osallistunut tiiviisti teoksen kuvituksen laadintaan.

Suomalaisen Kirjallisuuden Seuraa kiitän työskentelytilojen järjestämisestä kirjoitustyön alkuvaiheessa ja teoksen ottamisesta julkaisuohjelmaansa. Kustannuspäällikkö, filosofian maisteri Rauno Endén on huolehtinut suvereenisti teoksen toimittamisesta ja monista käytännön asioista. Kirjan graafinen asu ja kansi ovat 
graafisen suunnittelijan Ville Revon käsialaa. Kiitän heitä ja koko Suomalaisen Kirjallisuuden Seuran henkilökuntaa tuesta pitkän kirjoitustyön aikana.

Kiitän armollista kohtaloani siitä, että saatoin käyttää Kansallisarkiston, Kansalliskirjaston ja Helsingin yliopiston keskusarkiston palveluita ennen kuin valtion tuottavuusohjelma oli ehtinyt näyttää todellisen karvansa maan kulttuurielämälle. Sain laitosten ymmärtäväiseltä ja erinomaisen taitavalta henkilökunnalta paljon enemmän apua kuin virkatehtävien normien mukainen hoito olisi edellyttänyt.

Tutkijan ja varsinkin elämäkerturin työ on usein yksinäistä puuhaa, mutta onneksi sitä ei tarvitse aina tehdä yksin. Tutkijakollegat Jyrki Nummi, Juhani Sipilä, Seppo Aalto, Saulo Kepsu ja Harry Halén auttoivat minua Kansallisarkistossa monien ongelmien ratkaisemisessa ja toivat mukavalla seurallaan lämpöä ajoittain hyytävän kylmään tutkijansaliin.

Helsingin Meilahdessa tuomien kukkiessa toukokuussa 2011

Allan Tiitta 


\section{SIPERIA OPETTAA}

"Suuri työilo täyttää minut aina, vaikken olisikaan joka hetki kaikkein paraimmissa voimissa ruumiillisesti. En ole ollut päivääkään sairaana Suomesta lähdettyäni, vaikken toisaalta ole voimissa ja painossa vahvistunutkaan. Lohdutan itseäni sillä 'etteivät ajattelijat tavallisesti ole lihavia.'”' 


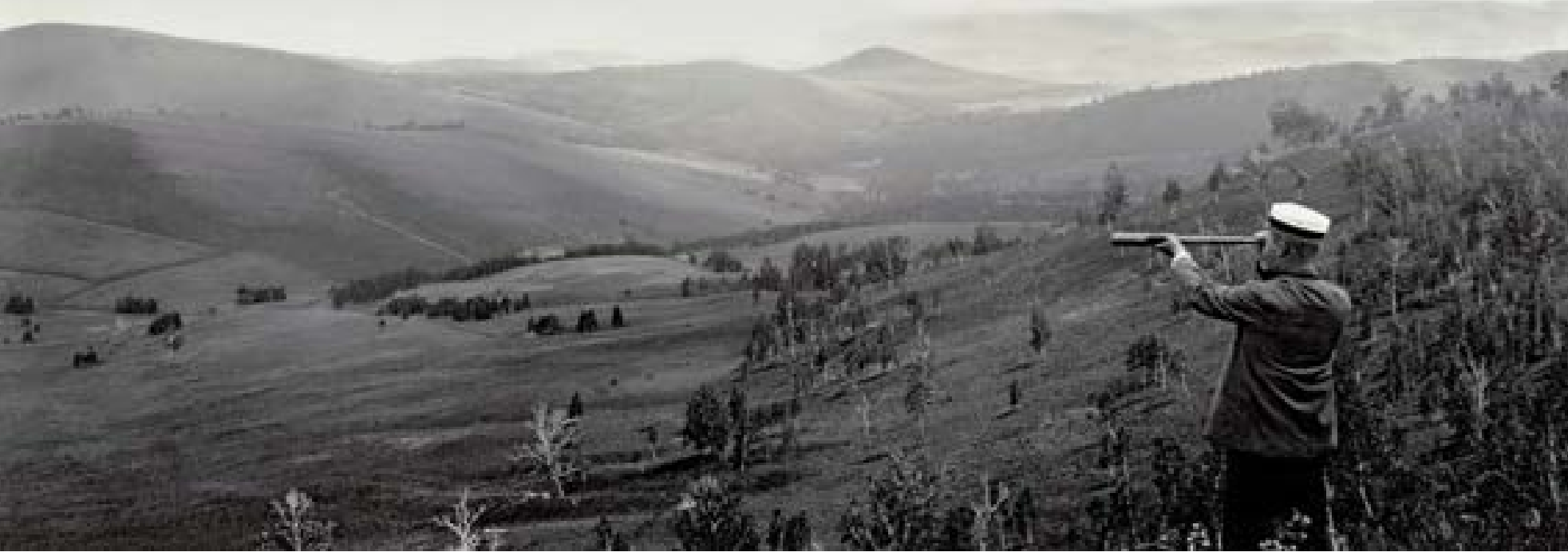

Näkymä Satulamäeltä Verhne Suetukin suomalaissiirtolan läheltä Sajanin vuoristossa Etelä-Siperiassa 1900-luvun alussa. 


\section{Perheen matrassa}

\section{Vanhemmat}

Lapualla syntyi maaliskuun 14. päivänä 1882 vt. kirkkoherra Johannes Granön perheeseen esikoispoika, joka sai kasteessa etunimet Johannes Gabriel. Puhuttelunimeksi tuli, erotukseksi isästä, Gabriel. Suomenkieliset ystävät alkoivat kutsua häntä nimen kansanomaisen muodon mukaan Kaapoksi, muutamat ruotsinkieliset myöhemmin Gabbukseksi. Itse hän alkoi jo nuorena käyttää etukirjaimia J. G. ${ }^{2}$

Johannes Granö oli neljä vuotta aiemmin mennyt naimisiin Alma Jakobina Fontellin kanssa. Puolisoiden taustat olivat tyystin erilaiset. Johannes Granö oli 25.9.1850 syntynyt yhdeksänlapsisen viljelijäperheen poika. Granön talo Granön kylässä Teerijärven kirkonkylässä Keski-Pohjanmaalla oli pitäjän vanhimpia ja ollut saman suvun hallussa 1500-luvulta alkaen. Talo oli saanut nimensä sen edustalla aikoinaan olleen, myöhemmin kuivatun järven kuusimetsäisen saaren mukaan. Perimätieto kertoi, että Granön esivanhemmat olisivat muuttaneet ruotsalaisten siirtolaisten mukana Taalainmaalta, joskin todennäköisenä pidettiin myös, että talo olisi välillä ollut savolaisen uudisasutuksen piirissä. ${ }^{3}$

Alma Fontell oli syntynyt kirkkoherran tyttärenä Lemlandissa Ahvenanmaalla 15.5.1848. Hänen sukunsa oli lähtöisin ruotsalaisesta Hasselblattien pappissuvusta, jonka jäsenet muuttivat 1600-luvulla Ruotsin aikana Viroon ja sieltä kaksi sukupolvea myöhemmin Suomeen nuorimman sukuhaaran jäädessä Baltiaan. Hänen isoisänsä oli ottanut kasvatti-isänsä mukaan nimen Fontell, jota suvun jäsenet olivat sen jälkeen käyttäneet. Heihin kuului Alman serkku, historiantutkija ja tilastotieteilijä A. G. Fontell. ${ }^{4}$ 


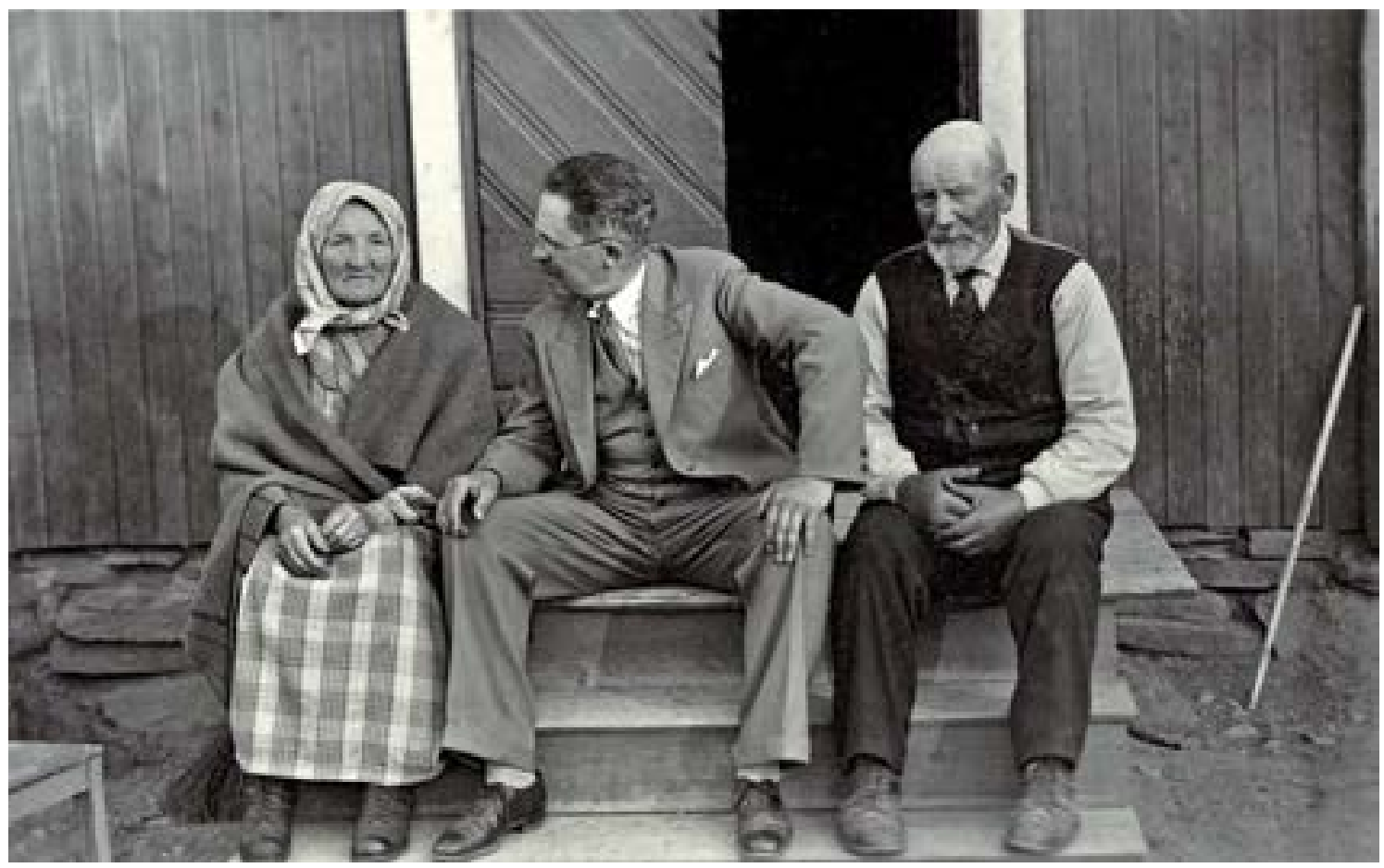

J. G. Granö istuu sukutalon rappusilla yhdessä tätinsä Edla Granön ja tämän aviomiehen Anders Forssander-Granön kanssa. Kuva on otettu heinäkuussa 1931, jolloin hän kävi yhdessä Hilma-puolisonsa kanssa tutustumassa lapsuutensa ympäristöön.

Alman vanhemmat olivat elämäntyönsä Ahvenanmaalla ja ruotsinkielisellä Pohjanmaalla tehneet Josef Fontell ja Johanna (Jeanette) Augusta Bomansson. Johannan äidin veljiä olivat Suomen arkistolaitoksen perustaja Karl August Bomansson sekä tunnettu sammaltutkija ja Suomen yliopistomaantieteen uranuurtajan Ragnar Hultin retkeilytoveri Johan Oskar Bomansson, jonka kanssa J. G. Granö oli myöhemmin paljon tekemisessä. ${ }^{5}$

Josef Fontell oli noussut jo Ahvenanmaalla toimiessaan evankelisen herätysliikkeen tunnetuksi puhujaksi, jota tultiin kuuntelemaan pitkienkin matkojen takaa. 


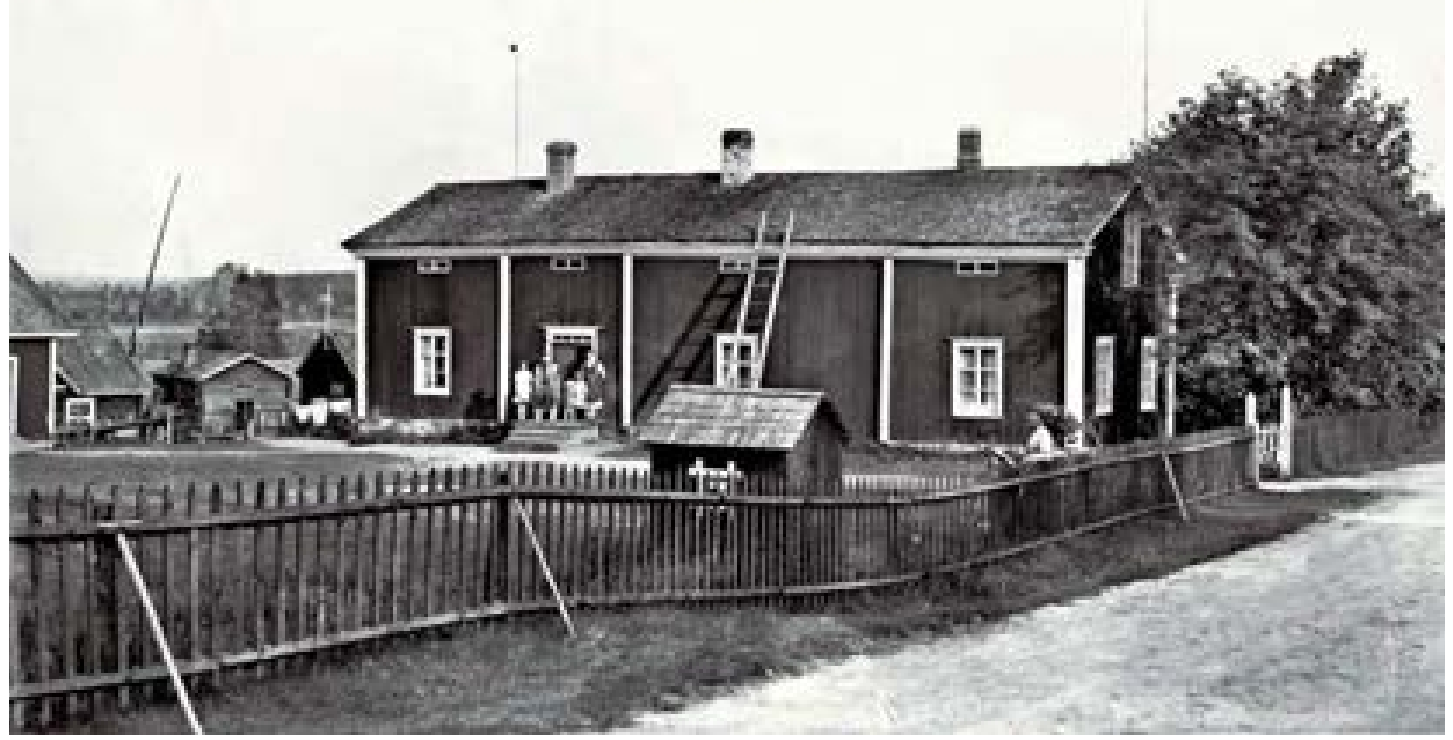

Granön suvun vanha sukutalo Teerijärvellä. Rappusilla pääoven edessä seisoo emäntä Jenny Granö lasten kanssa. Piha-aidan luona isäntä Teodor Granö ja vanhin poika Gabriel Granö. Teodor Granö oli isäntänä Granön tilalla vuosina 1929-63. Talo on edelleen suvun hallussa.

Siirryttyään ensin 1863 Teerijärven ja myöhemmin Vöyrin kappalaiseksi Fontell jatkoi voimakasta herätystyötään, jonka ansiosta häntä ryhdyttiin kutsumaan Pohjanmaan hengelliseksi herättäjäksi. Myös Granön perhe omaksui monien muiden pohjalaisten tavoin evankelisen uskonkäsityksen.

Granön suku oli taiteellisesti lahjakasta. Johannes Granön isoisä Petter Granö oli arvostettu talonpoikaismaalari, minkä vuoksi sukutalo tunnettiin myös nimellä Målas. Yksikään suvun edustajista ei ollut kuitenkaan lähtenyt opintielle. Eikä olisi lähtenyt Johannes Granökään, jollei Josef Fontell, tuleva appi, olisi huomannut hänen lahjakkuuttaan ja kiinnostustaan tiedollisiin harrastuksiin ja ohjannut hänet 18-vuotiaana Kokkolan ala-alkeiskouluun.

Valmistuttuaan ylioppilaaksi suurten taloudellisten vaikeuksien jälkeen Johannes Granö aloitti 1875 teologian opinnot yhtenä ensimmäisistä maaseutuylioppilaista Aleksanterin-yliopistossa. Opiskelijoista suuri osa oli yhä herrassäätyisiä, mutta hän 
kykeni opiskelutovereina olleiden Josef Fontellin poikien, Johan Wilhelmin ja Karl Oskarin, avulla sopeutumaan joukkoon. Hän omaksui monien tulevien teologien tavoin suomalais-kansallisen näkemyksen ja kuului koko elämänsä ajan suomenmielisiin. ${ }^{6}$

Saatuaan kovan uurastuksen jälkeen pappisvihkimyksen 1877 ja osoitettuaan kykenevänsä täyttämään paikkansa säädyssään Johannes Granöstä kehittyi asemastaan tietoinen, lujatahtoinen ja vahva kirkonmies, jolle Hjalmar Appelgren-Kivalon mukaan kirkkoruhtinaan sävy muodollisine pukeutumisineen ja seurusteluineen ei ollut aivan vieras. Alma oli luonteeltaan miehensä täydellinen vastakohta. Hän oli mukautuvainen, vaatimaton ja hienovarainen ihminen. ${ }^{7}$

Teerijärven pitäjä oli täysin ruotsinkielinen, mutta Johannes Granö oppi jo lapsena suomenkielisestä Lohtajan Perttulan talosta kotoisin olleelta äidiltään suomen kielen ja oli täysin kaksikielinen. Alma Granön äidinkieli oli ruotsi, eikä hän oppinut koskaan täysin suomea. Tämä johti siihen, että perheen lapset, Kaapo ja 1883 syntynyt Paul eli Paavo, pääsivät jo kotonaan kielikylpyyn. Vanhemmat puhuivat keskenään ruotsia, äiti puhui lastensa kanssa aina ruotsia, isä suomea. Isän vaikutuksesta pojat pantiin suomenkieliseen kouluun. ${ }^{8}$

Kaapo ja Paavo kasvatettiin kuuliaisuuteen. Vanhemmat olivat omaksuneet selkeän periaatteen: Lasten täytyi aina ja ehdottomasti totella. Siksi lasten oma tahto alistettiin jo ennen kuin he olivat oppineet puhumaan. Kun oppi oli mennyt perille, kasvattaminen sujui niin helposti, että ruumiillista kuritusta ei tarvinnut käyttää koskaan. ${ }^{9}$

\section{Ullavasta Kemiöön}

Johannes Granö aloitti pappisuransa Ullavan saarnahuonekunnan saarnaajana. Ullava kuului Kälviän seurakuntaan, ja sen väestö oli täysin suomenkielistä. Koska Kälviän kirkolle oli matkaa yli 30 kilometriä, saarnahuonekunta muodosti seura- 
kunnallisesti kiinteän kokonaisuuden. Granö sai siten heti tottua varsin itsenäiseen ja vastuulliseen viranhoitoon.

Vuonna 1879 Granö siirrettiin evankelisten seurakuntalaisten pyynnöstä kirkkoherra Fredrik Napoleon Ottelinin apulaiseksi Kauhavalle, jossa hän oli ollut opiskeluaikanaan saarna-apulaisena. Tä̈llä hän toimi tarmokkaasti evankelisen herätysliikkeen hyväksi vastustaen sekä lakia hyljeksivää evankelista kansanhurskautta eli antinomismia että yleistä maallistumista.

Granö oli väkevä julistaja, joka osasi vaikuttaa kuulijoihinsa. Monet kauhavalaiset kokivat uskonnollisen heräämisen hänen vaikutuksestaan, muun muassa "Kauhavan herra" Aadolf Hägglund, joka oli kymmenen vuotta aiemmin pistänyt ankaran komennon avulla kuriin Pohjanmaan tunnetuimmat häjyt, Antti Isotalon ja Antti Rannanjärven. Granö ja Hägglund ystävystyivät niin läheisesti, että Hägglundista tuli J. G. Granön kummisetä. ${ }^{10}$

Suoritettuaan 1880 tutkinnon vakinaisen papinviran saamista varten Granö siirtyi helmikuussa 1881 kirkkoherra Otto Mauritz Hohenthalin apulaiseksi Lapualle. Hän hoiti myös kappalaisen apulaisen tehtäviä, ja kun hän joutui Hohenthalin virkavapauden ja kuoleman jälkeen toimimaan virkaatekevänä kirkkoherrana, työtä riitti lähes 10000 asukkaan seurakunnassa. Silti hän ei tyytynyt vain virkatehtävien muodollisen puolen hoitamiseen, vaan paneutui täysin voimin taisteluun herännäisyyttä vastaan. Herännäisyyden asema ei ollut 1880-luvulla Lapualla enää yhtä vahva kuin aiemmin, mutta se oli edelleen seurakunnan huomattavin uskonnollinen liike. ${ }^{11}$

Granön aika Pohjanmaalla jäi lyhyeksi, sillä hän suostui jo syksyllä 1881 suuresti kunnioittamansa F. G. Hedbergin, evankelisen herätysliikkeen johtajan, pyyntöön hakea Kemiön kappalaisen virkaa. Paikka oli ollut useita kertoja auki, minkä vuoksi Hedberg oli päättänyt itse löytää työlleen seuraajan. Jouluaattona lähettämässään kirjeessään hän pyysi hartaasti Granötä, "pyhän evankeliumin puhdasta julistajaa tulemaan ja auttamaan meitä". ${ }^{12}$

Siirryttyään keväällä 1882 Kemiöön Granöstä tuli Hedbergin läheinen työtoveri ja sanansaattaja, joka monissa eri yhteyksissä esitti tämän uskonnäkemyksiä. 
Kemiössä Granö sai vihdoin toimia seurakunnassa, jossa asiat olivat kunnossa. Kirkkoherra huolehti tunnollisesti jumalanpalveluksista, lastenopetuksesta, kirkkokurista ja vähäosaisten auttamisesta. Granö tunsi Hedbergin toiminnan monella tapaa esikuvalliseksi ja ylisti hänen kristillistä nöyryyttään, vaatimattomuuttaan ja hienoa ulkonaista käyttäytymistään. Vastaavasti myös kirkkoherra arvosti nuorta apulaistaan. ${ }^{13}$

\section{Rohkea päätös}

Johannes Granön perheen asiat olivat ulkoisesti kunnossa Kemiössä. He asuivat kirkonkylässä ja elämä sujui isän keskittyessä kappalaisen moniin tehtäviin ja äidin hoitaessa kotia ja kahta pientä poikaa. Granö ei ollut kuitenkaan tyytyväinen. Hän ei ollut valmis asettumaan aloilleen vaan halusi päästä tehtäviin, jossa saattoi todella koetella rajojaan.

Suomessa ei ollut tarjolla sellaisia tehtäviä, joihin hänellä olisi ollut mahdollisuuksia edetä, joten katseet oli suunnattava maan rajojen ulkopuolelle. Pohjanmaalla oli juuri alkamassa laajamittainen muuttoliike ison veden taakse Amerikkaan, mutta maakunnassa tiedettiin, että maailmaa riitti myös idän puolessa. Venäjä oli pohjalaisille sekä mahdollisuuksien manner että jäätävän kauhun maa. Keisarikunta oli houkutellut eri tehtäviin lukuisia pohjalaisia, mutta sen kaukaiset kolkat olivat myös murhamiesten ja muiden rikollisten pelättyjä karkotuspaikkoja. Johannes Granö päätti yhdistää nämä vaihtoehdot. Hän alkoi suunnitella lähtöä karkotettujen rikollisten ja muiden suomalaissiirtolaisten papiksi Siperiaan. ${ }^{14}$

Puukkojunkkariseudulla toiminut Johannes Granö oli hyvin tietoinen siitä, että suomalaisia murhamiehiä oli karkotettu Siperiaan. Ajatus heidän seuraamisestaan tuli hänen mieleensä ensimmäisen kerran Turussa 1880, jolloin hän oli pastoraalitutkintoa suorittaessaan tutustunut lääninvankilan pastoriin, Georg Leonard Udeliukseen. Samanlaisen hengellisen näkemyksen omanneiden miesten ystävystyessä Udelius kuvasi Granölle suomalaisten hengellistä hätää Siperiassa 


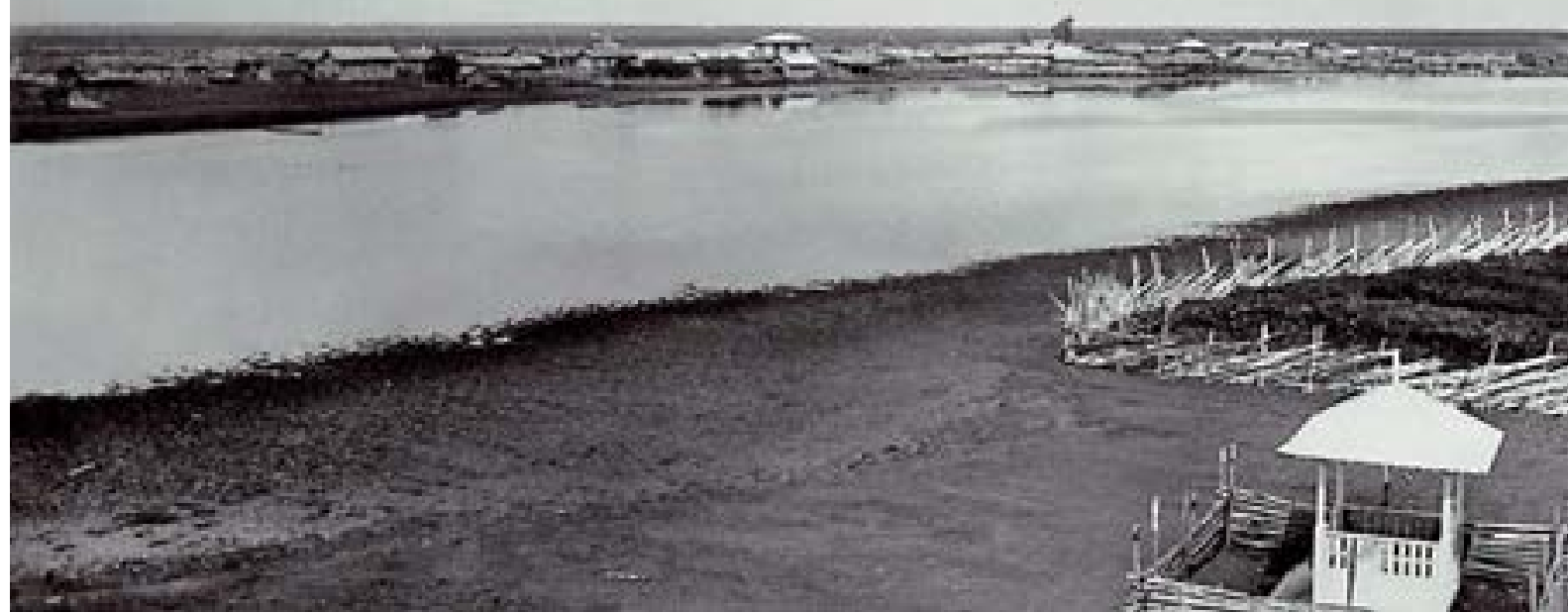

Panoraama Ryžkovan kylästä, Länsi-Siperian vanhimmasta suomalaissiirtolasta.

ja kehotti häntä nuorena miehenä lähtemään auttamaan maanmiehiään: ”Kun Jumala on antanut sinulle hyvän terveyden ja vahvan ruumiin, niin on sinun velvollisuutesi lähteä sinne." ${ }^{15}$

Vakuuttaakseen Johannes Granön tehtävän välttämättömyydestä Udelius vei hänet tapaamaan erästä Siperiasta kotimaahan karannutta ja Kakolaan joutunutta vankia, joka kertoi suomalaisten kohtaloista karkotusseuduillaan. Vanki antoi todentuntuisen kuvan suomalaisten viheliäisistä ja surullisista oloista, mutta totesi myös, että yleiset elinolosuhteet Länsi-Siperiassa olivat erinomaiset. Suomalaiset asuivat pääosin Om- ja Irtyšjoen yhtymäkohdassa olevan Omskin kaupungin ympäristössä, joka kuului viljaviin mustan mullan maihin.

Johannes Granö oli valmis ottamaan haasteen vastaan, mutta puolison ja suvun saaminen hankkeen taakse ei käynyt yhtä helposti. Viimein syksyllä 1882 kotijoukkojen vastarinta murtui, ja hän saattoi matkustaa Helsinkiin ilmoittautumaan halukkaaksi lähtemään suomalaisten sielunhoitajaksi Siperiaan. Hän oli liikkeellä hyvällä hetkellä, sillä keisarille oli juuri toimitettu esitys Siperian suomalaisten sielunhoidon uudelleen järjestämisestä. ${ }^{16}$ 
Siperiaan karkotustuomion saaneiden vankien pitkä matka alkoi Suomen rajalta. Suurin osa karkotetuista sijoitettiin 4000 kilometrin ja toista vuotta kestäneen kävelyn jälkeen Tobolskin kuvernementtiin. Siirtolaiset saivat avioitua, rakentaa mökit itselleen ja raivata maata maanviljelyä varten. Karkotetut asettuivat aluksi pääosin Tjukalinskin piirikunnan aroseudulla sijainneeseen Ryžkovan kylään, jonne Inkerinmaalta maaorjuutta pakoon lähtenyt väestö oli perustanut 1800-luvun alussa Länsi-Siperian vanhimman suomalaisen siirtolan. Suomalaisten keskuudessa Vanhana paikkana tunnetun kylän väkiluku kasvoi nopeasti, ja uralilaisten kielten tutkimuksen uranuurtajan M. A. Castrénin käydessä siellä 1848 asukkaita oli jo noin 700 .

Ryžkovan kasvu ja yhdyskuntaa pahoin vaurioittanut tulipalo pakottivat perustamaan uusia siirtoloita, varsinkin kun siirtolan seutu ei ollut maaperältään suotuisaa viljelykselle. Uusista siirtokunnista suurimpia olivat Tobolskin kuvernementin metsävyöhykkeelle perustetut Bugene ja Bojarka sekä aroseudun Om ja Aštšegul. Kaikissa siirtoloissa oli eri kansallisuuksia sekaisin, mutta Omissa, runsaan sadan kilometrin päässä Omskista, suomalaisilla oli oma kylä, Helsingin kylä.

Pahimpien rikollisten matka jatkui vielä Omskista lähes 2000 kilometrin päähän Itä-Siperian kaivoksiin ja kullanhuuhtomoihin. Ne harvat, jotka selvisivät hengissä 20 vuoden pakkotyöstä, saivat asettua Jenisein kuvernementin Minusinskin piirikuntaan Sajanin vuoristoon, 1850 perustettuun Verhne Suetuk -nimiseen siirtolaan, jossa oli useita erikielisiä luterilaisia kyliä. Siirtola oli monia muita siirtoloita paremmassa asemassa siinä suhteessa, että sen läheisyydessä oli pakkotyölaitoksia ja siten kysyntää viljalle.

Keisarin armollinen julistus lupasi, että karkotetuille järjestettäisiin mahdollisuus sielunhoitoon. Asian sai aluksi vastuulleen Moskovan evankelis-luterilainen kirkko, joka ei pienten ja hajanaisten siirtolaisryhmien kirkkona kyennyt 
täyttämään tehtävää edes kohtuullisesti. Suomen senaatti pyrki korjaamaan tilanteen 9.6.1863 annetulla asetuksella. Sen mukaan alueelle nimitettiin kirkkoherra ja katekeetta, joiden asemapaikkana oli Verhne Suetukin kylä.

Siperian suomalaisten vankien ja siirtolaisten ensimmäiseksi papiksi nimitettiin Herman Roschier, joka hallitsi sekä venäjän että saksan kielen. Venäjän ohella saksan osaaminen oli välttämätöntä, sillä Venäjän luterilaisen kirkon virkakielenä oli saksa. Roschier aloitti hengellisen työn katekeetaksi ottamansa Sylvester Adamssonin kanssa, mutta sen menestys oli heikko rikollisten suuren määrän ja alueen laajuuden vuoksi.

Suomalaisten hengellinen huolto koki 1878 pahan takaiskun, kun Verhne Suetukin päärakennus kirkkoherran asuntoineen ja jumalanpalvelushuoneineen ja ulkorakennuksineen tuhoutui tulipalossa. Roschier pyysi pikaista apua ainakin asunnon saamiseksi. Suomen senaatti ei kuitenkaan tähän suostunut, sillä se ei enää luottanut vanhojen järjestelyjen toimivuuteen. Siksi se päätti esittää juuri 1880-Iuvun alussa keisarille, että suomalaisten sielunhoito järjestettäisiin uudella tavalla. Samalla esitettiin papin virka-ajan lyhentämistä, palkan korottamista ja eläke-etujen parantamista.

Joulukuun 23. päivänä 1884 annettu keisarillinen asetus ratkaisi asian senaatin esittämällä tavalla. Noin parituhatta henkeä käsittävän seurakunnan papin asemapaikaksi määrättiin Omsk, josta oli hyvät yhteydet eri puolille Siperiaa ja jonka läheisyydessä pääosa siirtoloista oli. Papin vastuulle tulivat viisi siirtolaa Irtyšin ja Omjoen varsilla sekä kaukainen Verhne Suetukin siirtola, jossa toimi katekeetta. Venäjän kruunu maksoi edelleen korvaukset virkamatkoista, antoi papille maata ja oikeuden päästä tapaamaan suomalaisia tehtaissa, vankiloissa ja kaivoksissa. ${ }^{17}$ 


\section{Muutto Siperiaan}

Johannes Granön lisäksi Siperian suomalaisten papin virkaa oli hakenut kaksi muuta henkilöä, mutta senaatti antoi yksimielisesti 8. toukokuuta 1885 viran Granölle. Syynä oli todennäköisesti se, että hän oli jo kauan osoittanut mielenkiintoa Siperian

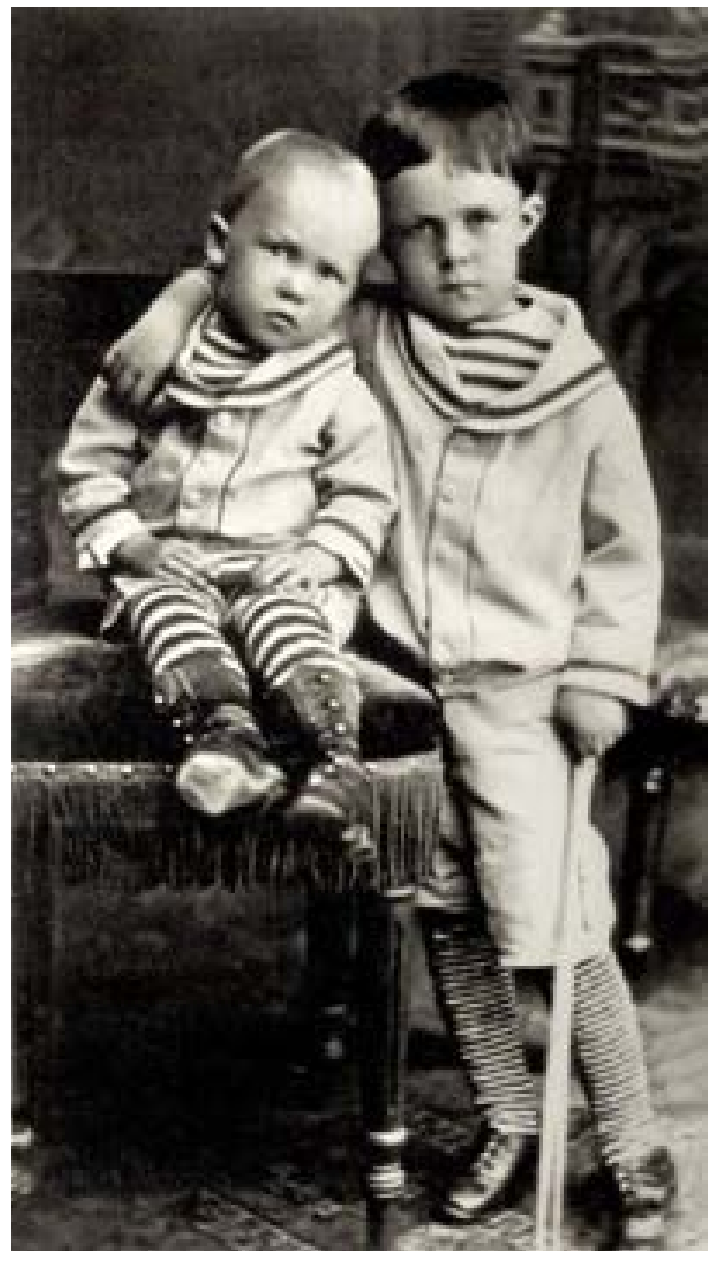

Kaapo ja pikkuveli Paavo Granö juuri ennen Siperiaan muuttoa kesällä 1885. suomalaisia kohtaan. Hän oli käynyt tarjoutumassa työhön, alkanut opiskella venäjää ja ilmoittanut pitävänsä suomalaisten auttamista elämäntehtävänään. ${ }^{18}$

Granö sai nauttia kaikkia virasta tulevia etuja kesäkuun 1885 alusta lähtien ja saattoi aloittaa heti valmistautumisen tehtävää varten. Hän kävi tapaamassa edeltäjäänsä Herman Roschieria ja kirkollisasiain toimituskunnan päällikköä Yrjö-Sakari Yrjö-Koskista, jotka antoivat paljon hyviä neuvoja. Työtoverikseen Verhne Suetukin katekeetaksi Granö sai kanttori P. E. Lindholmin. ${ }^{19}$

Matka Siperiaan alkoi 6. heinäkuuta 1885 Vasa-höyrylaivalla Turusta Pietariin. Ennen matkalle lähtöä isä vei vanhemman poikansa Kaapon Turun Tuomiokirkkoon antaakseen hänelle mieleen jäävän muiston kotimaasta. Helsingissä seurueeseen liittyi lasten hoitajaksi saatu Alma Granön serk$\mathrm{ku}$, diakonissa Elisabet Fontell, ja Pietarissa Granön veli, pehtori Anders eli Antti Granö, joka venäjän kieltä taitavana, riuskana ja monipuolisesti maataloustöihin perehtyneenä henkilönä oli luotettava kumppani. Keisari- 
kunnan pääkaupungissa Granö tapasi muun muassa Suomen ministerivaltiosihteerin ja vankien sijoituspaikoista vastanneen viraston päallikön, joka lupasi vaikuttaa siihen, että kaikki suomalaiset vangit koottaisiin samoihin paikkoihin. ${ }^{20}$

Pietarissa vietetyn viikon jälkeen matka jatkui kohti Omskia. Koska Siperian rautatietä ei vielä ollut, junalla päästiin Moskovan kautta vain Nižni Novgorodiin, josta edettiin höyrylaivalla Volgaa pitkin Permiin. Permistä matka suuntautui junalla Ural-vuorten rajalle Jekaterinburgiin; sieltä jatkettiin nelivaljakolla Tjumeniin ja sieltä edelleen höyrylaivalla Omskiin, jonne seurue saapui lähes 4000 kilometrin taipaleen jälkeen elokuun puolivälissä 1885.21

\section{Kansainvälinen Omsk}

Vuonna 1716 perustettu Omsk oli Länsi-Siperian hallinnollinen ja kulttuurinen keskus, joka oli kehittynyt nopeasti 1800-luvun jälkipuoliskolla. Kun kaupunkiin karkotettu kirjailija Feodor Dostojevski kuvasi sitä vuosisadan puolivälissä inhottavaksi kaupunkipahaseksi, jota kesäisin riivasivat tiheät pölypilvet, se oli muutaman vuosikymmenen kuluttua noin 30000 asukkaan elinvoimainen keskus.

Johannes Granö piti kaupunkia sopivana asuinpaikkana papille, sillä se oli riittävän iso tarjotakseen edulliset elinolot ja monipuolisen kulttuurielämän. Kaupungissa oli muun muassa lukio, naiskymnaasi, kadettikoulu, opettajaseminaari ja Venäjän Maantieteellisen Seuran Länsi-Siperian osaston piirissä toimiva korkeatasoinen tiedeyhteisö. ${ }^{22}$

Kielellisesti Omsk oli kansainvälinen. Siellä oli vilkas saksalainen siirtokunta ja saksankielentaitoinen ylempi virkamiehistö, joihin Johannes Granö, alussa vain auttavasti venäjää osaavana, joutui turvautumaan. Lisäksi kaupungissa oli ranskaa taitavia virkamiehiä ja tataarikieliä puhuvaa alkuperäisväestöä. Monien eri kansallisuuksia olevien siirtolaisten joukossa oli runsaasti virolaisia ja muita balttilaisia sekä tanskalaisia. ${ }^{23}$ 
Kaapolle kirjavat kieliolot sopivat hyvin, sillä hänellä oli hyvä kielipää. Kun alkeisopinnot Omskissa tapahtuivat venäjän kielellä ja tuttavapiirissä puhuttiin suomen ja ruotsin ohella saksaa, pojan kielitaito karttui vahvaksi.

J. G. Granö oppi elämänsä aikana puhumaan sujuvasti suomea, ruotsia, venäjää, saksaa sekä viroa. Hän osasi lukea vaikkakaan ei vaivattomasti puhua ranskaa, ymmärsi tanskaa ja tuli jossakin määrin toimeen myös Altain turkin ja mongolian kielillä. Ainoa kieli, joka osoittautui hänelle ylivoimaisen vaikeaksi, oli englanti. Vaikka hän opiskeli vakavasti kieltä myöhemmin Turussa ja pystyi lukemaan englanninkielisiä kirjoja, kielen ääntämyksestä ei tullut oikeastaan yhtään mitään. ${ }^{24}$

Lähes ensitöikseen Johannes Granö hankki perheelleen oman talon. Hyvää asuntoa tarvittiin, sillä Omskin ilmasto oli mantereinen. Talvella pakkasta saattoi olla lähes 50 astetta, kevät tuli yhtäkkiä, kesät olivat kuumia. Ilmasto oli paljon kuivempi kuin Suomessa, joten talvella pakkanen ei tuntunut pelätyn pahalta. Sen sijaan kesät olivat tukalia. Kuumuden lisäksi kiusana oli alituinen pöly, sillä katujen ollessa täysin kiveämättömät, talot ja ulkona olevat ihmiset olivat kauttaaltaan pölyn peitossa. ${ }^{25}$

Granöt siirtyivät aina keväisin heti kun vain oli mahdollista zaimkalleen eli pienelle viljelytilalleen 13 kilometriä Omskista itään Omjoen varrelle, pois kaupungin pölystä ja kuumuudesta. Muutto auttoi pitämään perheen talouden hyvässä kunnossa, sillä oman tilan tuotteet ja läheisestä joesta saalistetut kalat muodostivat huomattavan osan ruokavaliosta. Kalastaminen oli niin perheen isän kuin poikien lempiharrastus.

Johannes Granö harjoitti pientilallaan kasvinviljelyn ohella karjataloutta, joka oli tuolloin Siperiassa huomattavasti kehittymättömämpää kuin Suomessa. Monet suomalaiset siirtolaiset ja paikalliset asukkaat seurasivat pian pappinsa esimerkkiä. Pientilan alueelle rakennettiin talkootyön ja vapaaehtoisten avustusten turvin rakennuksia, joihin avun tarpeessa olevat, sairaat ja köyhät suomalaiset siirtolaiset saattoivat asettua asumaan. ${ }^{26}$ 
oppi pian, miten rekien ja kärryjen istuimet tuli asettaa tyynyistä ja muista matkatavaroista siten, että matkan aikana kykeni nukkumaan. Granö kävi jo varhaissyksyllä lähimmässä suomalaisessa siirtolassa Omissa, jossa hänet otettiin ilolla vastaan. Maanmiesten tapaamisen synnyttämää iloa lievensi synkkä havainto siitä, kuinka huonosti asiat siirtoloissa olivat. ${ }^{28}$

Suomalaisten siirtoloiden kehno tila oli monen tekijän summa. Venäjän viranomaiset eivät olleet tietoisia suomalaisten sijoittumisesta Siperiaan eivätkä katsoneet olevansa velvollisia huolehtimaan heidän henkisestä sen paremmin kuin aineellisesta hyvinvoinnistaan. Siirtoloiden maanviljely oli tuottoisaa viljavan maan ansiosta, mutta huonojen kuljetusolojen takia viljan kysyntä jäi vähäiseksi. Halvan hinnan vuoksi viljaa ryhdyttiin jalostamaan yhä enemmän alkoholiksi, joka veti puoleensa rangaistusaikansa loppuun kärsineitä entisiä murhamiehiä ja ja muita rikollisia. Viinan virratessa vapaasti väkivalta ja raju meno hallitsivat kylien elämää, laista ei juuri piitattu ja lapsista vain harvat osasivat lukea. ${ }^{29}$

Granö ymmärsi, että siirtoloiden tila oli niin huono, että Jumalan sanan levittämisen ohella oli pyrittävä kohentamaan niiden sosiaalista, taloudellista ja siveellistä järjestystä. Hän käynnisti säännöllisen seurakuntaelämän mutta ryhtyi samalla edistämään siirtolaisten lukutaitoa ja terveydellisiä oloja sekä erityisesti lasten kohtelua. Hän sai aikaan sen, että siirtoloihin perustettiin Suomesta kerättyjen varojen turvin lastenkouluja ja kirjastoja. Granön tuella kauas Venäjälle matkustaneisiin opettajiin kuului Wilhelm Juntunen, josta tuli yksi Siperian suomalaisseurakuntien pitkäaikaisimmista työntekijöistä. Juoppoutta pyrittiin vähentämään raittius- ja urheiluseurojen avulla, ja monien vankien kotioloja järjestettiin oikeaan uomaan..$^{30}$

Aadolf Hägglundin hengenheimolaisena Granö käsitti, että kovassa seurassa tarkoitus pyhitti keinot, eikä epäröinyt viedä sanomaa perille myös pampun ja kovien otteiden avulla. Varsinkin kapakoitsijat ja hevosvarkaat vastustivat kurinpalautuskampanjaa niin lujasti, että linjan täytyi olla tiukka. Granön tukena oli Anders Granö, joka ryhtyi Helsingin kylän koulumestariksi ja saarnaajaksi ja sittemmin myös valtion palkkaamaksi järjestyksen valvojaksi. Anders Granö ei vain antanut 
iskuja vaan sai myös ottaa niitä vastaan; kerran häntä viillettiin muun muassa puukolla selkään.

Lukuisten, usein veristen ottelujen jälkeen Johannes Granö sai Suomesta lähetetyn karskin apumiehen Porren avulla lopulta murretuksi rosvojen ja varkaiden vallan ja poistetuksi useimmat salakapakat siirtokunnasta. Karkotusten loputtua suomalaiskylien olot alkoivat vähitellen parantua. Rikollisuus ja juoppous vähentyivät, ja sosiaalihuolto sai alkunsa, kun vanhoja ja sairaita karkotettuja varten perustettiin vaivaistaloja. ${ }^{31}$

Helsingin kylään rakennettiin rukoushuone ja Verhne Suetukiin pystytettiin koulutalon ja katekeetan asunnon lisäksi oikea kirkko, jonka Johannes Granö vihki käyttöön 20. marraskuuta 1888. Siirtolan tilanne oli parempi kuin monissa muissa siirtoloissa, sillä katekeetta P. E. Lindholm toimi siellä aktiivisesti. ${ }^{32}$

\section{Virkamatkojen antia}

Johannes Granölle kertyi esimerkiksi vuoden 1888 aikana matkakilometrejä yli 10 000. Virkamatkoillaan hän kiinnitti huomiota moniin uuden asuinympäristönsä erikoisiin ilmiöihin. Erityisesti Bugenen siirtola oli mielenkiintoinen, sillä sen asukkaat olivat syrjäisen sijaintinsa ansiosta säilyttäneet hyvin vanhat tapansa. ${ }^{33}$

Granö keräsi siirtolaisten asukkailta kansanrunoutta, jota hän sekä esitteli ensimmäisen toimintakauden kokemuksiaan tilittävässä kirjassaan, 1893 ilmestyneessä teoksessaan Kunsi vuotta Siperiassa, että suoraan Suomalaisen Kirjallisuuden Seuralle 1891 lähettämissään kirjeissä. Väinö Salmisen mukaan Johannes Granön Bugenesta keräämät häärunot olivat säilyneet siinä muodossa, jossa niitä oli laulettu 1700-luvulla. ${ }^{34}$

Matkoillaan Granö tutustui myös Minusinskin aroilla havaitsemiinsa ainutlaatuisiin hautapatsaisiin, joita paikallinen väestö oli ilmeisesti aikoinaan palvonut uhrimenoin. Osalla patsaista oli selvät naiselliset tuntomerkit, minkä vuoksi niitä nimitettiin kiviakoiksi. Kiviakat erosivat selvästi muista Minusinskin alueen kiviveistoksista, eikä niille tunneta vastineita muualtakaan. 


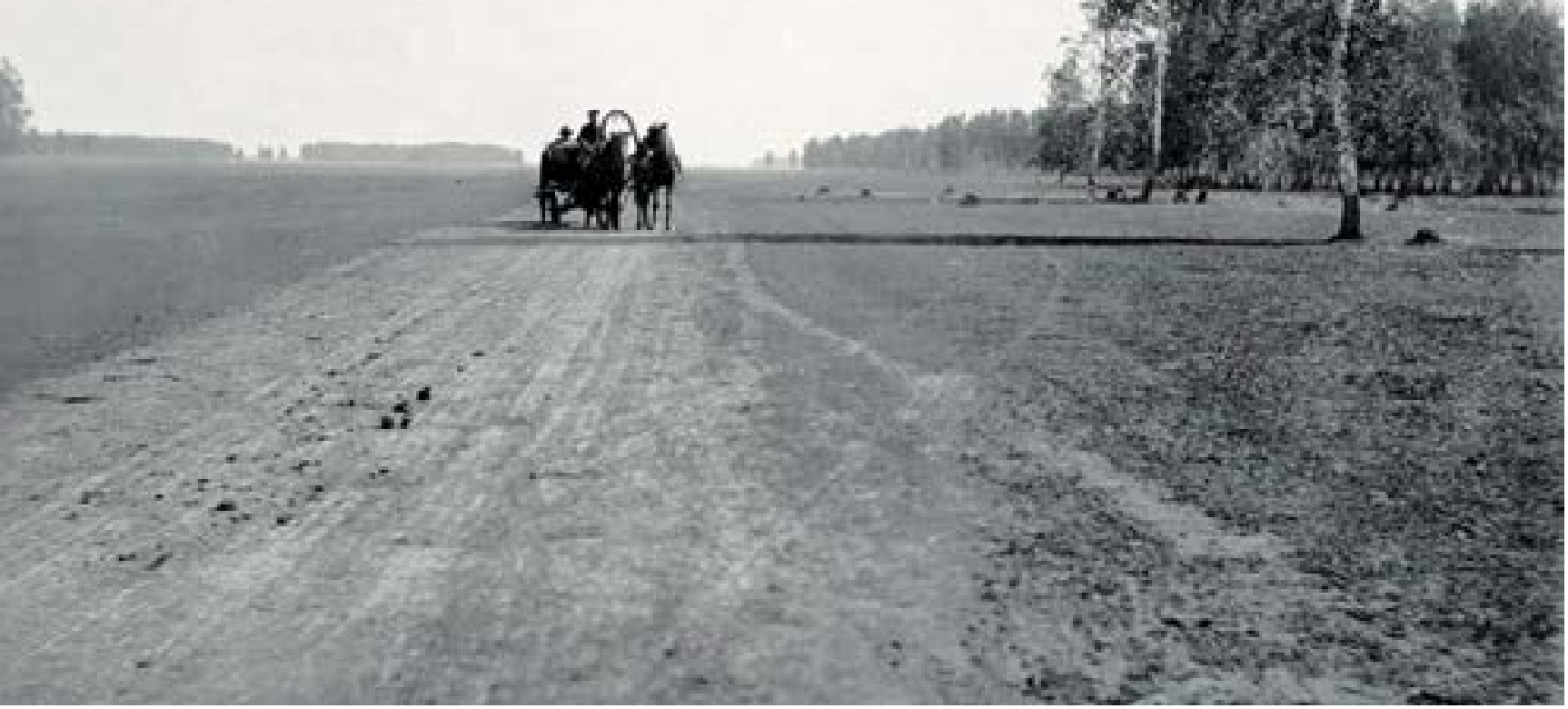

Aroa ja koivusaarekkeita Ryžkovan siirtolan lähistöllä Länsi-Siperiassa 1902.

Johannes Granö käytti virkamatkoillaan parivaljakon vetämiä tarantassi-vankkureita.

Minusinskin hautakentät kirjailtuine kivipaaseineen tekivät suuren vaikutuksen Granöön. Koska hänet oli kutsuttu 1885 kouluaikaisen ystävänsä Hjalmar Appelgren-Kivalon tuella Suomen Muinaismuistoyhdistyksen jäseneksi, hän koki velvollisuudekseen kertoa niistä yhdistykselle. Helmikuussa 1887 Appelgren-Kivalolle lähettämässään kirjeessä Granö kuvasi aroilla olevien hautamuistomerkkien moninaisuutta ja kehotti suuren Castrénin perintöön viitaten yhdistystä aloittamaan niiden tutkimisen. Samalla voitaisiin saada tukea pietarilaisen akateemikon Wilhelm Radloffin esittämälle ajatukselle, että altailaiset olisivat turkkilaistunut suomalainen heimo. ${ }^{35}$ 
Granön lähettämä kirje herätti Suomessa suurta huomiota ja sai J. R. Aspelinin vakuuttumaan siitä, että paaseihin hakatut kirjoitukset olivat jotakin suomensukuista muinaiskieltä, kenties peräti Castrénin otaksumaa suomalais-ugrilaista kantakieltä. Hän teki Suomalais-ugrilaiselle Seuralle esityksen niiden tutkimisesta, ja ehdotus hyväksyttiin. Muinaismuistoyhdistys järjesti kolme retkeä Siperiaan 1887, 1888 ja 1889.

Ensimmäisellä retkellä Granökin oli vähän aikaa mukana ja tapasi Aspelinin ja Appelgren-Kivalon. Retket eivät täyttäneet kansallisesti suuntautuneiden tutkijoiden toiveita, sillä niiden aikana varmistui, etteivät löydetyt kirjoitukset voineet mitenkään kuulua oletetuille esisuomalaisille. Lopullisesti haaveen Suomen suvun alkukodista Altain rinteillä puhalsi sammuksiin tanskalainen kielentutkija Vilhelm Thomsen, jonka onnistui 1893 murtaa outojen riimujen arvoitus toteamalla niiden olevan muinaisturkkilaisia. ${ }^{36}$

\section{Alatornion pappila}

Johannes Granön sopimuksen mukaan hänen virkakautensa oli kuuden vuoden pituinen kuitenkin niin, että koko perhe saattoi viettää kolmen vuoden kuluttua kesän kotimaassa. Kaapo oli suuren osan kesää 1888 suomea puhuvan isoäidin hoivissa Johanneksen kotitalossa Teerijärvellä. Heidän välilleen kehittyi läheinen suhde.

Granön perhe muutti poikiensa koulunkäynnin vuoksi Suomeen syksyllä 1891. Vuoden lopulla Johannes Granö sai määräyksen Helsingin ruotsalais-suomalaisen seurakunnan virkaatekeväksi kappalaiseksi, jota tehtävää hän hoiti vuoden 1892 loppuun. Tammikuussa 1893 hän haki Alatornion pitäjän kirkkoherran virkaa, johon hänet nimitettiin parin kuukauden kuluttua. Kun Tornion kaupungista muodostettiin oma seurakunta 1896, Granön seurakunnaksi jäi varsinainen Alatornio Tornionjoen varrella Ruotsin rajalla. ${ }^{37}$

Näin evankelisen herätysliikkeen edustajasta Johannes Granöstä oli tullut kirkkoherra vankalle lestadiolaisuusalueelle. Hän oli valmistautunut kamppailemaan lestadiolaisuutta vastaan mutta yllättyi hengellisen vastarinnan voimakkuudesta. Varsin- 
Granö pyrki yhdistämään kirkkoa ja seurakuntalaisia ja sai tunnustusta tarmokkaasta työstään raittiuden, nuorisoseuratyön sekä Perä-Pohjolan kansanopiston hyväksi, vaikka lestadiolainen herätysliike vaikeutti myös tätä työtä. Merkittävä panos paikkakunnan taloudellisen edistämisen hyväksi oli toimiminen Perä-Pohjolan Maamiesseuran puheenjohtajana sen perustamisvaiheessa. Katrineholmin tilan osaomistajana hän näytti esimerkkiä käytännön maanviljelyn alalla kuivattamalla tilan alueella olleen laajan suon. ${ }^{40}$

Granöllä riitti voimia myös valtakunnallisten asioiden ajamiseen. Vuoden 1900 valtiopäivillä hän teki pappissäädyn edustajana Pohjois-Pohjanmaan taloudellisia ja sosiaalisia kysymyksiä koskevia aloitteita. Hän otti osaa myös evankelisessa liikkeessä puhjenneisiin kiistoihin. Hän lukeutui oppositiosiipeen, niin sanottuun Kirkollisten Sanomien ryhmään, joka piti itseään Hedbergin henkisen perinnön aitona vaalijana. ${ }^{41}$

1900-luvun alussa Johannes Granö vakuuttui siitä, että hänen oli ehdottomasti päästävä pois Alatorniolta. Vaikka hän kuinka oli koettanut kovettaa itsensä, hän koki seurakuntalaisten vastustuksen lamaannuttavan hänet kokonaan. Hän päätti lähteä virastaan heti, kun pojat olivat päässeet ylioppilaiksi. ${ }^{42}$

\section{Koulunkäynti}

Granön pojat aloittivat koulunkäynnin Tornion yhteislyseossa 1893, Kaapo toisella ja Paavo ensimmäisellä luokalla. Kaapo sai koulusta päästötodistuksen 1896 ja siirtyi Oulun suomalaiseen lyseoon, ja kuopus seurasi esimerkkiä kahden vuoden kuluttua. Oulussa veljekset asuivat Johannes Granön vanhan tuttavan pankinjohtaja J. S. Hedmanin perheessä. Perhe kuului kaupungin seurapiirien tärkeimpiin, ja Kaapon näinä vuosina saamat kokemukset säätyläisten elämästä vaikuttivat häneen suuresti. Hän aloitti Oulussa muun muassa viulunsoiton opiskelun. ${ }^{43}$

Niin Torniossa kuin Oulussakin Kaapo oli kiinnostunut erityisesti luonnontieteistä. Hän oli Oulun lyseon kasvitieteellisen yhdistyksen "Esikon" ensimmäinen 


\section{Maantieteilijöiden hautomo}

J. G. Granö luki nuorena mielellään maantieteellistä kirjallisuutta, mutta maantieto oli hänelle Oulun suomalaisessa lyseossa vain yksi oppiaine muiden joukossa. Sattumalta juuri 1890-luvulla kaupungissa asui eräitä muitakin henkilöitä, jotka tulivat pian vaikuttamaan keskeisesti suomalaisen yliopistomaantieteen kehitykseen.

Kaapon siirtyessä 1896 Oulun lyseon viidennelle luokalle kaupungin ruotsalaisen lyseon lehtorina aloitti J. E. Rosberg, josta tuli Aleksanterin Yliopiston ja Suomen ensimmäinen maantieteen varsinainen professori 1912. Samana vuonna suomalaisesta lyseosta valmistui ylioppilaaksi livari Gabriel Leiviskä, josta tuli Ragnar Hultin jälkeen maantieteen toinen dosentti ja myös toinen professori 1921. Granö oli puolestaan kolmas maantieteessä väitellyt, kolmas dosentti 1911 ja myös kolmas professori 1923.

Leiviskän ja Granön opettajana Oulun lyseossa toimi Antti Rietrikki Helaakoski, joka väitteli 1912 maantieteessä oppilaittensa jälkeen neljäntenä. Hänen Oulussa 1893 syntynyt, paremmin runoilijana tunnettu poikansa Aaro Hellaakoski oli pitkään maantieteen dosenttina Helsingin yliopistossa.

Helaakosken väitöstilaisuus iskostui niin voimakkaasti paikalla olleen Granön mieleen, että hän muisteli ystävänsä J. K. V. Tuomisen kanssa mielellään sen tapahtumia. Erityisesti heitä ilahdutti väittelijän tyyni arvokkuus. Kun arvovaltainen vastaväittelijä Wilhelm Ramsay tivasi Helaakoskelta, miksei hän ollut tutkinut sitä ja tätä ja tehnyt niin ja niin, ukko ei alkanut selitellä vaan vastasi vain yksikantaan, "Sen minä jätän nuoremmille" tai "Ja senkin minä jätän nuoremmille".45 


\section{Poikien valinnat}

J. G. Granö valmistui Oulun lyseosta hyvin arvosanoin ylioppilaaksi 9. kesäkuuta 1900. Päättötodistuksen kympit tulivat käytöksen ja ahkeruuden ja tarkkaavaisuuden lisäksi ruotsin kielestä sekä kasvi- ja eläinopista. Maantieteestä ja historiasta hän sai yhdeksikön kahdeksan muun oppiaineen tavoin. ${ }^{46}$

Johannes Granö toivoi, että poika olisi valinnut isänsä tien ja lukenut itsensä papiksi, mutta tämä ei ollut siihen valmis. Hän oli kyllä omaksunut isänsä edustaman hartaan uskonnollisuuden mutta ei katsonut soveltuvansa Jumalan sanan ammattilaiseksi. Hän halusi ryhtyä lukemaan luonnontieteitä, erityisesti kasvitiedettä. Pojan valinta oli isälle kova paikka, sillä hän oli tottunut saamaan perheessä tahtonsa läpi. Hän ei

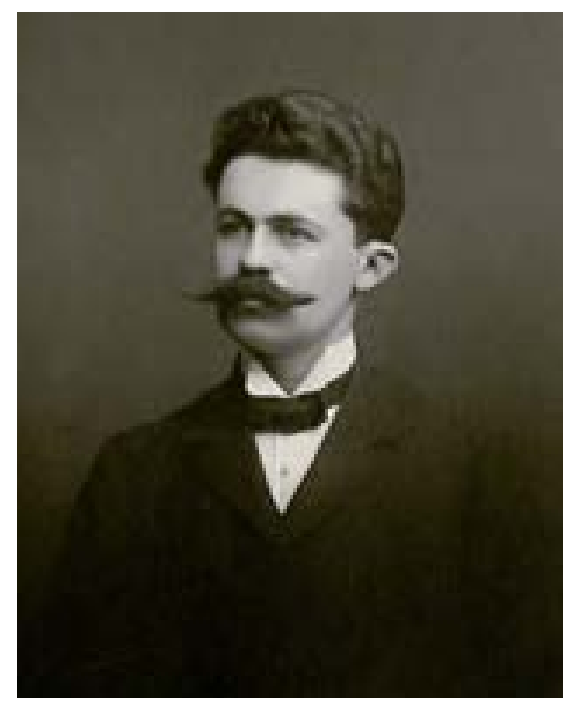

J. G. Granön henkilökuva 1900-luvun taitteessa. Valokuvaamo Ovesén Helsinki. tahtonut kuitenkaan asettua ehdottomaan vastarintaan. Asiaa oli harkittava huolella ja varmistuttava siitä, että poika tekee oikean ratkaisun ja saa yliopistossa parhaan mahdollisen opetuksen.

Johannes Granö oli vuoden 1900 valtiopäivillä tutustunut pappissäädyn edustajana historian professori E. G. Palméniin ja oppinut luottamaan tämän arvostelukykyyn. Siksi hän meni Palménin luokse puhumaan poikansa halusta luonnontieteiden opiskeluun tiedustellen samalla, kenen puoleen olisi sopivinta kääntyä. Tämä kehotti häntä kysymään neuvoa velipuoleltaan, eläintieteen professorilta ja tunnetulta lintututkijalta J. A. Palménilta, joka tunsi Suomen Maantieteellisen Seuran sihteerinä maan kaikki luonnontieteilijät. ${ }^{47}$

Johannes Granö seurasi neuvoa ja kääntyi J. A. Palménin puoleen. Tämä antoi selkeän vastauksen. Pojan toivomusta ei sopinut ryhtyä vastustamaan vaan hänen oli annettava suuntautua haluamalleen alalle. Palmén suositti, että poika opiskelisi aluksi useita luonnontieteitä, eläin- ja kasvitiedettä, geologiaa, fysiikkaa ja kemiaa, ja 
valitsisi vasta sitten, mihin aineeseen aikoi lopullisesti erikoistua. Opinnot olisi hyvä aloittaa hänen itsensä edustamasta eläintieteestä ja kasvitieteestä, jonka opettajaksi hän suositti ystäväänsä, kasvitieteen ylimääräistä professoria J. P. Norrlinia. ${ }^{48}$

\section{J. A. Palmén}

Eläintieteilijä J. A. Palmén syntyi Helsingissä 7.11 .1845 yhteen Suomen huomattavimmista kulttuurikodeista. Hänen isänsä oli lainopin professori Johan Philip Palmén, joka kohosi pian prokuraattoriksi ja senaatin oikeusosaston varapuheenjohtajaksi sekä yliopiston sijaiskansleriksi. Äiti Johanna Charlotta Bonsdorff kuului merkittävään Bonsdorffien yliopistosukuun.

J. A. Palmén kiinnostui jo nuorena luonnontieteistä. Hän pääsi 1864 yliopiston eläinmuseon ylimääräiseksi amanuenssiksi, ja kolme vuotta myöhemmin hän oli yksi neljästä nuoresta luonnontutkijasta, jotka Fauna et Flora -seura lähetti Lappiin keruu- ja havaintomatkalle. Luottamus nuoren miehen kykyihin näkyi myös muuten. Kun taiteilija Magnus von Wright kuoli 1868 ehtimättä saada Suomen linnustoa käsittelevän teoksensa toistaa osaa valmiiksi, käsikirjoitus annettiin Palménin viimeisteltäväksi. Teos valmistui huolellisen työn jälkeen 1873.

Palménin uraauurtava väitöskirja lintujen muuttoreiteistä valmistui 1874. Teos osoitti, että ainakin arktiset kahlaajat, hanhet ja sorsat noudattivat tiettyjä mutkikkaita muuttoreittejä, joiden kulku ei riippunut vain ilmastotekijöistä. Kaksi vuotta myöhemmin myös saksaksi ilmestynyt teos sivusi lajinmuodostusta, ja perehtyäkseen Darwinin teosten vaikutuksesta kukoistavaan vertailevaan anatomiaan Palmén opiskeli kuuluisan saksalaisen anatomin Carl Gegenbaurin laitoksessa Heidelbergissa 1875-76. 
Palmén nimitettiin eläintieteen ja vertailevan anatomian ylimääräiseksi professoriksi 1882, ja kaksi vuotta myöhemmin hän sai nimityksen eläintieteen professorin virkaan. Vuoteen 1908 kestäneen virkakauden aikana hän uudisti opetusta ottaen käyttöön muun muassa anatomiset leikkelyharjoitukset. Edistääkseen käytännön opetusta hän perusti 1902 omilla varoillaan tutkijoiden ja opiskelijoiden käyttöön Hankoniemen Tvärminneen biologisen tutkimusaseman, jonka hän testamentissaan lahjoitti Helsingin yliopistolle samoin kuin suuren osan omaisuudestaan.

Eläinmuseoon Palmén perusti erityisen arkiston, johon koottiin lintuhavaintoja kaikkialta maasta. Hän pani 1913 alulle lintujen rengastustoiminnan Suomessa ja toimi vuodesta 1892 Fauna et Flora -seuran puheenjohtajana. Hän oli myös luonnonsuojelutoiminnan uranuurtaja ja aloittaja Suomessa.

Vuonna 1887 Palmén julkaisi A. E. Nordenskiöldin Vega-retkikunnan lintutieteellisistä havainnoista ja kokoelmista tutkimuksen, joka käsittelee lintujen esiintymistä koko arktisella alueella ja erityisesti Siperian pohjoisrannikolla. Nordenskiöldin esimerkki innoitti Palménin kokoamaan suomalaisista tutkijoista retkikunnan, jonka Kuolan niemimaalle 1887 tekemä tutkimusretki poisti Euroopan kartalla viimeisen "valkoisen alueen".

Palmén oli isänmaallisena tutkijana omaksunut topeliaanisen näkemyksen, jonka mukaan Suomi voi merkittävillä kulttuuriansioilla saavuttaa tasavertaisen aseman maailman kansojen joukossa. Onnistuneen Kuolan-retken innoittamana hän perusti 1888 Suomen Maantieteellisen Seuran, jonka tavoitteena oli koota maan huomattavimmat tutkijat edistämään isänmaallista tutkimusta. Hän toimi seuran vaikutusvaltaisena sihteerinä lähes kuolemaansa saakka ja vaikutti huomattavasti siihen, että seura saattoi 1899 julkaista Suomen Kartaston.

Ihmisenä Palmén oli järjestelmällinen, avaramielinen ja ystävällinen. Hänellä oli aina aikaa seurusteluun ja keskusteluun ystäviensä kanssa. Hän suosi ja tuki myös itselleen vieraita aloja ja henkilöitä, jotka hän katsoi tuen arvoisiksi. Hän kuoli Forssassa 7.4.1919.49 


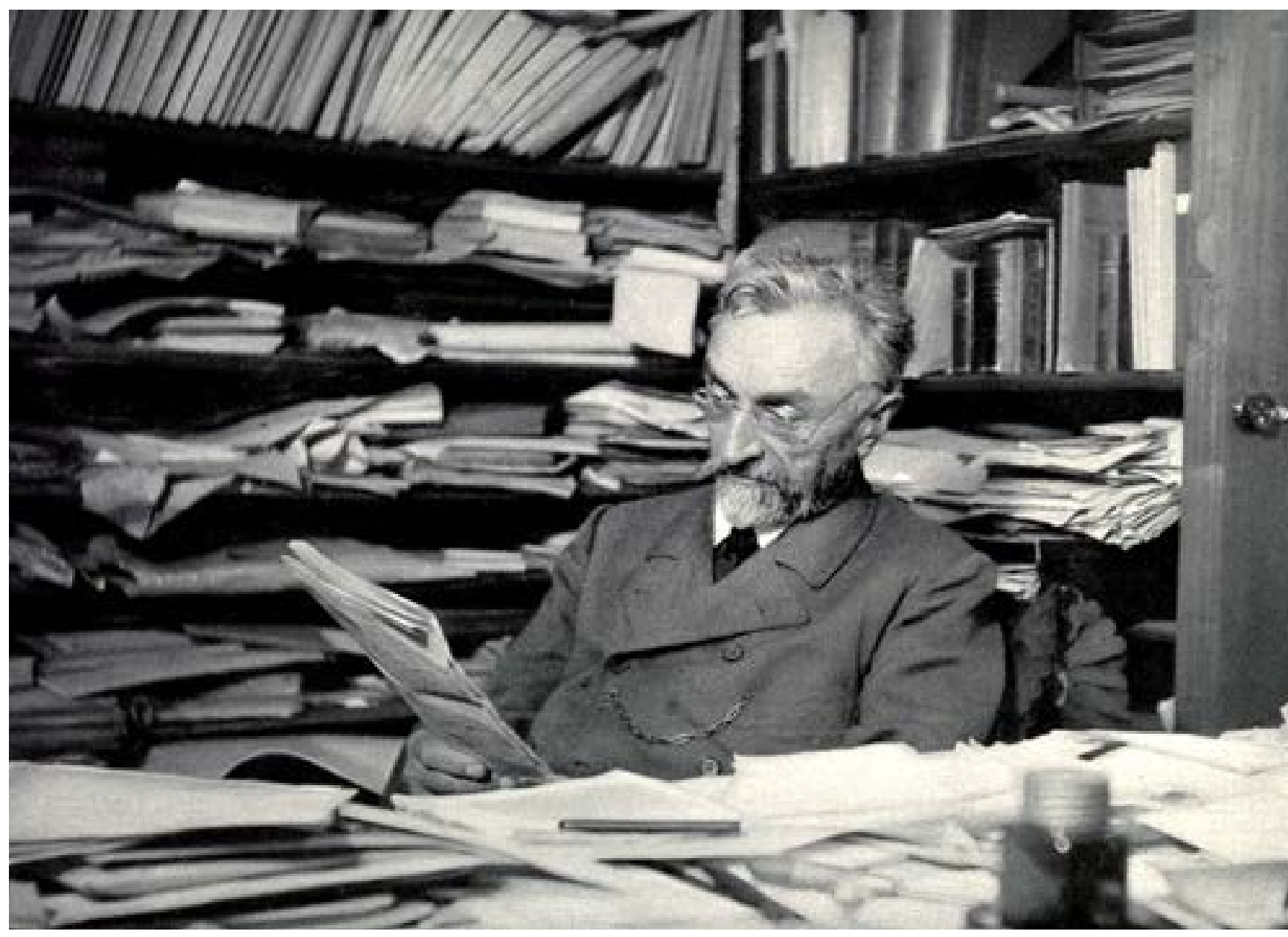

Professori Johan Axel Palmén.

Palménin kanta ratkaisi asian. Johannes Granön pettymystä esikoisen valintaan lievitti se, että kuopus Paavo oli selvästi suuntautumassa jatkamaan isän uraa. Vuonna 1902 ylioppilaaksi valmistunut Paavo Granö kirjoittautui lukemaan teologiaa Aleksanterin Yliopistoon ja vietti aina kesät Siperiassa isänsä apuna. ${ }^{50}$ 


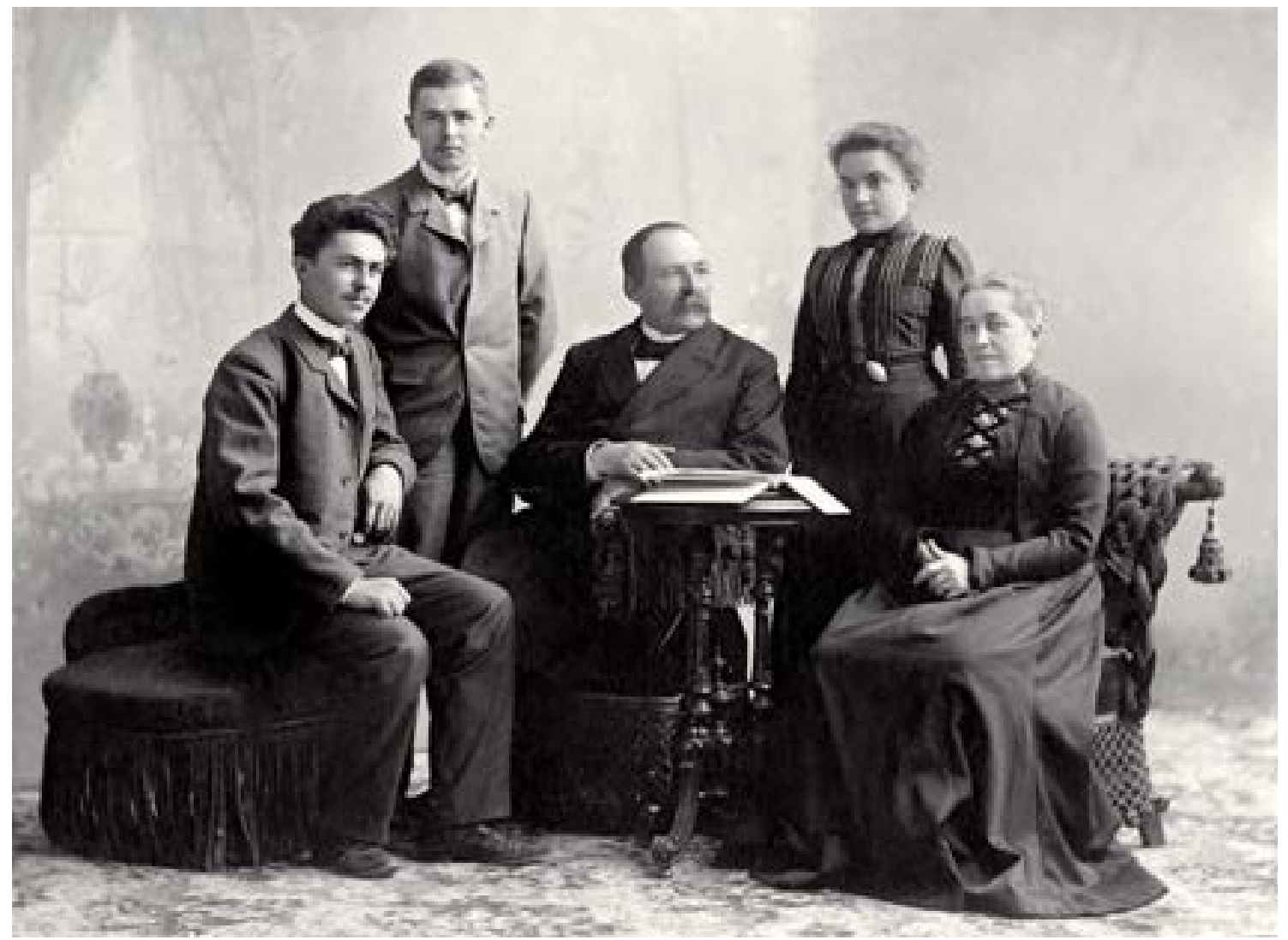

Vasemmalta Kaapo, Paavo, Johannes ja Alma Granö. Seisomassa perheen Omskissa kasvatiksi ottama saksalaissyntyinen orpotyttö Emilia Stenman. Kuva otettu Suomessa ennen Johanneksen ja Alman uutta muuttoa Siperiaan 1902.

\section{Paluu Siperiaan}

Poikien saatua ylioppilaslakkinsa Johannes Granö alkoi miettiä, mihin hän siirtyisi Alatorniolta. Pohjanmaa kutsui, mutta vielä enemmän häntä houkutti Omskin pappila. Siperiassa hän voisi toimia oikeiksi katsomiensa asioiden hyväksi vapaana lesta- 
diolaisuudesta ja evankelisen liikkeen suuntariidoista, jotka kahlitsivat hänen työtään Suomessa. Hän halusi hallita mieluummin itse kuin noudattaa muiden määräyksiä. Hän tahtoi luoda uusia toimintamuotoja ja määritellä miten päämääriin voitiin päästä. Kun Siperian suomalaiset vielä arvostivat vanhaa sielunpaimentaan, hän päätti hakea uudestaan entistä virkaansa. ${ }^{51}$

Johannes Granön työtä Siperiassa olivat jatkaneet ja laajentaneet muun muassa Sipoon kappalainen Petter Alfred Eriksson ja opettajat Pietari Toikka, Paavo Juntunen, Antti Kuismanen ja Ananias Lehto. Erikssonin terveys oli pettänyt 1890-luvulla, ja vuosikymmenen lopulla virkaa oli hoitanut useasti virolainen matkapastori N. Blumberg. Saatuaan virkavuotensa Siperiassa täyteen Eriksson muutti takaisin Suomeen, joten virka oli sopivasti vapaana.

Senaatin talousosasto nimitti Granön uudelleen Siperian suomalaisten papiksi vuoden 1902 alusta lähtien. Nimityksen jälkeen hän päätti jättää kotimaan asiat vähemmälle huomiolle ja keskittyä Siperian suomalaisten kaikinpuoliseen auttamiseen. Saavuttuaan Omskiin Granö oli kuin uudestisyntynyt. Päästyään eroon Alatorniolla kokemastaan musertavasta henkisestä paineesta hän tunsi itsensä vapaaksi. Hän tilitti syksyllä 1902 tuntojaan ystävälleen Josef Simeliukselle:

Kyllä minäkin hengitän täällä niin täydellä nautinnolla tuota puhdasta aro-ilmaa ja kun ajelee näitä laajoja aroja niin mieli vapautuu kaikista jokapäiväisistä murheista... Matkustamista minä levoton sielu rakastan ja olen saanut sitä tehdäkin tällä kuluneella puolella vuodella - eiköhän ole jo lähes 30000 virstaa kuljettu. ${ }^{52}$ 


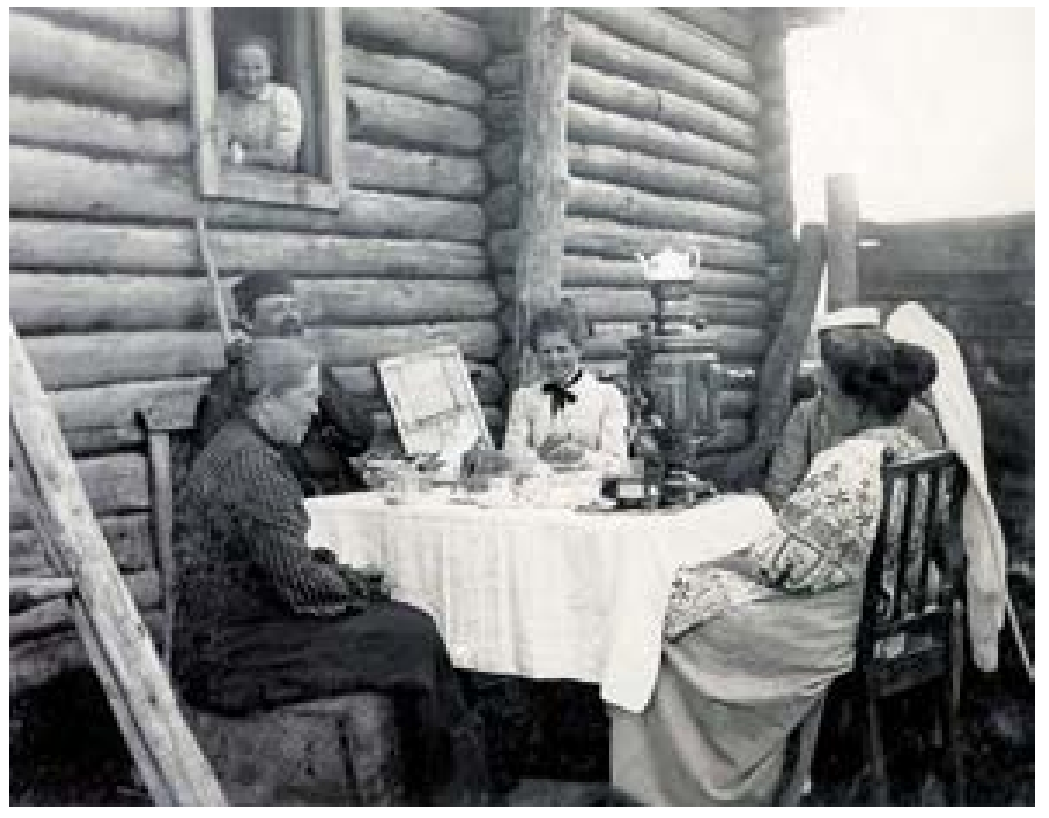

Aamuinen teehetki Suomesta muuttaneen Anna Aminoffin luona uudistilalla Bugenessa Länsi-Siperian aroalueella Omskin pohjoispuolella. Vasemmalta Alma ja Johannes Granö, Alman sisar Hanna Lignell, joka oli käymässä Omskissa, Anna Aminoff, sekä piilossa Annan takana kärpäshaavin vieressä, Paavo Granö. Ikkunassa on Annan Suomesta mukana tullut apulainen Greta.

Omskin kaupunki kasvoi ja vaurastui radan ansiosta 1900-luvun alussa nopeasti, kun viljan ja erityisesti voin hinnat kohosivat voimakkaasti. Myös sen henkinen elämä monipuolistui. Granön perheen kannalta oli tärkeää, että Omskin maantieteellinen seura alkoi juuri vuosisadan alussa muuttua sotilaiden hallitsemasta seurasta tieteelliseksi yhteisöksi, joka kokosi riveihinsä kaikkia maantieteellisistä asioista kiinnostuneita. Seura veti puoleensa vähitellen niin isä kuin poika Granön, jonka nimi sai jo varhain venäläisen muodon Gavriil Ivanovitš Grane. ${ }^{53}$

Omskin kasvu heijastui myös suomalaissiirtoloihin. Erityisen suotuisasti kehittyi Om-siirtola, jonka lähelle oli noussut yksi Siperian radan asemista, Kolonia. Yleistyvien hevosvetoisten niitto- ja haravakoneiden lisäksi taloihin alkoi tulla käsiseparaattoreita Amerikan ja Suomen tapaan. Vaikka Venäjän Japania vastaan 1904-05 käydyn tappiollisen sodan synnyttämä levottomuus heijastui Länsi-Siperiaan asti, karkotetuille perustetut kylät alkoivat vähitellen muistuttaa tavallisia siperialaisia kyliä. ${ }^{54}$ 


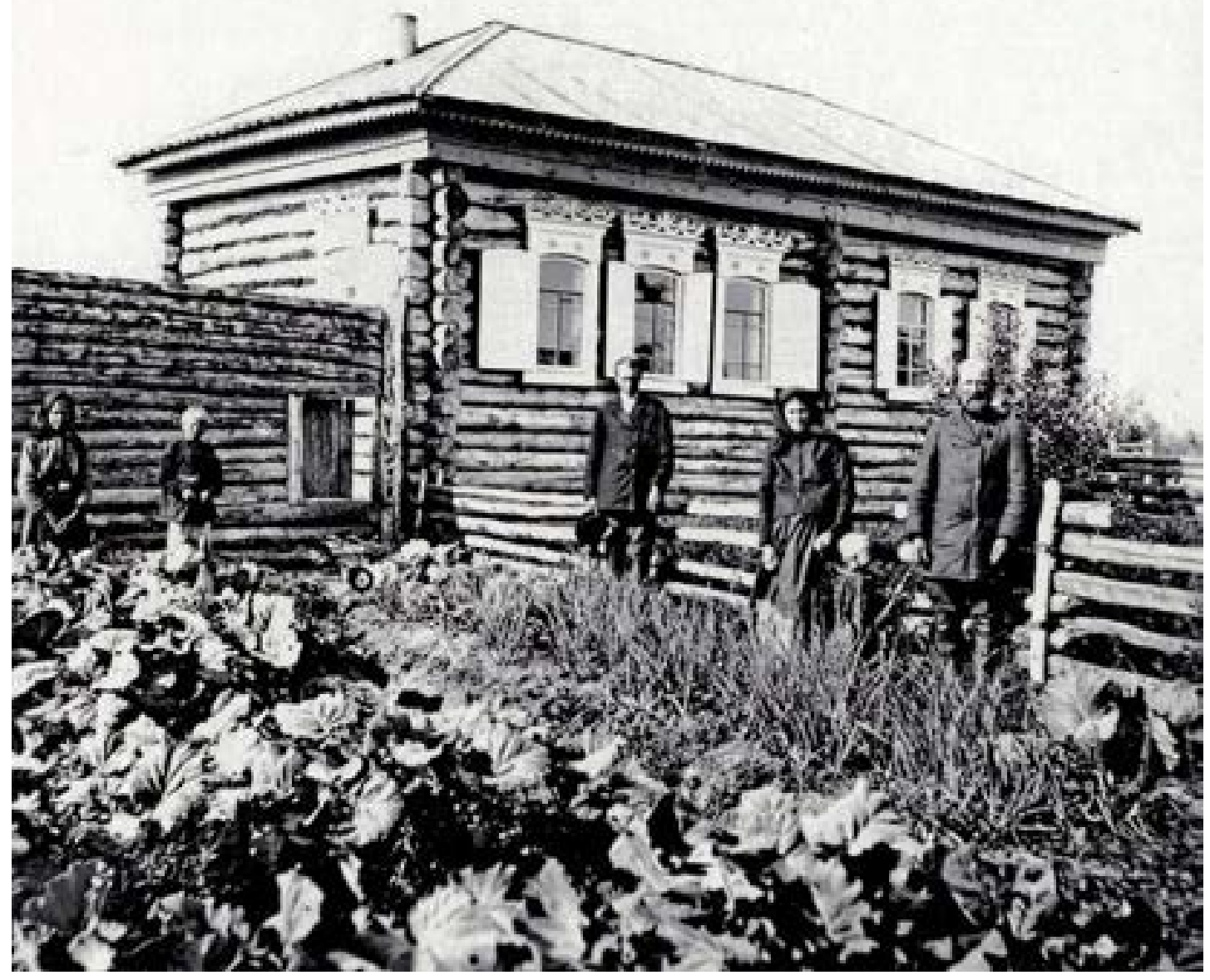

Granön perheen läheisen ystävän "Härmän miehen" Matti Unkurin talo Bugenen siirtolassa. Oikealla Unkuri emäntineen.

Johannes Granö perusti aluksi pappilansa vuokrataloon, jonka kunto ei tyydyttänyt häntä. Vuonna 1905 hän onnistui ostamaan kaupungissa vaikuttaneen virolaisen rakennusurakoitsija Valsin välityksellä Varlamovoskaja-kadun varrelta sembramäntyisen rakennuksen, johon kuului laaja tontti. Hän jakoi vanhan linjansa mukaisesti seurakuntatyönsä kolmeen päälohkoon: kansanvalistukseen, raittiustyöhön ja 


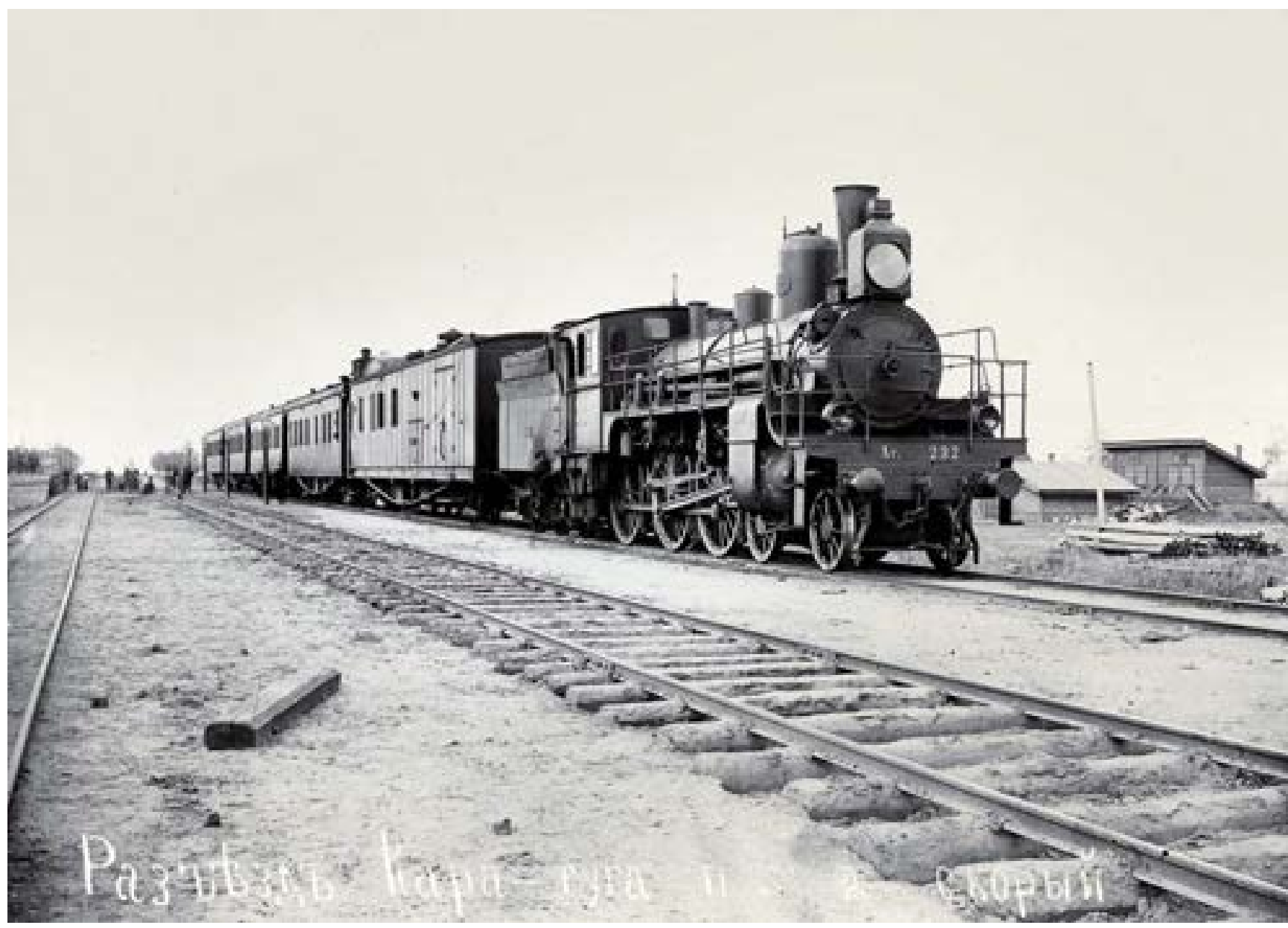

Siperian rataa liikennöineen pikajunan Kara-Tug nro 232:n lähtö Kolonian asemalta.

diakoniaan. Enää ei tarvittu yhtä ankaraa kuria kuin ensimmäisellä kaudella, sillä karkotetuista useimmat olivat jo kuolleet ja elossa olevatkin olivat jo pääosin iäkkäitä. Vuonna 1905 siirtoloissa asui 1354 suomalaista, joista vain 192 oli Siperiaan lähetettyjä ja vankeutensa jälkeen vapautettuja. Muut olivat vapaaehtoisia siirtolaisia tai Siperiassa syntyneitä. 55 


\section{Eetu Isto}

Granöt tutustuivat kesällä 1901 Alatorniolla taidemaalari Eetu Istoon. Suomalaisten Venäjän yhtenäistämispolitiikkaa vastaan kohdistaman vastarinnan symboliksi 1899 nousseen Hyökkäys-taulun maalannut Isto joutui rahapulassaan palaamaan takaisin kotiseudulleen Alatorniolle, kun venäläiset olivat pyrkineet takavarikoimaan taulun ja siitä tehdyt kopiot ja jäljennykset.

Kirkkoherra Johannes Granö kutsui Iston vieraakseen pappilaan, jossa Hyökkäys asetettiin aesille. Kun santarmit olivat saaneet tietää taulusta ja olivat tulossa takavarikoimaan sen, Kaapo ja hänen veljensä veivät taulun yöllä Tornionjoen yli turvaan Haaparantaan. Siellä se asetettiin näytteille luokkahuoneen peräseinälle, ja Suomesta soudettiin varta vasten katsomaan taulua.

Iston talouden turvaamiseksi Hyökkäys myytiin lopulta erikoisin järjestelyin 1900-luvun alussa. Siitä sai ostaa 300 kappaletta 20 markan osakkeita, joiden kesken taulu arvottiin. Työ oli pitkään liikemies Otto Nordbergin hallussa Ruotsissa, kunnes se siirtyi heinolalaisen liikemiehen Niilo Helanderin omistukseen. Helanderin leski lahjoitti sen lopulta Suomen Kansallismuseoon, jota voikin pitää oikeana paikkana Suomen tunnetuimmalle poliittiselle maalaukselle.

Dramaattisen ensikosketuksen jälkeen Eetu Istosta tuli Granön perheen läheinen ystävä. Hänen Alatorniolla maalaamiensa muotokuvien joukossa on muun muassa kaksi suurikokoista taulua Johannes Granöstä. Toinen on Aineen museossa Torniossa, toinen lahjoitettiin Alatornion vanhaan pappilaan sen tultua restauroiduksi.

Lähtiessään keväällä 1902 Siperiaan Johannes Granö kutsui Iston vierailemaan Iuonaan Omskissa. Salomo Wuorion maalausliikkeessä koristemaalarina toiminut Isto ei heti vastannut kutsuun myönteisesti, sillä niukat taloudelliset olot ja keuhkotautiin sairastuminen masensivat häntä. Saatuaan mesenaatiltaan E. W. Ponkalalta lupauksen omasta ateljeesta Katajanokalla hän päätti lopulta keväällä 1905 lähteä 
Granön poikien kanssa Siperiaan. Lähtöön kannusti usko siihen, että ilmanalan muutos saattaisi vaikuttaa myönteisesti hänen terveyteensä.

Miesten junamatka Venäjän halki oli jännittävä, sillä vaunuosastossa oli vallankumouksellisia venäläisiä ylioppilaita, joilla oli pienikokoisia jäljennöksiä Iston Hyökkäystaulusta. Suomalaiset päättivät kuitenkin santarmien pelossa pitää matalaa profilia, joten he eivät paljastaneet, että maalauksen tekijä oli junan kyydissä.

Isto asui Siperiassa Johannes Granön pappilassa Omskissa ja tämän maatilalla Omjoen varrella ja osallistui myös syksyllä 1905 tämän poikiensa kanssa tekemälle pitkälle Altai-vuoristoon ulottuneelle virkamatkalle. Hän maalasi Siperiassa kaupunkija maisemanäkymiä innostaen myös Paavo

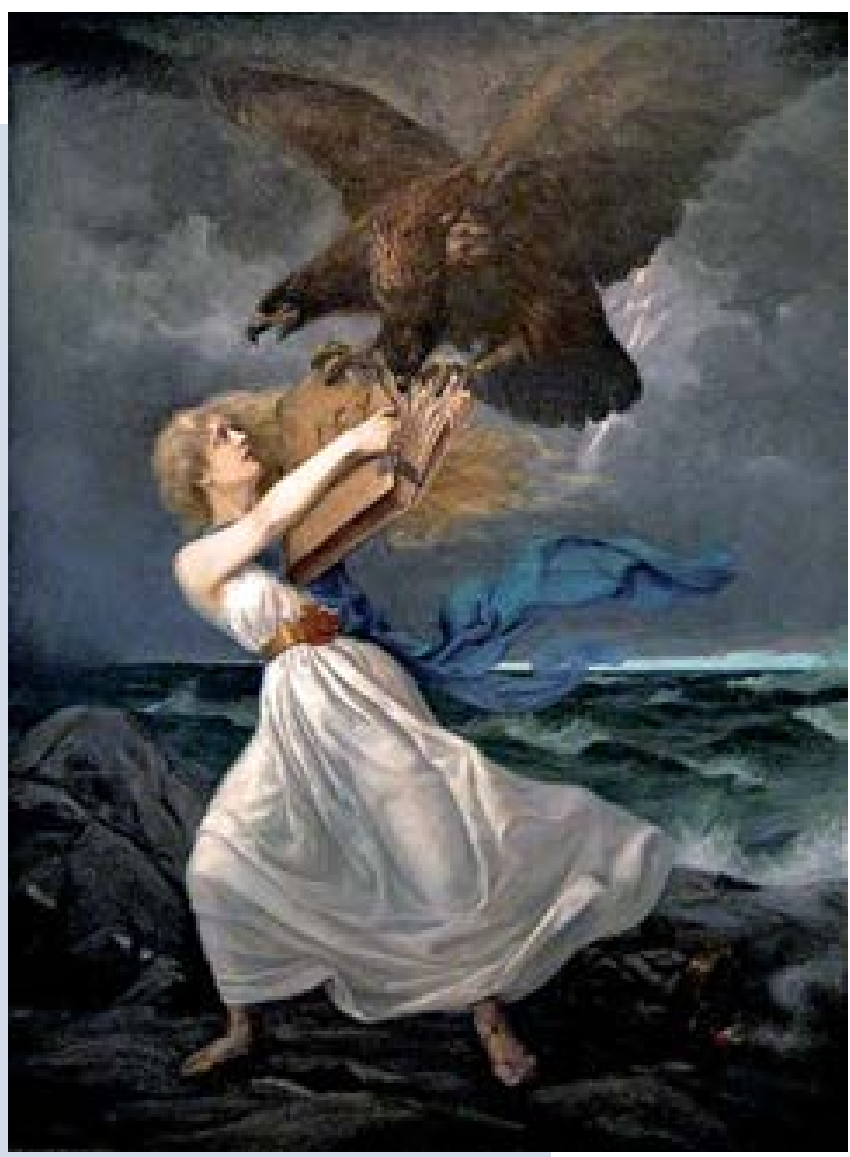
Granötä hänen maalausharrastuksessaan.

Hyökkäys.

Siperian-matka ei parantanut Iston terveyttä toivotulla tavalla. Hänen vointinsa tosin koheni aluksi, mutta huononi sitten nopeasti, kun hän sairastui Omskin alueella puhjenneeseen lavantautiepidemiaan. Palattuaan Suomeen Isto kuoli lokakuussa 1905 lavantaudin jälkitautina saamaansa keuhkokuumeeseen Granön perheen suureksi järkytykseksi. ${ }^{56}$ 


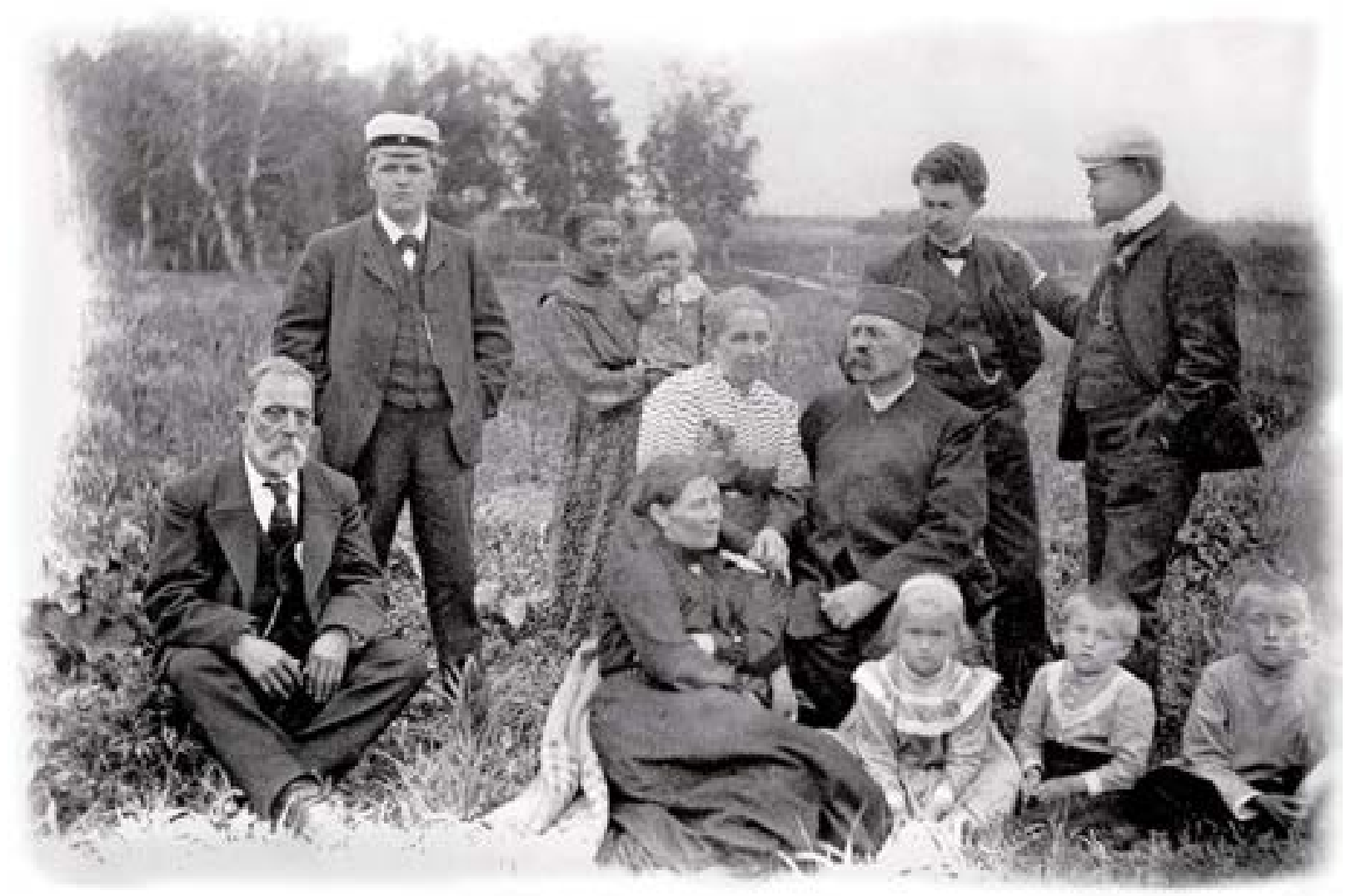

Suomalaisia arolla $0 \mathrm{~m}$-siirtolassa. Keskellä istumassa äiti Alma ja isä Johannes, takana seisomassa veli Paavo, opettaja Wilhelm Juntusen vaimo nuorimpansa kanssa, Kaapo ja silloin kesäänsä Siperiassa viettänyt taiteilija Eetu Isto, edessä istumassa Granön perheen ystävä Alexander E. Plathan, Kakolasta siirretty elinkautisvanki, joka toimi Omskissa kirjansitojana, diakonissa Elisabet Fontell ja opettaja Juntusen lapsia. 
Uuden kasvavan väestön koulutukseen ja suomalaisuuden vaalimiseen oli Johannes Granön mielestä kiinnitettävä erityisesti huomiota siksi, että lapset olivat vain osittain suomalaisten karkotettujen jälkeläisiä. Paitsi keskenään karkotetut olivat menneet naimisiin inkeriläisten ja virolaisten, toisinaan myös saksalaisten ja venäläisten kanssa. Lisäksi Siperiassa syntyneet olivat eri asemassa kuin karkotetut, sillä heillä oli täydet kansalaisoikeudet. Kun toiminta olisi vaatinut pitkäaikaisia ja kestäviä järjestelyjä, Granö ehdotti Länsi-Siperian suomalaisten opettajien virkojen vakinaistamista. Työtä oli kuitenkin jatkettava kolmi- tai viisivuotiskausittain myönnettyjen avustusten varassa. ${ }^{57}$ 


\section{OMAn tien alku}

\section{Vaikea valinta}

Opiskelujen aloittaminen merkitsi huomattavaa käännettä J. G. Granön elämässä. Enää hän ei voinut turvautua joka asiassa isäänsä vaan joutui tekemään itsenäisiä ratkaisuja. Lisäksi isän rinnalle nousi toinen auktoriteetti, J. A. Palmén, jota hän kunnioitti suuresti sekä tiedemiehenä että akateemisena opettajana.

Granö kirjoittautui Keisarilliseen Aleksanterin-Yliopistoon kesäkuun 11. päivänä 1900. Seuraavana syksynä käynnistyneiden yliopisto-opintojen alku tuotti hänelle raskaan pettymyksen. Palménin luennoista hän piti, mutta kasvitieteen opetus ei vastannut lainkaan hänen odotuksiaan. J. P. Norrlinin pyöreän pöydän ääressä pitämät yksitoikkoisen kuivat, tiukasti asiaan keskittyneet luennot tukahduttivat kokonaan vasta-alkajan mielenkiinnon botaniikkaan tieteenä. Tämän vuoksi Granön Hieracium-suvun taksonomiaa, Norrlinin silloista kiinnostuksen kohdetta, koskenut tutkielma ei edennyt alkua pitemmälle..$^{58}$

Botaniikan opinnot jäivät ensimmäisen lukuvuoden episodiksi, eikä Granö suorittanut siitä minkäänlaista arvosanaa kandidaatintutkintoa varten. Into kasvien keräämiseen ja kasvitieteen harrastamiseen kuitenkin säilyi, mikä näkyi siinä, että hän kykeni Siperian-matkoillaan kuvaamaan kasvillisuutta taitavasti. Esimerkiksi Terrassa 1931 julkaisemassaan tutkimuksessa Altain kasvillisuus hän antoi erinomaisen kuvan paikallisten kasvillisuusalueiden rakentumisesta sekä horisontaalisesti että vertikaalisesti täydentäen näin L. S. Bergin tutkimuksia Venäjän kasvillisuusvyöhykkeistä. ${ }^{59}$

Granö jatkoi Palménin ohjeiden mukaisesti eläintieteen, kemian, fysiikan ja geologian opiskelua, mutta syksyllä 1901 hänen opintonsa saivat uuden suunnan, kun 


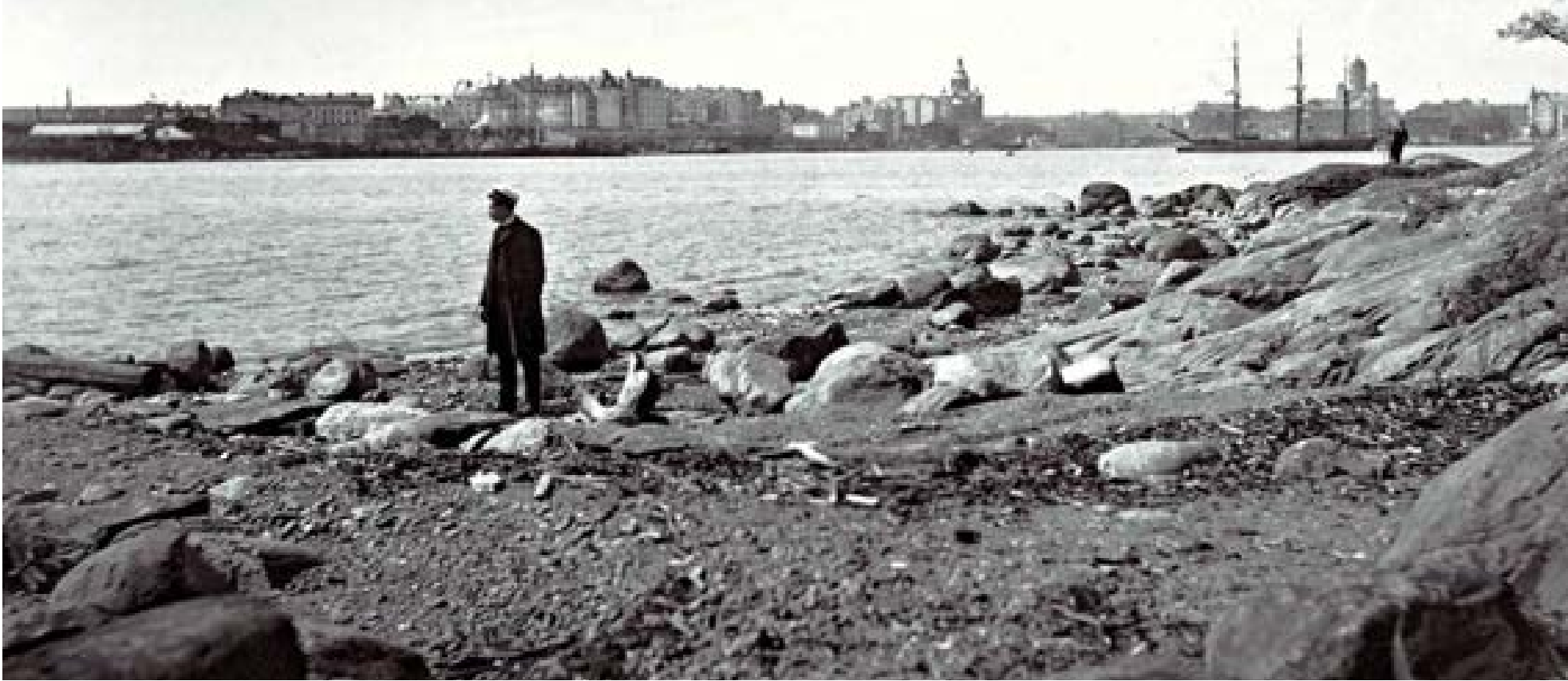

J. G. Granö Helsingissä 1900-luvun alussa.

hän meni kuuntelemaan vastikään maantieteen ylimääräiseksi professoriksi valitun J. E. Rosbergin luentoja. Rosberg oli juuri palannut Keski-Eurooppaan tekemältään opintomatkalta, joten hän saattoi välittää kuulijoilleen innostavia tietoja maantieteen kuumimmasta kiistasta, joka koski vuoristojen muotojen syntyä. Vastakkain olivat Albrecht Penckin ja Eduard Brücknerin Alpeilla kehittämä jääkausiteoria ja W. M. Davisin Appalakeilla Yhdysvalloissa luoma eroosiosyklioppi. ${ }^{60}$ 


\section{J. E. Rosberg}

Suomen ensimmäinen maantieteen professori Johan Evert Rosberg syntyi 18.6.1864 Kirkkonummella apteekkari, tilanomistaja Victor Rosbergin ja hänen puolisonsa Eva Charlotta Rosbergin (o. s. Bruncronan) perheeseen. Tultuaan filosofian kandidaatiksi 1886 Rosberg suuntautui koulualalle toimien opettajana Kuopion yksityislyseossa, Haminan kadettikoulussa ja Oulun ruotsalaisessa reaalilyseossa.

Koulutyön ohessa Rosberg jatkoi yliopistollisia opintojaan Keisarillisen Aleksanterin-Yliopiston maantieteen laitoksen perustajan Ragnar Hultin johdolla erikoistuen geomorfologiaan. Julkaistuaan 1895 väitöskirjansa Bottenvikens finska deltan hänestä tuli seuraavan vuoden alussa ensimmäinen suomalainen, joka suoritti filosofian tohtorin tutkinnon maantiede pääaineenaan.

Kun Hult lähti keväällä 1898 ulkomaiselle tutkimusmatkalle ja kuoli seuraavan vuoden lopulla, maantieteen tulevaisuus jäi laitoksen määräaikaiseksi esimieheksi valitun Rosbergin varaan. Rosberg jakoi Hultin käsityksen maantieteen itsenäisestä olemuksesta ja kehotti vuoden 1900 alussa yliopistoa ryhtymään toimeen alan opetuksen vakinaistamiseksi. Hän matkusti itse yliopiston myöntämän stipendin turvin Keski-Eurooppaan täydentämään opintojaan. Matkan aikana hän tutustui muun muassa alan johtaviin tutkijoihin Albrecht Penckiin ja Eduard Brückneriin, joilta hän sai runsaasti uusia ajatuksia sekä geomorfologian tutkimisesta että maantieteestä yliopistoaineena.

Rosbergin esittämän selonteon pohjalta yliopistoon perustettiin 1901 maantieteen ylimääräisen professorin virka, jonka ensimmäiseksi hoitajaksi hänet nimitettiin 1902. Vuonna 1912 Rosbergista tuli maantieteen varsinaisen professuurin ensimmäinen haltija, ja hän hoiti virkaa vuoteen 1929 saakka. Maantieteen vaki- 
naistumiseen yliopistoaineena vaikutti pyrkimys turvata maantieteen opettajien koulutus. Tätä tehtävää Rosberg toteutti erinomaisesti. Hän oli innostava ja kannustava opettaja, joka uudisti monipuolisesti tieteenalan opetusta.

Rosbergin aikana maantieteestä tuli suosittu oppiaine. Opiskelijoita tuli runsaasti myös historiallis-filologisesta osastosta, jonka opiskelijoiden tuli ottaa tutkintoonsa jokin oppiaine fyysis-matemaattisesta osastosta. Aiemmin tällaiseksi aineeksi oli yleensä valittu kasvitiede, mutta kun lempeän Sextus Otto Lindbergin tilalle professoriksi tuli ankara tentaattori Fredrik Elfving, lähes kaikki opiskelijat siirtyivät suorittamaan approbatur-oppimäärää maantieteessä.

Rosberg teki tärkeimmät tieteelliset työnsä geomorfologiassa, varsinkin rannikkomuotojen ja Itä-Karjalan päätemoreenimuodostumien tutkimuksessa mutta harjoitti myös alue- ja ihmismaantieteen, liikennemaantieteen sekä Lapin ja

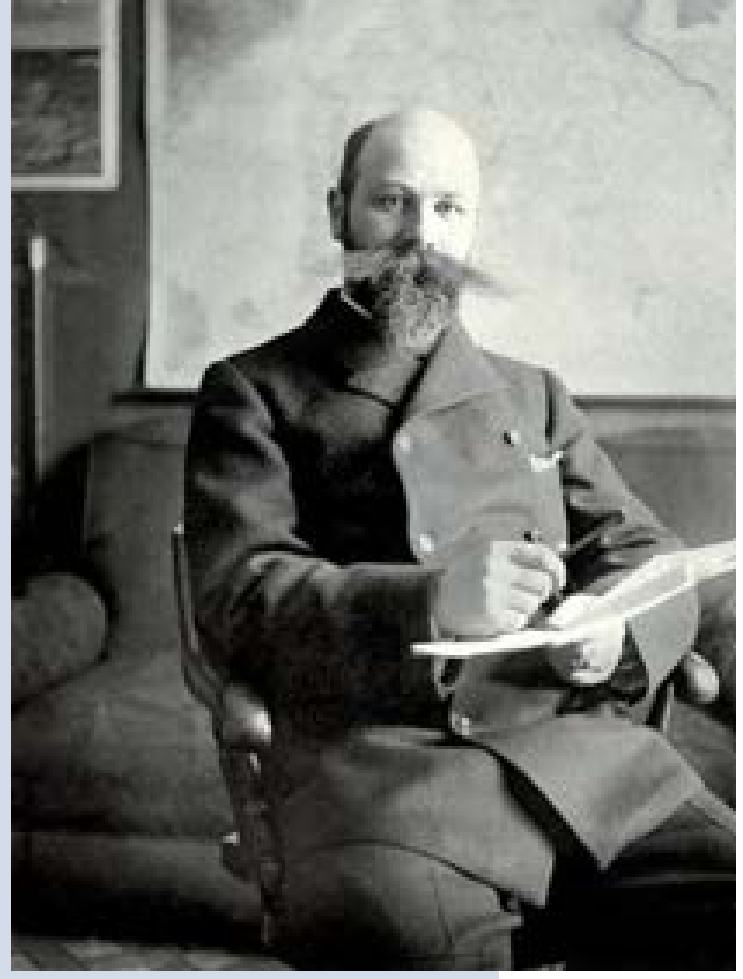

Professori J. E. Rosberg työhuoneessaan Aleksanterin Yliopiston maantieteen laitoksella 1912. saariston tutkimusta. Lapin oloihin hän tutustui monipuolisesti 1914-17 toimiessaan Ruotsin-Norjan poronlaidunkomission jäsenenä. Hän kuvasi Lappia paitsi useissa teoksissa ja artikkeleissa myös taitavasti ottamissaan valokuvissa. Sama monipuolisuus tuli näkyviin opetuksessa. Hän julkaisi karttoja ja oppikirjoja, joita käytettiin niin yliopistoissa kuin kouluissakin, ja hänen johdollaan järjestettiin 1912 Helsingissä ja 1919 Turussa ensimmäiset maantieteilijäpäivät, joiden tarkoitus oli antaa maantieteen opettajille uusia näkemyksiä. 
Yliopistollisen opetustoiminnan ohella Rosberg pyrki määrätietoisesti levittämään yleistä harrastusta maantieteeseen, matkailuun ja kotiseuduntutkimukseen. Hänen elävästi kirjoittamansa teokset tavoittivat suuren lukijakunnan ja lisäsivät tietoa niin kotimaan kuin ulkomaidenkin oloista. Laajasta tuotannosta mainittakoon Sääksmäen (1899) ja kotipitäjän Kirkkonummen (1901, Uno A. Fleegen kanssa) pitäjänkuvaukset, Maat ja kansat I-II (ruots. 1906, suom. 1908, uusi painos ruots. 1926, suom. 1931), Suomen maantiede maakuntakuvauksittain (1911, myös ruots.), Petsamon maa (1919) ja Autolla Suomesta Välimerenmaihin (1926). Rosberg oli myös sekä kotimaan tuntemuksen kannalta tärkeän Suomenmaan (1919-31) että Maapallon (1923-30) päätoimittaja.

Rosberg edisti päämääriään myös seura- ja järjestötoiminnan avulla. Hän toimi pitkään Suomen Maantieteellisen Yhdistyksen puheenjohtajana, Kotiseutututkimuksen keskusvaliokunnan puheenjohtajana ja Suomen Matkailijayhdistyksen varapuheenjohtajana. Maanpuolustuksen kannattajana hän työskenteli innokkaasti suojeluskunta-aatteen puolesta.

Muhkeat viikset kasvattanut J. E. Rosberg nautti elämänmyönteisyytensä ja ihmisläheisyytensä ansiosta suurta arvostusta sekä suomalaisissa että ulkomaisissa maantieteilijäpiireissä. Professorin kuoltua 20.3.1932 J. G. Granö sai kunniatehtävän jättää hänestä muisto jälkipolville:

Maantieteilijäpersoonallisuutena Rosberg näin ollen oli monivivahteinen ja tämän vuoksi viehättävä. Hänellä tosin harvoin riitti aikaa tieteellisten probleemain perinpohjaiseen ja tyhjentävään käsittelyyn, määrätietoisuus, järjestelmällisyys ja täsmällisyys eivät olleet hänen vahvimpia puoliaan, mutta hän eli elämäänsä suunnitelmien ja alotteiden kiihottavassa ilmapiirissä ja sen vuoksi nuoriso ihastuneena kerääntyi hänen ympärilleen. ${ }^{61}$ 
Davisin mukaan pinnanmuotojen kehitys noudatti säännönmukaista kiertokulkua, joka johti aina loivapiirteisen puolitasangon, peneplaanin, syntyyn, ennen kuin maanpinta alkoi uudelleen kohota ja uusi kehityssykli käynnistyi. Uusi näkemys saavutti nopeasti suuren suosion, sillä se sisälsi monia sellaisia elementtejä, jotka auttoivat sen hyväksymistä. Se oli esitettävissä selkeän pedagogisesti, siinä oli hyvä iskusana, peneplaani, se oli aktualistinen, evoluutio-opin mukainen ja positivistinen ja sen takana olivat vahvat tieteelliset voimat. Lisäksi se sopi hyvin ajan oppihistorialliseen tilanteeseen, jossa maantiede pyrki nousemaan perinteisten yliopistoaineiden rinnalle. ${ }^{62}$

Palattuaan matkaltaan Rosberg uudisti perinpohjaisesti maantieteen opetuksen, joka tuli nyt koostumaan luentojen ohella kartanpiirustustöistä, kenttämittauksista, seminaariharjoituksista ja kesäisistä retkeilyistä. Maantieteen laitos sijaitsi tuolloin Helsingin keskustassa Fabianinkatu 22:ssa, yksikerroksisessa puisessa Hällströmin talossa, samassa paikassa, jonne 1950-luvulla rakennettiin "Porthania".

Rosbergin eläytyvät luennot, hienotunteinen henkilökohtainen ohjaus ja aktiivinen kirjallinen toiminta innostivat J. G. Granötä niin paljon, että hän tunsi löytäneensä oman tieteenalansa. Jo syksyllä 1901 hän julkaisi opettajansa kehotuksesta Maantieteellisen Yhdistyksen julkaisusarjassa ensimmäisen yleistajuisen tieteellisen artikkelinsa. Sen aiheena oli Uuden-Guinean eksoottinen jättiläissaari, josta hän oli pitänyt seminaariesitelmänsä. ${ }^{63}$

Granön ratkaisun teki ongelmalliseksi se, että hänen alkuperäinen tieteellinen oppi-isänsä J. A. Palmén ei antanut Rosbergin edustamalle maantieteelle juuri minkäänlaista arvoa. Erimielisyyden taustalla oli Suomen johtavien luonnontieteilijöiden erimielisyys maantieteen olemuksesta.

\section{Maantieteen vaikea itsenäistymiskehitys}

Suomessa maantieteen asema oli 1880-luvulle saakka samanlainen kuin useimmissa muissa Euroopan maissa Saksan ulkopuolella. Vaikka Elias Lönnrot oli luonut sanan maantiede jo 1848, maantiedettä pidettiin yleisesti vain historian aputieteenä ja 
yleishyödyllisenä kouluaineena. Maantieteen kansallinen merkitys tiedostettiin kuitenkin hyvin, ja varsinkin H. G. Porthanin perinteen jatkajan Zacharias Topeliuksen kirjallinen toiminta ja yliopistoluennot olivat lisänneet kiinnostusta oman maan tuntemusta kohtaan. ${ }^{64}$

Maantieteen nousulle loi pohjaa J. P. Norrlinin käynnistämä kasvimaantieteellinen tutkimussuunta, joka saksalaisen luonnontieteilijän ja maantieteilijän Alexander von Humboldtin tapaan selvitteli kasvupaikan ja kasvillisuuden yhteyksiä. Norrlinin oppilaisiin lukeutui Ragnar Hult, joka julkaistuaan 1881 kasvitieteellisen väitöskirjan suuntautui maantieteeseen. Vuosina 1882-85 hän teki opinto- ja tutkimusmatkoja Tanskaan ja useisiin Keski-Euroopan maihin ja perehtyi johtavien tutkijoiden ja maantieteen laitosten toimintaan. Erityisesti hän arvosti geomorfologian kehittäjää Ferdinand von Richthofenia.

Hultin tekemä aloite maantieteellisen seuran perustamiseksi Suomeen kaatui 1887 erimielisyyksiin seuran tavoitteista. Seuraavana vuonna välirikko vakiintui pysyväksi kahtiajaoksi, kun maahan perustettiin kaksi maantieteellistä seuraa. Hultin johtama Suomen Maantieteellinen Yhdistys piti maantiedettä itsenäisenä oppiaineena ja pyrki mahdollisimman laajan jäsenpohjan avulla edistämään alan tutkimusta, harrastusta ja opetusta. J. A. Palménin johtaman Suomen Maantieteellisen Seuran mielestä Suomen maantiede tuli puolestaan parhaiten selvitetyksi siten, että maan luontoa ja kansaa tutkivien tieteiden huippuedustajat yliopistossa ja tutkimuslaitoksissa liittyivät samaan seuraan. Seuran päämääränä oli korostaa Suomen kansallista identiteettiä edistämällä maata ja sen lähialueita koskevaa tieteellistä tutkimusta. ${ }^{65}$

Suomen Maantieteellinen Seura saavutti nopeasti arvostetun aseman tiedeyhteisössä, ja myös Suomen senaatti tuki sitä rahoittamalla sen julkaisutoimintaa. Se ylti useisiin tieteellisiin ja isänmaallisiin saavutuksiin, joiden huipentumaksi kohosi 1899 ilmestynyt Suomen Kartasto, maailman ensimmäinen kansalliskartasto. Kartaston ilmestymisen taustalla oli tieteellisten tavoitteiden ohella halu korostaa Suomen valtiollista asemaa venäläistämispyrkimyksiä vastaan. Kartasto julkaistiin suomen, ruotsin ja ranskan kielellä, ja se palkittiin Pariisin maailmannäyttelyssä 1900. 
Suomen Maantieteellisen Seuran mielestä maantiede ei ollut itsenäinen tiede vaan näkökulma, tieteiden yhtymä. Maantieteeseen erillisenä oppiaineena seuran perustajajäsenet suhtautuivat yleensä kielteisesti ja vastustivat siksi Hultin pyrkimyksiä maantieteen aseman vakiinnuttamiseksi yliopistossa. Hult nimitettiin tammikuussa 1890 maantieteen dosentiksi fyysis-matemaattiseen osastoon, ja 1893 maantieteen laitos tunnustettiin virallisesti yliopiston laitokseksi. Koska Suomessa maantiede sijoitettiin luonnontieteiden yhteyteen fyysis-matemaattiseen osastoon, maantieteen yhteydet historiaan ja ihmisen käyttäytymistä koskeviin tieteisiin katkesivat suurelta osin päinvastoin kuin useissa muissa maissa. ${ }^{66}$

Vähitellen maantiede alkoi päästä yliopistollisissa tutkinnoissa tasa-arvoiseen asemaan muiden tieteiden kanssa: Syksyllä 1892 fyysis-matemaattinen osasto hyväksyi maantieteen filosofian kandidaatin tutkintoaineeksi, ja 1897 vastaavan oikeuden saivat myös historiallis-filologiseen osastoon kuuluvat opiskelijat. Osittaisesta menestyksestä huolimatta maantieteen opetus oli edelleen tilapäisten nimitysten varassa. ${ }^{67}$

Hult ei onnistunut vakiinnuttamaan maantieteen asemaa ennen kuin hän kuoli 1899, jolloin hänen oppilaansa J. E. Rosberg ryhtyi jatkamaan työtä. Rosbergin ollessa Keski-Euroopassa täydentämässä opintojaan maantieteen asemaan puuttui yksi Suomen Maantieteellisen Seuran johtohenkilöistä, kasvitieteen ylimääräinen professori A. O. Kihlman (Kairamo). Hän vaati Valvojassa julkaisemassaan artikkelissa maantieteen poistamista kokonaan tutkintovaatimuksista. Maantieteen opetus olisi tullut ratkaista siten, että yliopistoon perustettaisiin maantieteellinen seminaari, jonka johtoon otettaisiin jossakin maantieteen pääaloista tutkimustyötä harjoittanut tiedemies. ${ }^{68}$

Kihlmanin kirjoitus hermostutti Rosbergia niin paljon, että hän lähetti keväällä 1900 fyysis-matemaattiselle osastolle kirjeen, jossa hän selvitteli käsityksiään maantieteen olemuksesta ja sen opetuksen järjestämisestä. Hän katsoi, että maantieteen yliopisto-opetuksen tulisi rajoittua klimatologiaan, yleiseen hydrologiaan, geologiseen maantieteeseen ja eliömaantieteeseen. Tämän yleisen maantieteen lisäksi tulisi opettaa myös erikoismaantiedettä eli tiettyyn rajattuun alueeseen kohdistuvaa tutkimusta, jossa erityisesti ihmismaantiede olisi keskeisellä sijalla. ${ }^{69}$ 
Koska näin toteutetun rajauksen avulla voitaisiin parhaiten taata tulevien maantieteen opettajien pätevyys, Rosberg ehdotti, että yliopistoon perustettaisiin fyysisen maantieteen, erityisesti Suomen, oppituoli, jonka haltijaksi nimitettäisiin joku maantieteilijä. Kihlmanin ja Palménin vastustuksesta huolimatta konsistori päätti perustaa yliopistoon 11.7.1901 maantieteen ylimääräisen professorin viran. ${ }^{70}$

Rosbergin nimitys maantieteen ylimääräiseksi professoriksi 3. toukokuuta 1902 merkitsi maantieteen aseman vakinaistamista Aleksanterin-Yliopistossa. Maantiede voitiin nyt ottaa kandidaatin ja lisensiaatin tutkintoaineeksi ilman erityisiä anomuksia. Kun maantiede kohotettiin itsenäisen tieteen asemaan, sille luotiin samalla jatkuvuutta, joten opiskelijat saattoivat luottavaisesti aloittaa tieteenalan opinnot. ${ }^{71}$

\section{Kukkakimpun kimppuun}

J. G. Granö oli hyvin tietoinen Palménin suhtautumisesta maantieteeseen. Tämän vuoksi hänelle oli kova paikka mennä loppusyksystä 1901 kertomaan tukijalleen, että hän oli päättänyt valita juuri sen tutkintonsa pääaineeksi. Palmén pyrkikin painokkaasti saamaan Granön valitsemaan itselleen jonkin toisen pääaineen. Ripitys oli niin kova, että Granö pystyi vielä 19 vuoden kuluttua palauttamaan mieleensä hänen sanansa:

Tiedättekö nuori mies, mitä maantiede on? Maantieteen työala on kuin kaunis kukkakimppu, jonka jokaisesta yksittäisestä kukasta huolehtii eri tieteenhaara. Ette pysty selittämään tuota kukkakimppua muulla tavalla kuin siten, että tarkastelette ja selitätte erikseen jokaisen sen kukista. Ette kuitenkaan pysty siihen tuntematta niitä tieteitä, joiden erikoisalana yksittäiset kukat ovat. Luonnon suurenmoinen kokonaisuus on lumonnut teidät, mutta maantieteeseen erikoistuminen ei auta teitä tieteellisesti ymmärtämään tuota kokonaisuutta. $^{72}$ 
Granö oli kuitenkin valintansa tehnyt, joten Palménin painostus sai hänet vain syventymään aiempaa innokkaammin maantieteeseen. Uudeksi pontimeksi tuli näyttää eläintieteilijälle, että maantiede oli itsenäinen tiede. Tämän vuoksi hän kiinnostui käytännöllisen tutkimustyön ohella myös kysymyksistä, jotka liittyivät maantieteen tutkimuskohteisiin ja -menetelmiin, rajoihin ja tehtäviin.

Granö paneutui alusta alkaen opintoihin niin tarmokkaasti, että J. E. Rosberg valitsi hänet jo seuraavana syksynä maantieteen laitoksen ylimääräiseksi assistentiksi. Ratkaisu ei perustunut sopivien kandidaattien puutteeseen, sillä vaihtoehtona olisi ollut muun muassa laitoksen johtajana Rosbergin ulkomaanmatkan ajan toiminut Arthur Boman, vaan Granön osoittamaan kyvykkyyteen ja hänen kauttaan avautuviin mahdollisuuksiin vahvistaa maantieteen asemaa yliopistossa. ${ }^{73}$

Suomen tieteellistä ilmapiiriä hallitsi 1900-luvun vaihteessa niin sanottu Suomiprojekti. Se oli vähitellen laajentunut autonomian alkuaikojen kotimaan ja sen välittömässä läheisyydessä keisarikunnassa sijaitsevien alueiden eli "luonnonhistoriallisen Suomen" kasviston, eläimistön ja kallioperän selvittämisestä laaja-alaiseksi tutkimustoiminnaksi, joka kohdistui pitkälle itään, aina Siperian kaukaisiin osiin ja Mongolian ja Kiinan rajoille saakka. Geologien pyrkiessä löytämään idästä hyödynnettäviä mineraaliesiintymiä kielitieteilijät etsivät sieltä Suomen heimon muinaisia juuria. Rosberg uskoi, että Granön tiiviit yhteydet Siperiaan loivat hyvän mahdollisuuden liittää maantiede kansallisesti tärkeiden tieteiden eturiviin. ${ }^{74}$

Rosbergin keskittyessä pitemmälle opinnoissa ehtineiden opiskelijoiden ohjaamiseen Granön vastuulle tulivat erityisesti ensimmäisen vuoden opiskelijat ja Ragnar Hultin käynnistämien kartografisten harjoitustöiden uudelleen järjestäminen. Hän oli hyvä luennoitsija, joka osasi esittää asiat elävästi ja havainnollisesti. Koska kartanpiirustuksen opiskelu oli pitkään kärsinyt karttaprojektiokäsikirjan puutteesta, Granö julkaisi luentojen pohjalta 1911 kirjasen, johon hän oli koonnut keskeiset matemaattis-maantieteelliset ohjeet ja taulut. ${ }^{75}$

Harjoitustöiden johtajana Granö oli täsmällinen ja tiukka toimien siten tarpeellisena tukena varsin lepsuna pidetylle Rosbergille. Opettajien erilaisen suhtautumi- 
sen sai kokea muun muassa Uunio Saalas, joka suuresta ahkeroinnistaan huolimatta joutui huomaamaan epäonnistuneensa pahoin kartanpiirustustehtävässään. Rosbergin sattumalta nähtyä enemmän abstraktista maalausta kuin karttaa muistuttaneen tekeleen hän oli todennut lempeällä äänellään: ”Kyllä minä pelkään - kyllä minä pelkään - ettei assistentti ole oikein tyytyväinen." ${ }^{\prime 6}$

Sen enempää Rosberg ei raaskinut sanoa, ja kun Granö sitten tuli, hän totesi oitis, että Saalaksen oli piirrettävä kartta kokonaan uudestaan. Tiukasta linjastaan huolimatta assistenttia pidettiin yleisesti oikeudenmukaisena ja ystävällisenä opettajana, jonka puoleen saattoi luontevasti kääntyä pulmatilanteissa.

Granön tulevan toiminnan kannalta oli tärkeää, että Rosberg hankki laitokselle valokuvauskoneen, perusti maantieteellisten maisemakorttien kokoelman ja ryhtyi kokoamaan tietoja Suomen maantieteen alalta. Jokaisen maantieteen opiskelijan toivottiin tallentavan kokoelmaan kotiseudultaan tietoja, jotka järjestettiin tarkastuksen jälkeen pitäjittäin ja maakunnittain. Tavoitteena oli, että valokuvat, korttikokoelma ja pitäjäkohtainen tietopankki olisivat luoneet edellytyksiä maantieteellisiin kotiseutukuvauksiin, joita tehtiin seminaarien harjoitustöinä. ${ }^{77}$

Käytännön opetustyöt ja maantieteen olemuksen pohdinta saivat Granön nopeasti erottamaan maantieteen erilaiset painotukset oppiaineena ja tieteenalana. Hän ymmärsi, että opiskelun alkuvaiheessa oli perustan luomiseksi keskityttävä toisiin asioihin kuin niihin, jotka olivat tärkeitä tutkimustyössä. Opiskelussa oli aluksi paneuduttava huolellisesti kartanpiirustukseen ja erityistieteiden perusteisiin, esimerkiksi eläin- ja kasvitieteeseen, geologiaan, kemiaan, fysiikkaan ja historiaan. Laajentaakseen näkemystään Granö kävi muun muassa kuuntelemassa Väinö Voionmaan (vuoteen 1906 Wallin) historiallis-kielitieteellisessä osastossa pitämiä ja suuren suosion saaneita historiallisen maantieteen ja talousmaantieteen luentoja, joissa korostettiin maantieteen ja historian läheistä yhteyttä. ${ }^{78}$

Tutkimuksessa pääpaino oli kuitenkin suunnattava sen selvittämiseen, miten jokin alue oli saanut sille luonteenomaisen ulkoasun eli maiseman. Granö kiteytti asian seuraavasti: 
Havaitsin Palménin käsityksen maantieteestä pian vääräksi. Maantiede ei ole häntä lainatakseni - kimppu yksittäisten kukkien järjestelmällistä erityis- ja detaljoitua tutkimusta. Mikäli niin olisi, maantiede olisi, niin kuin monet väittävätkin, useiden tieteisen kasauma, konglomeraatti... On syytä huomata, että tieteenalamme tutkimuskohteena on ennen muuta kukkakimppu kokonaisuudessaan, t.s. koko maapallon pinta kokonaisuudessaan, ja että "kukat" (pinnanmuodot, kasvillisuus, ihmistoiminnan tuloksena syntyneet rakennukset jne.) kuuluvat sen piiriin vain sikäli kuin ne esiintyvät maisemassa tekijöinä... "Ollakseni maantieteilijä minun on pidettävä tärkeimpänä lopullisena päämääränäni luonnon valtavan "kukkakimpun" tieteellistä selittämistä, tuon kokonaisuuden, jonka kukat eivät ole sattumalta joutuneet vierekkäin, vaan joiden asema ja sisäiset suhteet riippuvat määrätystä menneisyydestä ja varmoista ikuisista lainalaisuuksista. ${ }^{79}$

\section{Henkinen kasvu}

Granölle oli ominaista nuoresta lähtien, että hän pyrki järjestämään asiansa saadakseen viettää tasapainoista ja monipuolista elämää. Mihinkään tehtävään ei saanut paneutua niin syvällisesti, että se olisi vienyt tyystin ajan muilta normaaliin elämään kuuluvilta asioilta tai jännittänyt henkisen kestokyvyn liian tiukille. Tähän oivallukseen Granötä oli opastanut kielentutkija Otto Donnerin viisas neuvo: "Måtta i allt; man skall inte spänna bågen för högt." 80

Jo 1900-luvun alussa Granöllä riitti opinnoista ja työkiireistä huolimatta aikaa myös yhteiskunnalliseen toimintaan, opiskelijaelämään ja harrastustoimintaan. Hän oli isänsä tavoin suomenmielinen, minkä vuoksi hän ajatteli usein sukunimensä suomalaistamista. Suomalaisen Nuijan hänelle ja Paavo-veljelle 1906 tarjoaman Aimonen-nimen veljekset torjuivat heti. Vakavimmin esille nousi nimi Teerijärvi isän synnyinpitäjän mukaan, mutta sekään ei tuntunut oikein omalta, vallankin kun selvisi, että sen taustalla oli maanmittarin erehdys. Nimen olisi pitänyt olla Tervajärvi. 
Saatuaan myöhemmin kuukausia kestäneen tutkimustyön jälkeen selville, että vanha sukunimi oli ollut Teerijärven sukutalon haltijoilla käytössä Birger Jaarlin ajoista lähtien, Granö vähitellen luopui nimen suomalaistamisesta. Hän kirjoitti K. Teerijärvi-nimellä joitakin kirjeitä ja pieniä tekstejä, ja kielitieteilijä L. Kettunen omisti hänelle sillä nimellä kirjojaan. ${ }^{81}$

Granö kirjoittautui Pohjalaiseen osakuntaan ja liittyi sen piirissä toimineeseen Paavo Virkkusen (vuoteen 1906 Snellman) johtamaan vanhasuomalaiseen ryhmään, joka katsoi, että keskusteluyhteys venäläisiin tuli säilyttää. Ilmeisesti jo lapsuudessa alkanut kanssakäyminen venäläisen väestön kanssa oli johtanut siihen, että Granössä ei voinut havaita lainkaan suomalaisissa tutkijapiireissä yleistä väheksyvää suhtautumista venäläisyyttä kohtaan. Päinvastoin, hän arvosti venäläisyyteen kuuluvaa ihmisläheistä, laveaa luonnetta, ja vierasti kaikenlaista Suur-Suomi-kiihkoilua. ${ }^{82}$

Granö osallistui ahkerasti maantieteellisten seurojen ja Vanamon kokouksiin toimien pitkään yhdistysten johtotehtävissä. Hän harrasti myös nuoruudestaan lähtien isänsä tärkeänä pitämää raittiustoimintaa ja liittyi ylioppilaiden musikaalisen yhdistyksen, Kolmisoinnun, toimintaan soittaen sen orkesterissa viulua. Vielä Oulun lyseon 1933 ilmestyneessä matrikkelissa hän mainitsi erikoisharrastuksekseen viulunsoiton. ${ }^{83}$

\section{Ylioppilaan Siperian-kesät}

Opiskelujen aloittaminen Helsingissä ei katkaissut Granön kiinteitä siteitä kotiin. Hän asui äidin sisaren Hanna Lignellin hyvässä hoivassa Ratakatu 3:ssa, oli tiiviissä kirjeenvaihdossa perheeseensä ja vietti myös pitkät lomansa vanhempiensa luona. ${ }^{84}$

Kun Granö matkusti lukukauden päätyttyä keväällä 1902 veljensä kanssa kotiin, suuntana ei ollutkaan Alatornio vaan isän uusi pappila Omskissa. Kaukainen määränpää osoittautui ratkaisevaksi hänen uransa kannalta, sillä Siperiassa hänestä tuli tutkimusmatkailija, matkakirjailija ja valokuvaaja ja siellä hän perehtyi tutkimussuuntaan, joka tuli muodostamaan suuren osan hänen tieteellisestä elämäntyöstään, geomorfologiaan. ${ }^{85}$ 


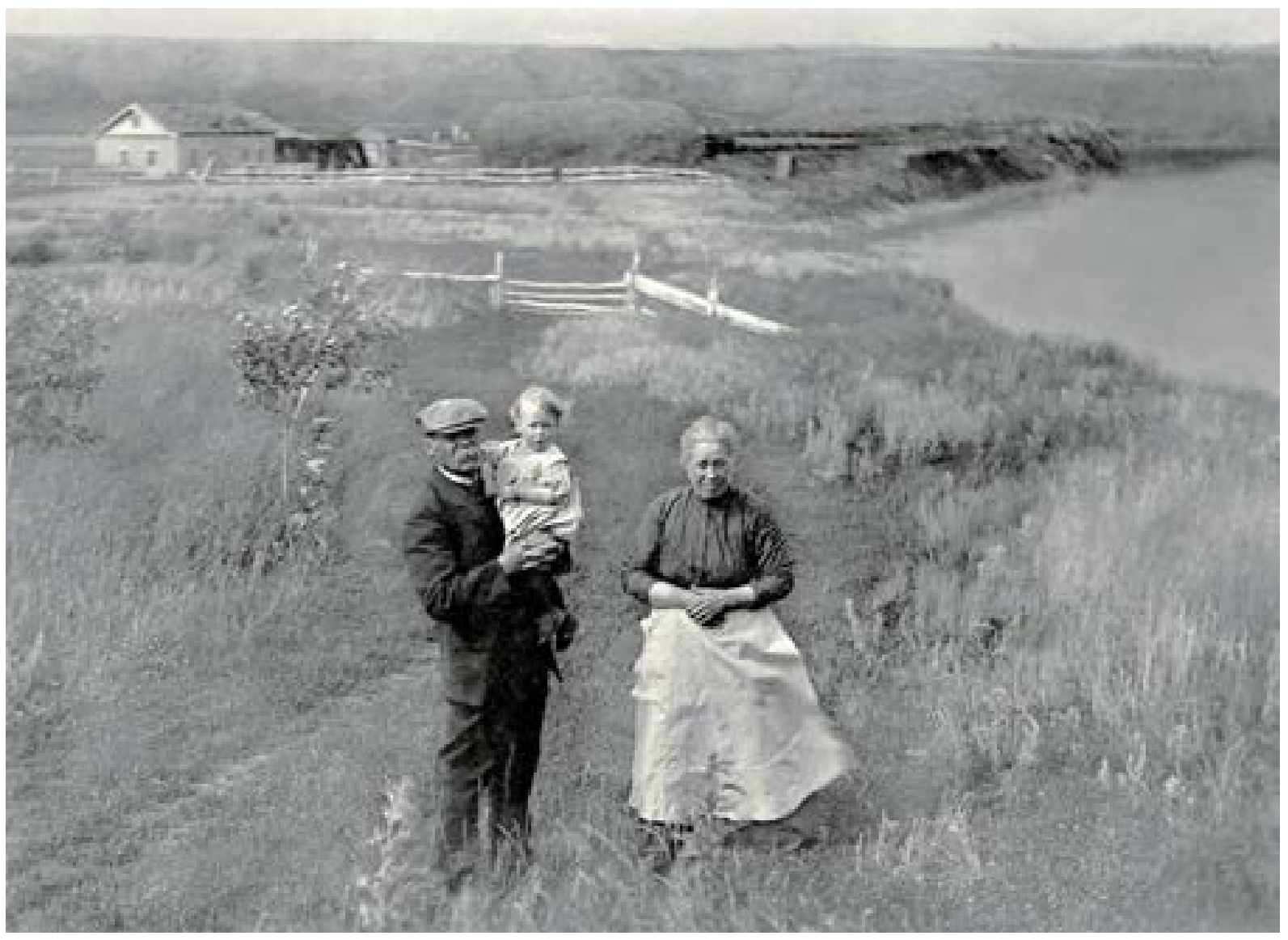

Isoisä ja mummu sekä Paavo Granön esikoistytär Greta kesäpaikallaan Omjoen rannalla 1912.

Vaikka Siperian rata oli jo saavuttanut Omskin, poikien taival Helsingistä isän pappilaan vei silti yli viikon. Aina matkaa ei tehty vain junalla, vaan toisinaan he matkustivat pitkiä taipaleita jokilaivalla Siperian suuria jokia pitkin. Matkustaminen ei päättynyt tähän, sillä Granö seurasi usein isäänsä tämän virkamatkoilla toimien muun muassa urkurina ja lukkarina. Kanttorin tehtävät hän jätti mielellään muille, sillä laulusta saatu vitonen oli hänen huonoin kouluarvosanansa. ${ }^{86}$ 


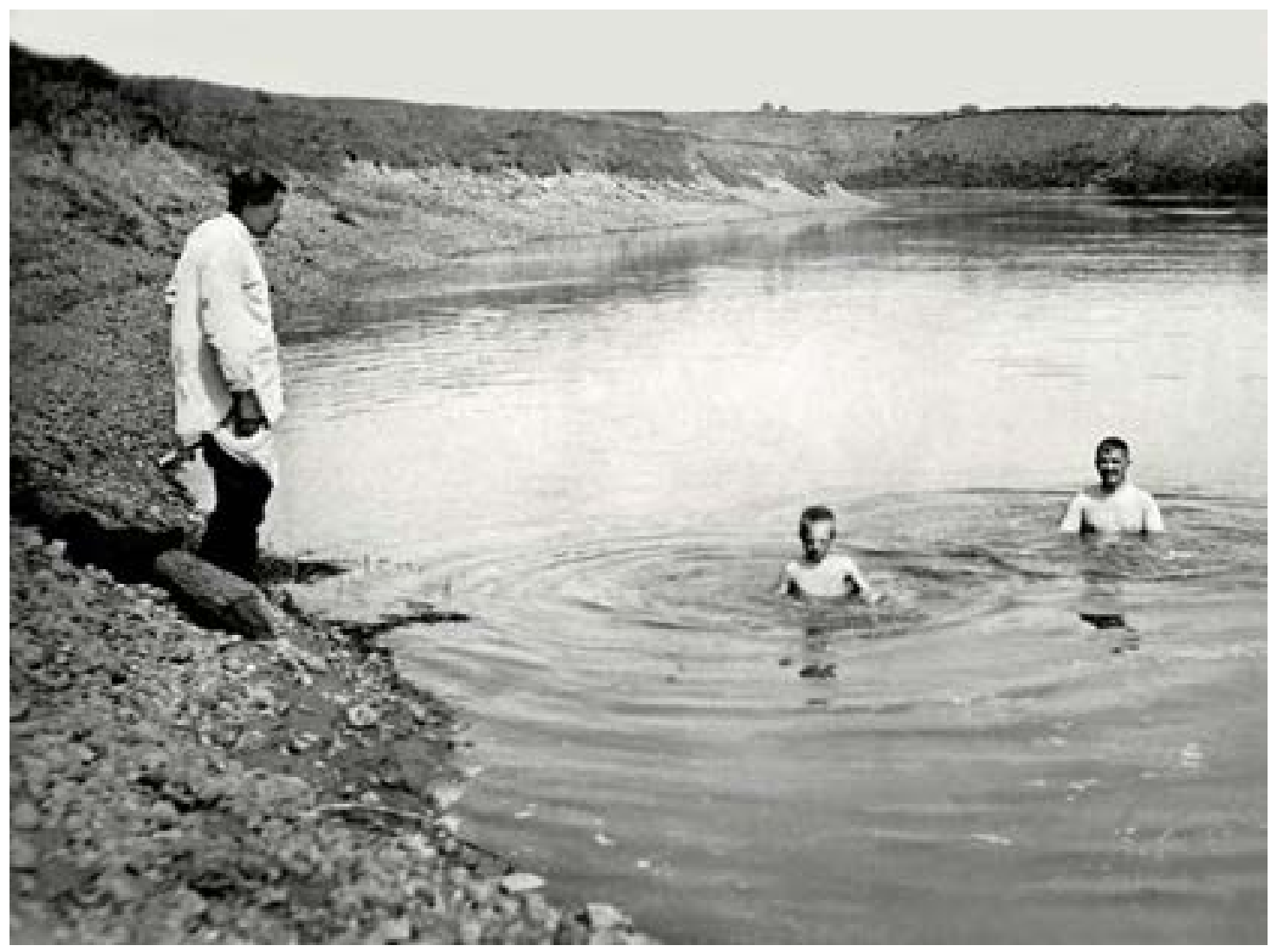

Helteisinä kesäpäivinä zaimkalla käytiin uimassa 0mjoessa.

Kaapon Antti-setä (Anders Granö) rannalla, vedessä serkku Paavo ja veli Paavo.

Heti kesällä 1902 tehty matka sai tieteellisen luonteen, kun Granö kokosi sen aikana aineistoa Rosbergilta saamaansa pro gradu -työhön, jonka aiheena olivat Siperian suomalaisten siirtoloiden maantiede. Siirtolaisiin liittyvien seikkojen lisäksi Granö kirjasi muistiin myös monenlaisia muita havaintoja sekä keräsi kasveja ja eläimiä yliopistoa varten. Matkan aikana hän otti myös ensimmäiset tutkimuksiin liittyvät valokuvansa, jotka olivat alkuna hänen merkittävälle toiminnalleen valokuvajana. ${ }^{87}$ 
Palattuaan Suomeen Granö kertoi havainnoistaan J. A. Palménille, joka kehotti häntä pitämään Suomen Maantieteellisen Seuran kokouksessa esitelmän Siperian suomalaisista siirtoloista. Maaliskuun 21. päivänä 1903 pidettyä esitelmää saapuivat Palménin lisäksi kuuntelemaan muun muassa Seuran puheenjohtaja O. Nordqvist ja arvovaltainen senaattori K. E. F. Ignatius. ${ }^{88}$

Korkeiden herrojen huomio sai Granön kiinnostumaan tutkimus- ja keräilytoiminnasta niin paljon, että hän lähti kesällä 1904 innokkaasti isän mukaan pitkälle virkamatkalle Itä-Siperiaan. Matka alkoi kesäkuun puolivälissä hitaasti edenneen sekajunan kyydissä Krasnojarskiin, josta edettiin höyrylaivalla Jeniseitä pitkin Minusinskiin. Sen konkreettisin anti oli Granön Suomeen tuoma pronssiveitsi, joka tallennettiin Suomen Kansallismuseon kokoelmiin. ${ }^{89}$

Granön pro gradu -työ ja samalla ensimmäinen tieteellinen tutkimus Siperian suomalaiset siirtolat valmistui tiiviin kirjoitusjakson jälkeen 1905. Suomen tärkeimmässä maantieteellisessä julkaisusarjassa Fenniassa samana vuonna ilmestyneessä tutkimuksessa hän selvitti niin monipuolisesti siirtoloiden syntyä, toimintaa ja levinneisyyttä, että siitä muodostui tärkeä tietolähde Siperian suomalaisia käsittelevälle tutkimukselle. ${ }^{90}$

Vaikka Granö sai gradustaan laudaturin, hän ei itse ollut aivan tyytyväinen lopputulokseen. Teoksen esipuheessa hän valittaa, ettei ollut kyennyt saavuttamaan sitä täydellisyyttä, johon oli toivonut yltävänsä:

Olisihan ollut paikallaan selittää tarkemmin esim. siirtolojen maalajit ja muut geologiset muodostumat. Niinikään olisi pitänyt puhua laajemmin kasvi- ja eläinkunnasta. Mutta toisaalta kävisi mahdottomaksi lyhyessä kirjotuksessa käydä tarkemmin yksityiskohtiin, kun tarkoituksena on saada, valaisemalla eri puolia tasa-arvoisesti, kokonaiskuva luoduksi. Olen sentähden tyytynyt pääpiirteisiin. ${ }^{91}$

Nuori tutkija oli turhan vaatimaton. 
Kolmannen matkansa Siperiassa J. G. Granö teki loppukesällä 1905. Tuolloin hän seurasi veljensä ja Eetu Iston kanssa noin 3600 kilometriä pitkälle virkamatkalle isäänsä, joka oli saanut Suomen senaatilta märäryksen etsiä Länsi-Siperian eteläosiin eri aikoina ja eri syistä muuttaneita suomalaisia. Miehet etenivät aluksi laivalla Semipalatinskiin eli nykyiseen Semeyn kaupunkiin ja sieltä hevoskyydillä Ustj-Kamenogorskiin. Sitten he jatkoivat hevoskyydillä Irtyšin rantaa kulkevaa tietä lounaaseen, Narymjoen suulle, ja sieltä itään suuren Altaiskaja-stanitsan kylän kautta Buhtarmájoen sivujoen Berelin varrella olevaan Berelskojen kylään, jonne maantie päättyi. He kävivät myös myös Katunin latvavesien lähistöllä olevilla kuumilla Rahmanovin-lähteillä, joissa he saattoivat "pestä pois matkan tomut itse maaemon lämmittämässä vedessä". ${ }^{2}$

Granö oli saanut 1904 Palménin tuella Sahlbergin rahastosta 300 markan apurahan Siperiassa tehtyjä eläintieteellisiä tutkimuksia varten, joten kysymyksessä ei ollut pelkkä lomamatka. Aivan kuten Alexander von Humboldt Latinalaisen Amerikan tutkimusmatkan aikana, Granö teki valistusajan hengessä tarkkoja muistiinpanoja havaitsemistaan asioista, keräsi kasveja ja kokosi erilaisia luonnonnäytteitä mutta kuvasi maisemia piirrosten ohella myös valokuvaamalla. Hän perehtyi niin hyvin alueella harjoitettuun paikallisen hirvilajin eli maralin hoitoon, että saattoi julkaista 1906 Luonnon Ystävässä tutkielman Maralinhoito Etelä-Siperiassa. ${ }^{93}$

Vaikuttavinta oli kuitenkin tutustuminen monessa suhteessa omaleimaiseen Altain vuoristoon. Keskeisestä sijainnistaan huolimatta se on reuna-aluetta, venäläisen ja mongolialaisen asutuksen, Venäjän valtakunnan ja Mongolian, laskujoellisen ja laskujoettoman Aasian välillä. Maailmassa ei ole toista vuoristoa, joka sijaitsisi niin syvällä sisämaassa kuin Altai. Sieltä voi kulkea kaikkiin ilmansuuntiin 3000 kilometriä ennen kuin saapuu merenrantaan, Jäämerelle, Bengalinlahdelle, Keltaisellemerelle tai Kaspianmerelle. Koillisessa Jenisein latvat erottavat Altain Sajan-vuoristosta, idässä Altai jatkuu kauas Mongolian puolelle ja etelässä kohoaa Tienšan-vuoristo. Lännen ja luoteen puolella leviää laaja Länsi-Siperian alanko. Altain jäätiköiltä saavat alkunsa Länsi-Siperian halki virtaavan Obin suuret lähdejoet, Bija ja Katun.94 


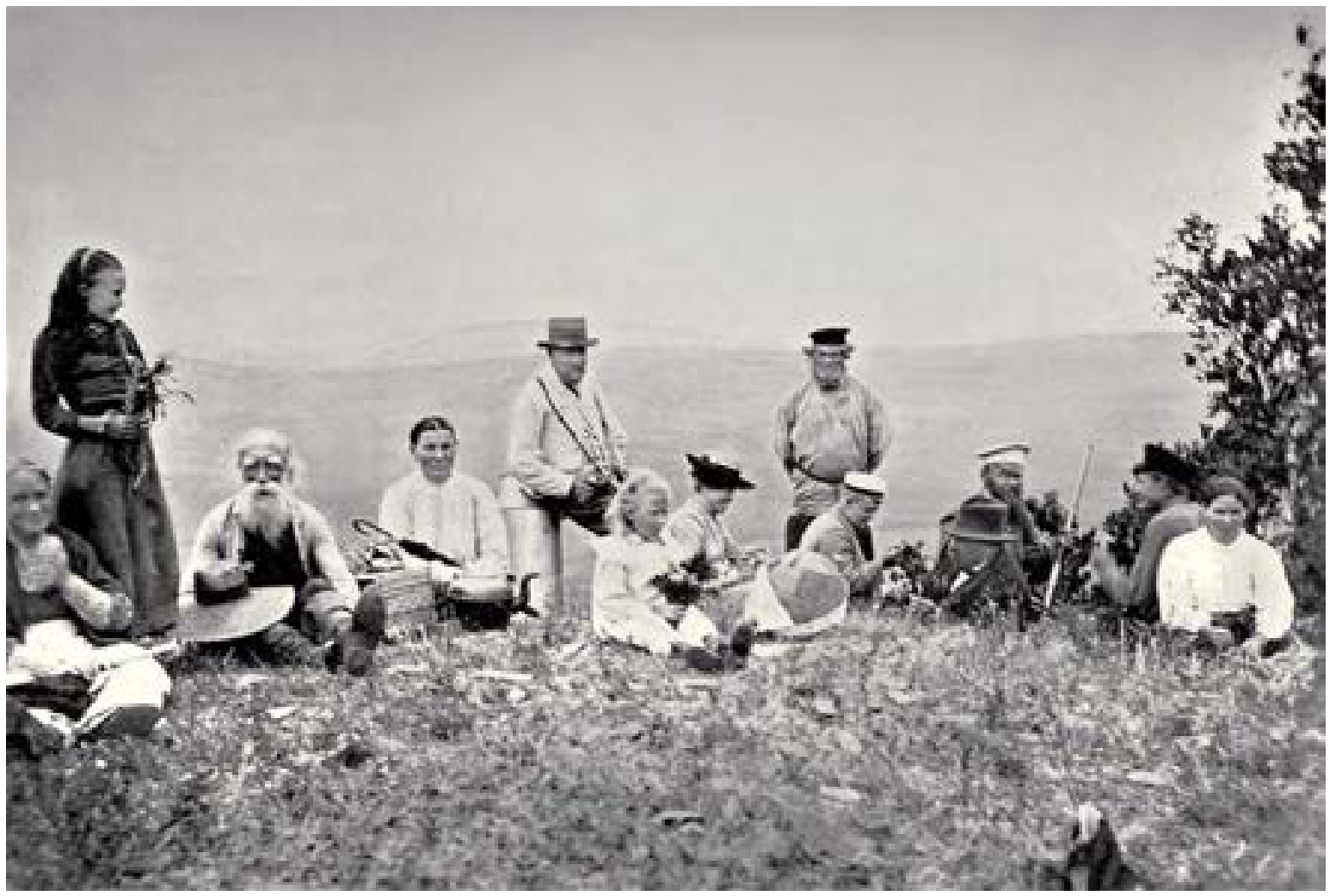

Iloinen seurue eväsretkellä Satulamäen laella lähellä Verhne Suetukin siirtolaa 1902. Vasemmalta rouva Toikka tyttärineen, vanha Möller rouvineen, opettaja Toikka ja tytär, Alma, ukko "Munsala", Paavo ja Johannes Granö, lättiläinen kauppias Kalinin ja suomalainen Ahonen rouvineen.

Altain maisemat laajoine epätasaisine metsämaineen, aukeine tunturiylänköineen, jäätiköiden ja lumikenttien peittämine alppiharjanteineen sekä syvälle sisäosiin tunkeutuvine ruuhilaaksoineen vaikuttivat voimakkaasti aro- ja jokimaisemien tasaisuuteen ja yksitoikkoisuuteen tottuneeseen tutkijaan. Erityisesti hänen mieleensä jäivät Altain korkeimman ylävuoriston Katunin pitkät jäätiköt.95 


\section{Arkeologiset tutikimusmatikat}

\section{Otto Donner ja Suomalais-ugrilaisen Seuran tutkimusohjelma}

Granö piti myöhäissyksyllä 1905 Suomen Maantieteellisen Yhdistyksen kokouksessa esitelmän ensimmäisestä Altai-matkastaan. Sankkaan kuulijajoukkoon kuului myös A. O. Heikel, joka oli yhdessä J. R. As-

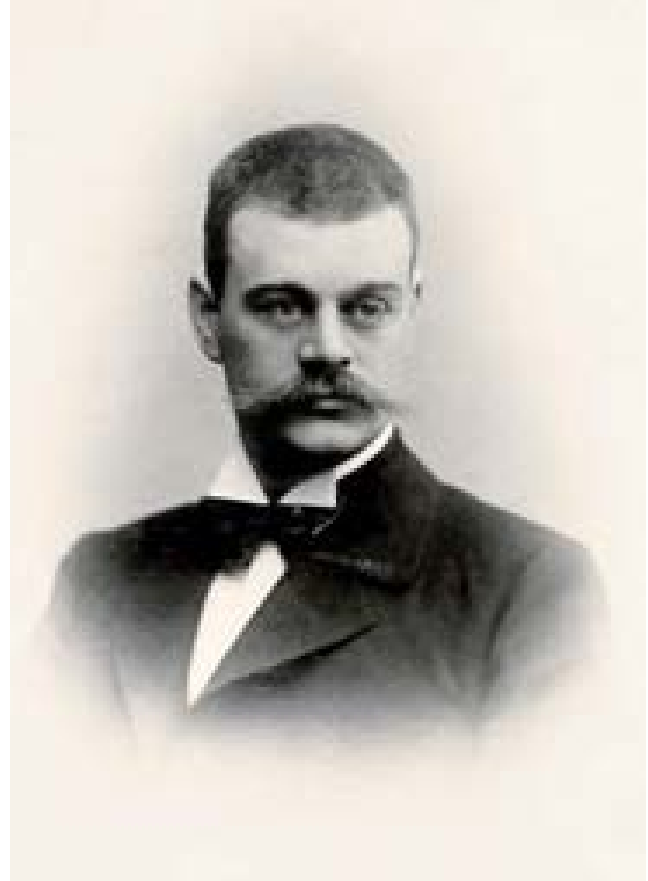
pelinin ja O. H. Appelgrenin kanssa käynyt tutkimassa piirtokirjoituskiviä Altain itäpuolella Sajanin vuorimaassa.

Heikel kertoi Granön kuvauksista Suomalais-ugrilaisen Seuran perustajalle ja puheenjohtajalle, senaattori ja professori Otto Donnerille. Hän oli aloittanut tutkimushankkeen Keski-Aasian muinaisten kansojen kielten ja kulttuurin

Granön tukijoihin kuulunut Wilhelm Ramsay nosti suomalaisen geologian opetuksen ja tutkimuksen kansainväliselle tasolle. Kulttuurihenkilöiden kuvaamiseen erikoistunut Daniel Nyblin ikuisti Ramsayn 1899, jolloin tämä sai nimityksen geologian ja mineralogian professoriksi. 
tutkimiseksi ja etsi parhaillaan henkilöä, jonka voisi lähettää Suomalais-ugrilaisen Seuran stipendiaattina Mongoliaan tutkimaan ja jäljentämään piirtokirjoituksia.. ${ }^{96}$

Vaikka Suomen kansan kuviteltu alkukoti oli jo siirtynyt pois Altailta, Suomalais-ugrilainen Seura ei ollut luopunut Altain tutkimuksista vaan laajentanut tehtävänsä käsittämään myös mongolialaisten ja turkkilaisten kielten ja kulttuurien tutkimisen. Kun Donner ymmärsi, että Granö kielitaitoisena, hyvänä piirtäjänä ja Siperian olot tuntevana henkilönä soveltuisi tehtävään, hän tarjoutui kustantamaan tämän matkan tuolloin Mongoliaan kuuluvaan Urjanhaihin (nykyisin Tuvan tasavalta Etelä-Venäjällä) ja Luoteis-Mongoliaan, joista oli niukasti tietoja. Granö oli valmis ottamaan tehtävän vastaan sillä edellytyksellä, että hänelle suotiin mahdollisuus saattaa ensin opiskelunsa loppuun ja tehdä matkan aikana myös maantieteellisiä havaintoja. ${ }^{97}$

Donnerin suostuttua ehtoihin Granö ei aikaillut. Hän valmistui filosofian kandidaatiksi toukokuun lopulla 1906 aineyhdistelmällä maantiede (laudatur), eläintiede (cum laude approbatur), kemia (cum laude approbatur), geologia (approbatur) ja kansantalous ja tilastotiede (approbatur). Hän päätti jatkaa opintojaan tohtorin tutkintoon saakka tekemällä väitöskirjan maantieteestä ja sivuerikoistyöt geologiasta ja eläintieteestä. ${ }^{98}$

\section{Kohtalokas ensimmäinen tutkimusmatka}

Granö alkoi valmistautua ensimmäisen tutkimusmatkaansa opintojensa ohessa huhtikuussa 1906. Matkan piti alkaa jo kesäkuun alussa, joten sekä Suomalaisugrilaisen Seuran että tutkimusmatkailijan itsensä kannalta kysymys oli huomattavan riskin ottamisesta. Vaikka Granö oli matkustellut paljon Siperiassa, matkat olivat olleet pääosin luonteeltaan tavanomaisia reittejä seuranneita virkamatkoja, joissa hänellä oli ollut apulaisen rooli. Nyt hän lähti yksin Siperian ja Mongolian tiettömille taipaleille. 
Granö tarvitsi matkaa varten lukuisia erilaisia lupia, ja sen vaatimat käytännön järjestelyt olivat mittavat. Jo matkareitti oli suunniteltava huolella, sillä se vei vaikeakulkuisten ja vaarallisten alueiden läpi. Korkeiden vuorien lisäksi uhkana olivat vuolaat kosket, tiettömät aavikkotaipaleet, rosvot sekä petoeläimet, sudet ja tiikerit. Granön oli perehdyttävä matkateknisiin kysymyksiin, kuten muonituksen ja varustukseen riittävyyteen ja tarvittavan apuhenkilöstön ja hevosten määrän arvioimiseen. Koska muistomerkkejä oli dokumentoitava myös valokuvaamalla, hän joutui ottamaan huomioon myös sen asettamat vaatimukset.

Tilannetta hankaloitti se, että Granön päämääränä olivat Venäjän ja Mongolian raja-alueet, jotka olivat sekä poliittisesti kiistanalaisia että huonosti tunnettuja. Suomalaiset tutkijat olivat liikkuneet pääosin Siperian pohjoisosien tundra- ja taigavyöhykkeillä. Kuuluisat ulkomaalaiset Aasian tutkimusmatkailijat olivat puolestaan ruotsalaisen Sven Hedinin tapaan suunnanneet matkansa etelämmäksi, Keski-Aasian vuoristoihin ja aavikoille, joita myös eversti C. G. Mannerheim tutki samoihin aikoihin alkaneella tiedustelu- ja tutkimusretkellään. Granö ja Mannerheim eivät olleet ilmeisesti vielä tuolloin tavanneet, vaikka Otto Donner kuului kummankin matkan taustavoimiin. ${ }^{99}$

Granö itse koki ongelmallisimmaksi sen, että tietopuolinen valmennus matkaan jäi hyvin puutteelliseksi. Sopimuksen mukaan hänen päätehtävänään oli etsiä vanhoja muistomerkkejä, erityisesti muinaisia kivikirjoituksia, kuvata ne mahdollisimman hyvin piirtämällä, valokuvaamalla tai muuten jäljentämällä ja selvittää samalla niiden levinneisyys. Tämän vuoksi hänen oli perehdyttävä arkeologiseen kirjallisuuteen ja erilaisiin tutkimus- ja jäljentämismenetelmiin. ${ }^{100}$

Valmistelujen pohjalta Granö laati tulevasta matkareitistään kartan, itineraarin, jonka hän esitteli Donnerille. Tämän hyväksyttyä suunnitelman Granö lähti isänsä kanssa Helsingistä kohti Pietaria kesäkuun 9. päivänä 1906. Turvakseen rosvoja ja villipetoja vastaan Granö otti mukaansa Mauser-pistoolin panoksineen, mutta ne olivat jäädä tullimiesten käsiin jo Valkeasaaren tulliasemalla. Vasta kun Granö oli kertonut matkansa tarkoituksen ja esittänyt visiittikorttinsa ja Suomalais-ugrilaiselta 


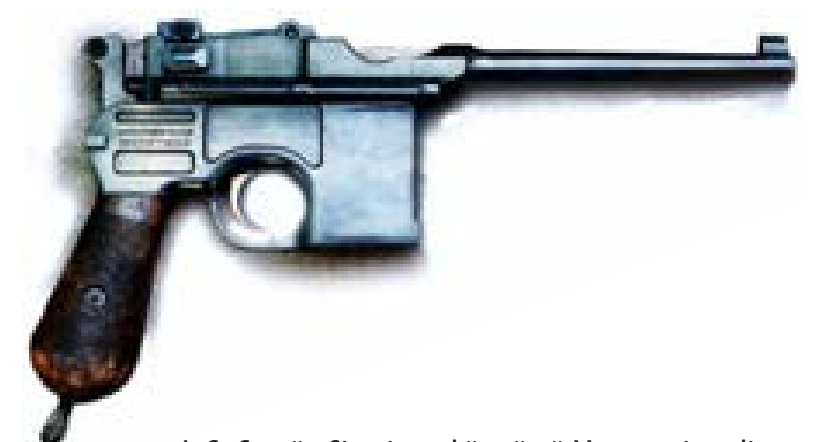

J. G. Granön Siperiassa käyttämä Mauser-pistooli kulkeutui Helsinkiin ja sijoitettiin myöhemmin yksityiseen asekokoelmaan.

Seuralta saamansa suosituskirjeet, matka saattoi jatkua aseen kera. ${ }^{101}$

Pietarissa Granö täydensi varusteitaan ostamalla muun muassa matkasängyn, teltan ja aurinkokellon. Lisäksi hän jatkoi jo Helsingissä aloittamaansa tiedollisen pohjan kartuttamista perehtymällä kirjastoissa, Tiedeakatemiassa ja Venäjän Maantieteellisessä Seurassa huolellisesti niihin tutkimuksiin, joita tutkimusalueella liikkuneet venäläiset tutkijat olivat julkaisseet. Saadakseen parasta mahdollista opastusta matkaa varten hän täydensi tietojaan Mongolian muinaisuuden suuren tuntijan akateemikko Wilhelm Radloffin opastuksella. Radloff toimi Etnografisessa museossa mutta asui tuolloin kesäasunnossaan Oranienbaumissa Pietarin lähistöllä, jonne myös Granön oli nopeasti kiiruhdettava.

Radloff tarjosi auliisti apuaan päteväksi havaitsemalleen suomalaiselle: Hän opetti kivikirjoitusten jäljentämistekniikkaa ja kirjoitti useita suosituskirjeitä sekä venäläisille että kiinalaisille viranomaisille. Hän antoi Granölle myös suosituksen maksuttoman ulkomaanpassin saantia varten sekä Kiinan lähettiläälle osoitetun ranskankielisen kirjeen, jossa Granölle anottiin kiinalaista suojeluskirjaa tieteellistä matkaa varten. Granö kävi kirjeen turvin tapaamassa Pietarissa asunutta suurlähettilästä, joka antoi hänelle "juhlallisen ja ihmeellisen paperin". ${ }^{102}$

Granö lähti Pietarista kesäkuun puolivälissä ja saapui viikon junamatkan jälkeen Omskiin. Siellä hän palkkasi apulaisekseen Siperiassa syntyneen inkeriläisen Elias Saaren, joka oli käynyt Sajanin vuorten rinteillä kullanhuuhtojana ja tunsi siten jossain määrin lähtöalueen. Omskista miehet etenivät Minusinskiin, jossa Granö kuvasi monta tuntia paikallisen museon piirtokiviä kokeillen samalla erilaisia jäljentämistapoja. ${ }^{103}$ 


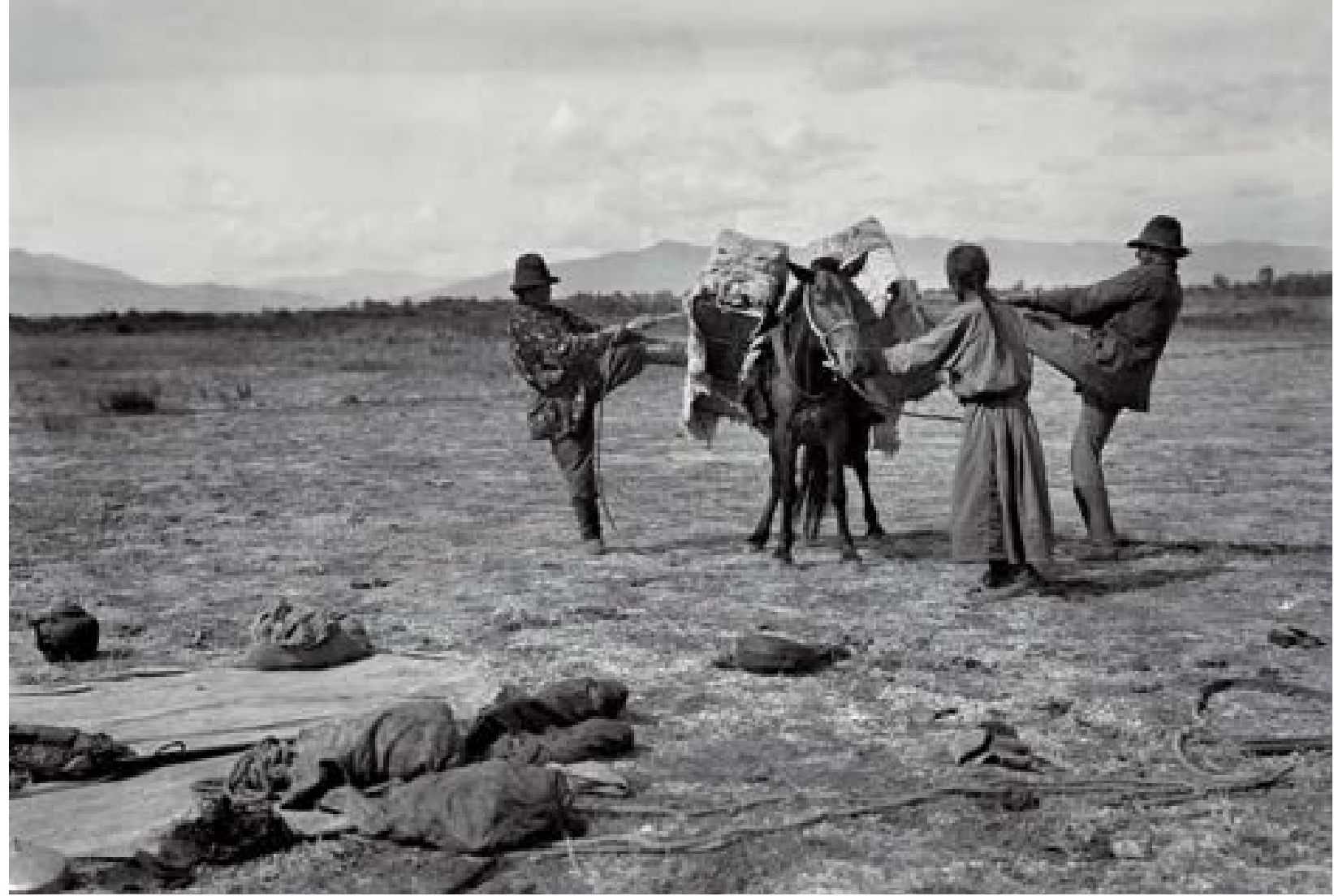

Karavaanihevosten kuormaaminen oli tehtävä huolella, sillä noin 50 kilon taakan paino koetteli hevosen kuntoa raskaassa maastossa. Granön luotettava apulainen Siperian virolainen Kalle Vokk (oikealla) johti kuormaamista Luoteis-Mongoliassa kesällä 1907.

Varsinainen tutkimusmatka alkoi heinäkuussa Kužebarin kylästä Jenisein sivujoen Amylin varrelta, Verhne Suetukin siirtolan eteläpuolelta. Sieltä Granö osti hevoset ja loput varusteet ja ruokatarvikkeet sekä palkkasi kaksi venäläistä hevosmiestä apulaisiksi. Karavaaniin kuului kaikkiaan yhdeksän hevosta, joista kukin kantoi paikallisen tavan mukaan noin 50 kilon kuorman. ${ }^{104}$

Granö ei ollut onnistunut saamaan lupaa arkeologisia kaivauksia varten, joten hänen päätehtäväkseen jäivät kivikirjoitusten valokuvaaminen ja mahdollisimman huolellinen piirtäminen sekä niiden levinneisyyden selvittäminen. Tämän virallisen 
tavoitteen ohella hän päätti myös kartoittaa tarkoin kulkemansa alueet sekä pitää täydellistä havaintopäiväkirjaa ympäristön ilmiöistä, kuten kasvillisuudesta, ilmastosta ja maanpinnan muodoista. Nuoren miehen tahdonlujuutta osoitti, että päätös myös piti. Olipa päivä ollut kuinka rankka tahansa, hän kirjasi illalla sen saldon tarkasti muistiin merkiten tieteellisten asioiden jälkeen sulkeisiin joitakin kommentteja päivän muista elämyksistä. ${ }^{105}$

Edetessän kohti Kiinalle tuolloin kuulunutta Urjanhaita Granö seurasi aluksi samoja vaikeita kullanhuuhtojien polkuja, joita M. A. Castrén oli käyttänyt 60 vuotta aiemmin tutkimusmatkallaan 1847 Kiinan rajalla asuvien sojoottien luokse. Näin Granö joutui kokemaan vaikeakulkuisessa maastossa ne samat rasitukset ja vaarat, joita Castrén on elävästi kuvannut matkakertomuksessaan.

Granö totesi itse myöhemmin, että ratsutie oli yksi vaikeimmista, joita hän oli elämänsä aikana kulkenut. Etelä-Siperian vuoriston suot olivat laajoja ja vajottavia, metsät vettä tihkuvia, kahluupaikat vuolaita ja syviä. Silti viikon kestänyt karavaanimatka Sajanin vuorimaassa oli hänen mukaansa mitä terveellisintä koulua ensikertalaiselle ja tarjosi unohtumattomia näkymiä:

Bei-kemin laaksoon päästyämme matkustelu kävi helpommaksi. Luonto oli suurenmoinen ja ihanat olivat näköalat, jotka avautuivat kukkuloilta Bei-kemin laajaan laaksoon. Rinteitä verhosi edelleenkin metsäkasvillisuus, laakson pohjalla kasvoi milloin miehenmittaista, parhaillaan kukkivaa ruohostoa - venäläiset sanoivat sitä sattuvasti suurruohostoksi, bolšetravie, milloin taaskin oli puistomaisia lehtikuusistoja ja koivulehtoja. Vauhkot kauriit, joiden mielipaikkoja tällaiset puoleksi metsäiset niittymaat ovat, pakenivat meitä korkein loikkauksin, metso- ja teiripoikuieta juoksenteli ympärillämme korkeassa ruohikossa, sorsat ja hanhet pitivät vesissä peliään. ${ }^{106}$

Retkikunnan päs̈styä elokuun alussa Kiinan rajalle ja siirryttyä Urjanhain puolelle sojoottien eli tuvalaisten seudulle hankalin taival oli takana. Pieneenkään herpaan- 
tumiseen ei silti ollut varaa: Sen osoitti pian sattunut onnettomuus, joka oli päättää koko tutkimusretken ja viedä myös retkeläisten hengen.

Voidakseen jatkaa matkaa länteen Granön retkikunnan oli ylitettävä yksi Jenisein lähdejoista, Hakem, joka oli pitkään jatkuneiden sateiden vuoksi paisunut vuolaaksi ja pyörteiseksi virraksi. Joki oli retkeläisille tuntematon, mutta he eivät malttaneet jäädä etsimään turvallista ylityspaikkaa vaan pakkautuivat tavaroineen rannalta löydettyyn, yhdestä puusta koverrettuun venepahaseen. Vain Elias Saari jäi rannalle kaitsemaan hevosia, jotka oli tarkoitus uittaa joen yli veneen päästyä turvallisesti

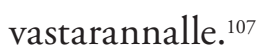

Leveän virran keskellä oli kaksi saarta, joiden välinen vuolas salmi osoittautui kohtalokkaaksi:

Kun lähdimme veneinemme liikkeelle ja tulimme kapeaan saarten väliseen salmeen, huomasimme virran yhä yltyvän. Ennen kuin aavistimmekaan, oli veneemme, joka oli huono, yhdestä puusta tehty, joutunut vettä reunustavien pajupehkojen alle. Nuolen nopeudelle kiisi se oksien alitse. Lakki lensi päästä ja kädet saivat olla nopeassa liikkeessä, etteivät oksat pistäisi silmiä puhki. Venettä emme kovassa virrassa ja pajurisukossa voineet pysäyttää, sillä pelkäsimme sen kaatuvan. Luulimme pajupensaikon toisella puolen olevan parempia paikkoja, joista saisimme veneen maihin ennen kuin onnettomuutta tapahtuisi. Mutta toiveemme ei toteutunut. Heti pensaikon alapuolella makasi vedessä nuori haapa, poikkipuolin edessämme. Jos olisimme sen ennen nähneet, olisimme kerinneet väistää, mutta nyt oli surma edessämme. Ennen kuin kerkesimme ajatellakaan, oli veneemme lyöttäytynyt puuta vasten ja sivulta syöksyi vesi kohisten siihen. Vaistomaisesti tartuimme kaikki kolme haapaan... Vene painui syvemmälle ja syvemmälle... Silloin kiipesimme peräkkäin maihin kapeaa puuta myöden... Yhdennellätoista hetkellä pelastuimme, sillä samassa kääntyi vene ympäri ja tavarat kelluivat pitkin virtaa, suunnaten kulkunsa jyrkännettä kohden... ${ }^{108}$ 


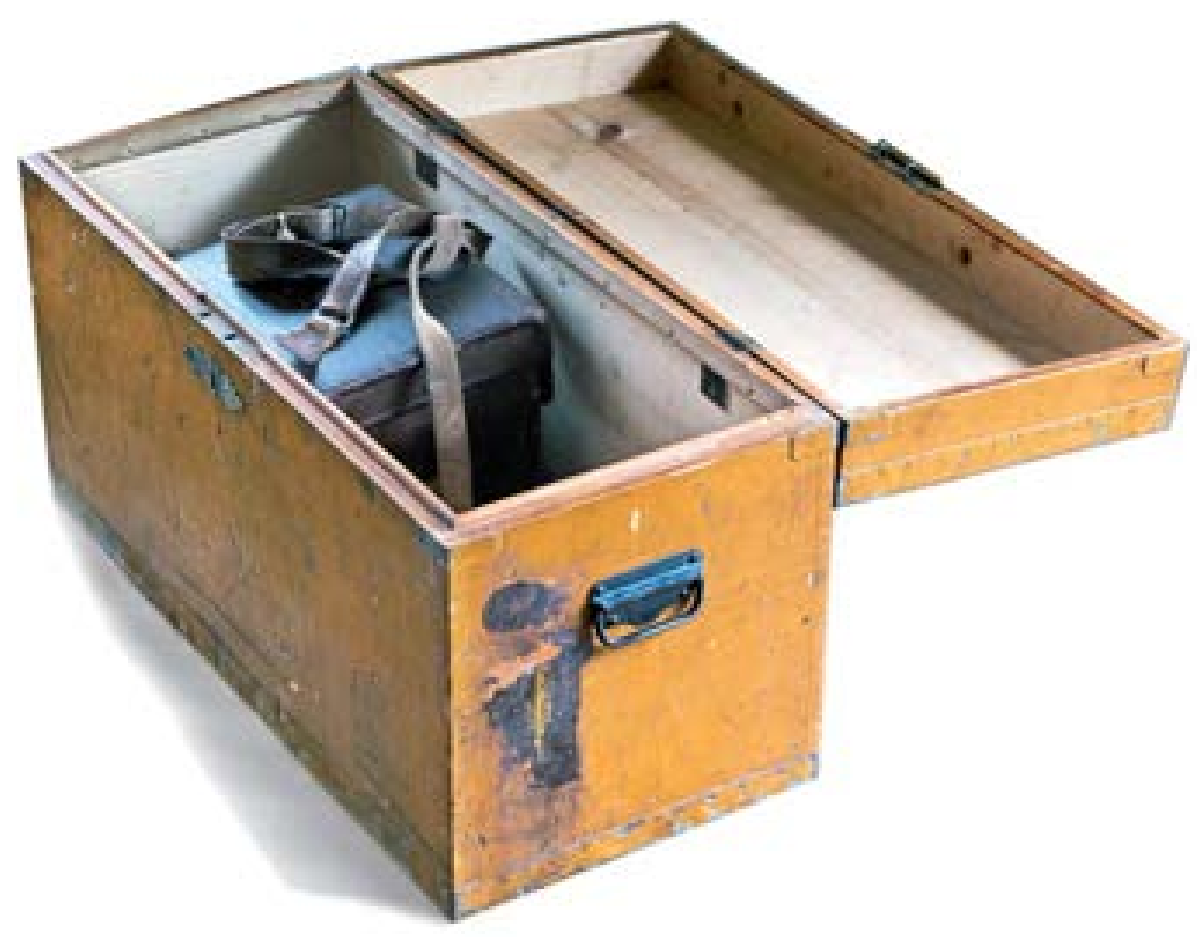

Yksi Granön matkoillaan käyttämästä

neljästä matka-arkusta.

Vene imeytyi virran kurimukseen ja hävisi tavaroineen pian kosken tyrskyihin. Pahaan paikkaan joutuneiden retkeläisten pelastukseksi koituivat paikalle leiriytyneet sojootit, jotka veivät heidät turvaan pienellä, uivan hevosen häntäjouhiin kiinnitetyllä lautalla.

Suurin osa matkatavaroista hävisi "tämän maailman tietä": muun muassa teltta, kaksi paria nahkalaukkuja, joissa oli säilykkeitä, voita ja muita elintarvikkeita koko matkaksi, makuuvaatteet, kapsäkit, joissa oli 20 tusinaa valokuvauslevyjä, 140 ruplaa eli pääosa rahavaroista, muistiinpanokirjoja ja pitovaatteita sekä kallis kamera. Vain ratsujen satulalaukoissa pidetyt muistiinpanovihot, parin päivän ruoka- ja lääkevarastot sekä mittauskojeet säilyivät. Lisäksi tallella oli vielä Granön vanha ylioppilaslakki, jota hän käytti eräänlaisena virkalakkina erityisen juhlallisissa tilaisuuksissa. ${ }^{109}$ 
Miehet etsivät tavaroita joen varrelta muutaman päivän ajan, mutta löysivät vain yhden kantamuksen, jossa oli lihasäkki, rikkilionnut valokuvauskone, suuri pressu sekä keittiöastioita. Granö joutui nyt tarkkaan miettimään, mitä tehdä. Tutkimusmatkan jatkaminen näytti mahdottomalta, sillä alkavan talven selkään ei ollut menemistä ilman telttoja ja kunnollisia varusteita. Lähes yhtä vaikealta tuntui palata Helsinkiin, sillä se olisi todennäköisesti merkinnyt lupaavasti alkaneen tutkimusmatkailijauran päättymistä. Niin monet suomalaiset olivat voittaneet ylivoimaiset vastukset idän retkillään, että ensimmäisen matkan kesken heittänyt tutkija olisi tuskin saanut toista mahdollisuutta. ${ }^{110}$

Asian ratkaisivat lopulta paikalliset venäläiset uudisasukkaat, jotka säälivät onnettomia matkamiehiä. He lahjoittivat heille elintarvikkeita, vaatteita ja muita tarvikkeita niin paljon, että Granö päätti jatkaa matkaa alkuperäisen suunnitelman mukaisesti. Ainoan kuormahevosen kannettavaksi lastattiin evässäkki, keittoastiat, turkit ja pakkalaatikko, jotka peitettiin pressulla.

Pressuja yritettiin käyttää telttojen puutteen vuoksi öisin myös tuulensuojana, mutta useimmiten matkalaiset joutuivat viettämään yönsä vain turkkeihin kääriytyneinä lantakokkareista tehdyn nuotion räiskyvän tulen ääressä. Toisinaan matkalaisilla oli tilaisuus majoittua myös paimentolaisten jurttiin, mutta tähän vaihtoehtoon turvauduttiin vain harvoin, sillä ne olivat usein likaisia ja ahtaita ja sairaalloisten asukkaiden läheisyys arvelutti: "... minä en ollut huvitettu istuskelemaan likaisen, puolialastoman naisväen kanssa, joista useimmilla oli syfilis..." ${ }^{111}$

Ei tiedetä, mitä Granö mielessään pohti, mutta jälkikäteen hän suhtautui vastoinkäymiseen positiivisesti. Kun hän joutui turvautumaan paikallisen väestön apuun, hän oppi ymmärtämään heidän näkökantojaan ja suhdettaan elämään. Lisäksi tapaus sai hänet päättämään lujasti, että enää hän ei tulisi ottamaan tarpeettomia riskejä. Uhkapelit olivat hänen osaltaan ohitse.

Päästyään jälleen matkaan retkikunta eteni ensin Jenisein suuntaisesti länteen noin 250 kilometriä ja kääntyi sitten suoraan etelään. Matka jatkui Ubsajärven itäpuolitse Kobdoon, Altain vuoriston eteläosien pääkaupunkiin, jonne saavuttiin syys- 
kuun alussa. Siellä lähes 1000 kilometrin taipaleen väsyttämät hevoset vaihdettiin uusiin ja koottiin voimia ja varusteita vielä pidempää matkaa varten. ${ }^{112}$

Vietettyään Kobdossa kaksi päivää Granö märäsi miehet taas liikkeelle. Retkikunta suuntasi aluksi lounaaseen ylittäen paikallisen mongolin opastamana Altain eteläharjanteet. Taival oli vaikea ja vaarallinen, koska pakkanen ja lumi olivat jo ehtineet vuorille. Päästyään jälleen alaville maille retkikunta joutui eksyksiin alavissa Dzungarian viidakoissa, joissa piti olla jatkuvasti varuillaan vaanivien tiikerien vuoksi. ${ }^{113}$

Vasta syyskuun 23. päivänä Granö kumppaneineen saapui kurjassa kunnossa yli 1500 kilometrin ratsastusmatkan jälkeen Zaisanin kaupunkiin Venäjän puolelle. Zaisanista matka jatkui hevoskärryillä Ustj-Kamenogorskiin ja edelleen Semipalatinskiin, jonne retkikunta saapui lokakuun alussa. Loppumatka Omskiin sujui mukavasti höyrylaivan kyydissä. ${ }^{14}$

Veneonnettomuuden vuoksi matka ei osoittautunut niin merkittäväksi kuin oli toivottu. Granö kopioi pääosin ennestään tunnettuja kivikirjoituksia, löysi yhden uuden sekä lukuisia muita kiinteitä muinaisjäännöksiä. Suurimmat kurgaanit olivat läpimitaltaan lähes 100 metriä, mutta kun niitä ei saanut

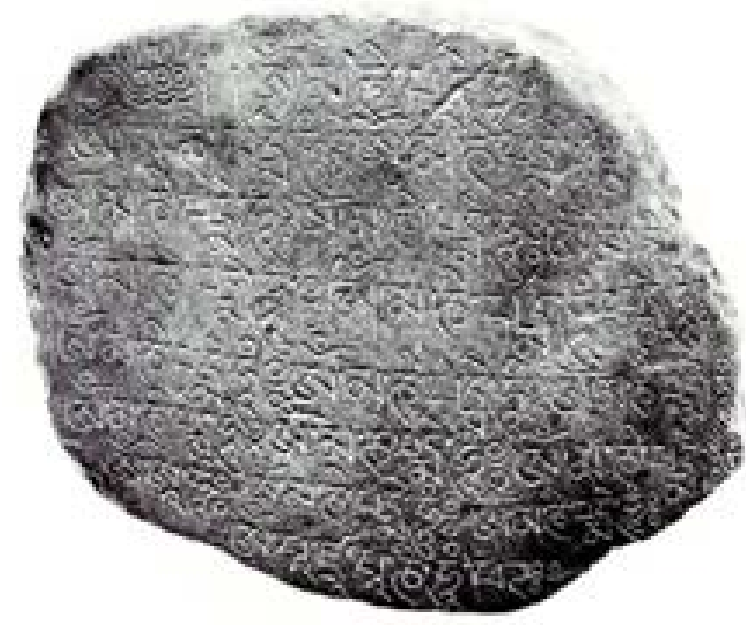

Yksi Granön Suomeen tuomista muinaista piirtokirjoitusta sisältävistä kivistä. kaivaa, niiden todellinen luonne jäi arvoitukseksi. Matkan suurin merkitys oli ehkä Granön vakuuttuminen siitä, ettei hänestä ollut arkeologiksi. Samalla oli kuitenkin käynyt myös selväksi, että Altain vuoristo tarjoaisi hänelle loistavan tutkimusmaaston maantieteilijänä. Hän oli matkan aikana havainnut selviä merkkejä, ruuhilaaksoja, kielekealtaita ja onsiloita, jotka osoittivat alueen olleen muinoin jäätikön peitossa. ${ }^{15}$ 


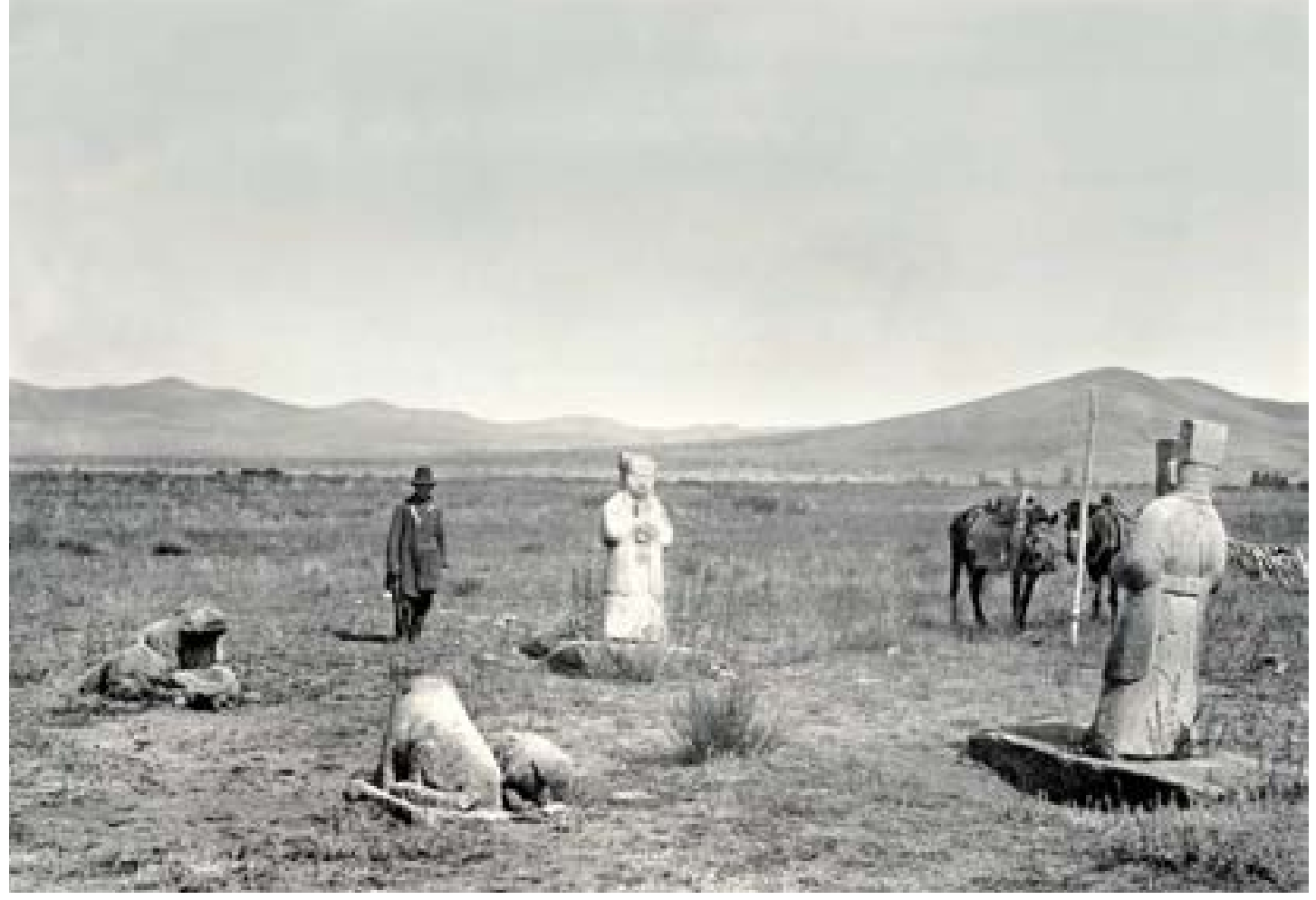

Pyhiä kiviä ja tulkki Semjon Askyroff Urjanhaissa 1907.

Vaikka luonnontutkija Friedrich von Gebler, maantieteilijä-anarkisti Pjotr Kropotkin ja tutkimusmatkailija G. N. Potanin olivat esittäneet olettamuksia laajasta jääkautisesta jäätiköitymisestä Keski-Aasiassa, 1900-luvun alussa yleisesti vallinneen käsityksen mukaan Keski-Aasian kuivassa ilmastossa ei olisi ollut suuria vuoristojäätiköitä jääkauden aikana. Tämän vuoksi edes selviin jääkautisiin kulutusmuotoihin ei ollut kiinnitetty juuri lainkaan huomiota, vaan niitä pidettiin rapautumisen, virtaavan veden ja siirrosten aiheuttamina.

Granön maantieteen ja geologian opettajat J. E. Rosberg ja Wilhelm Ramsay olivat molemmat perehtyneet glasiaalimorfologisiin kysymyksiin, joten he ymmärsivät hyvin, että Penckin ja Brücknerin Alpeilla kehittämän jääkausiteorian onnistunut sovellus Keski-Aasiassa olisi huomattava saavutus paitsi Granölle myös Suomen tieteelle. Väitöskirjan aihe oli siten selvä. ${ }^{116}$ 


\section{Pyhän kirjakiven tuonti Helsinkiin}

Palattuaan Suomeen Granö kirjoitti tutkimusmatkastaan artikkeleita sekä suomalaisiin että venäläisiin julkaisuihin. Samalla hän alkoi myös valmistella toista tutkimusmatkaansa, johon Otto Donner antoi jälleen aloitteen. Kohdealueina olivat edelleen Altain ja Sajanin vuoristojen välinen seutu ja sen pohjoispuolella oleva Urjanhai. ${ }^{117}$

Suunnitellessaan toista matkaansa Granö ei jättänyt mitään sattuman varaan. Varmistaakseen matkareitin suuntautumisen tutkimuksen kannalta keskeisille seuduille hän oli yhteydessä muun muassa riimukivien arvoituksen ratkaisseehen Vilhelm Thomseniin, joka sekä antoi hänelle neuvoja tutkimustyön suhteen että oli kiinnostunut hänen saavutuksistaan. ${ }^{118}$

Yhtä huolella Granö valitsi oikeat kulkuvälineet, varusteet ja matkamuonan. Ensimmäisen matkan kokemusten opettamana Granö päätti asettua aina karavaanin viimeiseksi voidakseen helpommin määrätä kompassisuunnat ja merkitä havaintonsa sekä karttaan että matkapäiväkirjaan. Satulastaan hän sitten tarkkaili huolellisesti maisemia sekä kokonaisuutena että yksityiskohdittain ja otti myös valokuvia. ${ }^{119}$

J. G. Granön tekemiä lyijykynäpiirroksia painettuina Suomalais-ugrilaisen Seuran julkaisuihin Archäologische Beobachtungen von meinen Reisen in den nördlichen Grenzgegenden Chinas in den Jahren 1906 und 1907 ja Archöologische Beobachtungen von meiner Reise in Südsibirien und der Nordwestmongolei im Jahre 1909.
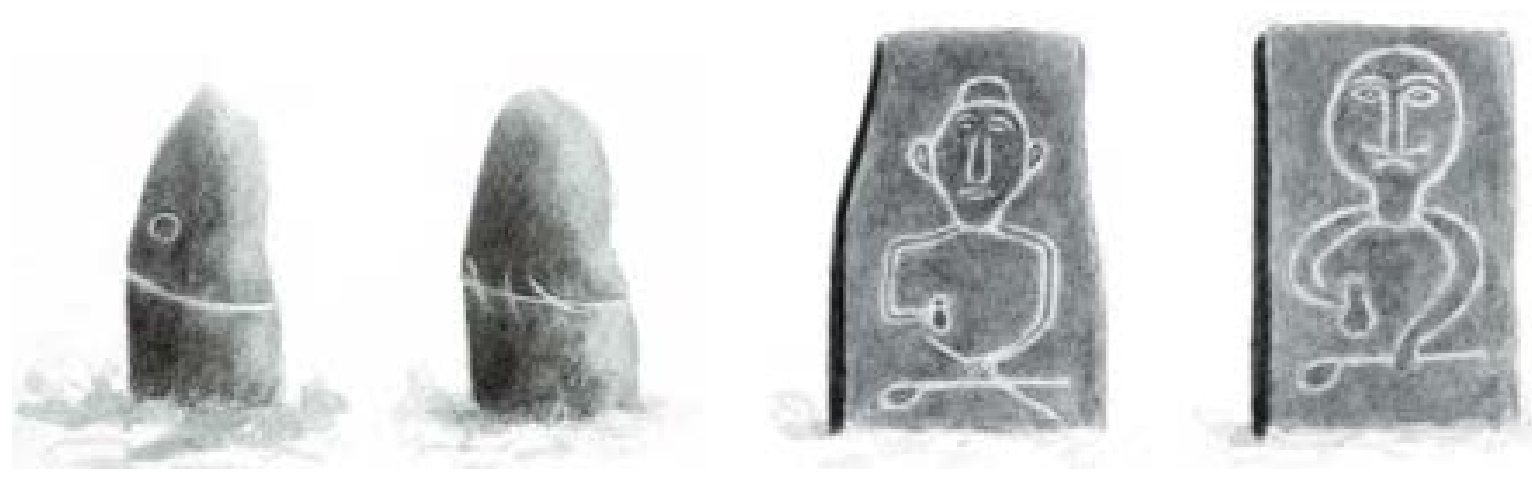


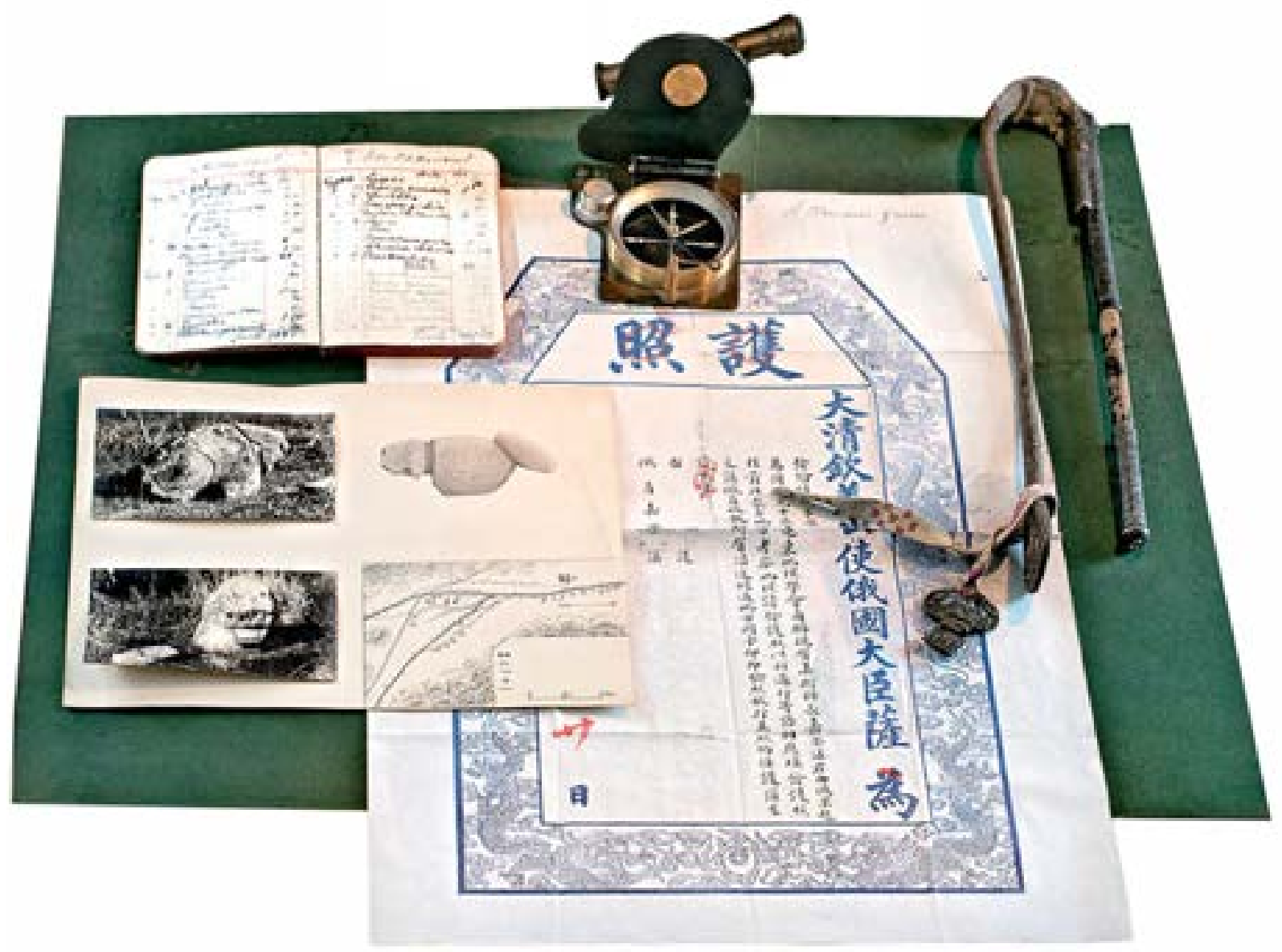

Arkeologisten matkojen mittausvälineitä ja Kiinan passi.

Granö lähti toukokuun puolivälissä 1907 Helsingistä kohti Siperiaa. Junassa oli niin paljon venäläisiä matkustajia, että hän tunsi alusta alkaen olevansa "suuressa isänmaassa”. Pietarissa Granö hankki kiinalaisen passin ja kävi tapaamassa akateemikko Radloffia, joka kirjoitti hänelle jälleen matkan onnistumisen kannalta ratkaisevan tärkeitä suosituskirjeitä. ${ }^{120}$

Omskissa Granö pestasi apulaisekseen Siperiaan karkotetun virolaisen Karl (Kalle) Vokkin, joka oli luotettava ja vahvana miehenä myös turvallinen matkakump- 
pani. Varsinainen tutkimusmatka alkoi kesäkuun alussa 1907 Altain länsipuolelta Bijskistä, Tomskin kuvernementin ja Altain vuoriston pohjoisosien pääkaupungista, jonne pääsi helposti laivalla Obia pitkin Novo-Nikolajevskistä, nykyisestä Novosibirskistä. Koska tavoitteena oli edetä mahdollisimman nopeasti Mongoliaan, reittinä käytettiin Tšujajokea seurannutta melko suoraa karavaanitietä, joka ikivanhana kauppaväylänä jatkui edelleen Mongolian halki Pekingiin saakka. ${ }^{121}$

Kesäkuun lopulla Granö ja Vokk saapuivat Ubsajärven eteläpuolelle, jossa he viettivät kolme viikkoa tutkien alueen muinaishautoja ja jäljentäen piirtokivien merkkejä. Tulkiksi ja apumieheksi oli palkattu eräs Altain telengiitti, Feodor, joka osasi paikallisten mongolien kieltä. Vaikka matka Mongolian järvialangolla sujui huomattavasti helpommin kuin edellisenä kesänä, ilman vaikeuksia ei sentään selvitty. Poikkeuksellisen kuivan kesän takia joet olivat kuivuneet niin tyystin, että kumppanukset olivat nääntyä janoon järvien välisillä sora- ja lentohiekka-alueilla. ${ }^{122}$

Järvialueelta Granö ja Vokk etenivät pohjoiseen Urjanhaihin, jossa tutkittiin kuukauden verran Jenisein lähdejokien alueita. Näiden alueiden muistomerkeistä oli aiemmin vain hajanaisia tietoja, joten Granön ja Vokkin löytämät

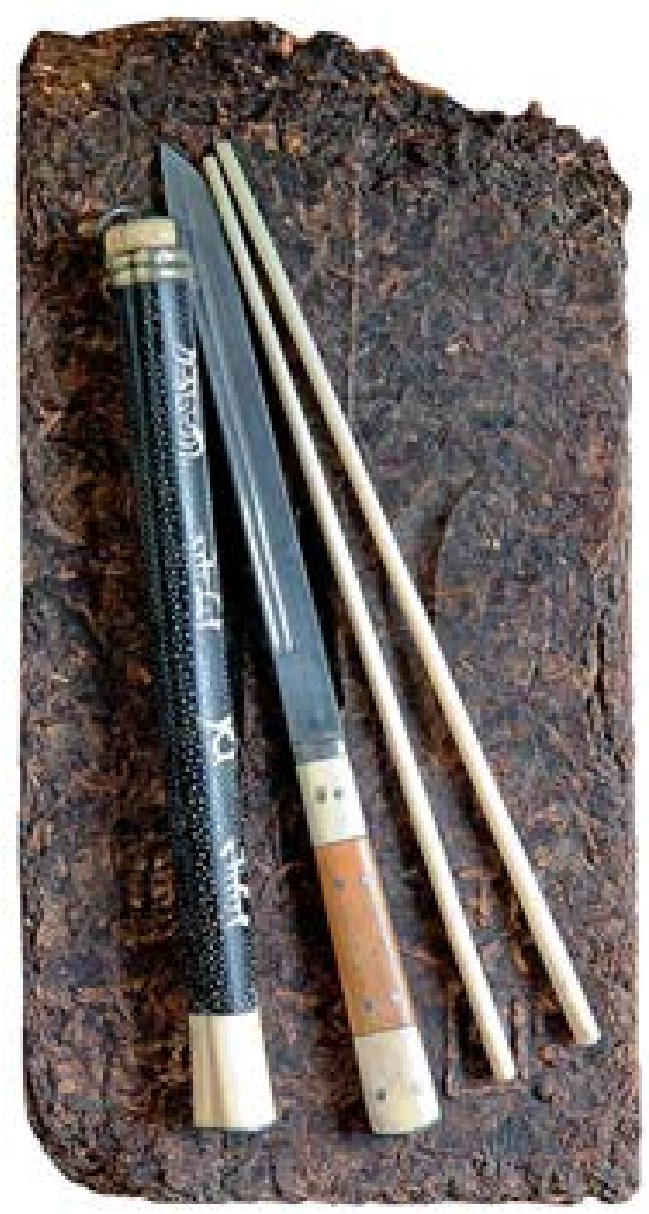

Tiiliteetä eli tiilen muotoon puristettuja teenlehtiä, norsunluiset syömäpuikot ja veitsi. kuvapatsaat ja kirjakivet antoivat uutta tietoa alueen kulttuurista. Löytöjen synnyttämää iloa pienensi se, että eräänä pimeänä heinäkuun yönä Feodor karkasi vieden mennessään kahden hevosen lisäksi osan matkavarusteista. ${ }^{123}$

Parin viikon kuluttua Granö sai palkatuksi uuden apulaisen, Semjonin, joka osasi hyvin sojoottien kieltä. Kun matka sujui nyt helpommin, Granö ei malttanut olla ottamatta mukaan miehen kokoista piirtokiveä, jonka he löysivät heinäkuun lopulla 
Jenisein lähdejoen Tšaa-kölin varrelta. Yli kaksimetrinen kivineula makasi kumollaan aron pölyn peitossa, mutta koska paikkaa asuttaneet sojootit kunnioittivat sitä pyhänä esineenä, se piti viedä vähin äänin. Granön laatima kaappaussuunnitelma oli yksinkertaisen tehokas: Väkivahva Vokk hiipi yön pimeydessä hiljaa paikalle ja koppasi kiven matkaan. ${ }^{124}$

Painavan kiven kuljettaminen Sajanin vuorten yli oli vaikea urakka, sillä käytössä oli vain kapeita ratsupolkuja. Operaatio toteutettiin siten, että kivi käärittiin kahteen huopaan ja pantiin purilaiden varaan hevosten vedettäväksi ja kiskottiin näin aina Minusinskiin Jenisein rannalle. Sieltä se kuljetettiin laivalla Krasnojarskiin, jossa se siirrettiin Siperian junaan. ${ }^{125}$

Kiven tuonti Suomeen oli pysähtyä Pietariin, jossa Granöltä vaadittiin lupaa sen viemiseksi pois Venäjältä. Lopulta tarvittavat luvat saatiin, ja niin kivi ehti juuri parhaiksi Helsingissä pidettyyn Suomalais-ugrilaisen Seuran vuosikokoukseen, jonka kohokohtiin kuului Granön matkaesitelmän lisäksi ensimmäisen Eurooppaan tuodun piirtokiven juhlallinen paljastaminen. ${ }^{126}$

Nykyisin Suomen Kansallismuseon kokoelmiin kuuluva kivi kertoo Harry Halénin mukaan vanhan vainajan viestin haudan takaa:

Minä olen Alp Urungu Tutuk. Minun oli erottava kamareissaan asuvista prinsessoistani ja kahdesta pojastani, teistä omistani, ainoasta tyttärestäni; nuorekkaista ikätovereistani ja ystävistäni erosin. En saanut enää nauttia sankareitteni seurasta. En enää saanut nauttia taivaallisesta maastani enkä johtavien ruhtinaiden seurasta. Jätin teidät 40 vuoden ikäisenä (tai 4. hallintovuotenani). ${ }^{127}$

\section{Pisin Mongolian-matka}

Granön väitöskirjan teemat alkoivat hahmottua toisen matkan aikana, joten hän päätti tehdä nopeasti valmiiksi tohtorin tutkintoon tarvittavat sivulaudaturit. Geologian sivutyön aiheen hän sopi Rosbergin ja Wilhelm Ramsayn kanssa ja eläin- 
tieteellisen sivulaudaturin teemaksi hän pyysi vuoden 1908 alussa J. A. Palménilta jotakin Omskin alueen sudenkorentoihin, heinäsirkkoihin ja arohyönteisiin liittyvää aihetta. Vanha professori ymmärsi kuitenkin oppilaansa erikoislaadun ja totesi tiukasti: "Se ei sovi sinulle yhtään. Kirjoita mieluummin eläinmaantieteen historiasta metodisesti aluejakoa selvittäen." ${ }^{128}$

Tämä sopi Granölle hyvin. Lähtiessään keväällä Siperiaan hän pakkasi laukkuihinsa Palménilta saamansa lähdekirjat, joihin tukeutuen hän julkaisi Maantieteellisen Yhdistyksen aikakauskirjassa 1909 tutkielman Piirteitä eläinmaantieteen historiasta, etenkin aluejakokysymystä silmällä pitäen. Kirjoituksessa hän tarkasteli kriittisesti globaaleja levinneisyys- ja aluejakokysymyksiä ja totesi, ettei aluejaon tulisi perustua levinneisyyteen vaan eläinkunnan ja ympäristön välisen "riippuvuustilan" alueellisiin vaihteluihin. Näin Palménin ohjeen kautta Granö paneutui ensimmäisen kerran aluejakokysymyksiin, jotka nousivat runsaan kymmenen vuoden kuluttua Virossa hänen keskeiseksi aihepiirikseen. ${ }^{129}$

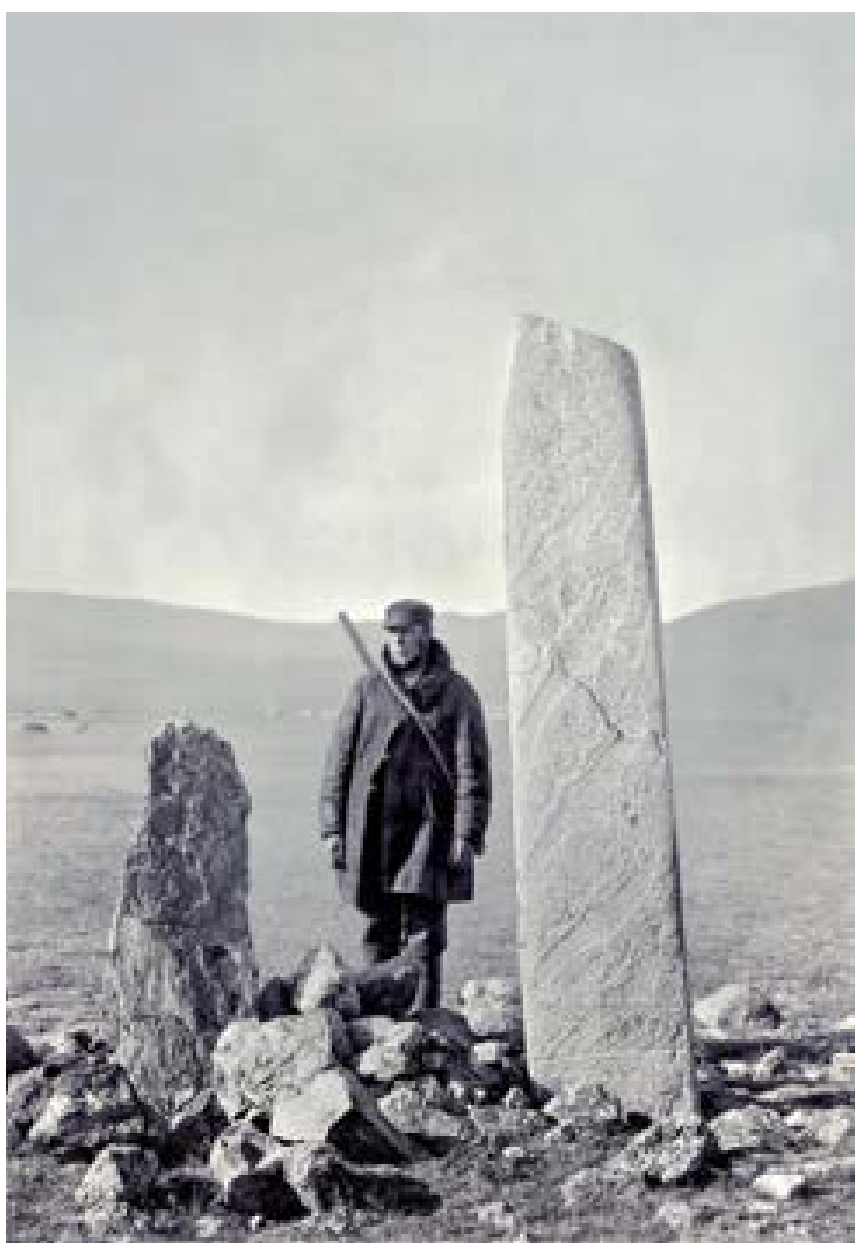

Hauta pystykivineen ja Tapani (Stepan) Unkuri. Mongolia, Hangaivuoristo 1909.

Opintojen hyvän etenemisen innostamana Granö suostui vuoden 1909 alussa Otto Donnerin pyyntöön tehdä vielä kolmas tutkimusmatka Mongoliaan. Granön ohella Suomalais-ugrilainen Seura lähetti itään myös toisen retkikunnan, jonka muo- 
dostivat mongolin kielen tutkija, tohtori G. J. Ramstedt ja tämän apulainen arkeologi, maisteri Sakari Pälsi. Matkan, jonka rahoittajina toimivat Donnerin ohella viipurilaiset kauppiaat Juho Lallukka ja Feodor Sergejeff, tavoitteena ei ollut niinkään uuden aineiston kokoaminen kuin varhaisemmin tehtyjen matkojen havaintojen täydentäminen ja kokoaminen. ${ }^{130}$

Tutkimusmatka alkoi toukokuun 21. päivänä 1909, jolloin Granö matkusti ensin junalla Helsingistä Pietarin ja Moskovan kautta Omskiin. Siellä hän oleskeli vanhempiensa luona vajaan viikon, jona aikana hän teki viimeiset matkavalmistelut. Omskista hän eteni kahdella höyrylaivalla Irtyšiä pitkin Semipalatinskin ohi Malo-Krasnojarskin kylään, josta matka jatkui edelleen postikyydillä Irtyšin sivujokeen Buhtarmáan laskevan Sarymsaktyn varrella olevaan Altaiskaja-stanitsaan. Kylä oli Venäjän Altain eteläpuoliskon keskuspaikka, jossa hän oli käynyt jo vuoden 1905 matkan aikana. ${ }^{131}$

Tällä kertaa Granön apulaisena oli Siperiassa syntynyt suomalainen Tapani (Stepan) Unkuri, jonka isä Matti Unkuri oli nuoruudessaan äkkipikaisuuksissa Ylihärmässä tekemästä taposta tuomittuna lähetetty omasta pyynnöstään Siperiaan. Bugene-siirtolasta kotoisin oleva Unkuri oli pitkä ja vankka nuorimies, joka puhui venäjää yhtä hyvin kuin äidinkieltään. Hänen kohtalonaan oli joutua ammutuksi vastavallankumouksellisesta toiminnasta tuomittuna Stalinin vainojen uhrina $1938 .{ }^{132}$

Altaiskaja-stanitsassa Granö ja Unkuri viettivät 10 päivää, jona aikana he tekivät lopulliset matkavalmistelut ja ottivat palvelukseensa erään kirgiisin, Turobai Aldajeffin. Tämä lupautui kuukausimaksua vastaan kuljettamaan matkalaisia ja heidän tavaroitaan omilla hevosillaan Venäjän Altailla ja Luoteis-Mongoliassa. Granö ja Unkuri käyttivät alkukesän Altain ja erityisesti sen Kiinan puoleisessa osassa olevien Kobdojärvien seudun tutkimiseen, sillä alue oli hyvin kiintoisa sekä muinaismuistojensa että jääkausigeologian kannalta. ${ }^{133}$

Aluetta hallitsee Venäjän, Kiinan ja Mongolian rajavuoristo, Tabun-Bodgo-uula, joka kohoaa 4400 metrin korkeuteen ja muodostaa Altain laajimman jätikköalueen. Siellä oli useita laaksoja, joita reunustivat porrasmaisesti ryhmittyneet moreenikerros- 

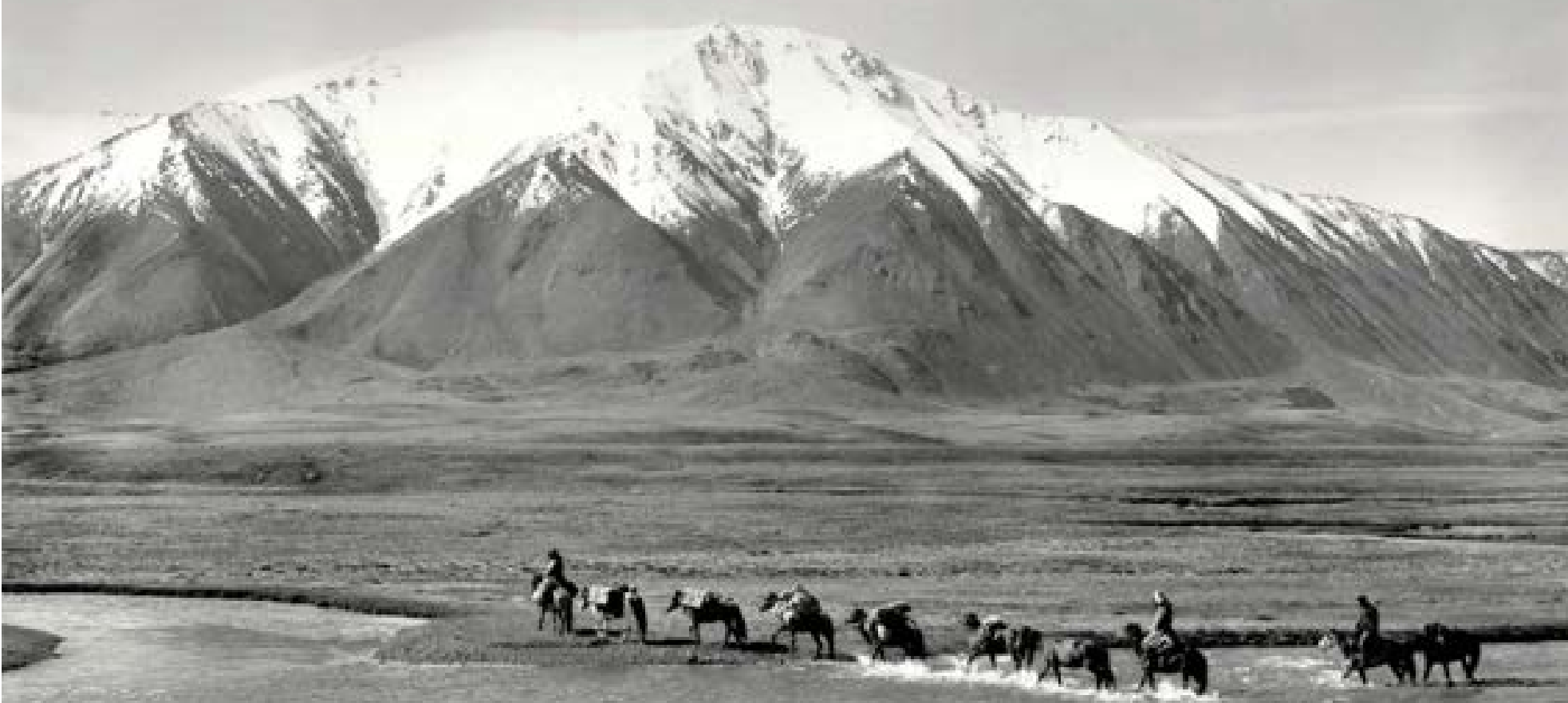

Heinäkuun alussa 1909 J. G. Granön retkikunta ylitti joen

Ülkön-Oigurin laaksossa Mongolian Altailla, lähellä Venäään rajaa.

tumat ja joiden alaosissa oli selviä päätemoreeneja. Näin ne muodostivat Granölle ratkaisevimman todisteen siitä, että Altain alue oli muinoin peittynyt jäätiköiden alle.

Granön oli tarkoitus edetä Kobdojärviltä Altain kautta takaisin Siperiaan. Suunnitelmaan tuli kuitenkin muutos, kun Turobai Aldajeff ja tämän avuksi palkattu Kosbatai Sudarhanoff varastivat retkikunnan hevoset voidakseen pitää ennakkopalkkiot ja päästäkseen omille teilleen. Vaikka hevoset onnistuttiin saamaan ta- 
Granö on itse antanut eloisan kuvauksen karavaanin etenemisestä:

Vastaamme tulee, täyttä laukkaa ratsastaen, joukko kelta- ja punakaapuisia buddhalaisia pappeja, lamoja. Mieliala on hilpeä, on ilmeisesti maistettu. Hidas menomme herättää naurua. Ohi vilahtaessaan he äänekkäästi tiedustelevat karjamme hyvinvointia. Tuossa lähestyy meitä köyhä mongoliäijä, pikku hölkkää ratsastaen. Kaipa matkalla johonkin naapurijurttaan, missä viinaa parhaillaan tislataan. Ukko kääntää hevosensa ja seuraa meitä hyvän matkaa, udelleen keitä olemme ja mitä kummaa Hangaissa teemme... Kärryt eivät ole voiteessa. Kuivat puuakselit vinkuvat ja narisevat pahanpäiväisesti, ja tällaisia akseleja on karavaanissa usein toista sataa. Karavaanimiehet ratsastavat jonon edessä tai sivuilla, hoilottaen täyttä kurkkua pitkäveteisiä laulujaan. Joku miehistä ajaa edellään muutamia lampaita, jotka matkan varrella teurastetaan sitä mukaa kuin tarve vaatii. Illalla, karavaanin käydessä yölevolle, kärryt asetetaan kehään jonkinlaiseksi vaunulinnaksi, jonka keskelle matkateltta pystytetään. ${ }^{136}$

Matkareitin muutoksen aiheuttamaa harmia lievensi hieman se, että Granö tapasi sattumalta 11. elokuuta Hangaivuorilla Suomalais-ugrilaisen Seuran Länsi-Mongolian stipendiaatit G. J. Ramstedtin ja Sakari Pälsin. Kolmen suomalaisen yllättävä kohtaaminen Aasian sisäosissa oli kaikille miellyttävä yllätystapaaminen, jonka Tapani Unkuri ikuisti Granön kameralla ottamallaan valokuvalla. ${ }^{137}$

Koko matkan aikana Granö teki luonnontieteellisiä havaintoja, keräsi kasveja sekä kokosi tietoja muinaismuistoista, hautakummuista, ihmishahmoisista kivistä ja pystykivistä, joihin oli hakattu erilaisia kuvioita ja kirjoituksia. Matkan merkittävin luonnonnähtävyys oli Orhonjoen sivuhaaran Tamirjoen varrelta Keski-Mongoliasta tavattu, tasaisesta sorakentästä 15 metrin korkeuteen kohonnut pystysuora graniittipaasi, mongolien "taihir-kivi". Kiven kaikkiin sivuihin oli kirjailtu muinaisturkkilaisia, mongolialaisia ja kiinalaisia piirtokirjoituksia, joita muun muassa Pentti Aalto tutki myöhemmin. ${ }^{138}$ 


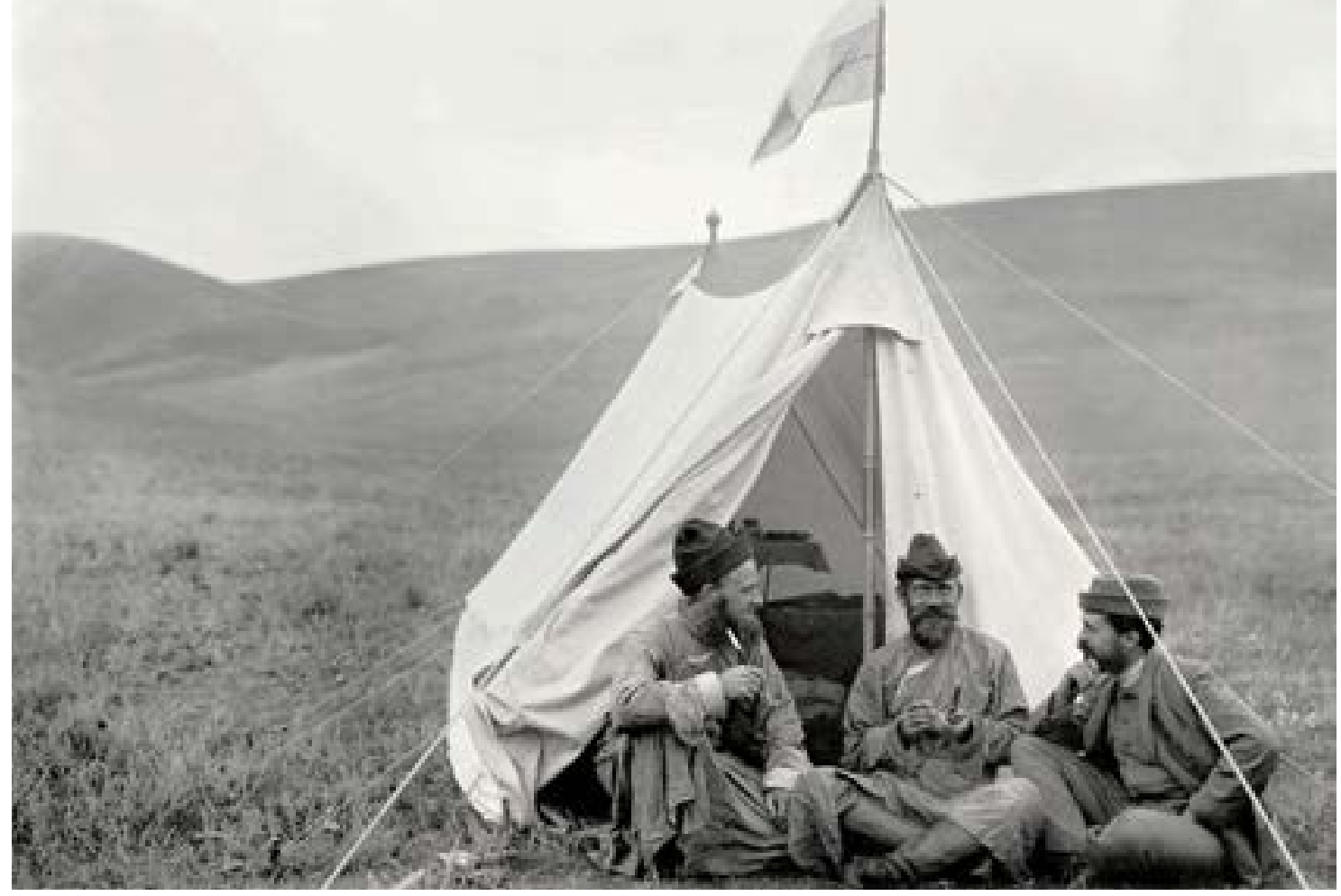

J. G. Granö koki elokuussa 1909 Pohjois-Mongolian Hangaivuorilla miellyttävän yllätyksen, kun hän sattumalta kohtasi mongoleiksi pukeutuneet suomalaiset tutkimusmatkailijat G. J. Ramstedtin (keskellä) ja Sakari Pälsin (vasemmalla). Miehet viettivät mukavan iltapuhteen kokemuksiaan kertoillen ja Alma Granön valmistamia herkullisia eväitä nauttien. Teltan harjassa liehui sinivalkoinen viiri.

Matkan päätepisteessä Urgassa Granö ja Unkuri havaitsivat erään ”luonteenomaisen piirteen” kaupunkilaisten elämässä:

Aamuisin käyvät kaupungin asukkaat, sekä miehet että naiset, luonnollisella tarpeellansa kaupungin kaduilla; Joka taholla näkee ihmisiä istumassa. Istuvien takana on joka paikassa pari kolme katukoiraa odottamassa ulostuksia. Näin toimittavat nälkäiset katukoirat, joita on satoja Urgassa, puhtauspoliisin tehtäviä. ${ }^{139}$ 
Miehet lähtivät Urgasta niin nopeasti kuin mahdollista pohjoiseen Venäjän puolelle Kjahtaan ja sieltä edelleen Baikaljärven rannalle Siperian radan varteen. Kolmas ja samalla Granön Mongolian matkoista pisin päättyi syyskuun 22. päivänä, jolloin miehet nousivat junaan Verhne-Udinskissa ja aloittivat neljä ja puoli vuorokautta kestäneen kotimatkan Jenisein jokialueen suurten metsien ja Länsi-Siperian ruohoaavikon halki Omskiin. ${ }^{140}$

Granö julkaisi arkeologisten tutkimusmatkojensa tuloksia kolmessa 1909-10 ilmestyneessä tutkimuksessa: Archäologische Beobachtungen von meinen Reisen in den nördlichen Grenzgegenden Chinas in den Jahren 1906 und 1907, Archäologische Beobachtungen von meiner Reise in Südsibirien und der Nordwestmongolei im Jahre 1909 ja Über die geographische Verbreitung und die Formen der Altertümer in der Nordwestmongolei.

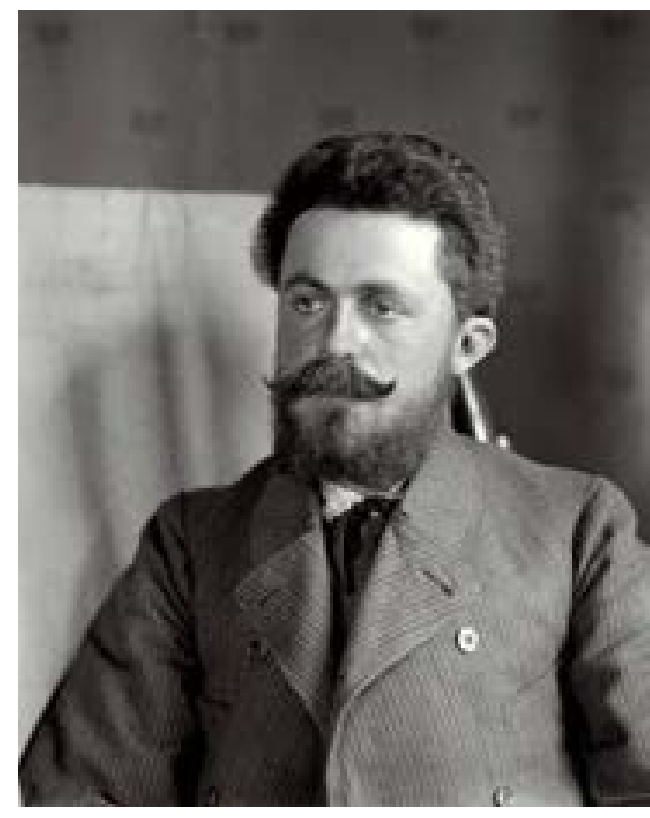

J. G. Granö valokuvattuna Omskissa välittömästi kolmannen arkeologisen tutkimusmatkansa jälkeen marraskuussa 1909.

\section{Teokset keskittyivät pääosin arkeologisten löytöjen}

systemaattiseen ja kuvailevaan esittelemiseen, mutta viimeisessä työssään Granö valotti myös eri muinaisjäännöstyyppien esiintymistä eri seuduilla ja niiden suhdetta luonnonympäristöön ja taivaankappaleiden liikkeisiin. Hänen mukaansa muinaisjäännökset keskittyivät aroseuduille, jotka olivat otollisimmat paimentolaisuudelle. Sen sijaan metsäalueilta arkeologisia muistomerkkejä ei ollut löytynyt. ${ }^{141}$

Granön päätös keskittyä muinaismuistojen luettelointiin, kuvaamiseen ja levinneisyyden kartoittamiseen osoittautui hyväksi ratkaisuksi, sillä hänen sadoilla piirustuksillaaan ja valokuvillaan tuli olemaan pysyvää tutkimuskäyttöä. Useat venäläiset tutkijat, kuten V. D. Kubarev ja D. Tseveendorj, ovat käyttäneet hyväkseen hänen tekemiään piirroksia vielä 2000-luvulla. Suomen Muinaismuistoyhdistys kutsui Granön vakinaiseksi jäsenekseen 1919 ja kunniajäsenekseen 1940. ${ }^{142}$ 


\section{IETEELLISEN URAN VAKIINNUTTAMINEN}

\section{Väitöskirja}

Kolmannen matkan aikana Granö sai koottua niin paljon maantieteellistä havaintoaineistoa, että hän katsoi olevansa valmis saattamaan väitöskirjatyönsä loppuun. Palattuaan kotiin Omskiin hän anoi syyskaudeksi virkavapautta yliopiston assistentin toimesta ja keskittyi vanhempiensa hoivissa täysin kirjoitustyöhön. Tavoitteena oli yhdistää tutkimusmatkojen aikana kertyneet kenttähavainnot Albrecht Penckin ja Eduard Brücknerin jääkausiteorioihin sekä laajaan, Siperiaa, Mongoliaa ja erityisesti Altaita käsittelevään tutkimuskirjallisuuteen.

Altai oli jo pitkään vetänyt eri syistä tutkijoita puoleensa. 1700-luvulta lähtien aluetta olivat tutkineet muun muassa saksalaiset Johan Georg Gmelin, Peter Simon Pallas ja Friedrich von Gebler sekä suomalais-ruotsalainen Eric Laxman. Yleismaantieteen perustajana pidetty Alexander von Humboldt kävi alueella 1829, samoin Tarton yliopiston kasvitieteen professori Carl Friedrich von Ledebour ja myöhempi Pietarin akateemikko Alexander von Bunge, jota voi pitää ensimmäisenä Altain kasvillisuuden tutkijana. ${ }^{143}$

1800-luvulla Altailla samoilivat myös sekä suomalaisugrilaisten kansojen kantaaluetta etsineet tutkijat, kuten virolainen kielitieteilijä, myöhempi Pietarin akateemikko Ferdinand Johann Wiedemann ja suomalaiset A. J. Sjögren ja M. A. Castrén. Toisen Pietarin akateemikon Gregor von Helmersenin osoitettua kiinnostusta alueen luonnonvarojen hyödyntämiseen vastuu alueen tutkimisesta siirtyi venäläisille tutkijoille, mutta vielä 1910-luvun lopulla myös suomalaiset geologit etsivät Altailta ja sen lähialueilta kultaesiintymï. Erityisen tarkkaan Granö perehtyi Venäjän Maantie- 


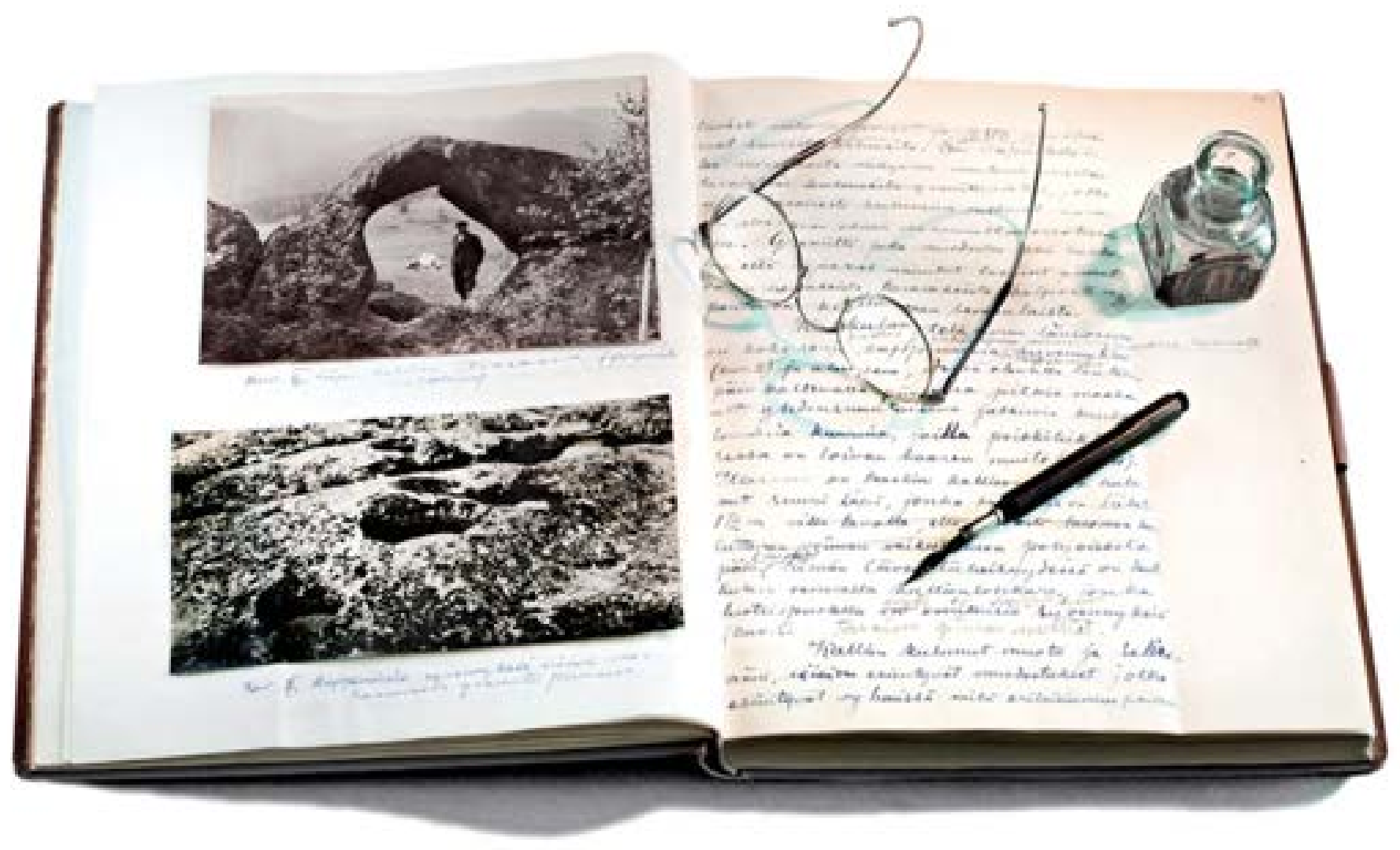

J. G. Granön 1913 ilmestyneen väitöskirjan Beiträge zur Kenntnis der Eiszeit in der nordwestlichen Mongolei und einigen ihrer südsibirischen Grenzgebirge käsikirjoitus.

teellisen Seuran Länsi-Siperian osaston julkaisemaan kirjallisuuteen, muun muassa Pjotr K. Kozlovin, V. V. Sapožnikovin ja S. A. Jakolevin teoksiin. ${ }^{144}$

Granö oli kuitenkin ensimmäinen tutkija, joka pyrki soveltamaan Penckin ja Brücknerin Euroopan Alpeilla kehittämää jääkausiteoriaa laajasti ja systemaattisesti Altailla. Tehtävä oli vaativa. Jo ennen kuin hän saattoi aloittaa varsinaiset tutkimuksensa, hänen täytyi kartoittaa laaja tutkimusalue, sillä Altain kartat olivat Alppeihin 
verrattuna usein ylimalkaisia ja puutteellisia. Tämä merkitsi, että hänen oli selvitettävä muun muassa kompassin, teodoliitin, kulmaprisman, bussolin ja aneroidibarometrin avulla kulloisenkin asemapaikkansa sijainti sekä horisontaalisesti että vertikaalisesti. ${ }^{145}$

Kun Granö sitten aloitti varsinaisen tutkimuksensa, hän koki heti alkuun takaiskun. Altailla laaksojen suilla ei ollut samanlaisia reunamoreeneja kuin Alpeilla, minkä vuoksi Granön oli kehitettävä uusi tutkimusmetodi, joka perustui pääjokien sivulaaksoihin muodostuneiden terassien sijaintiin toisiinsa nähden. Tämä merkitsi laajan havaintomateriaalin kokoamista Keski-Aasian vuoristojen pintamuodoissa ja maalajipeitteessä havaittavista muinaisen jäätikkötoiminnan jäljistä. ${ }^{146}$

Tutkimusmatkojen aikana tehtyihin geomorfologisiin ja geologisiin havaintoihin perustunut väitöskirja Beiträge zur Kenntnis der Eiszeit in der nordwestlichen Mongolei valmistui ankaran työrupeaman jälkeen loppuvuonna 1909. Työ painettiin Helsingissä vuodenvaihteen jälkeen, mutta väitöstilaisuus oli vasta toukokuun 28. päivänä 1910. Väittely sujui akateemisen arvokkaasti Theodor Homénin toimiessa kustoksena ja J. E. Rosberg vastaväittäjänä. Granö oli Rosbergin ja Iivari Leiviskän jälkeen kolmas maantieteessä väitellyt tutkija. ${ }^{147}$

Väitöskirjassaan Granö kykeni osoittamaan monipuolisen havaintoaineiston avulla vakuuttavasti, että vanhat käsitykset, joiden mukaan Altailla ei ole ollut jääkautista jäätiköitymistä, olivat virheellisiä. Luoteis-Mongoliassa ja Etelä-Siperiassa ei ollut ollut vain yhtä vaan ainakin kaksi erillistä jäätiköitymisvaihetta, ja lisäksi alueelta löytyi merkkejä vielä kolmannesta vanhasta jäätiköitymisestä. Keskeisen todistusaineiston muodostivat kolmannen matkan aikana Tabun-Bodgo-uulassa tehdyt havainnot. ${ }^{148}$

Granö oli ainoa ei-venäläinen tutkija, joka tuolloin tutki Altaita, joten hänen väitöskirjansa herätti laajaa kiinnostusta tieteellisissä piireissä. Tutkimusta kiitettiin yleisesti, ja se jäi pitkäksi ajaksi tärkeimmäksi Siperian eteläisten rajavuoristojen jääkautta selvittäväksi tietolähteeksi. Granön havaintoaineiston runsautta, tulkinnan perinpohjaisuutta ja esityksen selväpiirteisyyttä ylistettiin useissa alan aikakauslehdissä. Monet tutkijat, kuten A. Allix, V. V. Sapožnikov, Alexander Supan ja Louis Ravenau esittivät 
kiittäviä arvioita hänen näkemyksistään jääkautisen jäätiköitymisen levinneisyydestä ja merkityksestä Altain pinnanmuotojen kehityksessä. ${ }^{149}$

Arvovaltaisimman tunnustuksen työstään Granö sai itseltään Albrecht Penckiltä. Tämä totesi Rosbergille 1910 kirjoittamassaan yksityiskirjeessä perehtyneensä huolella Granön kirjaan ja tunteneensa suurta iloa siitä, että

\begin{abstract}
Granö laajentaa tietämystämme Keski-Siperian jääkaudesta mittavammin kuin kukaan aiemmin, ja olen häneltä myös muuten löytänyt joukon maantieteellisiä tosiseikkoja, joita voin seuraavilla Aasian-luennoillani menestyksellisesti käyttää. ${ }^{150}$
\end{abstract}

\title{
Dosentti, opettaja ja valistaja
}

Granön asema maantieteen laitoksella oli vahvistunut 1908, jolloin hän sai nimityksen vakinaiseksi assistentiksi. Nimityksen jälkeen laitoksen työnjako oli selkeä: Granö johti apulaisesimiehenä approbatur-arvosanaa tekevien opiskelijoiden opintoja, kun taas Rosberg vastasi korkeimpia arvosanaa varten vaadittavien käytännöllisten harjoitustöiden ohjaamisesta ja 1908 maantieteen dosentiksi nimitetty Iivari Leiviskä keskittyi luentojen pitämiseen. Harjoitustyöt koostuivat pääasiassa profiilien ja karttojen piirtämisestä sekä kenttämittaustehtävistä. Laitoksen perinteiset kesäretkeilyt suuntautuivat muun muassa Pohjois-Suomeen, Lohjan seudulle, Kokemäenjoen laaksoon ja Karjalan kannakselle. ${ }^{151}$

Granön ja Leiviskän nimitykset aloittivat yliopistomaantieteen vahvistumisvaiheen, jonka taustalla oli erityisesti suomenkielisten maantieteen opiskelijoiden määrän nopea kasvu. Kun Suomen eduskunta oli 1910 lausunut toivomuksen, että yliopiston konsistori ryhtyisi toimiin, joiden avulla opiskelijoille voitaisiin turvata keskeytymätön ja täydellinen opetus omalla äidinkielellään, maantieteen opettajakunnan lisääminen koettiin välttämättömäksi. Rosberg oli pyrkinyt palvelemaan kyökkisuomellaan suomenkielisiä opiskelijoita, mutta aivan tankkaamiseksi 


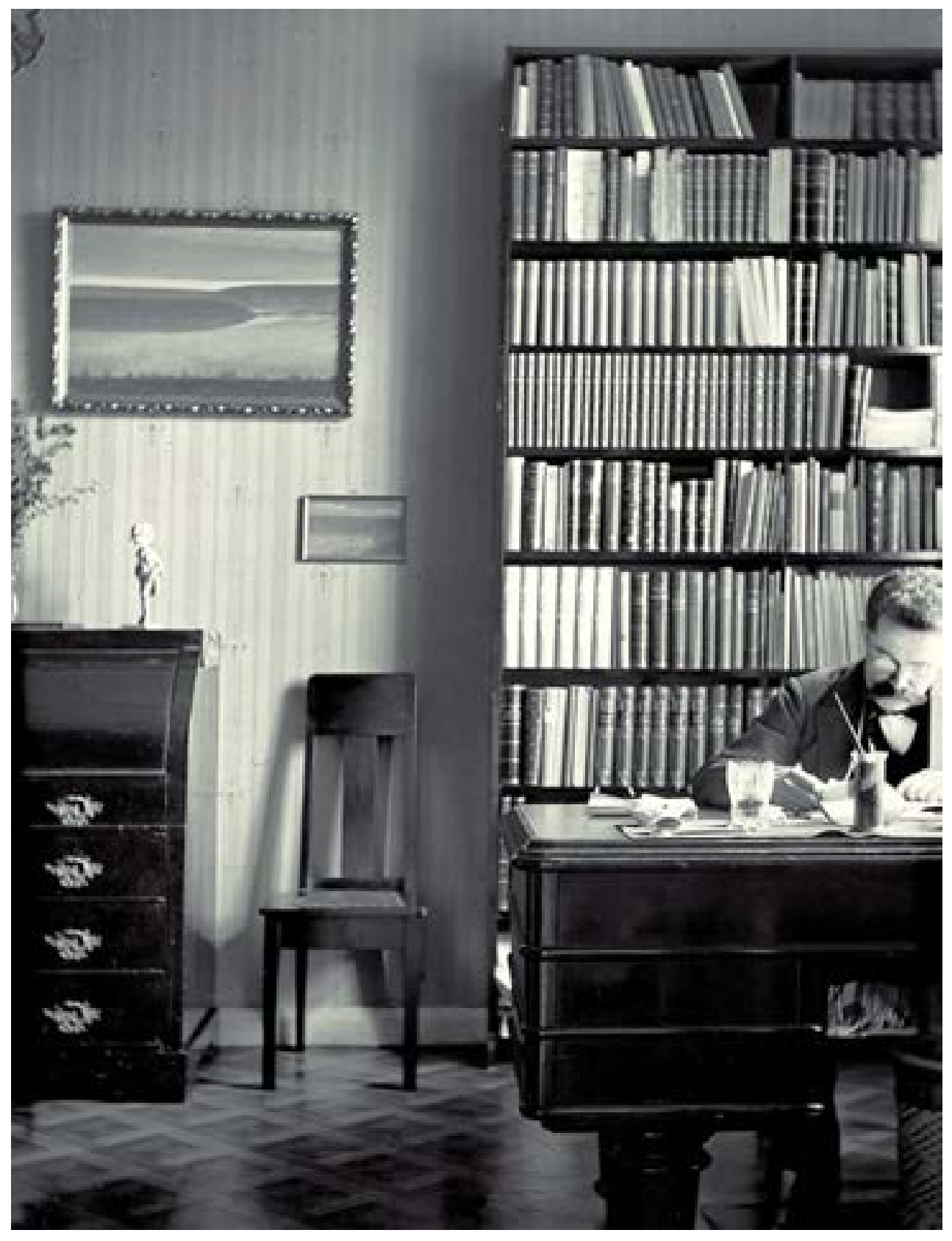

96 | Siperia opettaA 
J. G. Granö työhuoneessaan Kruunuvuorenkadulla Helsingin Katajanokalla 1912 ennen muuttoa Siperiaan. menneet luennot olivat olleet kiusallisia sekä pitäjälleen että kuulijoille. ${ }^{152}$

Kun yliopiston fyysis-matemaattinen osasto oli hyväksynyt helmikuun alussa

1911 Granön lisensiaatintutkinnon aineyhdistelmällä maantieteessä laudatur, geologiassa ja mineralogiassa approbatur ja eläintieteessä approbatur, hän saattoi anoa nimittämistään maantieteen dosentiksi. Rosbergin kirjoitettua assistenttinsa ansioista lausunnon, jossa ylistettiin hänen taitojaan sekä tutkijana että opettajana, konsistori hyväksyi yksimielisesti Granön nimityksen maantieteen dosentiksi 10. toukokuuta 1911. Hänen asemaansa tiedeyhteisössä vahvisti kutsu Suomalaisen Tiedeakatemian apujäseneksi $1912 .{ }^{153}$

Myönteisen kehityksen päätteeksi Rosberg sai 1912 nimityksen maantieteen ensimmäiseksi varsinaiseksi professoriksi. Samalla maantieteen laitos sai myös amanuenssin viran. Tehtävää ryhtyi hoitamaan Ernst Häyrén, joka oli toiminut aiemmin Granön tapaan laitoksen ylimääräisenä assistenttina. Uudet virat olivat tärkeitä maantieteen kehitykselle, sillä ne toivat tieteenalan piiriin myös lähitieteissä oppinsa saaneita tutkijoita ja eräällä tapaa sitoivat haltijansa edistämään maantieteellistä tutkimusta. ${ }^{154}$

Leiviskän ja Granön ansiosta maantieteen suomenkielisen opetuksen taso parani ratkaisevasti. Kun he kantoivat päävastuun suomenkielisestä opetuksesta, Rosberg saattoi pitää luentonsa äidinkielellään. Miesten merkitystä opetuksen tason kohentumiseen lisäsi se, että he kaikki olivat osallistuneet 1910 ilmestyneen maantieteilijöiden saksalais-suomalaisen sanaston laadintaan. ${ }^{155}$

Leiviskä johti pääosin laitosta Rosbergin useiden virkavapauksien aikana, mutta myös Granö hoiti esimiehen tehtäviä alkuvuonna 1909 ja suurimman osan syyslukukautta 1911. Osallistuessaan tuolloin fyysis-matemaattisen osaston kokouksiin hän oli yksi ensimmäisistä suomen kieltä käyttäneistä tutkijoista. ${ }^{156}$

Granön ensimmäiset luennot käsittelivät yleistä maantiedettä, Aasian maantiedettä, matemaattista maantiedettä ja ilmasto- ja eliömaantiedettä. Hänen erinomai- 


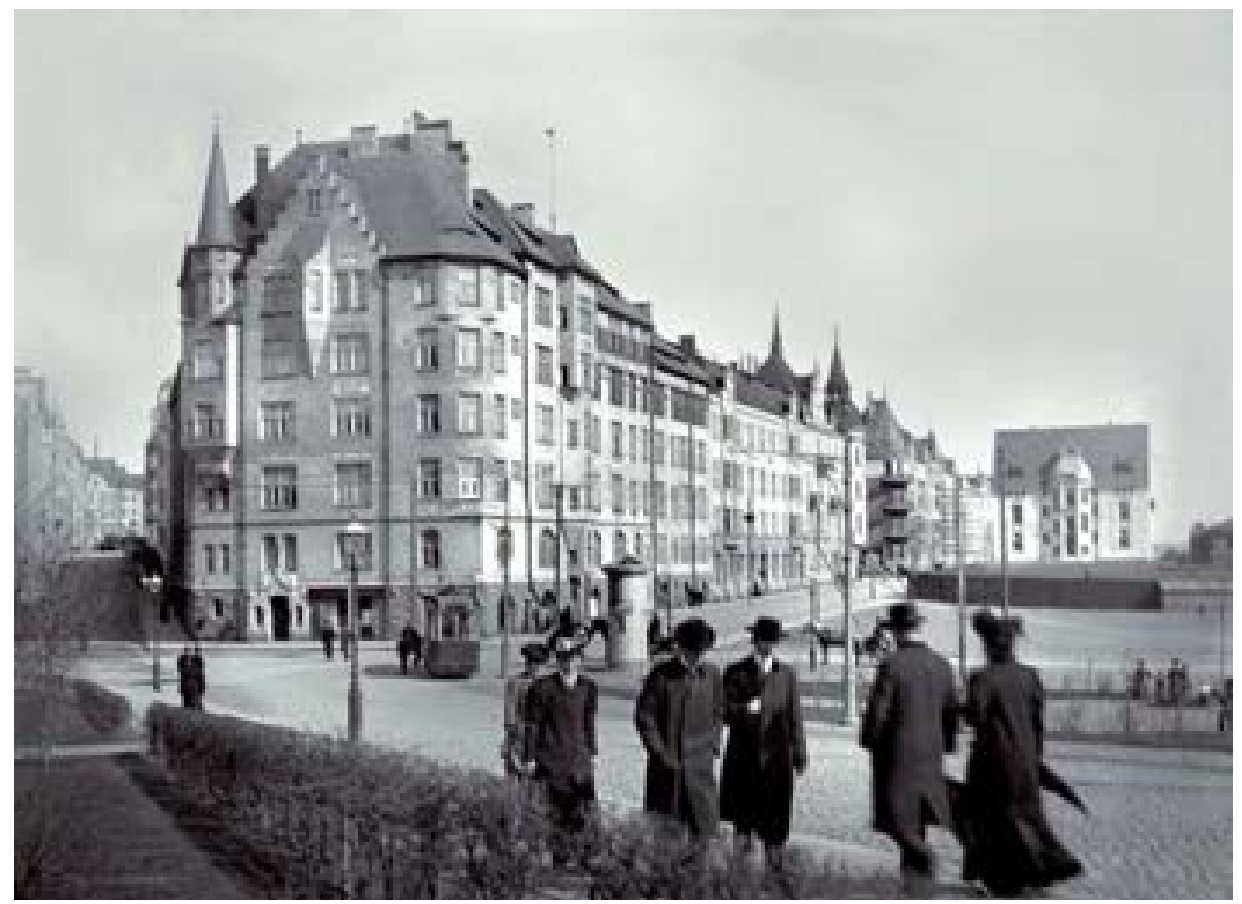

Katajanokkaa 1900-Iuvun alussa.

set opettajanlahjansa johtivat siihen, että hänen luentojaan kuunteli jo ensimmäisenä vuonna lähes 100 opiskelijaa, eli selvästi enemmän kuin Rosbergin ja Leiviskän luentoja. Luentojen ohella Granö ohjasi kartanpiirustustöitä ja erilaisia harjoitustöitä sekä johti seminaareja. ${ }^{157}$

Granön oppilaisiin liittyi 1910-luvun vaihteessa proviisoriksi ja filosofian kandidaatiksi kemia pääaineenaan valmistunut J. K. V. Tuominen, joka oli päättänyt vaihtaa alaa ja pätevöityä oppikoulun luonnonhistorian ja maantieteen opettajaksi. Tuominen saattoi nopeasti maantieteen opintonsa loppuun ja ystävystyi samalla läheisesti Granön kanssa. Granön matkustettua 1913 Altaille miehet aloittivat kirjeenvaihdon, joka kesti yli neljä vuosikymmentä. ${ }^{158}$

Muutettuaan tätinsä Hanna Lignellin luota poikamiesasuntoon Kruunuvuorenkadulle Katajanokalle Granö ei tullut enää toimeen assistentin palkalla ja yliopistosta saaduilla satunnaisilla palkkioilla, vaan hänen oli hankittava lisäansioita. Hän oli hoitanut jo vuoden 1902 alussa matematiikan ja luonnonhistorian kollegan viran- 
sijaisuutta Tornion alkeiskoulussa, joten aineopettajan tehtävät olivat luonteva vaihtoehto. Hän toimi opettajana Helsingin suomalaisessa jatko-opistossa 1906-13 ja Helsingin suomalaisessa tyttökoulussa 1907-08 ja 1912-13 sekä saman koulun yliopistoon johtavilla jatkoluokilla 1913. ${ }^{159}$

Granö suhtautui maantieteen kouluopetukseen niin vakavasti, että julkaisi 1908 koulukomitean työtä pohtineen artikkelin Maantieteellisen Yhdistyksen aikakauskirjassa. Hänen mielestään maantieteen opetuksen tuli olla elävää, kiinnostavaa ja oppilaiden ajatuskykyä kehittävää. Opettajan tuli olla aktiivinen ja keskittyä käsittelemään liian laveiksi kirjoitetuista maantiedon oppikirjoista vain tärkeimmät asiat. Tunneilla ei saanut missään tapauksessa kuluttaa aikaa pelkkien karttojen piirtämiseen. Opetuksessa tuli pääosin käyttää vain isoja seinäkarttoja, joihin merkittiin aina tunnin teeman kannalta keskeiset paikat, rajat ja viivat. ${ }^{160}$

Opettajan tehtävien ohella Granö kirjoitti 1910-luvun alussa tieteellisiä artikkeleita ja esitteli uutta maantieteellistä kirjallisuutta Uudessa Suomettaressa. Vuonna 1910 hän antoi lehden lukijoille perusteellisen kuvauksen juuri ilmestyneen Suomen Kartaston toisen painoksen sisällöstä. Hän ennakoi, että asultaan kaunis ja sisällöltään erinomainen kartasto tuli todennäköisesti saamaan ensimmäisen painoksen tavoin hyvän vastaanoton ulkomailla: "Se on varmaankin kaikkialla sivistyneessä maailmassa herättävä yhä kasvavaa myötätuntoa maatamme kohtaan ja hankkiva tunnustusta sen aikaansaamiseksi uhratulle työlle."

Kartasto oli Granön mielestä kuitenkin ennen kaikkea Suomen tieteen kansalleen omistama selonteko työstään. Siksi hän toivoi sen löytävän tiensä virkamiesten huoneiden lisäksi kouluihin ja sellaisiin koteihin, joissa ymmärrettiin antaa arvoa isänmaan tuntemiselle. ${ }^{161}$

\section{Maantieteen aseman vahvistaja}

Saavutettuaan tohtorin arvon Granö katsoi velvollisuudekseen ryhtyä ajamaan maantieteen asemaa julkisuudessa. Maantieteellisen Yhdistyksen Aikakauskirjassa 1910 
julkaisemassaan artikkelissa "Maantieteen maakuntajaon perusteista" hän esittelee uusia näkemyksiä maantieteen tutkimuskohteista ja -menetelmistä, rajoista ja tehtävistä. Arvostellessaan vuoden lopulla juuri ilmestyneen Ragnar Hultin teoksen Suomen maantieto kolmatta painosta hän ilmoitti selkeästi arvostavansa suomalaisen maantieteen uranuurtajan työtä. Hänen mukaansa kaikki maantiedon opettajat ja lukijat tervehtivät varmasti ilolla uuden, korjatun painoksen ilmestymistä, sillä Hultin johdonmukainen teos oli sopiva ja tarpeellinen täydennys uusille maantiedon

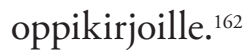

Maantieteen asemaa Granö käsitteli myös Uudessa Suomettaressa lokakuussa 1910 ilmestyneessä I. K. Inhan Saksanmaa-teoksen arvostelussa. Hän totesi, että maantieteelliselle kirjallisuudelle Suomessa asetetut vaatimukset olivat olleet sangen pienet, sillä se oli ollut usein vain se "romukasa, jonne kaikenmoiset kynäilijät ovat tuoneet sameista lähteistä saamansa tiedot". ${ }^{163}$

Maantiede oli kuitenkin jo aloittanut nousunsa alennustilastaan. Se oli tieteeksi tunnustettu, ja sillä oli oma metodinsa, joka erotti sen itsenäiseksi rajatieteistä. Tieteenalan edistystä oli hidastanut se, että maantieteellisten kuvausten kirjoittaminen ei ollut suinkaan helppo tehtävä. Maantieteilijän oli kyettävä antamaan tiedonhaluisille vastaus vaikeaan vaikka tavalliseen kysymykseen, minkälaista siellä on, ja kyettävä asettamaan sanansa niin, että
... kulloinkin kyseessä olevan maan ulkomuoto ja elämän eri puolet tulevat tasasuhtaisesti ja oikein esitetyiksi sekä samalla sillä tavalla, että eri paikkakun- tien maantieteellinen yhteenkuuluvaisuus mahdollisimman vähissä määrin tu- lee rikotuksi. Hänen tulee edelleen pitää huolta siitä, että maantieteelliset syyt ja seuraukset luonnollisella tavalla esiintyvät toisistaan riippumatta. ${ }^{164}$

Granön mukaan Inha oli ollut tietoinen työnsä vaikeuksista. Hän oli syventynyt tehtävään huolella ja tutustunut perinpohjaisesti Saksan oloihin. Hänen tekstinsä oli tieteellisesti perusteltua ja jodonmukaisesti etenevää vaikka keskittyi liikaa yksi- 
tyiskohtien kuvaamiseen ja yleisten tieteellisten lakien selostamiseen. Granö päätti arvionsa opettajaansa J. A. Palménia ja muita Suomen Maantieteellisen Seuran johtomiehiä vastaan suunnattuun toteamukseen:

Maantieteelliset ilmiöt voidaan kyllä selvittää helppotajuisella ja oikealla tavalla ilman minkäänlaisia täydennysselostuksia. Niihin turvautumalla annetaan myös tukea sille ennestän jo eräillä tahoilla vallitsevalle käsityskannalle, ettei maantieteellä ole koossa pitävää selkärankaa, vaan että se on irtainta yhtymää, konglomeraattia, mitä erilaisimmista aineksista. ${ }^{165}$

Etsiessään maantieteelle tukevaa selkärankaa Granö tutustui Immanuel Kantin näkemyksiin maantieteestä. Länsimaisen filosofian keskeisiin hahmoihin kuulunut Kant oli syventynyt 1700-luvun jälkipuoliskolla Königsbergissä eli nykyisessä Kaliningradissa perusteellisesti maantieteen olemukseen. Hän painotti Strabonin ja Ptolemaioksen tapaan, että ihmisen ja luonnon toiminnan tarkasteleminen kuului maantieteen eikä politiikan alaan.

Kantin mukaan maantieteelle oli erityistä korologinen eli alueellinen näkökulma, joka erotti sen kronologiaan perustuvasta sisartieteestään historiasta. Se ei vielä ollut tiede samassa merkityksessä kuin teoreettiset tieteet, kuten filosofia, matematiikka tai fysiikka, vaan pikemminkin historian ja antropologian tavoin propedeuttinen, empiirinen tiede. Jos se kiinnittäisi enemmän huomiota teorianmuodostukseen ja lainalaisuuksien löytämiseen, sillä olisi hyvät edellytykset saavuttaa eksaktin luonnontieteen asema. ${ }^{166}$

Kantin näkemys maantieteen olemuksesta ja kehitysmahdollisuuksista oli Granölle kuin vesi janoiselle. Jo Suomen ensimmäisillä maantieteilijäpäivillä 1912 pitämässään esitelmässä hän viittasi Königsbergin viisaan ajatuksiin siitä, minkälaista maantieteellisen tutkimuksen tulisi olla. Samalla hän sai tukevan perustan, jolle saattoi alkaa rakentaa omaa tulkintaansa maantieteen olemuksesta. ${ }^{167}$ 


\section{Uudet tutkimustavoitteet}

Väitöskirjan jälkeen Granö jatkoi tutkimusmatkojen aikana kertyneen aineiston hyödyntämistä julkaisemalla 1911-12 arvostetuissa maantieteellisissä sarjoissa Petermanns Geographische Mitteilungenissa ja Zeitschrift für Gesellschaft für Erdkunde zu Berlinissä kuvauksia matkojensa tuloksista. Kirjoitukset avasivat hänen kansainvälisen julkaisutoimintansa ja veivät hänen väitöskirjansa tulokset laajan saksankielisen tutkijayhteisön tietoon. Granön nopeasti saavuttamaa mainetta osoitti muun muassa se, että hänet värvättiin kirjoittamaan saksalaiseen Brockhaus Konversations-Lexikoniin Siperiaa ja Mongoliaa koskevia artikkeleita. Hänet kutsuttiin myös esitelmöimään tutkimuksistaan Leipzigiin ja Berliiniin, mutta hän joutui kieltäytymään tarjouksista uusien tutkimusmatkojen vuoksi. ${ }^{168}$

Kesällä 1911 Granöllä oli mahdollisuus laajentaa maantieteellistä näkemystään, kun hän saattoi seurata apulaisena ja urkurina isäänsä Johannesta pitkälle Aasian itäosiin suuntautuneelle matkalle. Matkan aikana Granöt kävivät Itä-Siperian vanhan vankikeskuksen Nertšinskin, Amurinmaan ja Vladivostokin ohella Japanissa, jossa he vierailivat Suomen Luterilaisen Evankeliumiyhdistyksen lähetysasemilla. ${ }^{169}$

Suomen senaatin tukeman matkan tarkoitus oli etsiä Kaukoitään ajautuneita suomalaisia ja tarjota heille hengellisiä palveluita. J. G. Granön kannalta kysymys oli lähinnä turistimatkasta, jonka huippukohta oli Japanin taikavuoren, valkohuippuisen Fujin, näkeminen. Tyylilleen uskollisena hän teki kuitenkin matkan aikana tieteellisiä havaintoja ja vertailuja. Hän kiinnitti muun muassa huomiota siihen, että ennen Siperian radan valmistumista Vladivostok oli lähempänä amerikkalaista kuin venäläistä kulttuuria. ${ }^{170}$

Japanin-matka sattui Granön ajattelun kehittymisen kannalta otolliseen ajankohtaan. Hän oli aloittanut Altain tutkimuksensa Albrecht Penckin glasiaalimorfologisten näkemysten innoittamana, mutta saatuaan nimityksen maantieteen dosentiksi hän oli syventynyt erityisesti W. M. Davisin kehittämään geomorfologiseen tutkimussuuntaan. Davisin työssä Granötä viehätti sen analyyttinen selkeys, joka näytti antavan maantieteelle tieteellisen sisällön. Nyt hän vakuuttui siitä, että 
maantieteen ytimenä tuli olla geomorfologia eli oppi maanpinnan muodoista. Kun geologia tutki vain maa- ja kallioperän rakennetta, maantieteen tuli selvittää, miten maanpinnan muodot olivat syntyneet. Näin myös ihmisen toiminta tuli mukaan maantieteen piiriin. ${ }^{171}$

Davisin näkemyksen omaksuminen johti siihen, että Granö alkoi kiinnittää huomiota maiseman yksityiskohtien sijasta itse kokonaisuuteen, siihen miten maisemat muodostuivat ja miten ne poikkesivat toisistaan. Suomessa hän oli jo tutustunut vaihteleviin metsä- ja järvimaisemiin, Siperiassa tasankomaisemiin, Altailla vuorimaisemiin, ja nyt Japanissa hän kohtasi jälleen uuden ja omaleimaisen maiseman, japanilaisen kulttuurimaiseman. ${ }^{172}$

Perehdyttyään Davisin eroosiosyklioppiin Granö päätti soveltaa sitä Altain pinnanmuotojen kehityksen kuvaamiseen. Tämä merkitsi sitä, että hänen tutkimusaiheensa laajeni vuoriston glasiaalihistoriasta kokonaiskuvan luomiseen sen pinnan rakenteesta ja synnystä. Hänen tavoitteenaan oli selittää, miten Altain maisema, "taivaisiin kohoavat vuorenhuiput, joiden hartioilla pilvet leijailivat, syvät rotkot, ihanat vuoristojärvet ja kevätauringossa hehkuvat kukkaniityt" olivat syntyneet. ${ }^{173}$

Granön asettama tutkimustavoite oli niin mittava, että se oli mahdollista toteuttaa vain huomattavan apurahan avulla. Siksi hän haki syksyllä 1911 yhtä Aleksanterin-Yliopiston tavoitelluinta apurahaa, dosenteille tarkoitettua kamarineuvos Herman Rosenbergin apurahaa. Suurista ulkomaanstipendeistä käytiin yliopiston tiedekunnissa kovaa kilpailua, sillä ne tarjosivat mahdollisuuden monivuotiseen tutkimukseen ulkomailla ja vahvistivat tieteenalan asemaa yliopistoaineena.

Suositellessaan apurahan myöntämistä oppilaalleen Rosberg totesi, että Granölle oli välttämätöntä luoda edellytykset tutkimustensa jatkamiseen. Muuten oli vaarana, että muiden maiden tutkijat korjaisivat hedelmät hänen aloittamastaan uranuurtavasta työstä. Jos Granölle myönnettäisiin apuraha, hän tulisi saavuttamaan kansainvälisesti huomattavia tuloksia, jotka lisäisivät Suomen tieteen mainetta maailmalla. ${ }^{174}$

Laatimassaan tutkimussuunnitelmassa Granö totesi, että hänen tavoitteenaan oli tutkia yksityiskohtaisesti Länsi-Siperian ja Mongolian rajoilla olevan Altai-vuoriston 
glasiaaligeologiaa ja geomorfologiaa kiinnittäen erityistä huomiota niihin tieteellisesti lähes tutkimattoman vuorimaan osiin, jotka kuuluivat Länsi-Siperian suurvirtojen Obin ja Irtyšin lähdealueisiin. Tekemällä mahdollisimman tarkkoja geomorfologisia ja geologisia tutkimuksia, korkeusmittauksia ja kartografisia töitä hän pyrki ratkomaan muun muassa seuraavia kysymyksiä: glasiaalisten ja glasifluviaalisten muodostumien levenemislaajuus ja -laatu, jääkausien ja mahdollisten interglasiaaliaikojen lukumäärä, jääkauden tai jääkausien jääpeitteen laajuus ja vahvuus sekä glasiaalisen kulutuskauden aiheuttamat muodostumat ja niiden suhtautuminen aiempien kulutuskausien pinnanmuotoihin. ${ }^{175}$

Granön mukaan koko geomorfologisen tietämyksen kannalta olisi tärkeätä, että Aasian keskiosien osalta kyettäisiin antamaan vastauksia näihin kysymyksiin, jotka oli jo selvitetty Euroopassa ja Pohjois-Amerikassa. Tutkimusten pohjalta voitaisiin myös tehdä johtopäätöksiä muidenkin Aasian pohjoisten reunavuoristojen jääkausihistoriasta, sillä Altai oli tutkimuskohteena otollinen. Se oli suurmuotojensa vuoksi hyvin vaihteleva ja niin korkea, että jäk̈kauden merkit olivat selvästi näkyvillä. Sen ylimmissä osissa oli lukuisia jätiköitä, joista muutamat olivat lähes 20 kilometriä pitkiä. Altai oli ilmastollista raja-aluetta kuivien kirgiisiarojen ja metsäisten Sajanin vuorten välillä, joten sen eri osissa näkyivät ilmastollisten tekijöiden vaikutukset eri muodoissaan. Lisäksi se oli verraten helppokulkuinen, koska se oli suureksi osaksi metsätön ja lähellä Länsi-Siperian suuria liikennereittejä. ${ }^{176}$

Keväällä 1912 Granön kanssa kahdesta stipendistä kilpailivat muun muassa Rafael Karsten, Julius Ailio, Herman Gummerus, Arthur Långfors, Johannes Sundwall ja Alex. Luther. Granö ei menestynyt kilpailussa, vaikka arvovaltainen geologian professori Wilhelm Ramsay kannatti lämpimästi stipendin myöntämistä hänelle tieteellisten ansioiden ja korkeatasoisen tutkimussuunnitelman vuoksi. Fyysis-matemaattinen osasto päätyi äänestyksen jälkeen asettamaan erityisesti vesieläinten tutkijana kansainvälisesti ansioituneen Alex. Lutherin niukasti Granön edelle, mutta suositti apurahan myöntämistä pikaisesti myös hänelle. Lopulta stipendin saivat Luther ja Sundwall. ${ }^{177}$ 
Vuoden lopulla Granö haki jälleen toista Rosenbergin kahdesta matka-apurahasta. Kilpailu oli edelleen kova, sillä hakijoiden joukossa olivat muun muassa Julius Aulio, Arthur Långfors, Herman Gummerus, Liisi Karttunen ja Sulo Kilpi. Nyt Granöllä oli kuitenkin se etu, että hän oli suuren fyysis-matemaattisen osaston ykkösehdokas. Osaston mukaan Granö oli aiemmilla pitkillä matkoillaan
... saavuttanut suuremman pätevyyden kuin kukaan muu maantieteen tutki- ja... oli toivottavaa valmistaa dosentti Granölle tilaisuus laajan ja kalliin tutki- musmatkansa tekemiseen, ennenkuin muut tiedemiehet olisivat ehtineet käyttää hyväkseen hänen aiempien töittensä hedelmiä tällä alalla. ${ }^{178}$

Fyysis-matemaattisen osaston ratkaisu merkitsi Granölle matkalippua Siperiaan. Konsistorin äänestyksessä Julius Ailio sai 37 ääntä, Granö 22 ääntä ja Långfors 15 ääntä muiden jäädessä alle kymmenen äänen. Näin stipendit myönnettiin Ailiolle ja Granölle. ${ }^{179}$

Rosenbergin apuraha - 8000 markkaa vuodessa kolmen vuoden ajan - oli niin mittava, että se riitti peittämään laajojen tutkimustöiden vaatimat kulut ja mahdollisti myös Granön asettumisen asumaan tutkimusmatkajaksojen väliajaksi Omskiin. Granö alkoi välittömästi valmistella siirtymistään Altaille yli kolmen vuoden ajaksi. Hän anoi virkavapautta yliopistosta, ja maantieteen assistentuuria ryhtyi hoitamaan filosofian kandidaatti Wilho Sjöström. ${ }^{180}$

Kiireisen järjestelytyön rikkoi kesän 1913 aikana kaksi ihmisen inhimilliseen kiertokulkuun kuuluvaa merkittävää tapahtumaa: Isän kuolema ja avioliiton solmiminen Hilma Ekholmin kanssa.

Johannes Granö oli alkanut jo 1907 väsyä laajan seurakuntansa hoitoon ja kaipasi apua. Tilanne helpottui yllättäen 1908. Juuri papiksi vihitty Paavo Granö oli saanut virkamääräyksen Rengon vt. kirkkoherraksi, mutta hän sairastui vakavasti. Kriittisimmän vaiheen mentyä ohitse isä haki poikansa Omskiin lepäämään. Kesän aikana Paavo Granö toipui kokonaan ja nimitettiin isänsä apulaiseksi lokakuun alussa 1908. ${ }^{181}$ 


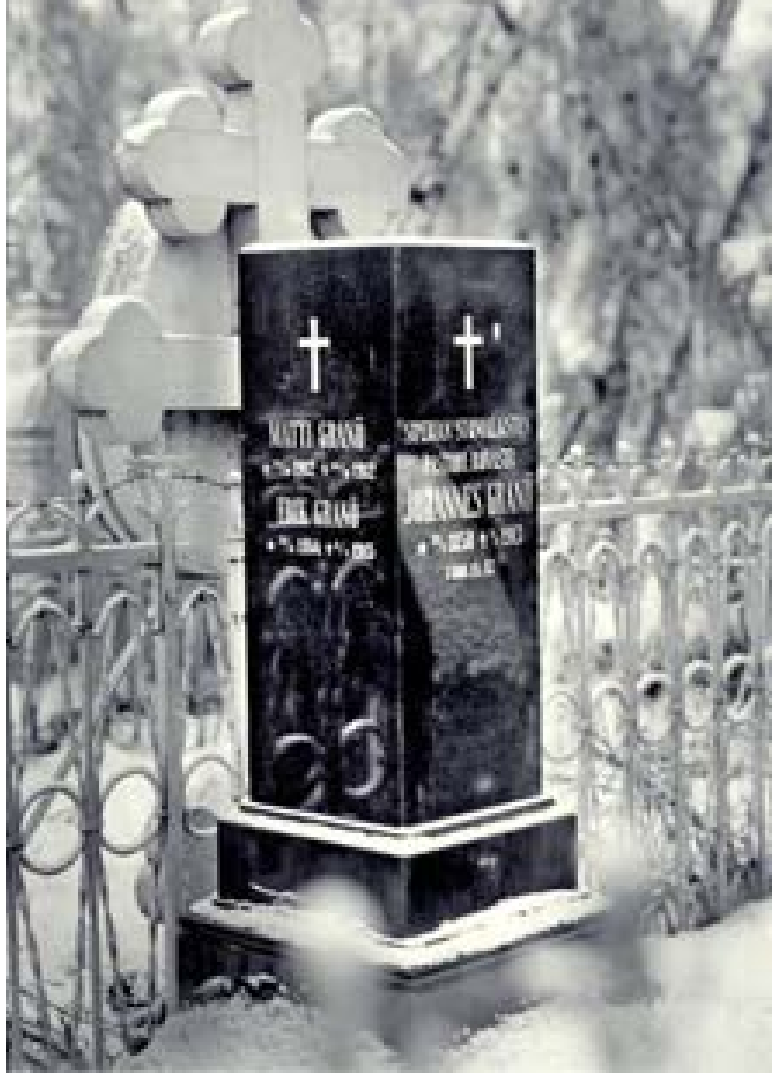

Johannes Granön suomalaisesta graniitista veistetty hautakivi Omskin luterilaisella hautausmaalla 1915. Samaan hautaan siunattiin myös J. G. Granön veljen Paavon kaksi poikaa Matti (k. 1912) ja Erik (k. 1914) sekä Paavon vaimo Elin (k. 1919). Hautausmaa on myöhemmin hävitetty.
Johannes Granö pyysi eroa virastaan vuoden 1912 toukokuussa. Hän katsoi, että hänen terveytensä oli heikentynyt niin paljon, että pitkät ja vaivaloiset virkamatkat olivat hänelle liian rasittavia. Senaatti myönsi hänelle eron 17 vuoden palvelusajan jälkeen ja esitti, että hänen seuraajakseen nimitettäisiin viidestä ehdokkaasta Paavo Granö. Kenraalikuvernööri hyväksyi valinnan helmikuussa 1913.

Tarkkaan oli vanha kirkkoherra tuntenut tilansa ja aikansa. Toukokuun alussa eläkkeelle siirtynyt Johannes Granö kuoli 9. kesäkuuta 1913 polyyppileikkauksen jälkiseurauksiin. Helsingistä Omskin kotiin saapunut Kaapo ehti parahiksi hyvästellä isänsä tämän sairasvuoteen äärellä. Johannes haudattiin Omskin luterilaiselle kirkkomaalle. ${ }^{182}$

Granö kuvasi isänsä elämän hiipumista J. K. V. Tuomiselle:

Päivät hänen tautivuoteensa ääressä eivät taida mielestäni häipyä. On merkillistä mitenkä elävä usko voi ihmisen täältä erkanemisen tehdä suorastaan sankarilliseksi... On hyvin opettavaista olla kuolinvuoteen ääressä ja varmaan myös kasvattavaa; mutta kauan saan vielä, veliseni, maailman rantoja kiertää, ennen kuin pääsen tieteen ja ymmärryksen kahleista elämän suurimmassa kysymyksessä niin avoimille vesille kuin isävainajani. ${ }^{183}$ 
Knaapilan talossa Rymättylässä lapsuutensa viettänyt Hilma Ekholm oli myös koulutukseltaan maantieteilijä. Nuoret olivat tavanneet toisensa ensimmäisen kerran Hanna Lignellin kotona, jossa molemmat olivat täysihoidossa. Suhde oli alkanut ja syventynyt maantieteen laitoksella, ja Hilma oli auttanut Granötä jo väitöskirjan karttojen piirtämisessä. Heinäkuun 1. päivän häähumu Helsingissä jäi lyhyeksi, sillä nuori pari matkusti jo hääpäivänä Omskiin valmistelemaan Granön tutkimustyön aloittamista. ${ }^{184}$

Käytännöllisenä miehenä Granö yhdisti häämatkan tutkimusmatkaan siten, että nuoripari lähti yhdessä Tapani Unkurin kanssa tutustumismatkalle Altain maisemiin. Heinäkuun puolivälissä alkanut, kuukauden kestänyt matka suuntautui Altain itäosaan, vuonomaisen syvän ja kauniin Telétskojejärven, altailaisten tarujen Kultajärven, Altyn-kölin, ja siitä edelleen jatkuvan Tšulyšmanin rotkomaisen jokilaakson ympäristöön. Ilmeisesti Granö halusi näyttää morsiolleen parasta, mitä Altai saattoi tarjota. ${ }^{185}$

Granön tavoitteena oli osoittaa, että järvi oli syntynyt jääkautisen jäätikkövirran muovaamana, minkä hän saattoikin ilokseen todeta heti saavuttuaan paikalle. Matkan aikana Granö kartoitti Telétskojejärven rantoja ja tutki Katunin ja Bijan vierinkivikkoja etsien jokien laaksoissa olevia jäätikköjen päätemoreeneja. Hilma Granön tehtävänä oli erityisesti kasvinäytteiden kerääminen. ${ }^{186}$

Vaikka Hilma Granö sai pääosin vastuulleen ajan akateemisten perheiden tapaan lasten hoidon ja käytännön arjen pyörittämisen, hän osallistui koko avioliiton ajan monin tavoin miehensä tieteellisen työn tukemiseen ja avustamiseen. Granö noudatti periaatetta, jonka mukaan koti oli rauhoitettu työelämän ongelmilta, ja kehitti tieteelliset teoriansa ja metodinsa työhuoneensa rauhassa. Tähän työhön puoliso ei osallistunut edes sparraajan roolissa, vaikka muuten olikin tärkeä keskustelukumppani puolisolleen. ${ }^{187}$

Vietettyään muutaman päivän Omskissa Granö matkusti 19. elokuuta Pietariin, josta hän lähti J. E. Rosbergin kanssa yhteiselle opintomatkalle Krimille, Kaukasukselle, Kirgiisiarolle, Tienšanin vuoristoon ja Siperiaan. Matkan tarkoituksena oli 


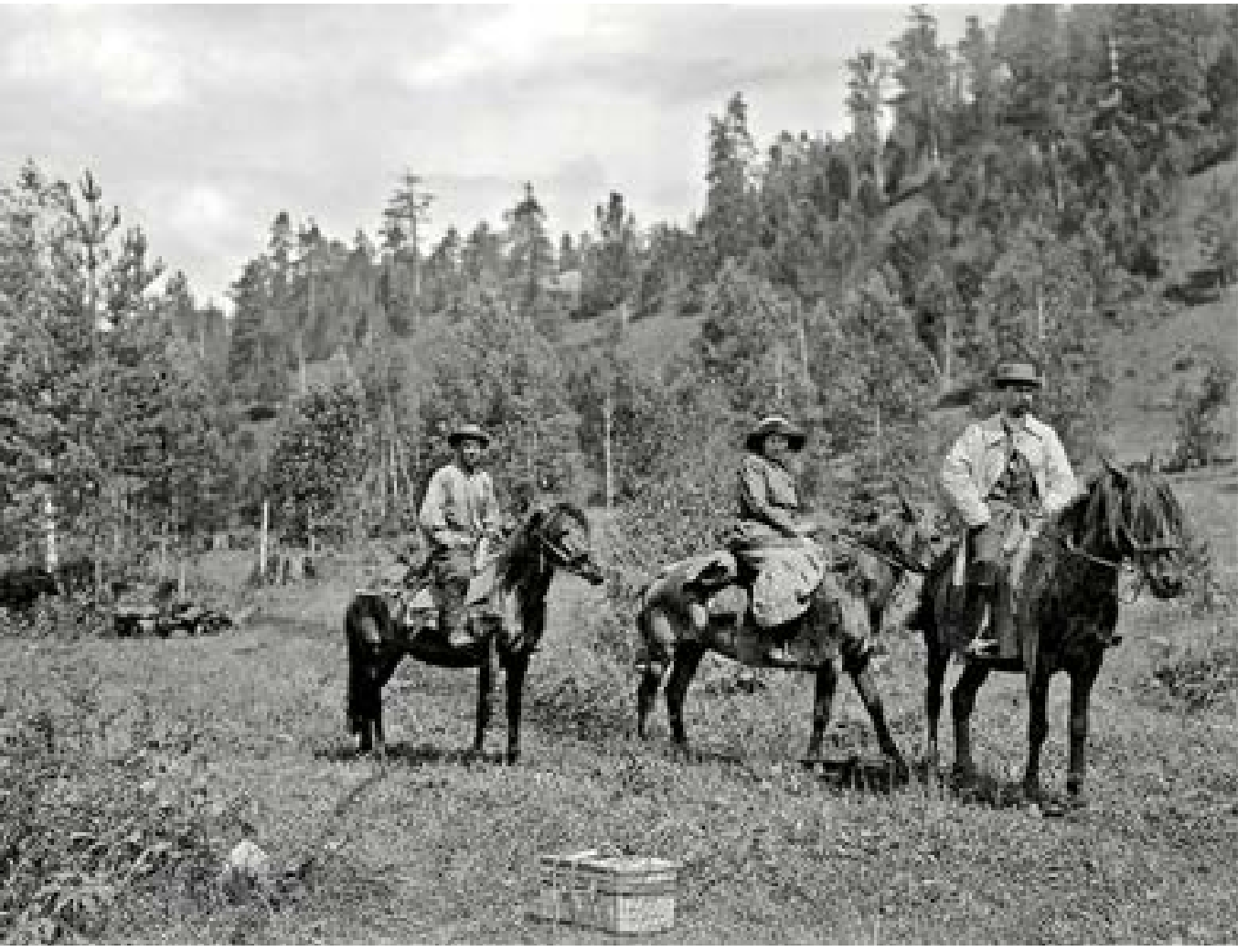

Solmittuaan avioliiton heinäkuun alussa 1913 J. G. Granö vai nuorikkonsa Hilman kuukauden kestäneelle tutkimusmatkalle Altain itäosiin, jossa he tutustuivat muun muassa Telétskojejärven lumoaviin maisemiin. Kolmantena ratsastaa venäläinen opas.

tutustua vertailumielessä vuoristoon, jossa W. M. Davis oli yhdessä yhdysvaltalaisten maantieteilijätovereidensa E. Huntingtonin ja R. Pumpellyn kanssa tehnyt tutkimuksia $1903 .{ }^{188}$

Tutkimusmatkan aihe oli tieteellisesti hyvin ajankohtainen, sillä Davisin maine Euroopassa oli suurimmillaan juuri 1910-luvun vaihteessa. Tuolloin hän toimi vierailevana professorina Berliinissä ja Sorbonnessa Pariisissa ja julkaisi Saksassa monumentaalisen tutkimuksensa Die Erklärende Beschreibung der Landformen. ${ }^{189}$

Miesten matka uhkasi pysähtyä alkuunsa, sillä Rosberg sairastui Pietarissa. Muutaman päivän kuluttua miehet lähtivät kuitenkin matkaan, ja vähitellen potilas tervehtyi. Matka eteni junalla Kiovaan, joka "pyhyydessä” oli miltei Moskovan veroinen, 
sieltä edelleen laivalla Dnepriä pitkin Jekaterinoslaviin eli Dnipropetrovskiin, josta jatkettiin vuorokaudessa junalla Sevastopoliin. Keisarikunnan laivaston tukikohtakaupungista matka jatkui laivalla Krimin jyrkkien rantojen viini-istutusten ja lumivalkoisten huviloiden ohi Novorossijskiin ja sieltä edelleen junalla Vladikavkaziin. ${ }^{190}$

Kaukasuksen yli Granö ja Rosberg pääsivät onnekkaasti helpolla tavalla. He tapasivat Vladikavkazissa erään ajurin, joka vei heidät parihevosten vetämillä kumirattaisilla vaunuilla Gruusian sorateitä pitkin Tbilisiin: "Mukavasti istuessamme vaunuissa emme tarvinneet vaivata muuta kuin silmiämme, saadaksemme käsityksen eräästä maapallon suurenmoisimmista selänteistä., ${ }^{191}$

Tbilisistä miehet matkustivat junalla Bakuun, paloöljyn kaupunkiin, sieltä edelleen laivalla yli myrskyisän Kaspianmeren Krasnovodskiin eli nykyiseen Türkmenbašiin,

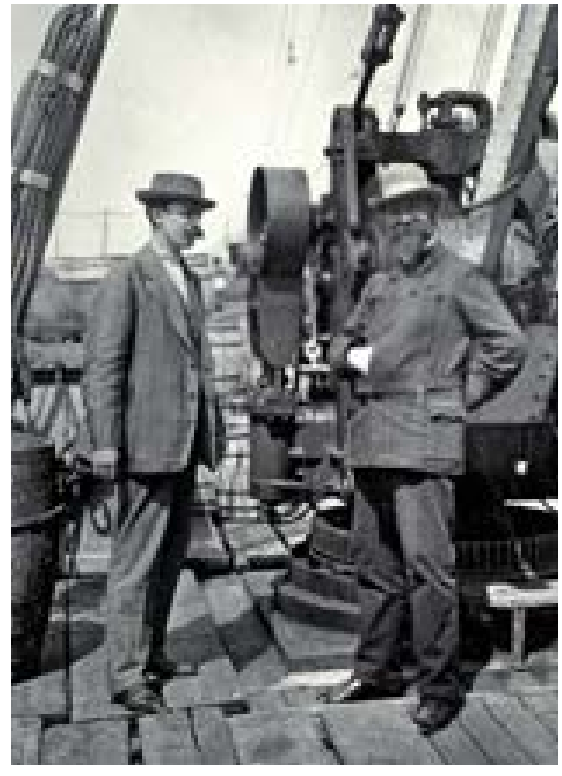

J. E. Rosberg ja J. G. Granö Kaspianmerellä matkalla Krasnovodskiin 1913. josta he siirtyivät muutamassa päivässä Turkmenistanin arojen ja hiekka-autioiden kautta hedelmälliseen Ferganan laaksoon. Siellä, syrjäisessä Namangaanissa, jossa viinirypäleet maksoivat 20 penniä kilo, miehet valmistautuivat ratsumatkaan yli 4 500-7 000 metriin kohoavan Tienšanin vuoriston poikki. ${ }^{192}$

Vaivaloinen ylitys onnistui, ja viisi päivää satulassa heiluttuaan Granö ja Rosberg saapuivat vuoriston pohjoispuolelle. Hetken levon jälkeen alkoi retken raskain vaihe, pari viikkoa kestänyt, noin 1600 kilometrin matka postihevosilla Semipalatinskiin eli nykyiseen Semeyn kaupunkiin. Loppumatka taittui komealla jokilaivalla, joka toi matkalaiset Omskiin eräänä koleana syysaamuna. ${ }^{193}$

Matka oli ollut rasittava mutta tieteellisesti antoisa. Kaukasuksen ja Tienšanin muodostumien tarkastelu auttoi ymmärtämään monia Altain syntyyn liittyviä kysymyksiä, ja myös Etelä-Siperian arovuoristot tarjosivat useita hyödyllisiä vertailukohtia. ${ }^{194}$ 


\section{Altain tutkimusmatikat 1913-16}

\section{Valtava urakka}

Altain tutkimuksen perustavoitteena oli selvittää Venäjän Altain yli 100000 neliökilometrin eli Suomen Lapin laajuisen alueen jääkausihistoria, mutta tämän pääteeman rinnalla Granö pyrki tutkimaan myös muita tähän aiheeseen liittyviä kysymyksiä ja vuoriston Mongolian puoleisia osia. Ulko-Mongolia oli itsenäistynyt Kiinasta 1912, mutta vanha emämaa piti sitä yhä omanaan ja valloittikin sen jälleen 1919. ${ }^{195}$

Granö pyrki aluksi tukeutumaan mahdollisimman suoraan W. M. Davisin eroosiosyklioppiin, minkä vuoksi hän kiinnitti huomiota erityisesti Altain eri tasoilla oleviin rotkolaaksoihin ja tunturilakeuksiin. Varsin pian hän kuitenkin huomasi ottaneensa liian suuren urakan tehtäväkseen. Keski-Altai oli geomorfologisesti lähes tutkimatonta aluetta, joten häneltä meni paljon aikaa alueen kartoittamiseen ja yleisiin perustutkimuksiin. Tämä merkitsi sitä, että Granön oli aluksi keskityttävä mahdollisimman monipuolisen havaintoaineiston keruuseen. Päähuomio kohdistui Obin suurten lähdejokien Bijan ja Katunin laaksosysteemeissä havaittavien jääkautisten jäätiköiden muodostamiin kerrostumiin ja kulutusmuotoihin. ${ }^{196}$

Tutkimusmatkojen luontevaksi lähtöpaikaksi valikoitui Altain vuoriston pohjoisreunalla, lähellä Bijan ja Katunin yhtymäkohtaa oleva Bijskin kaupunki. Yliopiston myöntämä apuraha ei mahdollistanut suuren retkikunnan varustamista, joten Granö joutui tekemään suuren osan tutkimusmatkoistaan yksin, mukanaan vain pari hevosmiestä ja paikallinen opas. Aina, kun vain oli mahdollista, hän pyrki ottamaan mukaan luotettuja matkakumppaneita ja tutkimusavustajia.

Kesällä 1914 apulaisena oli Siperiassa syntynyt serkku, teknikko Paavo Granö ja osan aikaa myös Suomesta saapunut ylioppilas Kaarlo Hildén, myöhempi Helsingin kauppakorkeakoulun pitkäaikainen talousmaantieteen professori ja rehtori.

110 Siperia opettaA 


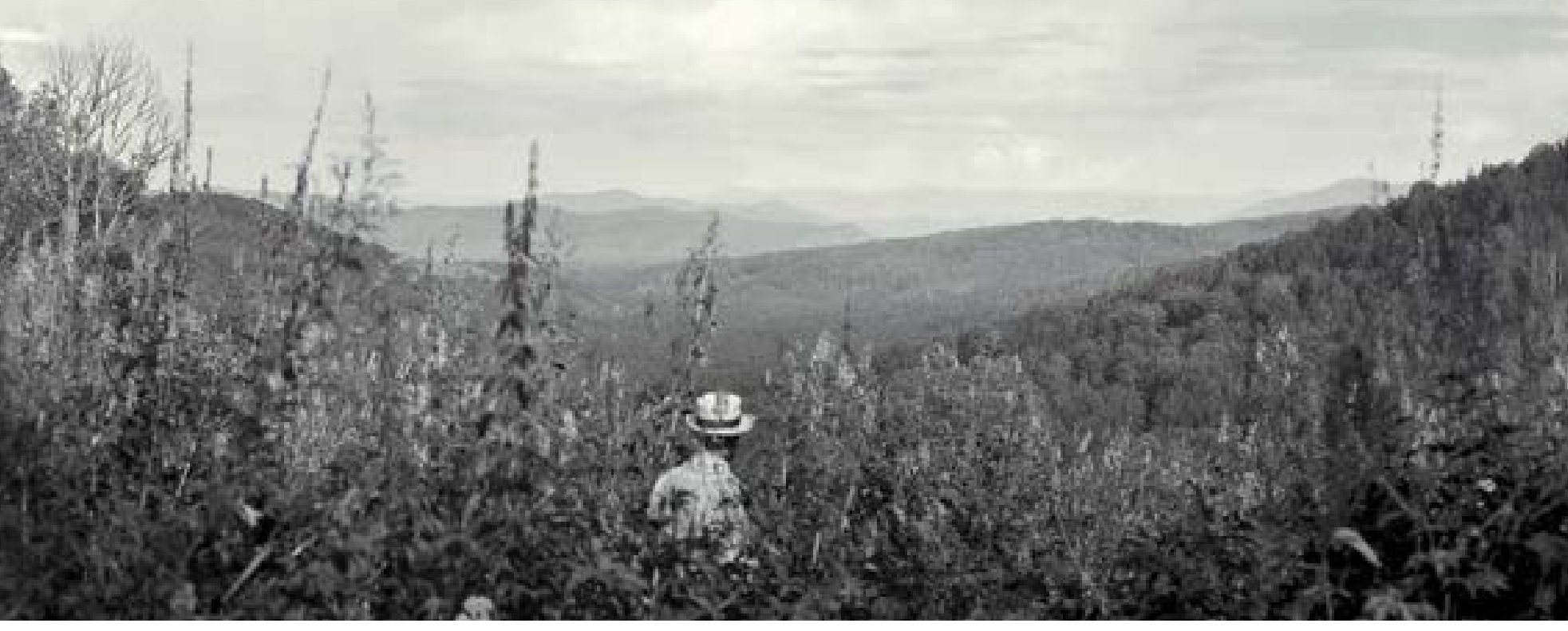

Bijan laakson suurruohostoa Venäjän Altailla 1913.

Paavo Granön tehtävänä oli vastata retkikunnan ruokahuollosta ja muista käytännöllisistä puuhista, kun taas Hildén keskittyi kansantieteellisiin ja antropologisiin tutkimuksiin. ${ }^{197}$

Miesten majoittuessa toukokuun lopulla 1914 Bijskissa vaatimattomaan Moskóvskoje Podvórjen majataloon Hildén sai ensimmäisen oppitunnin siitä, mitä jokaisen kunnon tutkimusmatkailijan piti tietää: 


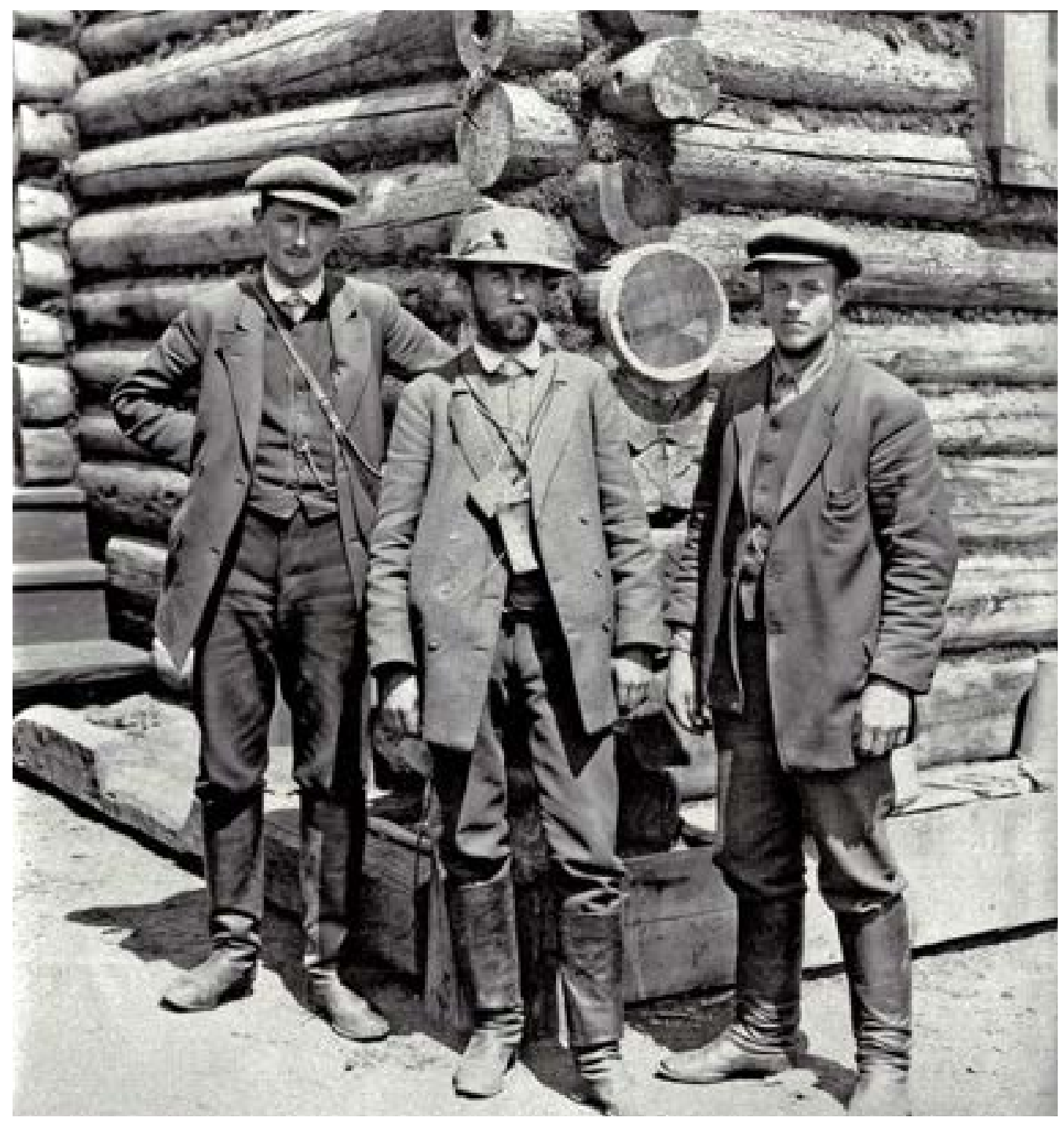

Alkukesän 1914 tutkimusretkikunnan jäsenet vasemmalta maisteri Kaarlo Hildén, J. G. Granö ja hänen serkkunsa, teknikko Paavo Granö. Ongudai-kylä, Katunin alue 1914. 
Purkaessamme matkatavaroitamme ja järjestäessämme niitä tulevaa ratsastusmatkaa varten tuli suureksi hämmästyksekseni eräästä Granön repusta esiin virallisluontoisilla aamupäiväkutsuilla vuosisadan alussa käytetty takki, ns. bonšuuri. Tämä silitettiin huolellisesti, ja siihen sonnustautuneena dosentti J. G. Granö lähti viralliselle tervehdyskäynnille korkeimman sikäläisen hallintoviranomaisen, "hänen korkeasyntyisyytensä ispravnikin" luokse. Kaduilla liikkuessaan hän herätti yleistä huomiota - niin hienosti pukeutunutta herraa kaupunkilaiset ilmeisesti eivät ennen olleet nähneet. Mutta tervehdyskäynti tuotti suuria etuja, niin kuin oli toivottu. Iloisesti yllättynyt ja imarreltu "korkeasyntyisyys" suostui ilman muuta siihen, että ei vain retken johtaja, vaan myös "Keisarillisen Aleksanterin yliopiston ylioppilas" sai bumaakan, joka oikeutti hänet kaikkialla käyttämään valtakunnan kievarikyytiä, joko parivaljakkoa tai ratsuhevosta, ja maksamaan korkeimpien virkamiesten tavoin vain kolme kopeekkaa virstaa kohden. ${ }^{198}$

Lähdettyään Bijskistä toukokuun lopulla miehet kiertelivät aluksi Altain itäisimmässä osassa, Obin itäisen lähdejoen Bijan ja sen sivujoen Lebedjin ympäristössä, missä maisemaa hallitsivat enimmäkseen tiheät ja soiset metsät. Granön Mustaksi-metsäksi kutsuman alueen väestö oli hyvin mielenkiintoista. Kristinusko ei ollut vielä ehtinyt muuttaa juuri lainkaan vanhoja tapoja, minkä vuoksi väestö uhrasi vielä joka kesä hevosia pyhien koivujen juurella ja samaanit rämäyttelivät suuria rumpujaan sairasvuoteiden ääressä matalissa, pimeissä mökeissä.

Kesäkuun puolivälissä Granölle tarjoutui harvinainen tilaisuus kuvata yhdeksän kuvan sarja samaanin rituaaleista Lebedjin sivujoen Sadran laaksossa. Granösta tuntui kuin hän olisi siirtynyt vuosisatoja taaksepäin ajassa. Hildénille paikka oli luonnollisesti oikea antropologinen Eldorado. ${ }^{199}$

Tutkittuaan Bijan muinaisen suuren jäätikön salpaavaa vaikutusta sivulaaksoihin miehet etenivät Kebezeniin ja edelleen Telétskojejärven pohjoispuoliseen erittäin vaikeakulkuiseen vuorimaahan. Matkareitti oli Granön kannalta tutkimuksellisesti 


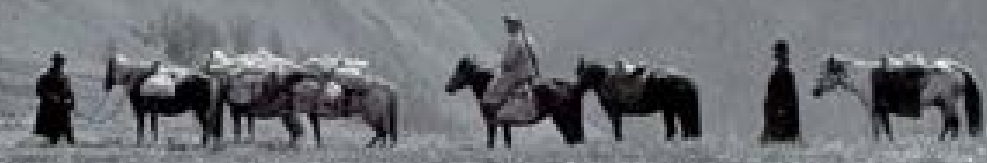

Elokuussa 1914 J. G. ja serkunsa Paavo Granö etenivät kahden telengiitin opastamana Altun Tardain latvalueiden kautta loivakaarteiselle tunturiylängölle, jota Granö piti mannerjäätikön suojaamana peneplaanina.

varsin yksitoikkoinen, mutta sen aikana hän saattoi kirjata muistiin ensimmäiset tarkat tiedot järvialtaassa muinoin olleen jättiläisjäätikön vahvuudesta ja sulamistavasta. Samalla hän vakuuttui "ainakin kahden jääkauden olemassaolosta näillä tienoin". ${ }^{200}$

Matkustettuaan vesitse Telétskojejärven eteläpäähän miehet ryhtyivät ratsain seuraamaan järven kaakkoispoukamaan laskevan Kygýn laaksoa. Tavoitteena oli 
Urjanhain rajoilla oleva asumaton ja puutteellisesti tunnettu tunturiseutu, joka oli jäkaudella ollut kauttaaltaan ikilumen peitossa. Nyt sieltä saivat alkunsa sekä Akaban että Tšulyšmaniin virtaava Tšöltšy, jonka latvavesiin kuuluva kaksiosainen järvi, Ity-köl, oli tutkimusmatkan eteläisin kohta. ${ }^{201}$

Kartoitettuaan Ity-kölin altaan tutkimusretkeilijät suuntasivat länteen, Tšulyšmanin laaksoon. Laskeutuessaan muutamassa tunnissa kylmäviimaiselta ylängöltä pelottavan jyrkkää rinnettä lähes 1000 metriä alempana olevaan lämpöiseen laaksoon Granö ymmärsi "jääkauden syvien ruuhilaaksojen muodostavan Itä-Altaissa erikoisen, syvälle avaraan tunturimaahan painuneen pienoismaailman, jonka olemassaolo suureksi osaksi oli muinoisten jättiläisjäätikköjen aiheuttama”. ${ }^{202}$

Tšulyšmanin laaksosta Granö suuntasi sen suurimman sivujoen, vuolaan Baškausin laaksoon, joka oli myös muinoin ollut paksun jäätikön peittämä. Ratsastettuaan Kurain vuoriston yli Tšujan laaksoon miehet palasivat heinäkuun puolivälin jälkeen sitä seuraavaa tietä pitkin Bijskiin. Hildén lähti omiin tutkimustuloksiin tyytyväisenä takaisin Suomeen, mutta kesän aikaiset yhteiset kokemukset tekivät hänestä elinikäisen luottoystävän Granön kanssa. ${ }^{203}$

Granöt suuntasivat kolmen päivän levon jälkeen uudelle matkalle. Mukana oli myös kaksi altailaista apulaista, telengiittiä, joiden kanssa Granö tuli jo tulkitta toimeen. Ensin Granöt etenivät kärrykyydillä ja ratsain Telétskojejärven luoteispuolella olevalle suurten metsien alueelle, jota he tutkivat vaikeissa oloissa. Lämpötila laski öisin useita asteita pakkasen puolelle, ja vettä satoi päivästä toiseen niin paljon, että miehet olivat likomärkiä aamusta iltaan ja melkeinpä myös illasta aamuun, sillä kylmässä teltassa vaatteet eivät juuri kuivanneet. Granön valokuvauskone oli homehtua piloille, ja fotogrammetrin puinen kirstu vääntyi kosteuden vuoksi vinoksi. Alueella saavutetut tieteelliset tulokset olivat vain välillisesti tärkeät. ${ }^{204}$

Elokuun puolivälissä Granöt aloittivat päätehtävänsä, Tšulyšmanin ja sen suurimman lisäjoen Baškausin laakson tutkimisen. Miehet etenivät aina Mongolian rajan läheisille tunturiylängöille, "missä suurten jokien latvalaaksoissa sadat mo- 
reenijärvet sinertävät vaivaiskoivua ja lapinvuokkoa kasvavien kumpujen välissä ja missä juhlalliset tunturit häikäisevine lumivaippoineen näköpiiriä rajoittavat”. ${ }^{205}$

Voimakasvaloinen ja autio ylämaa oli jäätikkötutkijalle oikea luonnon laboratorio, jossa olisi ollut tutkittavaa vaikka koko kesäksi. Syksyn tehdessä tuloaan ja lämpötilan laskiessa säännöllisesti useita asteita pakkasen puolelle miesten oli kuitenkin lähdettävä takaisin ihmisten ilmoille. Paluumatkalla Bijskiin Granö selvitti Katunin sivujokien suhtautumista päälaaksossa olleeseen jäätikkövirtaan. Syyskuun alussa miehet tutkivat vielä alisen Katunin seutua kiiveten muun muassa Bobyrganin vuorelle, joka kohoaa vuoriston laitimmaisena etuvartiona tuhatkunta metriä ympäröivää aroa korkeammalle ja jolta siten sai erinomaisen yleiskäsityksen alueesta. ${ }^{206}$ Granö kuvasi näkymäänsä näin:

\begin{abstract}
Voimakkaimmin kenties vetävät kuitenkin nämä kaksi toisilleen täysin vastakkaista maisemaa: toisaalta arojen lainehtiva silmänkantamaton meri, joka keväisin loistaa mitä ihanimmissa väreissä ja toisaalta taas tunturiylängöt, jotka ovat kauneinta, mitä Altailla on tarjottavana koskemattoman luonnon ihailijalle. Tuntureilla alppiniityt pukeutuvat lyhyenä kesänä kultaiseen kukkaisloistoon, kuu luo öisin hohdettaan sadoille lammikoille, joilla vesilinnut yönsä viettävät, ja vaaleille jäkälämaille. Alhaalla ovat ruuhilaaksot kimaltelevine jokineen, ja taivaan sineen kohoaa lukuisia alppiharjanteita ja huippuja. Ihminen on kaukana maailman hyörinästä, puhtaammat tuulet puhaltavat. ${ }^{207}$
\end{abstract}

Granön tavoitteena oli alusta alkaen luotettavien tulosten saavuttaminen, ei mahdollisimman laajojen alueiden kytkeminen tutkimuksen piiriin. Tämän vuoksi hän anoi alkuvuonna 1915 yliopiston konsistorilta oikeuden saada muuttaa alkuperäistä tutkimussuunnitelmaansa siten, että hän saattoi uusien alueiden kartoittamisen sijasta keskittyä täydentämään Bijan laaksoa koskevaa tutkimusmateriaalia.

Luvan saatuaan Granö matkusti toukokuun puolivälissä 1915 Omskista Bijskiin. Matkakumppanina oli ruokapalkalla Omskin opettajaseminaarin maantieteen opet- 


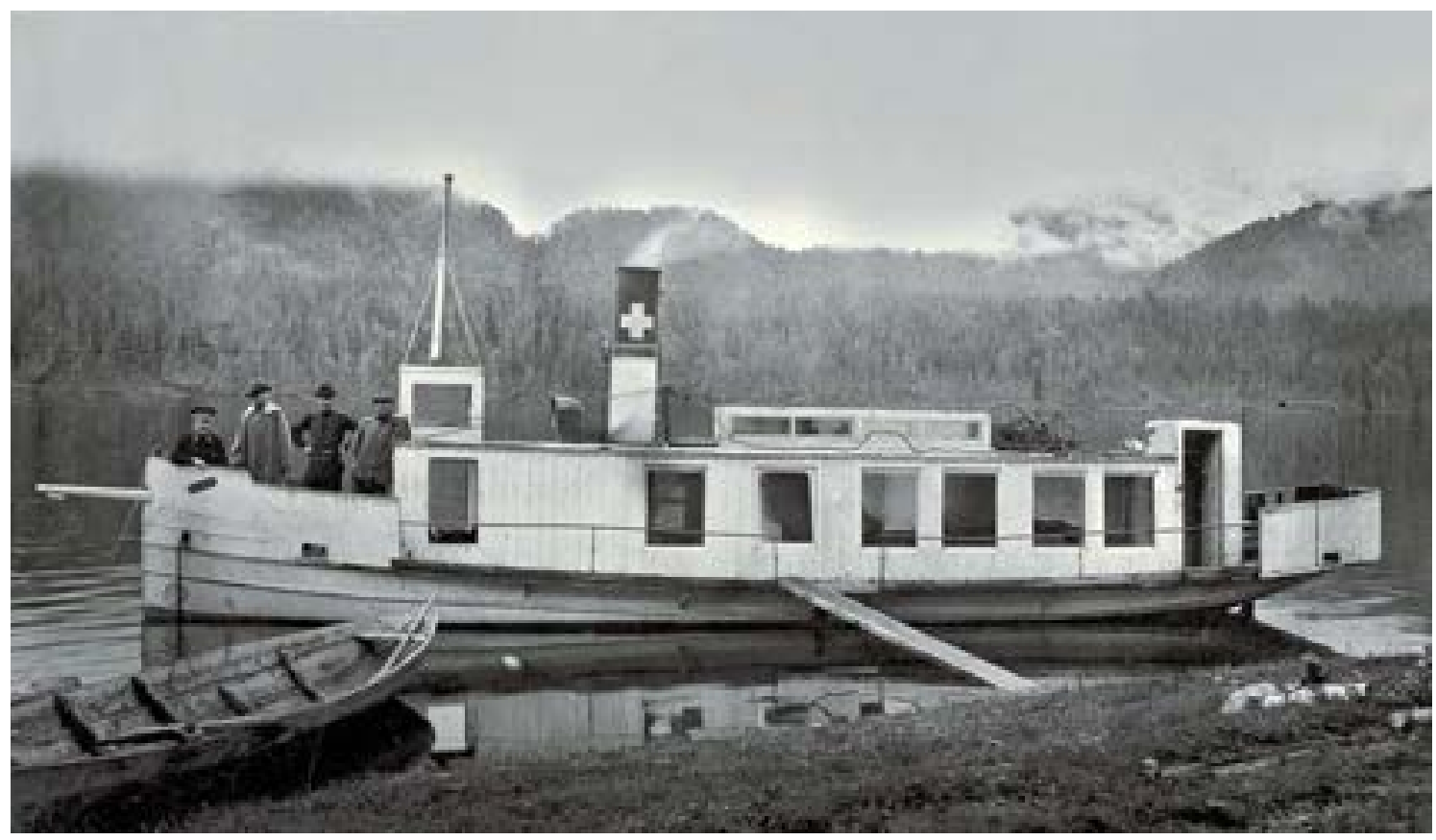

Tšulyšmanin luostarin höyrylaiva kesällä 1915 valmiina lähtöön Artybašin rannassa, Bijajoen niskassa Telétskojejärven pohjoispäässä.

tajan ja Altai-tutkijan Aleksandr Sédeljnikovin suosittelema vastavalmistunut kansakoulunopettaja Ilja Kotéljnikov, joka oli suvultaan Altain kasakoita ja taisi kirgiisin kielen. Hänen tehtävänään oli huolehtia meteorologisista mittauksista ja kerätä kasveja Omskin maantieteellisen seuran museota varten. ${ }^{208}$

Bijskistä miehet etenivät Bijan sivujokien suulaaksoja tutkien Telétskojejärvelle. Järvelle päästyään miehet matkustivat Tšulyšmanin luostarin omistamalla, alkuaan ruotsalaisella höyrypurrella sen kaakkoisrannalla olevalle Pelén asuinpaikalle, jota ympäröivät suuret moreenikasaumat ja maapyramidit. ${ }^{209}$

Kesän päätehtävänä oli Luoteis-Altain pääjoen Tšaryšin ja ennen kaikkea Katunin laaksojärjestelmän tutkiminen, minkä vuoksi miehet lähtivät nopeasti kohti 


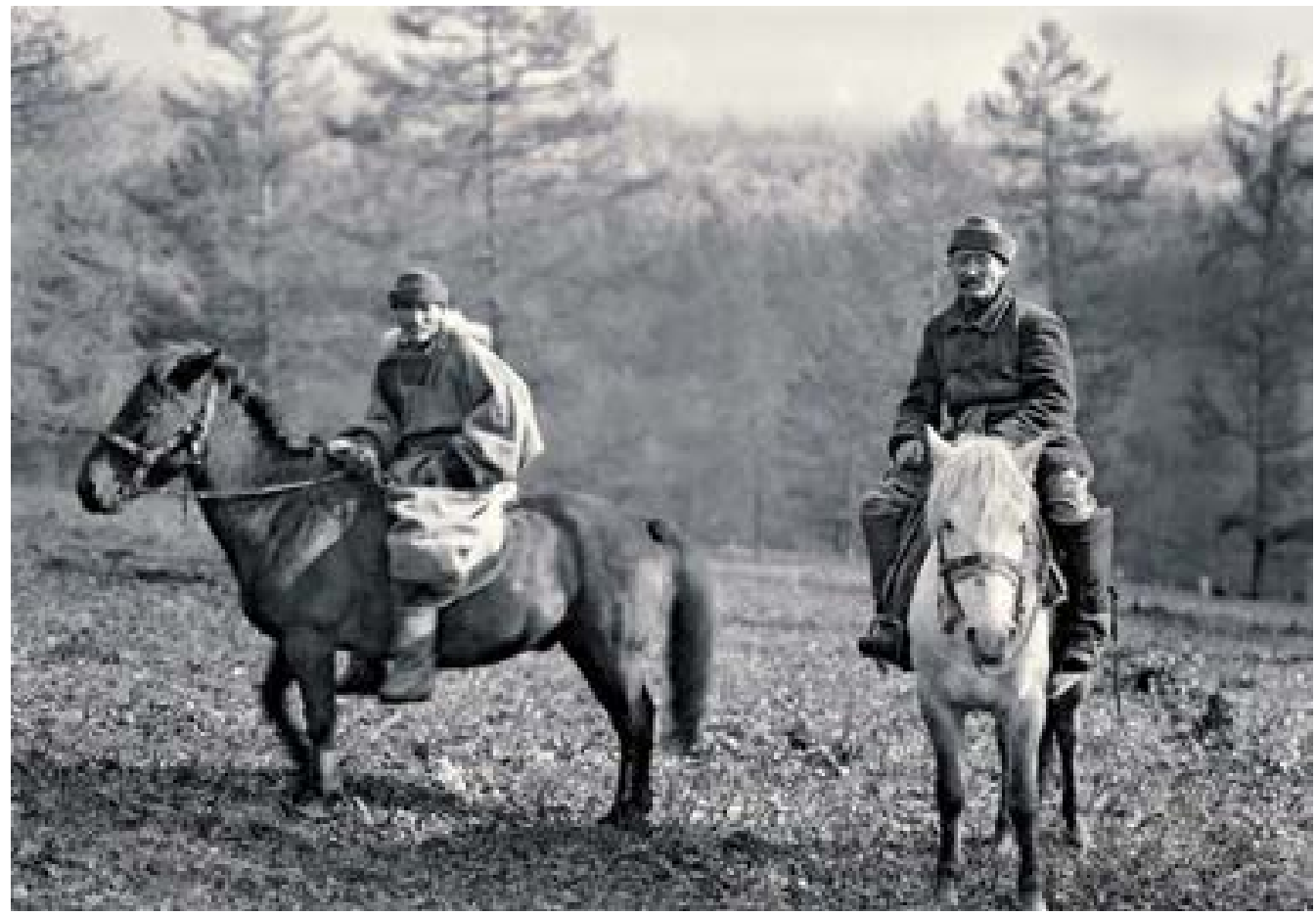

Katunin telengiittejä ratsain. Sēman vuorimaa, Venäjän Altai 1915.

Venäjän Altain eteläosaa. Matka oli kuitenkin pysähtyä alkuunsa, kun Kotéljnikov oli Granön muistutuksesta ja sota-ajasta huolimatta unohtanut passinsa Omskiin. Humalainen kyläkirjuri pidätytti matkakumppanin muitta mutkitta, ja Granö joutui askaroimaan kovasti ennen kuin sai hänet vapaaksi.

Kuukauden kestäneen työskentelyjakson aikana Granö ja Kotéljnikov seurasivat Tšaryšin laaksoa aina sen suuhun saakka eli Obin laaksoon, kauas vuoriston ulkopuolelle. Arolaaksojen puuttomissa rinteissä Granö saattoi erottaa helpommin kuin metsäisillä seuduilla eri jäätiköitymisiä vastaavien kulutusjaksojen vaiheet. ${ }^{210}$

Miesten palattua Bijskiin ja Kotéljnikovin matkustettua takaisin Omskiin Granö päätti heinäkuun puolivälissä edetä Altain sydämeen, jäätiköille ja korkeille lumivuorille. Hän ajoi aluksi yksin hevoskyydillä Kotandáan, vanhaan Altain-tutkijoiden suosiman kylään, jossa hän varusti kuuden hevosen karavaanin ja palkkasi iäkkään 


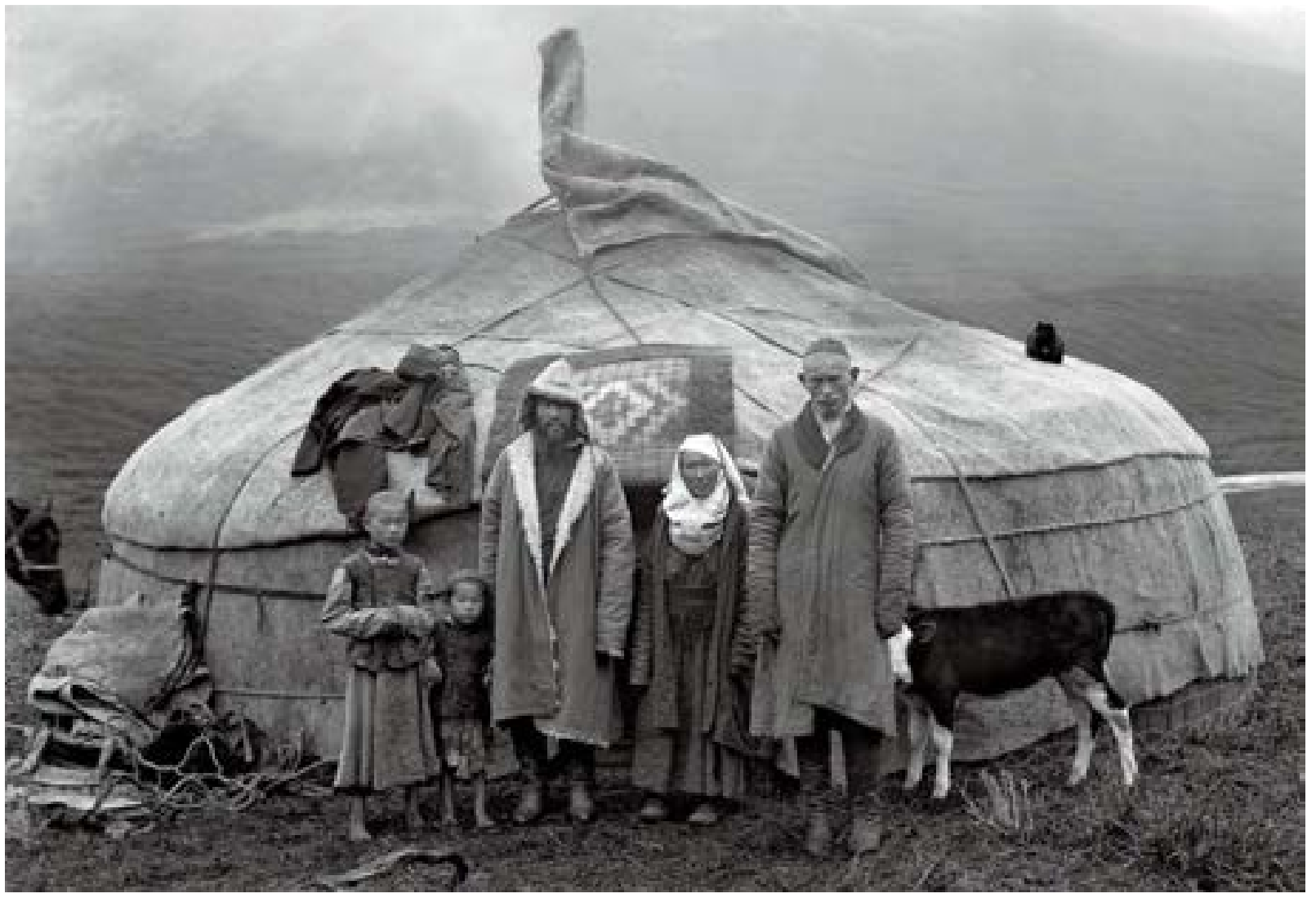

Granö tuli niin hyvin toimeen paikallisen väestön kanssa, että ihmiset suostuivat asettumaan valokuvattaviksi. Kesällä 1915 hän kuvasi jurttansa eteen asettuneen Sultanbai Koldajeffin perheen Venäjän Altain puoleisessa Tšujan-vuoristossa.

metsästäjän Kyprián Subbótinin oppaakseen ja 16-vuotiaan Pávelin apupojaksi. Sodan takia apulaisten pestaaminen oli vaikeutunut, sillä hinnat ja palkat olivat nousseet kaksinkertaisiksi. ${ }^{211}$ 


\section{Tutkimusmatkailijan telttakoti}

\section{J. G. Granö on Altai-kirjassaan kuvannut, minkälaista tutkimusmatkailijan arki oli päivän taipaleen taituttua:}

Lähdin telttaani. Nostin kapeat kirstut, joissa kallisarvoisimmat ja helposti särkyvät tavarat säilytettiin, peräseinälle. Sivuseinälle sijotin isot ratsulaukut, jotka yhdessä telttojen kanssa muodostivat toisen hevoskantamuksen. Otin niistä esille makuuvaatteeni: ison lammasnahkaturkin, jonka taitoin kaksinkerroin lattiapresenningille toisen sivuseinän ääreen patjaksi, sekä peitteen ja päänaluksen. Jätin esille myös pikkuturkin, siltä varalta että illemmalla, kirjottaessa, tulisi vilu.

Oma koti oli valmis! Aina samanlainen, riippumaton vaihtelevista yöpaikoista. Tällaisena kuin se nyt esiintyi Kara-sun unohdetussa laaksonmutkassa, olin sen nähnyt lukemattomia kertoja. Jenisein latvoilla, Mongoliassa, Altain ulkorajalla.

Kynttilä valaisi pientä huonetta: seiniä, ränsistyneitä matkatavaroita, kolmesta osasta kokoonpantuja kannatinseipäitä ja näillä lepäävää tervattua kurkiköyttä. Ainoastaan takanani oleva osa on pimeässä. Sillä suunnalla näin itsestäni muodottoman varjon, joka ulkona oleville juorusi, mitä kulloinkin tein.

Yhtä muuttumaton kuin huoneeni ja sen sisustus oli, yhtä muuttumattoman samankaltaiset olivat jokailtaiset askartelut sen seinien sisällä. Kynttilä kului kynttilän perästä, kuukausi seurasi toista, - aina laitettiin ensin vuode, sitten syötiin iltanen, lopuksi piirrettiin matkakartta ja kirjoitettiin päiväkirjaa. Kirjoitettiin myöhään yöhön. Teltta seisoi pimeässä ympäristössään kuin 


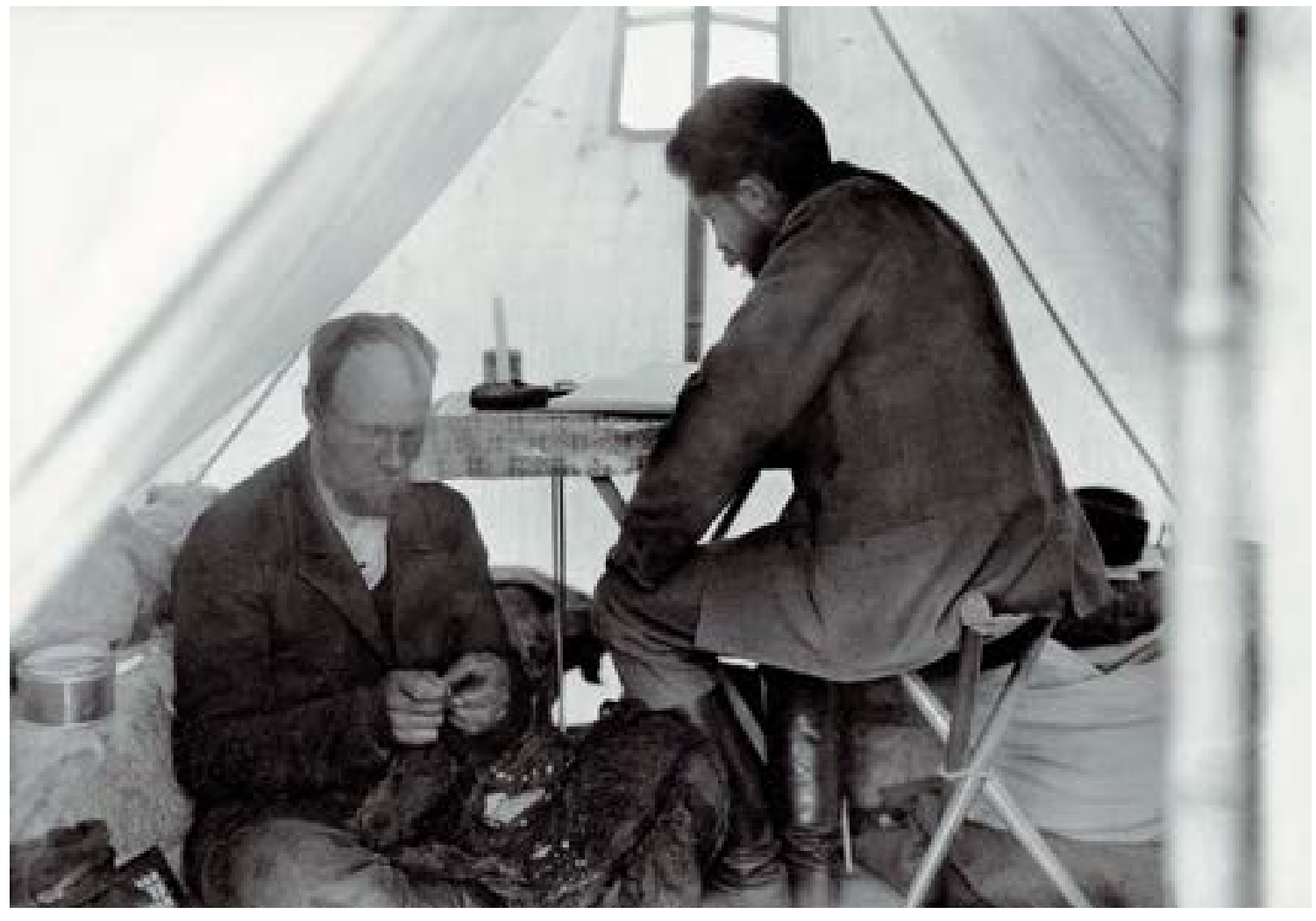

Tutkimusmatkailijoiden telttaelämää päivän taipaleen päätyttyä. J. G. Granön kirjoittaessa päiväkirjaansa Tapani Unkuri paikkaa paitaansa. Mongolia, Hangaivuoristo 1909.

suunnaton paperilyhty, jonka sisällä joku jättiläismäinen hyönteinen kömmiskeli, luoden varjoa sen seiniin. Syrjäisten korpien pedot ja yön peikot, jotka eivät usein sellaista näe, muistavat kyllä sen valon. ${ }^{212}$ 


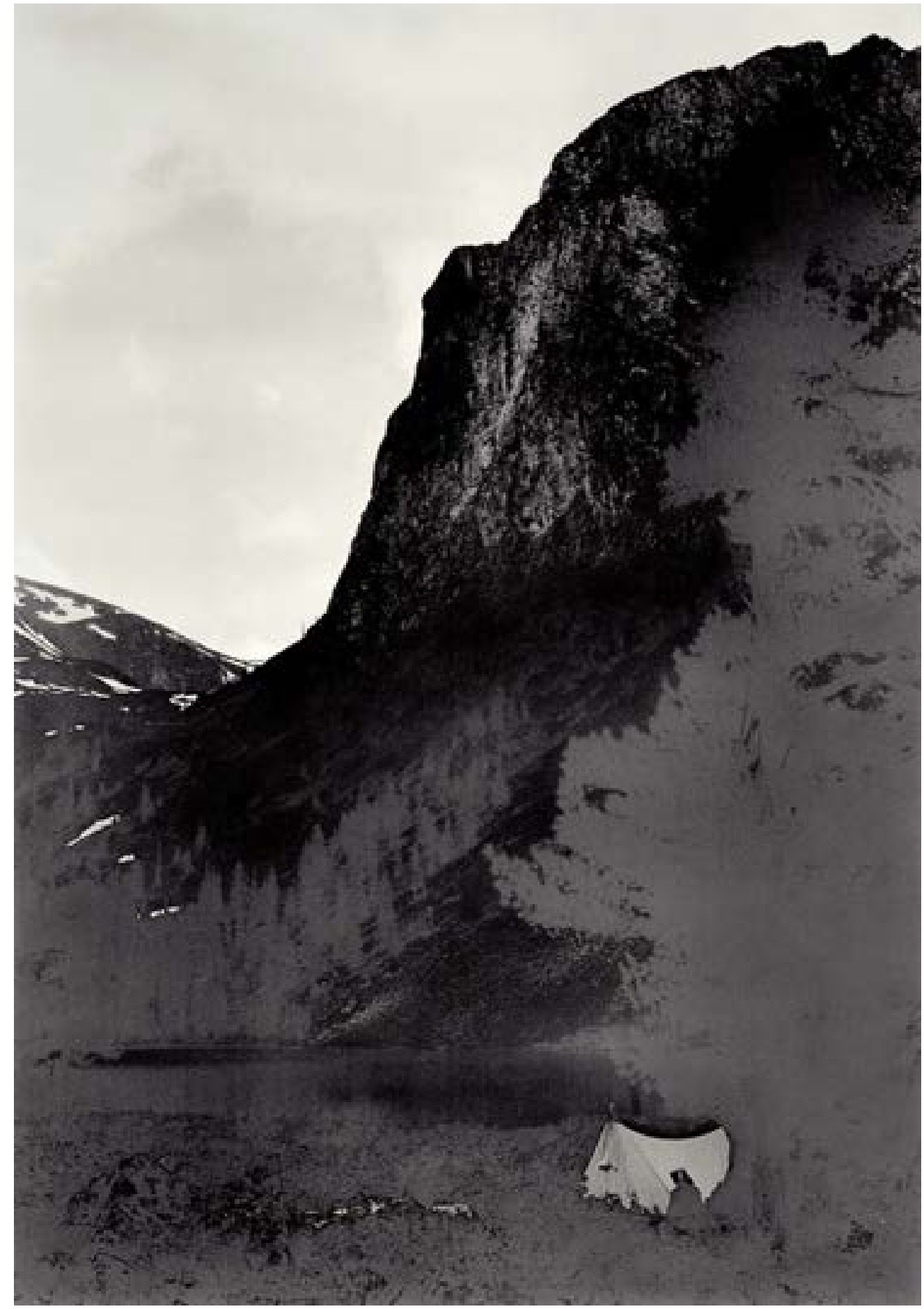


Kotandásta Granö johdatti retkikuntansa Katunin laaksoa seuraten aivan Altain korkeimman huipun, Katunin pylväiksi ja Kultaiseksi vuoreksi kutsutun Belúhan (4 500 metriä) rinteille saakka. Matkan kohokohtia oli tutustuminen kauniiseen Talménjejärveen, joka oli Telétskojejärven tavoin syntynyt jäätikön kasaamien kerrosten sulkemaan laaksoon.

Retkeiltyään järven ympäristössä ja kartoitettuaan sen altaan Granö eteni aivan Belúhan juurelle. Hän teki myös retken Katunin-jäätikölle, jota kutsuttiin myös alueen ensimmäisen tutkijan mukaan Geblerin-jäätiköksi. Jäätikkö oli aiempien tutkijoiden jättämien merkkien mukaan supistunut vuodesta 1911 lähtien 150200 metriä. Sieltä hän ratsasti Buhtarmán erään

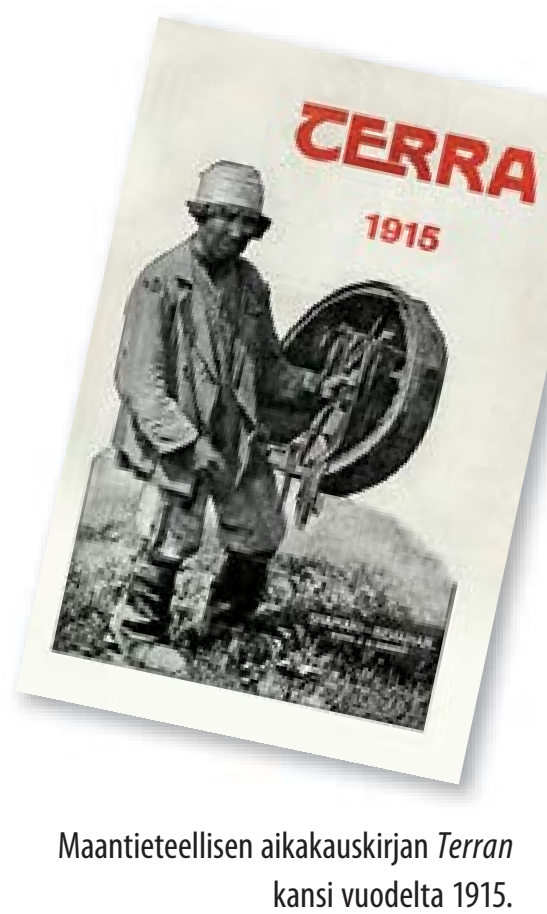
sivujoen, Bélyi-Berelin laaksoon ja edelleen Argutiin laskevan Kok-sun varrelle ja Argutin rotkolaaksoon, joka oli Venäjän Altain jylhin. ${ }^{213}$

Seurattuaan Argutin laaksoa sen latvoille saakka Granö suuntasi Tšujan-vuoristoon, joka muodosti Katunin alppien itäisen jatkon. Hän ratsasti itään Koš-agatšiin, jossa oli nähtävillä paljon muinaisen jäätikön merkkejä. Tšujajokea ylitettäessä tapahtui jälleen paha veneonnettomuus, kun voimakas virta kaatoi toisen retkikunnan

Stipendikauden viimeisenä kesänä 1916 Hilma Granö seurasi miestään tutkimusmatkalle. Kesäkuun puolivälissä Granöt leiriytyivät syrjäisen Ytš-mongolin sysimustaan rotkomaiseen laaksoon. Synkkä paikka sai Granön miettimään, mitä tapahtuisi, jos jompikumpi aviopuolisoista sairastuisi yllättäen. Palytkty-köl, Venäjän Altai 1916. käyttämistä veneistä. Venettä ohjannut telengiitti ja Pável pelastuivat täpärästi, mutta venekuormallisesta tavaroita säästyi vain pieni osa. ${ }^{214}$

Koš-agatšista retkikunta palasi Tšujan eteläpuolitse Kotandáan. Sieltä Granö teki vielä retket muun 
muassa Uimonin-arolle sekä Argutin lisäjoen Kajirin alueelle ennen kuin vakuuttui siitä, että kesän ohjelma oli valmis. Hän oli havainnut kaikkialla Katunin ja siihen laskevien jokien laaksoissa selviä jäkauden merkkejä, joten hän saattoi luottavaisin mielin palata syyskuun lopulla Bijskiin. ${ }^{215}$

J. K. V. Tuomiselle lähettämässään kirjeessä Granö totesi, että kesän 1915 matka oli hänen tutkimusmatkoistaan kaikkein onnistunein siinä suhteessa, että se oli opettavaisin:
En ole ainuallakaan matkallani saanut niin paljon vaikutteita, niin paljon aineksia. Jumala auttoi todellakin heikkoa matkamiestä askel askeleelta alusta loppuun. Suuri yksinäisyys oli minulle myös varsin terveellinen. Elämän hyöri- nässä ja ihmisten keskuudessa ei ole tilaisuutta hiljaisuudessa käydä tiliä itsensä kanssa.
En sanoa tätä, painostaakseni sitä että olisin päässyt nyt selvyyteen tär- keissä ijäisyyskysymyksissä. Sanon vaan että muutamat kysymykset alkoivat minulle selviytyä. Tämän kesän yksinäiset illat teltassa - kaukana ihmisistä -, ne ovat parhaimpia muistojani vaellusvuosiltani. Toisaalta tietysti ne olivat ikäviä, nuo pitkät pimeät illat (sen ymmärtänet, vaikket ole tainnut olleen- kaan erotettuna niin kauan ja niin kauas perheestäsi), mutta sittenkin. ${ }^{216}$

Tutkimusalueen laajuuden vuoksi Granö oli käyttänyt kaksi ensimmäistä vuottaan miltei pelkästään aineiston keräämiseen ja tarkkojen topografisten karttojen valmistamiseen. Tutkimuksen edetessä tärkeimmäksi ongelmaksi nousi päälaakson ja sivulaaksojen välisten yhtymäkohtien terassien sijainnin märittely. Tämä edellytti tarkistusmittausten tekemistä Itä-Altain tunturiseuduilla.

Granö aloitti viimeisen stipendivuotensa 1916 tutkimukset etenemällä kesäkuun puolivälissä puolisonsa Hilman kanssa Bijskistä Kumanin vuorimaahan, joka muodostaa vedenjakajan alisen Tšulyšmanin ja Katunin välillä. Edjiganista Granöt etenivät osin Iljá Tungerekin ja muiden oppaiden johdattamana mutta pääosin karttojen 
ja kompassin avulla Baškausin syvään rotkolaaksoon ja edelleen Venäjän ja Mongolian rajaseudulle ja jopa eteläisen naapurivaltion puolelle. ${ }^{217}$

Mongoliasta palattuaan Granöt ratsastivat ensin Baškausin latvalaaksoa seuraten kohti alavia maita ja sitten Kurain vuorten yli Koš-agatšiin, jossa he luopuivat viimeisestä oppaastaan. Työskenneltyään vielä lyhyen aikaa Keski-Altailla Pestšánan alueella Granö katsoi viimein, että nyt hänellä oli riittävästi havaintoaineistoa johtopäätöstensä tueksi. Paluumatka Bijskin kautta Omskiin saattoi viimein alkaa elokuun puolivälissä. ${ }^{218}$

\section{Omskin koti}

Koska vuorilla ei ollut mahdollista liikkua talvisin, Granö noudatti selkeää vuosirytmiä. Tutkimusmatkoille lähdettiin mahdollisimman aikaisin keväällä, ja niiltä palattiin vasta talven tehdessä liikkumisen vuoristossa mahdottomaksi. Sydäntalven aika käytettiin Omskissa havaintoaineiston muokkaamiseen, valokuvien kehittämiseen, tutkimusten kirjoittamiseen ja tulevien matkojen valmisteluun. ${ }^{219}$

Granöt asuivat ensimmäisen vuoden Paavo-veljen isännöimän pappilan läheltä vuokraamassaan huoneistossa. Nuori pari viihtyi hyvin, ja Granö nautti saadessaan keskittyä vaimonsa avustamana tutkimustyöhön. Ystävälleen J. K. V. Tuomiselle lähettämässään kirjeessä hän kuvailee autuasta oloaan: "Kaikki viihtymisen edellytykset ovat siis olemassa. Ja kun ajattelen, miten rauhassa saan työskennellä erikoisalallani, lämpenee oikein mieleni!"220

Hyvä työvire näkyi tieteellisenä tuottavuutena. Granö kirjoitti alkutalven 1914 aikana merkittäviin saksalaisiin maantieteellisiin sarjoihin kaksi artikkelia, joissa hän kuvasi sekä elokuun Kaukasuksen matkan että syksyn Itä-Altain matkan tuloksia. Seuraavaksi hän alkoi työstää painokuntoon vuosien 1906-09 matkoilta peräisin olevaa aineistoa, korkeusmittauksia ja meteorologisia havaintoja ja itineraareja. ${ }^{221}$

Tämän jälkeen Granö kävi käsiksi syksyn aikana kokoamaansa materiaaliin. Jo kevääseen mennessä hän oli kirjoittanut noin 100 sivua uutta tekstiä. Havaintoai- 


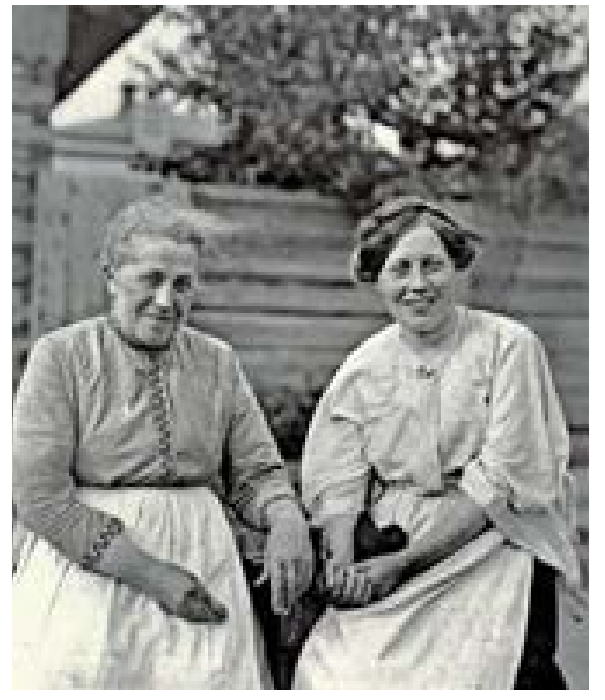

Äiti Alma Granö ja puoliso Hilma Granö pappilan pihalla 1913. neiston käsittelyn ohella Granö valmistautui tuleviin matkoihin. Hän aloitti jo loppuvuonna 1913 paikallisen mongolian kielen tehokurssin. Kaksi kertaa viikossa Granön luona vieraillut "mulla" opetti sekä puhuttua että kirjoitettua kieltä. Hyvän kielipäänsä ansiosta Granö oppi uuden kielen niin nopeasti, että tuli sillä vuoden alussa toimeen arkisissa asioissa ja oppi pian myös vaihtamaan ajatuksia. ${ }^{222}$

Granö tutustui nopeasti Omskin ja Siperian toisen keskuksen Tomskin tutkijoihin ja viranomaisiin, joilta piti hankkia tarvittavia matkustuslupia. Hän saavutti pian arvostetun aseman Siperian maantieteellisissä piireissä, mitä kuvastivat valin-

nat Venäjän Maantieteellisen Seuran ja Länsi-Siperian Maantieteellisen Yhdistyksen jäseneksi 1913-14 sekä epävirallinen pyyntö hakea Tomskin yliopiston maantieteen professuuria.

Granö kirjoitti myös kaksi venäjänkielistä tutkimusta, jotka ilmestyivät seuraavina vuosina paikallisissa tieteellisissä sarjoissa. Näistä toinen oli Siperian tutkimuksen suurmiehen G. N. Potaninin 80-vuotispäivän kunniaksi julkaisu juhlakirja $O$ znachenii lednikovago perioda dlya morfologii sev.-vost. Altaya. ${ }^{223}$

Olo Omskissa vakiintui edelleen lokakuussa 1914, jolloin Granöt pääsivät muuttamaan pappilan tontille rakennuttamaansa omaan taloon. Isännän luonnoksen pohjalta suunniteltu ketripuinen talo oli hyvä suoja sydäntalvella, jolloin lämpötila saattoi laskea yli 40 pakkasasteeseen. Nyt lämpöä tarvittiin vielä aiempaa enemmän, sillä nuoren parin esikoinen, Aune, oli syntynyt heinäkuussa, kun Granö oli serkkunsa Paavo Granön kanssa saattamassa Hildéniä Bijskiin. ${ }^{24}$ 


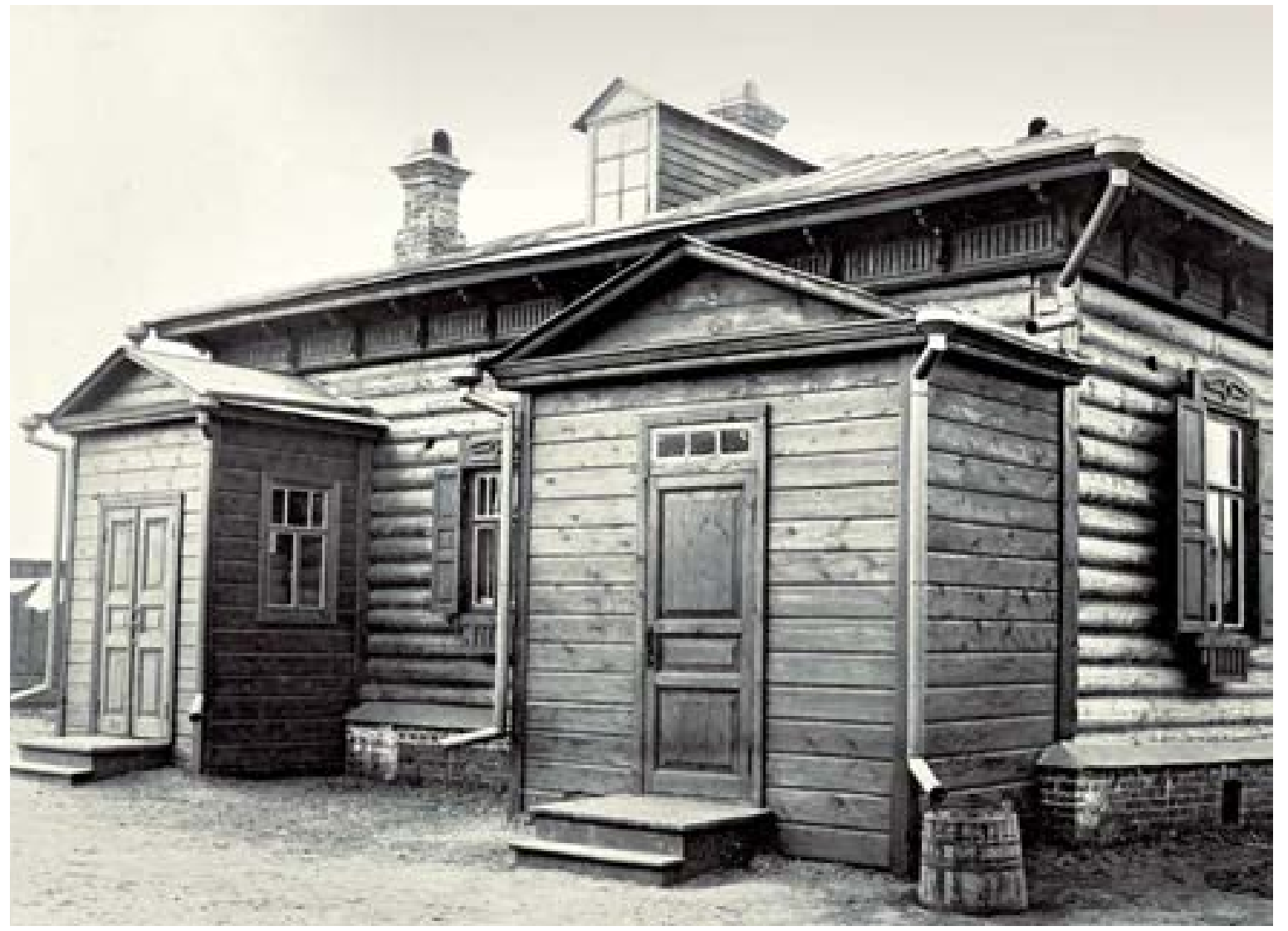

J. G. Granö kuvasi 1915 edellisenä vuonna Omskin suomalaisen pappilan pihamaalle rakennuttamansa ketripuisen talon. Talo jäi tyhjilleen seuraavan vuoden lopulla, jolloin Granöt joutuivat matkustamaan Suomeen. Pian se siirtyi suomalaisten punasotilaiden majapaikaksi ja lopulta uuden neuvostovallan omistukseen. Rakennus purettiin 1980-luvulla.

Kesällä 1914 puhjennut ensimmäinen maailmansota vaikutti myös Granön perheen elämään, sillä Omskissa ryhdyttiin jo varhain valmistautumaan sodan leviämisen varalle. Kaupungin elintarviketilanne pysyi aluksi hyvänä, mutta jo vuoden 1915 lopulla sodan mainingit ulottuivat Siperian keskukseen saakka. Granö tilitti jälleen tunteitaan Tuomiselle: 


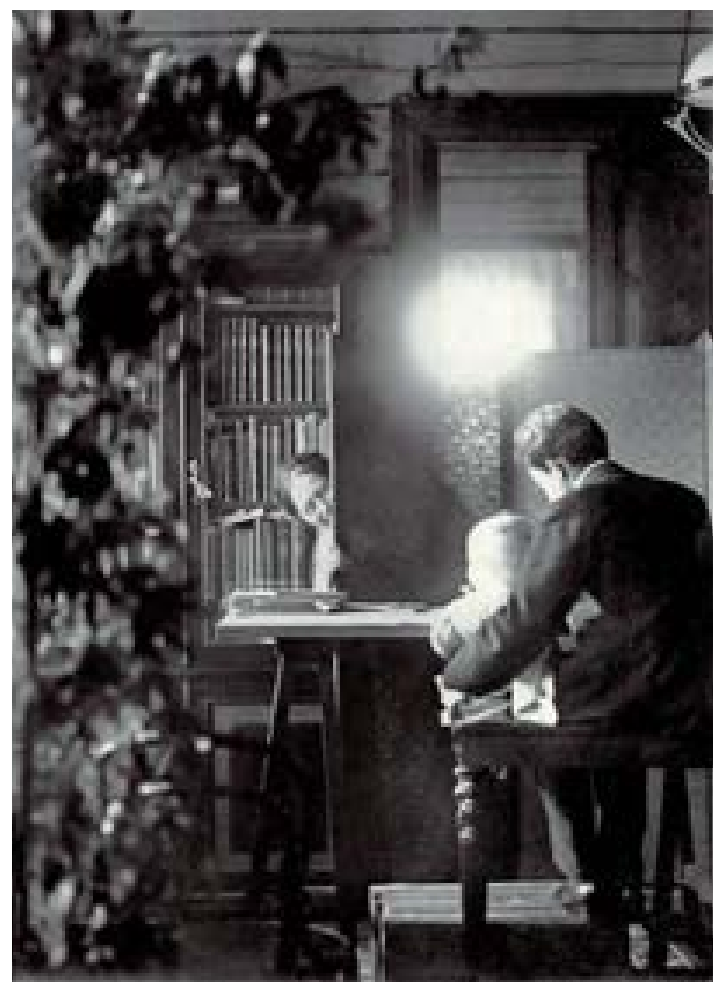

Kaapo sylissään 0mskissa heinäkuussa 1914 syntynyt esikoistytär Aune. Äiti Hilma kurkistaa kaihtimen takaa.
Ruoka-aineet eivät juuri ole kallistuneet, erittäinkään jauhot ja liha, mutta muut tarveaineet käyvät päivä päivältä kalliimmiksi. Jos tätä kehitystä jatkuu, ei Antellin stipendi kauas riitä vaikka kotonakin istuisi ja enimmäkseen vesivelliä söisi. ${ }^{225}$

Kun Venäjän joukot menestyivät sodan alkuvaiheessa eteläisellä rintamalla, ne saivat paljon sotavankeja, joita sijoitettiin eri puolille keisarikuntaa. Osa vangeista päätyi Omskiin, jossa he saivat kulkea varsin vapaasti. Granö pestasi erään tšekkivangin avustamaan puutarhatöitä, jotka hän oli aloittanut vaimonsa kanssa heti keväällä 1915. Kotitalon ympärille istutettiin muun muassa poppeleita, sireeneitäja omenapuita,

pieni keittiöpuutarha perustettiin ja tontin muuhun vapaaseen osaan kylvettiin matalakasvuista ruohoa ja nurmikukkasia. Näin perhe sai viihtyisän lepopaikan kesän pölyistä kärsivässä kaupungissa. ${ }^{226}$

\section{Davisilainen tulkinta Altain pinnanmuotojen synnystä}

Pelkästään stipendivuosina 1913-16 tekemänsä kolmen pisimmän tutkimusmatkan aikana Granö taittoi Altain vuoristossa taivalta yli 6500 kilometriä. Jos mukaan lasketaan vuosina 1906-09 tehdyt matkat, hänen vuoristossa tekemiensä tutkimusmatkojen yhteenlaskettu pituus - juna- ja laivamatkoja lukuun ottamatta - oli lähes 
10000 kilometriä. Kun hän oli lisäksi perehtynyt huolellisesti aluetta käsittelevään tutkimuskirjallisuuteen, hän oli kohonnut yhdeksi tämän laajan vuorimaan parhaista tuntijoista maailmassa. ${ }^{227}$

Granön 1915-16 Siperian Maantieteellisen Seuran sarjassa julkaisemat tutkimukset saivat pääosin myönteisen vastaanoton, vaikka kaikkia hänen näkemyksiään ei hyväksytty. Eniten vastustusta herättivät hänen tulkintansa Altain tunturiylänköjen synnystä ja syvien rotkolaaksojen väittäminen jäätikön uurtamiksi, sillä esimerkiksi tunnettu venäläinen tutkija V. A. Obrutšev katsoi niiden syntyneen maankuoren liikkeiden seurauksena. Kritiikin seurauksena Granö pyrki kehittämään tulkintaansa siten, että se otti huomioon sekä jäätikön kulutustyön että jokikulutuksen syklit. ${ }^{228}$

Granö julkaisi Altain tutkimustensa tuloksia myös kahdessa 1916 Terrassa ilmestyneessä suomenkielisessä artikkelissa Jä̈̈kauden geomorfologisesta vaikutuksesta Venäjän Altain Bija-alueeseen ja Jä̈̈kausitutkimukseni Venäjän Altaissa, jotka olivat luonteeltaan ennakkoraportteja ja tutkimusaiheen kuvauksia. Samaan aikaan hän valmisteli kansainväliselle tiedeyhteisölle tarkoitettua kokonaisesitystä, jonka hän oli alun perin ajatellut julkaisevansa saksaksi. Kun ensimmäinen maailmansota katkaisi tieteelliset yhteydet Saksaan, Granö katsoi parhaaksi vaihtaa julkaisukieleksi ranskan. ${ }^{229}$

Vuonna 1917 ilmestynyt Les formes du relief dans l'Altaï russe et leur genèse oli yli 120 sivun laajuinen geomorfologinen kuvaus Altain pinnanmuodoista ja niiden syntyvaiheista. Tutkimuksessa Granö esitti, että Altain vuorimaa oli muodostunut myöhemmin kuin aiemmin oli otaksuttu. Seudun syvien laaksojen vastakohtina olevat tasaiset tunturiylängöt olivat hänen mukaansa pitkäaikaisen kulutuksen lopputuloksia. Tämän vuoksi hän kutsui niitä aluksi Davisin mukaan peneplaaneiksi, kunnes ryhtyi käyttämään suomenkielistä nimitystä tasaantumispinta. ${ }^{230}$

Sota-ajan ja Suomen Maantieteellisen Seuran talousongelmien vuoksi tutkimus pääsi kansainväliseen tietoisuuteen vasta 1919, jolloin se ilmestyi Fenniassa. Se sai hyvän vastaanoton, sillä Granö oli ensimmäinen tutkija, joka tukeutui Keski-Aasian ylängön syntyä selittäessään Davisin eroosiosykliteoriaan. Tärkeimmän tunnustuksen Granö sai itseltään Davisilta. Tämä totesi vuoden 1921 Geographical Reviewissä 


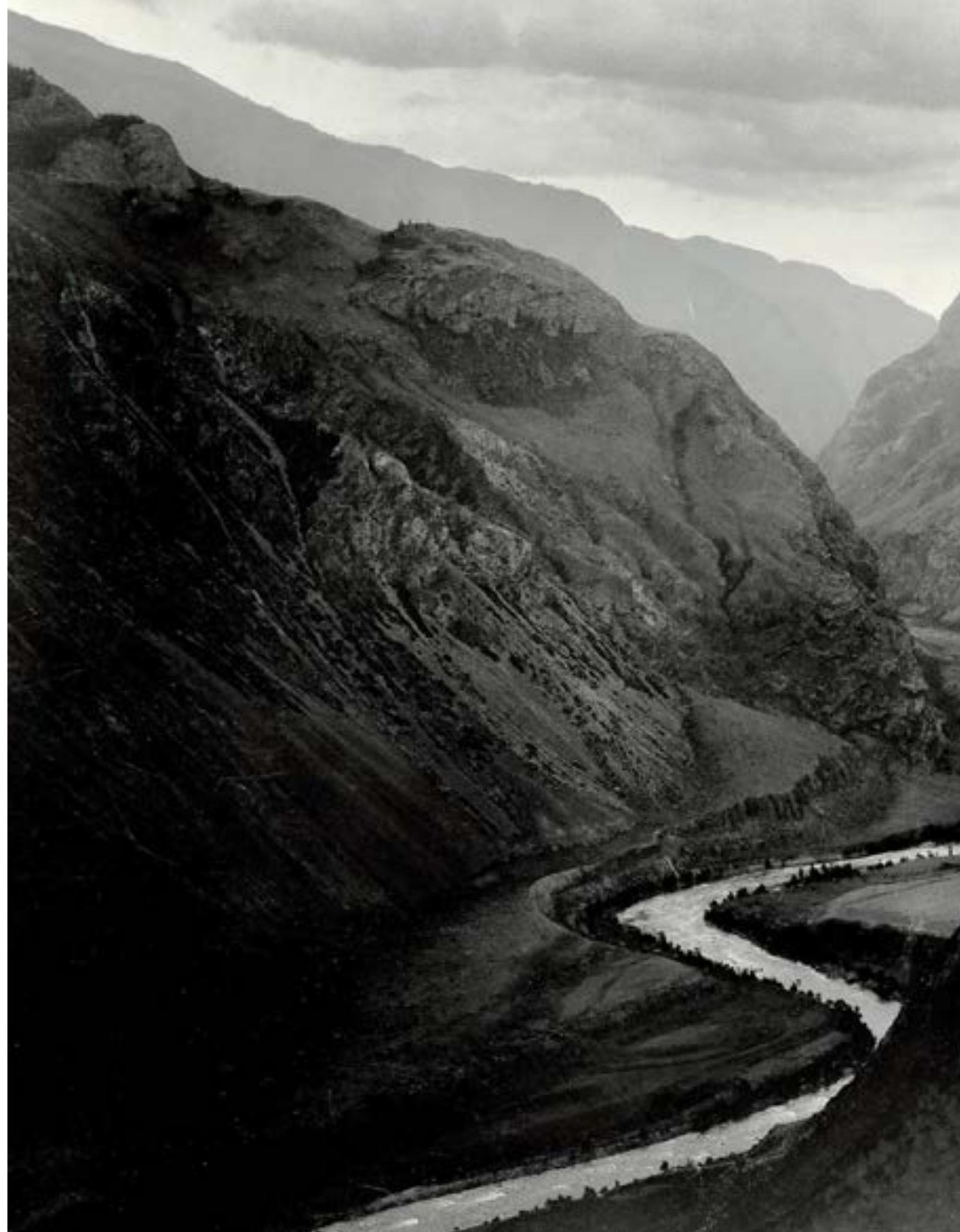



julkaisemassaan arviossa, että suomalaiEdellinen aukeama: Tšulyšmanin jäätikön uurtama rotkosen maantieteilijän Granön tutkimus oli mainen jokilaakso oli Granön keskeisiä tutkimuskohteita. viime vuosien huomattavin vuorimuotojen syntyä selvittänyt työ. Samalla Davis tahtoi luonnollisesti myös sanoa, että Altaitutkimukset osoittivat, että hänen näkemyksiään voitiin soveltaa yleisesti. ${ }^{231}$

Davisin Granötä kohtaan tuntemaan arvostusta osoittaa se, että miehet olivat 1920-luvun vaihteessa kirjeenvaihdossa ja lähettivät toisilleen teoksiaan. Granö tunnusti omissa kirjeissään tuntevansa itsensä monessa suhteessa Davisin oppilaaksi, ja Davis puolestaan arvosti suomalaisen asettumista tukemaan häntä saksalaisen maantieteilijän Siegfried Passargen hyökätessä ankarasti eroosiosyklioppia vastaan. ${ }^{232}$

Myös monet venäläiset ja myöhemmin neuvostoliittolaiset tutkijat tutustuivat huolella Granön tutkimukseen. Vaikka hänen näkemyksensä eivät saaneet yksimielistä hyväksyntää, ne saivat aikaan sen, että Altain pinnanmuotojen synnyn tutkimuksessa ryhdyttiin kiinnittämään aiempaa enemmän huomiota jäätikköjen vaikutukseen. Esimerkiksi Telétskojejärven altaan ei enää katsottu syntyneen vajoamisen seurauksena vaan jäätikkövirtojen uurtamana. ${ }^{233}$

\section{Katkera paluu}

Granö ei ollut itse täysin tyytyväinen tutkimustensa tuloksiin. Häneltä oli mennyt niin paljon aikaa tutkimusalueen kartoittamiseen ja havaintomateriaalin keruuseen, ettei ollut ehtinyt analysoida aineistoaan kunnolla. Lisäongelmia aiheutui siitä, että hän oli tutkimuksen edetessä havainnut, että Davisin eroosiosyklioppi ei soveltunut sellaisenaan Altain pinnanmuotojen selittämiseen. Erityisesti jääkautisen jäätikön merkitystä olisi tullut tutkia syvällisemmin:

Olen itse työskennellyt vuosikausia Davisin syklusopin lumoissa ja tiedän pitää arvossa merentakaisen mestarin teoksista saamaani opetusta. Mutta olen myös tietoinen niistä epäkohdista, jotka aiheutuvat siitä, että nuori, kokematon tut- 
kija, joka ei ole tietoinen tunnollisen morfografisen käsittelyn merkityksestä eikä vielä riittävässä määrässä tunne alueella esiintyviä geomorfologisia tapahtumia, joutuu kosketuksiin viettelevän selvän ja yksinkertaisen geneettisen järjestelmän kanssa. ${ }^{234}$

Les formes du relief dans l'Altaï russe et leur genèse oli Granölle vain eräänlainen välitilinpäätös, jonka avulla hän pyrki näyttämään, että tutkimustyö oli johtamassa merkittäviin tuloksiin. Tämä näkyi siten, että heti saatuaan tutkimuksen käsikirjoituksen valmiiksi maaliskuun 1916 lopulla hän vei sen henkilökohtaisesti Omskista Helsinkiin Fennian toimittajalle J. A. Palménille. Matkan syynä ei ollut epäluottamus Venäjän postilaitosta kohtaan vaan Granön yritys saada Rosenbergin stipendille kahden vuoden jatkoaika, jonka avulla hän olisi voinut täydentää tutkimuksiaan Altailla. ${ }^{235}$

Granön yritys ei ollut aivan vailla mahdollisuuksia, sillä erityisistä syistä suurten apurahojen nauttimista voitiin pitkittää toisella kaudella. Esimerkiksi Rafael Karsten oli saanut poikkeuksellisesti sekä Aleksanterin että kahdesti Rosenbergin stipendin koko 1910-luvun kestäneille matkoilleen Etelä-Amerikkaan. ${ }^{236}$

Keväällä 1916 Granön tilanne näytti hyvältä, sillä fyysis-matemaattinen osasto päätti Wilhelm Ramsayn ja Iivari Leiviskän lausuntojen perusteella suosittaa konsistorille uuden apurahan myöntämistä hänelle. Palattuaan Helsingistä Siperiaan hän oli varsin toiveikas jatkoajan suhteen, sillä hän uskoi, että osaston kanta oli jo muotoutunut. Hän anoi siksi edelleen virkavapautta yliopistosta ja jäi Omskiin valmistelemaan seuraavan kesän tutkimusmatkaansa, jonka hän aikoi toteuttaa Kaarlo Hildénin kanssa. ${ }^{237}$

Syksyllä tilanne kuitenkin muuttui, kun Ramsayn oppilas, 1910-luvun puolimaissa nopeasti kansainväliseen maineeseen kohonnut Pentti Eskola, päätti hakea samaa apurahaa. Hänen tavoitteenaan oli jatkaa erityisesti tektoniikkaan, stratigrafiaan ja petrografiaan keskittyviä geologisia tutkimuksiaan Itä-Karjalassa.

Fyysis-matemaattisen osaston kannan käytännössä ratkaisseen Ramsayn ja Leiviskän lausunnon mukaan Granö oli täyttänyt erinomaisesti ne tavoitteet, joihin hän 
oli tähdännyt kolme vuotta kestäneillä Altai-tutkimuksillaan, joten myös uusi kausi tuottaisi ilmeisesti "kauniita tuloksia". Eskolan tutkimuksilla oli kuitenkin paitsi huomattava tieteellinen myös suuri kansallinen merkitys, sillä Itä-Karjalan katsottiin kuuluvan erityisesti Wilhelm Ramsayn luoman Fennoskandia-käsitteen perusteella suomalaisten geologien reviiriin. Lausunnon mukaan molemmat hakijat olivat apurahan arvoisia, mutta nyt etusija oli annettava dosentti Eskolalle. Konsistori myönsi Eskolalle apurahan tiukan äänestyksen jälkeen.238

Granön oli siten jätettävä Altain tutkimukset, "tieteen avaruudet" ja palattava Helsinkiin opetustehtäviin. Tämä oli hänelle raskas takaisku, sillä se merkitsi lupaavia näkymiä avanneen tutkimusjakson päättymistä ja paluuta Helsinkiin. Omskin pappilan pihalle rakennettu koti jäi tyhjilleen joulukuussa 1916, jolloin Granö perheineen matkusti Suomeen. ${ }^{239}$

Ilmeisesti pettymys olisi ollut vielä suurempi, jos Granö olisi tiennyt, että lähtö oli lopullinen. Lokakuun vallankumous johti siihen, että hän ei kyennyt koskaan palaamaan tutkimusalueelleen eikä saanut myöskään minkäänlaista korvausta Omskiin jääneestä omaisuudestaan. Altain tutkimusta hän ei kuitenkaan jättänyt kokonaan koskaan, sillä vuorimaa oli jättänyt hänen mieleensä pysyvät muistot ja retkillä koottua muokkaamatonta tutkimusaineistoa riitti vuosikausiksi. ${ }^{240}$ 


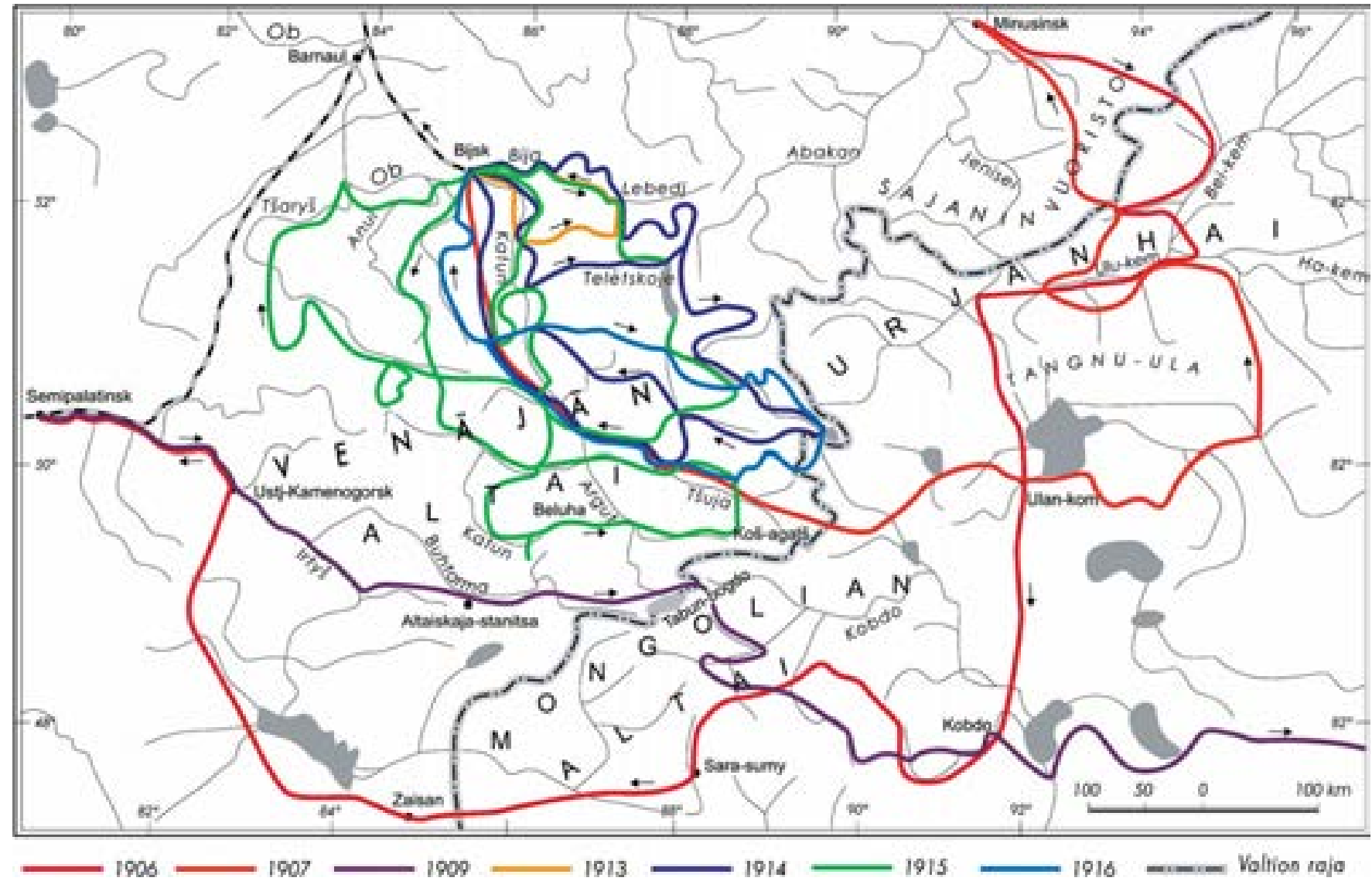

J. G. Granön tutkimusmatkat Altailla, Luoteis-Mongolian järvialueella ja Urjanhaissa 1906-16. 


\section{EPÄVARMUUDEN VUODET}

"Nyt otan minä askeleen, jolle ei nauraa sovi. Uskallettuahan tietysti on Tarttoonlähtö, mutta uskallettua on oikeastaan koko elämämmekin, oleskelimme ja elimmepä missä tahansa, - ainakin tätä nykyä. Jos katson asiaa yliopistomaantieteilijän silmillä, on tietysti vakinainen ja itsenäinen opettajatoiminta korkeakoulussa parasta, mitä yleensä voisi olla tarjona; jos aprikoisin kysymystä perheenhuoltajana, tulee minun muistaa, että tätä nykyä olen täällä palkaton dosentti. Ja vaikkapa katsoisin asiaa isänmaalliselta kannalta ja arvioisin kykyni pari kertaa suuremmaksi kuin mitä se todellisuudessa on, niin olisi tulos sama: suurempi ilo olisi maallemme siitä, jos kunnialla edustaisin suomalaista tiedettä eestien maassa kuin jos jatkuvasti pänttäisin matemaattista maantiedettä ja kartografiaa täkäläisten discipulusten päihin."241 


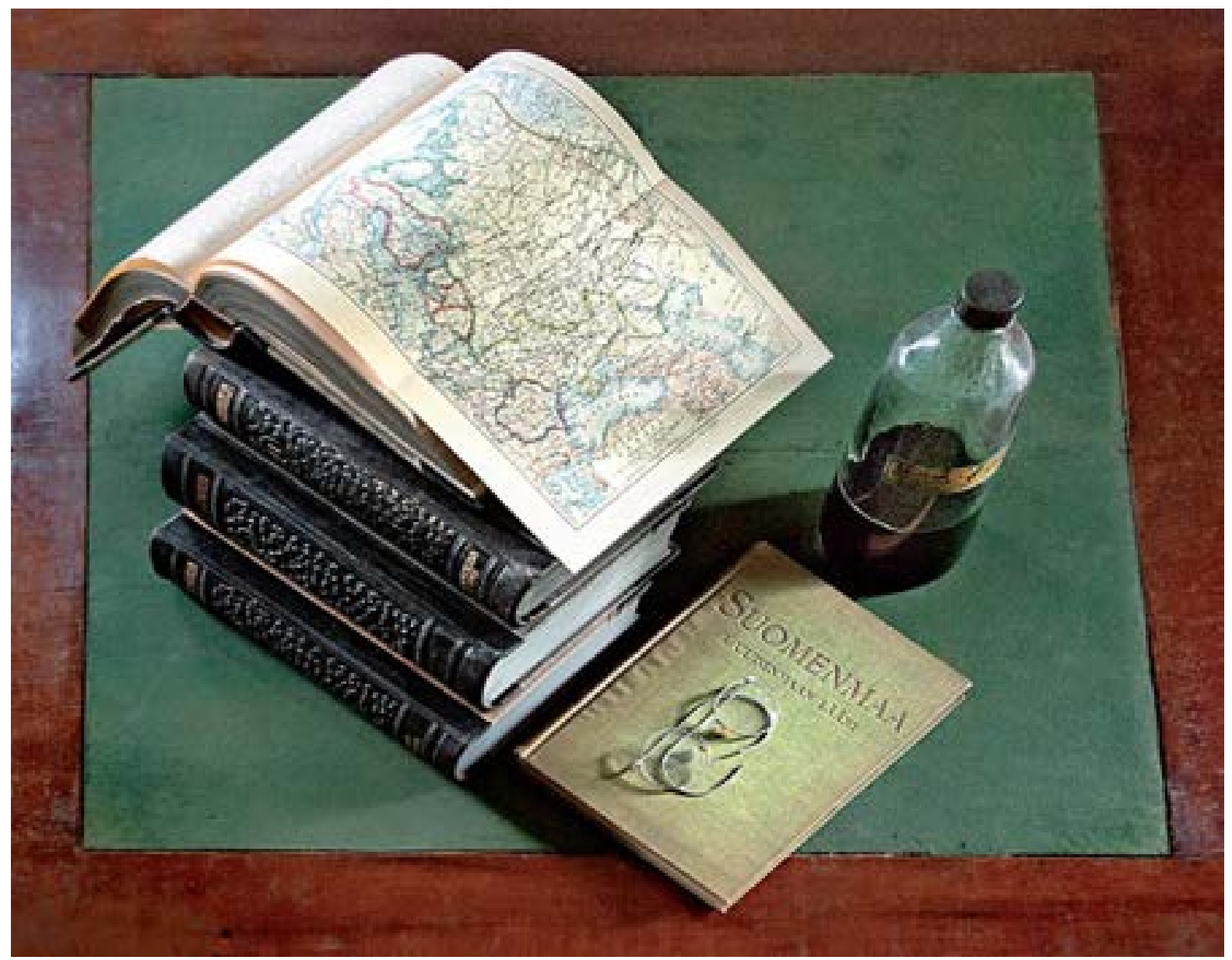

J. G. Granö kirjoitti 1919 ilmestyneen Tietosanakirjan kymmenenteen osaan laajan artikkelin Venäjästä. Samana vuonna hän työskenteli myös Suomen kuntia monipuolisesti esittelevän Suomenmaan toimituskunnassa ja laati käsikirjoitusta teoksen Uuttamaata koskevaan osaan. 


\section{VAIKEA AIKA}

\section{Pohjoinen Rautatiekatu 11}

Tutkimusrahoituksen loppuminen oli Granölle raskas takaisku sekä tieteellisesti että käytännöllisesti. Laajan havaintoaineiston kokoamisen jälkeen hän oli ehtinyt työstää materiaalia niin paljon, että oli kehittynyt tutkijana uudelle tasolle. Pyrittyään aluksi vain soveltamaan W. M. Davisin eroosiosyklioppia hän oli vähitellen ymmärtänyt, että se ei tarjonnut ratkaisua kaikkiin esille nousseisiin kysymyksiin. Hän oli alkanut luoda omaa peneplaanimuodostuksen teoriaa, joka otti Davisin tulkintaa enemmän huomioon jäätikön toiminnan merkityksen. Tämä työ jäi nyt kesken, sillä hypoteesien testaaminen olisi vaatinut uusia tutkimuksia paikan päällä. ${ }^{242}$

Nopea paluu Helsinkiin merkitsi myös sitä, että Granö joutui taloudellisesti ahtaalle. Suuri osa hänen omaisuudestaan oli kiinni Omskiin jääneessä talossa, joten hän joutui miettimään tarkoin, miten turvata perheen elanto. Hänellä ei ollut kevätlukukaudella 1917 muuta vakituista palkkavirkaa kuin maantieteen laitoksen assistentuuri, sillä dosentin tehtävästä hän sai vain opetuspalkkioita. Kun maantieteeseen ei ollut vapautumassa uusia yliopistovirkoja, hän joutui sekä miettimään vaihtoehtoja tutkijan uralle että hankkimaan lisäansioita sivutöillä. ${ }^{243}$

Toimeentulohuolia lisäsi se, että Helsinki alkoi vuodenvaihteessa 1917 kärsiä aiempaa pahemmin maailmansodan vaikutuksista, erityisesti asuntopulasta ja nälänhädästä. Sota oli pysäyttänyt rakennustoiminnan, mutta kun kaupungin väkiluku jatkoi tasaista kasvuaan, ihmiset joutuivat asumaan osin ala-arvoisissa oloissa. Tilannetta pahensi se, että lähes kaikki elintarvikkeet olivat tulleet 1916 säännöstelyn 


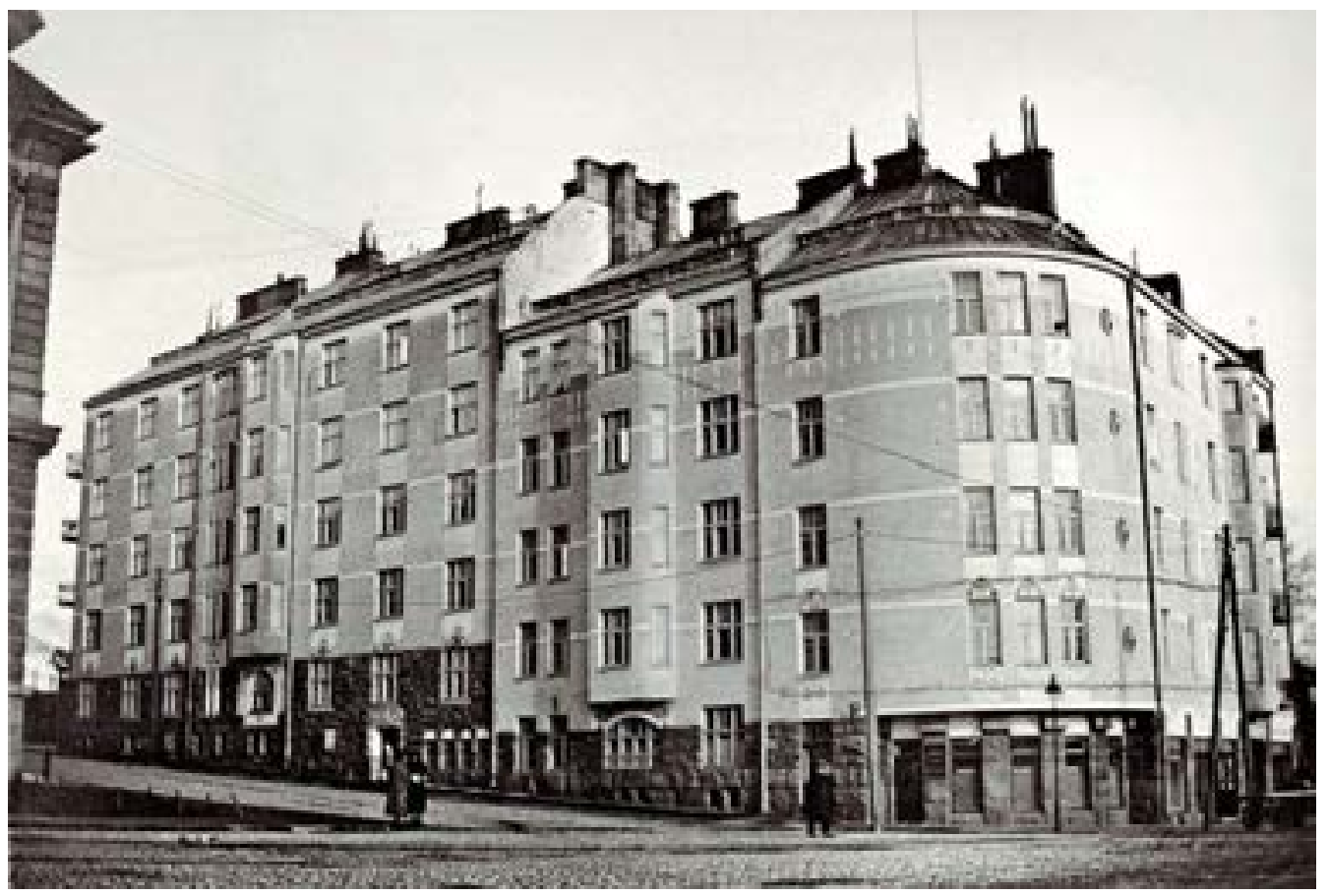

Palattuaan Suomeen loppuvuonna 1916 Granö osti kulmahuoneiston Asunto-osakeyhtiö Kotirinteestä Pohjoisen Rautatiekadun ja Nervanderinkadun kulmauksesta.

piiriin. Seuraavana vuonna elintarvikepula paheni, kun Helsinkiin virtasi runsaasti uutta väkeä etelärannikon linnoitustöiden päätyttyä. Erityisesti sokerista, maidosta, voista ja viljasta oli suuri puute. ${ }^{244}$

Granöt joutuivat kärsimään elintarvikkeiden vähyydestä muiden helsinkiläisten tavoin, mutta heidän asuntokysymyksensä ratkesi jo vuoden 1916 viimeisenä päivänä. Tuolloin he ostivat osakehuoneiston Asunto-osakeyhtiö Kotirinteestä Pohjoisen Rautatiekadun ja Nervanderinkadun kulmasta. Suomenkielisten kansakoulunopettajien omaksi talokseen 1910-luvun alussa rakennuttaman jugendlinnan oli suunnitellut arkkitehti Usko Nyström. 


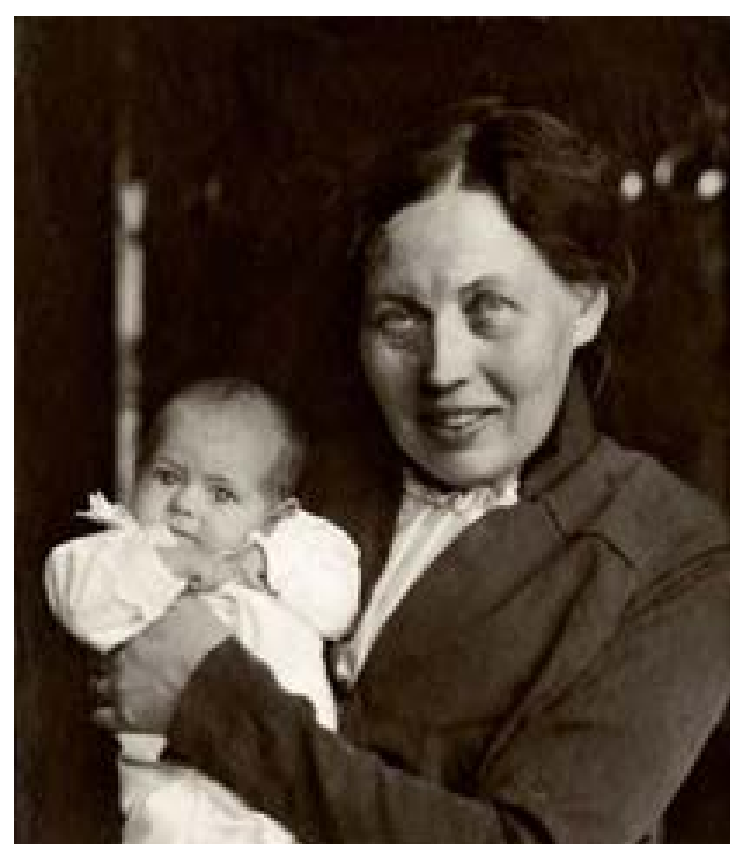

Granön perheen palattua Suomeen tammikuun alussa 1917 syntynyt Granön toinen tytär sai Altain vuosien muistoksi etunimet Siine ja Taiga.
Oman kodin hankkiminen ajoittui hyvin, sillä perhe kasvoi vain muutaman viikon kuluttua yhdellä jäsenellä, kun Granöt saivat "pienen kalliinajan lisäyksen, pikku tyttösen (n:o 2) hahmossa”. Altain aikojen muistoksi tytär sai kasteessa etunimet Siine ja Taiga. ${ }^{245}$

Granö palasi maantieteen laitokselle jatkamaan assistentin ja dosentin töitä. Sopeutuminen vanhoihin tehtäviin vei oman aikansa, sillä tutkimustyön katkeaminen kaiversi mieltä ja ajatukset karkasivat vähän väliä Altain maisemiin. Vähitellen varsinkin luennot alkoivat jälleen maistua, ja opetustyö pääsi kunnolla käyntiin. ${ }^{246}$

Kasvavan perheen paineessa Granö pohti myös vakavasti opettajanuralle suuntautumista, minkä vuoksi hän ryh-

tyi jatkamaan 1900 lopettamiaan kasvitieteen cum laude -opintoja professori Fredrik Elfvingin ja assistentti Karl Boldtin johdolla. Granö katsoi järjestelmällisten kasvitieteellisten opintojen olevan välttämättömiä myös maantieteen tutkimus- ja opetustyön kannalta, mutta tälläkin kertaa ne jäivät kesken. Hän päätti kevätlukukauden aikana, että tyytyy pysymään kasvitieteen harrastajana. ${ }^{247}$

Vaikka Granö hylkäsi ajatuksen vakituiseksi opettajaksi ryhtymiseksi, hän jatkoi neljä vuotta aiemmin lopettamiaan maantieteen aineenopettajan tehtäviä Helsingin suomalaisessa jatko-opistossa ja Helsingin suomalaisen tyttökoulun yliopistoon johtavilla jatkoluokilla. Samalla hän mietti mahdollisuutta siirtyä maantieteen oppikirjojen kirjoittajaksi. Hän oli koulutyönsä aikana havainnut, ettei 


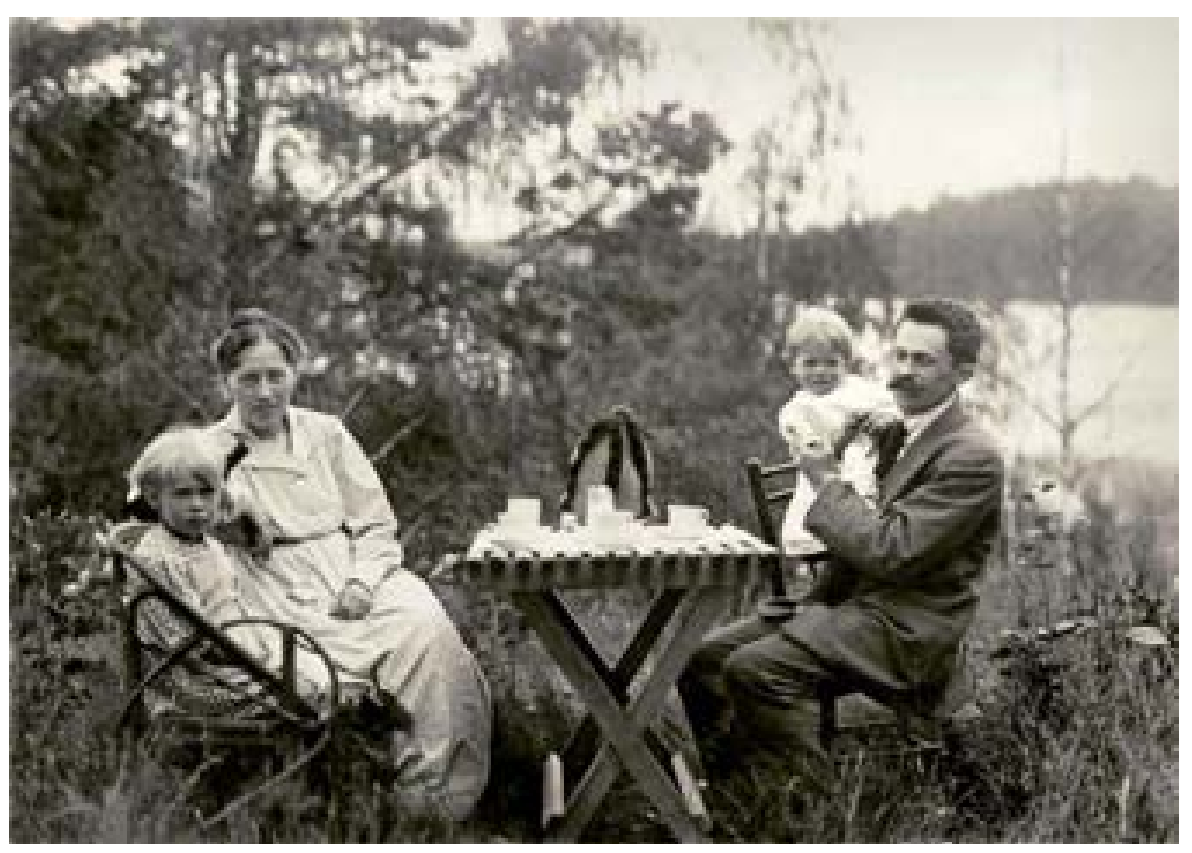

Aamupäiväkahvit Karjalohjalla 1918. Aune, Hilma ja Kaapo Siine sylissään.

markkinoilla ollut yhtään kunnollista maantieteen oppikirjaa. Hyvän oppikirjan menekki olisi siten ollut taattu. ${ }^{248}$

Granö jatkoi vanhaa yliopisto-opettajien perinnettä, jonka mukaisesti kesät oli pyhitetty virkistäytymiseen sekä omiin tutkimuksiin ja kirjallisiin töihin. Yliopistoopetuksen päätyttyä keväällä 1917 Granöt jättivät Helsingin kesäkuukausien ajaksi. Hän oli jo alkuvuonna ehtinyt vuokrata kesähuvilan Karjalohjalta mutta perunut varauksen keväällä, kun Jyväskylän kesäyliopiston vetäjät tarjosivat hänelle "kesäprofessuuria”. Jyväskyläläisten luovuttua opetuksen järjestämisestä elintarvikepulan vuoksi Granö joutui etsimään uuden loma-asunnon. Valinta osui luonnonkauniiseen Kuhmoisten kuntaan, josta hän vuokrasi Pasin talon noin kuusi kilometriä kirkonkylästä pohjoiseen. ${ }^{249}$

Kesä 1917 oli vuoden 1901 jälkeen ensimmäinen kesä, jonka Granö vietti kotimaassa. Hän nautti hiljaisesta maalaiselosta, joka tarjosi perheelle rauhan kiireisen kevään ja Siperian-vuosien jatkuvan matkustelun jälkeen. Hän saattoi rentoutua, har- 
joittaa pientä puutarhaviljelyä ja harrastaa lempipuuhaansa kalastamista. Toki lomaan mahtui myös kirjallisia töitä ja tieteellistä puuhastelua, sammalien ja jäkälien tutkimusta E. A. Wainion näytekokoelman, mikroskoopin sekä käsikirjojen avulla. ${ }^{250}$

\section{Murrosvaihe}

Kesän jälkeen Granöt palasivat Helsinkiin, jossa ilmapiiri oli kireä. Maaliskuun vallankumous oli lopettanut Venäjän keisarikunnan ja työntänyt syrjään myös Suomen vanhat vallanpitäjät kenraalikuvernööri Frans Albert Seyn ja senaatin talousosaston varapuheenjohtaja Mihail Borovitinovin. Venäjällä valtaan noussut väliaikainen hallitus oli pyrkinyt pitämään Suomen olot vakaina, sillä maassa oleva 100000 miehen vahvuinen venäläinen sotaväki oli vallankumouksellista. Siksi se oli suostunut porvarillisten puolueiden vaatimukseen ja antanut niin sanotun maaliskuun manifestin, joka kumosi helmikuun manifestin ja muut valtakunnan yhtenäistämispolitiikan mukaiset lait ja asetukset. ${ }^{251}$

Maaliskuun manifesti palautti Suomelle perustuslailliset oikeudet, mutta se oli voitto myös väliaikaiselle hallitukselle. Ottamalla manifestin vastaan suomalaiset hyväksyivät väliaikaisen hallituksen tsaarin vallan perijäksi. Manifesti ei tuonut Suomeen yhteiskuntarauhaa. Venäläinen sotaväki liikehti edelleen kurittomasti, ja porvarillisten puolueiden ja sosiaalidemokraattien mielipiteet maan asioiden hoidosta poikkesivat suuresti toisistaan. Työväestöä ärsyttivät työttömyys, inflaatio ja nälänhädäksi kehittyvä elintarvikepula. Lakot yleistyivät nopeasti teollisuudessa ja maataloudessa.

Marraskuussa 1917 bolševikit syrjäyttivät Pietarissa lähes verettömässä vallankaappauksessa väliaikaisen hallituksen. Vallankumouksen vaikutukset tuntuivat välittömästi Suomessa, kun lokakuussa pidetyissä eduskuntavaaleissa tappion kärsineet sosiaalidemokraatit alkoivat kääntyä luokkataistelun kannalle. Maahan julistettiin yleislakko, jonka aikana eduskunta päätti ottaa korkeimman vallan käsiinsä. Se vahvisti uudet kunnallislait sekä kahdeksan tunnin työaikalain. Vallankaappauspäätöksen puolue perui viime hetkellä. ${ }^{252}$ 
Vallankumouksen leviämistä Suomeen pelännyt ja Saksan tukeen luottanut P. E. Svinhufvudin senaatti antoi 4. joulukuuta 1917 itsenäisyysjulistuksen, jonka eduskunta hyväksyi kaksi päivää myöhemmin. Leninin johtaman kansankomissaarien neuvoston tunnustettua asian vuoden viimeisinä tunteina Suomen itsenäisyys sai nopeasti kansainvälisen hyväksynnän.

Itsenäistyminen ei ratkaissut maan sisäisiä ongelmia, ja Suomi ajautui tammikuun lopulla 1918 veriseen sisällissotaan. Rauha palautui vasta toukokuun puolivälissä Mannerheimin johtamien valkoisten joukkojen valloitettua Tampereen, saksalaisen avustusretkikunnan miehitettyä Helsingin ja viimeisten punaisten sekä venäläisten joukkojen poistuttua maasta. ${ }^{253}$

Granöt elivät koko murroskauden 1917-18 tapahtumien ytimessä Helsingin kodissaan, jonne he palasivat Kuhmoisista loppukesällä. Paluuseen ei olisi ollut kiirettä, sillä yliopisto päätettiin pitää suljettuna syyslukukaudella 1917 elintarviketilanteen huonontumisen ja Baltiassa olevien Saksan joukkojen nopean etenemisen vuoksi. Ratkaisusta ei koitunut syksyllä 1917 yliopistonlehtorin palkkaa vastanneen dosenttistipendin saaneelle Granölle taloudellista haittaa, sillä dosenttien toimeentulon turvaamiseksi heille taattiin palkkiot ilman opetusta. Maantieteen laitoksen assistentuurin hän joutui kuitenkin jättämään vuoden lopussa, sillä hän oli luvannut luovuttaa sen Wilho Sjöströmille, jos saa dosenttistipendin. ${ }^{254}$

Vapauduttuaan opetusvelvollisuuksista Granö pyrki hankkimaan lisäansioita kirjoitustehtävistä. Hän ryhtyi suunnittelemaan matkakirjaa Altain kokemuksista, mutta koska siitä ei siunaantunut välittömiä ansioita, hän astui 1917 Tietosanakirja Oy:n palvelukseen kirjoittamaan maantieteellisiä artikkeleita suuren kymmenosaisen Tietosanakirjan eli "ison mustan" viimeisiin osiin. Hänen osakseen tulleista yksittäisistä hakusanoista merkittävin oli Venäjä, johon hän laati maan luontoa, väestöä ja asutusta, elinkeinoja ja liikennettä sekä kulttuuria koskevan osuuden. Paljon perustutkimusta vaatinut noin 90000 merkin laajuinen teksti antoi hyvän kuvan myrskyisään vaiheeseen ajautuneen itäisen suurvallan oloista. ${ }^{255}$ 
Samoihin aikoihin Granö kytkettiin mukaan Kustannusosakeyhtiö Otavan julkaisemaan ja Theodor Homénin toimittamaan tietokirjahankkeeseen Itä-Karjala ja Kuollan Lappi suomalaisten luonnon- ja kielentutkijain kuvaamana. Hän suhtautui "hieman Suur-Suomi-haihatteluna" pitämäänsä hankkeeseen varauksellisesti, sillä hän vieroksui Suomen tutkijapiireissä yleistä pyrkimystä siirtää valtionraja kauas itään. Hän otti kuitenkin vastuulleen sekä teoksen toimitusvaliokunnan jäsenyyden että Kuolan niemimaan kuvauksen, kun työn suunnitellut geologi Väinö Tanner oli punaisten vallankaappauksen pelästyttämänä siirtynyt pikaisesti Ruotsiin. ${ }^{256}$

Granö kantoi päävastuun Kuolan niemimaata käsittelevän osan laadinnasta tehden karttoja ja kirjoittaen johdannon lisäksi muun muassa merta, valosuhteita ja ilmastoa sekä väestötilastoja koskevat tekstit. Hän kokosi myös venäläisistä lähteistä kaiken Itä-Karjalaa koskevan aineiston ja kirjoitti sitä käsittelevän osan alkutekstin. Työ piti tehdä salaa, sillä Venäjän uudet vallanpitäjät eivät katselleet suopeasti maan suomalaisalueita koskevan julkaisun valmistelemista. ${ }^{257}$

Akateeminen työ oli tarkoitus aloittaa vuoden 1918 alussa, mutta tammikuun lopulla puhjennut valkoisten ja punaisten välinen sisällissota sulki yliopiston huhtikuun puoliväliin asti. Granö kannatti laillista valkoista hallitusta ja noudatti empimättä Suomen virkamiesyhdistyksen keskusjohtokunnan kehotusta, jonka mukaan virkamiesten ei pitänyt olla missään tekemisissä kansanvaltuuskunnan kanssa. Hän keskittyi sotakuukausien aikana kirjallisiin töihin ja perheen arkipäivän turvaamiseen. ${ }^{258}$

Sisällissodan aika sujui Granön perheen osalta suuremmitta vaikeuksitta. Vaikka Helsingin ruokatilanne oli huonontunut jo syksyllä, heillä asiat olivat varsin hyvin, kiitos jo kesällä alkaneen varautumisen talven yli elämiseen. Voita, silavia, perunoita, silakoita, sieniä, vihanneksia ja marjoja oli varastoituna eri puolilla asuntoa, kellaria ja ullakkoa niin paljon, että jotakin olisi voinut antaa myös niille, "jotka revolveri kädessä kohteliaimmin pyytävät exproprioida pienen annoksen sitä tai tätä suuhun sujuvaa". ${ }^{259}$

Maidon vähyys muodosti kuitenkin pienten lasten vuoksi sellaisen uhkatekijän, että vanhemmat joutuivat vakavasti miettimään maaseudulle siirtymistä siltä varalta, että maidon jakelu lopetettaisiin kokonaan. Maidon riittävyydestä huolestuneet 
vanhemmat olivat autuaan tietämättömiä siitä, että perheen lapset kärsivät osin laktoosi-intoleranssista.

Elintarvikkeiden niukkuuden ohella eniten huolta aiheuttivat tietämättömyys maan kohtalosta ja yleinen turvattomuus. Punaisten odottamattomien vierailujen varalta Granö piilotti 1906 hankkimansa Mauser-pistoolin olohuoneen lattiaa mattona peittäneen Siperiasta tuodun ison karhuntaljan pään sisään. Talja pysyi perheen matkassa 1940-luvulle asti, jolloin se karvansa menetettyään vietiin vähin äänin kaatopaikalle. ${ }^{260}$

Granön perheen ja muiden valkoisten kannattajien piina-aika päättyi vasta vajaan kolmen kuukauden kuluttua, kun saksalaiset joukot kenraali Rüdiger von der Goltzin johdolla valloittivat Helsingin 12.-13. huhtikuuta. Granö saattoi seurata aitiopaikalta kotinsa ikkunasta saksalaisten etenemistä: "Saksalaiset asettivat kuularuiskun ikkunamme alle ja soittelivat sillä "prestissimo" tahdissa hyvän aikaa Heikin puistoon (AT: nyk. Mannerheimintielle) päin. Haavoittuneita kannettiin, mutta suurempaa tuhoa ei meidän kohdallemme ollut.”

Varmuuden vuoksi juuri valtauspäivänä syntyneen perheen kolmannen tyttären Eevan korisänky sijoitettiin kylpyammeeseen turvaan harhaluodeilta. ${ }^{261}$

Valkoisten siirrettyä päämajansa pääkaupunkiin Granö kytkettiin toukokuun alussa mukaan sen suunnittelutehtäviin. Hänen työnsä liittyi todennäköisesti niihin valmisteluihin, joita päämajassa tehtiin Itä-Karjalan kysymyksen ja Suomen ja Neuvosto-Venäjän rajan vetämisen suhteen. Analyyttisenä tutkijaluonteena hän toimi hyvänä vastavoimana monelle turhan innokkaalle itärajan vetäjälle. Kaiken kiireen keskellä hän sai filosofian tohtorin arvon toukokuun lopulla. ${ }^{262}$

Astuminen päämajan palvelukseen takasi Granölle päivittäisen ruoka-annoksen, mikä helpotti koko perheen tilannetta. Maan elintarviketilanne oli vaikein juuri keväällä 1918, jolloin suomalaisten oli tultava toimeen oman maan elintarviketuotannon turvin. Esimerkiksi viikoittain jaetun leipäannoksen määrä tippui kesään 1918 mennessä noin 700 grammaan. Kun kansanravitsemus oli laajalti lähinnä leivän varassa, määrä merkitsi todellista nälkäkuuria. ${ }^{263}$ 
Kesäkuun alussa perheen naisväki, Hilma Granö sekä Aune, Siine ja Eeva, jättivät nälkää näkevän Helsingin ja matkustivat Karjalohjalle, missä he viettivät Puujärven kylässä kesän 1918. Seutu oli tunnettu luonnonkauneudestaan, vaihtelevista maisemistaan ja kalaisesta järvestään. Isä J. G. kykeni vapautumaan päämajan tehtävistä vasta heinäkuun alussa, jolloin hän liittyi muun perheen joukkoon. Ruokavalio koostui pääosin perunoista, sienistä ja perheenpään pyytämistä kaloista, joten uutta satoa odotettiin hartaasti. ${ }^{264}$

Granön lomasta ei tullut pitkäaikaista, sillä hän joutui palaamaan pääkaupunkiin elokuun puolivälissä. Työtehtävien lisäksi hänellä riitti tarmoa myös maanpuolustustyöhön, sillä hän liittyi syksyllä eräiden nuorten yliopistonopettajien kanssa juuri muodostettuun tarkka-ampujapataljoonaan, jonka harjoituksia johti vänrikki Gustaf Forsgren. Osasto sai Granön vanhan opettajan J. E. Rosbergin syttymään maanpuolustustyöhön niin tarmokkaasti, että hänen esityksestään Helsingin yliopistoon perustettiin joulukuussa opettaja-, virkamies- ja palveluskunnasta oma suojeluskuntaosasto, yliopistokomppania. Pian myös Teknillisen korkeakoulun opettajilla ja palvelusmiehillä oli mahdollisuus liittyä komppaniaan. ${ }^{265}$

Yliopistokomppania aloitti välittömästi harjoitukset, mutta alusta lähtien pidettiin selvänä, että sen päätarkoituksena oli hyvällä esimerkillä vaikuttaa opiskelevaan nuorisoon, "joka ei ollut astunut lippujen alle niin lukuisasti kuin oli toivottu". Alkuvuonna komppanian vahvuus nousi Rosbergin mieliksi 130:een, mutta into laantui pian. Granö osallistui ryhmäpäällikkönä komppanian toimintaan ja saavutti erityisen alipäällystökurssin käytyään alkuvuonna 1919 kersantin arvon. ${ }^{266}$

Granö itse piti sotilasuransa huipennukseksi jääneitä kersantin natsoja osoituksena siitä, kuinka sekaisin maailmankirjat olivat: "Mikä merkillinen aika! Olisinko viime vuonnakaan uskonut, että minusta milloinkaan tulisi kersantti ja rekryyttien opettaja!"267

Koko perheen palattua pääkaupunkiin alkoi taas varautuminen talven varalle. Vaikka pahin nälänhätä oli jo ohitse, Granöt ajattelivat pelonsekaisin tuntein pitkiä talvikuukausia ja pyrkivät jälleen varastoimaan talteen niin paljon erilaisia ruoka 
Vakava hätä on käsissä; sen tuntee itse kukin kotonaan, sen näkee ihmisten kasvoissa. Parempaa maaperää ei sosiaalisilla levottomuuksilla voisi olla.

Mikäli asia koskee erikoisesti tämän kyhääjää, olen koettanut kerätä varastoon voimieni mukaan. Perunoita ja juurikkaita on tietysti suuret kasat, on vähän jauhojakin, mutta rasvasta on puute, niin voista kuin sianlihasta. Maitoa ovat pienet saaneet toistaiseksi osansa. Mutta näkee heidänkin kasvoistaan sen, ettei ravinto ole riittävä tai oikeammin: kyllin ravitseva. ${ }^{268}$

Tuominen oli ilmoittanut kykenevänsä auttamaan ystäväänsä lähettämällä Helsinkiin leipää ja muita ruokatarvikkeita. Granö kieltäytyi tarjouksesta vetoamalla viranomaisten kieltoihin ja tarkastuksiin, joilla pyrittiin ehkäisemään ruoan mustan pörssin kauppaa. Toimelias Tuominen keksi kuitenkin keinon viranomaisten harhauttamiseksi. Hän postitti Granölle Adolph Wüllnerin isokokoisen teoksen Lehrbuch der Experimentalphysik, jonka sivut hän oli ulkoreunoja lukuun ottamatta kaivertanut pois ja täyttänyt näin syntyneen ison onkalon voipaketilla. Kun Granö paketin lähetekirjeestä oivalsi, minkälaisesta fysiikan kirjasta oli kysymys, hän järjesti koko perheelle yhteisen riemuhetken:

Toin paketin kotiin, aukaisin sen kaiken kansan - suurten ja pienten - läsnäollessa. Ulkoapäin Wüllner kuin Wüllner! Mutta sitten kirja avattiin ja....!!”

Kuvailukykyni ei riitä pitemmälle. Pääasia on minä, he, me kaikki yhdessä olemme tuota rakasta Wüllneriä suurella hartaudella lukeneet, niin kuin ainoastaan sota-ajan suomalaiset voivat sen tehdä. Olemme sitä lukeneet, siihen syventyneet. Parempaa sota-ajan kirjallisuutta ei voi ajatella. Se on "sellainen teos, ettei sitä mielellään laske käsistään”, ennen kuin on sen kannesta kanteen lukenut”. Kerrassaan sulavasti kirjoitettu!

Kiitollisuutemme vaivannäöstäsi on suuri. Kun ajattelen yksistään sitäkin, miten suuri vaiva Sinulla on ollut sahautua tuon paksun "knigan” läpi, niin tunnen muutakin kuin kiitollisuutta, tulen suorastaan liikutetuksi. ${ }^{269}$ 


\section{Siirtyminen kustannusalalle}

Granö jatkoi 1918 työtään Tietosanakirja Oy:ssä, jossa hän lukuisten tietosanakirja-artikkelien kirjoittamisen lisäksi suunnitteli J. E. Rosbergin johtaman toimituskunnan jäsenenä uuden valtion kuntia esittelevää Suomenmaa-kirjasarjaa. Vuonna 1919 ilmestymään alkanut teos oli suuri isänmaallinen hanke, jonka tekemiseen pyrittiin viranomaisten lisäksi valjastamaan koko valistunut kansa. Zacharias Topeliuksen 1800-luvun puolivälissä toimittaman Finland framstäldt $i$ teckningar -teoksen tapaan jokaiseen Suomen kuntaan lähetettiin kyselylomakkeita paikkakuntien oloja tuntevien henkilöiden täytettäviksi. ${ }^{270}$

Granö ehti lopulta laatia vain alustavan käsikirjoituksen teossarjan Uuttamaata koskevaan osaan ja piirtää maakunnasta korkokuvakartan. Syventyminen mittavaan hankkeeseen antoi hänelle kuitenkin paljon sellaista kokemusta, josta oli hyötyä tulevissa töissä.

Tärkeimmäksi kustannusalan työnantajaksi tuli kuitenkin WSOY, jonka palvelukseen Granö siirtyi Jalmari Jäntin aloitteesta. Bulevardin kirjankustantamossa hänen tärkeimpänä tehtävänään oli kirjoittaa laaja teos Altain matkojen kokemuksista, mutta hän joutui vastaamaan myös muista töistä. Tehtävää oli niin paljon, että hän päätti vuoden 1918 lopulla, että nyt oli aika lopettaa voimien hajottaminen, heiluminen "koulun ja tieteen ja monen muunkin homman välillä”. ${ }^{271}$

Granö oli jo luopunut koulunopettajan tehtävistä ja maantiedon oppikirjan kirjoittamisesta, mutta nyt hän mietti myös tieteellisen työn jättämistä. Hän oli pohtinut vakavasti jatkavansa Altain tutkimustyötä Kordelinin säätiön myöntämän rahoituksen turvin, minkä vuoksi hän oli anonut virkavapautta yliopistosta kevätlukukauden 1919 ajaksi. Koska ratkaisu merkitsi dosenttistipendin menettämistä, hän vakuuttui kevään aikana siitä, että vaikeassa taloudellisessa tilanteessa oli "jotenkin mahdotonta antautua rakkaan spesiaalikysymyksen käsittelyyn koko työvoimallaan”. Siksi oli paras keskittyä palvelemaan kustannusmaailmaa, joka tarjosi kohtuulliseen työmäärään nähden hyvän palkan. ${ }^{272}$ 


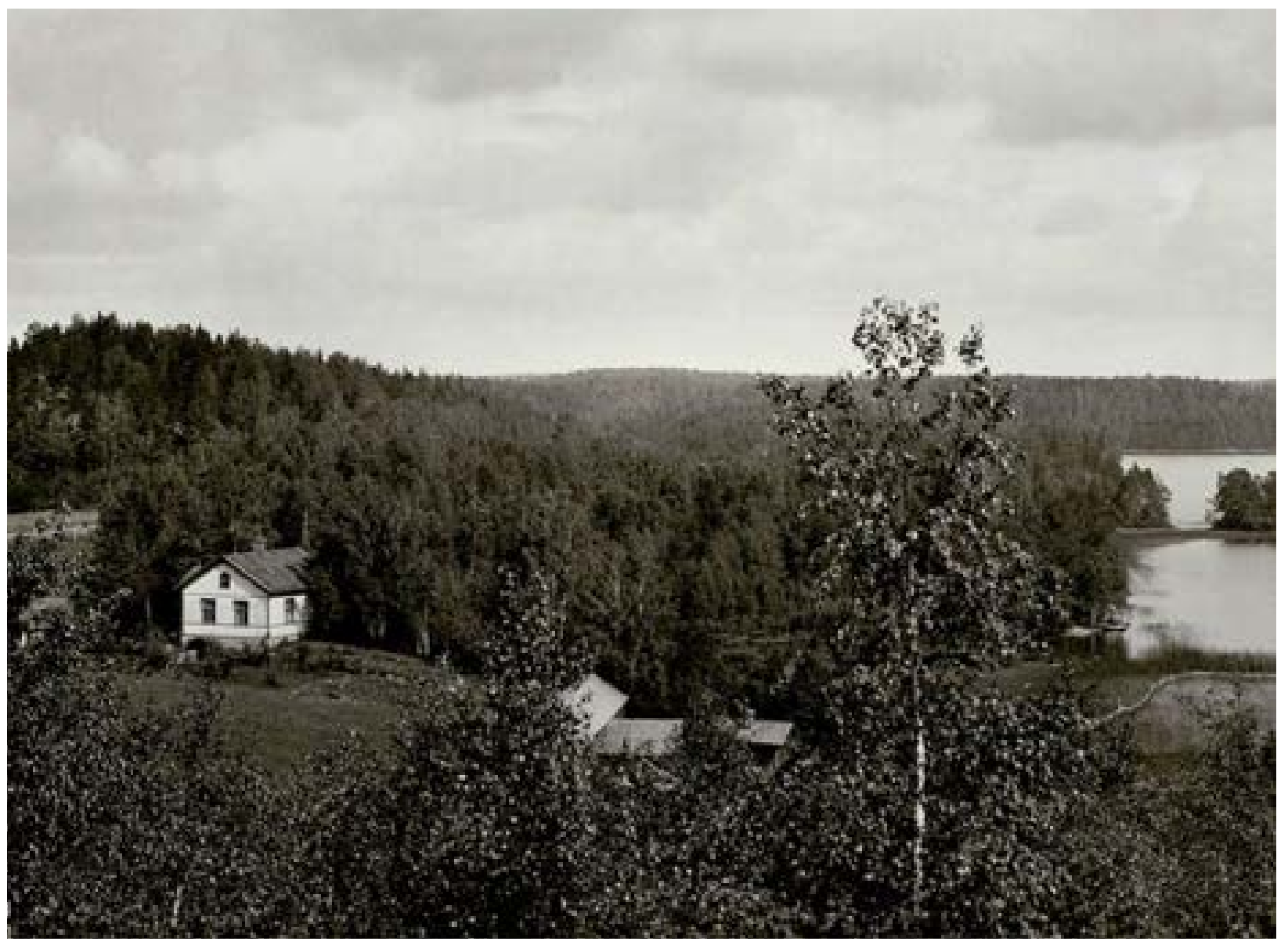

Kilpisen huvila Karjalohjan Puujärvellä.

150 || EpäVarmuUden Vuodet 
Kirjoitustyöt keskeytyivät maaliskuun 1919 alkupuolella. Tuolloin maailmanlaajuisesti kymmenien miljoonien ihmisten hengen vieneen espanjantaudin kolmas aalto saavutti Suomen ja iski myös Granön perheeseen. Ensin sairastui perheenpää, sitten lapset yksitellen ja lopulta myös äiti. Lapset selvisivät vähimmin vaivoin, muutaman päivän lepäämisellä, sen sijaan Hilman kunto heikkeni uhkaavasti. Granö oli itse vuoteessa neljä päivää, lisäksi "saman verran kamariherrana". Sairaus aiheutti liki 40 asteen kuumeen, suuria kipuja ei ollut, mutta jälkitautina ollut paha yskä hirvitti vanhempia. Kaiken kaikkiaan espanjantauti vaivasi perhettä kolmen viikon ajan. ${ }^{273}$

Kesän 1919 Granöt viettivät jälleen Puujärvellä Karjalohjalla. Loma sujui vanhaan malliin rentouttavan yhdessäolon, puutarhanhoidon, kalastuksen, lukemisen ja kirjoitustöiden merkeissä heinäkuun lopulle saakka, jolloin se keskeytyi yllättäen.

Granö sai tarjouksen, josta hän ei voinut kieltäytyä. 


\section{@LLÄTTÄVÄ RATKAISU}

\section{Kutsu Tarton yliopiston professoriksi}

Venäjän keisarikunnan romahtaminen avasi Suomen tavoin Virolle tien itsenäistymiseen. Bolševikkien oli ollut pakko luovuttaa Brest-Litovskin rauhassa maaliskuussa 1918 Viro Saksalle, mutta Saksan romahdettua saman vuoden marraskuussa punaarmeija pyrki valloittamaan maan takaisin. Hyökkäys käynnisti Viron vapaussodan, joka päättyi runsaan vuoden kuluttua osin suomalaisten vapaaehtoisten voimin virolaisten voittoon. Viro ja Neuvosto-Venäjä solmivat vuoden 1919 lopulla välirauhan ja seuraavana vuonna Tarton rauhan, jossa ne tunnustivat toisensa. ${ }^{274}$

Jo sotatoimien aikana Virossa ryhdyttiin toimiin Tarton yliopiston avaamiseksi mahdollisimman nopeasti. Virolaisten tavoitteena oli kansallistaa Kustaa II Aadolfin Ruotsin valtakunnan kaakkoisnurkkaan 1632 perustama yliopisto, jonka opettajat tulivat pääosin Saksasta. Pitkiä kausia suljettuna ja lakkautettuna ollut yliopisto oli avattu 1802 uudelleen saksankielisenä venäläisenä yliopistona. Se kehittyi voimakkaasti vuosisadan alkupuolella, jolloin siellä toimivat muun muassa galvanoplastiikan keksijä Moritz Hermann Jacobi, evoluutioteorian ja embryologian kehittäjä Karl Ernst von Baer, fysikaalisen kemian perustaja, suolaefektien löytäjä Wilhelm Ostwald sekä veren maksoittumisen käymisteorian ja verensiirron perusteiden laatija Alexander Schmidt. ${ }^{275}$

Yliopiston opetuskieli oli saksa vuoteen 1893, jolloin sen tilalle tuli venäjä. Opetuskielen vaihdos liittyi vuosisadan lopulla voimistuneeseen venäläistämispolitiikkaan, minkä seurauksena yliopiston tieteellinen taso laski. Opiskelijat olivat aluksi 
pääosin ruotsalaisia, suomalaisia, inkeriläisiä ja saksalaisia; virolaisten osuus kasvoi vain hitaasti. ${ }^{276}$

Venäläisen yliopiston lakkauttaminen vuoden 1918 keväällä mahdollisti uuden Tarton saksalaisen provinssiyliopiston synnyn. Se avattiin syyskuussa 1918 mutta suljettiin jo runsaan kahden kuukauden kuluttua, jolloin se luovutettiin Viron väliaikaisen hallituksen muodostamalle komissiolle. Se puolestaan nopeutti jo käynnistämiään toimia oman vironkielisen yliopiston perustamiseksi. ${ }^{277}$

Joulukuun 1. päivänä 1919 - vapaussodan vielä riehuessa - avatun Tarton yliopiston tärkeänä tehtävänä oli yleisten akateemisten tavoitteiden ohella yhtenäistää uutta Viron kansakuntaa ja luoda sille omaa kulttuuria. Yliopistoon perustettiin seitsemän tiedekuntaa, joista yksi oli astronomis-geologinen tiedekunta. Sen oppiaineisiin kuului astronomian, meteorologian, geologian ja mineralogian ohella maantiede. Virolainen Elmar Rosenthal Varsovan yliopistosta oli ehdolla meteorologian professoriksi, ja hänen oletettiin ottavan haltuunsa myös maantieteen oppituolin. Rosenthal kuoli kuitenkin yllättäen 1919, joten kumpikin oppituoli jäi vaille haltijaa. ${ }^{278}$

Venäjän vallan aikana virolaisille tiedemiehille ei ollut tarjoutunut professuureja Tarton venäjänkielisessä yliopistossa, mutta monet heistä olivat työskennelleet keisarikunnan puolella. Sieltä heitä alkoi siirtyä Tarttoon, mutta aluksi vain 19 yliopiston kaikkiaan 52 professuurista saatiin täytetyksi virolaisin voimin. Muut uudet professorit tulivat pääosin Venäjältä, Saksasta, Ruotsista ja Suomesta, josta virolaiset kutsuivat jo läheisen kielisukulaisuuden vuoksi mielellään tutkijoita. Suomesta saapui kaikkiaan kahdeksan professoria, joista yksi oli J. G. Granö. ${ }^{279}$

Miksi juuri Granö kutsuttiin Tarton yliopiston professoriksi, on jäänyt osin arvoitukseksi. Se tiedetään, että Tarton yliopiston kuraattori eli kansleri Peeter Pöld vieraili heinäkuussa 1919 Helsingin yliopistossa keskustelemassa mahdollisuuksista nimittää uusiin professuureihin suomalaisia tutkijoita. Eräästä päiväämättömästä luonnoksesta käy ilmi, että maantieteen oppituolin haltijaksi ehdotettiin kahta suomalaista: Iivari Leiviskää ja J. G. Granötä. ${ }^{280}$ 
Lyhyt ehdollepano suosi Granötä. Kun Leiviskää luonnehdittiin vain "herrasmieheksi”, Granön ansioita kuvattiin vuolaasti: Osasi venäjää, oli tutkinut Siperiaa, oli miellyttävä ja kirjoittanut huomattavia tutkimuksia. Granön puolesta puhui myös kielitieteilijä Heikki Ojansuun 23.7.1919 Tarton yliopiston kanslerille, kasvatustieteen professori Peeter Pöllulle, lähettämä kirje, jonka mukaan "maantieteen professoriksi olisi dosentti Granö erittäin ansioitunut, jos hän vain suostuu lähtemään”. ${ }^{281}$

Granön saamat hyvät puoltolauseet vakuuttivat Tarton yliopiston johdon. Yliopiston väliaikainen dekaani Johannes Piiper lähetti elokuussa Granölle virallisen kutsun tulla Tarttoon professoriksi. Granö otti kutsun vastaan yllättävän nopeasti. Tarttolaisen Postimees-sanomalehden elokuun 26. päivän numero tiesi kertoa, että Granö tulee yliopiston maantieteen professoriksi ja että hän on parhaillaan vierailulla kaupungissa. Parin viikon kuluttua Viron opetusministeri tiedotti, että filosofian tohtori J. G. Granö määrätään hoitamaan virkaansa 7. syyskuuta 1919 lähtien. ${ }^{282}$

\section{Hyvät perusteet}

Granö joutui märitttelemään parissa viikossa kantansa Tarton yliopiston kutsuun. Hän oli tutkimusmatkojensa aikana tottunut tekemään nopeasti päätöksiä, mutta nyt asiaa mutkisti se, että ratkaisu ei koskenut vain häntä vaan myös vaimoa ja kolmea pientä tytärtä. Viro oli yhä sotatilassa, joten henkilökohtaisten ja taloudellisten seikkojen ohella piti miettiä myös perheen hyvinvointia ja turvallisuutta.

Loppujen lopuksi ratkaisu syntyi helposti. Granölle ei ollut Suomessa tarjolla hänen koulutustaan vastaavaa virkaa vaan lähinnä erilaisia tilapäistöitä. Hän oli kokemiensa pettymysten jälkeen vakuuttunut siitä, ettei palkkatuloilla elävän perheellisen miehen ollut mahdollista antautua tutkimustyöhön jonkin säätiön tai epävarman yksityisen rahoituksen turvin. Kustannusala antoi hyvän toimeentulon mutta pakotti tekemään myös töitä, jotka eivät tyydyttäneet häntä riittävästi hen- 
kisesti. Tarton yliopiston professuuri tarjosi sentään valtion leipää: "kovaa mutta varmaa" ja toi myös muita etuja: Mahdollisuuksia itsenäiseen akateemiseen toimintaan ja pitkiä lomia, joiden aikana saattoi keskittyä omien tutkimusten tekemiseen. ${ }^{283}$

Granö ei myöskään epäröinyt kykyjään hoitaa uutta virkaa. Hän oli toiminut J. E. Rosbergin assistenttina vuodesta 1902 alkaen ja hoitanut myös tämän professuuria syyslukukauden 1911, joten hänellä oli ne hallinnolliset taidot, joita pienen laitoksen johtaminen edellytti. Lisäksi hänen kielitaitonsa oli riittävä. Hän osasi hyvin Tartossa tärkeitä venäjää ja saksaa, ja virokaan ei ollut hänelle vieras, sillä hän oli liikkunut paljon Siperian virolaisten parissa. Hän aloitti jo Helsingissä päivittäiset kieliopinnot oppiakseen "eesti keelt" mahdollisimman nopeasti, sillä viro oli julistettu 1919 maan viralliseksi kieleksi. ${ }^{284}$

Siirtymistä Viroon edisti myös se, että Granö oli jo pitkään kärsinyt maantieteen huonosta arvostuksesta Suomessa. Tarton professuuri vapautti Granön kotimaan henkisistä kahleista ja antoi hänelle mahdollisuuden toteuttaa ajatuksiaan maantieteen oppisisällöstä ja metodiikasta perinteisessä yliopistomiljöössä, jossa vanhan kansainvälisen sivistysyliopiston akateeminen traditio liittyi hedelmällisellä tavalla kansallisiin tavoitteisiin. ${ }^{285}$

Granön siirtyminen pois Suomesta tuli tieteelliselle yhteisölle täydellisenä yllätyksenä ja aiheutti voimakkaan vastareaktion hänen pysyttämisekseen maassa. Arvovaltainen Anders Donner katsoi, että Granö teki suuren virheen jättäessään Suomen, sillä hänen kaltaiselleen lahjakkuudelle, "en forskare av rang", olisi varmasti järjestynyt sopiva virka, jos hän olisi vain puhunut asiasta vanhemmille kollegoilleen. Granön vanha oppilas Börje Olsoni totesi puolestaan Studentbladetissa, että oli sääli, että Suomi antoi tämän lähteä Tarttoon. ${ }^{286}$

E. N. Setälä kirjoitti syyskuun alussa 1919 Uuteen Suomeen artikkelin, jossa hän totesi olevan hienoa, että Suomi saattoi auttaa veljeskansan tiedettä nousemaan jaloilleen, varsinkin kun oleskelu toisessa yliopistokaupungissa ja toiseen kansaan kuuluvien oppilaiden keskuudessa oli "nuorille ja miksei vanhemmillekin tutkijoille itselleen varsin opettavaa ja kehittävää". 
Suomalaisten oli kuitenkin pidettävä huolta myös omasta tieteellisestä jälkikasvusta, minkä vuoksi Setälä ei voinut muuta kuin surra,

... että niin etevä ja meillä välttämättömän tarpeellinen tiedemies kuin toht. J.

Granö joutuisi muuttamaan maasta pois. Minusta olisi yliopistoviranomaisten vielä asiata sangen tarkasti harkittava, ennen kuin antavat tämän tapahtua. Ensi sijassa olisi Fyysillis-matemaattisen osaston otettava asiassa jokin aloite toht. Granön pysyvämmäksi kiinnittämiseksi omaan yliopistoomme. ${ }^{287}$

Myös Granön opettaja J. E. Rosberg murehti ykkösoppilaansa ja työtoverinsa lähtöä mutta ymmärsi hyvin, miksi tämä oli päätynyt ratkaisuunsa. Suomi ei voinut tarjota hänelle muita kuin tilapäistöitä, kun taas Virossa hän sai vakinaisen viran ja mahdollisuuden itsenäiseen toimintaan. Granö oli myös Tarton yliopiston kannalta paras vaihtoehto sekä kielitaitonsa että tietämyksensä perusteella. Hän oli aikakauden monipuolisin Sisä-Aasian ja erityisesti Altain tuntija, sillä hän ei ollut perehtynyt vain alueen maantieteeseen vaan myös sen geologiaan, historiaan, kieliin ja arkeologiaan. ${ }^{288}$

Granön Helsingin yliopistossa nauttimaa yleistä arvostusta etevänä ja itsenäisenä tiedemiehenä kuvasti Kalle Väisälän ja tämän opettajan, matematiikan professorin Ernst Lindelöfin keskustelu nuoren matemaatikon suunnitelmasta ottaa vastaan Tarton yliopiston professuuri:

- Aion siirtyä Tarton yliopiston matematiikan professoriksi.

- Oletko aivan hullu.

- Meneehän Granökin.

- No Granö, hän on asia erikseen, kiertää ja kulkee aina milloin missäkin. ${ }^{289}$ 
Suuresta arvostuksesta kertovat lausunnot ja artikkelit liikuttivat Granötä, joka kuitenkin suhtautui asiaan huomattavasti käytännöllisemmin kuin useimmat muut. Hän ei pitänyt Tarton professuuria eläkevirkana vaan ikään kuin muutaman vuoden työkomennuksena. Tämän vuoksi hän ei edellyttänyt virolaisilta pitkäaikaista työsopimusta eikä myöskään luopunut Pohjoisen Rautatiekadun huoneistostaan. Myymisen sijasta se päätettiin vuokrata eräälle tutulle perheelle. ${ }^{290}$ 


\section{MATKAKIRJALLISUUDEN KLASS IKKO}

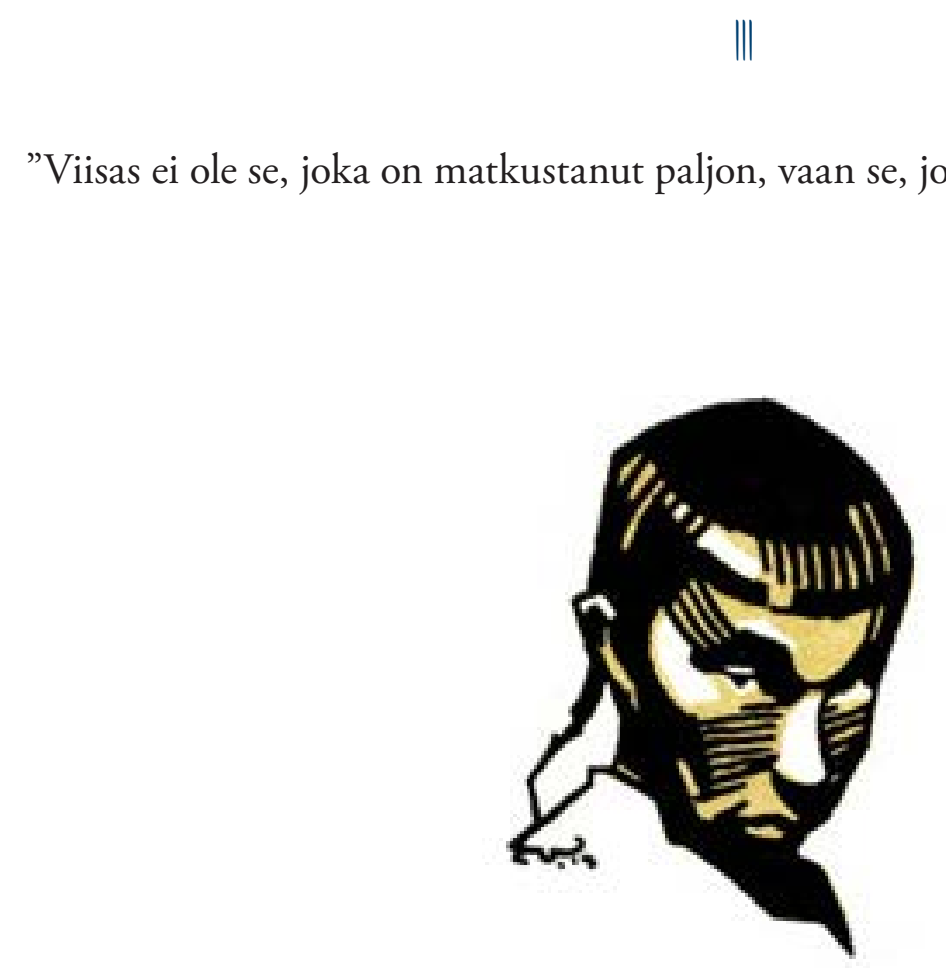




\section{TEOKSEN SYNTY}

\section{Kirjalliset lähtökohdat}

J. G. Granö oli saanut synnyinlahjoikseen kirjallisen ja kielellisen lahjakkuuden ja hyvän ajattelu- ja havaintokyvyn, mutta pelkät lahjat eivät tehneet hänestä tietokirjailijaa. Siihen tarvittiin myös muiden opastusta ja tukea sekä omaa halua kehittää taitojaan tällä alueella.

Johannes Granön perheessä pidettiin itsestään selvänä, että ihminen ajoi paitsi teoriassa myös käytännössä tärkeiksi katsomiaan asioita. Tämän vuoksi Granö pyrki aktiivisesti edistämään suomen kielen asemaa antamalla yliopistossa yhtenä ensimmäisistä maantieteen opetusta suomen kielellä ja luomalla taitavana kielenkäyttäjänä suomenkielistä maantieteellistä sanastoa ja käsitteistöä.

Myös lähipiirin esimerkki viitoitti ja kannusti. Isä Johannes oli julkaissut muistelmateoksen Siperian-vuosistaan. Akateeminen opettaja J. E. Rosberg oli tuottelias tietokirjailija, joka oli kirjoittanut ja toimittanut lukuisia teoksia. Professorin huomattua assistenttinsa lahjat hän järjesti tälle töitä kustantamoista. Granö toimitti muun muassa 1902 kartat A. R. Niemen kokoamiin teoksiin Elias Lönnrotin matkat 1828-44 I-II ja suomensi Rosbergin 1904 ilmestyneen teoksen Maat ja kansat I.292

Granö ryhtyi jo varhain julkaisemaan aikakausjulkaisuissa ja sanomalehdissä yleistajuisia artikkeleita ja perehtyi erilaiseen tieto- ja matkakirjallisuuteen. Kuten Anne Buttimer on todennut, hän arvosti erityisesti maantieteellisen aluekuvausperinteen kehittäjä Alexander von Humboldtia, jonka tavoitteena oli luoda tutkimistaan alueista itse kerätyn tiedon avulla tieteellinen ja taiteellinen synteesi. Granö mieltyi niin paljon von Humboldtin tapaan kuvata maisemia ja ihmisiä, että hankki kirjastoonsa kaksi tämän teosta, Voyage aux régions équinoxiales (1818-25) ja Asie Centrale 
(1843). Hän tutustui myös huolellisesti tämän 1799-1804 yhdessä lempiystävänsä Aimé Bonplandin kanssa tekemän Latinalaisen Amerikan kiertomatkan kuvauksiin. ${ }^{293}$

Toinen suuri tutkimusmatkailija, joka teki Granöhön suuren vaikutuksen, oli kehitysopin luoja Charles Darwin. Hän oli aluksi suhtautunut isänsä esimerkin mukaisesti kielteisesti jumalankieltäjäksi koettuun brittiläiseen luonnontutkijaan, mutta ilmeisesti Palmén oli auttanut hänet vapautumaan ennakkoasenteistaan. Darwin ei ollut Granön mielestä esitystapansa puolesta niin loisteliaan kaunopuheinen kuin von Humboldt tai niin historiallisen syvämietteinen kuin Carl Ritter, mutta hänen kertomustapansa oli aivan jokapäiväisen luonnollinen ja selvä.

Darwin kykeni luomaan havaintojensa no-

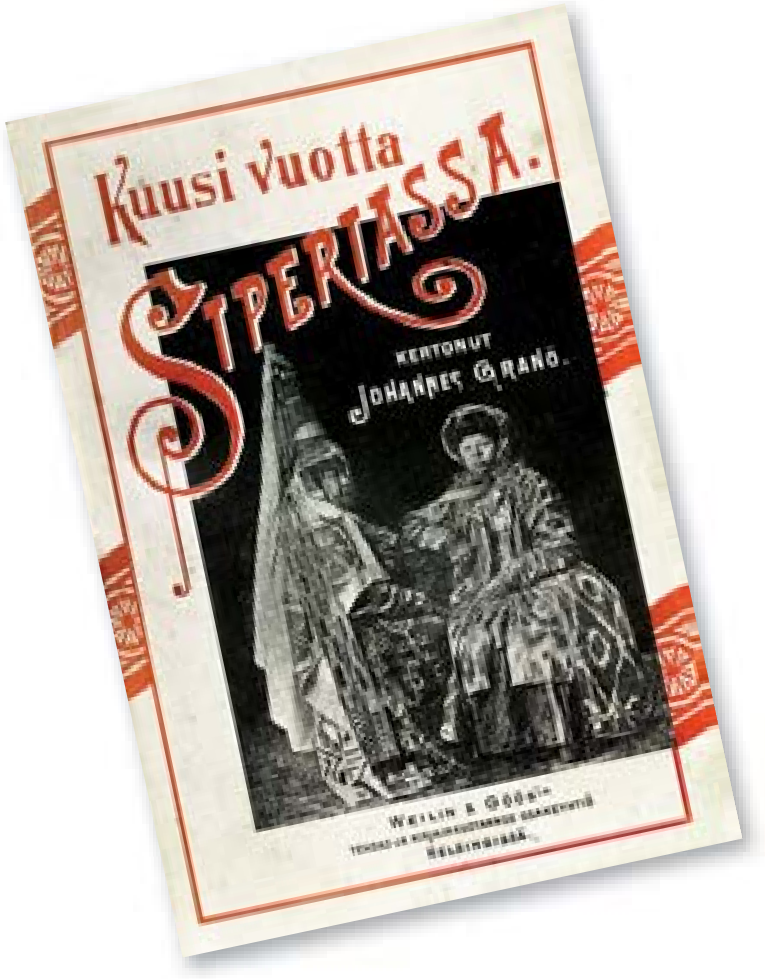

Johannes Granön muistelmateos vuodelta 1893. jalla kokonaiskuvia ja selittämään "luonnon suurta syiden ja seurausten moninaisuutta". Esimerkiksi 1845 ilmestyneessä matkakertomuksessaan Voyage of a Naturalist Round the World kirjoittaja oli antanut Granön mukaan erinomaisen kuvauksen Beagle-laivan maailmanympärimatkasta:

Kaikki, mikä on lukijaa turhanpäiten rasittavaa, on jätetty pois. Darwin ei pidä tarpeellisena kertoa yksitoikkoisista päivistä meren ulapoilla, elämästä Beaglelaivalla eikä myöskään omista seikkailuistaan ja vastoinkäymisistään sillä tavalla, että hän itse astuisi esityksen etualaan. Mutta toisaalta ottaa hän suurella huolella esille kaikki sellaiset piirteet, pienetkin, jotka tavalla tai toisella kaukaisten maiden luonnon laatua tai sikäläisten ihmisten elämää ja ajatustapaa valaisevat. ${ }^{294}$ 
Saksankielisten tieteellisten matkaraporttien lisäksi Granö kuvasi vuosien 1906-09 arkeologisia tutkimusmatkojaan Maantieteellisen Yhdistyksen Aikakauskirjassa julkaisemissaan matkakertomuksissa Matkamuistelmia Länsi-Siperiasta ja Mongoliasta I-III sekä Luonnon Ystävässä julkaisemissaan artikkeleissa "Kobdo" ja "Eurooppalaista betsoaaria Mongoliassa". Kirjoitukset olivat luonteeltaan pääosin kuvauksia tutkimusmatkan kokemuksista, mutta ne sisälsivät myös tarkkoja ja eläviä havaintoja vaeltajan silmiin osuneista luonnonilmiöistä, kasveista ja eläimistä. ${ }^{295}$

Granön taitoa elävään kuvaamisen osoittaa katkelma hänen 1930-luvulla pitämästään radioesitelmästä, jossa hän kuvaa ratsumatkan näkymiä:

Olemme jättäneet Kobdo-kaupungin. Edessämme avautuu Altain ja Hangain välinen aavikko, jonka alimmat kohdat ovat n. 1000 metrin korkeudella. Siellä tälllä kohoaa tasangosta jyrkin rintein yksinäisiä, alastomia kalliokukkuloita, kuin saaret merestä. Nousemme erään tällaisen kohouman laelle, saadaksemme yleiskuvan alueesta. Raikas tuuli kuljettaa valkoisia keräpilviä tummansinisellä taivaalla. Pilvien varjot vaeltavat - nopeasti toisiaan seuraten - tummina aloina häikäisevän kirkkaasti valaistun tasangon yli. Näemme kellahtavaa aroa, ruskeanvihreitä Caragana-pensastoja, vaaleita hietikoita, lumivalkoisia suolatantereita ja vuorilta alkavia, nauhamaisesti kaareilevia, rehevänvihreitä purojen varsia vaaleina jurttaryhmineen ja kirjavine karjalaumoineen. Kaukana tasangon alimmassa osassa päilyy laakarantaisen järven pinta.

Eläinmaailma on odottamattoman rikasta. Kukkulalle noustessamme pelotamme lentoon ison parven hietakanoja. Tuossa utelias aromurmeli nousee takajaloilleen, nähdäkseen paremmin, mitä puuhailemme. Etäällä erottuu lauma nopeasti pakenevia antilooppeja. Ne ovat ns. kuhertaja- eli kupugaselleja. Korkealta havaintopaikaltamme emme erota alhaalla arolla astelevia komeita trappeja emmekä järven suunnatonta vesilintumäärää. Sikäläisten arovesien linnut ovat tavattoman kesyjä. Lystikkästi kävi eräälle 
tutkimusmatkustajalle tällaisen järven rannalla. Hän tähtäsi revolveripahasellaan hanhea, mutta saikin sorsan. ${ }^{296}$

Täysinä Siperian-vuosinaan 1913-16 Granö keskittyi niin tyystin tieteellisiin töihin, että luopui lähes kokonaan yleistajuisten kirjoitusten julkaisemisesta. Palattuaan Suomeen ja yliopiston suljettua ovensa maailmansodan vuoksi hän suuntasi jälleen osan tarmostaan matkojensa yleistajuiseen kuvaamiseen. Granö oli jo osoittanut matkakirjoillaan ja muilla kirjoituksillaan olevansa taitava kirjoittaja, minkä vuoksi eri lehdet ja kustantajat tarjosivat hänelle auliisti tehtäviä.

Sanomalehtiartikkeleista tärkeimmäksi osoittautui Uudessa Suomessa viidessä osassa 1917 julkaistu yli 25 tekstiliuskan laajuinen Altain matkojen kuvaus. Se miellytti niin paljon Werner Söderström Oy:n johtoon kuuluneita Jalmari Jänttiä ja Kaarle Krohnia, että he kehottivat Granötä kuvaamaan matkakokemuksiaan ja tutkimustuloksiaan kansanomaisessa muodossa. Kun mielellään mesenaattina esiintynyt liikemies Aleko Lilius tarjosi Granölle mahdollisuuden keskittyä kolmen vuoden ajan Altain matkoja kuvaavan käsikirjoituksen laatimiseen ja painokuntoon saattamiseen ja WSOY ilmoitti ottavansa kirjan ohjelmaansa, hän ryhtyi valmistelemaan kirjoitustyötä Kuhmoisissa alkukesällä 1917. ${ }^{297}$

Hanke uhkasi kuitenkin pysähtyä alkuunsa, kun Lilius ajautui vain muutama kuukausi kustannussopimuksen allekirjoittamisen jälkeen konkurssiin ja poistui kiireesti maasta. Granön onneksi WSOY otti osin vastuun myös kirjoitustyön rahoittamisesta - tosin huomattavasti yksityistä mesenaattia huonoimmin ehdoin. Granö ei voinut keskittyä vain matkakirjan kirjoittamiseen, vaan hänen oli jatkuvasti tehtävä myös muita töitä. ${ }^{298}$

Granöllä oli tapana tarkastella vaikeuksia niiden tarjoamien mahdollisuuksien kautta. Niin nytkin: Hänelle jäi aikaa miettiä teoksen rakennetta, muotoa ja kuvitusta, jonka hän päätti rakentaa omien karttojensa ja valokuviensa varaan. 


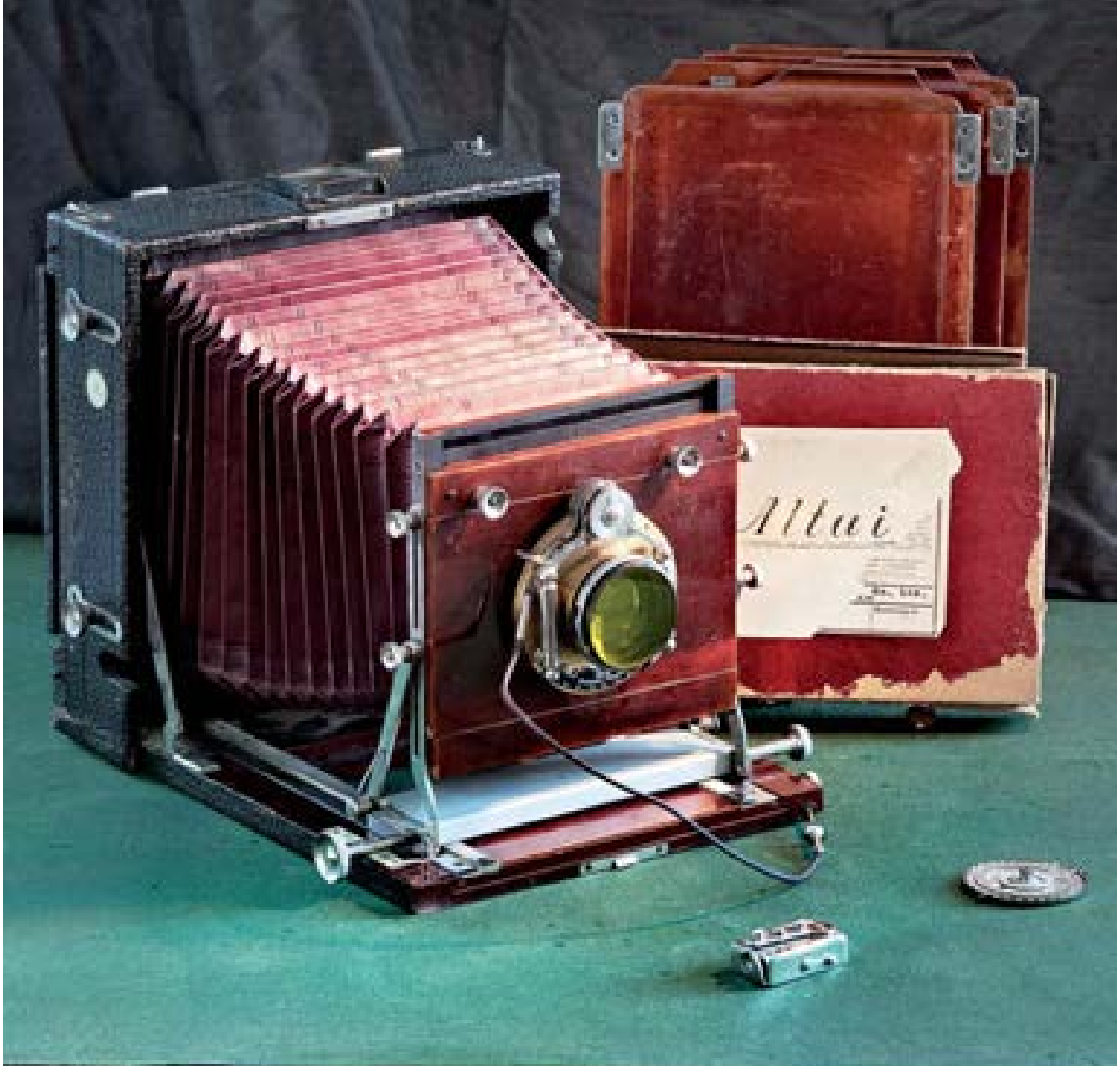

\section{Valokuvauksen kehittäjä}

J. G. Granön iso matkakamera tarvikkeineen.

Tieteellisten ja yleistajuisten teosten kuvituksena aiemmin olleet piirrokset ja maalaukset alkoivat menettää 1840-luvulta alkaen asemiaan valokuville. Monet tutkijat katsoivat, että valokuvat näyttivät aidosti ja tieteellisen tarkasti sen, minkä ihminen saattoi silmillään havaita fyysisestä maailmasta. Vuosisadan loppuun mennessä valokuvauksen merkitys kasvoi positivistisen tieteenihanteen vauhdittamana entisestään, kun valokuvien käyttöön perustuva fotogrammetria alkoi yleistyä maastonmittausmenetelmänä. ${ }^{299}$ 


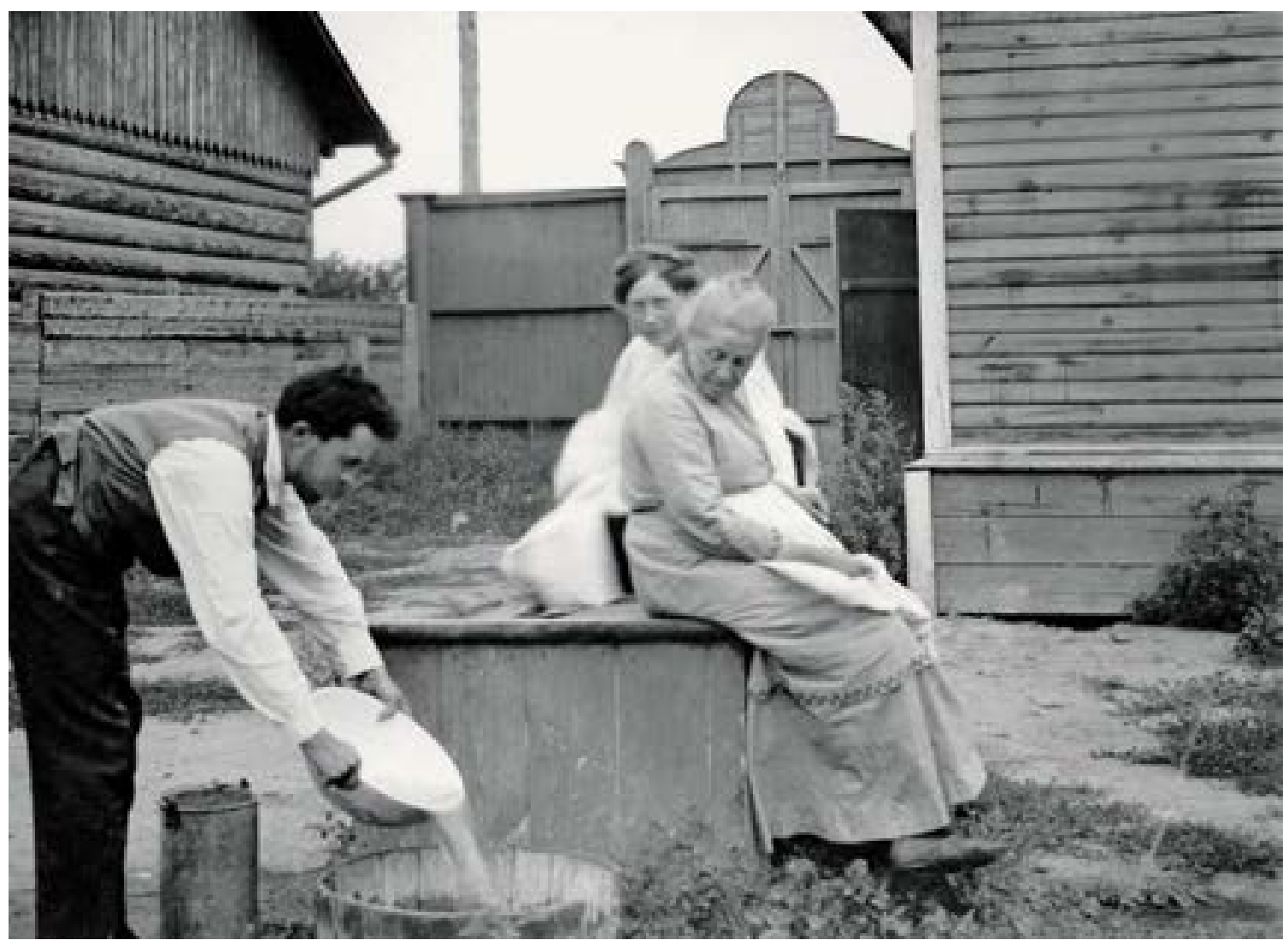

Palattuaan Hilman kanssa tekemältään ensimmäiseltä yhteiseltä matkaltaan Altaille Granö huuhtoo elokuussa 1913 filmejään Omskin suomalaisen pappilan kaivolla.

Puolison lisäksi työtä seuraa äiti Alma.

Suomen maantieteen piirissä valokuvaus nousi 1890-luvulla kartografian rinnalle tärkeäksi esityskeinoksi. Suomen Maantieteellinen Yhdistys järjesti Ragnar Hultin johdolla keväällä 1894 Ateneumissa suuren suosion saaneen maantieteellisten kuvien näyttelyn. Hultin oppilas ja seuraaja J. E. Rosberg ymmärsi geomorfologina ja matkakirjojen kirjoittajana hyvin valokuvauksen soveltuvuuden tutkimuskohteiden 


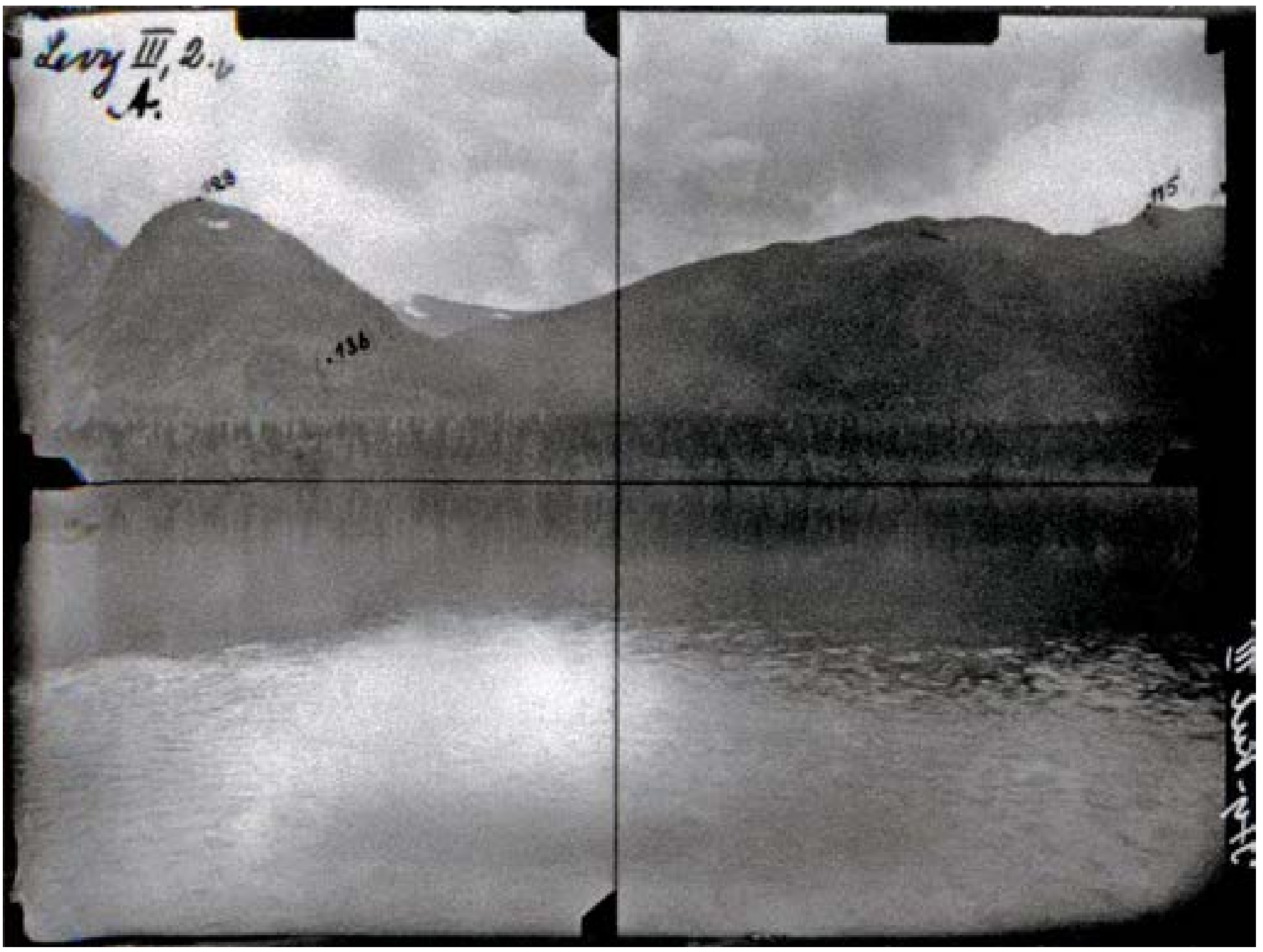

Granö kehitti maastofotogrammetriaa erityisesti kartoittaessaan kesäkuussa 1914 Venäjän ja Mongolian rajaseudulla, noin 10 kilometriä pitkän Ity-köl-järven. 
visualisointiin, fotogrammetrisiin mittauksiin ja aineistojen keruuseen. Hän hankki maantieteen laitokselle ensimmäisen kameran 1900-luvun alussa.

Rosbergin ja Granön perehtymistä valokuvaukseen auttoi laitoksen vahtimestari Felix Jonasson, joka hallitsi uuden tekniikan niin perusteellisesti, että hänestä tuli myöhemmin yliopiston valokuvaaja. Granö tutustui Jonassoniin läheisesti, mikä näkyi muun muassa siten, että hän antoi tälle esimerkiksi valtuudet hoitaa kotimaan asioitaan Siperian-vuosiensa aikana. ${ }^{300}$

Granö paneutui valokuvaukseen jo maantieteen opiskelujensa alkuvaiheessa. Hän otti heti ensimmäiselle ylioppilaana tekemälleen Siperian-matkalle 1902 mukaan puisen matkakameran, jolla hän tallensi suunnitelmallisesti niin maisemia ja erilaisia tieteellisiä kohteita kuin paikallisia ihmisiä, erilaisia ilmiöitä ja elämäntapahtumia. Kesällä Ryžkovan siirtolasta otettu hieno panoraamakuva osoitti, että hän oli nopeasti oppinut hyödyntämään uuden tekniikan tarjoamia mahdollisuuksia.

Vuoden 1902 jälkeen Granö käytti kameraa jokaisella Siperian-matkallaan ja ryhtyi kuvittamaan julkaisujaan paitsi itse tehdyin piirroksin ja kartoin myös omin valokuvin. Ensimmäisen pienen matkakameran rinnalle hän hankki alkuvuonna 1906 hienon ja kalliin laitteen, joka kuitenkin tuhoutui seuraavan kesän veneonnettomuudessa. Sen takia Mongolian puoleisen Altain kuvaaminen jäi harmittavan vähäiseksi, mutta Granön onnistui irrottaa kamerasta ehjänä säilynyt objektiivi. Tämän hän siirsi seuraavaa matkaa varten hankkimaansa Globus-matkakameraan, joka palveli häntä 1940-luvulle asti. ${ }^{301}$

Valokuvaus oli Granölle osa tutkimusmatkailijan ja tiedemiehen työtä. Tämä tuli esiin

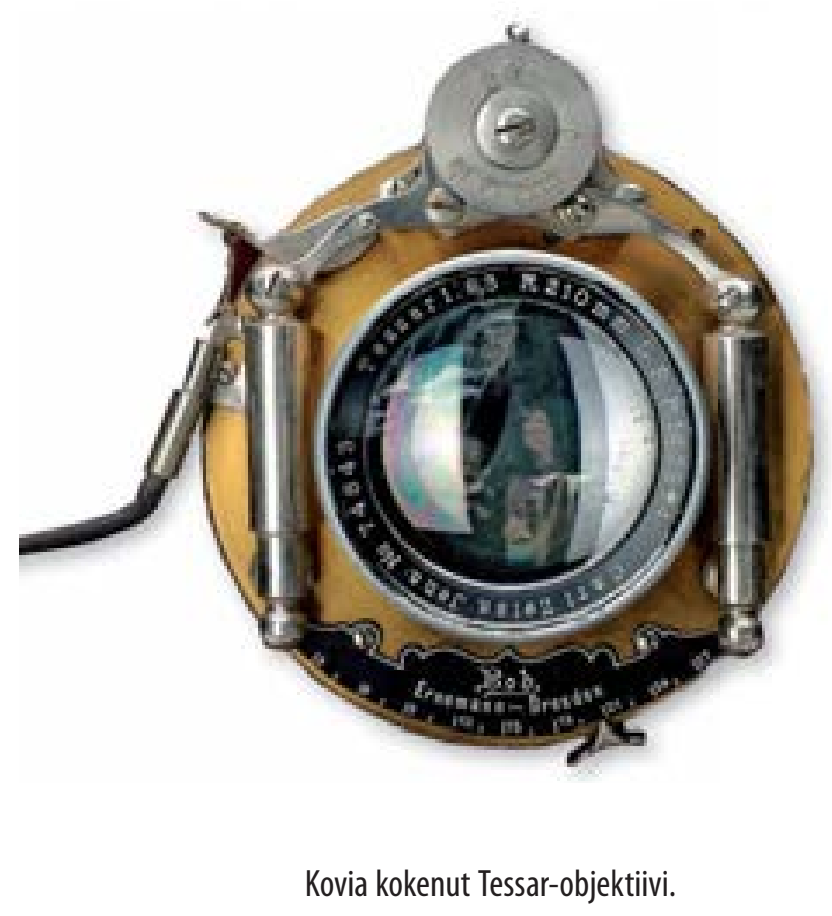

TEOKSEN SYNTy $\quad \| \quad 167$ 
kahdella tapaa. Ensinnäkin hän kuvasi yleensä kesäaikaan ja pääasiassa ulkoilmaelämää. Talvisin hän paneutui niin tiiviisti tutkimusten kirjoittamiseen, että valokuvaaminen jäi vain muutamiin otoksiin. Toiseksi hänen valokuvaustoimintansa keskittyi Siperian vuosiin ja maisemamaantieteen luomisvaiheeseen 1920-luvulla. Hän käytti Siperiassa ottamiaan valokuvia kaikissa Altaita ja Mongoliaa koskevissa tutkimuksissaan. Samoin Pubtaan maantieteen valokuvat koostuvat pääosin Granön tutkimusmatkojen aikana ottamista valokuvista, mutta mukana on myös myöhempiä Valosaaren kuvia. ${ }^{302}$

Sen sijaan Suomen maantieteelliset alueet -teoksessa Granö käytti vain Ilmavoimien, Matti Sauramon ja Erkki Mikkolan ottamia valokuvia, ja myös muissa 1930-luvun vaihteen jälkeen julkaisemissaan Suomea koskevissa tutkimuksissaan hän tukeutui pääosin muiden ottamiin kuviin. Toki valokuvaus säilyi edelleen tärkeänä osana Granön elämää, mutta nyt hän keskittyi kuvaamaan perhe-elämään liittyviä tapahtumia, kuten lapsia, perhejuhlia ja retkiä. ${ }^{303}$

Granö oppi pitkien matkojensa aikana tarkoin hallitsemaan tutkimusmatkavalokuvauksen tekniikan. Noin 10 kilon painoinen kameravarustus jalustoineen ja filJ.G.Granön meineen ja muine välttämättömine tarvikkeineen pakattiin ja sidottiin tutkimusvälipieni matkakamera. neiden ohella huolellisesti satulareppuihin. Valotetut filmit kehitettiin yöllä pimeässä

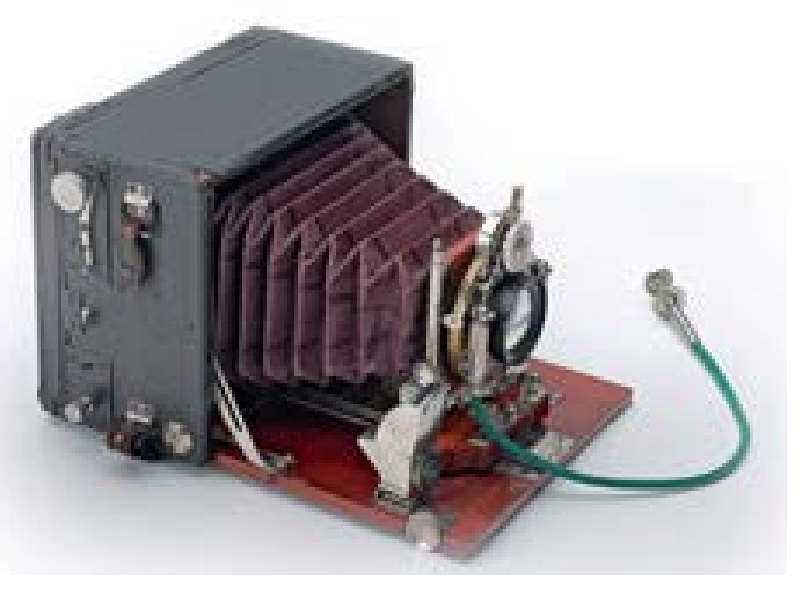
teltassa punaisen lyhdyn ääressä, vedokset huuhdottiin vuoripuroissa, järvillä tai kaivoilla ja ripustettiin teltan kattoon roikkumaan. Kun negatiivit olivat kuivuneet, matka saattoi jatkua.

Taneli Eskolan mukaan valokuvaus oli Granölle näkyväksi tekemisen, viestinnän ja ilmaisun sekä taltioinnin ja havainnollistamisen keino. Samalla se tarjosi hänelle kuitenkin myös kirjalliselle kuvaamiselle rinnakkaisen visuaalisen keinon tallentaa 


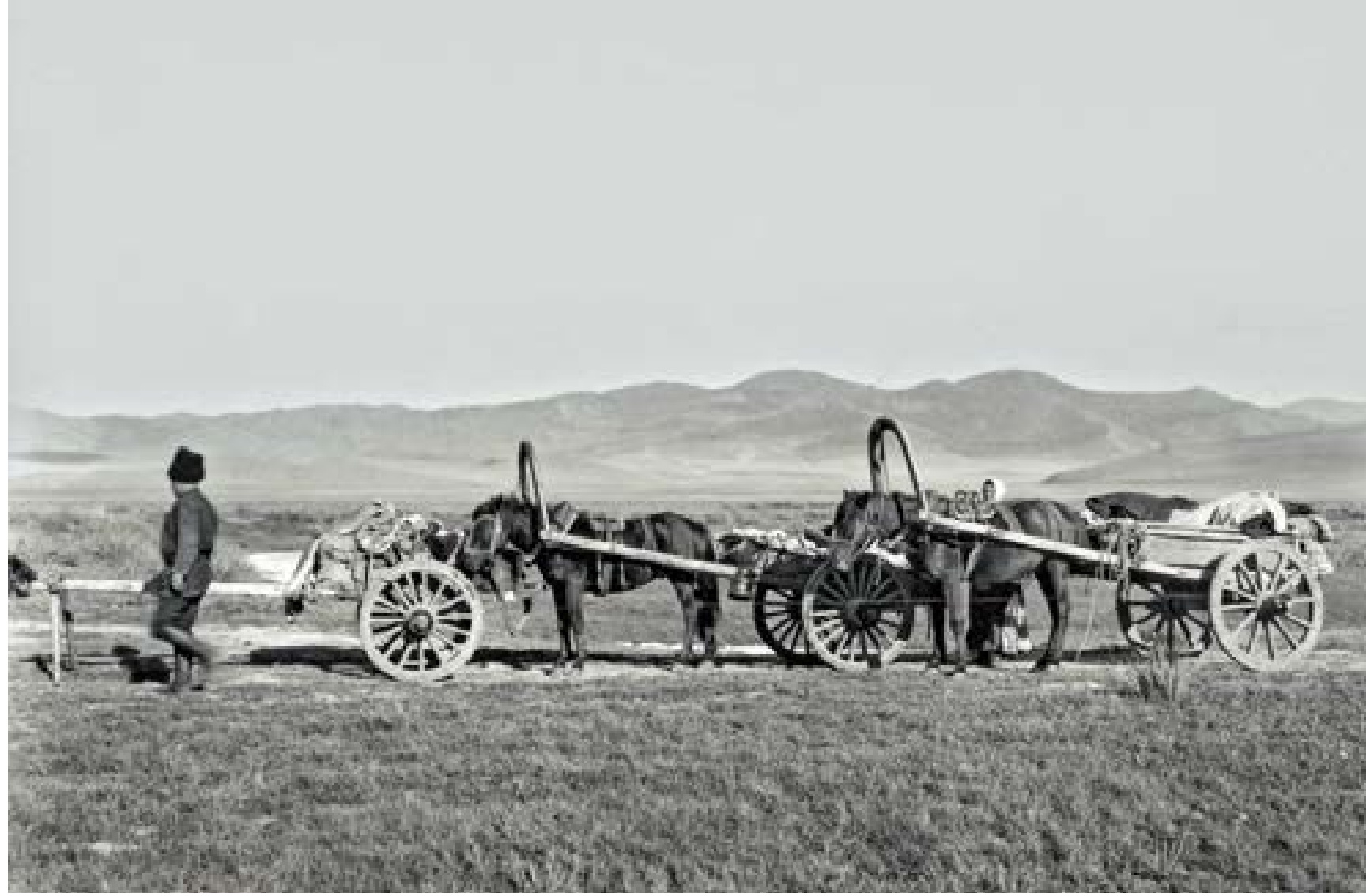

Granö kuvasi syyskuussa 1909 venäläisiä tarataikkoja, kaksipyöräisiä kärryjä, Urgan (nykyisen Ulaanbaatarin) ja Kjahtan välisellä karavaanitiellä Borojoen laaksossa Pohjois-Mongoliassa.

tutkimusmatkojen aikaisia tunnelmia ja kokemuksia. Hän paneutui huolellisesti kuvausjärjestelyihin, mietti tarkoin kuvakulmat ja rajaukset mutta osasi vangita myös matkojen ohikiitäneitä hetkiä. Käyttämällä itselaukaisinta hän saattoi myös itse esiintyä kuvissa. ${ }^{304}$

Granö oli taitava tilan ja liikkeen kuvaaja, jonka vuoksi valokuvat puhuttelevat välittömyydellään ja konkreettisuudellaan. Kuvien aiheet vaihtelevat intiimeistä henkilökuvista Altain majesteettisiin maisemiin, silmänkantamattomiin ulottuville aroille, tunnelmallisiin järvimaisemiin, tummiin metsiin ja jylhiin vuorijonoihin, herkkiin 
eläinkuviin sekä humoristisiin tilannekuviin. Hän kuvasi paljon myös tutkimusmatkalaisten arkea: Oppaita ja apulaisia, hevosia, härkävaljakoita, karavaaneja ja karavaanihevosen kuormaamista sekä esimerkiksi iltahetkeä teltassa päivämatkan taituttua, kun tutkimusmatkailija kirjoittaa matkapäiväkirjaansa ja apulainen paikkaa nuttuaan. ${ }^{305}$

Granö kuvasi suunnitelmallisesti ja oli valmis näkemään paljon vaivaa hyvän lopputuloksen varmistamiseksi, kuten kertomus maral-peurojen kuvauksesta 1907 osoittaa:

\begin{abstract}
Eläimet olivat niin vauhkoja, että valokuvaus läheltä vaati aivan erikoisen menetelmänsä. Suoraan aitausta kohti ei voitu ratsastaa, sillä silloin maralit olisivat tulleet siihen käsitykseen, että meidän tulomme tarkoitti niitä, jolloin ne - niin vakuutti opas - olisivat voineet lähteä käpälämäkeen. Rupesimme ratsastelemaan aitauksen ulkopuolella edestakaisin, vähitellen yhä lähemmäs siirtyen, kunnes vihdoin olimme aivan aidan luona. Astuin nyt maahan ja aloin, matkatoverieni edelleen ratsastaessa edestakaisin, asetella hitaasti ja varovasti konetta statiiville. Maralit, näyttivät todella tulleen siihen uskoon, ettei homma niitä tarkottanut, sillä ne tulivat rohkeasti aivan lähelle ja tarkastelivat uteliaasti meitä. ${ }^{306}$
\end{abstract}

Hyvien valokuvaajien tapaan Granöllä oli ihmisluonteen, valon ja tilanteen tajua ja kykyä hallita niitä samanaikaisesti. Hän kuvasi dokumentaarisesti mutta samalla ajattomasti ja taiteellisesti. Hänen kuvissaan on pilkettä, kokeilevuutta ja humoristisuutta, elämän monipuolisuuden ikuistamista. Kuvat on otettu ihmisyyttä kunnioittaen, niissä ei ole mitään pahansuovuutta tai ihmisten aliarvioimista, pilkasta puhumattakaan.

Varsinkin Altain vanhauskoinen väestö suhtautui kielteisesti tai vähintään epäluuloisesti valokuvaukseen, sillä he uskoivat kameran levittävän pahan hengen vaikutusta ja kuoleman saastaa. Granö onnistui kuitenkin saavuttamaan ihmisten luottamuksen rauhallisella ja hyväntahtoisella käytöksellään:

Valokuvaaminen oli arkaluontoisempi asia. Siitä neuvoteltiin pitkän aikaa. Kysymys oli lähinnä siitä, oliko valokuvausta tässä tapauksessa pidettävä jumaluuden 
pilkkaamisena ja pyhäkön häpäisemisenä, vai eikö... Lopuksi kumminkin suostuttiin pyyntööni, sitten kuin oikein joukolla oli katseltu koneen rakennetta ja himmeälle levylle syntyvää kuvaa. ${ }^{307}$

Granö dokumentoi kuvansa alusta alkaen tarkasti ja tieteellisen täsmällisesti. Muistiin merkittiin aika, paikka, kuvan henkilöt, valotusaika, himmenninaukko, taivaan pilvisyys ja usein myös kompassisuunta. Hän yhdisti kuvat myös taustatietoihin, pitämäänsä päiväkirjaan ja muuhun kirjallisuuteensa. ${ }^{308}$

Aloittaessaan 1913 varsinaiset Altain tutkimuksensa Granö perehtyi maastofotogrammetriaan, joka soveltui erityisesti työskentelyyn laajoilla, metsättömillä järvi- ja vuoriseuduilla. Menetelmän avulla hän kykeni tutkimaan jäätikön vaikutusta maanpinnan muotoihin myös sellaisilla alueilla, joille jalkamiehellä ei ollut menemistä. Granön mukaan menetelmä oli varsin käytännöllinen, kunhan näköala oli kyllin aukea:

Otetaan kahdesta tai useammasta, tietyn välimatkan päässä toistaan olevasta paikasta tähtäyslaitteella ja kuplavaa’alla varustetulla valokuvauskoneella, n.s. fotogrammetrilla, sarja valokuvia samasta alueesta. Näiden valokuvien, fotogrammien, avulla voidaan laatia kysessäolevasta seudusta yksityiskohdittain tarkka kartta.

Kartografisten taitojensa ja matemaattisen lahjakkuutensa ansiosta Granösta tuli merkittävä maastofotogrammetrian kehittäjä. ${ }^{309}$

Ennen lopullista paluutaan Siperiasta Suomeen Granö ehti ottaa valokuvia seitsemän matkan aikana. Hän kuvasi itse valokuvaustaan Terrassa 1916 julkaisemassaan artikkelissa:

Kaikilla matkoillani olen valokuvannut. Enimmäkseen ovat kuvat otetut morfologisia näkökohtia silmällä pitäen; on kumminkin sellaisiakin, jotka esittävät 
luonnontieteellisiä, kansatieteellisiä tai muinaistieteellisiä nähtävyyksiä. Kaikkiaan on kehitettyjä, käyttökelpoisia filmejä ja levyjä - lukuun ottamatta fotogrammeja - jonkun verran yli 400. Useimmat ovat kokoa 13 x $18 .^{310}$

Taneli Eskolan mukaan Granön ilmoitus valokuvien määrästä oli turhan vaatimaton. Käytännössä mielenkiintoisia kuvia on kaksinkertainen määrä, ja kaikkiaan hänen Siperian negatiivejaan on noin $1150 . .^{311}$

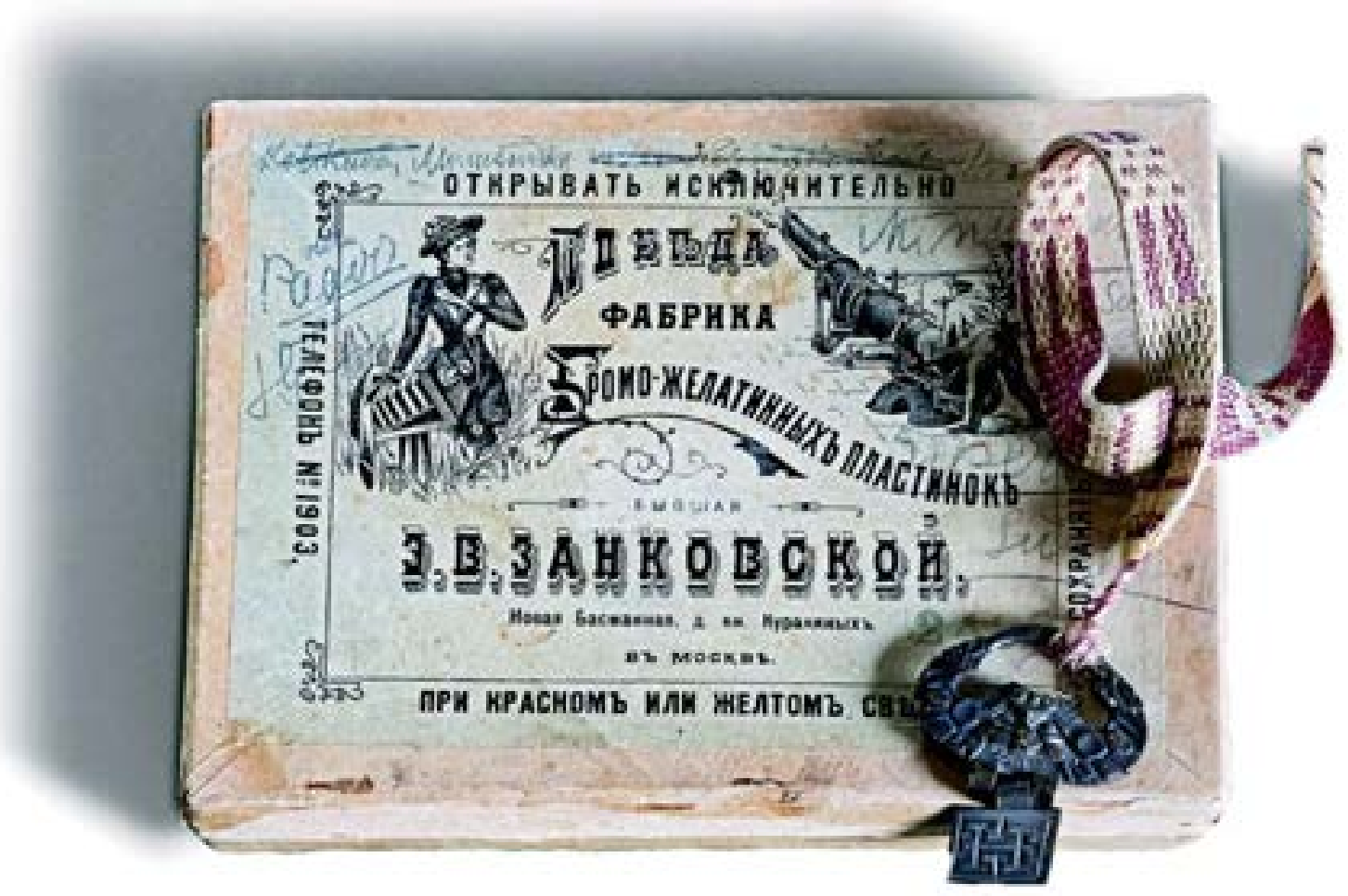

Venäläinen negatiivirasia ja ratsupiiskan solki. 


\section{Tavoitteet ja toteutus}

Granö on itse todennut, että Altai oli hänen vaikeimmin syntynyt teoksensa. Hankaluus ei johtunut sanottavan puutteesta, sillä eri puolille Siperiaa ja Mongoliaa suuntautuneiden matkojen ansiosta hän oli perehtynyt tutkimusalueeseen erinomaisen hyvin. Hän oli työskennellyt 1900-luvun alusta alkaen miltei joka kesä alueen eri osissa, retkeillen niin pohjoisilla aroseuduilla ja keskiosien koskemattomissa metsämaissa kuin etelässä kohoavilla tunturilakeuksilla ja vuorilla. ${ }^{312}$

Granö hallitsi paikallisia kieliä ja oli liikkunut Altain kaikkien heimojen alueilla ja tutustunut niiden elämään, tapoihin, uskomuksiin ja maailmankatsomukseen. Lisäksi hän saattoi tukeutua kirjoitustyössä monipuoliseen aineistoon: Matkapäiväkirjoihin, jo julkaistuihin kirjoituksiin, valokuviin ja lukuisiin itse tehtyihin karttoihin.

Valtavan aineistonsa ansiosta Granö olisi sujuvakynäisenä kirjoittajana voinut helposti täyttää teoksillaan pienen kirjaston. Hän ei kuitenkaan halunnut enää kirjoittaa perinteisiä kronologisia matkakertomuksia vaan luoda jotakin uutta ja omaperäistä, teoksen, joka liittyisi Alexander von Humboldtin aloittamaan tieteellistä ainesta kaunokirjallisuuteen liittävään esteettiseen aluekuvausperinteeseen mutta pyrkisi samalla uudistamaan sitä. ${ }^{313}$

Granön tavoitteena oli luoda kirjalle rakenne, jossa maantieteelliset seikat muodostaisivat rungon Altain alueen kaunokirjalliselle kuvaukselle. Tekstin tuli olla ehdottoman totuudenmukaista ja tosiasioihin pitäytyvää, seikkailun kuvaaminen sai 


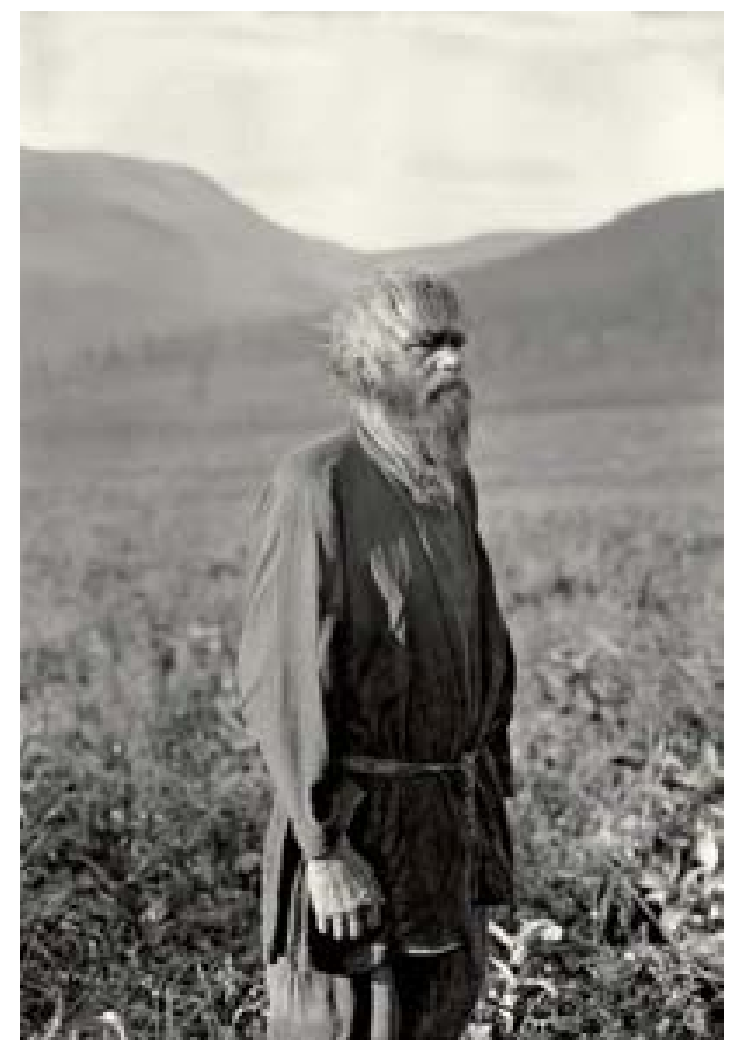

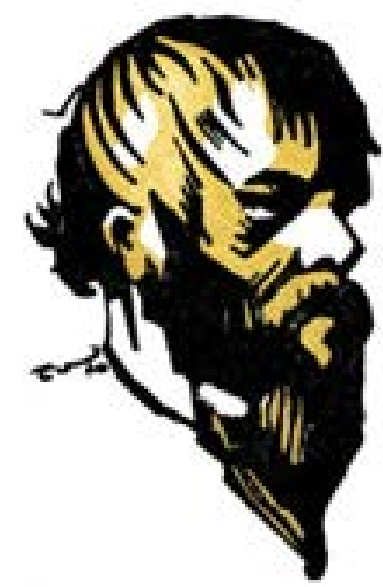

Toivo Vikstedtin valokuvan perusteella tekemä piirros Subbótinista hallitsi Altai /I -teoksen kantta.

Jo iäkäs metsästäjä Kyprián Mihailovitš Subbótin oli Granön oppaana kesän 1915 tutkimusmatkalla.

jäädä aivan sivuasiaksi. Tavoitteena oli löytää esitystapa, joka nostaisi esiin "jokapäiväisyyden" ihmiselämässä ja "tavallisuuden" luonnossa, sillä juuri niistä kokonaisuus sai "karaktäärinsä". Merkillisyydet, harvinaisuudet ja muut poikkeamat tavanomaisuudesta tuli työntää tutkijan persoonan tavoin sivuosaan. ${ }^{314}$

Kokeneena pedagogina Granö ymmärsi, että laajalle lukijakunnalle suunnattua teosta ei voinut kirjoittaa akateemisen teoksen tavoin. Tämä ei tarkoittanut tieteellisen aineksen karsimista vaan pyrkimystä sen muuntamiseen yleistajuiseen kaunokirjalliseen muotoon siten, että lukija sai ikään kuin ohimennen, oman oivalluksen tai mielikuvituksen kautta käsityksen Altain luonnon, maisemien ja väestön ominaispiirteistä. ${ }^{315}$ 


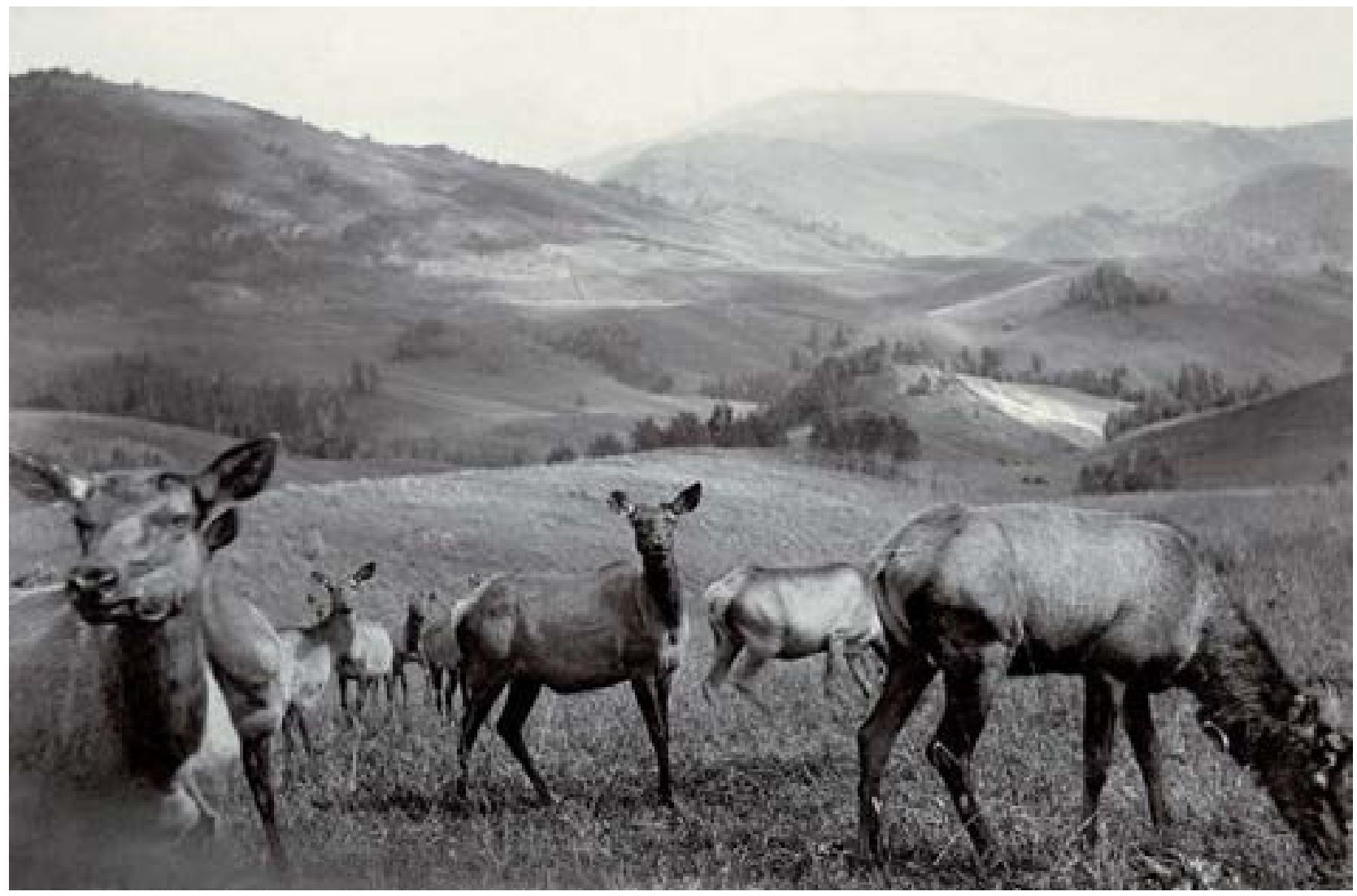

Granön huolellisten valmistelujen jälkeen ottama harvinainen tilannekuva maral-peuroista. Venäjän Altai, Berelskoje 1907.

Mietittyään ja suunniteltuaan pitkään teoksen rakennetta ja tyyliä Granö pääsi viimein itseään tyydyttävään ratkaisuun. Hän päätti kirjoittaa teoksen, jossa tarina ei edennyt kronologisesti vaan alueittain, jotka kuvattiin maisemallisina kokonaisuuksina. Tavoitteena oli vuoristoromantiikan hengessä kytkeä von Humboldtin tavoin yhteen korkeusvyöhykkeet ja kasvillisuuden ilmenemismuodot ja luoda kokonaiskuva tutkimusalueesta "ilman raskaasti tieteellisen koneiston tukea". ${ }^{316}$ 
Aluksi huomio kohdistettiin alueen yleiskuvaukseen sekä teoksen päähenkilöiden eli oppaiden esittelemiseen sekä pohjoisessa Siperian arotasangosta nousevan kumpuilevan etumaaston tarkasteluun. Sitten kuvaus etenee synkkien metsien verhoamien jyrkkien rinteiden ja vuolaitten virtojen kautta avarille tunturilakeuksille ja päättyy lumipeitteisten huippujen kautta Mongolian puolelle, joka siihen aikaan oli lähes valkea läiskä maailmankartalla. ${ }^{317}$

Loppukesällä 1917 alkanut kirjoitusvaihe eteni aluksi niin hyvin, että Granö toivoi saavansa kirjan valmiiksi kevääseen 1918 mennessä. Pian kävi kuitenkin ilmi, että aikataulu oli liian tiukka kunnianhimoisiin tavoitteisiin nähden. Granö joutui yleensä kirjoittamaan kaiken kolmeen kertaan ennen kuin lopputulos tyydytti häntä, ja nyt tekstin lyyristen kohtien hiominen vei tavallistakin enemmän aikaa. Lisäksi kirjoitustyön edetessä havaittiin tekstiä syntyvän niin paljon, että teos oli julkaistava kahdessa osassa. ${ }^{318}$

Kultajärven eli Telétskojejärven kuvaukseen päättynyt Altai I ilmestyi syksyllä 1919. Toisen osan oli tarkoitus ilmestyä seuraavana keväänä, mutta Granön siirtyminen Tarton yliopiston professoriksi pakotti muuttamaan julkaisuaikataulua. Saatuaan yliopiston lukuvuoden päätökseen Granö muutti kesäkuussa 1920 perheineen Kabinan kartanoon. Muutto maalle merkitsi hänelle ankaran työpaineen hetkellistä hellittämistä, ja hän viettikin koko kuukauden "suloisessa levossa", toki lähiympäristöönsä tutustuen. ${ }^{319}$

Heinäkuun alussa Granö tarttui jälleen kynään, sillä hän oli päättänyt kirjoittaa teoksen toisen osan valmiiksi:

Minulla oli suuri eristetty sali käytettävänä. Siellä istuin ja annoin ajatusteni lentää Siniseen Altaihin. Alkuperäinen suunnitelma tuli pääpiirteissään toteutetuksi, mutta tehtävä oli kyllä - sen niin selvästi huomasin - tekijän edellytyksiä suurempi. Lukija antakoon anteeksi, - sen suuren rakkauden tähden, jolla tuota kaukaista maata rakastan. Joka tapauksessa tunsin sanomatonta iloa tuossa työssä, sillä tiesin, etten ollut milloinkaan mitään niin vierailta vaikutteilta eristettynä ja niin oman pienen pääni mukaan tehnyt kuin Altai-kirjani. ${ }^{320}$ 
Koko loppukesän kestänyt ja vähintään viisi tuntia päivästä vienyt tiivis työrupeama tuotti kaivatun tuloksen, sillä hän onnistui saamaan käsikirjoituksen valmiiksi. Teos pyrittiin saamaan vuoden 1920 joulumarkkinoille, mutta hidas postiliikenne Helsingin ja Tarton välillä ja 20 painoarkin tarkastaminen kahteen kertaan muiden työkiireiden keskellä loka-marraskuussa veivät niin paljon aikaa, että Altai II ilmestyi vasta vuoden 1921 puolella. $^{321}$ 


\section{Glusta, qALKOINEN JA SININEN ALTAI}

\section{Sanojen ja kuvien liitto}

Granö onnistui hyvin tavoitteissaan. Teoksessa kesäinen Altai näyttäytyy mahtavana, tasankojen ympäröimänä vuorimaana, joka kohoaa korkean mantereen tavoin Siperian ja Mongolian lakeuksista. Kuvaus liikkuu ennakkoluulottomasti tieteen ja taiteen rajamailla liittäen empiiriseen kuvaukseen ja selittämiseen kaunokirjallisen ja runollisen elementin, joka sallii pistäytymisen myös myyttien maailmaan. ${ }^{322}$

Granö jakaa Altain seitsemään omaleimaiseen maisema-alueeseen: esimaan aroihin ja aavikoihin, Metsä-Altaihin, Telétskojejärven eli Kultajärven seutuun, telengiittien tunturiylänköihin ja -laaksoihin, Keski-Altain vuoristoon, Irtyšjoen laaksoon ja Mongolian puoleiseen seutuun. Aluejaon pohjana ovat maanpinnan muodot, vesistöt, kasvillisuus ja erilaiset kulttuuritekijät.

Kustakin alueesta Granö piirtää voimakkaan subjektiivisesti koetun kuvan, joka perustuu sekä hänen laajaan lukeneisuuteensa että alueilla saamiinsa aistimuksiin ja vaikutteisiin. Erityisen paljon hän kiinnittää huomiota luonnonympäristöön, niihin sopeutuneen ihmisen toimintaan ja paikallisiin elinkeinoihin, tapoihin ja uskomuksiin.

Granö toteaa alkusanoissaan, että hänen esityksensä rakentuu tekstin ohella karttojen ja valokuvien varaan. Teoksessa on kaikkiaan 10 vinjettipiirrosta, 26 karttaa ja piirrosta sekä 153 valokuvaa, jotka muodostavat yhdessä tekstin kanssa saumattoman ja ehyen kokonaisuuden. Granön pyrkimystä kokonaiselämyksen tuottamiseen osoitti se, että Jalmari Jäntin vastustuksesta huolimatta hän sai läpi ratkaisun, jossa kuvatekstit napattiin pääosin suoraan varsinaisesta tekstistä. ${ }^{23}$ 

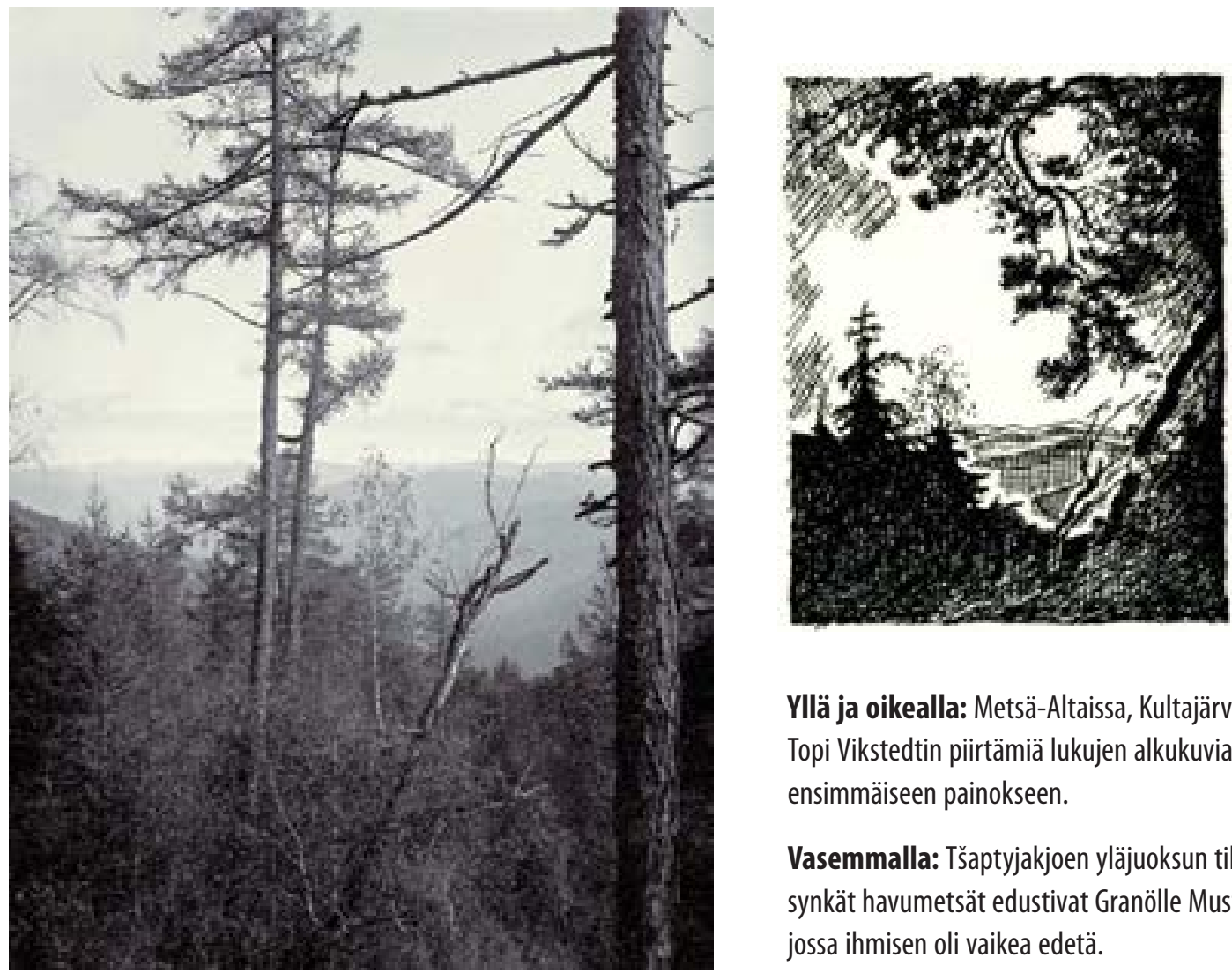

Yllä ja oikealla: Metsä-Altaissa, Kultajärvi ja Telengiittien maassa. Topi Vikstedtin piirtämiä lukujen alkukuvia Altai-teoksen ensimmäiseen painokseen.

Vasemmalla: Tšaptyjakjoen yläjuoksun tiheät ja synkät havumetsät edustivat Granölle Mustaa Altaita, jossa inmisen oli vaikea edetä.

Granö kuvaa maisemia paljon matkustaneen tiedemiehen silmin mutta tuo samalla esiin, että erilaiset ihmiset voivat kokea samat maisemat eri tavoin. Esimerkiksi Altain monet kansat suhtautuvat eri tavoin vuorimaan sisäosia luonnehtiviin tunturiylänköihin:

Turpeeseen sidottu venäläinen talonpoika sanoisi teille jotenkin seuraavaan tapaan:

Siellä on metsää vähän. Seutu on niin tasaista, että voisi rattailla ajaa missä tahansa, ellei olisi paikoin jyrkkäreunaisia jokilaaksoja ja pahaa suota. Ikävä vain, ettei vilja siellä menesty. Kesäisin usein on lumipyryjä, ja lämpiminäkin vuodenaikoina on öisin kuuraa maassa. 

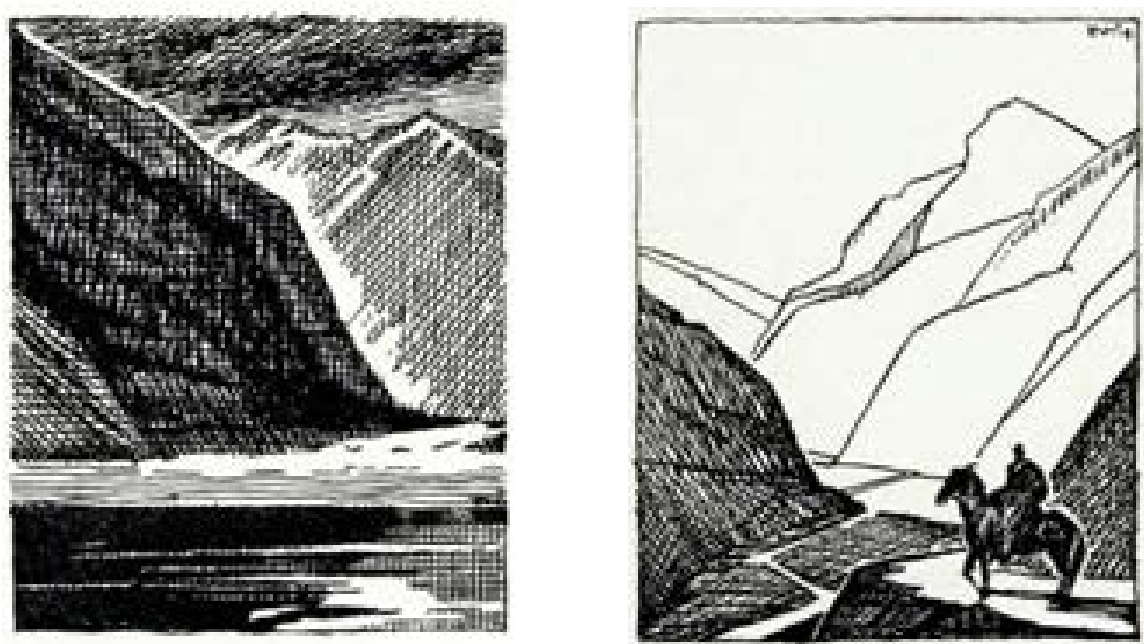

Kirgiisi, jolla on tapana siirtyä kesäisin karjoineen tunturien alppiniityille vastaisi: Mainiota seutua. Ei ole sääskiä eikä paarmoja. Karja lihoo. Raikkaat tuulet puhaltavat. Ruokahalu on erinomainen.

Altailainen metsästäjä kertoisi teille jalohirvistä ja peuroista, vuorikauriista ja karhusta, jolla on tapana kesähelteessä loikoilla tunturien lumilaikoilla. Hän muistelisi ehkä myös alppiniittyjen kukkaisloistoa ja öiden lumoavaa kuutamoa; vaipuisi ehkä mietteisiin ja kysyisi kuin itseltään vanhan morsiusrunon sanoin:

Kukkineeko kultakukat vielä Altain tuntureilla,

kumottaneeko valju kuu kultavuoren kukkuloilla?... ${ }^{325}$

Granö ei tyytynyt vain esittämään yksityiskohtaista ja tieteellisesti pätevää tietoa Altain pinnanmuodoista ja luonnosta vaan kiinnitti paljon huomiota kielen rikkauteen ja ilmaisuvoimaan. Hän vie lukijan mukaansa Altain rinteille ja kertoo havainnollisesti, miten tämä voi kokea maiseman ja sen muotoutumisen kaikilla aisteillaan: 
Elävän luonnon edustajia et näe ympärilläsi kuin poikkeustapauksessa. Siltä kannalta katsoen maisema on kuollut. Mutta toisaalta toteat pian, etteivät ilmastolliset tekijät missään muualla Altaissa niin voimakkaasti ja uupumatta työskentele kuin juuri ylävuoristossa. Tuhannet purot uurtelevat rinteitä, jäätiköt tekevät työtään, vinha tuuli puhaltaa. Kuuluu joka suunnalta jyskettä, kohinaa, etäisten laukausten kaltaista pauketta. Alastomat kalliot halkeilevat, murenevat, kiviä putoilee, lohkarekasoja ja sorakartioita syntyy. Seisot tasaavien voimien suuressa työpajassa. ${ }^{326}$

Kirjoitustapa on edustavimmillaan Telétskojejärven kuvauksessa. Samalla kun Granö antaa tieteellisesti arvokkaan esityksen vuonomaisen järven ympäristön geomorfologiasta, hän piirtää jylhän kuvan pohjoisen ja syvän järven kauneudesta:

Synkkänä, jäätävän kylmänä vesi peittää sen syvät haudat. Kaamean jylhinä vartioivat sitä molemmin puolin pilviäpiirtävät kallioseinät. Tyvenenäkin se on pelottava. Sen pinnalla ei näy minkäänlaista eloa. Vain pirstoutuneita puunrunkoja ja rantojen rikkaa sen vedenkalvolla kelluu.

Mikä painostava luonnon suuruus! ${ }^{327}$

Granö saapui Altaihin kaudella, jolloin venäläinen uudisasutus oli jo työntänyt alueen alkuperäiskansat metsätataarit, telengiitit ja teleuutit tieltään vuoriston kaukaisimpiin osiin. Näiden kansojen lisäksi Altaille oli tullut lännestä, etelästä ja idästä eri mongoli- ja turkkilaiskansoja, jotka olivat luonteeltaan toimintahaluisempia, tarmokkaampia ja vilkkaampia kuin altailaiset mutta joilla ei ollut näille ominaista "hienotunteisuutta, nurkumattomuutta, mukautumiskykyä ja metsien hiljaisuudessa kasvatettua mielenmalttia". ${ }^{328}$

Granö myönsi, että luonnon ja ihmisen asettaminen selkeään riippuvuussuhteeseen oli hyvin kyseenalainen ratkaisu. Luonto toimii omien lakiensa mukaan ja ihminen elää niin kuin parhaaksi näkee. Silti hän ei malttanut olla tekemättä rinnastuk- 


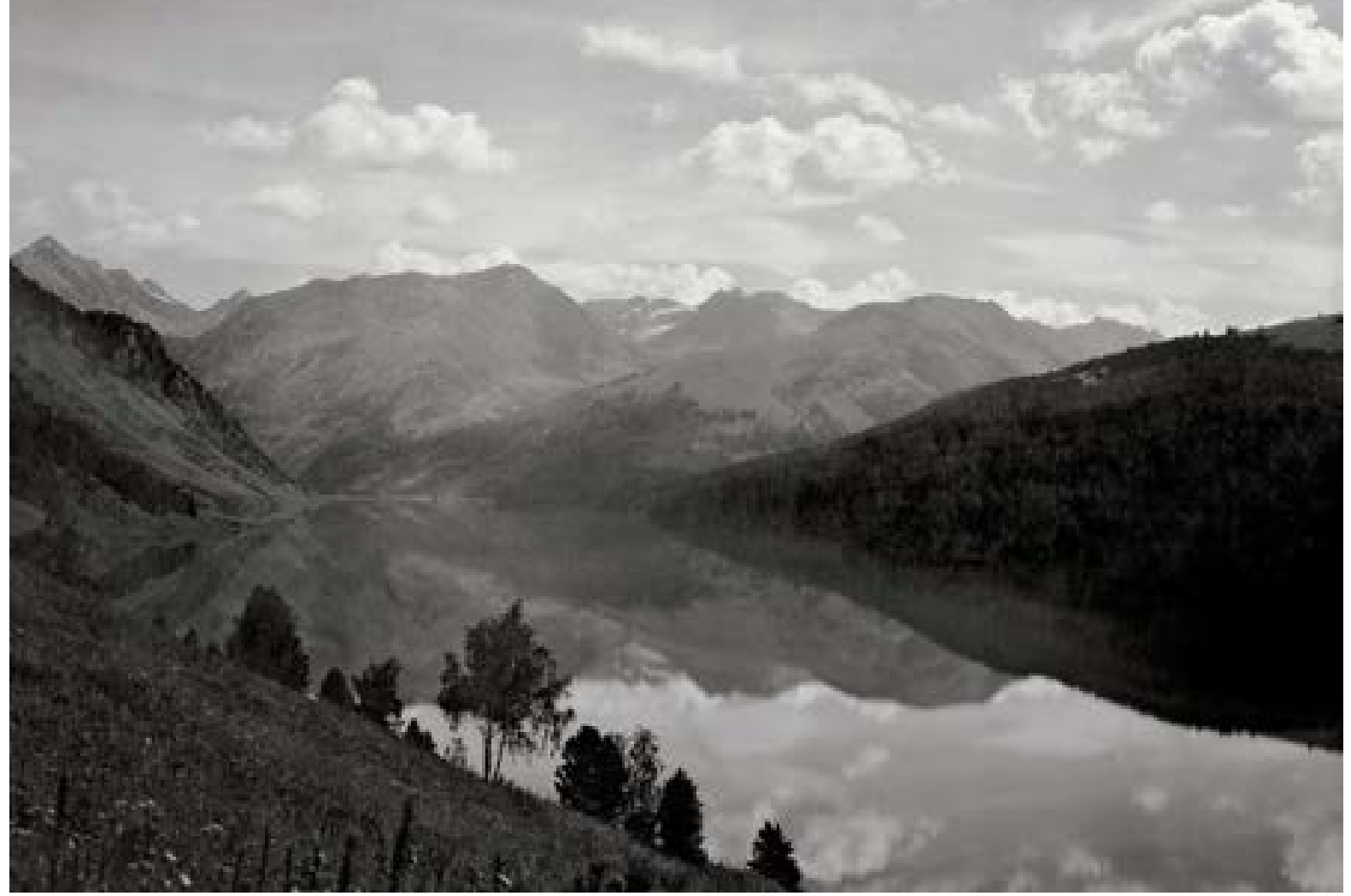

Kesän 1915 tutkimusmatkan aikana Granö tutustui luonnonkauniiseen Talménjejärveen Venäjän Altailla.

sia. Esimerkiksi luvussa ”Joutsenjoki ja Ivan Ivanovitš” hän vertaa joen oikullisuutta ja yllätyksellisyyttä sen rantamilla asuneen miehen omia etuja ajavaan toimintaan: ”hoitaa mehiläisiään, kokoo pähkinöitä, tekee kauppoja, nylkee matkustavia." 329

Pitkäaikainen oleskelu Altailla ja monien paikalliskielten hallinta antoivat Granölle ainutlaatuisen mahdollisuuden eri väestönryhmien elämänpiirin tarkasteluun ikään kuin sisältä päin. Hän oli tarkka havainnoija ja ihmistuntija, jolla oli kyky luoda muutamalla vedolla kohtaamistaan ihmisistä eläviä luonnekuvia. Hän oli huolissaan Altain alkuperäiskansojen tulevaisuudesta muiden kansanryhmien paineessa mutta kuvasi kaikkia kansoja ymmärtävästi ja kunnioittavasti. Jokaisella kansalla ja ihmisellä oli valoisat ja tummat puolensa niin kuin Altain rinteiden ketripuilla eli sembramännyillä. ${ }^{330}$ 
Kunnioittava suhtautuminen määräsi myös hänen kanssakäymistään paikallisen väestön kanssa. Kun Granölle, kyläpäällikön kunniavieraalle, tarjottiin Kara-sunin laaksossa syötäväksi lampaan pää silmineen ja kaikkine muine herkkuineen, hän ei halunnut loukata isäntäänsä. Hän nakerteli ja kaiveli isäntänsä kanssa hartaasti lampaan päätä seuraten samalla kateellisesti, kun hänen vierashierarkian häntäpäähän noteeratut apulaisensa saivat pistellä nälkäisiin suihinsa parhaita selkälihoja. ${ }^{331}$

Granö myönsi, että Suomessa muukalaisille annettu neuvo "Maassa maan tavalla tai maasta pois" päti varsin hyvin myös Altailla. Siksi hän arvosti suuresti altailaisia päöoppaitaan Mataita, Tungerekia, Subbótinia, Kyngrakia ja Tömeniä, jotka olivat suhtautuneet ymmärtäväisesti kokemattomaan tutkijaan:

Miten elävinä astuvatkaan eteeni muistojen komeroista maallisen hahmonne tutut piirteet! Palautuvat myös mieleeni vaellustemme vaivat, joihin tähteni alistuitte, sekä palveluksessani suorittamanne suuriarvoinen työ.

Tunnustan mielelläni, että tieteelliset tulokset, joihin yhteiset matkamme ovat johtaneet, suureksi osaksi välillisesti ovat teidän saavutustanne, - niin vähäiset kuin tietonne ovatkin geomorfologiassa yleensä ja jääkausiopissa erikoisesti. ${ }^{332}$

Tärkeintä Granölle oli, että ihmiset olivat aidosti sitä, mitä he olivat. Lomailevan herrasväen, erinäisten puoliherrojen ja kirkon kosteasilmäisten palvelijoiden toimintaa kuvataan selvästi kriittisemmin kuin tavallisen kansan juoppoutta, ahneutta ja ajattelemattomuutta, jota usein pehmennetään lempeällä ja ymmärtäväisellä huumorilla. ${ }^{333}$

Granön lempiopas Matai oli joutunut pahaan pulaan ollessaan tunnetun venäläisen kasvitieteilijän Vasili Vasiljevitš Sapožnikovin apulaisena. Hän oli saanut nyljettäväkseen pienen harvinaisen sorsanpoikasen, mutta tärvellyt sen taitamattomuuttaan niin pahoin, että jokin selitys oli keksittävä: 
Siinä kävi silloin nylkiessäni niin hullusti, että linnun ohut kaulanahka repesi. Mitä tehdä? Teltassaan oli professorilla neula ja lankaa - ikävä kyllä mustaa esillä. Hädissäni neuloin niin hyvin kuin osasin repeämän kiinni. Illalla herrat tulivat kotiin.

- No, Matai, oletko nylkenyt linnun, Sapozhnikov kysyy.

- Olen, vastaan, tässä se on, Vasilij Vasiljevitš. Hän ottaa linnun, tarkastelee sitä ja huomaa paikkaukseni.

- Mitä tämä merkitsee? hän osottaa mustaa lankaa.

- En tiedä, Vasilij Vasiljevitš, täytyy kysyä linnun vanhemmilta, ne sen paremmin tietävät. ${ }^{334}$

Myönteisestä suhtautumisestaan huolimatta Granö joutui myöntämään, että altailaiset elivät aineellisesti ja henkisesti hyvin alkeellisissa oloissa. Taudit saattoivat raivota esteettä surkeissa ja siivottomissa asumuksissa, jotka olivat kaiken yhteiskunnallisen turvan ulkopuolella. Siksi väestö turvautui usein samaaneihin, joilta haettiin uskonnollisen tuen lisäksi myös lääkinnällistä apua.

Samaanin avun osoittauduttua tehottomaksi altailaiset kääntyivät usein muukalaisen puoleen, josko hän tietäisi jonkin keinon tai taian. Granöllä oli matkassa Tuomisen huolella varustama matka-apteekki, mutta sen rohdot auttoivat vain päänsärkyyn ja vatsakipuihin, eivät esimerkiksi ruttoon. ${ }^{335}$

Granö suhtautui altailaisiin ymmärtäväisesti mutta ei kritiikittömästi. Hän kohdistaa huomiota juopotteluun, erityisesti piimästä tislatun viinan, arakátan, alituiseen tissuttelemiseen ja muihin sosiaalisiin epäkohtiin, kuten naisten huonoon asemaan. Hän kuvaa harvalukuisia oppia saaneita altailaistyttöjä ja vierailuaan eräässä jurtassa, jossa mies poikkeuksellisesti auttoi vaimoaan kotitaloustöissä ja oli muutenkin hellä ja hyväsydäminen. Paimentolaisille nainen oli Granön mukaan pääosin pelkkä kotieläin: 
Yleensähän naista pidetään Altaissa miestä alempiarvoisena olentona, jonka arvo riippuu yksinomaan siitä työmäärästä, jonka hän kykenee kodissa suorittamaan. Mies ”ostaa” vaimonsa määrätystä, etukäteen sovitusta summasta, "kalymista" ja pitää häntä siis tavallaan - totta puhuakseni - kotieläimenään. Naisella ei ole milloinkaan, pukuaan ja vuodettaan lukuun ottamatta, omaa omaisuutta. $^{336}$

Kunnon tutkimusmatkailijan tavoin Granö oli avoin uusille kokemuksille. Yhden matkan harvinaisimmista tapahtumista hän koki kesällä 1914, jolloin hänelle tarjoutui tilaisuus seurata ja valokuvata Katunin laakson Mustassa-metsässä samaanin seremoniaa ja rituaaleja rummutuksineen:

Hiilloksen lämmössä pingottuu rummun hirvennahkainen kalvo pingottumistaan. Yhä selvemmällä kumauksella se vastaa kapulan hiljaiseen kosketukseen. Nyt, nyt se on käytettäväksi valmis. Miten täyteläinen onkaan sen ääni: on kuin taivaan jyrinä kaikuisi. Kuuletko loitsut, näetkö hypyt! Manalan-matka on alkanut

Ääh! Ää-äh! Murtuipa auki syvimmän kamaran kansi, aukesipa maailmoista alin. Noita saapuu matkansa määrään, Manalan herran majoille. Kaukaa, kaukaa kajahtaa rummun kumina kahdeksan kerroksen takaa. ${ }^{337}$

Matkapäiväkirjat takasivat myös tekstin paikkansa pitävyyden, sillä hyväkään muisti ei ole pettämätön. Tämän sai kokea myös Granö, kun tarkasti tekstin lukenut J. K. V. Tuominen suuntasi kesällä 1920 hänen huomionsa kirjan sivun 171 toteamukseen "kiehahdutin hypsotermometreja, saadakseni tietää todellisen ilmanpaineen ja sen välityksellä Katunin pinnan korkeuden”. ${ }^{338}$

Granö ymmärsi heti, että hänen ystävänsä oli oikeassa. Hän oli alun perin ajatellut sivuuttaa kokonaan hypsotermometrimittaukset, mutta oli myöhemmin lisännyt asiasta pari riviä ajattelematta asiaa loppuun saakka: 

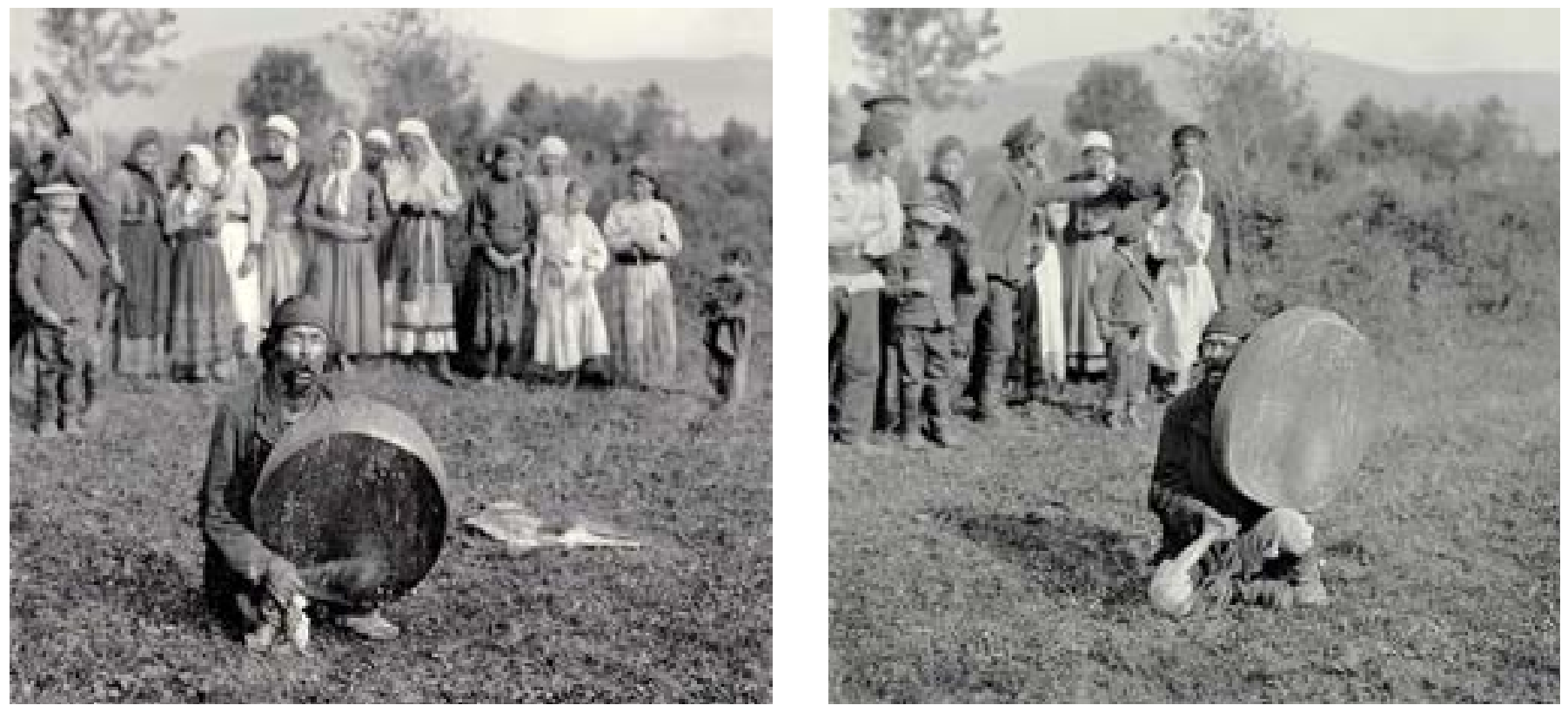

Kesäkuussa 1914 Granölle tarjoutui harvinainen tilaisuus kuvata samaanin rituaaleja Telétskojejärven tuntumassa.

En kohdistanut lainkaan siihen huomiota, ettei spriikään sellaisella säällä ilman tulitikkuja palamaan syty. Riittäköön tästä! Asia on sivulliselle yhtä vähäpätöisen koomillinen kuin se on tekijälle harmillinen ja vastaisen varalle opettavainen. ${ }^{339}$

Granön kieli on persoonallista ja eeppisen leveää. Teksti on vivahteikasta ja kuvailevaa, mutta samalla myös konkreettista ja johdonmukaista. Ihmisten ja matkatapahtumien kuvauksessa hän etäännyttää itsensä kentästä, piirtää lukijalle yleissilmäyksen tilanteesta sisällyttäen siihen johtopäätöksensä. Sitten hän erittelee ja perustelee esittämäänsä. Hänen kuvauksessaan on jotakin Kalle Päätalon kirjojen yksityiskohtaista tarkkuutta. Mikään seikka ei ole merkityksetön vaan kerronta etenee verkkaisesti kuin kohti laaksoa vakaasti valuva ikijää, joka tempaa mukaansa kaiken irtonaisen aineksen sulattaen sen kokonaisuuden osaksi. 


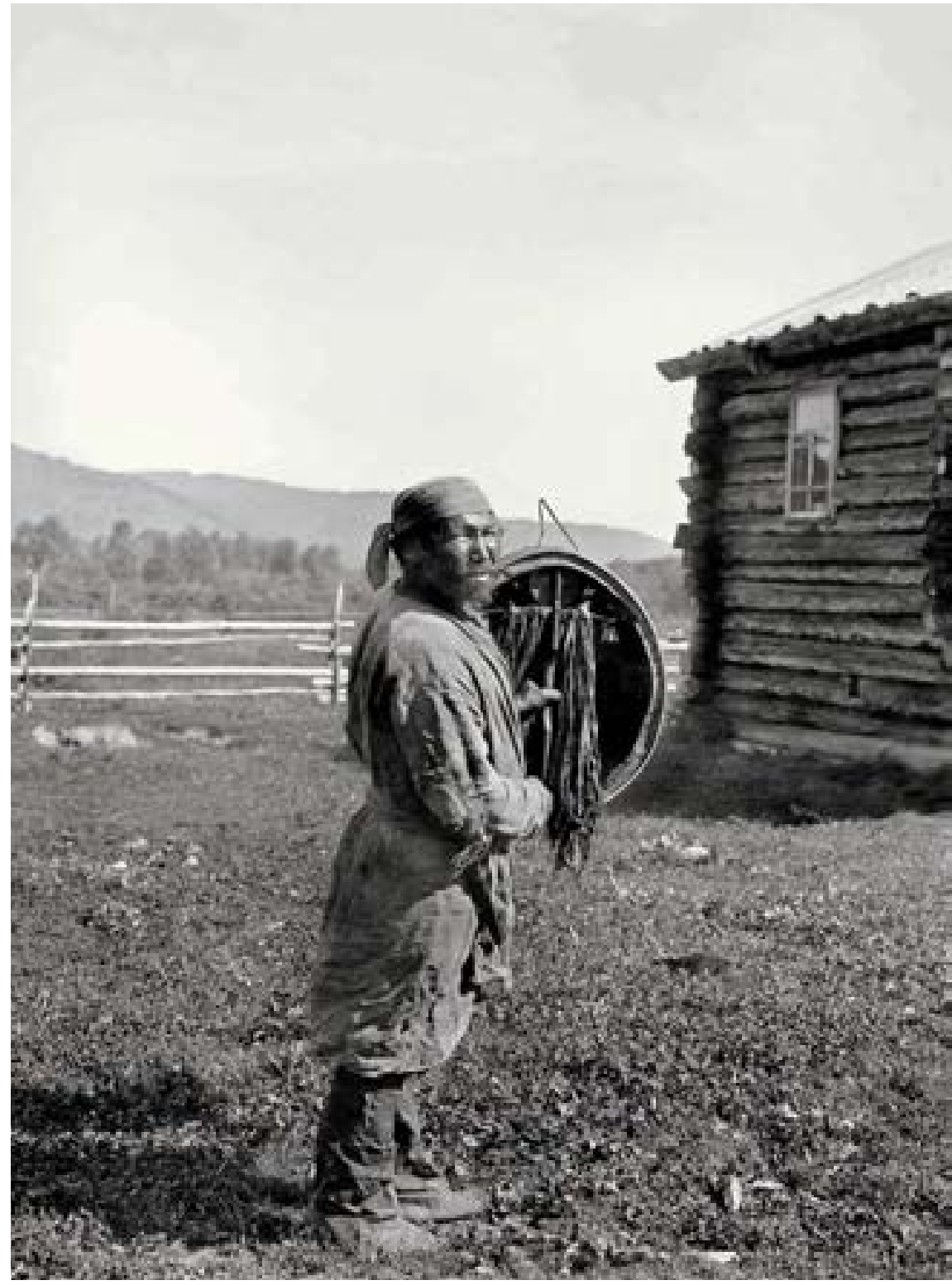

Katse kertoo, että samaani tietää mitä on tekemässä.

188 || Matkakirjallisudden klassikko 
Teoksen ajaton sanoma paljastuu Altain ydinosia kuvaavan luvun "Vuorimaan sydämessä" alkuun sijoitetusta altailaisen tarun katkelmasta:

... ja he lähtivät päivän puoleen. Näkevät ennen pitkää Valkoisen Altain, näyttäytyy valkoinen joki. Valkoisen Altain vieressä kohoaa Sininen Altai, valkoisen virran rinnalla vyöryttää vesiään sininen virta. Sinisen Altain edessä nostaa harjanteensa Musta Altai, sinisten vesien vieressä virtaavat mustat vedet... Kolmen Altain keskitse kiemurtelee musta tie, kuopalle kulunut. ${ }^{340}$

Granö kuvaa elämän ikuisia lakeja kolmen eri Altain avulla. Musta Altai symbolisoi ihmisen raskasta taivalta vaikeakulkuisessa maastossa, metsässä ja viidakossa. Se on aina läsnä, se on mullanhajua, jokapäiväistä työtä ja vaivaa. Valkoinen Altai on taivaanrannalla kirkkaana väikkyvä vuorenhuippujen ryväs, jonka ihminen näkee jatkuvasti edetessään sitä kohti vaivalloisesti louhikoissa, lumirinteillä ja jyrkänteillä. Sen voi saavuttaa vain sellainen ihminen, joka uskaltaa edetä tuntemattomille alueille. Sininen Altai on alati pakeneva sinisinä välkkyvien järvien ja utuisten harjanteiden maa. Sinne voi edetä vain katsein ja ajatuksin, sillä se ei ole maallinen paikka vaan muistojen, kokemusten ja toiveiden synnyttämä kultamaa. ${ }^{341}$

Granölle Altai ei ollut vain vuoristo. Se oli myös kauneuden lähde ja pyhäkkö, joka osoitti hänelle elämän rikkauden ja ihmisen osan maailmankaikkeudessa. Kukaan ei selviydy yksin elämässä, mutta yksikään ei myöskään ole niin vähäpätöinen, ettei hänessä olisi jotakin inhimillisesti merkityksellistä.

\section{Merkitys}

Altai I-II oli ensimmäinen suomalainen kaunokirjalliseen asuun puettu luontokirja. Kirjoittajan ja kustantajan kannalta teokseen julkaisemiseen liittyi siten riskejä, koska kukaan ei tiennyt, millaisen vastaanoton kirja saisi. Huolet osoittautuivat pian turhiksi, sillä yleisesti mestariluomukseksi tunnustettu teos sai loistavan arvostelumenestyksen. 
T. J. Hintikka katsoi Iltalehdessä, että teos oli "maantieteellisen kirjallisuutemme parhaita", mutta Viljo Tolvanen pisti Uudessa Suomessa vielä paremmaksi toteamalla, että teos "on parasta, mitä suomenkielellä tältä alalta on koskaan kirjoitettu". Voiton taisi silti viedä Yrjö A. Jäntti, jolle eivät enää riittäneet Suomen rajat:

\begin{abstract}
Tämä teos ei ollut varsinaisesti matkakertomus, eikä tieteellinen tutkimus, ihmeteltävällä taidolla tekijä oli osannut yhdistää molemmat puolet, joten teos oli sekä opettava että jännittävä ja lisäksi taiteellisessa suhteessa mitä arvokkain suurenmoisten luonnonkuvaustensa vuoksi. Siitä onkin sanottu, ettei sen viehättävämpää maantieteellistä teosta eikä runollisen lennokkaampaa kuvausta ole mistään maailman kolkasta kirjoitettu. ${ }^{342}$
\end{abstract}

Myös J. E. Rosbergin mielestä Altai oli yksi kaikkein onnistuneimmista monografioista, jotka käsittelivät ihmisen ja luonnon vuorovaikutusta. Samalla kun se antoi lukijalle kokonaisvaikutelman tästä mielenkiintoisesta vuoristomaasta ja sen ympäristöstä, se oli tieteellinen teos, jota Keski-Aasian tutkijat saattoivat käyttää luotettavana lähdekirjana. Tässä arviossa Rosberg osui oikeaan, sillä Granön kuvilla ja kuvauksilla tuli olemaan pysyvää luonnontieteellistä, kulttuurihistoriallista ja kansatieteellistä merkitystä. ${ }^{343}$

Granön taitoa yhdistää tieteellinen kuvaus yleistajuiseen kaunokirjalliseen ja runolliseen tekstiin ylistettiin vuolaasti. Hän ei ollut tyytynyt luettelemaan tieteellisiä tosiasioita vaan on esittänyt ne "viehkeästi, paikoitellen runollisen lennokkaasti, mutta aina selvästi ja kiteytetyn kirkkaasti”. Teoksen kieli vakuutti myös Suomalaisen Kirjallisuuden Seuran, sillä matkakirja vaikutti Pubtaan maantieteen ja Suomen Kartaston 1925 ohella siihen, että seura myönsi vuosisatajuhlassaan maaliskuussa 1931 Granölle kirjallisuuspalkinnon. ${ }^{344}$

Olavi Granön mukaan Altai-kirjan vaikuttavuus johtui paitsi kirjoittajan kyvystä ymmärtää vuorimaan luonnon ja väestön läheinen vuorovaikutus myös hänen taidostaan kuvata luontoa tavalla, joka ottaa huomioon kaikki aistit. Kun lukija seuraa 
tutkimusmatkailijaa Altain metsiin ja jättiläisruohostoihin, laaksojen painanteisiin, jokivarsille, vuorten rinteille ja huipuille, hän saa samalla tuntuman siitä, miltä luonto näyttää, kuulostaa, tuoksuu, maistuu ja tuntuu, esimerkiksi silloin, kun voimakas virta uhkaa viedä vaeltajan mennessään kimpsuineen ja kampsuineen. ${ }^{345}$

Altai ilmestyi heti tuoreeltaan ruotsiksi 1919-21 J. E. Rosbergin suoraan käsikirjoituksesta kääntämänä. Suunnitellun venäjänkielisen painoksen julkaiseminen jäi sen sijaan vallankumouksen jalkoihin, ja kun vaikea taloudellinen tilanne maailmansodan jälkeen tyrehdytti suunnitelmat teoksen kääntämiseksi jollekin suurelle eurooppalaiselle kielelle, teos jäi kansainvälisesti lähes tuntemattomaksi.

Käännöshankkeet nousivat uudelleen esille vasta 2000-luvun vaihteessa, jolloin suunniteltiin sen kääntämistä venäjäksi ja englanniksi. Englanninkielisen laitoksen ilmestyminen lykkääntyi, mutta Alla Alieva sai 2010-luvun vaihteessa valmiiksi venäjänkielisen laitoksen käsikirjoituksen. Työ osoittautui hyvin hankalaksi Granön vaikeasti käännettävän elävän ja runollisen kielen vuoksi. ${ }^{346}$

Teos olisi avannut Granölle mahdollisuuden hankkia suuren osan toimeentulostaan matkakirjojen kirjoittajana, mutta saatuaan nimityksen Tarton yliopiston professoriksi hän päätti suunnata voimavaransa tieteellisen maantieteen kehittämiseen. Tämä merkitsi sitä, että vaikka päämäärä, omaleimaisten alueiden mahdollisimman tarkka rajaaminen ja kuvaaminen, säilyi ennallaan, menetelmä sen tekemiseksi muuttui täysin. Puhtaassa maantieteessä ympäristökokonaisuuksia ei muodostettu Altai-teoksen tapaan subjektiivisesti vaan tiukan loogisen ja järjestelmällisen analyysin avulla.

Granön luovuttua matkakirjojen julkaisemisesta Altai jäi vähitellen tutkimusmatkakirjallisuuden lähes unohdetuksi klassikoksi. Alan harrastajat toki tiesivät sen samoin kuin monet kirjailijat, joita sen luonnonkuvaus viehätti. Aaro Hellaakoski ja Reino Kalliola ovat kertoneet saaneensa vaikutteita teoksesta, ja Kerttu-Kaarina Suosalmi nimesi jopa romaaninsa Ihana on Altyn-köl (1988) vaikuttavasti kuvatun Kultajärven mukaan. ${ }^{37}$

Teos oli 1900-luvun lopulla jäämässä pääasiassa vain bibliofiilejä kiinnostavaksi rariteetiksi, kun se koki eräänlaisen kaksinkertaisen uudelleen tulemisen. Ensimmäi- 
sen sysäyksen aloitti Yleisradio, joka valitsi sen kesäkirjakseen 1991. Tuomas Anhavan taitavasti lukema teksti sai niin suuren suosion, että teosta ei saanut enää antikvariaateistakaan edes tiskin alta. ${ }^{348}$

Nopeasti virinnyt kiinnostus sai Suomalaisen Kirjallisuuden Seuran harkitsemaan teoksen ottamista ohjelmaansa, ja kun Repola-Yhtymä tarjosi rahallista tukea, uusi painos voitiin julkaista 1993. Uusintapainos oli yksiosainen mutta formaattia ja joitakin taittoratkaisuja lukuun ottamatta muuten entisen kaltainen. Uuden painotekniikan avulla mustavalkoiset valokuvat toistuivat jopa paremmin kuin alkuperäisessä teoksessa. ${ }^{349}$

Teos sai jälleen erinomaisen vastaanoton. Aamulehteen arvion kirjoittanut Erkka Lehtola piti paljon sekä teoksen kuvista että tekstistä. Hän toivoi saavansa kuvista suurennettuja kopioita seinilleen ja kehui vuolaasti Granön elävää, monipuolista ja humaania tekstiä. Arvostelu päättyi toteamukseen: "Kaikella muotoa: voitte tietysti jättää J. G. Granön kirjan lukematta, mutta omapahan on vahinkonne.”350

Uusintapainos lisäsi yleistä kiinnostusta Granön valokuvia kohtaan ja johdatti myös valokuvaaja Taneli Eskolan tutustumaan niihin. Saatuaan 1997 Aulanko-kuviin keskittyneen väitöskirjansa valmiiksi Eskola otti yhteyttä Granön poikaan akateemikko Olavi Granöön ja kyseli kuvista. Kun kävi ilmi, että huolella säilytetyt kuvat olivat hajallaan suvun hallussa, Eskola sai aikaan sen, että ne järjestettiin, konservoitiin ja dokumentoitiin huolellisesti Taideteollisessa korkeakoulussa. Valtavan urakan jälkeen suku luovutti maaliskuussa 1992 kuvat Suomalaisen Kirjallisuuden Seuran arkiston turvalliseen huomaan. ${ }^{351}$

Kysymyksessä oli laajin yhtenäinen suomalaisen tutkija-valokuvaajan Siperia-kokoelma. Siihen kuului noin 750 alkuperäisen nitraattinegatiivin, 350 lasinegatiivin ja yli tuhannen alkuperäisvedoksen lisäksi myös alkuperäisiä käsikirjoituksia, karttoja ja piirroksia.

Eskola myös kokosi kokoelman pohjalta J. G. Granön syntymän 120-vuotismuiston kunniaksi Helsingin kaupungin taidemuseoon Meilahteen näyttelyn Sininen Altai. Koko kevään 2002 ajan esillä oli parinsadan valokuvan lisäksi Granön vuosien 


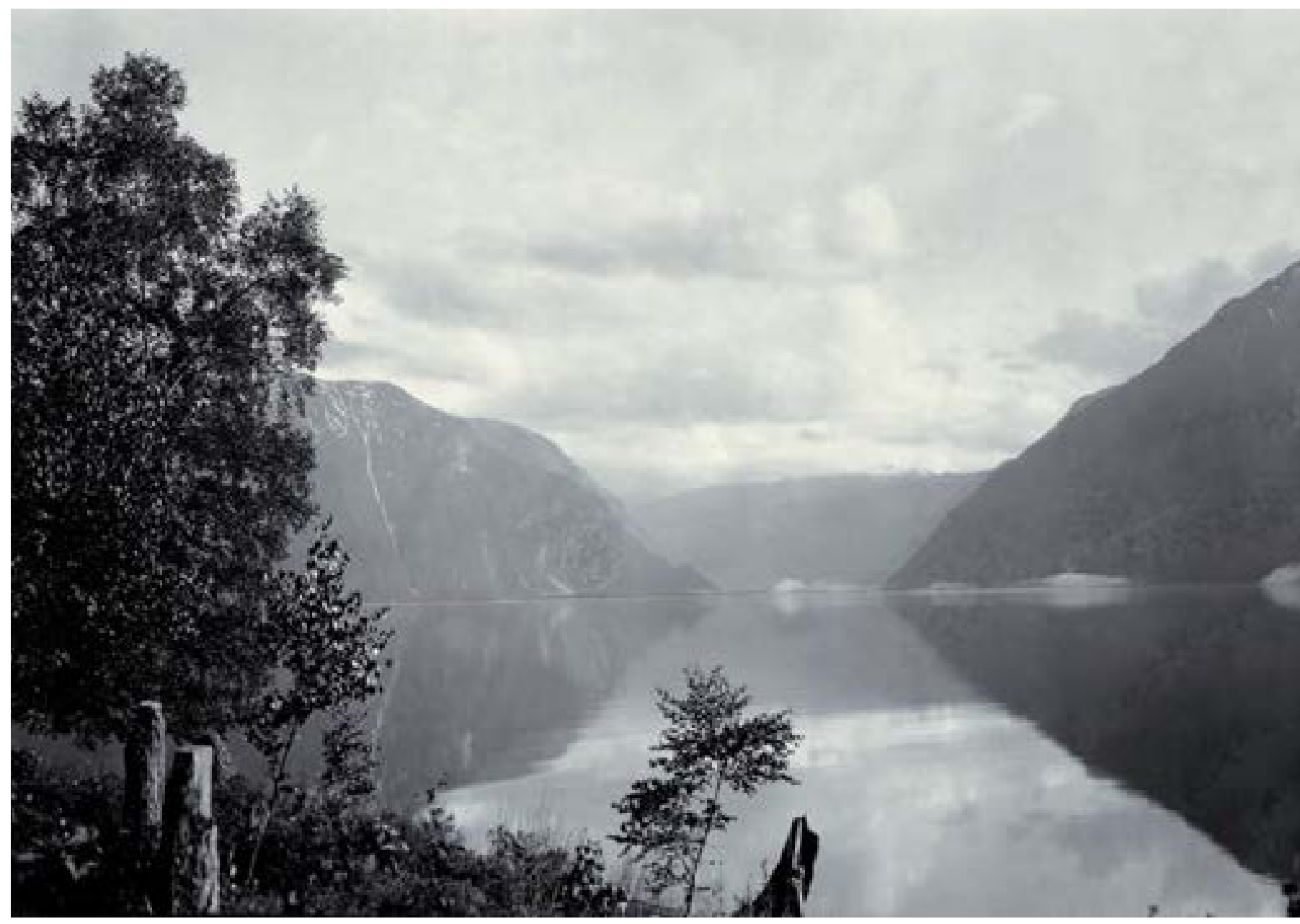

Altailaisten tarujen kultajärven Altyn-kölin eli Telétskojejärven huikeat maisemat jättivät Granön mieleen ikuisen kaipuun.

1902-16 matkoilla käyttämiä kameroita ja tieteellistä välineistöä sekä hänen kirjoittamiaan muistiinpanoja. Osa kuvista oli alkuperäisten negatiivien kokoisia, 9 x 12 tai 13 x 18 senttimetriä, mutta osasta oli tehty nykyajan menetelmin suurennoksia, sävytettyjä hopeagelatiinivedoksia ja digitaalisia mustesuihkutulostuksia. ${ }^{352}$ 
Näyttely ja siihen liittynyt merkittävä samanniminen teos osoittivat vakuuttavasti, että Granö oli paitsi tutkimusmatkailija ja tiedemies myös suomalaisen maisema- ja luonnonvalokuvauksen edelläkävijä. Kun suomalaiset maantieteilijät olivat pääosin arvostaneet Granötä vain geomorfologina, Puhtaan maantieteen kirjoittajana ja Suomen alueiden hahmottajana, tarvittiin alan ulkopuolinen henkilö osoittamaan, että hän ei ollut vain yhden suunnan mies. Eskolan mukaan Granö oli suomalaisessa valokuvataiteessa I. K. Inhan vertainen mestari. ${ }^{353}$

Eskolan nostettua Granön Siperiassa ja Mongoliassa ottamat valokuvat tasavertaiseen asemaan Altai-teoksen jo ennestään mestarilliseksi koetun tekstin rinnalle paljastui, että Granö oli kansallisesti ja kansainvälisesti huomattava valokuvauksen pioneeri sekä tieteen ja taiteen yhdistäjä. Tiukan logiikan mestarista kuoriutui esiin taiteellinen, luova, esteettinen ja emotionaalinen puoli. Jylhien vuorilaaksojen ja vuoristojen kuvien johdattaessa katsojia ikiaikaisten maisemien ihailuun omassa miljöössään ikuistetut ihmiskuvat kertovat ajasta, jolloin elämä oli ankaraa taistelua jokapäiväisestä leivästä.

Helsingin kaupungin taidemuseon jälkeen Granön kuvat olivat esillä muun muassa Pietarissa, Tartossa ja Turussa, mutta niiden menestys ei päättynyt tähän. Suomen TV-1 esitti vuoden 2005 alussa Rauli Virtasen toimittaman tutkimusmatkailijasarjan, jossa Granö esiintyi muiden suomalaisen tutkimusmatkailun uranuurtajien G. A. Wallinin, A. E. Nordenskiöldin, Martti Rautasen ja Rafael Karstenin kanssa. ${ }^{354}$

Taneli Eskola kokosi puolestaan syksyllä 2005 Minnesotan yliopiston Katherine E. Nash -galleriaan Minneapolikseen näyttelyn ja näyttelyjulkaisun Boundary Crossings - Rajanylityksiä, jossa Granön kuvat saivat rinnalleen hänen itsensä, Jorma Purasen ja Pentti Sammallahden kuvia Kalmukiasta, Lapista, Vienan Karjalasta, Burjatiasta ja Tuvasta. Näyttely oli eri muodoissa ja laajuudessa esillä muun muassa Seattlessa Yhdysvalloissa, Torontossa Kanadassa ja Suomessa Akseli Gallen-Kallelan museossa Espoon Tarvaspäässä, Laterna Magicassa Helsingissä ja Galleria Colmiossa Oulussa. ${ }^{355}$ 
Rajanylityksiä-teoksen ja -näyttelyn saama suosio Pohjois-Amerikassa vahvisti käsitystä siitä, että Granön kuvilla oli laajaa kansainvälistä merkitystä. Häntä verrattiin amerikkalaisen valokuvan mestareihin, Yhdysvaltain länsiosien ja Yosemiten kansallispuiston jylhistä kuvista tunnettuun Ansel Adamsiin ja kuuluisaan intiaanien kuvaajaan Edward S. Curtisiin. ${ }^{356}$

Eskolan näyttelyt ja teokset nostivat esiin kysymyksen, oliko Granö myös taiteilija. Hänen valokuvansa olivat kansainvälistä tasoa, mutta oliko hän ottanut ne tutkijana vai taiteilijana.

Granö oli itse uskonut valokuviensa merkitykseen niin paljon, että oli tallentanut ne huolella. Toisaalta valokuvaaminen liittyi niin saumattomasti hänen Siperian-vuosiinsa ja 1920-luvun alun Valosaaren lähimaisemien tutkimiseen, että myöhemmin hän ei enää tuonut itseään esiin valokuvaajana. Ehkä luontevinta on pitää häntä maiseman mestarina, jonka työskentelyssä taiteellinen näkemys limittyi saumattomasti tutkimuksellisiin tavoitteisiin. ${ }^{357}$ 


\section{VIRON \\ YLIOPISTOMAANTIETEEN PERUSTAJA \\ IV}

”Ja mikäpä hätä minulla täällä on? Minun vähäpätöisyyttäni tarvitaan nyt täällä.

Niin pian kuin joku oppilaistani tulee vähänkin kompetentiksi - siihen kuluu vielä joitakin vuosia - niin, - vasta sitten lähden, mutta silloinkin lähden varmasti, vaikkei olisikaan professuuria tarjona kotimaassa. Sillä silloin olisi täkäläinen tehtäväni, jota varten tänne tulin, suoritettu. Jos kuitenkin minut nyt kutsuttaisiin Suomeen, niin pitäisin velvollisuutenani ensi kädessä omaa maata palvella; ja olot täällä olisi väliaikaisesti järjestettävä sille perustalle, jota nyt on koetettu rakennella." ${ }^{358}$ 


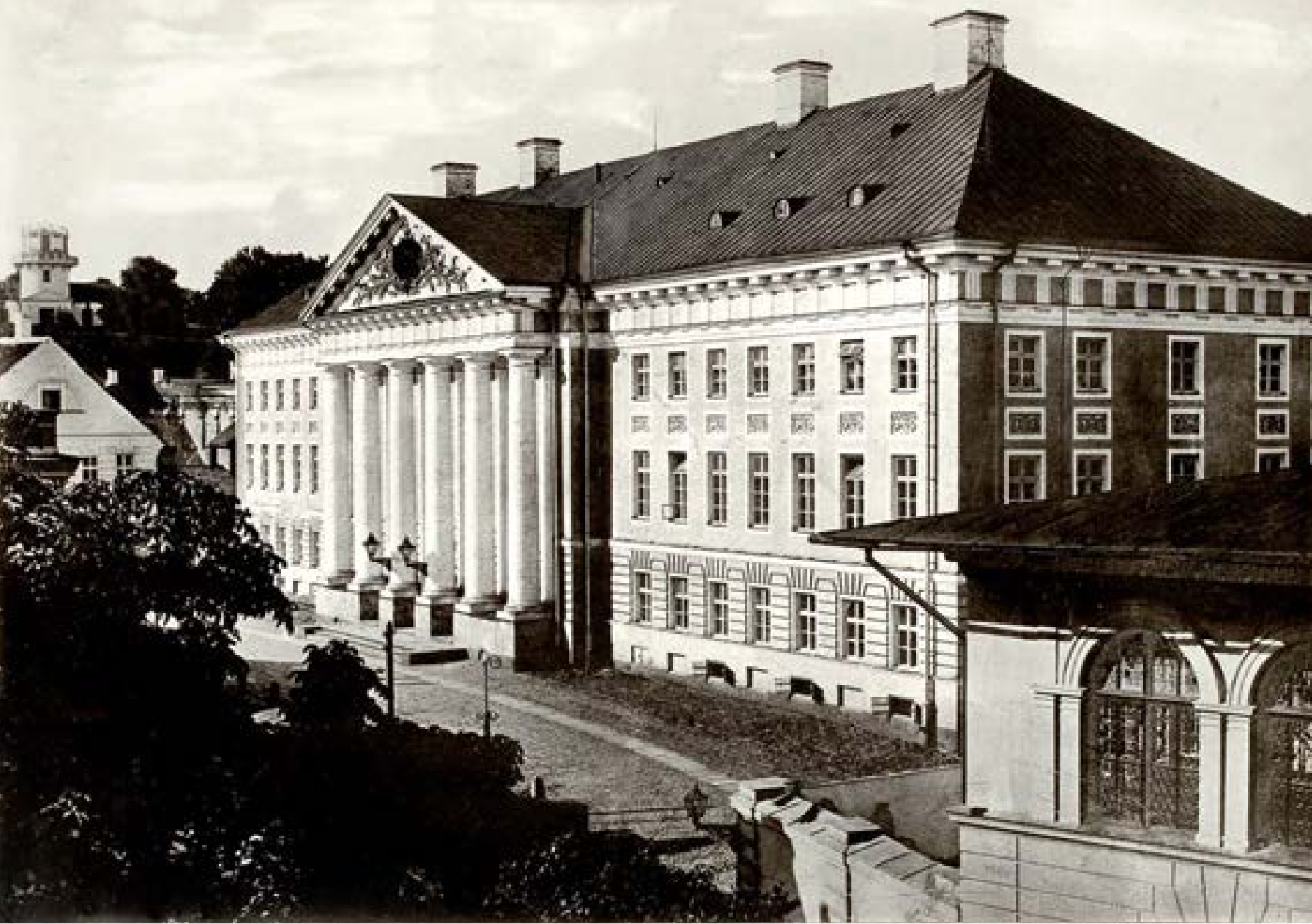

Johann Wilhelm Krausen suunnittelema Tarton yliopiston uusklassinen päärakennus valmistui lopullisesti 1809. 


\section{Asettuminen garttoon}

\section{Uskalias muutto}

Granön hyväksyessä Tarton yliopiston kutsun Viron vapaussodassa oli käynnissä pieni suvantovaihe. Syksyllä 1919 sotatoimet alkoivat kuitenkin uudelleen, kun Neuvosto-Venäjällä puhjennut sisällissota laajeni myös Viron alueelle. Bolševikkeja vastaan nousseiden valkoisten kenraalien johtoon kuulunut Nikolai Judenitš aloitti lokakuussa 1919 Virosta suurhyökkäyksen Pietarin valloittamiseksi. Lev Trotskin johtama puna-armeija torjui hyökkäyksen kaupungin edustalla ja aloitti puolestaan vastahyökkäyksen Narvajoen yli Viron alueelle. Virolaiset joukot kykenivät joulukuun lopulla vain vaivoin torjumaan hyökkäyksen yhdessä vapaussotansa ankarimmista taisteluista. ${ }^{359}$

Pohtiessaan Tarttoon siirtymistä Granö joutui ottamaan sotatilan lisäksi huomioon Viron huonon terveystilanteen. Espanjantaudin ohella Suomenlahden eteläpuolella uhkana olivat monet muut kulkutaudit, jotka olivat vaarallisia erityisesti lapsille. Tämän oli saanut traagisesti kokea Granön ystävä, Tarton yliopiston itämerensuomalaisten kielten professoriksi valittu Lauri Kettunen, jonka pieni poika kuoli punatautiin kaupungissa syyskuun alkupuolella. Granölle lähettämässään kirjeessä Kettunen kehotti tätä muuttamaan aluksi Tarttoon yksinään ja kutsumaan koko perheen paikalle vasta vuoden lopulla. ${ }^{360}$

Varmistaakseen perheensä turvallisen muuton Granö matkusti syyskuun puolivälissä Kettusen kanssa kaksistaan tutustumaan kaupungin oloihin ja tulevaan työ- 


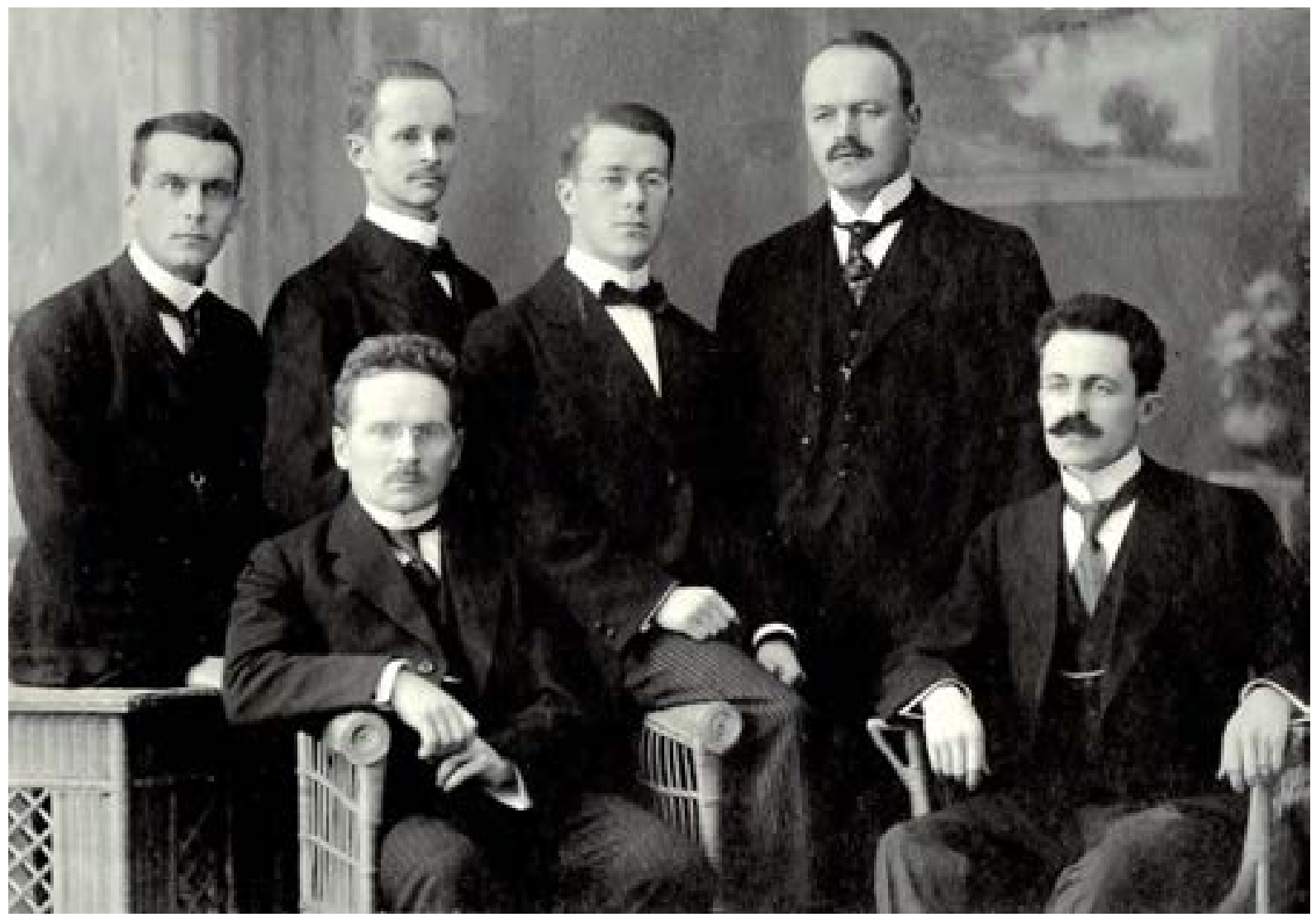

Tarton yliopiston ensimmäiset suomalaiset professorit marraskuussa 1920. Istumassa Lauri Kettunen ja J. G. Granö, seisomassa vasemmalta A. M. Tallgren, Kaarlo Teräsvuori, Kalle Väisälä ja A. R. Cederberg.

paikkaansa yliopiston maantieteen laitokseen. He asuivat Kettusen hankkimassa asunnossa ja ryhtyivät etsimään asuntoa myös Granölle. Sellaista ei heti löytynyt mutta Granö vakuuttui siitä, että hän saattoi tuoda perheensä kaupunkiin. Nopean muuton puolesta puhui se, että Tarton yliopiston lukukausi alkoi jo 6 . lokakuuta 1919. ${ }^{361}$ 
Granön ystävä kuvasi Tarttoon saapunutta Granötä näin:

Tuo ylen miellyttävä, kultivoitunut herra, joka Altai-tutkimuksillaan oli ehtinyt tiedemiehenä jo saada kansainvälistä mainetta ja josta tuli pian parhaita ystäviäni, oli itse vaatimattomuus, mutta vaati paljon itseltään ja teki varovaisesti myös kaikki kannattavuuslaskelmat etukäteen. Niinpä esim. totesimme, että kala on suhteellisen kallista, liha halpaa - siis täytyy syödä enemmän lihaa kuin kalaa. Vuokrat ovat ylen halvat, palkalla tultaisiin toimeen, jos vain, jos vain... luottamus työnantajaamme kohtaan... "ole varma siitä" (missä suhteessa hän myöhemmin reilusti tunnusti erehtyneensä). Tallustellessamme kaupungilla hänen kengänpohjansa rupesivat aukeamaan, mutta hänpä sen asunnossamme naputteli omin käsin kiinni. Kaikin puolin käytännöllinen mies, tuo jo sitten syksyllä maantieteen professoriksi kutsuttu, heti yleisön suosion saanut oppinut, ja ulkoasultaan aina tip top, kuten sisäiseltäkin rakenteeltaan... ${ }^{362}$

Palattuaan takaisin Helsinkiin Granö ryhtyi valmistelemaan puolisonsa kanssa perheen muuttoa Tarttoon. Pohjoisen Rautatiekadun koti tyhjennettiin; osa tavaroista vietiin varastoihin ja osa pakattiin mukaan Viroon. Suurin urakka oli kirjojen kuljettamisessa, sillä Granö päätti noudattaa vanhaa tarttolaista perinnettä, jonka mukaan professorin omat kirjat muodostivat laitoksen seminaarikirjaston ydinosan. ${ }^{363}$

\section{Lepiku 9}

Granöt saapuivat kolmen tyttärensä ja iäkkään Alma-muorin kanssa Tarttoon 14. lokakuuta 1919. Huoneistokysymys tuotti aluksi päänvaivaa, minkä vuoksi Granö jopa harkitsi ostavansa Kettusen kanssa kivitalon kaupungin keskustasta. Omskin talon kohtalo oli kuitenkin niin hyvässä muistissa, että hän päätti luopua omistusasunnon hankkimisesta ja vuokrata eräältä vanhalta leskirouvalta kalustetun huoneiston Lepiku 9:stä, lyhyen kävelymatkan päästä yliopistolta. ${ }^{364}$ 


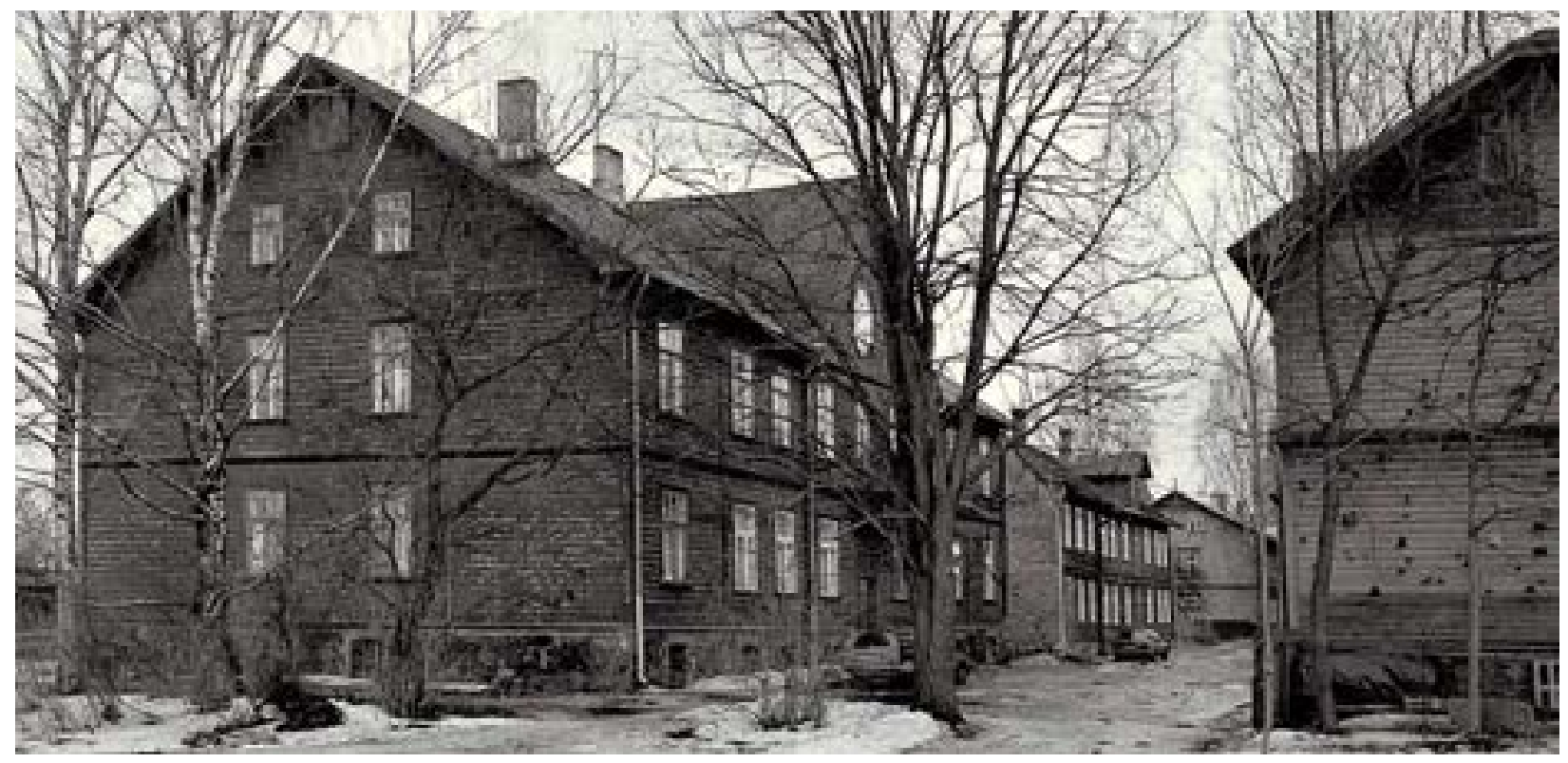

Granön perheen Tarton asuntona 1919-22 ollut Lepiku 9 kuvattuna 2000-luvun alussa.

Puurakennuksen toisessa kerroksessa sijainnut huoneisto ei tarjonnut juuri muita mukavuuksia kuin sähkövalon ja juoksevan veden. Kylpyhuonetta ei ollut, keittiö jaettiin vuokraemännän kanssa ja polttopuiden puutteen vuoksi Granöjen oli poltettava Pohjois-Saksan rantamaiden asukkaiden tavoin turpeita. Perheen jouduttua luopumaan monista Helsingissä käytössä olleista mukavuuksista Granön puoliso ja äiti toivoivat jo keväällä 1920 pikaista paluuta Suomeen. Tilanne vaikeutui vuoden lopulla, jolloin Eeva-tytär sairastui pelättyyn punatautiin. Huolellisella hoidolla ja "ennen kaikkea Jumalan avulla" lapsi onneksi parantui, ja sisarukset välttivät taudin. ${ }^{365}$

Vaikeuksista huolimatta Granö pyrki suhtautumaan tilanteeseen myönteisesti ja uskoi kärsivällisyyden kannattavan, koska "Siperia on opettanut". Sopeutumista uusiin oloihin auttoi Tarton tiivis suomalainen yhteisö, jonka kokouksiin ja juh- 


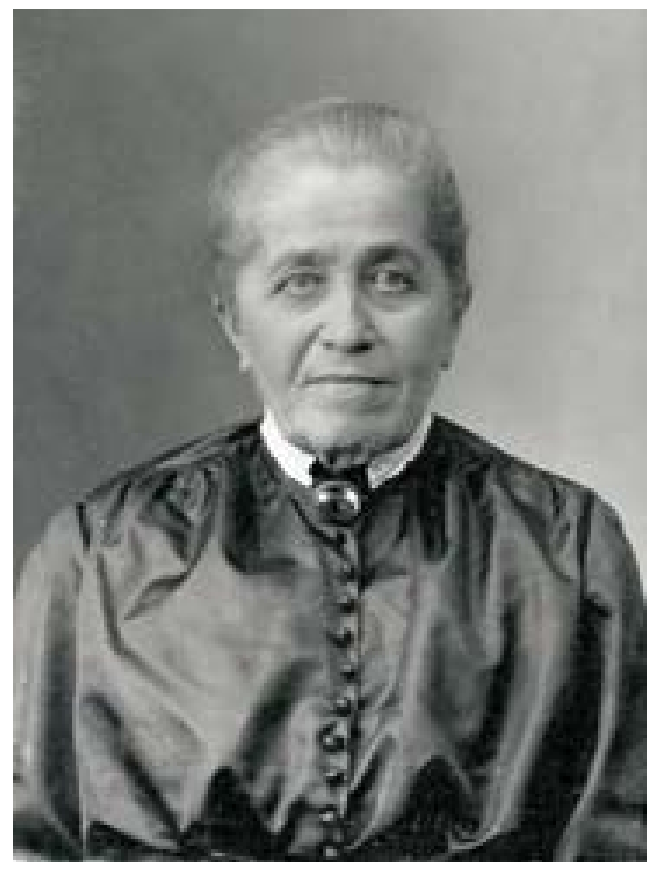

Mummu Alma Granö Tartossa 1921.

liin virolaiset, kuten Gustav Suits, Wilhelm Grünthal ja Friedebert Tuglas, osallistuivat mielellään. ${ }^{366}$

Myös Virossa Granöt hakeutuivat aina kesäisin maaseudun rauhaan. Kesäkuun 1920 alussa he matkustivat Tartosta vajaan peninkulman päässä olevaan Kabinan kartanoon Emäjoen varrella. Huoneisto oli iso mutta hyvin puutteellisesti kalustettu, joten perheen naisväelle riitti työtä huushollin hoidossa. ${ }^{367}$

Kesän 1921 Granöt viettivät noin 40 kilometriä Tartosta pohjoiseen Palamusen kunnassa Kaareperen aseman lähistöllä olevassa Luuan kartanossa, jossa heidän käytössään oli tilava ja välttävästi kalustettu kaksikerroksinen huvilarakennus. Rakennusta ympäröi suurenmoinen puisto, jossa oli toista sataa erilaista puu- ja pensaslajia. Lähistöllä oli pari lammikkoa, joissa lumpeet ja kurjenmiekat kukkivat, sekä kilometrin päässä, puiston ulkoreunalla, suurempi järvi, jossa saattoi käydä uimassa. Omien töidensä ohella Granö ohjasi alueelle maastotöihin saapuneita opiskelijoita: ”Istun täällä Palamusessa kuin hämähäkki keskellä tätä 'työverkkoa', ja tavan takaa pistäytyy luonani stipendiaatteja (oppilaitani) neuvottelemassa tai töitään selostamassa." ${ }^{368}$

\section{Maantieteen laitoksen perustaminen}

Tarton yliopisto oli noussut 1800-luvulla merkittäväksi tieteelliseksi keskukseksi, joka yhdisti idän ja lännen kulttuuripiirejä ja välitti saksalaisen tieteen ajatuksia Venäjälle. 


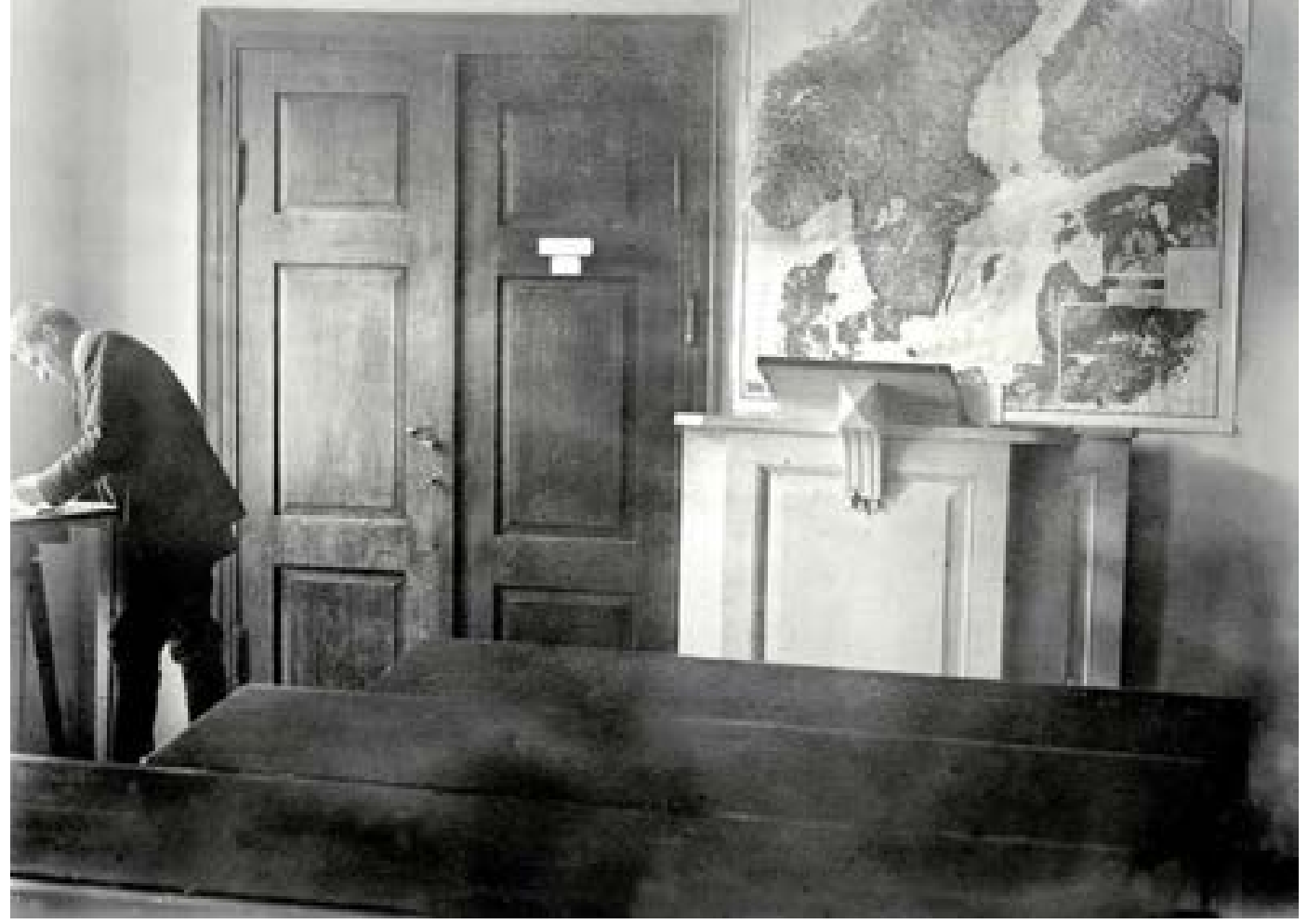

Tarton yliopiston maantieteen laitoksen luentosali 1919. Ikkunan luona piirtää sittemmin useassa maassa maantieteen professorina toiminut Konstantin Regel Liettuasta.

Tarttolaisen tutkimusmatkailijan Carl Friedrich von Ledebourin johtama retkikunta tutki Altaita 1826-27 ja kokosi muun tiedon ohella suuren määrän tieteelle aiemmin tuntemattomia kasvilajeja. Myös Pietarin tiedeakatemian toimesta järjestetty Alexander von Humboldtin käänteentekevä tutkimusmatka Aasiaan ja Keski-Siperiaan valmisteltiin Tartossa 1829, ja retkeen osallistui useita tarttolaisia tutkijoita. ${ }^{369}$

Granö oli hyvin tietoinen Tarton yliopiston kunniakkaista perinteistä. Ystävälleen J. K. V. Tuomiselle vuoden 1919 lopulla lähettämässään kirjeessä hän kuvaa tuntojaan uuden tehtävän edessä:

Muuten on myöntäminen, että kaupunkimme on varsin sovelias rauhallisen tieteellisen mietiskelyn tyyssijaksi. Kun astelen Emäjoen rannoilla tai Tuomio- 
mäen kauniissa puistossa, astuvat elävästi silmieni eteen Tartossa vaeltaneiden suurten tutkijain - v. Baerin, Ledebourin, Helmersenin y.m:den hahmot, - tutkijain, joiden kengännauhoihinkaan ei tämän professoripolven sopisi puuttua. "Miljöö” tarjoo siis toiminnalle erinäisiä edellytyksiä, ja muistot velvoittavat. ${ }^{370}$

Käytyään tutustumassa Tarton yliopistoon syyskuun puolivälissä Granö oli joutunut toteamaan, että hänen täytyisi aloittaa opetuksensa lähes tyhjästä. Yliopistossa ei ollut maantieteen laitosta varten muuta kuin tilat. Ülikoolikadun kivitalon toisessa kerroksessa oli kaksi isoa salia (luentosali sekä piirustus- ja seminaarikirjastosali) ja kaksi pienempää huonetta (esimiehen huone ja piirustussali), joissa oli hyvä valaistus ja tarvittavat pöydät, tuolit ja kirjahyllyt, mutta ei mitään muuta. ${ }^{371}$

Granö ei jäänyt surkuttelemaan tilannetta vaan käynnisti välittömästi laitoksen perustamistoimet assistenttinsa August Mielerin kanssa. Hän päätti aloittaa opetuksen omien kirjojensa, karttojensa ja erilaisten instrumenttiensa avulla. Kirjaston kokoamisessa häntä auttoi puoliso Hilma Granö, joka järjesti sen kortiston. Samaan aikaan Granö aloitti aktiivisen keräystoiminnan, joka tähtäsi laitoksen kirjaston muodostumiseen hankintojen ja lahjoitusten avulla. ${ }^{372}$

Maantieteen laitoksen oli tarkoitus aloittaa toimintansa vuoden 1920 alussa, mutta Granö järjesti jo lokakuussa 1919 ensimmäisen kartografian peruskurssin, johon osallistui muutamia opiskelijoita. Aiheen valintaan vaikutti paitsi kartografisen tiedon suuri tarve Virossa myös se, että hän oli oppinut alan perussanaston niin hyvin, että pystyi hoitamaan opetuksen viron kielellä. ${ }^{373}$

Opetuksen aloittamisen ohella Granö tutustui yliopistohallintoon ja lähimpiin kollegoihinsa. Hän piti "maailman eri kulmilta kokoon" haalittuja professorikollegoitaan "mukiinmenevinä miehinä", vaikka vierastikin "itsetietoista saksalaista klikkiä", jota vastaan suomalaiset ja virolaiset professorit joutuivat lujasti käymään tiedekunnan kokouksissa. Koska tiedekunnan 14 jäsenestä vain kuusi oli virolaista, keskustelut käytiin pääosin venäjäksi tai saksaksi. ${ }^{374}$ 


\section{Paavo Granön kohtalonvuodet}

Paavo Granön ryhtyessä 1913 jatkamaan isänsä työtä Siperian suomalaisten pappina olosuhteet olivat aivan toiset kuin neljännesvuosisata aiemmin. Jokaisessa kylässä oli kirkko ja koulutalo, ja seurakuntien ylläpitämissä kirjastoissa oli satoja kirjoja ja lehtiä. Diakonissat huolehtivat vanhuksista ja sairaanhoidosta. Pyhäkoulut, naistenpiirit, nuorisokuorot ja raamattupiirit toimivat viikoittain. Raittiusjuhlat olivat muuttuneet lähetysjuhliksi.

Tasaisen kehityksen kausi katkesi maailmanhistoriallisiin mullistuksiin. Ensin kesällä 1914 syttynyt maailmansota heikensi hengellisen työn edellytyksiä, ja sitten lokakuun vallankumouksen puhkeaminen 1917 katkaisi yhteydet Suomeen. Suomalaisten seurakuntien elämä jatkui kuitenkin lähes normaalina vuoden 1918 alkuun asti, jolloin Venäjän sisällissodan vaikutukset ulottuivat Omskiin saakka.

Siperian pääkaupungin vilja-aittojen hallinta kiinnosti niin bolševikkejä kuin vastavallankumouksellisia valkoisia. Kaupunki oli siirtynyt lokakuun vallankumouksessa bolševikkien hallintaan, minkä vuoksi se oli tärkeä myös Suomessa vallankumouksen tehneen kansanvaltuuskunnan elintarvikehuollon kannalta. Saadakseen nälänhädästä kärsineet suomalaiset puolelleen kansanvaltuuskunnan elintarvikeasioista vastannut Oskari Tokoi lähetti helmikuun 1918 lopulla kolme junaa Omskiin noutamaan Leninin Suomen punaisille lupaamaa 400 junavaunullista viljaa. Junat pääsivät perille, mutta matka takaisin läpi vallankumouksessa kuohuvan Venäjän ei onnistunut yhtä suotuisasti. Lopulta Suomeen palasi vain yksi juna, joka toi Helsingin Rautatieasemalle 32 junanvaunullista siperialaista vehnää.

Vallanvaihdoksen jälkeen Omskin seutu joutui erityisesti Suomesta ja Virosta tulleiden punasotilaiden mielivallan kohteeksi. Kotimaassaan tappion kärsineet punaiset panivat vahingon kiertämään Siperiassa. Vaikka suurimmat taistelut käytiin rautateiden varsilla, satunnaisia ryösteleviä joukkoja vieraili muun muas- 
sa Helsingin kylässä. Omskin pappilan otti joksikin aikaa hallintaansa Suomesta paennut punakaartilaispäällikkö Heikki Kaljunen, jonka komennossa Paavo Granö ja opettaja Paavo Juntunen joutuivat perheineen asettumaan pappilan ahtaaseen vierashuoneeseen. Terijoen punaisten ylipäällikkönä sisällissodan aikana useisiin teloituksiin syyllistynyt Kaljunen pohti myös Paavo Granön tappamista mutta luopui sitten tuumasta, kun hänen tuli niin "niitä pieniä kakaroita sääli".

Kaljusen mellastelu loppui loppuvuonna 1918, jolloin Venäjän valkoiset valloittivat kaupungin ja vangitsivat punaisten johtajat. Venäjän keisarillisen laivaston entinen amiraali Aleksandr Koltšak perusti Omskiin valkoisen hallituksen ja julisti kaupungin Venäjän pääkaupungiksi.

Länsivaltojen vedettyä joukkonsa pois Venäjältä valkoisten joukot joutuivat väistymään puna-armeijan tieltä, ja Omsk siirtyi suurten taistelujen jälkeen bolševikkien valtaan marraskuussa 1919. Pian sodan jälkeen kaupunki menetti merkittävän hallinnollisen asemansa, kun Novosibirsk nousi Länsi-Siperian pääkaupungiksi.

Murrosvuosien aikana Paavo Granö leimattiin pappina yhteiskunnalle hyödyttömäksi, minkä vuoksi hän ei voinut ostaa muita elintarvikkeita kuin ryynejä ja suolaa. Suurimman murheen aiheutti kuitenkin vaimo Elinin kuolema aivokalvontulehdukseen huhtikuussa 1919, minkä jälkeen hän jäi yksin kolmen pienen tytön kanssa. J. G. Granö sai Tarttoon tietoja veljensä perheen vaikeasta tilanteesta mutta ei voinut auttaa mitenkään. Sen sijaan hänen vanha matkatoverinsa, Bugenessa kauppiaana toiminut Kalle Vokk, kykeni ennen paluutaan Viroon järjestämään Paavolle jonkin verran elintarvikkeita.

Kun bolševikit olivat saaneet valtansa vakiinnutettua, he aloittivat järjestelmälliset toimet uskonnon tukahduttamiseksi. Kun viranhoito kävi mahdottomaksi, Paavo Granö ja muut suomalaiset päättivät palata Suomeen. He joutuivat sinnittelemään Siperiassa kesäkuuhun 1921, jolloin Suomen ja Neuvosto-Venäjän solmima Tarton rauhansopimus oli rauhoittanut maiden välisiä suhteita niin paljon, että kotimaahan paluuseen uskallettiin ryhtyä. 
Omskista härkävaunussa lähteneen noin 40 hengen pakolaisryhmän matka pysähtyi Moskovaan, jossa piti viettää neljä viikkoa ratapihalla eri maihin lähtöä odottavien pakolaisjunien keskellä. Kun lähdön hetki koitti, nuorin Paavon tytöistä oli kovassa tungoksessa vähällä joutua väärään junaan. Moskovasta Petrogradiin (Pietariin) edettiin viidessä päivässä, mutta ennen Suomeen pääsyä piti vielä viettää rajalla kaksi viikkoa karanteenissa. Pakolaiset pääsivät perille vasta elokuun lopussa 1921. ${ }^{375}$

\section{Muut tehtävät}

Granö keskittyi Tarton vuosina opetus-, tutkimus- ja kirjoitustöihin siinä määrin, että hän kieltäytyi johdonmukaisesti muista tehtävistä. Päätös oli niin ehdoton, että hän torjui jopa Suomen rauhanvaltuuskunnan puheenjohtajan J. K. Paasikiven kesällä 1920 esittämän pyynnön ottaa vastaan Suomen ja Venäjän välisten rauhanneuvottelujen asiantuntijan ja tulkin tehtävät, joihin hän olisi soveltunut hyvin hallitessaan kaikkia tarvittavia kieliä. Granö sai kuitenkin kutsun rauhanvaltuuskunnan Peeterburin hotellissa tarjoamille päivällisille, joiden aikana Paasikivi kiitti suomalaisia professoreita avusta neuvottelujen aikana. Suomen ja Neuvostoliiton välinen Tarton rauhansopimus allekirjoitettiin Eesti Üliópilaste Seltsin (Viron ylioppilasseuran) kansallisromanttisessa tiilirakennuksessa lokakuun 14. päivänä $1920 .^{376}$

Vaikka Granö torjui poliittiset ja valtiolliset toimeksiannot, tieteellistä asiantuntemusta vaativien kysymysten ratkaisemiseen hän oli valmis osallistumaan. Kun Viron ja Latvian väliset kiistat maiden välisen valtionrajan sijainnista olivat kiristyneet vuoden 1919 lopulla sotilaallisen yhteenoton partaalle, Granö antoi Viron ulkoministeriön pyynnöstä asiantuntija-apua rajan määrittelyyn liittyvissä kartografisissa töissä. Hän osallistui myös Tallinnassa 1921 pidettyyn ensimmäiseen Suomen, Viron ja Latvian konferenssiin, jossa käsiteltiin Itämeren tieteellisen tutkimuksen kysymyksiä. ${ }^{377}$ 
Granö selviytyi tehtävästä toimituskokemuksensa ja hyvän organisointikykynsä ansiosta. Kesäkuun 1921 alussa hän saattoi ilmoittaa yliopiston hallitukselle, että yliopiston sarjan Acta et Commentationes Universitatis Dorpatensis ensimmäinen vihko oli ilmestynyt. Toimitustyö oli vienyt niin suuren osan Granön ajasta, että hän ilmoitti lokakuun alussa joutuvansa luopumaan tehtävästä muiden työtehtävien vuoksi. Toimittajaehdokkaaksi tuli toinen suomalainen, arkeologian professori Aarne Michaël Tallgren, mutta Granö hoiti toimituskunnan pyynnöstä toimittajan velvollisuuksia marraskuun loppupuolelle saakka. Granön toimittajakauden aikana sarjasta ilmestyi kolme nidettä. ${ }^{379}$

Aikaa vei myös Granön toiminta vironkielisten kouluoppikirjojen tarkistajana sekä Suomessa ilmestyneiden tieteellisten artikkeleiden referoijana. Vuonna 1920 hänestä tuli Tarton Luonnontutkijoiden Seuran jäsen. Hän toimi seuran järvikomission varapuheenjohtajana ja oli perustamassa seuran ornitologijaostoa. ${ }^{380}$ 


\section{Garton YLIOPISTON PROFESSORI}

\section{Maantieteen identiteetti tieteenä}

Granö oli pohtinut maantieteen olemusta 1900-luvun alusta lähtien närkästyttyään J. A. Palménin maantieteen merkitystä vähättelevään näkemykseen. Hän oli seurannut tieteenalan kehitystä erityisesti sen johtavassa maassa Saksassa ja vakuuttunut sen merkityksestä. Siksi hän asetti Tarton yliopistossa ensimmäiseksi tehtäväkseen maantieteen arvostuksen nostamisen. Tämä oli välttämätöntä myös siksi, että 1900-luvun alussa oli yliopistomaailmassa käynnissä yleinen oppiainerakenteen vahvistumisvaihe, jossa eri aineet pyrkivät vakiinnuttamaan paikkansa tieteiden joukossa.

Tilannetta pahensi se, että Virossa maantieteen asema oli vielä heikompi kuin Suomessa. Vuonna 1881 perustetun Viron maantieteellisen seuran toiminta oli keskeytynyt jo vuosikymmenen lopulla saksalaisten tutkijoiden poistuttua maasta. Tarton yliopistossa maantiede ei ollut itsenäinen tieteenala, ja kouluissakin se oli vain alkeiskoulun ja lukion oppiaineena. Ryhtyessään vuoden 1919 lopulla laatimaan suunnitelmaa Tarton yliopiston maantieteen opetusta varten Granö päätti samalla perustella sekä professorikollegoilleen että Viron viranomaisille ja poliitikoille, miksi maantiede ansaitsi paikkansa yliopistossa. ${ }^{381}$

Tartossa vuoden 1920 alussa ilmestyneessä ohjelmajulistuksessaan Geograafia kui teadus ja ülikooli aine Granö kuvaa maantiedettä tieteenä ja yliopistollisena oppiaineena. Maantiedettä oli hänen mukaansa vanhastaan pidetty maapalloa selittävänä yleistieteenä, jonka tehtävänä oli ollut selventää maapallon kokoa, muotoa, karttakuvaa ja liikkeitä sekä kuvata luonnonilmiöitä, eri alueiden erityispiirteitä ja erilaisia kansoja. Luonnontieteiden nopean kehityksen ja erikoistumisen seurauksena vanha yleismaantiede oli 1800-luvun lopulla alkanut hajota, ja erityisesti Ferdinand von Richthofenin vaikutuksesta geomorfologia oli noussut maantieteen keskeiseksi osaksi. ${ }^{382}$ 
1900-luvun vaihteesta alkaen vanhan yleismaantieteen asema oli heikentynyt entisestään, kun useat tutkijat, kuten Alfred Hettner, Ewald Banse, E. Löffler, Paul Vidal de la Blache, L. S. Berg ja W. M. Davis, olivat alkaneet yhä äänekkäämmin kieltää sen arvon maanpallon ilmiöitä tutkivana yleisenä tieteenä. Heidän mielestään maantieteen olisi tullut keskittyä maanpinnan ilmiöiden jakautumisen ja vuorovaikutuksen, luonnon ja ihmisen suhteen sekä visuaalisen maiseman tutkimiseen. ${ }^{383}$

Maantieteen uusista suuntauksista Granö nosti esiin Saksassa 1900-luvun alussa kehitetyn maisematieteen, Landschaftkunden. Erityisesti Siegfried Passargen ja Otto Schlüterin johdolla kehittyneen suuntauksen edustajat katsoivat, että Alfred Hettnerin edustama levinneisyyksien vertailuun perustuva geodiversiteetin tutkimus ei luonut riittävää perustaa maantieteen omaleimaisuudelle. Heidän mukaansa Granönkin aiemmin harjoittamasta pinnanmuotojen analyyttis-geneettistä ja deduktiivisesta tarkastelusta oli siirryttävä maisemallisen kokonaisuuden induktiivis-empiiriseen selvittelyyn. ${ }^{384}$

Landschaft-suuntauksessa ei palattu Alexander von Humboldtin tieteellisiä faktoja sisältävään esteettiseen maisemakuvaukseen, vaan tavoitteena oli rajata, luokitella ja kuvata yksittäisiä maisema-alueita. Tämä suuntaus tulkitsi maiseman yhtenäiseksi aluekokonaisuudeksi, joka oli eri kriteerein erotettavissa muista alueista poikkeavien ominaisuuksiensa perusteella. Aluejakojen tavoitteena oli erityisesti suurten, fyysiseltä ulkoasultaan yhtenäisten aluekokonaisuuksien määrittäminen ja niiden erityispiirteiden selvittäminen. ${ }^{385}$

Maisematiede oli Granön mukaan vanhaa yleismaantiedettä vastannut tieteenala, joka otti huomioon maanpinnan muodot eli geomorfologian ja tiettyjä hydrologian sekä ilmastotieteen osia, tutki kasvistoa maisemallisena tekijänä, tarkasteli eläimistön ja ihmistoiminnan luontoon jättämiä näkyviä merkkejä sekä määritteli ja luokitteli erilaisia maisematyyppejä. Maisematieteen erikoisosana oli vanhaa aluemaantiedettä vastannut aluetiede, joka tutki yksittäisiä maisema-alueita. Kirjoituksensa lopuksi hän esitteli kaksi maisematutkimukseen ja aluetieteeseen perustuvaa opetussuunnitelmaa, joista toinen oli suppea muunnelma Tarton yliopistoa varten. ${ }^{386}$ 
Granön näkemys maantieteestä oli paitsi ennakkoluuloton myös omaleimainen. Hän oli saavuttanut Altain syntyä koskeneilla tutkimuksillaan korkean kansainvälisen tason, joten olisi ollut luontevaa, että hän asettanut geomorfologian maisemien sijaan maantieteen keskeiseksi tutkimuskohteeksi. Ratkaisun taustalla oli useita syitä.

Granö oli geomorfologisissa tutkimuksissaan päätynyt suvantovaiheeseen. Davisin eroosiosyklioppi ei enää tyydyttänyt häntä, mutta hän ei ollut vielä varma siitä, mihin suuntaan olisi tullut edetä. Uuden teorian kehittäminen olisi edellyttänyt Altain-matkoilta kertyneen aineiston perinpohjaista muokkaamista ja käsittelyä, mutta siihen ei nyt ollut aikaa.

Granö näki tärkeimmäksi tehtäväkseen luoda maantieteelle uuden oppirakennelman, joka takaisi sille kiistattoman paikan yliopistoaineiden joukossa. Hän suhtautui asiaan käytännöllisesti. Geomorfologiaa ei kannattanut valita maantieteen ydinalueeksi, koska se olisi johtanut väistämättä reviirikiistoihin geologien kanssa. Sen sijaan maantieteen tuli keskittyä täyttämään isänmaallista ja yhteiskunnallista tehtävää Viroa koskevan tiedon tuottajana ja tieteellistä tehtävää yleisenä alueellisen tiedon tuottajana, maisematieteenä. ${ }^{387}$

Tutkimusmatkavuosien aikana Immanuel Kantin korostama näkemys maantieteestä alueellisena tieteenä oli avautunut Granölle sekä teoreettisesti että käytännössä. Valmistautuessaan matkoille hän oli perehtynyt venäläisten tutkijoiden Siperian luonnonvyöhykkeitä koskeviin tutkimuksiin, minkä ansiosta hän oli tietoinen siitä, että tunnettu maantieteilijä ja suuri Alexander von Humboldtin ihailija L. S. Berg oli ottanut jo 1913 saksalaisen Landschaft-käsitteen tieteelliseen käyttöön osoittamaan luonnollisia alueita, joina oli Venäjällä vanhastaan pidetty kasvillisuusvyöhykkeitä. Kun Granö sitten liikkui laajalti maan eri osissa, hän saattoi havaita omin silmin, miten eri tekijöiden yhteisvaikutus tuli näkyviin nimenomaan maisemallisina ilmentyminä, kuten tundrana, havumetsä-taigana ja arona. ${ }^{388}$

Altai-teos oli tämän henkisen prosessin tieteellis-taiteellinen tulos, mutta Granö ymmärsi, että siinä sovellettu yksilöllinen kuvaustapa ei ollut siirrettävissä tieteeseen. Samoista aineksista oli luotava uusi oppirakennelma, joka vastasi tieteelle asettavia vaatimuksia. 
Altain tutkimukset olivat osoittaneet, että Granö ei tyytynyt soveltamaan muiden luomia teorioita vaan että hän toi tieteeseen uusia näkemyksiä. Lisäksi hän erosi monista muista tutkijoista siinä, että hän ei vain julkaissut teoreettisia oppirakennelmia vaan pyrki niiden soveltamiseen käytännön tutkimustyössä. Tämä ominaisuus johti siihen, että siirtyminen Viroon merkitsi täydellistä käännettä hänen tutkijantyössään. Tartossa Altain vuoriston pinnanmuotojen ja niiden synnyn tutkijasta kehittyi maisematieteen ja aluetieteen teoreetikko ja maisemien empiirinen kuvaaja. ${ }^{389}$

Vuoristotutkimukset olivat vaatineet Granöltä 10 vuoden työn ja tuhansien kilometrien vaellukset, nyt edessä oli urakka, joka oli henkisellä tasolla vähintään yhtä rankka. Työ alkoi Tartossa, jatkui Helsingissä ja sai lopullisen muotonsa Turussa, jossa ilmestyi 1920-luvun lopulla Granön teoreettinen päätyö Puhdas maantiede.

\section{Opetuksen tavoitteet}

Granö osasi Tarttoon tullessaan täydellisesti neljää kieltä: suomea, ruotsia, saksaa ja venäjä, joten hänellä oli vaihtoehtoja luentokielen valinnassa. Hän päätti kuitenkin luennoida viroksi, minkä vuoksi hän oli aloittanut kieliopinnot jo Helsingissä. Hyvän kielipäänsä ja intensiivisen opetuksen ansiosta hän oppi maantieteen ammattisanaston ja koko kielen niin nopeasti, että saattoi vuoden 1920 alussa ryhtyä luennoimaan ja julkaisemaan sanomalehtiartikkeleita viroksi.

Granö oli ystäviensä kielitieteilijä Lauri Kettusen ja matemaatikko Kalle Väisälän ohella ensimmäinen professori, joka opetti Tarton yliopistossa virolaisia heidän omalla äidinkielellään. Väisälän mukaan suomalaiset olivat kansalliskiihkoisempia virolaisia kuin virolaiset itse. ${ }^{390}$

Opetuskielen valinnassa oli kysymys periaatteesta. Granö oli tiedemiehenä monta kieltä hallinnut kosmopoliitti, joka vaihtoi julkaisukieltä aina kulloisenkin tilanteen vaatimusten mukaan. Hän ymmärsi kuitenkin hyvin pienten kansojen ja kieliryhmien ongelmat. Ikäviä kokemuksia paikallisen väestön valtakielten sortamisesta oli kertynyt niin Siperiasta kuin ruotsin kielen hallitsemasta Helsingin yliopistosta. 
Viron nuoriso oli joutunut odottamaan lähes 300 vuotta saadakseen korkeinta opetusta äidinkielellään, joten enää ei ollut aikaa hukattavaksi. ${ }^{391}$

\section{Tieteen kaksi kieltä}

Granön mielestä vanhaa hyvää periaatetta, ajattele maailmanlaajuisesti, toimi paikallisesti, tuli soveltaa myös tieteessä. Koska tiede oli perusluonteeltaan kansainvälistä, tutkijan tuli suuntautua sellaisiin tutkimusongelmiin ja -tehtäviin, joilla oli yleistä merkitystä. Tämän vuoksi hän hakeutui systemaattisesti yhteyksiin kansainvälisten huippututkijoiden kanssa lähettämällä heille julkaisujaan ja oli säännöllisessä kirjeenvaihdossa useiden kymmenien ulkomaisten tutkijoiden kanssa.

Tieteen tulosten levittämiseen tuli käyttää ensi sijassa suuria kieliä, mutta tieteellisen koulutuksen oli sen sijaan tapahduttava opiskelijan äidinkielellä kansallisissa yliopistoissa. Opetus oli järjestettävä siten, että samalla kun uudet tutkijasukupolvet oppivat ymmärtämään, että tiede oli kansainvälistä, he myös oivalsivat oman isänmaansa ja kielensä merkityksen.

Granön näkemyksen taustalla oli usko siihen, että kieli oli eräänlainen henkinen isänmaa. Ihminen saattoi saavuttaa korkeimman tieteellisen ja taiteellisen tason omalla äidinkielellään, joka tarjosi täsmällisimmän ja ilmaisuvoimaisimman sanaston paikallisten olojen ja kulttuurien kuvaamiseen. Tämä näkemys johti siihen, että täydellisestä kielen hallinnasta huolimatta hän yleensä pyrki kustannuksista piittaamatta käännättämään myös saksankieliset työnsä.. 392 
Virossa kielen merkitys oli erityisen suuri. Maa oli aina ollut pieni osa jotakin suurta naapurimaata, minkä vuoksi sen tiedettä olivat edustaneet ja harjoittaneet hallitsevien vähemmistöjen edustajat, ruotsalaiset, saksalaiset ja venäläiset. Itsenäistymisen jälkeen virolaiset pyrkivät nopeasti ottamaan oman kielen käyttöön, mutta siinä kohdattiin ongelmia, sillä monella alalla työ oli aloitettava lähes perusteista ja kielen kehittäjiä oli vähän. Granö myönsi ongelmat mutta uskalsi silti jo kesäkuussa 1920 toivoa, että "olosuhteet vähitellen kehittyvät siihen suuntaan, että vironkieli saa yksin määräävän aseman”. ${ }^{393}$

Granön hyvä kielitaito ei tullut näkyviin vain luentojen pitämisenä, vaan hän ryhtyi kehittämään perustaa myös maan omakieliselle terminologialle. Viron Kirjallisuuden Seura oli julkaissut 1911 maantieteellisten termien vironkielisen sanaston, mutta se oli monelta osin puutteellinen ja vanhentunut. Kun Granö tajusi terminologian niukkuuden, hän ryhtyi 1920 johtamaan myös maantieteen ammattisanaston komissiota.

Seuraavan vuoden loppuun mennessä komissio ehti tarkistaa lähes 2200 maantieteen, astronomian, meteorologian, geologian ja muiden lähitieteiden sanaa. Granön kehittämät tai täsmentämät vironkieliset käsitteet - kuten lähi- ja kaugkeskkond (lähi- ja kaukoympäristö), lähestik ja maastik (lähiö ja maisema), geograafiline indiviid (maantieteellinen yksilö) - vakiintuivat nopeasti yleiseen käyttöön. ${ }^{394}$

Terminologian uudistaminen liittyi Granön tavoitteeseen kytkeä virolainen maantiede alan kansainvälisen kehityksen yhteyteen. Hänen yliopistoon tuomansa kirjasto sisälsi paljon muun muassa saksan-, ranskan ja englanninkielisiä teoksia, ja hän solmi välittömästi useita julkaisunvaihtosopimuksia Tarton yliopiston ja eri puolilla maailman olevien yliopistojen ja tutkimuslaitosten kanssa. Näkemys laajan kielitaidon tuomista eduista ja välttämättömyydestä välittyi hänen oppilailleen, joista Edgar Kant osoittautui kielellisesti erityisen lahjakkaaksi. ${ }^{395}$

Suomen Maantieteellisen Seuran isänmaallisten tavoitteiden kannattajana Granö tiedosti hyvin, että maantieteellä oli Virossa tieteellisen tehtävän lisäksi myös tärkeä yhteiskunnallinen ja kansallinen rooli. Viron kielen aseman parantamisen ohella 
Granön toisena päätavoitteena oli opettaa virolaiset tuntemaan oman maansa kotiseudulta valtion rajoille saakka. Tietoa Virosta alueellisena kokonaisuutena ja sen eri osista tarvittiin kipeästi, sillä virolaiset tunsivat huonosti toisensa ja oman maansa. Kun Suomi oli ollut Lappia lukuun ottamatta selvärajaisena autonomisena alueena yli sata vuotta ennen itsenäistymistä, virolaisten asuinalue oli ollut vuoteen 1917 saakka jaettuna kahden Baltian (Estland ja Livland) ja kahden Venäjän (Pietarin ja Pihkovan) kuvernementin välillä. ${ }^{396}$

Nyt Tarton yliopiston oli osoitettava omalle kansalle ja maailmalle, minkälainen maa uusi itsenäinen Viro oli. Tämä työ oli kansallisesti tärkeä paitsi alueellisen identiteetin synnyn myös hallinnon ja elpyvän talouselämän kannalta. Maantieteellistä tietoa tarvittiin alueiden kehittämiseen ja aluehallinnon muodostamiseen. Poliitikot, virkamiehet ja liike-elämän edustajat oli saatava tukemaan työtä, ja siihen oli kytkettävä mukaan kaikki kotiseuduntutkimusta harjoittavat tahot ja eri yliopistoaineet, erityisesti maisemaympäristöä integroivasti tutkiva maantiede, henkistä miljöötä tutkiva sosiologia ja ympäristön ajallista muutosta käsittelevä historia. ${ }^{397}$

Suurten tehtävien määrittelyn ohessa Granö oli miettinyt tarkoin oman tehtävänsä luonteen. Hän koki itsensä vain alkusysäyksen antajaksi, suunnittelijaksi ja kouluttajaksi. Hän katsoi, että vaikka virolaiset eivät asiasta puhuneet, heidän luonnollisena pyrkimyksenään oli miehittää professuurit omilla maanmiehillään mahdollisimman nopeasti. Siksi hänen tavoitteenaan oli perustaa maantieteen laitos, käynnistää sen toiminta, määritellä työn tavoitteet, kouluttaa työlleen jatkajia ja palata sitten takaisin Suomeen: "On siis laitettava laitos kuntoon, on kasvatettava oppilaita ja sitten, kun sydän ehkä on toimintaan siellä kiintynyt, lähdettävä, - mihin, sen tietää yksin Herra taivaassa..." ${ }^{398}$

\section{Käytännön opetustyö}

Granön aktiiviset toimet johtivat siihen, että Tarton yliopiston maantieteen laitoksen toiminta käynnistyi ja laajentui nopeasti. Laitoksen kirjaston kokoelmat alkoivat 
kasvaa hankintojen ja lahjoitusten avulla, ja Granö sai aikaan sen, että yliopiston tieteellisen kirjaston karttakokoelma sijoitettiin laitoksen suojiin.

Laitoksen toimintaedellytykset paranivat huomattavasti syksyllä 1920, jolloin se pääsi muuttamaan uusiin tiloihin Aiakatu 46:een eli nykyiseen Vanemuise 46:een. Vuoden 1923 lopulla laitoksella oli jo lähes 1600 kirjaa, yli 740 vuosikertaa tieteellisiä julkaisuja, yli 1650 karttaa ja kartastoa, noin 650 diapositiivia ja valokuvaa ja käyttövaroja yli kymmenen kertaa enemmän kuin $1920 .{ }^{399}$

Suunnitellessaan maantieteen laitoksen toimintaa Granö tukeutui jo varhain omaksumaansa humboldtilaiseen tiedenäkemykseen, joka korosti omakohtaiseen tutkimukseen perustuvan opetuksen merkitystä. Hän katsoi, että tutkimuksen ja opetuksen tiivis nivoutuminen toisiinsa auttoi opiskelijoita omaksumaan parhaiten tieteenalan sisällön, mutta että se tarjosi samalla myös mahdollisuuden tutkimuksen uudistumiseen ja lisäarvon tuottamiseen yhteiskunnalle. Tarton yliopiston maantieteen laitoksella hän sai tilaisuuden kokeilla näkemystään käytännössä, sillä yliopisto pyrki yli 20 vuotta kestäneen venäläistämisajan jälkeen palauttamaan vanhan korkean tasonsa, joka oli perustunut juuri vahvoihin humboldtilaisiin vaikutteisiin. ${ }^{400}$

Granö katsoi, että maantiede oli niin laaja oppiaine, että yksi opettaja ei voinut pitää kaikkia vaadittavia luentoja. Siksi hän keskittyi johtamaan vain keskeisimmät kurssit ja ohjasi oppilaitaan kuuntelemaan lähitieteiden opettajia. Tästä huolimatta hänelle lankesi melko suuri opetustaakka - lukukaudesta riippuen 13-17 viikkotuntia. Kevätlukukaudella 1920 hän piti edellissyksyn tapaan kartografian peruskurssin mutta johti myös maisematieteen peruskurssin. Syyslukukaudella hän hoiti seminaaritöiden lisäksi maisematieteen perusteiden jatkokurssin. ${ }^{401}$

Kevätlukukaudella 1921 Granön opetustahti oli edelleen tiukka, sillä muiden opetustöiden ohella hän luennoi yleisestä maantieteestä ja Fennoskandian maantieteestä. Syyslukukaudella ohjelma oli muuten sama, mutta Fennoskandian maantieteen luennot olivat vaihtuneet ihmismaantieteen luentoihin. Viimeisenä opetuslukukautenaan keväällä 1922 Granö luennoi yleis- ja ihmismaantieteen jatkokurssit. ${ }^{402}$ 
Maantieteen opetusta täydensivät seminaarit, jotka Granö otti syyslukukaudella 1920 ensimmäisenä käyttöön Tarton yliopiston matemaattis-luonnontieteellisessä tiedekunnassa. Seminaareissa opiskelijat saivat tietoa maantieteen eri puolista, sen historiasta ja metodologiasta. Heidän oli myös opiskeltava kartografiaa ja osallistuttava harjoitustöihin, joiden aikana opittiin tuntemaan kompassi, mittakaava, arvionvarainen mittaustapa ja erilaisia maastotöissä tarvittavia instrumentteja. Hänen tavoitteenaan oli opetusmetodi, jossa luonnon-, ihmis- ja aluemaantieteellinen teoreettinen opetus yhdistyi luontevasti käytännön töihin. ${ }^{403}$

\section{Etevät oppilaat}

Maantiede oli Tarton yliopistossa uusi tiede, joten oppilaiden määrässä Granö ei kyennyt kilpailemaan useimpien professorikollegojensa kanssa. Hänen aikanaan vain yhdeksän ylioppilasta ryhtyi opiskelemaan maantiedettä pääaineenaan, mutta luennoille ja harjoitustöihin osallistui runsaasti eri luonnontieteiden opiskelijoita. Esimerkiksi 1921 Granön luentoja kuunteli 45 opiskelijaa. Luku oli korkea, sillä tuona vuonna koko luonnontieteellisen tiedekunnan oppilasmäärä oli vajaat sata. ${ }^{404}$

Granö oli hyvä opettaja, joka kykeni paitsi välittämään opiskelijoille laajaa tietämystään myös näyttämään esimerkillään tutkimustyön mallia. Uusi opetusmetodi herätti opiskelijoissa innostusta ja arvostusta, joka jätti esimerkiksi August Tammekanniin pysyvän muiston:

Oli onni kuulua hänen tarttolaisiin oppilaisiinsa ja olen myöhemmin suorastaan ihmetellyt sitä melkein yli-inhimilliseltä tuntuvaa tarmoa, sitkeyttä ja uhrautuvaisuutta, jolla Granö omistautui tähän ylivoimaiselta tuntuvaan tehtävään; hän loi tyhjästä uuden maantieteellisen laitoksen ja järjesti sen opetustoiminnan. ${ }^{405}$ 
Granön oppilaissa laatu korvasi runsain mitoin määrän. Hänen kolme merkittävintä oppilastaan olivat Jaan Rumma (1887-1926), August Tammekann (18941959) ja Edgar Kant (1902-78), jotka kaikki saavuttivat paikan Viron maantieteen historiassa. Granö itse arvosti oppilaistaan aluksi eniten Rummaa, josta hän toivoi seuraajaansa. Rumma teki vuodesta 1920 alkaen suuren työn Viron maakuntien maantieteelliseksi, taloudelliseksi ja historialliseksi kuvaamiseksi, kunnes hän yllättäen kuoli alle 40 vuoden ikäisenä. ${ }^{406}$

Tammekann oli Granön virolaisista oppilaista ehkä kaikkein uskollisin opettajalleen. Granön palattua Suomeen Tammekann seurasi häntä pian stipendiaattina Helsingin yliopistoon. Hän valmistui filosofian kandidaatiksi, 1926 lisensiaatiksi ja väitteli 1932 tohtoriksi saksankielisellä tutkimuksella Die Oberflächengestaltung des nordostestländischen Küstentafellandes, jonka aiheena oli Koillis-Viron rannikon geomorfologia. Ajan

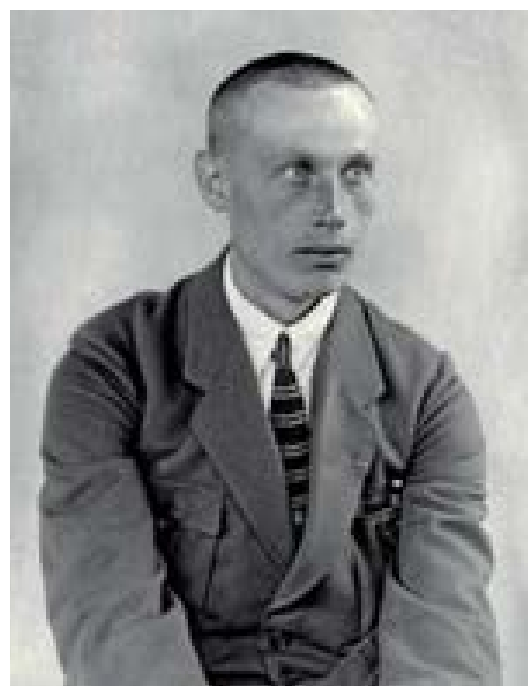

Granön virolaisista oppilaista August Tammekann seurasi opettajaansa Suomeen, väitteli Helsingissä 1924 ja siirtyi professoriksi Tarttoon. Hän toimi myöhemmin Helsingin yliopiston maantieteen professorina 1950-59. Kuva on vuodelta 1923.

tapaan Granö toimi väitöstilaisuudessa vastaväittelijänä vaikka oli toiminut myös työn ohjaajana. ${ }^{407}$

Tammekann nimitettiin Tarton yliopiston maantieteen ylimääräiseksi professoriksi 1930 ja varsinaiseksi professoriksi 1934. Hän oli matemaattisesti ja kartografisesti lahjakas ja laati 1930-luvulla muun muassa 1:300 000 seinäkartan Virosta sekä teemakarttoja maanpinnan muodoista ja väestöstä käyttäen hyväksi ilmakuvia. Maisematutkimuksissaan hän paneutui Granön tapaan erityisesti luonnon- ja kulttuurimaisemaan, mutta opettajastaan poiketen hän tarkasteli laajasti myös maisemien syntyä. Hän jakoi Viron maisemat neljään tyyppiin ja erotti toisistaan Ylänkö- ja Alanko-Viron. Neuvostoliiton valloitettua Viron Tammekann siirtyi heinäkuussa 1940 Suomeen suomalaisen puolisonsa ja kahden lapsensa kanssa. ${ }^{408}$ 


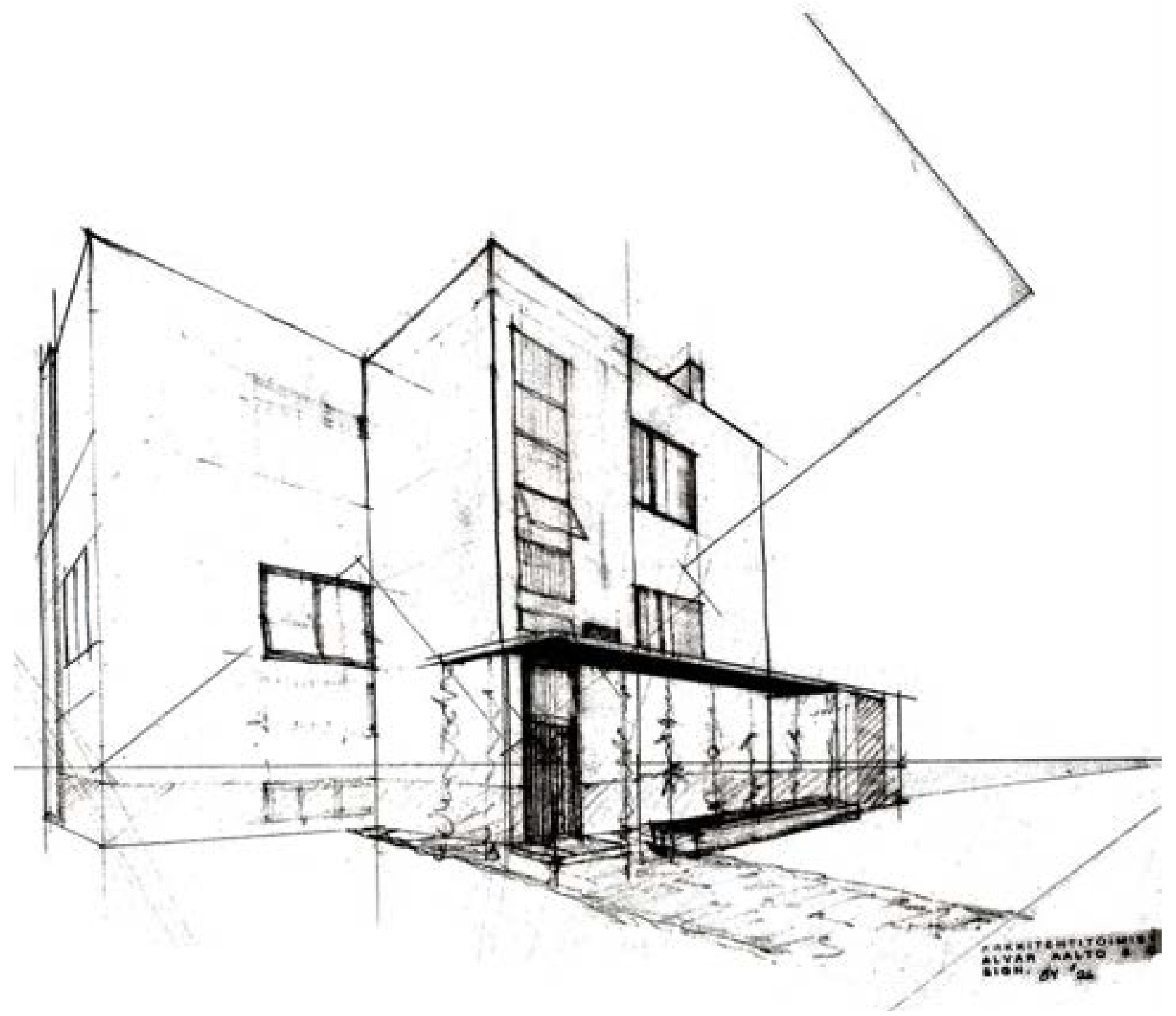

Yllä ja seuraavalla aukeamalla: Alvar Aallon suunnitelmapiirroksia Villa Tammekannia varten. 


\section{Villa Tammekann}

August Tammekannin ja Granön läheistä yhteyttä kuvastaa nykyisin parhaiten Turun yliopiston ja Tarton yliopiston yhdessä vuonna 2000 avaama Granö-keskus, joka sijoitettiin Villa Tammekanniin Tähtveren puutarhakaupunginosaan Tartossa. Ainoan Aallon Viroon suunnitteleman talon historia alkoi siitä, kun arkkitehti Alvar Aalto ja Tammekann sattumalta tapasivat toisensa keväällä 1932 J. G. Granön kotona Turussa. Kun Aalto kertoi, että hän oli ollut Paimion parantolan valmistumisen jälkeen vailla työtehtäviä, Tammekann totesi, että hänellä oli Tartossa tontti, mutta ei taloa eikä arkkitehtiä. Pian jo lyötiin kättä päälle työsopimuksen sinetiksi.

Aallon nopeasti suunnitteleman Villa Tammekannin rakennustyöt käynnistyivät heti kesällä 1932. Viroon pian levinnyt lamakausi ja vaikeudet tavarantoimituksissa hankaloittivat rakentamista eikä sitä ehditty saattaa loppuun Aallon suunnitelmien mukaisesti ennen kuin Tammekannit muuttivat keskeneräiseen rakennukseen 1933. Perheen paettua neuvostomiehittäjiä Suomeen kesällä 1940 talo jäi aluksi tyhjilleen. Toisen maailmansodan jälkeen rakennus kansallistettiin ja muutettiin neuvostojärjestelmälle tyypillisesti pienkerrostaloksi, jossa asui enimmillään 6-8 taloutta.

Neuvostoliiton romahduksen ja Viron uudelleen itsenäistymisen jälkeen Turun Yliopistosäätiö osti rakennuksen Tammekannin lapsilta 1998, ja se korjattiin vastaamaan mahdollisimman tarkasti Alvar Aallon alkuperäistä suunnitelmaa. Granökeskusta käytetään Turun yliopiston ja Tarton yliopiston yhteistyöhön liittyviin virka-, tutkimus- ja opetustarkoituksiin. Granö-keskus on vuodesta 2000 järjestänyt suomalaisten tutkijoiden Tarton yliopistossa pitämiä Granö-luentoja. ${ }^{409}$ 

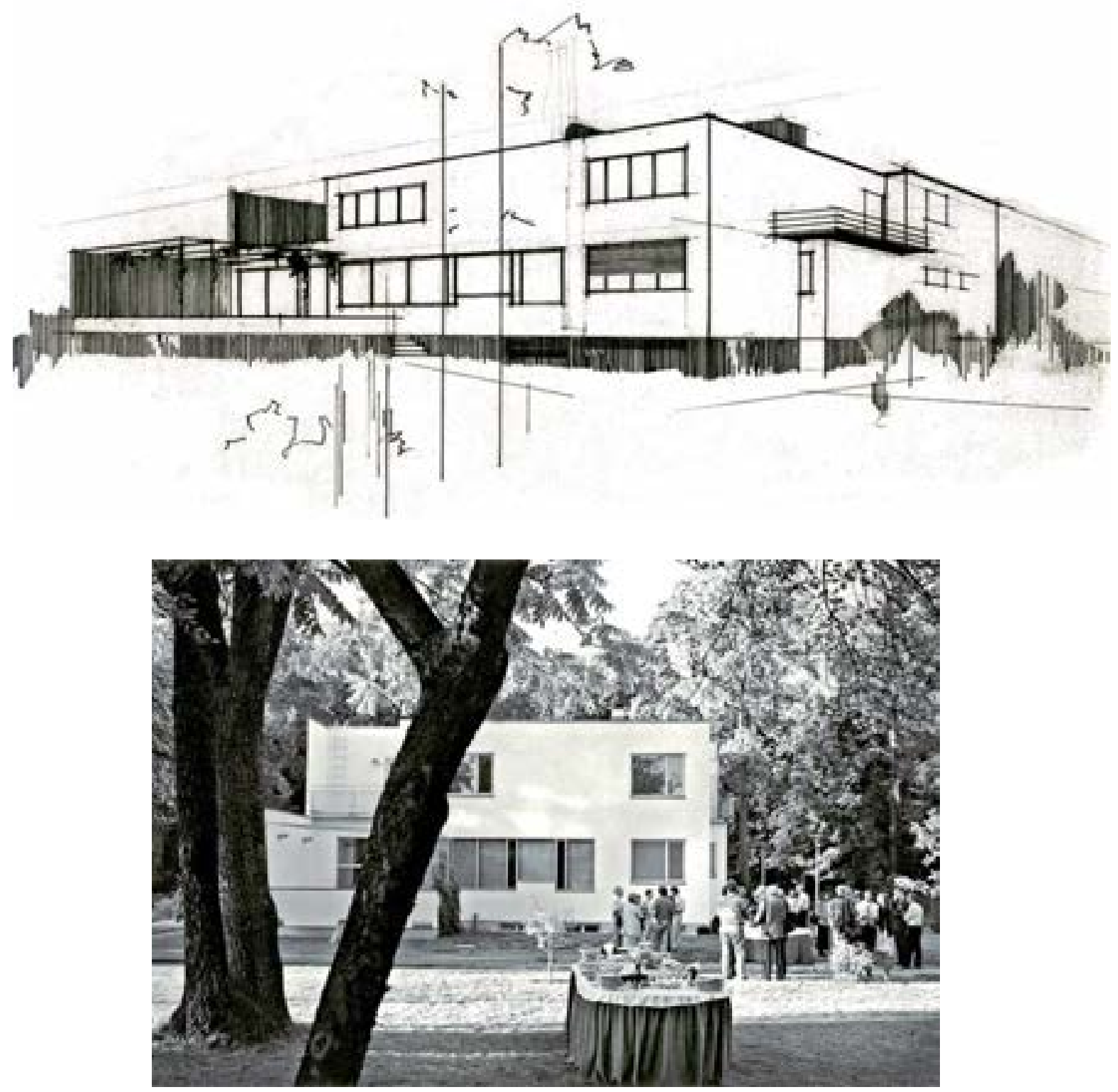

Granö-keskuksessa järjestettiin elokuussa 2002 kansainvälinen konferenssi

J. G. Granön 120-vuotissyntymän ja Edgar Kantin 100-vuotissyntymän kunniaksi.

222 V Viron yliopistomantieteen perustaja 
Granön virolaisista oppilaista komeimman uran teki Edgar Kant, joka aloitti maantieteen opinnot syksyllä 1921. Hän oli patrioottinen opiskelija, joka oli osallistunut lukiolaisena Viron vapaussotaan Neuvosto-Venäjää vastaan 1918-19. Hän koki läheiseksi opettajansa näkemyksen maantieteen tehtävästä tehdä Viroa tunnetuksi ja menestyi opinnoissaan erinomaisesti. Kielellisesti etevänä hän avusti Granötä virolaisen maantieteellisen sanaston kokoamisessa, mistä hän saattoi saada virikkeen koko loppuelämän ajan kestäneelle kiinnostukselle terminologisia kysymyksiä kohtaan. ${ }^{410}$

Granön poistuttua Suomeen Kantista tuli sekä Tarton yliopiston maantieteen laitoksen assistentti että kotiseuduntutkimuksentoimikunnan sihteeri. Hän aloitti tutkimustyönsä Granön oppien mukaisesti, mistä oli osoituksena 1926 ilmestynyt tutkielma Tartu: Linn kui ümbrus ja organism: Linnageograafiline vaatlus, ühtlasi lisang kultuurmaastiku morfoloogiale.

Vanha opettaja laati työstä Terraan arvostavan kirjoituksen, jossa hän muun muassa totesi:

Teos on maantieteellisenä saavutuksena huomattava. Kant on suorittamallaan työllä osottanut olevansa alallaan täysin aikansa tasolla. Niin suuresti kuin iloitsenkin tästä Eestin maantieteen uudesta voitosta, en toisaalta voi olla tuntematta mielenapeutta sen johdosta, ettei meillä Suomessa ole ainoatakaan Kantin kirjaan verrattavaa antropogeografista tutkimusta. ${ }^{411}$

Granö osui arviossaan oikeaan. Kantin Tartu-tutkimus sai pari vuotta myöhemmin merkittävän kansainvälisen tunnustuksen ja vaikutti kaupunkimaantieteen kehitykseen paitsi Suomessa myös monessa muussa maassa. ${ }^{412}$

Kantin patrioottisuus tuli näkyviin siinä, että hän kiinnitti paljon huomiota ruotsalaisen maantieteilijän Sten De Geerin luomaan käsitteeseen Baltoskandia, joka korosti Itämerta pohjoisessa, etelässä ja lännessä reunustavien valtioiden yhtenäisyyttä. Maailmanpoliittisen tilanteen kiristyessä jatkuvasti 1930-luvulla Kant päät- 
ti liittää Tarton kaupunkitutkimuksen aikana kertyneen konkreettisen materiaalin Baltoskandia-käsitteen eli poliittisen maantieteen yhteyteen. Näin Viro saisi ikään kuin tieteellistä suojaa Neuvostoliiton uhkaa vastaan. ${ }^{413}$

Vuonna 1935 julkaisemassaan väitöskirjassa Bevölkerung und Lebensraum Estlands. Ein anthropoökologischer Beitrag zur Kunde Baltoskandias Kant tarkastelee Viroa Baltoskandian ekosysteemin osana ja käsittelee yksityiskohtaisesti muun muassa maan aluerakennetta, väestön ja ympäristön vuorovaikutusta sekä maaseutuväestön ja kaupunkiväestön riippuvuutta elinympäristöstään. Samalla hän kehitti itsenäisesti keskus- ja vaikutusalueteoriaa ja edisti ajatusta yhteisestä geopoliittisesta Baltoskandian alueesta. Myöhemmin huonoon valoon joutuneesta Lebensraum-käsitteestä huolimatta Kantilla ei ollut mitään tekemistä natsien elintila-ajattelun kanssa. ${ }^{414}$

Kant toi niin paljon uusia näkemyksiä kaupunki- sekä keskus- ja vaikutusaluetutkimukseen, että hän nousi uuden maantieteellisen tutkimuksen kansainväliseen eturiviin. Saatuaan osin Granön tuella nimityksen Rockefeller-stipendiaatiksi Kant vieraili useissa Euroopan yliopistoissa ja oli yhteydessä moniin huomattaviin tutkijoihin, kuten keskus- ja vaikutusaluetutkimuksen saksalaiseen uranuurtajaan Walter Christalleriin. ${ }^{415}$

Paitsi tieteellisesti Kantin väitöskirja oli tärkeä myös käytännön kannalta. Se loi yhdessä hänen oppilaansa Endel Krepin tutkimuksen pohjalta teoreettisen ja metodisen perustan Virossa 1938 toteutetulle kuntauudistukselle. ${ }^{416}$

Granö tuki "lahjakkaimmaksi oppilaakseen" kutsumaansa Kantia rohkaisevin kommentein ja erilaisin suosituskirjein ja johdatti suomalaisia tutkijoita tämän viitoittamien aiheiden pariin. Menestyksestään huolimatta Kant luopui 1930-luvulla osin aluetieteellisistä tutkimusteemoista ja keskittyi talousmaantieteelliseen tutkimukseen. Hänet valittiin 1936 Tarton yliopistoon perustetun talousmaantieteen professuurin hoitajaksi ja tiedekunnan dekaaniksi, ja kahden vuoden kuluttua hän nousi yliopiston vararehtoriksi.

Toisen maailmansodan vuosina Kant toimi yliopiston rehtorina vuodesta 1941 alkaen. Saksalaisvallan aikana oli suurelta osin hänen ansiotaan, että Tarton yliopisto 
säilyi melko itsenäisenä eikä sitä siirretty Königsbergiin, mitä saksalaiset olivat suunnitelleet. ${ }^{417}$

Kantin aika Tartossa päättyi syksyllä 1944, jolloin Neuvostoliitto miehitti jälleen Viron. Hän oli yksi viimeisistä virolaisista, jotka onnistuivat pakenemaan maan luoteisrannikolta ennen puna-armeijan tankkien saapumista. Matka pimeän Itämeren yli Ruotsiin oli dramaattinen, sillä noustessaan veneeseen Kant liukastui niljakkailla rantakivillä satuttaen lonkkansa niin pahoin, että kärsi siitä koko loppuelämänsä..418 


\section{Aluetutikimuksen kehit'täminen}

\section{Virolaisen maisematieteen perustaminen}

Otettuaan vastaan Tarton yliopiston maantieteen professuurin Granö asetti tärkeimmäksi tieteelliseksi tehtäväkseen Viron maisematieteellisen aluejaon tekemisen. Tavoitteena oli jakaa Viro omaleimaisiin alueisiin, jotka erosivat toisistaan sekä luonnonolojen että ihmisen toiminnan osalta.

Teoreettisena esikuvana oli erityisesti Siegfried Passarge, joka oli Granön mukaan ensimmäisenä tutkijana asettanut aluekuvauksensa perustaksi maiseman eri muotojen yhteisesiintymisen. Passargen 1908 tekemä Afrikan jako "luonnollisiin maisemiin" oli määrätietoinen yritys aluejakometodiikan kehittämiseksi, ja hän oli myös luonut johdonmukaisen järjestelmän sekä maiseman muotojen esittämistä että aluejakoa varten. ${ }^{419}$

Aivan sellaisinaan Granö ei kuitenkaan Passargen käsityksiä hyväksynyt. Hän katsoi tämän sivuuttaneen ihmisen vaikutuksen maisemaan ja ottaneen aluejaoissaan huomioon myös vuoristotyypit ja ilmastoalueet, joilla ei ollut suoranaista vaikutusta ihmisten maisemakokemusten muodostumiseen. Lisäksi hän pyrki saksalaista tutkijaa täsmällisempään käsitteiden ja muotojen määrittämiseen. ${ }^{420}$

Granö päätti kehittää oman aluejakometodin, joka soveltuisi käytettäväksi kaikkialla maapallolla. Hän ymmärsi, että metodin kehittäminen vaatisi vuosien työn, mutta koska tuloksia vaadittiin nopeasti, hän esitti jo Geograafia kui teadus ja ülikooli aine -kirjoituksessa järjestelmänsä pääpiirteet. Kaikkia maisemaan vaikuttavia tekijöitä oli mahdotonta ottaa huomioon, joten maantieteilijän oli pyrittävä kokonaiskuvan hahmottamiseen johdonmukaisesti ja lyhintä tietä. Tämä voitiin tehdä siten, että aluejako toteutettiin pääosin karttojen antaman informaation avulla ja 


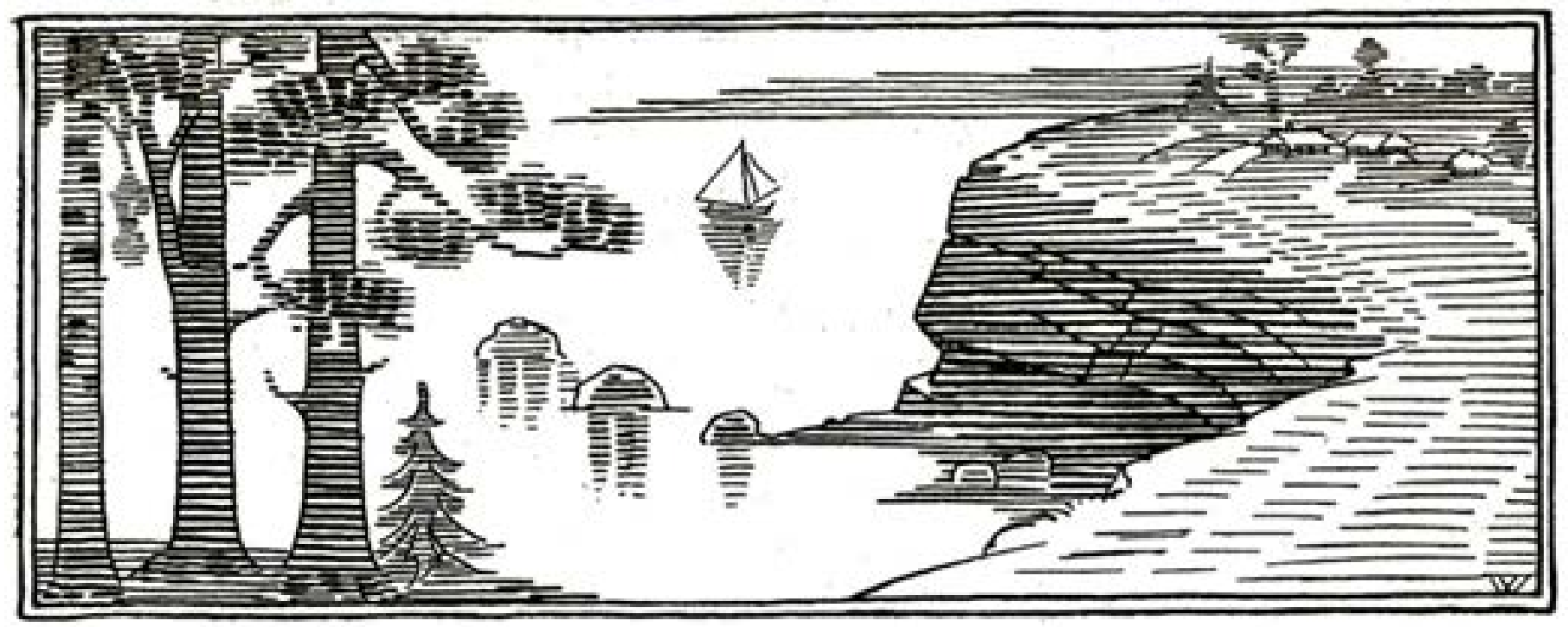

Jyrkkä rantatöyräs, klintti, on virolaisen rannikkomaiseman tunnus ja oli August Tammekannin väitöskirjan aiheena. Kuva on 1920-luvulta.

huomioon otettiin vain maiseman neljä perustekijää: Maanpinnan muodot, vesistön ja kasvillisuuden jakautuminen sekä ihmisen synnyttämät tekomuodot, erityisesti asutus ja tiestö. ${ }^{421}$

Työ aloitettiin maaston kartografisella analyysilla. Sen jälkeen laadittiin neljä karttaa, joihin oli merkitty kunkin maiseman perustekijän levinneisyys. Sitten kartat asetettiin päällekkäin ja pyrittiin erottelemaan syntyneiden rajakuvioiden perusteella maisemallisesti yhtenäisiä alueita, joissa kaikki neljä pääelementtiä esiintyivät maisemallisesti muuttumattomina. Epäselvissä tapauksissa lisäinformaatiota oli mahdollista hankkia maastotutkimusten avulla. ${ }^{422}$

Granön kehittämä aluejakomenetelmä oli teoriassa yksinkertainen, mutta sen soveltaminen käytäntöön oli vaikea, suuritöinen ja paljon sovelluksia vaativa urak- 
ka. Lisäksi työ oli tehtävä professuurin hoidon ja monien muiden tehtävien ohessa. Maantieteen laitoksen perustaminen, opetuksen käynnistäminen ja kotiseuduntutkimuksen aloittamiseen liittyvät tehtävät veivätkin alkuvuonna 1920 Granön ajan niin tyystin, että hän ei ehtinyt juuri kehittää metodiaan.

Toukokuussa 1920 paineet vihdoin helpottivat hieman yliopiston sulkiessa ovensa kesäksi. Vaikka Granö käytti kesän 1920 pääosin virkistäytymiseen ja Altai-teoksen toisen osan kirjoittamiseen, hän tutustui myös Tarton ympäristön ja Etelä-Viron maastoon. Maastotutkimukset jatkuivat seuraavina kesinä, jolloin hän tutki erityisesti Keski- ja Kaakkois-Viron maisemia. Tärkeimpänä kulkuvälineenä oli polkupyörä, joka oli ahkerassa käytössä maan idyllisillä sorateillä.

Varsin pian Granö havaitsi, että neljän päätekijän perusteella tehdyt rajaukset johtivat siihen, että maisemallisesti yhtenäiset alueet jäivät suhteellisen pieniksi, kun taas niiden raja-alueet muodostuivat laajoiksi vaihettumisvyöhykkeiksi. Tämän vuoksi hän päätyi rajaamaan myös alueita, jotka olivat yhtenäisiä kolmen tai vain kahden maisematekijän perusteella. Näin oli mahdollista muodostaa riittävän isoja alueita, jotka saattoi nimetä keskeisen paikkakunnan tai jonkin tahi joidenkin tyypillisten piirteiden perusteella. ${ }^{423}$

Parin vuoden uurastuksen jälkeen Granö katsoi työn edenneen riittävän pitkälle. Vuodenvaihteen tiiviin kirjoitusjakson jälkeen hän julkaisi keväästä 1922 alkaen Loodus-aikakirjassa kolmessa osassa tutkielman Eesti maastikulised üksused (Viron maisemalliset yksiköt). Siinä Granö jakoi neljän maisematekijän perusteella Viron 12 maantieteelliseen alueeseen, joista seitsemän, kuten Kesk-Harjumaa lausmaa, Palamuse-Aksi suurvortte, Otepää suurkuplite ja Viljandi ürgorgunde, olivat selkeitä maisemallisia kokonaisuuksia viiden ollessa maisemallisesti niitä hajanaisempia. ${ }^{424}$

Tämän pääjaon lisäksi Granö jakoi Viron alueisiin myös kolmen ja kahden maisematieteellisen tekijän perusteella. Kolmen tekijän perusteella hän erotti 35 ja kahden tekijän perusteella 24 aluetta, jotka jakaantuivat edelleen seitsemään suuralueeseen: Meri-Viroon, Saari-Viroon, Länsi-Viroon, Pohjois-Viroon, Keski-Viroon, Itä-Viroon ja Etelä-Viroon. Erityisesti kahden tekijän perusteella muodostetut alueet 
Granö nimesi täsmällisesti ja kuvaavasti, kuten Rohnu, Rotala, Lahemaa, Vahemaa, Pöltsamaa, Sakala, Peipsimaa ja Palumaa. ${ }^{425}$

Granön tutkimus oli Viron maisematieteen pioneeritutkimus. Monet hänen muodostamistaan maisema-alueiden nimistä osoittautuivat niin osuviksi, että ne jäivät osittain täsmennettyinä pysyvään käyttöön. Tunnetuimpia hänen nimeämiään alueita ovat Kaakkois-Viron Palumaa ja Suomenlahden etelärannikolla noin 50 kilometriä Tallinnasta itään oleva Lahemaa, jota luonnehtivat lukuisat niemet ja lahdet. Alueelle perustettiin 1971 Viron ja koko entisen Neuvostoliiton vanhin kansallispuisto, jonka keskus on Palmsen kartano. ${ }^{426}$

Maisematyyppien hahmottamisen lisäksi Granö ansioitui tutkimuksellaan Viron pinnanmuotojen, kasvipeitteen ja asutuksen kuvaajana. Esimerkiksi Liivia Laasimer on todennut, että "Granö tarjoaa Viron alueesta ensimmäisen todellisen geobotaanisen aluejaon”. Monista Viron maantieteen oppikirjoista löytyi vielä 1950- ja 1960-luvulla osia hänen koostamistaan asutuksen ja pinnanmuotojen kartoista. ${ }^{427}$

Granö jatkoi maisematieteen kehittämistä seuraavina vuosina, jolloin hän julkaisi viroksi tutkimukset Maastik ja ümbrus (Maisema ja ympäristö, 1923) ja Maastikuteaduse ülesanded ja maastiku vormide süsteem (Maisematieteen tehtävät ja maisemamuotojen systeemi, 1924). Nämä kirjoitukset olivat luonteeltaan teoreettisia ja metodisia, joten niiden vaikutus ei muodostunut niin konkreettiseksi kuin hänen pioneerityönsä. Yhdessä kirjoitukset muodostivat Vello Paatsin mukaan virolaisen maisematieteen kulmakiven. ${ }^{428}$

\section{Kotiseuduntutkimuksen käynnistäminen}

Suomessa kotiseuduntutkimukselle oli luonut tukevan pohjan H. G. Porthan, joka ryhtyi 1700-luvun lopulla korostamaan oman maan tutkimisen merkitystä. Harrastus sai uutta syvyyttä, kun 1831 perustetun Suomalaisen Kirjallisuuden Seuran käynnistämä järjestelmällinen keruutoiminta synnytti kenttätyöntekijöiden verkon, joka loi edellytykset aatteelliselle kotiseututyölle. Aluksi toiminta oli pääosin sivistyneistön 


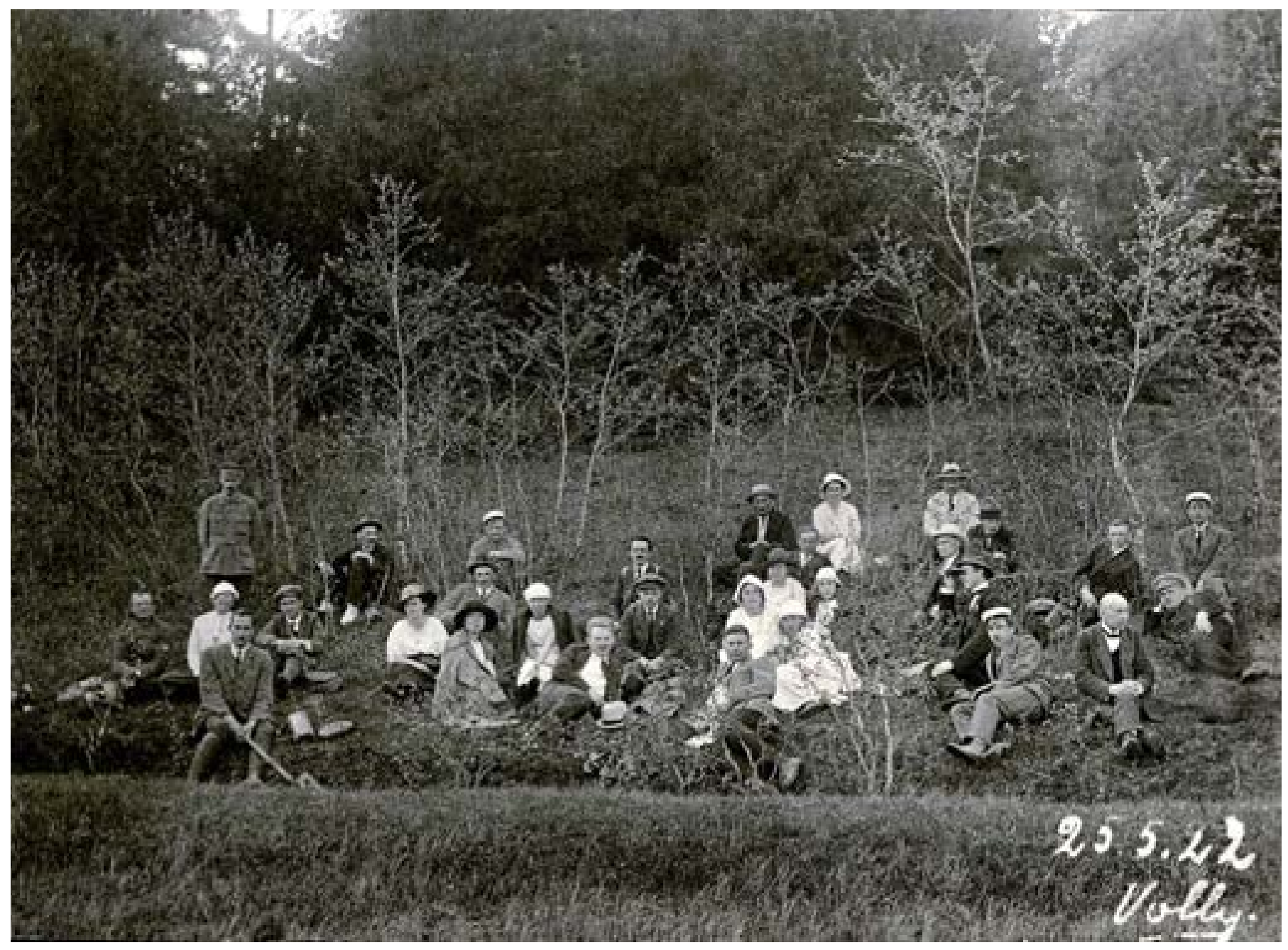

Viron kotiseuduntutkimuksen toimikunta järjesti keväällä 1922 erikoiskurssit, joiden tavoitteena oli perehdyttää tulevat kotiseuduntutkijat kenttätöihin. Toukokuun lopulla osanottajat kokoontuivat ryhmäkuvaan Elvan kuntaan tehdyn retken aikana. 
ja ylioppilaiden varassa, mutta vuosisadan lopulla Robert Boldtin johdolla ryhdyttiin houkuttelemaan myös tavallista kansaa mukaan oman ympäristön ja kulttuuriperinnön tutkimiseen. Erityistä huomiota suunnattiin historiaan, luontoon ja kansanperinteeseen liittyvän tiedon ja materiaalin keräämiseen. Vuonna 1908 valtakunnallisen kotiseututyön johtoon perustettiin Suomen Kotiseutututkimuksen Keskusvaliokunta. ${ }^{429}$

Zacharias Topeliuksen Finland framstäldt $i$ teckningar -teos oli levittänyt tietoa Suomen maasta ja kansasta 1800-luvun puolivälistä alkaen, ja saman kirjailijan lukukirja Maamme kirja opetti maan koululaiset rakastamaan Suomea kuin "isoa kotiaan". Suomen Maantieteellinen Seura oli pyrkinyt Suomen Kartastojen avulla levittämään nimenomaan ulkomaille tietoa Suomesta 1800-luvun lopulta lähtien, ja maan itsenäistymisen jälkeen nousi esiin tarve kuvata suomalaisille, millainen maa kotimaa oli, minkälaista väestöä siellä asui ja miten sen eri seudut poikkesivat toisistaan. Tarvetta ryhtyi maan itsenäistyttyä täyttämään 1919-29 ilmestynyt 9-osainen Suomenmaa-teos, jonka kahden ensimmäisen osan suunnittelijoihin ja toimittajiin J. G. Granö kuului. ${ }^{430}$

Virossa tilanne oli 1800-luvun lopulla kotiseuduntutkimuksen suhteen huomattavasti huonompi kuin Suomenlahden pohjoispuolella. Maa oli jakautunut hallinnollisesti moneen osaan, joten kansallisen yhteenkuuluvaisuuden tunne oli kehittynyt heikosti. Tilanne huolestutti kansallisia piirejä 1870-luvulta lähtien, mutta asiassa edettiin vasta 1914, jolloin Eesti Kirjanduse Seltsi (EKS) eli Viron Kirjallisuuden Seura asetti asiaa ajamaan erityisen kotiseuduntutkimuksen toimikunnan, Kodu-uurimise toimkondin. Sen työ pysähtyi kuitenkin ensimmäisen maailmansodan puhkeamiseen, ja vasta sodan päättyminen, Viron itsenäistyminen ja Tarton yliopiston toiminnan alkaminen loivat edellytykset kotiseuduntutkimuksen nousulle. ${ }^{431}$

Granö kytkeytyi voimakkaasti mukaan Kodu-uurimise toimkondin toimintaan, sillä Eesti Kirjanduse Selts valitsi hänet sen puheenjohtajaksi helmikuussa 1920 pidetyssä kokouksessa. Valintaan vaikutti hänen tiedemiesmaineensa ja vironkielen taitonsa lisäksi se, että hän oli Suomessa perehtynyt muutaman vuoden ajan kotiseuduntutkimukseen ja Suomenmad-teoksen toimitustyöhön. ${ }^{432}$ 
Granö oli tietoinen siitä, että toimikunnan varat olivat hyvin rajalliset. Työ oli siksi suunnattava aluksi kotiseuduntutkimustyön käytännön suunnitteluun, avustajien värväämiseen ja rahoittajien sekä yhteistyökumppanien hankkimiseen. Tiedot pyrittiin keräämään vapaaehtoisten paikallisavustajien välityksellä, minkä vuoksi sanomalehdissä julkaistiin artikkeleita, joissa tuotiin esiin hankkeen isänmaallinen merkitys. Kesäkuussa 1920 toimikunta julkaisi Granön johdolla laaditun 24-sivuisen pitäjänkertomuksen kirjoittamiskaavan, johon liittyi muun muassa 229 kysymystä selvitettävistä asioista. Lehtistä jaettiin opettajille, papeille ja muille asiasta todennäköisesti kiinnostuneille henkilöille. ${ }^{433}$

\section{Ryhtykäämme kuvaamaan kotimaatamme}

Viron Kirjallisuuden Seuran kotiseuduntutkimuksen toimikunnan johtokunta laati

J. G. Granön johdolla vetoomuksen, joka julkaistiin keväällä 1920 maan kaikissa suurissa sanomalehdissä ja aikakauslehdessä Kasvatus. Vetoomuksen avulla pyrittiin perustamaan maan jokaiseen kuntaan oma kotiseuduntutkimustoimikunta:

Jokaisen on tarpeen tuntea kotimaansa - tuntea oma syntymäpaikkansa ja koko se maa, jossa häntä ympäröivä oma kansa asuu ja työskentelee ja järjestyy valtiollisesti. Jokaista meistä jopa velvoittavat sen tekemään monenlaiset yhdyssiteet, jotka kytkevät meidät lähemmin kotimaahan kuin muihin maihin. Pitääpä vielä sekin palauttaa mieliin, miten haparoivaa on maan- ja luonnontieteen, mutta myös kotiseutuopin käsittely koulussa, jos opettaja ei tunne kotimaata. Voipa myös tarpeellinen yhdistävä suhde muiden maiden kanssa tuntua huomattavasti todellisemmalta, jos me pystymme jo suhteita solmiessamme tarjoamaan yksityiskohtaisemman kuvauksen itsestämme kansana sekä maamme luonnonvaroista ja tuotantomahdollisuuksista... ${ }^{434}$ 
Alku näytti varsin lupaavalta. Toimikunta sai eri puolilta Viroa viestejä, joissa kerrottiin keräyksen lähteneen hyvin käyntiin. Tarjoutuipa eräs maakuntahallitus hankkimaan sen alaisista kunnista kaikki tarvittavat tiedot, mutta pian törmättiin samoihin ongelmiin kuin useimmissa muissa vastaavissa keräyksissä. Tehtävän osoittauduttua paljon aluksi ajateltua suuritöisemmäksi alkuinnostus ei enää kantanutkaan. Keräystyö pysähtyi lähes kokonaan. ${ }^{435}$

Granö oli Suomen kokemustensa ansiosta osannut varautua siihen, että asia ei etene pelkin vapaaehtoisvoimin. Siksi hän pyrki kytkemään opiskelijansa mukaan kotiseuduntutkimukseen samalla tavoin kuin Helsingin yliopiston maantieteen laitoksella oli tehty. Hän alkoi luennoida maantieteen laitoksella kevätlukukaudella 1920 maisematieteen alkeista kohdistaen huomionsa erityisesti Viron maisemiin. Ohjatakseen aatteellisen innostuksen käytännöllisiin uomiin hän kytki maantieteen laitoksen seminaarit palvelemaan kotiseuduntutkimusta. Jokainen opiskelija sai tutkittavakseen jonkin Viron alueen, josta kokoamansa aineiston pohjalta hänen oli laadittava esitelmä seminaarissa esitettäväksi. Aivan kuten suomalaiset ylioppilaat matkustivat perinteen keräysmatkoille maakuntiin, virolaiset opiskelijat kokosivat kesäisin maan eri osista kartografista, luonnontieteellistä, historiallista ja kansatieteellistä tietoa, jota voitiin käyttää myös kansallisen identiteetin rakentamiseen. ${ }^{436}$

Näin saatu materiaali ei vastannut kaikkia toimikunnan julkaisutyölle asettamia vaatimuksia, mutta kokeilusta oli se hyöty, että se avasi kotiseuduntutkimuksen laajentamiselle uuden mahdollisuuden. Granön kerrottua kokemuksistaan muille yliopiston professoreille useat Viron luonnon ja kansan tutkimista harjoittaneiden tieteiden edustajat ilmoittivat olevansa valmiita lähettämään omia opiskelijoitaan tutkimaan niitä maan osia, jotka Kodu-uurimise toimkond oli asettanut etusijalle tai joista muuten kaivattiin tietoa kipeimmin. Erityisen ansiokkaasti asiaa edisti arkeologian professoriksi 1920 nimitetty A. M. Tallgren, joka piti velvollisuutenaan kohdistaa päähuomionsa Viron esihistoriaan ja kasvattaa oppilaistaan ennen kaikkea kotimaan tutkijoita. 
Vuoden suunnittelutöiden jälkeen Kodu-uurimise toimkond loi suuntaviivat virolaiselle kotiseuduntutkimukselle. Päätavoitteena oli koota kattavat tiedot uuden Viron valtakunnan maasta ja kansasta ja julkaista niiden pohjalta Suomenmaata vastaava maan maakuntia ja kuntia esittelevä Eesti-kirjasarja. ${ }^{437}$

Koska toiminta oli lähtenyt verkkaisesti liikkeelle, ensimmäisenä toimikunnan ohjelmassa ollut Tartumaan eli Tarton maakunnan tutkiminen jäi kesällä 1921 maantieteilijöiden ja arkeologien tehtäväksi. Kun muutama yksityinen lahjoittaja oli turvannut tutkimustyön rahoituksen, parikymmentä ylioppilasta lähetettiin Tartumaan kuntiin aineksia keräämään. Parhaimmat tulokset saatiin Palamusen kunnasta, jossa kesäänsä viettänyt Granö saattoi opastaa opiskelijoita. Tutkimustyö herätti kunnassa niin paljon huomiota, että sinne perustettiin kotiseutuyhdistys, joka julkaisi Eesti kirjanduse seltsin kustannuksella eripainoksena pitäjänkertomuksen Palamuse kihelkond: maadeteadusline, majandusline ja ajalooline kirjeldus malliksi suunniteltuun suurteokseen aiotuille aluekuvauksille. ${ }^{438}$

Ponnistus onnistui yli odotusten. Ylioppilaiden kesän aikana kokoama aineisto oli niin runsas, että se sai niin toimikunnan kuin yliopiston johdon vakuuttumaan keräystyön tärkeydestä. Toimikunta käynnisti syksyllä 1921 Tartumaata käsittelevän teoksen laadinnan. Työtä varten palkattiin toimitussihteeri, perustettiin kotiseuduntutkimusarkisto ja saatiin Eesti kirjanduse selts lupautumaan teoksen kustantajaksi. Yliopiston hallitus puolestaan loi edellytykset Eesti-kirjasarjan tekemiseen perustamalla maantieteen laitokseen erityisen kotiseuduntutkimukseen keskittyneen osaston. ${ }^{439}$

Menestyksestä huolimatta Granö ei ollut täysin tyytyväinen keräystoiminnan tuloksiin. Pahimpana ongelmana oli kerätyn aineiston laadullinen epätasaisuus, mikä johtui stipendiaattien koulutuksen puutteista. Nuoret opiskelijat eivät olleet aina osanneet keskittyä olennaisiin kysymyksiin ja tutkia asioita riittävän syvällisesti.

Kun toimikunta valmistautui keväällä 1922 Võrun ja Petserin tutkimiseen, se päätti kiinnittää erityistä huomiota stipendiaattien valmentamiseen ja heidän työtehtäviensä täsmälliseen määrittämiseen. Lisäksi pyrittiin solmimaan jo etukäteen 
yhteyksiä paikallisiin sivistysvaikuttajiin, joilta toivottiin saatavan apua aineiston keräämisessä. ${ }^{440}$

Toimikunnassa ymmärrettiin, että tutkimustyötä ei ollut mahdollista kehittää vain isänmaallisen innostuksen voimin, vaan sen tueksi oli saatava vakaa rahoitus. Siksi puheenjohtaja J. G. Granö sai tehtäväkseen käydä Tallinnassa maan johtomiesten puheilla. Tulos oli parempi kuin oli uskallettu toivoakaan. Riigivaném Konstantin Päts kertoi Granölle seuranneensa erityisellä mielenkiinnolla kotiseuduntutkimustoimikunnan työtä, sillä hän oli ymmärtänyt hyvin sen isänmaallisen merkityksen. Pätsin esityksestä maan valtiopankki antoi voittovaroistaan toimikunnalle 350000 Viron markkaa, jotka tuli käyttää pääosin Tartumaata käsittelevän käsikirjoituksen painokuntoon saattamiseksi ja osin Vörun maakuntaa ja Petserin aluetta tutkivien ylioppilaiden stipendeiksi. ${ }^{441}$

Rahoituksen varmistuttua toimikunta järjesti yliopiston kevätlukukauden päätyttyä toukokuussa 1922 erikoiskurssit tulevia kotiseutututkijoita varten, ei vain maantieteessä ja arkeologiassa vaan myös geologiassa, maaperäopissa sekä kasvi- ja eläintieteessä. Pidettiin luentoja, retkeiltiin Tarton ympäristössä ja annettiin neuvoja paitsi arkistotutkimukseen myös historiallisten aineiden keräilyyn, sillä tavoitteena oli koota samalla vapaussotaa koskevia tietoja. Jokaiselle stipendiaatille laadittiin yksityiskohtainen matkasuunnitelma. Maantieteilijöille ja kasvitieteilijöille oli merkitty topografiselle kartalle kaikki ne kohdat, jotka vähintäänkin oli tutkittava.

Varsinainen tutkimus alkoi kesäkuun alussa, jolloin stipendiaatit matkasivat tutkimusalueilleen. Stipendiaattien joukossa olivat muun muassa Granön oppilaat, Jaan Rumma, August Tammekann ja Edgar Kant. Kesän kuluessa eri tieteiden opettajat kiertelivät kunnissa neuvomassa oppilaitaan ja kontrolloimassa, missä määrin annettuja ohjeita oli noudatettu. Samalla he luonnollisesti saattoivat myös ottaa huomion kohteeksi uusia asioita. Granö opasti jälleen omien töidensä ohella Tarton lähistöllä liikkuneita kotiseudun- ja kaupunkitutkijoita ja kävi itse heinäkuussa Kaakkois-Virossa tarkastelemassa keräystyön edistymistä. ${ }^{442}$ 
Virossa 1922 vieraillut kuuluisa saksalainen maantieteilijä Albrecht Penck katsoi, että kotiseuduntutkimuksen järjestelyt oli toteutettu niin hyvin, että Saksassakin olisi tullut käynnistää samantapaista toimintaa. Myönteiseen arvioon oli aihetta, sillä tutkimustyö tuotti huomattavasti aiempia kesiä suuremman tietoaineksen toimikunnan arkistoon ja monia kokoelmia yliopiston museoihin.

Järjestelmän osoittauduttua toimivaksi seuraavana vuonna jatkettiin samalla linjalla. Uuden riigivanemin Juhan Kukkin aloitteesta toimikunnalle myönnettiin riittävät tutkimusvarat - yksistään stipendiaatteja varten 200000 Viron markkaa -, yliopiston opettajat antoivat edelleen auliisti apuaan ja stipendiaatteja ilmoittautui tarpeellinen määrä. Jotkut opiskelijoista osallistuivat työhön jo kolmatta kertaa, joten heistä oli kehittynyt lähes ammattimaisia kotiseuduntutkijoita. ${ }^{443}$

Kesällä 1923 tutkimukset keskittyivät Viljandimaahan ja Valgamaahan. Työ eteni hyvin, sillä ponnistelut paikallisen sivistyneistön kytkemiseksi keräystyöhön johtivat nyt tulokseen siten, että erityisesti Viljandimaan ylioppilaita tarjoutui runsaasti stipendiaattien vapaaehtoisiksi avustajiksi. Apu otettiin luonnollisesti ilomielin vastaan, sillä näin kotiseuduntutkimus sai tarpeellista tukea paikallisväestöltä.

Granö luopui keväällä 1923 kotiseuduntutkimustoimikunnan puheenjohtajuudesta, mutta hänen panoksensa työn organisoinnissa oli niin suuri, että häntä on kutsuttu virolaisen kotiseuduntutkimuksen isäksi. Hänen johdollaan aluksi hapuilevasta ja vapaaehtoisuuteen perustuvasta toiminnasta tuli osin valtiollisesti rahoitettua, johdonmukaisesti suunniteltua ja ammattimaisesti ohjattua keruutyötä, jonka tuloksena yliopiston laitoksiin, kirjastoihin ja museoihin onnistuttiin kokoamaan monenlaista tietoa ja aineistoa. Työ tarjosi useiden tieteenalojen opiskelijoille mahdollisuuden tutustua opiskeluaikanaan opettajiensa johdolla käytännön tutkimustyöhön ja -metodeihin kenttäolosuhteissa. ${ }^{444}$

Viroa koskevan kirjallisuuden suhteen toimikunnan tavoitteet täyttyivät erinomaisesti. Hans Kruusin toimittama luonnon ja kulttuurin yleisesitys Eesti. Maa. Rahvas. Kultuur ilmestyi 1926, mutta varsinainen suurteko oli maan maakuntia esittelevän mahtavan sarjan valmistuminen 1925-39. Ensimmäinen maakuntateos 
oli 1925 ilmestynyt Tartumaa, jota seurasivat Vôrumaa (1926), Setumaa (1928), Pärnumaa (1930), Valgamaa (1932), Saaremaa (1934), Läänemaa (1938) ja Viljandimaa (1939).

Granön suuri merkitys kirjasarjan valmistumiseen näkyi siinä, että hän toimitti itse sen ensimmäisen osan Jaan Rumman ja J. V. Veskin kanssa, kun taas kaikkien muiden teosten toimituskuntaan kuului joku hänen oppilaistaan Rumma, August Tammekann tai Edgar Kant. Kant toimi Eesti-sarjan päätoimittajana 1927-36, ja 1938-40 hän johti myös Viron kartaston toimitustyötä.

Viron luontoa ja kansaa koskevan tiedon kokoaminen oli saavutus, jolla oli merkitystä sekä kansallisen ja paikallisen identiteetin että maan hallinnon ja talouselämän kehittämiselle. Laaja tietoaineisto loi myös mahdollisuuden uusiin tieteellisiin sovelluksiin. Perinteisen, aikaan ja paikkaan pohjautuvan tarkastelun rinnalle nousivat analyysit, joissa pohdittiin muun muassa monenlaisia tilaan liittyviä kysymyksiä ja maisemaympäristön ja tilan alueellisia suhteita. Näin saivat vähitellen alkunsa maantieteen uudet alat, kuten maisema- ja aluetiede sekä alue- ja ihmisekologia. ${ }^{445}$

\section{Kaupunkitutkimuksen aloittaminen}

Kodu-uurimise toimkondin muotoilema kotiseuduntutkimusohjelma koski niin maaseutukuntia kuin kaupunkeja ja kauppaloita. Kun toimikunta ryhtyi valmistelemaan tutkimustyön käytännön toteuttamista, se havaitsi nopeasti, että kaupunki ja maaseutu poikkesivat toisistaan niin paljon, että niitä oli tutkittava eri menetelmin. Siksi toimikunta katsoi välttämättömäksi laatia kaupunkien tutkimusta varten omat ohjeet, jotka edellyttivät läheistä yhteistyötä kaupunkien viranomaisten, asukkaiden ja opiskelijoiden kanssa. ${ }^{446}$

Granö laati loppuvuonna 1921 kaupunkitutkimusta varten suunnitelman "Linna voi alevi uurimise kava" ja käynnisti neuvottelut ensimmäiseksi tutkimuskohteeksi valitun Tarton edustajien kanssa. Kaupunginhallituksen, yliopiston rehtorin ja ylioppilasosakuntien johtohenkilöiden kanssa käydyt keskustelut johtivat nopeasti myön- 
teiseen ratkaisuun. Vuonna 1922 perustettiin Granön johtama kaupunkitutkimustoimikunta "Tartu Linna Uurimise toimkonna", jonka jäseniksi tulivat muun muassa yliopiston rehtori ja kaupunginjohtaja. Kaupunginhallitus suostui myöntämään tutkimuksen tarvitsemat varat sillä ehdolla, että koottu aineisto luovutettaisiin kaupungin tilastolliselle toimistolle, jonka johtaja oli uudessa toimikunnassa sihteerinä. ${ }^{447}$

Tarton kaupunkitutkimuksen joutuessa näin oman toimikunnan johtoon ja kaupungin rahoituksen piiriin sen tavoitteet ja menetelmät muodostuivat huomattavasti laajemmiksi kuin kotiseuduntutkimuksen toimikunta oli alun perin kaavaillut. Siksi päätettiin jo varhain, että kerättyä aineistoa käytettiin Tartumaan maakuntateoksen lisäksi myös itse kaupungista julkaistavassa kokoomateoksessa, jonka kirjoittamisessa päätettiin käyttää hyväksi vuoden 1922 lopulla toimeenpannun yleisvaltakunnallisen väestönlaskennan yhteydessä kerättyjä tietoja. ${ }^{448}$

Kun toimikunnan tutkimusohjelma oli noudattanut maaseutukuntien osalta eri maista tuttua käsittelyjärjestystä luonnonolojen, asutuksen, talouselämän ja historian kuvauksen osalta, Tarton kaupungin tutkimuksessa tavoitteet ja menetelmät poikkesivat perinteisistä ratkaisuista. Granön tutkimusohjelma, jonka hän todennäköisesti loi ilman esikuvia, suuntasi huomiota muun muassa rakennusten, katujen, aukioiden ja istutusten ulkomuotoon, liikenteeseen, asukastiheyteen, kaupungin sosiaaliseen ja toiminnalliseen erilaistumiseen sekä Tarton ja sitä ympäröivän maanseudun suhteeseen. ${ }^{449}$

Tutkimusohjelman ensimmäiset tehtävät, kaupungin ulkoasuun vaikuttavien tekijöiden, katujen liikennemäärien sekä väestön jakautumisen selvittäminen, toteutettiin vuoden 1922 loppuun mennessä. Toimikunnan kouluttamat stipendiaatit - toistakymmentä ylioppilasta - kiersivät kesäkuukausina koko kaupungin talosta taloon ja merkitsivät tekemiinsä pohjapiirrosaihelmiin ja painettuihin kyselykaavakkeisiin tiedot rakennusten ryhmityksestä ja suuruussuhteista sekä muista keskeisistä seikoista. Työtä varten oli luotu yksityiskohtainen rakennusmorfografinen sanasto.

Katujen liikennetiheyttä tutkittiin kahden vuorokauden aikana keväällä ja yhden aikana syksyllä. Noin 50000 asukkaan kaupunki jaettiin tarkoitusta varten kahteen 


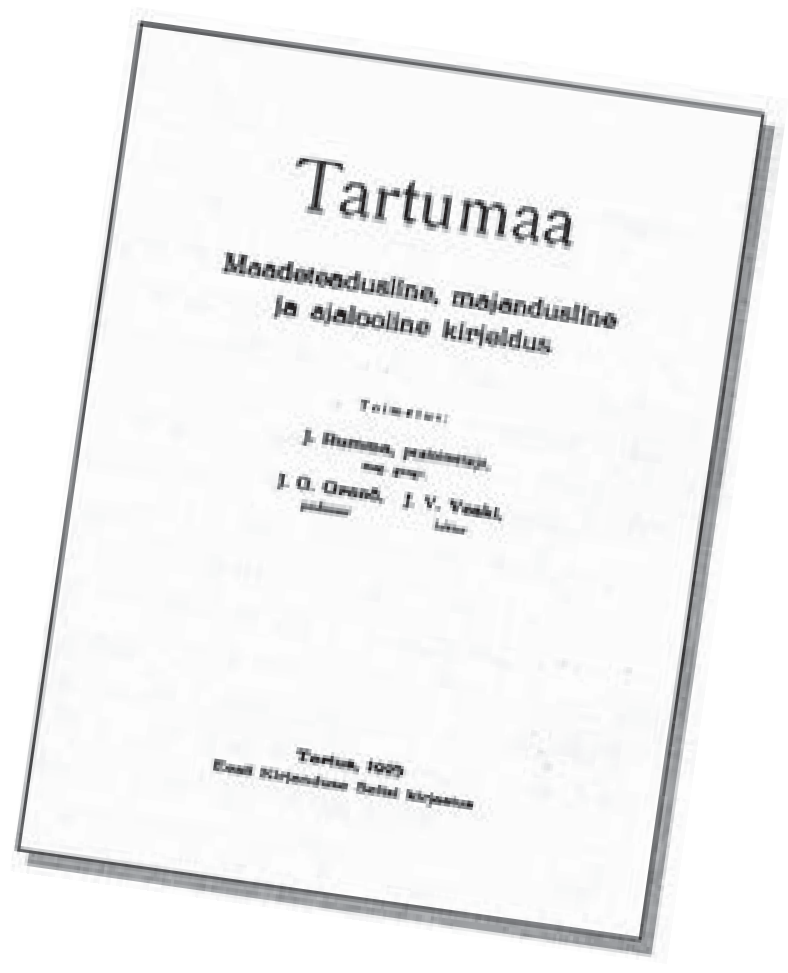

Eesti-sarjan avausteos Tartumaa ilmestyi 1925. osaan. Kummassakin oli oma "päämaja", joista havaintojen tekijät lähetettiin kahden tunnin välein havaintopaikkoihin. Havaintojen teosta vastasi noin 150 ylioppilaan vapaaehtoisjoukko, joka saattoi tarvittaessa turvautua poliisien apuun. ${ }^{450}$

Havaintoja tehtiin kaupunkiin johtavien maanteiden varsilla koko vuorokauden ajan, ja saadut lukemat merkittiin painetuille lomakkeille. Näin saatiin selville jalankulkijoiden, kuormaa kuljettavien tai muuten liikkuvien ajoneuvojen, niiden kuljettajien ja matkustajien lukumäärä sekä liikkumissuunta vuorokauden kaikkina tunteina ja kaupungin kaikissa osissa. Samoin kirjattiin muistiin, mitä kaupunkiin maaseudulta tuotiin (mistä kunnasta, kuinka paljon) ja mitä kaupungista vietiin (mihin, kuinka paljon).

Vaikka kaupunkitutkimus ulottui moniin muihinkin Viron kaupunkeihin, tärkeimmät tulokset saavutettiin Tartossa, jossa työ toteutettiin Granön laatiman ja organisoiman, hyviin resursseihin tukeutuneen yksityiskohtaisen suunnitelman mukaisesti. Granö osallistui ahkerasti toimikunnan työhön kevääseen 1923, jolloin hän palasi Suomeen. Granön seuraajaksi kotiseuduntutkimustoimikunnan johtajaksi nimitettiin Tarton yliopiston rehtori Heinrich Koppel, mutta kaupunkitutkimusta ryhtyi johtamaan Edgar Kant, joka oli läheisessä yhteydessä opettajaansa koko tutkimusajan. ${ }^{451}$ 
Yli 700-sivuinen Tartu-teos ilmestyi 1927. Vaikka merkittävimmän työn teoksen valmistumiseksi teki Kant, Heinrich Koppel totesi teoksen julkistamistilaisuudessa, että suurin ansio perusteellisesta kaupunkitutkimuksesta kuului Granölle:

Että me olemme saaneet Tartosta tällaisen perusteellisen tutkimuksen, jollaista harva toinen kaupunki pystyy esittämään, siitä olemme ensi sijassa kiitoksen velkaa professori Granölle. ${ }^{452}$ 


\section{ФaluU SUOMEen}

\section{Maantieteellinen uskontunnustus}

Suomessa maantiedettä pidettiin 1920-luvun vaihteessa edelleen pääasiassa vain kansallisesti tärkeänä alueellisen tiedon kokoajana ja kouluaineena. Tätä kantaa edusti ennen kaikkea arvovaltainen Suomen Maantieteellinen Seura, jonka puheenjohtaja, maailmankuulu geologi J. J. Sederholm oli Fenniassa 1912 julkaisemassaan artikkelissa erääseen englantilaiseen everstiin vedoten kieltänyt maantieteeltä lähes kaiken tieteellisen arvon. ${ }^{453}$

Muodollisten arvojen edustajana Granö ei halunnut lähinnä kahdesta syystä ryhtyä kumoamaan vanhoja käsityksiä. Ensimmäinen syy oli hänen kunnioittava suhtautumisensa eläintieteen professori J. A. Palméniin, joka oli vaikuttanut ratkaisevasti siihen, että hän oli saattanut aloittaa luonnontieteelliset opinnot ja oli myöhemmin edistänyt hänen opintietään. Palmén oli kuitenkin ollut myös maantieteen itsenäistymiskehityksen tärkeimpiä vastustajia. Hän oli Suomen Maantieteellisen Seuran arvovaltaisena sihteerinä vaikuttanut ratkaisevasti siihen, että maan tieteellisissä piireissä maantiedettä pidettiin yleisesti pelkkänä paikkatieteenä, joka vain kokosi yhteen perinteisten luonnontieteiden tulokset.

Granö torjui tiukasti Palménin näkemyksen, mutta hänen kunnioituksensa vanhaa lintututkijaa kohtaan esti häntä kumoamasta tämän mielipiteitä julkisesti. Tämä este poistui huhtikuun alussa 1919, jolloin merkittävä eläintieteilijä ja Tvärminnen biologisen tutkimusaseman perustaja kuoli 73-vuotiaana Forssassa.

Toinen syy oli Granön yliopistollinen asema. Hänellä oli vain perin vaatimaton maantieteen dosentin vakanssi, joten hän katsoi, ettei hän voinut alkaa esiintyä tieteenalan ylimpänä auktoriteettina. Tämä rooli olisi kuulunut hänen opettajalleen 
ja maantieteen vakinaiselle professorille J. E. Rosbergille, jonka tehtävänä olisi ollut puolustaa Ragnar Hultin tavoin maantieteen asemaa tieteiden joukossa.

Rosberg ymmärsikin velvollisuutensa ja julkaisi 1918-19 Åbo Akademis Årskriftissa ja Terrassa lähes samansisältöiset artikkelit, joissa hän tuomitsi selkeästi Suomen Maantieteellisen Seuran edustaman kannan. Hänen mukaansa maantiede ei ollut vain yhdistelmä eri tieteiden osista tai pelkkä näkökohta vaan itsenäinen tiede, "oppi maanpinnan ulkonäöstä ja tämän syntysyistä”.

Rosberg myönsi maantieteen alan olevan liian laajan yhden tutkijan kapasiteetille mutta painotti, että maantieteilijän tuli hallita jonkin erikoisalan ohella erityinen maantieteellinen tutkimusmetodi. Suomen Maantieteellisen Seuran tieteenaloistaan ylpeisiin luonnontieteilijäprofessoreihin viitaten Rosberg totesi, että vaikka entomologi saattoi tulla kuuluisaksi tutkimalla itikoita, maantieteilijä ei voinut koko ikäänsä tutkia esimerkiksi hiidenkirnuja vaan hänen täytyi ottaa huomioon niiden syntyhistoria. ${ }^{454}$

Laajasta asiantuntemuksestaan huolimatta Rosberg ei ollut maantieteen teorian syvällinen tuntija. Päinvastoin hänen käsityksensä maantieteen olemuksesta oli varsin jäsentymätön. Tätä osoittaa se, että Rosberg oli valmis hyväksymään geomorfologian maantieteen ja geologian yhteiseksi "omaisuudeksi" ja sivuutti maantieteen keskeisemmäksi osaksi nimeämänsä erikoismaantieteen vain lyhyellä luonnehdinnalla. Kirjoituksen käsitteelliset ongelmat ja Rosbergin tutkijana tiedemaailmassa nauttima melko vähäinen arvostus johtivat siihen, että Suomen Maantieteellisen Seuran johto katsoi, ettei seuralla ollut mitään syytä luopua suuren Palménin viitoittamasta toimintatavasta. ${ }^{455}$

Ratkaisu ärsytti Granötä, joka Palménin kuoltua ja maantieteen professuurin haltijana katsoi, että hänen oli viimeinkin astuttava esiin. Hän julkaisi vuoden 1920 alussa Terrassa poleemisen artikkelin "Maantieteestä, sen asemasta yliopistossamme ja sitä meillä edustavista seuroista", jossa hän uuden maantieteellisen tutkimuksen olemuksen esittelyn ohella tuomitsi ankarasti Suomen Maantieteellisen Seuran toiminnan. ${ }^{456}$ 
Granö toteaa kirjoituksensa alussa, ettei hänen tarkoituksensa ollut "itsekyllöisesti mestaroida" maantieteellistä tutkimustyötä vaan puuttua niihin kysymyksiin, joiden oikeasta ratkaisusta riippui sekä maantieteellisten seurojen että maantieteilijöiden olemassaolon oikeutus. Hän katsoi, että seuran toiminta oli perustunut ja perustui yhä epämääräiselle ja vanhentuneelle käsitykselle maantieteestä. Maantieteilijöiden täytyi nyt itse selkeästi määritellä, mitä heidän tieteensä oli, koska

$$
\begin{aligned}
& \text {... olisi helppo luetella tunnettujakin maantieteilijöitä, jotka tahtovat käydä } \\
& \text { maantieteilijöistä, mutta joiden "maantieteellinen" työ on selvää geologiaa, } \\
& \text { meteorologiaa, geodesiaa, kansatiedettä, tilastotiedettä, muinaistiedettä tai his- } \\
& \text { toriaa. }{ }^{457}
\end{aligned}
$$

Granön mukaan maantieteilijöiden oli aika lakaista kaikki turhat rönsyt pois tieteestään, sillä
Ainoana, metodisesti oikeana järjestyksenä pysyy: ensin tehtävän täsmällinen määrittely, sitten tehtävän suoritustavan selvittely. Tieteelliselle työlle, joka tahtoo käydä määrättyyn tieteeseen kuuluvasta, on ehdottomana vaatimuksena asetettava tämän tieteen mukainen horjumaton teoreettinen perustus ja hallit- seva päämäärä - siinäkin tapauksessa, ettei rohjettaisikaan pitää tällöin mää- rääviä näkökohtia lopullisesti oikeina ja objektiivisesti pätevinä..58

Uusi maantieteellinen tutkimus koostui maisematieteestä ja aluetieteestä. Maisematiede eli yleismaantiede kohdisti päähuomionsa maanpinnan muotoihin, hydrografiaan ja klimatologiaan, kasvillisuuteen maisemallisena tekijänä sekä eläinkunnan ja ihmisen luontoa muokkaavaan toimintaan pyrkien määrittelemään ja luokittelemaan näiden tekijöiden synnyttämiä maisematyyppejä. Siksi maantieteilijä tarvitsi tietoja muun muassa geologiasta, kemiasta, kasvitieteestä, fysiikasta, klimatologiasta, mineralogiasta, petrografiasta ja erityisesti kartografiasta. ${ }^{459}$ 
Aluetiede vastasi vanhaa erikoismaantiedettä, sillä se pyrki soveltamaan maisematieteen yleisiä lainalaisuuksia tietyn rajatun alueen, kuten vaikkapa jonkin valtion tutkimiseen. Aluetieteen tutkimusala oli siinä mielessä laajempi kuin maisematieteen, että se edellytti myös muutamien uusien aputieteiden, kuten kansatieteen, taloustieteen ja historian, tuntemusta. ${ }^{460}$

Uudella tavoin määriteltynä maantiede oli Granön mukaan tiede eikä mikään tieteiden yhtymä. Se ei myöskään ollut enää vain koulujen oppiaine vaan tietyissä suhteissa syvällisempi ja vaikeampi kuin muut tieteet. Hänen mukaansa tätä kantaa oli jo varhain edustanut unhoon jäänyt Suomen yliopistomaantieteen edustaja, Ragnar Hult, jonka nerokkaat ajatukset olivat "vain huutavan ääntä, kuuroille korville kaikuvaa". ${ }^{461}$

Maantieteilijän oli pidettävä tärkeimpänä, lopullisena tavoitteenaan "luonnon suuren kukkasvihon tieteellistä selittämistä, tuon kokonaisuuden, jonka kukkaiset eivät ole satunnaisesti toistensa vieressä, vaan joiden asema, toisiinsa suhtautuminen ja leveneminen on riippuva määrätystä menneisyydestä ja varmoista ikuisista laeista”. Näin Granö jälleen osoitti, kuinka raskaasti hän oli kokenut Palménin maantiedettä vähättelevän asenteen. ${ }^{462}$

Granö ei vaatinut maantieteelle uusia vakituisia virkoja Helsingin yliopistoon. Maantieteen professori voisi aivan hyvin rajoittaa opetustoimintansa maisema- ja aluetieteeseen sekä kartografiaan. Kaikkien muiden maantieteen alaan liittyvien aineiden opetuksesta voisivat vastata erikoistieteiden edustajat. Tällä tavoin Granö käänsi ikään kuin päinvastaiseksi Sederholmin toteamuksen, jonka mukaan maantieteen professorin oli ohjattava perusteellisia tietoja haluavat oppilaansa erikoistutkijoiden luo. Granön mielestä tulevien maantieteilijöiden oli ensin suoritettava tärkeimpien aputieteiden peruskurssit ja vasta sitten suunnattava tiensä "maantieteen työhuoneisiin". ${ }^{463}$

Suomen Maantieteellinen Seura nautti tunnettujen johtohenkilöidensä ja julkaisemiensa Suomen Kartastojen vuoksi suurta arvostusta, joten Granön avoin hyökkäys sitä vastaan herätti huomiota. Suomalaiskansalliseen tapaan mielipiteet lausuttiin 
kuitenkin vain taatussa ja luotetussa piirissä ja jyrkkiä kannanottoja vältettiin. Kukaan ei noussut julkisesti sen paremmin vastustamaan kuin puoltamaan hänen näkemyksiään.

"Maantieteellisen uskontunnustuksensa" saama vaisu vastaanotto sai Granön turhautumaan. J. K. V. Tuomiselle kesäkuussa 1920 lähettämässään kirjeessä hän kertoi nauttivansa työskentelystään Tartossa, jossa ei ollut "havaittavissa tuota merkillistä antigeograafista suuntaa, joka tiedekunnassamme Helsingissä täysin määräävänä esiintyy". Virossa tarkasteltiin "nuortunutta ja puhdistunutta tiedettämme erikoisella kunnioituksella". ${ }^{464}$

Kun tilanne pysyi muuttumattomana vuoden lopulle asti, Granö purki jälleen tunteitaan vanhalle ystävälleen:

\begin{abstract}
Mielentilani on tuon purkauksen jälkeen ollut kevyt ja kirkas. Olenhan lakaissut ja siistinyt asuntoni edustan. Suunta on varma, linjat ovat suorat. Vähät siitä, jos erinäisissä piireissä suhtautuminen J. G. G:hön on muuttunut... Tahdon nimittäin sanoa, että antamasi hyväksyvä lausunto on ainoa, jonka olen saanut vastaanottaa tuolta puolen Suomenlahden. Siellä vaietaan visusti - sekä Fennian että Terran puolella. Väärinymmärryksen välttämiseksi mainittakoon kuitenkin, etteivät sydämelliset henkilökohtaiset suhteeni J. E. R:iin (AT: Rosbergiin) millään tavalla ole muuttuneet. ${ }^{465}$
\end{abstract}

\title{
Operaatio "Granö takaisin Suomeen"
}

Jo hyväksyessään Tarton yliopiston kutsun Granö oli lähtenyt siitä, että kysymyksessä oli vain lyhyt pesti. Hän palaisi Suomeen heti, kun virolaiset pystyisivät itse kantamaan vastuun maantieteen kehittämisestä ja kun hänelle löytyisi kotimaasta tehtävä, joka vastaisi hänen kykyjään ja turvaisi perheen toimeentulon.

Granön ilmoitus Tarttoon siirtymisestä oli käynnistänyt nopeasti toimet hänen kutsumisekseen takaisin Suomeen. Asia pysähtyi kuitenkin siihen, että sopivaa 
tehtävää ei ollut helppo löytää. Maassa oli vain yksi maantieteen professuuri, jonka hoitaja, J. E. Rosberg, ei ollut vielä lähelläkään eläkeikää. Lisäksi mahdollisia uusia professuureja täytettäessä Granö ei ollut itsestään selvästi ykköspaikalla, sillä kovana kilpailijana oli geomorfologian ja kasvimaantieteen tutkija Iivari Leiviskä..666

Leiviskä oli sekä väitellyt että tullut dosentiksi ennen Granötä, toiminut Helsingin yliopiston maantieteen vt. professorina 1914-17 ja saanut juuri valmiiksi massiivisen tutkimuksensa Der Salpausselkä. Hän oli myös voimakastahtoinen ja itsetietoinen henkilö, joka ei ollut vapaaehtoisesti valmis väistymään kenenkään tieltä. Granö tulikin saamaan Leiviskästä tiukimman tieteellisen kilpailijansa ja vähitellen myös vastustajansa. ${ }^{467}$

Tilanne konkretisoitui jo syksyllä 1920, jolloin ryhdyttiin valmistelemaan sekä maantieteen professuurin perustamista Turun yliopistoon että maantieteen henkilökohtaisen ylimääräisen professorin nimittämistä Helsingin yliopistoon. Granö mainittiin yhtenä ehdokkaana molempiin virkoihin, mutta asiat eivät edenneet hänen kannaltaan suotuisasti. Turun-hanke siirtyi tulevaisuuteen, ja Helsingissä perinteinen akateeminen virkaikäkäytäntö peri voiton, kun Leiviskä sai 1921 maantieteen henkilökohtaisen ylimääräisen professuurin. ${ }^{468}$

Leiviskän nimitys ei tapahtunut soraänittä. Vaikka J. E. Rosberg esitti fyysismatemaattisen osaston kokouksessa syyskuun puolivälissä 1920 myönteisen lausunnon hänen kyvyistään, professorit Enzio Reuter, Hjalmar Tallqvist, Wilhelm Ramsay ja Fredrik Elfving tukivat nimitystä vain varauksellisesti. Konsistori hyväksyi silti ratkaisun pääosin Leiviskän suurten opetuksellisten ansioiden vuoksi, sillä hän oli vastannut suurelta osin maantieteen suomenkielisestä opetuksesta ja paine sitä kohtaan oli kova kasvaneiden opiskelijamäärien vuoksi. ${ }^{469}$

Granö suhtautui asiaan filosofisesti. J. K. V. Tuomiselle hän kertoi, että jos hän olisi saanut valita Helsingin ja Turun välillä, hän olisi epäilemättä valinnut Aurajoen kaupungin, sillä näin hän olisi voinut työskennellä samassa kaupungissa ystävänsä kanssa. Tuominen oli muuttanut 1921 Heinolasta Turkuun saatuaan vanhasta kotikaupungistaan suomalaisen lyseon lehtorin viran. ${ }^{470}$ 
Granön levollisuus oli sikäli perusteltua, että Suomenlahden pohjoispuolella valmisteltiin toimia hänen saamisekseen takaisin Helsinkiin. Kauppakorkeakoulun rehtori Wäinö Bonsdorff olisi ollut valmis kutsumaan Granön korkeakoulun talousmaantieteen professoriksi melko joustavin ehdoin, mutta tämä torjui tarjouksen asettaen mahdollisen yliopistoprofessuurin etusijalle. Tehtävään nimitettiin 1921 Granön oppilas ja ystävä Kaarlo Hildén. ${ }^{411}$

Helsingin yliopistossa paluumuuton puolesta työskenteli erityisesti J. E. Rosberg. Hän sai maaliskuun 1921 lopulla Granön tutkijan- ja opettajankykyjä ylistävän lausunnon perusteella aikaan sen, että fyysis-matemaattinen osasto päätti yksimielisesti ehdottaa konsistorille, että tämä nimitettäisiin maantieteen ylimääräiseksi professoriksi eduskunnan tarjoaman apulaisen viran sijasta. Konsistori hyväksyi ehdotuksen huhtikuun lopulla, jolloin se päätyi puoltamaan Granön nimittämistä virkaan heti kun se tuli mahdolliseksi. ${ }^{472}$

Koska uusien virkojen perustamiseen liittyi monenlaisia epävarmuustekijöitä, Granölle pyrittiin rakentamaan tehtäväkokonaisuus, jonka luominen tuli mahdolliseksi Suomen Maantieteellisen Seuran ja Suomen Maantieteellisen Yhdistyksen yhdistyessä 1921 uudeksi Suomen Maantieteelliseksi Seuraksi. Uuden seuran syntyyn vaikutti osin Granön, Rosbergin ja muiden yliopistomaantieteilijöiden voimistunut kritiikki Suomen Maantieteellisen Seuran maantiedekäsitystä vastaan, mutta pääosin sen taustalla oli Suomen muuttunut valtiollinen asema.

Suomen itsenäistyttyä maantieteellinen tutkimus oli menettänyt valtiolta saamastaan tuesta sen osan, joka oli liittynyt maan autonomisen aseman puolustamiseen. Tämän vuoksi seurojen johtomiehet ymmärsivät, että keskinäisen kilpailun aika oli ohi. ${ }^{473}$

Uuden Suomen Maantieteellisen Seuran tarkoituksena oli "edistää ja toimittaa maantieteellisiä tutkimuksia ja edistää harrastusta maantieteeseen". Yhdistyminen ei ratkaisut välittömästi kaikkia maantieteeseen liittyviä erimielisyyksiä, sillä monet perinteisten yliopistotieteiden edustajat suhtautuivat siihen yhä epäillen tai vähättelevästi. Sopu paransi kuitenkin huomattavasti maantieteen asemaa yliopistoaineena ja loi edellytykset voimien keräämiseksi yhteisten hankkeiden taakse. 
Ensimmäinen suuri tavoite oli saada aikaan Suomen Kartaston uusi laitos, jonka avulla voitaisiin osoittaa sekä suomalaisille että maailmalle, minkälainen maa itsenäinen Suomi oli. Kartaston kunniakkaan historian jatkuvuuden turvaamiseksi sen julkaisutyö haluttiin uskoa mahdollisimman luotettaviin käsiin. Ykkösvaihtoehdoksi nousi Granö, joka erinomaisten kartografisten taitojensa lisäksi nautti tutkijana tehtävän vaatimaa arvovaltaa. ${ }^{474}$

Ongelmaksi nousi se, että pelkkä Suomen Kartaston toimitustyö ei olisi riittänyt vetämään Granötä takaisin Suomeen. Siksi hänelle päätettiin tehdä tarjous, jota oli vaikea torjua. Suomen Maantieteellisen Seuran johtomiehet kutsuivat Granön neuvotteluun, jossa hänelle luvattiin professoritason palkka tehtäväkokonaisuudesta, joka sisälsi sekä uuden seuran sihteerin pestin että vastuun Suomen Kartaston kolmannen laitoksen ja Fennian toimittamisesta. Lisäksi Granölle luvattiin, että hänen toimeentulonsa tultaisiin turvaamaan joka tapauksessa eri tavoin. ${ }^{475}$

Granö suhtautui tarjoukseen hänelle tavanomaisen alkukursailun jälkeen myönteisesti. Kertoihan se jopa imartelevan suuresta luottamuksesta hänen kykyihinsä ja vastasi hänen perimmäisiä toiveitaan. Suomalaisena tutkijana hän koki isänmaalliseksi velvollisuudekseen palvella kotimaataan, ja myös perheen kannalta paluu Suomeen tuntui houkuttelevalta. Eniten häntä askarruttikin se, mistä hän löytäisi miehen, joka jatkaisi hänen Tartossa aloittamaansa työtä:

Omat oppilaani eivät ole vielä niin pitkällä, Suomessa ei ole ketään täysin sopivaa, Saksasta ei viitsi importeerata. Unkari voisi tulla kysymykseen, ja ehkäpä sieltä löytyisikin mies, joka ymmärtäisi virolaisuuden asian siinä määrässä, että lähtisi omalle maalleen takaisin, niin pian kuin joku virolaisista valmistuisi... Kun on joutunut tällaista hommaa organisoimaan, niin ei ole niinkään helppoa mennä sanomaan: 'Nyt pistän pillit pussiin ja lähden. ${ }^{2} 476$

Helpottaakseen Granön päätöksentekoa seuran johtomiehet käynnistivät Helsingin yliopistossa toimet hänen asemansa turvaamiseksi. Hän sai muun muassa vakuuden 
siitä, että saisi uudelleen dosenttistipendin syksyllä 1922. Kun vielä Suomen Kartaston rahoitus varmistui lopullisesti keväällä 1922, Granö ilmoitti voivansa ottaa syksyllä sihteerin toimen vastaan sillä ehdolla, että voisi toimia Virossa niin kauan, että kykenisi luovuttamaan vastuullaan olevat tehtävät luotettaville henkilöille. ${ }^{477}$

Maantieteellisen seuran suostuttua pyyntöön Granö teki vaikean päätöksen: Hän palaisi Suomeen lopullisesti heti, kun tilanne Virossa oli ratkennut myönteisellä tavalla ja kun hänellä oli Suomessa vakituinen virka. Siihen asti hän aikoi toimia siten, että pitäisi virkavapauksien turvin hallussaan sekä Tarton yliopiston professuurin että Helsingin yliopiston dosentuurin. Takaportti paluuseen Tarton yliopistoon jäi siis yhä auki. ${ }^{478}$

\section{Siirtymävaihe}

Tarton yliopiston kevätlukukauden pätyttyä toukokuussa 1922 Granön perhe jakautui kahtia. Puoliso, äitimuori ja lapset muuttivat asumaan Espoon pappilaan, jossa Granön eno oli pappina. Professori itse jäi pääosin Viroon varmistamaan aloittamiensa töiden jatkuvuuden ja hoitamaan Suomen Maantieteellisen Seuran sihteerin ja julkaisujen toimittajan tehtäviä. Koska työ ei vaatinut vakituista asumista Tartossa, Granö luopui Lepiku 9:n asunnosta ja siirtyi asumaan yhteistalouteen professorikollegansa Kaarlo Teräsvuoren kanssa. ${ }^{479}$

Suodakseen Granölle mahdollisuuden keskittyä omaan tutkimustyöhön ja kotiseudun- ja kaupunkitutkimuksen johtamiseen Tarton yliopisto vapautti hänet syyslukukaudella 1922 opetustyöstä lukuun ottamatta seminaarien johtamista ja maisterintutkintojen järjestämistä. Hän asui kesän pääosin kaupungin lähistöllä Raadin kartanossa, jossa hän myös aloitti Suomen Kartaston kolmannen laitoksen suunnittelun. ${ }^{480}$

Syksyllä 1922 Granö siirtyi Helsinkiin, jossa häntä odotti sekä dosentintehtävät stipendeineen että Suomen Maantieteellisen Seuran maksama kuukausipalkka Suomen Kartaston ja Fennian toimittamisesta. J. K. V. Tuomiselle Tartosta lähet- 


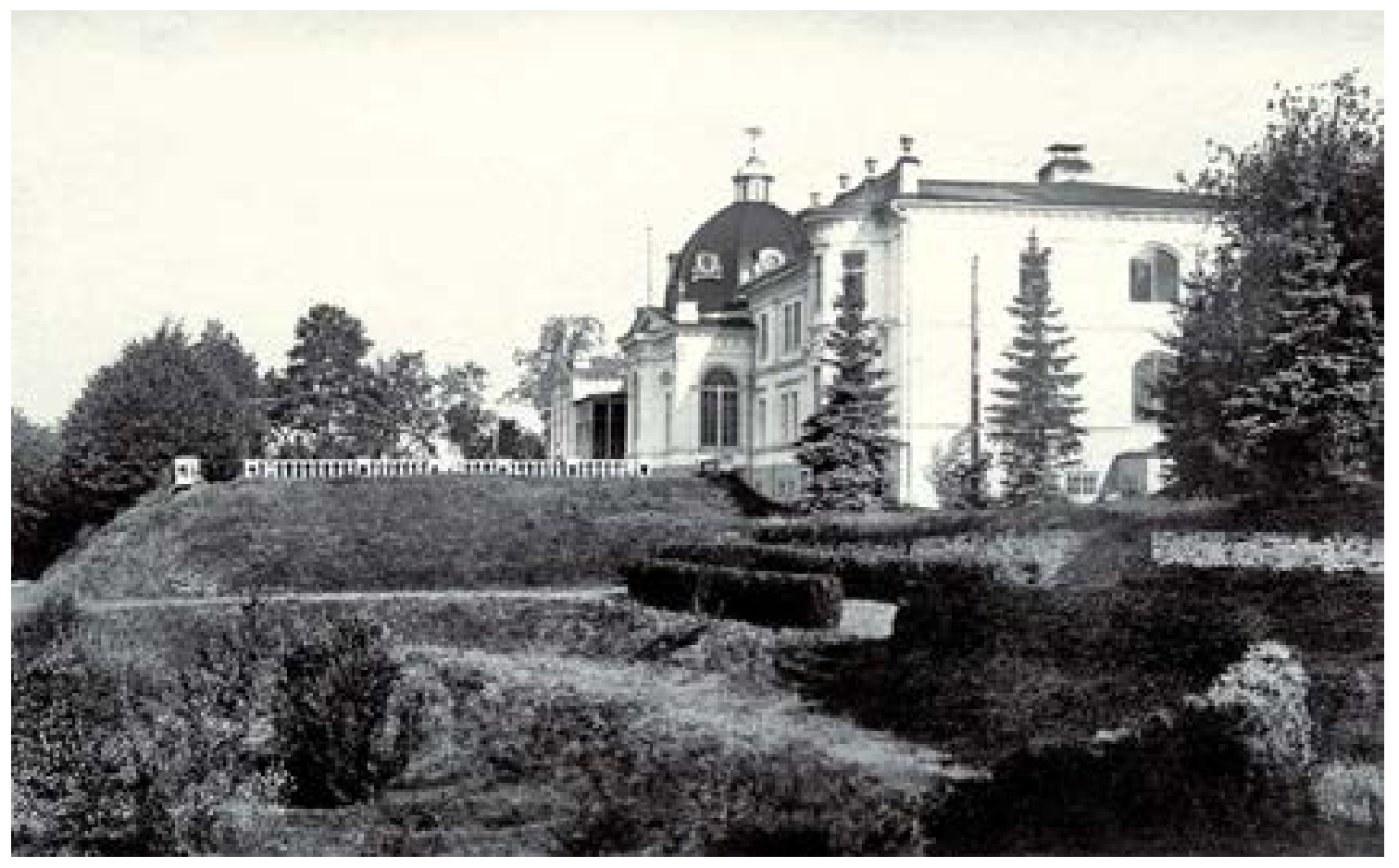

Muun perheen muutettua Suomeen ja asetuttua aluksi asumaan Espoon pappilaan Granö vietti kesän 1922 Raadin kartanossa Tarton lähistöllä. Hän johti edelleen Viron kotiseudun- ja kaupunkitutkimustyötä mutta aloitti myös Suomen Kartaston kolmannen laitoksen suunnittelun.

tämässään kortissa Granö kuvaa siirtymävaihetta, jota leimasivat alituinen kiire ja matkustelu Helsingin ja Tarton välillä:

No niin, täällä ollaan - toisella jalalla. Professuurista en ole vielä päässyt, pari kertaa täytyy talven kuluessa Tartossa käydä, mutta vuoden kuluttua toivon lopullisesti vapautuvani. Täällä juoksen ja hääräilen kaikenmoisissa Fenniaaskareissa, niin etten ehdi nyt Sinullekaan, veljelleni maantieteessä ja parem- 
massakaan kunnollista kirjettä kokoonpanna. Jonkun viikon kuluttua helpottaa ehkä hiukan. ${ }^{481}$

"Granö takaisin Suomeen" -operaatio eteni ratkaisevasti helmikuun 23. päivänä 1923, jolloin hän sai nimityksen Helsingin yliopiston maantieteen ylimääräiseksi professoriksi. Nimitystä edelsi tiukka kilpailu, jota kiristi nopeasti kuumentuvan yliopiston kielikiistan ohella tutkimusrahoituksen niukkuudesta kärsivien tieteenalojen kamppailu kaivatuista lisäresursseista. Suomalaisen perinnöllisyystieteen perustajana pidetyn Harry Federleyn saatua toisen eduskunnan myöntämästä kahdesta virasta toisen kärkiehdokkaiksi nousivat yliopiston rehtorin Hugo Suolahden kannattama kielitieteilijä Arthur Långfors, Granön vanha kilpakumppani, edellisen rehtorin Ivar August Heikelin suosikki kirjallisuuden tutkija Gunnar Castrén ja luonnontieteilijöiden varsin yksimielisesti tukema Granö. ${ }^{482}$

Granön asemaa pian ykkösehdokkaaksi noussutta Castrénia vastaan heikensi sekä neljä vuotta kilpakumppania lyhyempi dosentuuri että maantieteen vain vajaat pari vuotta aiemmin saama vastaava professuuri. Ilmeisesti juuri Leiviskän virka vaikutti siihen, että konsistorin äänestys päättyi ennakkokaavailujen mukaisesti: Castrén 23, Granö 18 ja Långfors 7 ääntä. Näin konsistori päätti esittää Castrénin valitsemista henkilökohtaiseksi ylimääräiseksi professoriksi. ${ }^{483}$

Asia ei kuitenkaan ratkennut konsistorin äänestykseen vaan virantäytöstä päätti lopullisesti Kyösti Kallion marraskuussa 1922 virkaan astunut vähemmistöhallitus. Pääosin maalaisliiton ja edistyspuolueen edustajista muodostunut hallitus ei hyväksynyt konsistorin esittämää ehdollepanoa vaan halusi ratkaista nimityksen itse. Asiaan vaikutti suomen kielen huono asema yliopistossa. Vaikka ylioppilaista yli kolme neljännestä oli suomenkielisiä, enemmistö professoreista luennoi yhä ruotsiksi. ${ }^{484}$

Kielikysymyksen ohella Granön asema paransi se, että asian esitellyt opetusministeri Niilo Liakka ja valtioneuvoston istuntoon osallistunut Helsingin yliopiston kansleri Anders Donner kannattivat voimakkaasti hänen nimittämistään. Altain tutkijan saavutuksiin jo sukuyhteyksiensä ansiosta hyvin perehtynyt Donner totesi lau- 


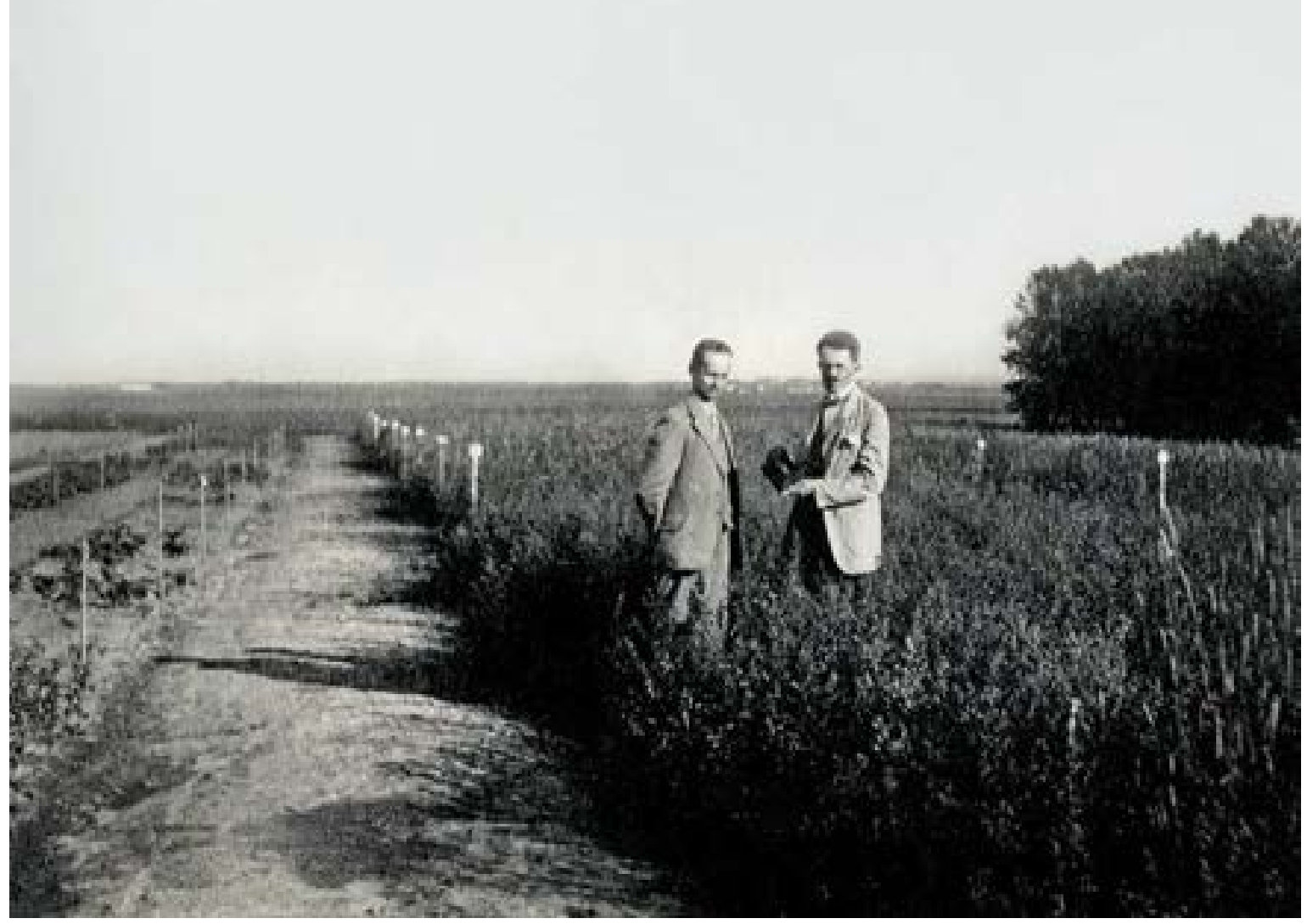

Granön asuinkumppani Raadin kartanossa oli kasvinviljelyn professori Kaarlo Teräsvuori (vasemmalla). Kartanon mailla oli Tarton yliopiston maatalouskoelaitos.

sunnossaan muun muassa, että fyysis-matemaattiset tieteet tarvitsivat tieteenalojen tasa-arvon vuoksi uusia virkoja ja että Granö oli ainakin yhtä oppinut tutkija kuin Castrén. Hän oli lisäksi kyennyt työllään ja tutkimuksillaan osoittamaan, että maantiede todellakin oli itsenäinen tiede, mikä ei ollut Donnerin mukaan ollut näihin päiviin saakka aivan selvä asia. ${ }^{485}$

Konsistorin ehdollepano ei kestänyt Granön kannattajien vyörytystä. Kallion hallituksen käsitellessä asiaa 19. tammikuuta ja 22. helmikuuta 1923 vain maalaisliittoon kuulunut ruotsalaismielinen oikeusministeri Otto Åkesson kannatti Castrénia muiden ministereiden tukiessa Granön nimitystä. Tämä johti siihen, että tasavallan 
presidentti K. J. Ståhlberg nimitti 23. helmikuuta 1923 hänet Harry Federleyn tavoin henkilökohtaiseksi ylimääräiseksi professoriksi. ${ }^{486}$

Nimityksen jälkeen Granö anoi heti vapautta Tarton yliopiston professuurista ja alkoi siirtää Virossa hoitamiaan tehtäviä muiden käsiin. Seuraajakysymys yliopiston maantieteen laitoksen johdossa ratkesi siinä mielessä hänen toivomallaan tavalla, että professoriksi nimitettiin unkarilainen Mihály Haltenberger. Hän julkaisi muun muassa joitakin talousmaantieteellisiä kuvauksia Viron kaupungeista ja perusti julkaisusarjan Publicationes Instituti Universitatis Dorpatensis (Tartuensis) Geographici series. ${ }^{487}$

Haltenberger ei osannut viroa, joten hän ei kyennyt luomaan läheisiä yhteyksiä virolaisiin vaikuttajiin eikä myöskään kouluttamaan itselleen oppilaita. Granön mielestä hän oli kuitenkin parempi valinta kuin Eduard Markus. Tämä oli Granön mukaan kansakouluopettajatyyppiä, "jonka sielun syvyyksissä on mitä hämmästyttävin tietämättömyyden pimeys", joten hänestä yliopisto ei olisi saanut muuta kuin harmia. ${ }^{488}$

Jyrkkä luonnehdinta johtui siitä, että vaikka Granö arvosti suuresti Markuksen pietarilaista opettajaa L. S. Bergiä, hän ei tullut toimeen oppilaan kanssa. Antipatia perustui ainakin osin miesten välisiin tieteellisiin näkemyseroihin, sillä Markus arvosteli ankarasti Granön ja hänen virolaisten oppilaittensa tutkimuksia. Vaikka Markus ei saanut aluksi Tartossa tieteellistä hyväksyntää, hänestä kehittyi Bergin tutkimusten soveltajana 1930-luvulla edelläkävijä maiseman alueellista muuttumista selvittävälle suunnalle. ${ }^{489}$

Neuvostoliiton miehitettyä Viron Markus siirtyi Saksan kautta Yhdysvaltoihin, jossa hän ansaitsi pääasiallisen toimeentulonsa kanafarmarina ennen kuin osin Granön tuella sai koulutustaan vastaavia tehtäviä. Granön poika Olavi Granö kiinnitti huomiota Markuksen teorioihin omissa tutkimuksissaan 1950-luvulta alkaen, mutta esimerkiksi Yhdysvalloissa niitä ryhdyttiin soveltamaan vasta 1980-luvulla maisemaekologisen tutkimuksen yleistyessä. ${ }^{490}$ 


\section{Jäähyväisluento Tartossa}

Granön uurastus Tarton yliopiston professorina jatkui kevätlukukauden 1923 loppuun, jolloin hän piti 14. toukokuuta 1923 yliopiston täydessä juhlasalissa jäähyväisluentonsa "Maastik ja ümbrus" (Maisema ja ympäristö). Luento osoitti, että kaiken muun työn ohessa hän oli jatkanut tiiviisti sekä maisematieteen teorian että aluejakometodin kehittämistä. ${ }^{41}$

Granö aloitti luentonsa maantieteen olemuksen määrittelyllä. Hän katsoi Immanuel Kantin ja Alfred Hettnerin tavoin, että eri tieteet hahmottivat ihmistä ympäröivää todellisuutta eri näkökulmista. Eräät keskittyivät todellisuuden laadulliseen vaihteluun (niin sanotut laatutieteet), toiset ajalliseen (kronologiset tieteet) ja kolmannet alueelliseen vaihteluun (korologiset tieteet). Maantiede kuului korologisiin tieteisiin, mutta sille ei ollut ominaista vain alueellinen näkökulma, vaan myös alueellisuuden yksilölliset ilmentymät, maisematieteelliset yksiköt. Siksi maantiede oli nimenomaan maisematiedettä. ${ }^{492}$

Käsitteeseen "maisema" sisältyi sekä näkymä että havaitsija, mutta lisäksi sillä oli tilaan liittyvä ulottuvuus. Huone, jossa ihminen asui ja jonka hän näki, ei ollut maisema, ei myöskään pieni metsäalue. Maisema oli havaitsijaa ympäröivä näköpiiri. Havaitsijan siirtyessä paikasta toiseen myös näköpiiri liikkui, maisema muuttui ja vaelsi eli oli mahdollista puhua vaeltavista maisemista. Jos näillä vaeltavilla maisemilla oli yhtenäinen luonne, ne voitiin kartografisesti ikään kuin kiinnittää maapallon pinnalle enemmän tai vähemmän yhtenäisiksi alueiksi. Tällöin havaitsijan sijainnilla ei enää ollut ratkaisevaa merkitystä, vaan maisema oli tietty maankamaran osa, alueellinen yksikkö, jolla oli vain sille luonteenomaiset, näköaistin avulla määritellyt maisemalliset ominaisuudet. ${ }^{493}$

Granön ratkaisu muodostaa alueita yksinomaan ihmisten maisema-aistimusten perusteella poikkesi aiemmasta tutkimuksesta, sillä perinteiseen Landschaft-käsitteeseen sisältyi sekä konkreettinen, maapallon pintaan rajattu alue että subjektiivinen visuaalinen ympäristö, maisema. Tämä ero selittyi osin kielellisten syiden perusteella. Saksan ja ruotsin kielissä Landschaft- ja landskap-käsitteet merkitsivät sekä maisemaympäris- 
töä että maantieteellistä aluetta (maakuntaa), kun taas esimerkiksi suomen, englannin ja ranskan kielissä maisemalla, landscape, paysage, tarkoitetaan nimenomaan näkemällä havaittavaa ympäristöä, ilman rajattua aluetta osoittavaa merkitystä. Esimerkiksi Suomen luonnon suuri kuvaaja Z. Topelius käytti maisemista harvoin käsitettä landskap, useimmiten ilmaisuna oli utsigt, toisinaan myös totalbild, vy tai scen. ${ }^{494}$

Maapallon pinta koostui Granön mukaan usein monimutkaisesti rakentuneista maisemista. Nämä maisemat olivat tietyllä tavalla eliöitä, joita oli mahdollista tutkia yksikköinä sekä yleis- että erikoistieteen näkökohdista. Tämä luonnollisesti edellytti yksiköiden mahdollisimman tarkkaa rajaamista, jonka toteuttamista varten oli luotu kaksi menetelmää:
a) Passargen kehittämä menetelmä, jossa otettiin huomioon myös sellaiset tekijät, jotka eivät olleet maisemassa suorastaan vaikuttavina (kuten maannos tai ilmasto) tai
b) Viron maisemien rajaamisessa käytetty menetelmä, jossa aluksi määriteltiin pysyvien, olennaisten ja näkyvien maisemallisten tekijöiden alat ja sitten niiden perusteella rajattiin omaleimaiset alueet. ${ }^{495}$

Viron menetelmässä maisemien määrittelyä ja nimeämista seurasi niiden ryhmittely jonkin tietyn luonteenomaisen ilmiön perusteella. Tämän jälkeen ryhdyttiin selvittelemään maiseman olemusta eli tutkittiin sen ulkoasu, muoto, levinneisyys ja syntyhistoria siten, että päähuomio kiinnitettiin nykyisen maisemakuvan syntyyn, ei niinkään yksittäisten muotojen geologiseen kehitykseen. Maiseman synty ei aina ollut hidas prosessi, vaan joskus se saattoi olla romahdusmaisen nopea (maajäristykset, tulivuorenpurkaukset). Näissä tapauksissa voitiin Granön mukaan puhua maisemien aukeamisesta.

Maisematieteen kehittäminen tälle asteelle oli vienyt Virossa kaksi vuotta, mutta sitten oli ajauduttu ongelmiin. Tämä oli Granön mukaan johtunut pääosin siitä, että vaikka monet maantieteen kansainväliset auktoriteetit olivat painottaneet maiseman merkitystä, kukaan ei ollut määritellyt selkeästi sen olemusta. ${ }^{496}$ 
Yleisen ja hyväksytyn teorian puutteen vuoksi tarttolaisten maantieteilijöiden oli täytynyt ryhtyä itse etsimään vastauksia kahteen pääongelmaan: Oliko maantieteen otettava huomioon näkemisen ohella myös muut aistit ja sisällytetäänkö maisemaan myös sen henkinen olemus. Vastausten etsiminen näihin kysymyksiin oli johtanut Granön mukaan siihen, että hänen vain pari vuotta aiemmin esittämänsä näkemykset maisematieteestä olivat vanhentuneet täysin.

Ratkaisevinta oli ollut sen tosiasian ymmärtäminen, että jos tavoitteena oli muodostaa kokonaiskuva tietyn alueyksikön olemuksesta, maisema-käsitettä oli joko laajennettava tai sitten oli kehitettävä kokonaan uusi käsite. Koska maisema oli joka tapauksessa määriteltävä näköaistin välityksellä - sitä ei voinut kuulla tai haistaa - oli luotava uusi tarkka maantieteellinen käsite - lähiympäristö eli miljöö. Se oli ihmisen lähin ympäristö, jonka hän koki kaikilla aisteillaan. ${ }^{497}$

Granö valaisi asiaa esimerkillä. Kun ihminen seisoi jollakin avaralla kentällä, näkyvä maisema ympäröi häntä laajalti joka puolella, mutta aivan hänen lähiympäristössään oli maisemaa pienempi kaikkien aistien välityksellä havaittava miljöö. Maiseman lailla myös miljöö vaihtui sitä mukaa kuin ihminen liikkui, ja vaeltava miljöö vaihtui luonnollisesti huomattavasti useammin kuin vaeltava maisema. Tämä antroposentrisyys katosi kuitenkin heti, kun havaittu maisema tai miljöö kiinnitettiin kartografisesti maanpinnalle.

Maantieteilijä tutki siis tieteensä yleis- ja erikoisosassa maisemaa ja miljöötä. Hän määritti sekä miljöön että maiseman tyypit: Jos ihminen katsoi esimerkiksi Itä-Venäjän tai Länsi-Siperian avaraa aromaisemaa, se vaihtui vuodenajoittain mutta oli kuitenkin yksitoikkoinen. Sen sijaan miljöön suhteen vaihtelua oli, kuten kavioeläinten lauma, paimentolaisten leiri, jyrsijöiden ja leivosten liike ja postivaunujen eteneminen. Viidakossa, tuuheassa himmeässä sademetsässä, oli omaleimainen miljöö mutta ei kunnolla avautuvaa maisemaa, samoin Tarton kaupungissa, jossa jalankulkijoiden ja ajoneuvojen liikkeet ja kaikki muut kaupunkielämän ilmiöt aiheuttivat sen, että miljööt olivat yleensä maisemaa vaihtelevampia ja dynaamisempia. 
Vaikka miljööt vaihtelivat suuresti, joitakin yleislajeja oli mahdollista erottaa. Ulkomiljöissä havaitsijan yllä oli taivaankansi, kun taas sisämiljöissä katto tai tiheä puun latvus. Liikkuvat miljööt erosivat liikkumattomista, muuttuvat muuttumattomista ja luonnonmiljööt tekomiljöistä. ${ }^{498}$

Granön mukaan oli luonnollisesti selvää, että miljöötutkimuksen tehtävä oli laaja ja siihen liittyi paljon ongelmia. Yksi keskeinen kysymys oli, kuinka laaja miljöö saattoi olla. Täsmällisen vastauksen antaminen oli hänen mielestään vaikeaa, koska tilanteet vaihtelivat. Joka tapauksessa alueen täytyy olla sellainen, että ihminen kykeni kokemaan sen kaikin aistein.

Vaikka miljöö oli maantieteilijöille tutkimuskohteena pääosin uusi ja epämääräinen käsite, kirjailijoille ja runoilijoille se oli aina ollut läheinen. Samoin matkakirjallisuus ja maantieteelliset lukemistot olivat kiinnittäneet paljon huomiota miljööseen, kun taas maisema oli ollut tieteellisten tutkimusten kohteena. Tämä merkillinen ero matka- ja tiedekirjallisuuden välillä kuvasti Granön mukaan parhaiten nykyisen maantieteellisen tutkimuksen vajaavaisuutta. ${ }^{499}$

Granön mukaan maiseman ja todellisuuden välisen tyhjän paikan täyttäminen toteutui vasta, kun miljöö oli otettu mukaan maantieteelliseen tutkimukseen. Ratkaisu laajensi ja syvensi maantiedettä asettaen sen rinnalle samansuuntaisen ympäristötieteellisen tutkimuksen. Kun maantieteen tehtävät tulivat näin kasvamaan, oli välttämättä erikoistuttava ja supistettava tutkimusalaa. Näin kannatti kuitenkin Granön mukaan tehdä, sillä uuden tutkimuskohteen ansiosta vastakohtaisuudet yleis- ja erikoismaantieteen välillä hävisivät ja "uuden maantieteen kaunis, sointuisa ja suurenmoinen rakenne ja sen kaunis ydin kirkastuvat yhä enemmän”. ${ }^{500}$

Jäähyväisluentoa leimasi tilaisuuteen kuuluva retoriikka, mutta se kertoi myös Granön tinkimättömästä pyrkimyksestä rakentaa maantieteelle aukoton teoreettinen järjestelmä ja looginen metodi. Hänen teoreettisen päätyönsä Pubtaan maantieteen perusteemat rakentuivat siten jo Tarton yliopistossa. ${ }^{501}$

J. G. Granön kolmatta vuotta kestänyt toimikausi Tartossa oli päättynyt. Hän palasi Suomeen eikä enää koskaan käynyt Emäjoen kulttuurikaupungissa. Tästä 
huolimatta Tartto ja Viro olivat hänelle läheisiä koko loppuelämän. Tartossa hahmottuneet ajatukset olivat tärkeitä hänen kehittäessään maantiedettä Helsingin ja Turun yliopistoissa, ja siellä aloitetut luennot, seminaarit ja harjoitustyöt jatkuivat muuntuneina Suomenlahden pohjoispuolelle.

Myös Tartossa Granötä muisteltiin lämmöllä. Viron Kirjallisuuden Seuran kotiseuduntutkimuksen toimikunta ja Tarton kaupunginhallitus myönsivät läksiäisiksi hänelle kunniakirjan, ja Viron opetusministeriö kiitti häntä perustan laskemisesta maan kotiseuduntutkimukselle. Vuonna 1932 Viron Kirjallisuuden Seura ja Luonnontutkijoiden Seura valitsivat Granön kunniajäsenekseen ja 1933 hänelle myönnettiin Tarton yliopiston kunniatohtorin arvo..$^{502}$

Granön muutettua Suomeen hänen ympärilleen muodostunut virolais-suomalainen maantieteellinen koulukunta alkoi jakaantua. Suomessa jatkettiin töitä maisemakuvauksen ja maantieteellisen aluejaon ja myöhemmin myös kaupunkitutkimuksen aloilla. Virossa puolestaan keskityttiin erityisesti kaupunkitutkimukseen, josta versoi ihmisen elinympäristön toiminnallisten suhteiden tutkimus.

Granön työ loi perustan maantieteen vahvalle asemalle Tarton yliopistossa. Kunnioittaakseen perustajansa työtä maantieteen laitos nimesi loppuvuonna 2010 luentosalin, jossa hän piti luentonsa 90 vuotta aiemmin, Johannes Gabriel Granön mukaan. $^{.03}$ 


\section{TIETEEN TEKIJ Ä JA NÄKIJ $\ddot{A}$}

V

"Kun nyt kerran on joutunut vakinaiseksi, tahtoisi mieluimmin keskittää

voimansa yliopistolliseen ja tieteelliseen toimintaan. Kartastohomma on liikaa, mutta näyttää pimeältä sopivan henkilön löytäminen.”504 


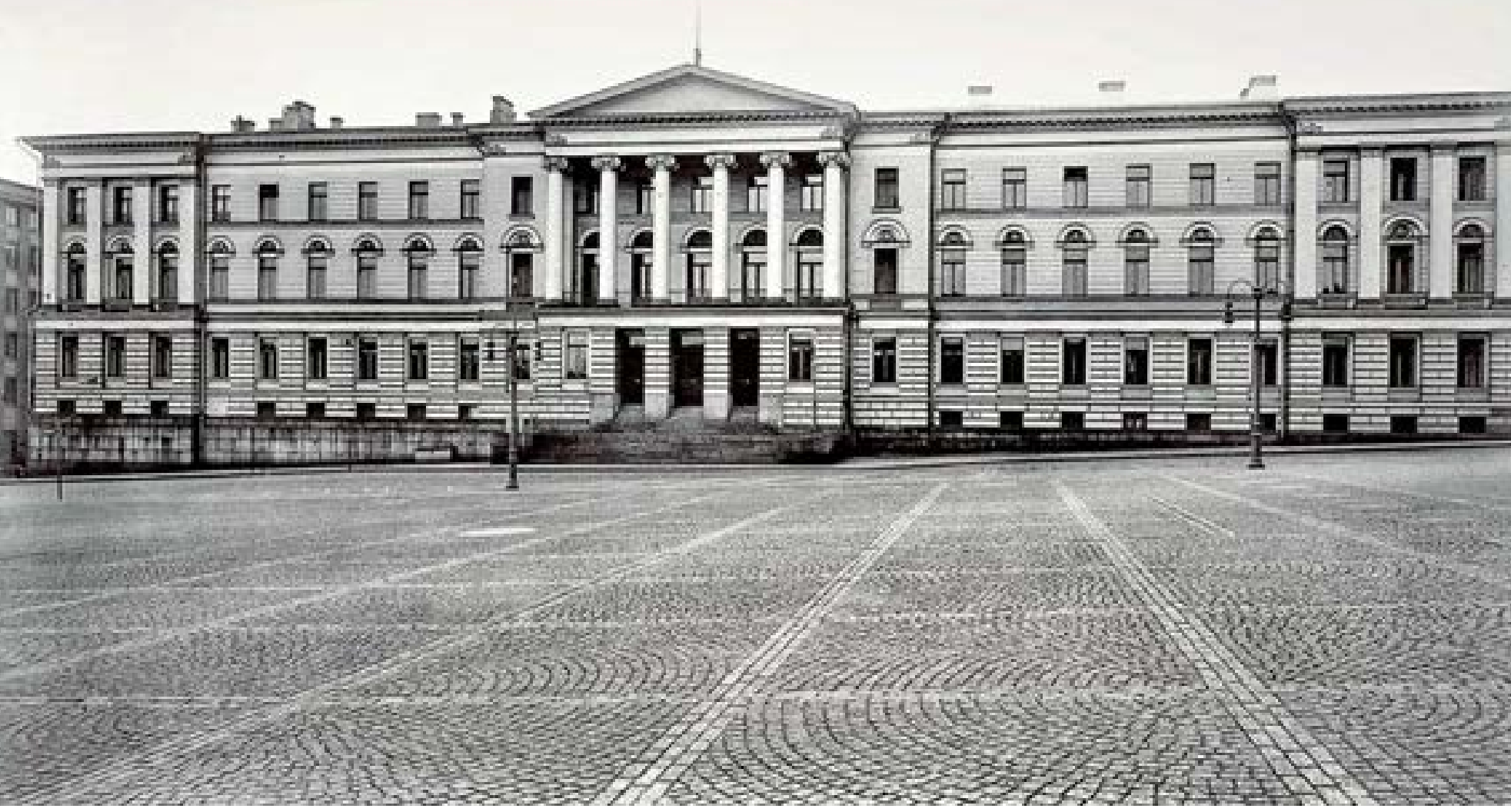

Carl Ludvig Engelin suunnittelema Helsingin yliopiston päärakennus valmistui 1832. 


\section{HeLSingin yLiopiston professori}

\section{Maantieteen laitoksen työnjako}

Helsingin yliopiston maantieteen laitoksella toimi keväällä 1923 kolme professoria, vakituinen J. E. Rosberg sekä ylimääräiset Iivari Leiviskä ja J. G. Granö. Lisäksi sen opetushenkilökuntaan kuuluivat assistentti, filosofian maisteri Wilho Sjöström, amanuenssi, kasvitieteen dosentti Ernst Häyrén ja dosentiksi helmikuussa 1922 nimitetty Väinö Auer. ${ }^{505}$

Opettajakunta oli tieteellisesti pätevää ja laaja-alaista, sillä professorien monipuolista geomorfologian ja kasvimaantieteen tietämystä täydensivät hyvin Auerin suotutkimukset ja Häyrénin saariston vyöhykkeisyyttä ja jätevesien ympäristövaikutuksia selvittäneet työt. Ilmapiiri ei kuitenkaan ollut paras mahdollinen, koska tutkijat kilpailivat keskenään tieteellisistä meriiteistä ja harvoista viroista. Suhteiden yleisluonnetta voi kuvata siten, että Rosberg tuli toimeen kaikkien kanssa, kun taas Leiviskä ei juuri kenenkään kanssa. Työt oli kuitenkin hoidettava, joten muodollisesti asiat sujuivat. ${ }^{506}$

Professorien työnjako muodostui sellaiseksi, että Rosberg luennoi pari kertaa viikossa kahden tunnin ajan ruotsiksi pääosin eri maanosien maantieteestä ja karttaopista sekä piti luentojen yhteydessä seminaariharjoituksia. Lisäksi hän ohjasi harjoitustöitä neljästi viikossa. Leiviskän suomenkieliset luennot käsittelivät laajasti maantieteen eri osalohkoja. Hänen aiheinaan olivat muun muassa yleis- ja talousmaantiede, geomorfologia ja Fennoskandian pinnanmuodot sekä arktiset alueet ja Välimeren maat. Hän johti myös kenttämittaustöitä ja retkeilyjä. ${ }^{507}$

Granö puolestaan luennoi suomen kielellä matemaattisen maantieteen, kartografian ja aluetieteen perusteista, valtiollisesta ja talousmaan-

Helsingin yliopiston maantieteen laitoksen piirustus- ja kokoelmahuoneita Fabianinkatu 22:ssa. 


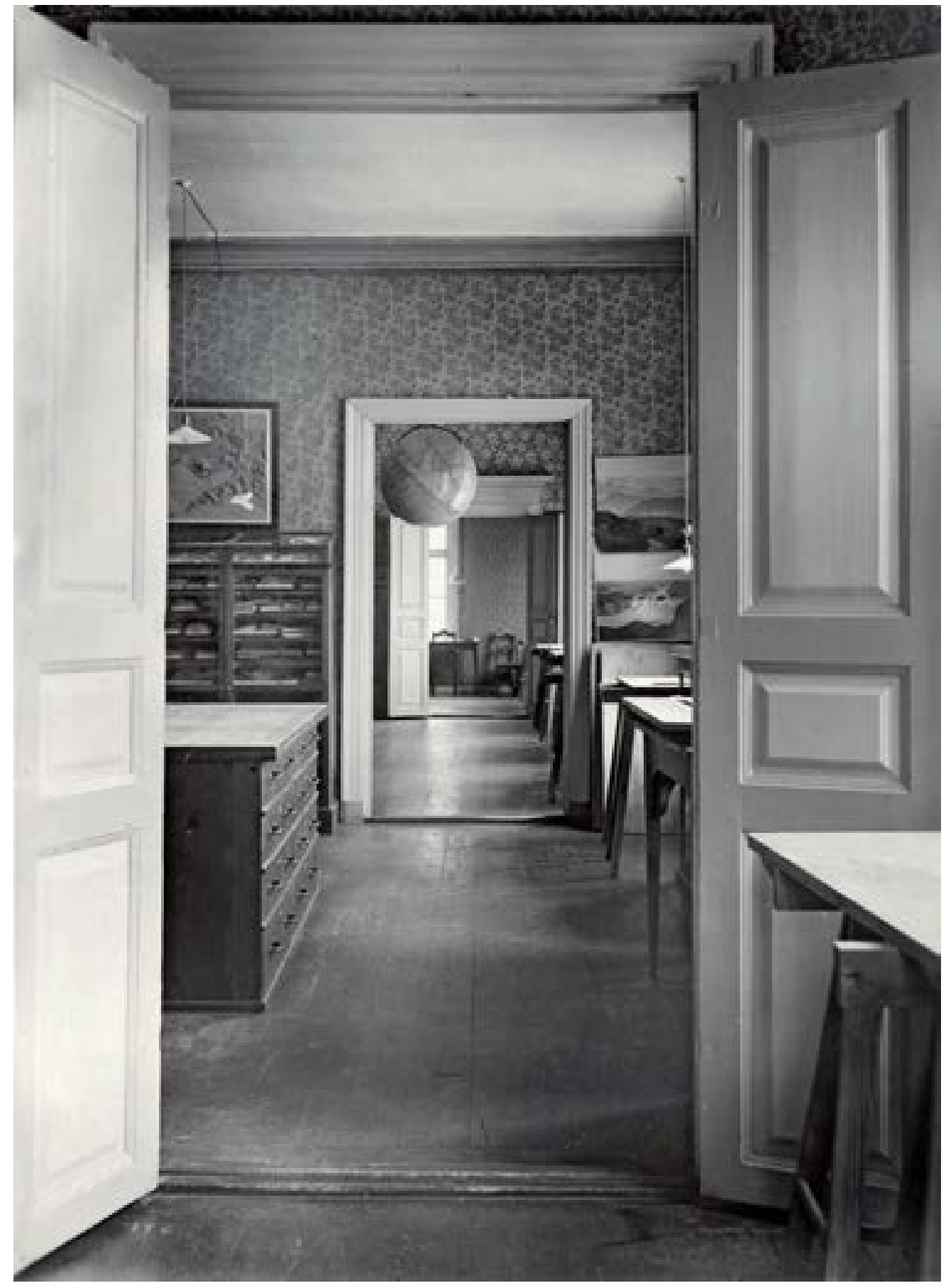




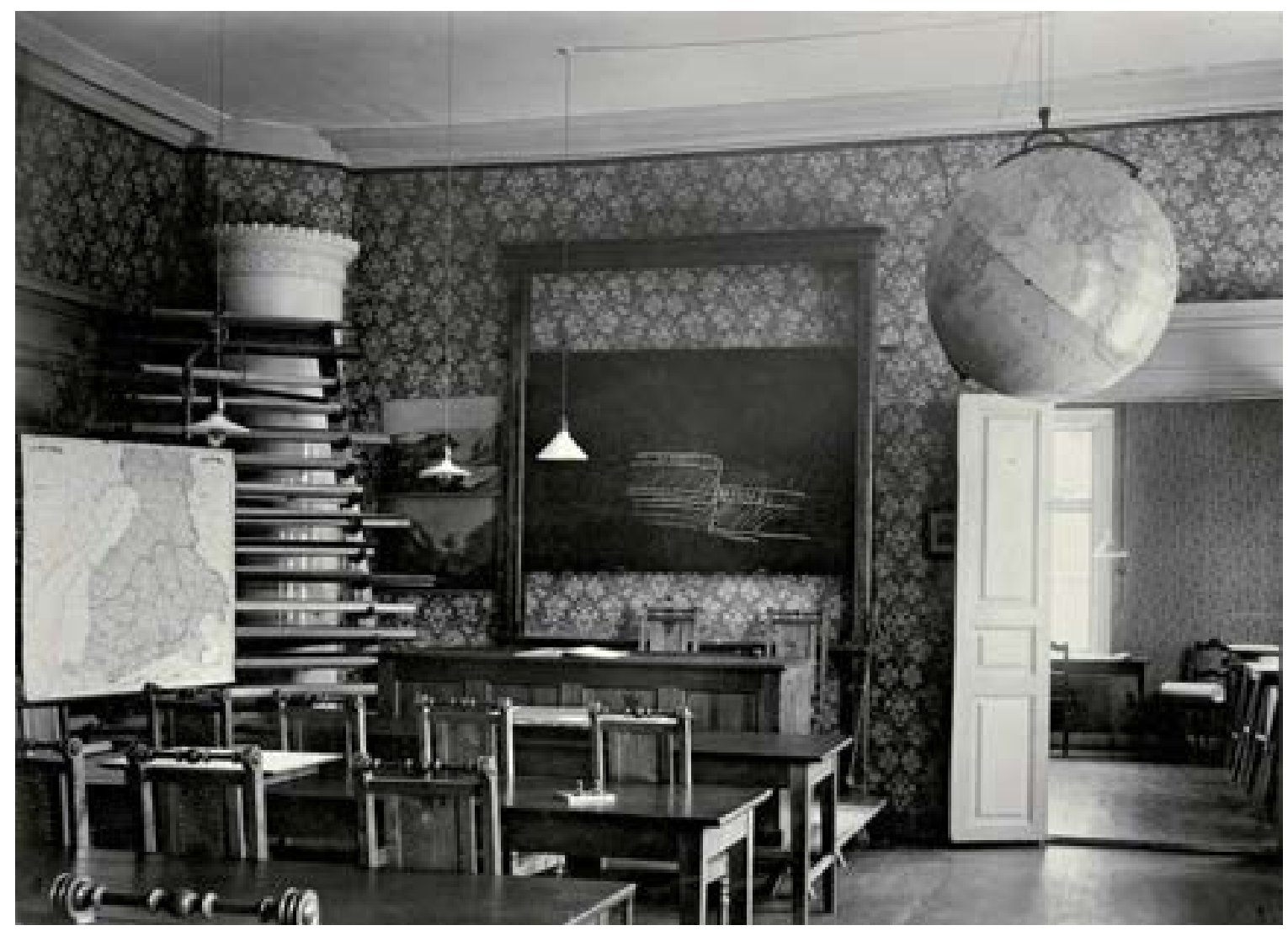

Maantieteen laitoksen luentosali.

tieteestä, maisematieteen alkeista sekä maantieteen olemuksesta ja tehtävistä. Hän osallistui myös seminaariharjoitusten ja kartografisten töiden ohjaamiseen. Dosentti Auer luennoi suomeksi ihmis- ja eliömaantieteen perusteista ja suomorfologiasta ja yleensä soista. Lisäksi hän osallistui professorien kanssa maantieteen peruskurssin opettamiseen..$^{508}$

Granö oli hoitanut ylimääräistä professuuriaan vain vajaan vuoden, kun hänet kutsuttiin yllättäen helmikuun alussa 1924 maantieteen vaihtuvan professorin vir- 
kaan. Nimitys liittyi edellisenä kesänä annettuun lakiin Helsingin yliopiston järjestysmuodon perusteista, jonka mukaan yliopistossa oli annettava opetusta sekä suomen- että ruotsinkielellä suhteessa näitä kieliä puhuvien opiskelijoiden määrään. Lain tavoitteiden toteuttamiseksi perustettiin yhdeksän vaihtuvaa professuuria aloille, joilla oli paljon suomenkielisiä opiskelijoita. ${ }^{509}$

Konsistorin pohtiessa tammikuun 19. päivänä 1924 professuurien täyttämistä luonnontieteilijöiden valintaan vaikutti ratkaisevasti fyysis-matemaattisen osaston esitys, jossa suositettiin petrologian ja mineralogian, matematiikan ja maantieteen professuurien perustamista. Osasto katsoi, että Pentti Eskola ja J. G. Granö voitaisiin nimittää hakemuksetta petrologian ja mineralogian sekä maantieteen professoreiksi, kun taas matematiikan professuuri olisi julistettava haettavaksi. Granön kannalta myönteinen esitys perustui J. E. Rosbergin ja Wilhelm Ramsayn laatimaan lausuntoon, jossa hänet asetettiin "erittäin etevänä" Leiviskän edelle niin tieteellisesti kuin opetuksellisestikin..$^{510}$

Granön tieteelliset näytöt toivat hänelle myös Suomen Tiedeseuran (1922) ja Suomalaisen Tiedeakatemian jäsenyyden (1924), mutta menestys ei herättänyt kilpailuhenkisessä yliopistoyhteisössä pelkästään hurraa-huutoja. Erityisen katkerasti kollegan urakehitykseen suhtautui Iivari Leiviskä, joka katsoi, että hänet oli sivuutettu viran täytössä kielipoliittisin ja muin asiattomin syin.

Leiviskän mukaan professorit Ramsay ja Rosberg olivat muotoilleet nimityksen ratkaisseen fyysis-matemaattisen osaston lausunnon siten, että se korosti Granön ansioita ja vastaavasti vähätteli hänen saavutuksiaan. Leiviskän todettiin muun muassa saaneen ylimääräisen professuurinsa pääosin pitkän dosenttiaikansa ja maantieteen opettajavoimien puutteen ansiosta, kun taas Granön nimityksen taustalla olivat hänen saavutuksensa tutkijana ja akateemisena opettajana. ${ }^{11}$

Leiviskä oli menettänyt luottamuksensa Ramsayhin jo aiemmin, sillä hän katsoi tämän vaikuttaneen ratkaisevasti hänen ensimmäisen väitöskirjansa hylkäämiseen vuodenvaihteessa 1906. Nyt hän koki, että molemmat lausunnonantajat olivat syyllistyneet totuuden vääristämiseen. Hän valitti asiasta, mutta päätös ei muuttunut.. ${ }^{512}$ 
Tapahtumien kulku ei miellyttänyt Granötä, joka ymmärsi, että hän tulisi varmasti saamaan osansa hävinneen kollegan kiukusta. Tämän vuoksi hän oli prosessin aikana tähdentänyt Rosbergille, että Leiviskän olisi saatava professuuri ennen häntä, koska tämä oli dosenttina vanhempi. Ratkaisun jälkeen J. K. V. Tuomiselle lähettämässään kirjeessä hän totesi, että hänet tehtiin
vakinaiseksi professoriksi tavalla, joka ei minua miellyttänyt ja joka sai veljemme Iivarin aivan suunniltaan. Olisihan virka voitu julistaa haettavaksi / jolloin ei sitä olisi tarvinnut hakea/, tai olisi edes voitu pyytää ulkomaisten asiantuntijain lausuntoa meistä kahdesta... Sanottakoot kuitenkin, että persoo- nalliset välini Iivarin kanssa eivät ole rikkoutuneet, mikä ei tietysti estä häntä asettamasta itselleen päämääräksi "granölaisen suunnan" murskaamisen. ${ }^{513}$

Granön arvio osoittautui oikeaksi. Leiviskä suhtautui Granöhön virkatehtävissä ja julkisessa kanssakäymisessä pidättyvän asiallisesti, mutta tieteellisessä keskustelussa hän asettui vastustamaan jyrkästi oikeastaan kaikkea, mitä tämä esitti.

Kun Granö oli pitänyt 7. toukokuuta 1924 virkaanastujaisluentonsa aiheesta "Ympäristö maantieteen tutkimusesineenä", hän saattoi vannoa konsistorin istuntosalissa virka- ja tuomarivalan ja asettua paikalleen muiden professorien joukkoon. Uuden vakinaisen professorin ensimmäisiä merkittäviä tehtäviä oli toimia tunnetun unkarilaisen maantieteilijän kreivi Pál Telekin ja professori Károly Kogutowiczin johtaman 30-henkisen maantieteilijäretkikunnan tieteellisenä oppaana matkalla Suomen läpi etelästä pohjoiseen. Pääkaupungista unkarilaiset vietiin Viipuriin, Saimaalle, Heinäveden reittiä Kuopioon, Iisalmelle, Kajaaniin ja edelleen Oulujoen koskia laskemaan. Oulusta matka jatkui Rovaniemelle ja Sodankylään ja sieltä Petsamoon ja Salmijärveltä Norjan puolelle. ${ }^{514}$

Osanottajat olivat hyvin tyytyväisiä retkeen, mikä johti siihen, että monet heistä olivat myöhemmin vilkkaassa kirjeenvaihdossa Granön kanssa. Ollessaan Unkarin opetusministerinä Teleki valmisteli 1930-luvun lopulla vierailua Suomeen esittäen 
kollegalleen Uuno Hannulalle, että Granö toimisi vierailun aikana hänen lähimpänä miehenään. Granö lupasi ottaa tehtävän vastaan, mutta matka ei toteutunut koskaan. Euroopan ajauduttua sotaan pääministeriksi 1939 kohonnut Teleki riisti itseltään hengen huhtikuun 1941 alussa vastustaakseen Saksan vaikutusvallan kasvua Unkarissa. ${ }^{515}$

\section{Talvet Helsingissä, kesät maalla}

Granöt muuttivat syksyllä 1922 takaisin Pohjoisen Rautatiekatu 11:n asuntoon, jossa he asuivat seuraavat neljä vuotta. Ratkaisu oli varsinkin perheen naisväen mieliin, sillä taloudenhoito sujui Helsingissä huomattavasti helpommin kuin Tarton alkeellisissa oloissa. Helsingissä perheen lapsiluku kasvoi vielä yhdellä, kun neljäs lapsi ja samalla ensimmäinen poika, Olavi, syntyi toukokuussa 1925:

Olisin Sinulle jo aiemmin kirjoittanut, mutta minä kun tässä kesken kaikkea ja ikämiehenä sain perheenlisäyksen, pikku pojan, niin ymmärrät, että muu askartelu on jäänyt hiukan syrjään. Lapsukainen syntyi 27.V. ja täyttää siis huomenna ensimmäisen kuukautensa. Toistaiseksi on kaikki niin kuin olla pitää, mutta onhan sitä, eritoten äidillä, puuhaa öin ja päivin, vaikka poika onkin rauhallinen. ${ }^{516}$

Perheen vuosirytmi sujui vanhaan malliin. Syksyt, talvet ja keväät asuttiin kaupungissa perheenpään keskittyessä viranhoidon vaatimiin velvollisuuksiin ja muihin tieteellisiin tehtäviin, joista varsinkin talvisaikaan kahdesti kuukaudessa kokoontuneen Suomen Maantieteellisen Seuran sihteerin toimi vei paljon aikaa. Myös Suomen Kartaston vaatimat karttatyöt olivat niin vaativat, että niitä oli tehtävä myös kodin työhuoneessa iltaisin ja viikonloppuisin.

Tieteelliset tehtävät rasittivat Granötä niin paljon, että hän ei enää halunnut suunnata voimiaan erilaiseen aatteelliseen työhön ja yhdistystoimintaan. Sen sijaan 


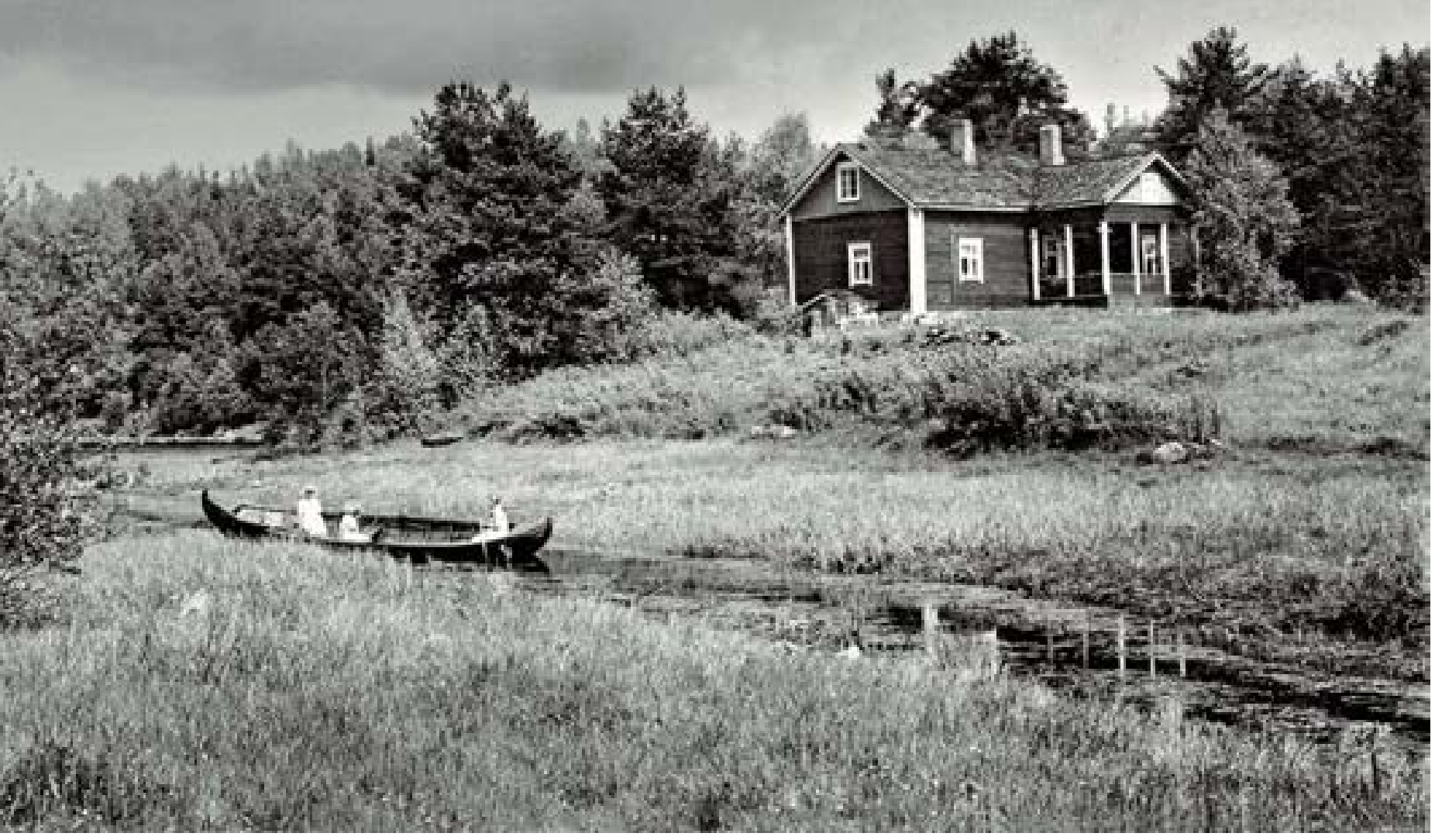

Granön tyttäret veneessä kapeassa salmessa, taustalla näkyy Valosaaren huvila.

perheen sosiaalinen elämä oli yhä varsin vilkasta. Sukulaisten kanssa oltiin tiiviisti yhteydessä, ja läheinen ystäväpiiri koostui pääosin yliopiston professoreiden perheistä. Luotetuimpana ystävänä säilyi J. K. V. Tuominen.

Kesäkuukausiksi Granöt muuttivat edelleen maaseudulle. Muutot merkitsivät kaupunkimukavuuksista luopumista ja asettumista usein varsin alkeellisiin oloihin, mutta perhe katsoi, että vaatimatonkin mökki veden äärellä oli sentään kesäkuumalla toista kuin tunkkainen kaupunkimiljöö. Erityisesti perheenpää oli eri linjoilla kuin humanistiprofessori Arthur Långfors, joka oli kerran jyrkästi julistanut: ”Kesällä asuvat ihmiset kaupungissa ja lehmät asuvat maalla!"517 


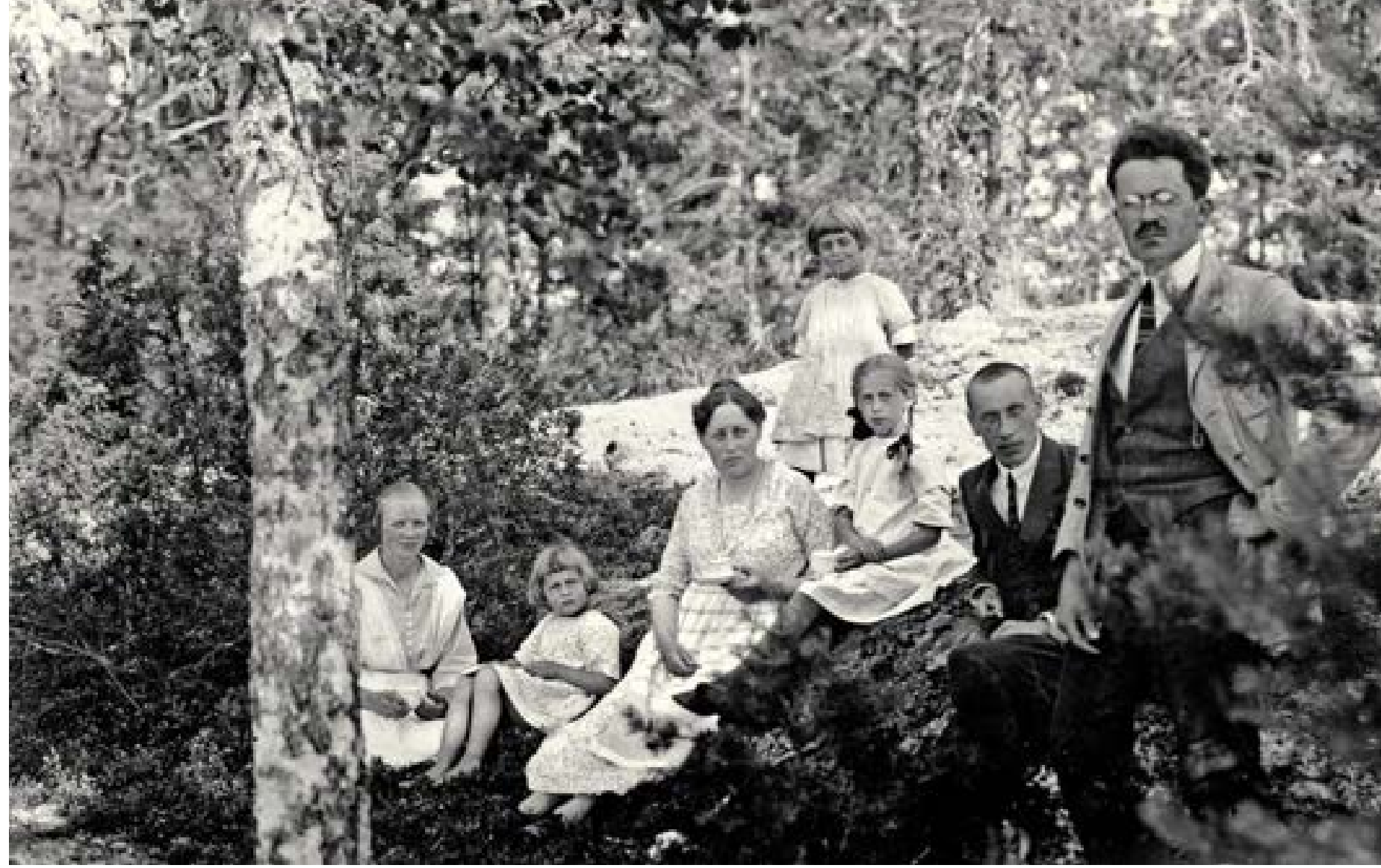

August Tammekann kävi tapaamassa opettajaansa Valosaaressa.

Oikealta J. G. Granö, Tammekann, Hilma Granö ja tytöt sekä kotiapulainen.

Kesinä 1923 ja 1924 perheen lomanviettopaikkana oli pieni Valosaari Suomen järvialueella, hieman yli 10 kilometriä Mikkelistä kaakkoon. Granö nautti suuresti suomalaisesta järviluonnosta ja hyvästä mahdollisuudesta harrastaa lempipuuhaansa kalastusta, joka tuotti lähes joka aamu runsaasti mustaniskaisia haukia ja raitapaitaisia ahvenia. Silti hän ei malttanut vain lomailla, vaan paneutui alkukesän täydellisen levon jälkeen jälleen myös tutkimustyöhön.

Niin antoisaa aikaa kuin Valosaaren kesät olivat olleetkin, Granö kaipasi pysyvää kesäpaikkaa, jonne hän olisi voinut palata vuodesta toiseen. Siksi hän pani 
varhaiskeväällä 1925 sanomalehteen ilmoituksen, jossa perheelle haettiin kesäasuntoa Helsingin lähettyviltä. Tarjolle tuli useita hyviä vaihtoehtoja, mutta Granöt tarttuivat jo yhteen ensimmäisistä. Valituksi tuli reilut
Granö oli koko elämänsä ajan intohimoinen kalastaja.

Myös Valosaaressa kalastus kuului päivittäiseen ohjelmaan. 20 kilometriä Porvoon keskustasta etelän työntyvän

Tirmon niemimaan kärjessä ollut huvilamallinen talo, jossa oli kolme huonetta ja keittiö alakerrassa ja kaksi kesähuonetta yläkerrassa, kaikki tyydyttävästi kalustettuja. Vuokranantajat - isäntä emäntineen - asuivat kesäajan pienoisessa mökissä pihamaan toisella puolella. ${ }^{518}$

Uudella kesänviettopaikalla oli monia etuja. Luonto huvilan ympärillä oli puhdasta ja vaihtelevaa ja tarjosi hyvän lähtökohdan monenlaisille kasvi- ja maisematieteellisille retkeilyille. Meren puolelta huvilaa suojasi saaristo, pohjoisessa tiheä kuusimetsä. Lähin laivalaituri oli vain parinkymmenen minuutin soutumatkan päässä, Vähä-Pellingissä. Sieltä pääsi joka arkipäivä höyrylaiva Lovisalla Helsinkiin ja kaupungista takaisin vielä samana päivänä, sillä matka kesti vain kolme tuntia. ${ }^{519}$

Varsinkin J. G. nautti siitä, että lähistön merenlahdet olivat kalaisia. Hänestä kehittyi Tirmossa niin taitava kalastaja, että lähiseudun asukkaat epäilivät hänen käyttävän jonkinlaisia ihmekeinoja kalojen narraamiseen. Kysymys ei ollut kuitenkaan taikuudesta vaan tieteellisessä työssä hyviksi havaittujen analyyttisten periaatteiden noudattamisesta:

Verkkokalastuksesta on minulla se kokemus - sanon tämän, koska kirjeessäsi pohdit kysymystä, mihin verkko on kulloinkin pantava - että verkko on laskettava sinne, missä vesi kulloinkin on lämpöisintä, lämpiminä päivinä ja tuulen ollessa rantaan päin siis lähelle rantaa, ilman jäähtyessä ja tuulen ollessa ulapalle käsin (jolloin kylmempi pohjavesi nousee rantaan) kauemmas. Voi olla, että tämä "työhypoteesini” on väärä, mutta toistaiseksi en tiedä parempaakaan esittää. Tämänmukaisesti valitsen onkipaikkanikin. Sellaisina helteisinä päivinä kuin nämä nyt meille siunautuneet, lähden ennen auringon laskua 


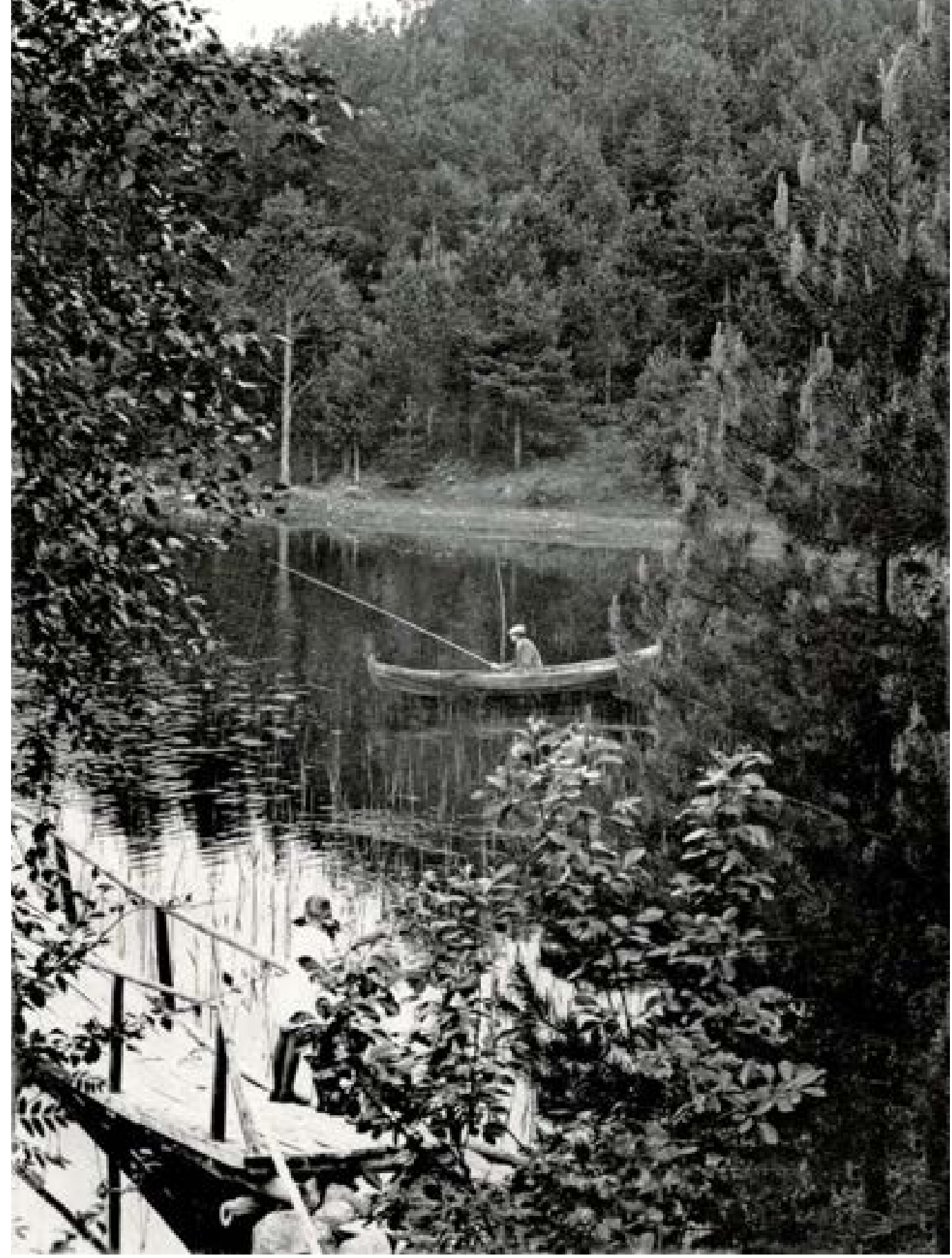

HELSINGIN YLIOPISTON PROFESSORI V 271 
ongelle kivenheiton päähän omasta laituristamme, potamogeton-vyöhykkeen sisäreunaan; jos on kylmempi ja rauhattomampi sää, ongin reimarien luona, missä on vettä $4-5$ metriä.. ${ }^{520}$

Runsaat kalansaaliit johtivat siihen, että kesäisin meren antimet täyttivät useimmiten herrasväen ruokapöydän. Lapset saivat syödä kalaa kyllästymiseen saakka, ja myös perhettä auttaneet tilapäistyöntekijät tuskastuivat ajoittain siihen, ettei ruokalistalla ollut juuri mitään muuta kuin kalaa eri muodoissa. Kuurilla saattoi olla oma vaikutuksensa siihen, että Olavi Granö ei enää jakanut isänsä ja isoisänsä innostusta kalastamiseen..$^{21}$

Granöt viihtyivät Tirmon huvilallaan alusta alkaen niin hyvin, että se pysyi perheen yhteisenä kesänviettopaikkana muutamia kesiä lukuun ottamatta vuoteen 1956 saakka. Perheen isän kuoltua äiti Hilma ja Aune ja Eeva viettivät kesät siellä vuoteen 1965 saakka, jolloin tyttäret hankkivat oman tonttinsa saman kylän mailta. ${ }^{522}$

Olavi Granö tuli ensimmäisen kerran huvilalle kahden viikon vanhana vauvana ja vietti siellä siitä lähtien kesiään, vuodesta 1953 alkaen myös puolisonsa Eevan kanssa, kunnes he muuttivat 1967 läheltä hankkimaansa omaan huvilaan. Pellingin kaunis saaristo tarjosi hänelle paitsi hyvän miljöön kesäisille veneretkille myös tieteellisen tutkimuskohteen. Olavi Granön 1955 ilmestynyt saksankielinen väitöskirja käsitteli Porvoon edustan saaristorannikon luontoa ja taloutta sovitettuna alueelliseen vaihettumis- ja vyöhyketeoriaan. ${ }^{523}$ 


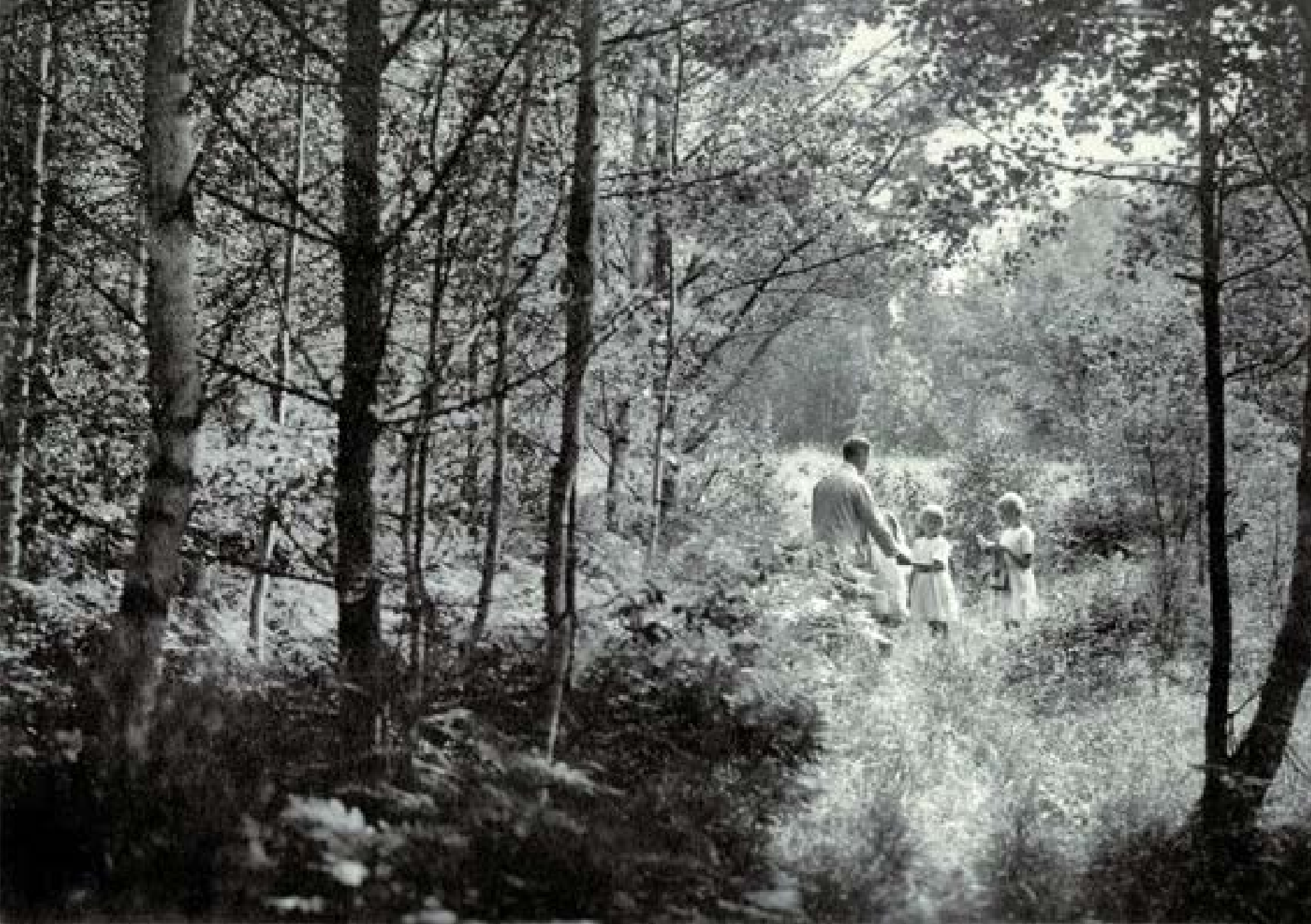

J. G. Granö ja tytöt Valosaaren koivikossa 1924.

Helsingin yliopiston professori $V 273$ 


\section{Suomen Kartaston toimitustyö}

Ottaessaan vastaan Suomen Kartaston kolmannen laitoksen toimitustyön Granö ei osannut arvata, kuinka mittavan hankkeen vetämiseen hän oli sitoutunut. Hän aloitti kartaston valmistelutyöt ollessaan maantieteen dosentti, joten aluksi hän saattoi käyttää melkoisesti työajastaan karttatöihin. Perustyöt saatiin valmiiksi vuoden 1923 alkuun mennessä. Tuolloin lyötiin lukkoon kartaston alustava jäsennys, sovittiin eri virastojen ja asiantuntijoiden kanssa karttojen sisällöstä ja aloitettiin peruskarttojen valmistaminen. ${ }^{524}$

Työn suunnittelusta vastanneen Merentutkimuslaitoksen johtajan, professori Rolf Wittingin, johtaman toimitusvaliokunnan tavoitteena oli saada aikaan kartasto, joka antaisi mahdollisimman luotettavan kuvan Suomen luonnosta, väestöstä sekä talous- ja sivistyselämästä 1920-luvulla. Siksi kartastosta poistettiin edellisissä laitoksissa olleet historiallis-geologiset, arkeologiset ja historialliset kartat, samoin kaupunkeja esittävät karttalehdet, ja päähuomio suunnattiin olemassa olevien olojen kuvaamiseen. Kartasto oli tarkoitus julkaista suomen-, ruotsin- ja englanninkielisenä. ${ }^{25}$

Nopeasti tapahtuneet professorinimitykset asettivat Granön vaikeaan tilanteeseen. Hän olisi halunnut keskittää voimansa yliopistolliseen ja tieteelliseen toimintaan, mutta katsoi, ettei hänellä ollut oikeutta jättää kartaston toimitustyötä, sillä hänen korvaajakseen ei ollut tarjolla sopivaa henkilöä. Kysymys oli täysin Granön velvollisuudentunnosta, sillä toimitustyöstä Maantieteelliseltä Seuralta saamastaan kuukausipalkasta hän luopui maaliskuun ensimmäisestä päivästä 1923 alkaen saatuaan nimityksen maantieteen ylimääräiseksi professoriksi. ${ }^{526}$ 
Kartaston alkuperäinen valmistumisaikataulu osoittautui aivan liian toiveikkaaksi. Tämä johtui osin siitä, että kartastoon otettiin mukaan uusia aihekokonaisuuksia, jotka edellyttivät pitkällisiä alkuvalmisteluja ja laajoja kartografisia esitöitä. Osin viivästyminen johtui Maanmittaushallituksen ja F. Tilgmann Oy:n kivipainoissa tehtyjen töiden paljoudesta sekä taloudellisten ja henkilöstöresurssien vähäisyydestä.

Kartasto sai 1923 valtionapua vain 60000 markkaa, josta piti maksaa piirtäjien palkkaus, kartakkeiden painatus sekä toimittajan palkka vuoden kahden ensimmäisen kuukauden osalta. Seuraavana vuonna valtion tuki nousi 200000 markkaan, mutta rahatilanne pysyi kireänä vapaaehtoisten yhteistyökumppaneiden vähälukuisuuden vuoksi. Granö toivoi, että sama isänmaallinen henki, joka oli synnyttänyt edelliset kartastot, olisi edelleen ollut niin paljon voimissaan, ettei ihan kaikesta työstä olisi pyydetty korvausta. Toive ei aina toteutunut, sillä tutkijakunnan talous oli niin tiukalla 1920-luvulla, ettei kaikilla ollut varaa talkootöihin. ${ }^{527}$

Toimitusvaliokunta ymmärsi nopeasti, että kartaston ilmestyminen tulee viivästymään usealla vuodella. Teoksen otsikko päätettiin kuitenkin pitää ennallaan, koska suuri osa käytetystä aineistosta oli peräisin vuoden 1925 tienoilta. Viivästyminen koski eniten Granöhön, jonka omat työt jäivät kartastokiireiden varjoon. Hänen työtaakkaansa lisäsi se, että hän oli ottanut vastuulleen kasvillisuuden ja asutuksen jakautumista sekä maantieteellisiä alueita kuvaavat kartat, jotka kuuluivat kartaston suuritöisimpiin mutta samalla myös tieteellisesti merkittävimpiin saavutuksiin. ${ }^{528}$

Koska kartaston valmistuminen oli suurelta osin Granön varassa, hänen työpaineitaan pyrittiin helpottamaan eri tavoin. Vuoden 1924 lopulla hänen tuekseen pestattiin toimitussihteeriksi maisteri Rafael E. Rehn, ja Suomen Maantieteellinen Seura vapautti hänet sihteerin tehtävistä vuoden kahden viimeisen kuukauden ajaksi. Yliopiston konsistori puolestaan myönsi hänelle vapauden kahden luentotunnin 
pitämisestä kevätlukukauden 1924 ja syyslukukauden 1925 aikana kartaston toimitustöiden ja siihen tulevien karttojen laatimisen vuoksi. ${ }^{529}$

Vuoden 1925 loppuun mennessä kartaston valmistuminen oli edennyt niin pitkälle, että 26 sen kaikkiaan 38 karttalehdestä oli toimitettu kivipainoon. Kun kartaston valmistuminen näytti olevan enää kiinni onnistuneesta loppurutistuksesta, Maantieteellinen Seura pyrki tukemaan Granön työmotivaatiota taloudellisin kannustein. Se myönsi vuoden 1926 alusta sihteerille 6000 markan vuotuisen palkkion ja kartaston toimittajalle 1000 markan palkkion kuukaudessa sen kuukauden loppuun saakka, jolloin kartasto oli valmistunut. ${ }^{530}$

Granölle kysymys ei kuitenkaan ollut rahasta. Vuoden 1925 lopulla hän ilmoitti Maantieteelliselle Seuralle haluavansa päästä seuraavan vuoden alusta eroon joko Seuran sihteerin tai Kartaston toimittajan tehtävästä. Hän perusteli esitystään toteamalla, että näiden tehtävien hoito ja hänelle uskotut kartografiset työt olivat vaatineet niin paljon odotettua enemmän aikaa, ettei hän kyennyt hoitamaan virkavelvollisuuksiaan tyydyttävällä tavalla. Seura suostui myöntämään Granölle vain vuoden virkavapauden sihteerin tehtävästä. ${ }^{531}$

Tilanne kuitenkin muuttui tammikuun 1926 lopussa, jolloin Granö sai kutsun Turun Suomalaisen Yliopiston maantieteen professoriksi. Granön muutettua Turkuun Seura myönsi hänelle syksyllä eron sihteerin tehtävästä mutta sai hänet jatkamaan kartaston toimittajana. Toimitussihteeri Rafael E. Rehnin erottua keväällä Granön aputoimittajaksi nimitettiin syyskuussa maisteri Osmo H. Porkka, joka vastasi käytännön toimitustyöstä Helsingissä. Porkka sai työstään 2000 markan kuukausipalkkaa Granön jatkaessa päätoimittajana palkatta. ${ }^{532}$

Työt etenivät vuoden 1926 aikana niin hyvin, että toimitusvaliokunta toivoi, että kartasto olisi ilmestynyt kevään 1927 aikana. Kun tämä aikataulu ei pitänyt, Suomen Maantieteellinen Seura asetti tavoitteekseen esitellä kartasto seuraavana vuonna suuressa kansainvälisessä maantieteilijäkongressissa Cambridgessä Englannissa. Seuran johtomiesten suureksi harmiksi tämäkään tavoite ei toteutunut viimeisten karttojen painatuksen ja tekstin viimeistelyn viivästymisen vuoksi. Kartasto valmistui lopulta 
Kustannusosakeyhtiö Otavan kustantamana 1928, ja tekstiosa ilmestyi vasta maaliskuussa $1929 .{ }^{533}$

Kun suuri urakka oli saatettu kunnialla loppuun, Granö sai ravistettua painavan taakan harteiltaan. Tiettyä ylpeyttä tuntien hän päätti kartaston johdannon sanoihin, jotka viittasivat teoksen kahtalaisiin päämääriin: "Olkoon tämä teos isänmaalle hyödyksi ja todistakoon osaltaan muille kansoille, mitä Suomi on.”534

Uusi kartasto sai hyvän vastaanoton kotimaassa ja ulkomailla. Kaarlo Linkola katsoi kartaston olevan ainoa lajiaan karttakirjallisuudessa. Ruotsalaiset Sten De Geer ja Helge Nelson totesivat sen antavan monipuolisen kuvan Suomen maantieteellisistä oloista ja esittävän useita kartografisesti uusia ratkaisuja. Hans Schrepferin mukaan saksalaisilla ei ollut esittää yhtä merkittävää kartastoa, jonka sisältö vastasi itse asiassa moniosaista ensyklopediaa. Myös kartaston värinkäyttö arvioitiin sekä tieteellisesti että esteettisesti korkeatasoiseksi, mikä osoitti, että Granö kiinnitti jatkuvasti huomiota töidensä taiteelliseen puoleen. ${ }^{535}$

\section{Maisematieteen perusteiden luominen}

Kun Granön tukijat puuhasivat hänelle professuuria Helsingin yliopistoon, heidän tavoitteenaan oli luoda hänelle olosuhteet, joissa hän olisi voinut keskittyä työstämään Venäjän ja Mongolian tutkimusmatkoillaan keräämäänsä havaintomateriaalia. Tavoite ei onnistunut, sillä Granö katsoi, että maantieteen asema oli Helsingin yliopistossa niin huono, että hänen täytyi jatkaa Tartossa aloittamaansa teoreettista kehitystyötä. Hänen tavoitteen oli luoda maantieteelle itsenäinen oppirakennelma, joka erotti sen muista tieteistä.

Granö aloitti Helsingissä uusien oppien julistamisen heti saatuaan nimityksen Suomen Maantieteellisen Seuran sihteeriksi. Seuran kokouksessa marraskuun 17. päivänä 1922 pitämässään puheessa hän totesi, että maisematiede ei ollut maantieteen osa. Päinvastoin uudenaikaisen maantieteen tuli olla maisematiedettä, jossa johdonmukaisesti pyrittiin omaleimaisten maantieteellisten alueiden rajaamiseen 
ja niiden olemuksen kaikinpuoliseen selvittelyyn. Tämä merkitsi sitä, että maantiede ei esiintynyt enää vain entisestään paljon rajoitetumpana, vaan myös "metodisesti täysin selväpiirteisenä ja erittäin itsenäisenä tieteenä.".536

Granö joutui aloittamaan suomalaisen maisematieteen luomisen Viron tapaan aivan alusta. Kun hän ryhtyi syyskuun alussa 1923 laatimaan luentojaan maisematieteen perusteista, hän huomasi, ettei suomenkielistä maisematieteellistä sanastoa ollut oikeastaan lainkaan ja myös ruotsinkielinen sanasto oli hyvin puutteellista. Tämän vuoksi hänen ensimmäiseksi tehtäväkseen tuli alan keskeisen sanaston luominen. ${ }^{537}$

Granö ymmärsi, että kyseessä oli liian suuri urakka yhden miehen tehtäväksi. Hän otti aluksi yhteyttä Väinö Aueriin ja Matti Sauramoon, jotka tunsivat jo ennestään hänen maisematieteelliset tutkimuksensa ja tavoitteensa. Neuvottelujen jälkeen miehet perustivat erityisen sanastovaliokunnan, jonka kielitieteelliseksi asiantuntijaksi kutsuttiin maisteri Y. H. Toivonen, etevä etymologi ja tuleva Suomen Akatemian jäsen. Sanastovaliokunta kokoontui kaksi kertaa viikossa ja sai syksyn aikana määrätyksi huomattavan osan maisematieteen keskeisestä sanastosta, muun muassa tärkeimmät yleiskäsitteet sekä maanpinnan ja veden muodot. ${ }^{538}$

Varsinaisten jäsenten lisäksi sanastovaliokunnan työhön osallistuivat professorit Pentti Eskola, Iivari Leiviskä, U. T. Sirelius ja filosofian tohtori Ernst Häyrén, jotka vaikuttivat asiantuntemuksellaan sanojen valintaan. Suuri osa maisematieteen sanoista oli tavallisia sanoja (kuten tekijä, muoto, jono, laakso, vesi, joki, sade ja pilvi), mutta niiden merkitys oli usein muotoiltu täsmällisemmäksi kuin jokapäiväisessä kielenkäytössä. Päävastuun uusista "sanakeksinnöistä ja -tekaisuista" kantoivat Granö ja Toivonen, jotka sommittelivat esimerkiksi kasvillisuuden muotojen, rakennusten ja niiden muoto-osien, asumusten ja kylien eri tyyppien nimitykset sekä joitakuita muita yksittäisiä termejä. ${ }^{39}$

Uusia sanoja luodessaan Granön ja Toivosen pääkriteereinä olivat selvyys, täsmällisyys sekä lyhyys ja mahdollisimman suuri tukeutuminen suomen kielen omiin sanavaroihin. Murteellisetkin sanat pyrittiin soveltamaan käyttöön ja siten rikastuttamaan kieltä. Jos oma sanavarasto ei riittänyt, turvauduttiin uusiin johdannaisiin, 
yhdyssanoihin ja kuvainnollisiin nimityksiin. Luonnollisesti mahdollisuuksien mukaan käytettiin entisiä maantieteen ja muiden tieteiden suomenkielisiä oppisanoja.

Monet uusista sanoista, kuten kohouma, laskeuma, laakio, kero, kuru, kuuluma, näkymä ja autiomaa, tulivat myöhemmin yleiseen käyttöön, jotkut, kuten lähiö, tosin toisessa merkityksessä, asumalähiönä. Sen sijaan esimerkiksi vuorimaata korkeampaa aluetta merkitsevä ylhiömaa, seutua pienempää aluetta tarkoittava seuduke ja lähiötä vastaava kohdake sekä pinnanmuotoja kuvaavat termit nyhä, purto, kehlo tai kulpannepatamo-onsilo eivät jääneet elämään. ${ }^{540}$

Samaan aikaan kun Granö kehitti talvisin maisemamaantieteen suomenkielistä sanastoa, kesäisin hän jatkoi Mikkelin Valosaaressa Virossa aloittamaansa maisemien hahmottamiseen soveltuvan metodin kehittämistä. Pääosin alava saari tarjosi hyvät edellytykset erityisesti lähiötieteellisen tutkimuksen kehittämiseen. Saari oli Saimaan pinnan laskemisen vuoksi kasvamassa yhteen sen länsipuolella olleen Puuskansaaren ja mantereen kanssa, mutta sen ohitti vielä kapea vesiuoma, joka toimi kesäisin veneväylänä ja talvisin talvitienä. Seutu oli tyypillistä Saimaan viljelyaluetta, perinteisen huvila-asutuksen leimaamaa harju- ja järvimaisemaa. Luonto oli monipuolista kasvistoltaan ja eläimistöltään.

Granön tavoitteena oli luoda menetelmiä, joiden avulla voitiin selvittää, miten luonnossa oleva, liikkuva ja toimiva ihminen koki eri aistein lähiympäristönsä. Siksi hän paneutui Valosaaressa muun muassa ihmisten, kulkuvälineiden ja karjan liikkumisen, valon ja ilmaston maisemallisen vaihtelun sekä erilaisiin ääniin. Lisäksi hän valokuvasi ahkerasti ja teki niin paljon lähiympäristön havaitsemiseen liittyviä karttoja ja profiileita, että kutsui saarta myöhemmin "Puhtaan maantieteen syntymäsijaksi”. ${ }^{441}$

Granön esitteli Valosaaren maisematutkimustensa tuloksia ja sanastoryhmän töitä vuoden 1923 lopulla Suomen Maantieteellisen Seuran kokouksessa pitämässään esitelmässä, jonka aiheena oli "Maantieteen lähiympäristöstä ja sen kartografisesta käsittelystä". Diapositiivein elävöitetty esitelmä sisälsi niin paljon uutta asiaa, että Granö epäili aiheellisesti, miten hänen sanomaansa suhtaudutaan: "Nousin suurella 


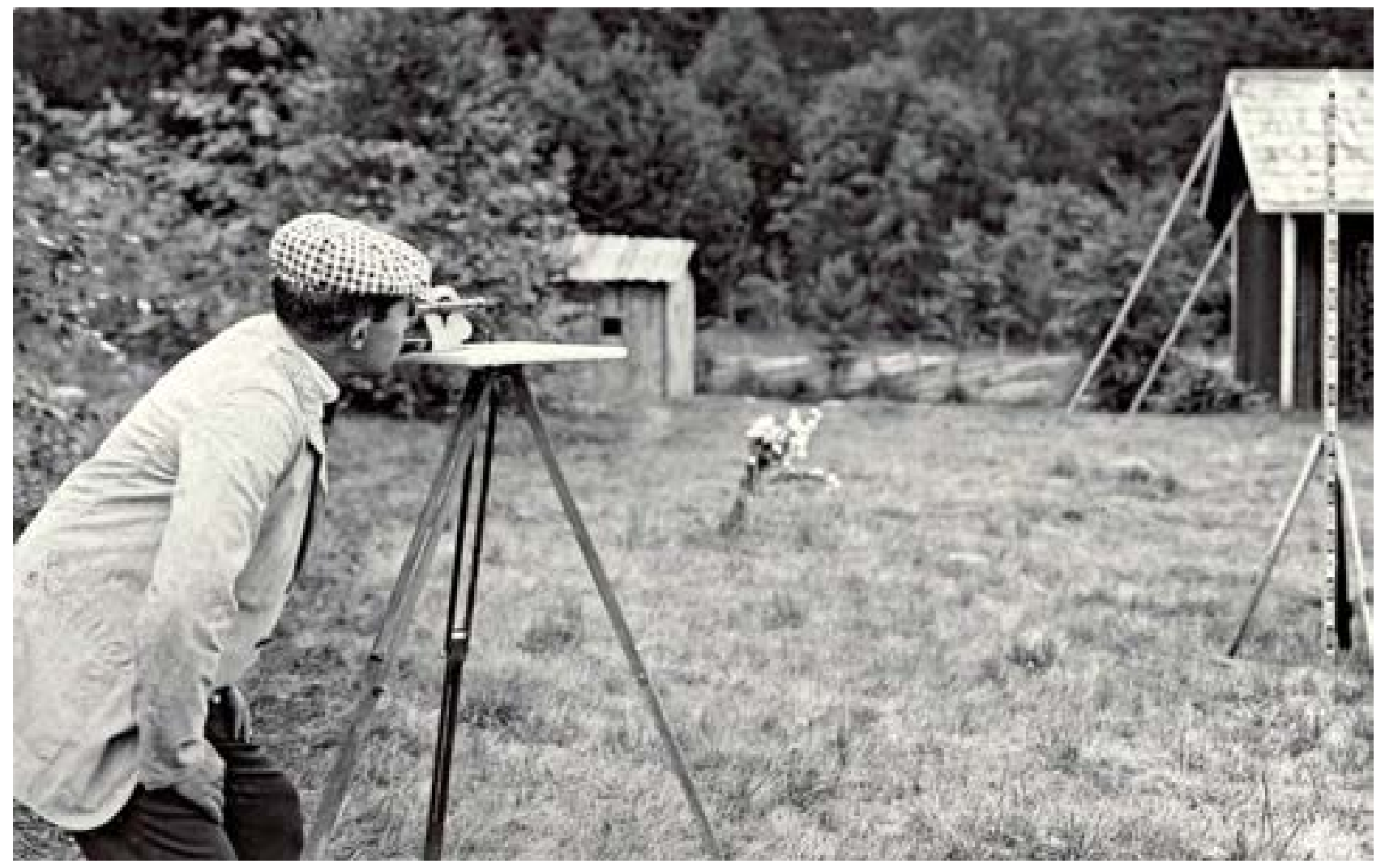

Valosaaressa kehitetty lähiötiede edellytti tarkkoja maastomittauksia.

pelolla ja vapistuksella puhumaan Korkean Raatin eteen, sillä ajatelin että Ramsay y.m. eivät ollenkaan voisi oppiani sulattaa." ${ }^{542}$

Vaikka puheen sisältö ei varmasti ollut sitä, mitä monet kuulijat olisivat odottaneet Altain pinnanmuotojen tutkijalta, sen välitön vastaanotto oli myönteinen. Seuran puheenjohtaja Wilhelm Ramsay piti "koetta” erittäin mielenkiintoisena ja onnistuneena, mutta muut kuulijat tyytyivät vain nyökyttämään päätään ja taputtamaan hillitysti. Granön yllätykseksi edes Leiviskä ei pyytänyt puheenvuoroa mutta kulki kuitenkin miehestä mieheen vakuuttaen, "ettei hän tällaisesta merkillisestä mitään ymmärtänyt”. 543 


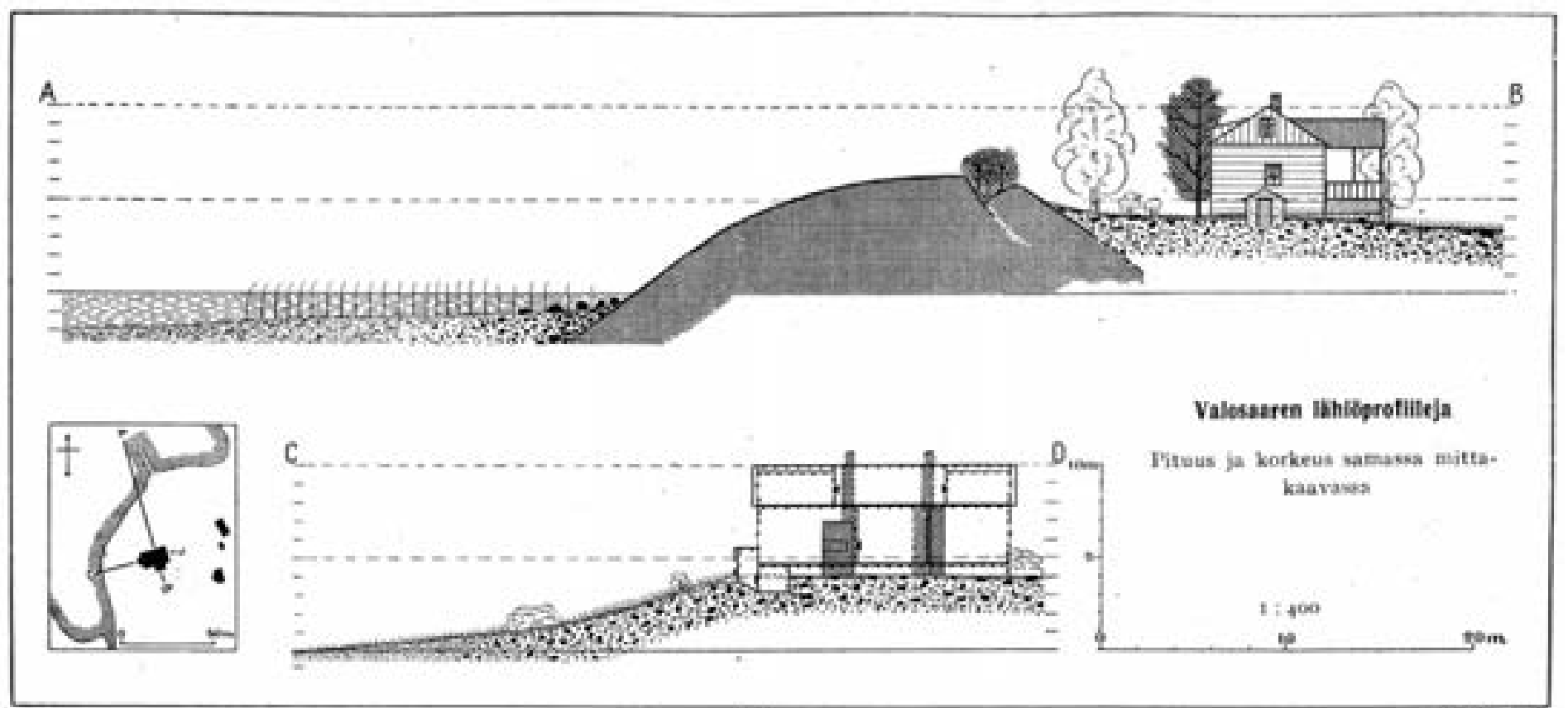

Pirr, 12.

Graso 1923

Valosaaren lähiöprofiilit esittävät läpileikkaukset alustasta ja rantavedestä, kasvillisuuden sekä päärakennuksen ulkomuodon ja sen sisälähiöt.

Kokonaisuudessa Granö oli ajatustensa saamaan vastaanottoon varsin tyytyväinen. Hän arveli

... asiain kehittyvän siihen suuntaan, että saan parhaat kannattajani muiden tieteiden taholta, kuten fysiikka, kemia, biologiset tieteet, geologia, tähtitiede, kun sen sijaan ammattimaantieteilijöiden kanssa syntyy sota. Näin kehittyy asia psykologisesti luontevimmin. ${ }^{544}$ 


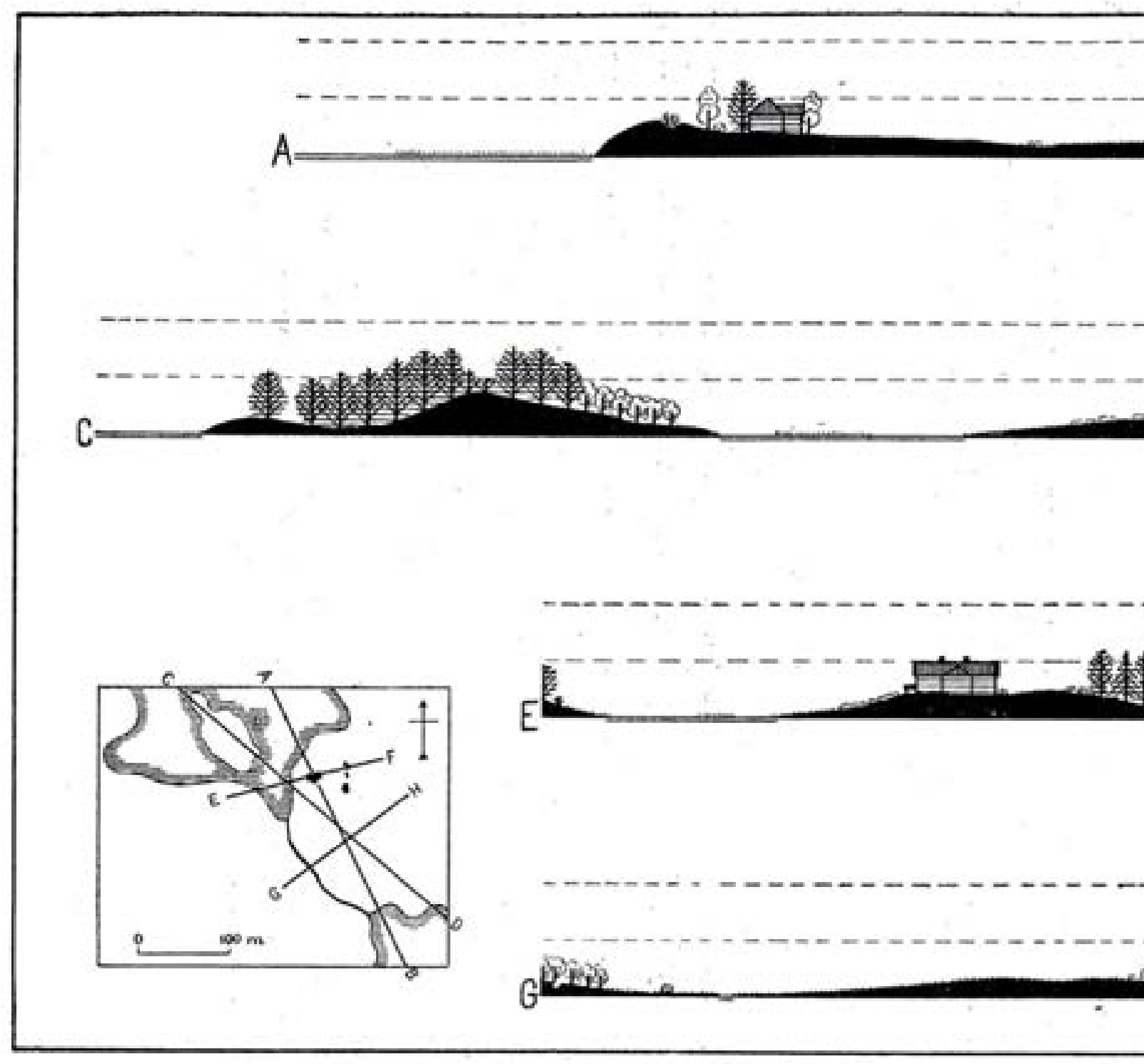

Piirr.

Profilitit esittăvăt; paitsi lăpileikkausta maakamarasta (tăysimusta), mittakaavanmukaisesti m koivut (profilleissa $\mathrm{A}-\mathrm{B}, \mathrm{E}-\mathrm{F}$ ja $\mathrm{G}-\mathrm{H}$ ), matalammat lepăt

Valosaaren maisemaprofilit neljään eri suuntaan esitettyinä. 


\section{Ohjelmajulistus}

Granö jatkoi maisematieteen sisällön ja sanaston kuvaamista artikkelissa, jonka hän julkaisi vuoden 1924 alkupuolella sekä suomeksi Terrassa ("Maisematieteen tehtävät ja maiseman muotojen järjestelmä") että viroksi Looduksessa ("Maastikuteaduse ülesanded ja maastiku vormide süsteem”). Esitys perustui hänen Tartossa esittämiensä ajatusten jatkokehittelyyn. ${ }^{545}$

Maisematieteen tehtävänä oli Granön mukaan tutkia maapallon pintaa ihmisen ympäristönä ja pyrittävä selvittämään, millaisia ympäristöjä oli olemassa, miten ne levittäytyivät, muuttuivat ja vaihettuivat. Maantieteellisiä ympäristöjä voitiin tutkia joko niiden visuaalisen ulkoasun, fysiognomian, tai niissä esiintyvän toiminnan, fysiologian, perusteella, mutta huomiota oli kiinnitettävä vain nykyhetkeen. Menneisyyteen oli syytä syventyä vain siltä osin kuin nykyisyyden ymmärtäminen sitä edellytti.

Koska ihminen koki lähiympäristönsä eri tavoin kuin kauempana aukeavan ja lopulta horisonttiin päätyvän maiseman, maantieteellinen ympäristö oli jaettava lähi- ja kaukoympäristöön. Lähiympäristö oli ihmisestä joidenkin kymmenien metrien päähän ulottuva alue, jonka saattoi kokea kaikilla aisteilla. Joidenkin kymmenien metrien päästä alkavan kaukoympäristön ihminen koki puolestaan vain näköaistin avulla, se oli siis vain visuaalinen kokonaisuus, ei tietty alueyksikkö..546

Kaukoympäristö ja lähiympäristö eivät käytännössä olleet toisistaan jyrkästi erotettavissa, sillä liikkuva tai paikallaan pysyvä ihminen muodosti tavallaan niiden keskipisteen. Maantieteellisessä tutkimustyössä oli kuitenkin vapauduttava havaitsevasta ihmisestä, "etten sanoisi egosentrisuudesta", ja koetettava saada selville tutkittavan alueen maisemalliset ja lähiölliset ominaisuudet riippumatta määrätystä havaintopaikasta ja havaintomahdollisuuksien rajoittuneisuudesta. ${ }^{577}$

Koska kaikkia maisemaan vaikuttavia tekijöitä ei ollut mahdollista ottaa huomioon, oli keskityttävä vain merkittäviin ja pysyviin aineksiin. Näiden periaatteiden pohjalta Granö loi seuraavat maantieteellisiä ympäristöjä koskevat päämääritelmät: 
1) Maantieteellinen maisema on alueykseys, jolla on määrätyt näkyvät, pysyvät, kaukoympäristönä esiintyvät piirteet.

2) Maantieteellinen lähiö on kaikkiin aisteihin vaikuttava lähiympäristö.

Maantieteellinen tutkimus jakautui yleismaantieteeseen, joka puolestaan jakautui maisematieteeseen ja lähiötieteeseen, sekä erikoismaantieteeseen, joka tutki maisematieteen ja lähiötieteen määrittelemiä alueyksiköitä ja niiden ominaisuuksia. ${ }^{548}$

Maisematieteen pääkäsitteitä olivat maiseman ainekset, joista näkyvä maisema muodostuu. Näitä aineksia tarkasteltaessa käytännöllisintä oli erottaa ihmisten ja eläinten synnyttämä tekoaines luonnonaineksista, joita oli kaikkiaan kuusi: maankuori (kallioperä, maalajit), vesi, ilma, kasvillisuus, eläinkunta ja ihmiskunta. Nämä eivät aina esiintyneet maisemassa yhtaikaa, mutta vähintään niitä oli kuitenkin aina kaksi (esimerkiksi ulappamaisemassa). Jos tulevaisuudessa yläilmoissa liikkuminen tulisi jokapäiväiseksi tapahtumaksi, joutuisi maisematieteilijä Granön mukaan puhumaan myös yksiaineksisista maisemista, joissa ilmakehässä esiintyvät muodostumat olivat yksin määrääviä.. ${ }^{59}$

Maisemajako perustui pysyviin piirteisiin, joten käytännössä huomio kohdistettiin maankamaran, vesistöjen, kasvillisuuden ja tekoaineksen muotoihin. Maantieteelliset ainekset esiintyivät maisemassa ilmentäjien eli muotojen, värien ja valojen välityksellä, minkä vuoksi maisematiede jakautui kolmeen osaan: muoto-oppiin eli morfologiaan, värioppiin eli kromologiaan ja valo-oppiin eli fotologiaan. Sekä aineksien että ilmentäjien osalta oli tärkeää selvittää niiden ryhmitys ja leviäminen.

Maantieteessä ei ollut Granön mukaan maisematutkimukseen soveltuvaa metodia, joten sen luominen oli uuden tieteenalan kehityksen peruskysymys. Metodin tuli olla tarkka, sen terminologian ja perustelujen oli oltava täsmällistä ja systemaattista ja sen tuli soveltua kartografisiin menetelmiin. Tämän takia Granö esitti yksityiskohtaisen luokittelujärjestelmän, jonka avulla hän pyrki kuvaamaan ja nimeämään periaatteessa kaikki maiseman osatekijät. ${ }^{50}$ 
Perimmäisenä tavoitteena oli luoda järjestelmä, jonka avulla maisemat olisi kyetty kuvaamaan pitkien sanallisten esitysten sijasta tietyllä maisemakaavalla. Systeemi oli loogisen johdonmukainen mutta samalla myös hyvin kaavamainen ja perusteellisessa yksityiskohtaisuudessaan raskas. Esimerkiksi erilaisia laakioita Granö erotti viisi, veden avomuotoja samoin viisi, ilmanmuotoja seitsemän, puumuotoja kuusi ja harjakaton muotoja kahdeksan. ${ }^{51}$

Nyt Granö myös täsmensi esitystään maisematieteellisen aluejaon toteutuksesta. Aluksi tutkittavasta alueesta tehtiin samaan mittakaavaan neljä analyyttista karttaa. Ensimmäiseen hahmoteltiin maankamaran, toiseen veden, kolmanteen kasvillisuuden ja neljänteen asutuksen, tiestön ja muun tekoaineksen muodostamat yhtenäiset muotoalueet. Tämän jälkeen näiden analyyttisten karttojen tulokset yhdistettiin synteettisesti samalle kartalle laittamalla ne päällekkäin ja katsomalla, missä määrin eri muotoalueiden rajavyöhykkeet yhtyivät ja kuinka laajat alueet jäivät koskemattomiksi kaikkien muotoalueiden rajavyöhykkeiden väliin. Koskemattomat alueet olivat luonnollisesti kaikkien ainesten puolesta enemmän tai vähemmän yhtenäisiä maisema-alueita.

Koska eri muototyyppien vaihettumisalueet saattoivat olla hyvinkin laajat, aluejaon tekijän tuli pyrkiä yleistämään esitystään. Granön mukaan hyvänä nyrkkisääntönä oli, että mitä suurempia alueita aluejako koski, sitä kovempaa yleistystä oli käytettävä. Voimakkaaseen yleistämiseen liittyvä ongelma oli luonnollisesti se, että se saattoi peittää ne alueelliset erot, jotka oli saatu esiin hyvin yksityiskohtaisen maisematekijöiden luokittelujärjestelmän avulla..52

Granö jatkoi maisematieteen esittelyä toukokuun 1924 alussa pitämässään virkaanastujaisesitelmässä "Ympäristö maantieteen tutkimusesineenä". Hänen mukaansa tärkeintä oli ymmärtää, että

... ihmisen aistiympäristö on maantieteellisen tutkimuksen keskeinen ja tär-
kein työala”... Se on luonnontieteellinen objekti, jonka erikoisuus aiheuttaa,
jos niin saa sanoa, aistimusperäisen, voimakkaasti antroposentrisen tutkimus-

286 V Tieteen tekijä ja NäKiJä 
menetelmän, mikä kuitenkaan ei merkitse pyrkimystä subjektiivisuuteen.

Olemmehan kaikki - niin kuuluu filosofien tuomio - vain näennäisyyksien tutkijoita. Olemme aistimuksiimme sidottuja, asetimmepa sitten tutkittavamme ja aistintemme väliin mitkä suurentavat tai täsmällistävät kojeet tahansa. ${ }^{553}$

Nyt Granö puuttui ensimmäisen kerran laajasti 1900-luvun alussa käytyyn keskusteluun taiteen asemasta maantieteessä. Eräät arvovaltaiset tutkijat, kuten Ewald Banse ja Francis Younghusband, olivat esittäneet tieteellisen maantieteen lopettamista tarpeettomana. Se ei heidän mielestään kyennyt esittämään ympäristöä elävänä kokonaisuutena, kun taas runoilijat, kirjailijat ja maalarit pystyivät luonnon kauneuden ja ihmisen elämän todelliseen kuvaukseen. ${ }^{554}$

Granö suhtautui varsin epäilevästi taiteen antiin maantieteellisessä kuvauksessa, sillä se olisi helposti noussut rengistä isännän asemaan työntäen tieteen syrjään. Silti hän ei kieltänyt taiteen merkitystä vaan päinvastoin katsoi, että taiteilijoina maantieteilijät voisivat saada selville paljonkin sellaista, joka "kömpelöissä pihdeissämme on muotoaan muuttanut tai musertunut, tai jota emme ole, sivuteitä harhaillessamme, edes huomanneetkaan”. 555

Maantieteilijöiden epäonnistuminen aidossa aluekuvauksessa oli kuitenkin johtunut vain heidän omista virheistään ja tieteenalan kehittymättömyydestä. Granö uskoi, että maisematiede oppi vielä käsittelemään ympäristöä oikein, joten erityisesti Bansen mystiset ajatukset maiseman sielusta, miljööstä, joka uinuu salaperäisenä voimana jokaisessa maisemassa, voitiin huoletta jättää sen ulkopuolelle. ${ }^{556}$

Granön linjaus vastasi hyvin ajan maantieteilijöiden yleisnäkemystä, sillä myös saksalaisten maantieteilijöiden enemmistö ja useimmat 1900-luvun alun yhdysvaltalaiset maantieteilijät tutkivat maisemaa "objektiivisesti”. Esimerkiksi yhdysvaltalainen Carl Sauer pyrki sulkemaan subjektiivisen elementin pois maisematutkimuksesta todeten kuitenkin 1925, että "paras maantiede" ei ollut koskaan hylännyt maiseman esteettisiä ulottuvuuksia, joita oli mahdollista tutkia ainoastaan "subjektiivisen" lähestymistavan avulla. ${ }^{557}$ 
Vuonna 1924 ilmestyneet artikkelit olivat syntyneet niin kiireisen työskentelyn tuloksena, että Granö korosti maisematieteen sisällön vaativan vielä kehittämistä. Terrassa 1925 julkaisemassaan artikkelissa "Maantieteen rajat" hän totesi, että hän oli edellisissä artikkeleissaan käsittänyt yleisen maantieteen tehtävät ja alan liian laajaksi. Hän katsoi 1900-luvun alun johtavan maantieteen teorian kehittäjän Alfred Hettnerin tavoin, että yleismaantiede oli loogisesti mahdoton, historiallisesti perustelematon ja käytännössä vahingollinen, joten maantieteen oli tulevaisuutensa turvaamiseksi keskityttävä oman tutkimusalansa rajoittamiseen. ${ }^{558}$

Tukeutuen Otto Schlüterin 1906 esittämään näkemykseen, että kaikkien aistihavaintojen kokonaisuus oli maisema, Granö asetti sen maantieteen varsinaiseksi tutkimuskohteeksi. Siksi kaikki voimat oli suunnattava entistä määrätietoisemmin ja keskitetymmin maiseman kaikinpuoliseen selvittämiseen. ${ }^{559}$

Tämä merkitsi sitä, että Granö oli nyt valmis luopumaan monista vanhaan yleismaantieteeseen kuuluneista tieteistä, kuten klimatologiasta, limnologiasta, kasvi- ja eläinmaantieteestä, geologiasta ja jopa geomorfologiasta, joka oli pitkään muodostanut maantieteen keskeisen osan ja joka oli ollut hänen oma erikoisalansa lähes koko 1910-luvun. Myös henkisiin tieteisiin päin hän oli yhtä ehdoton. Kansatiede oli jo kehittynyt itsenäiseksi tieteeksi, samoin valtiollinen, taloudellinen ja poliittinen maantiede, vaikka niillä oli yhä kannattajia maantieteilijöiden keskuudessa. Historialla ja muilla ihmisen toimintaan keskittyneillä tieteillä oli omat selkeät alansa, jotka maantieteilijöiden tuli jättää rauhaan. ${ }^{560}$

Eniten Granötä askarrutti maantieteen suhde sosiologiaan, jonka asema oli Suomessa vahva jo 1920-luvulla Edvard Westermarckin saavuttaman maailmanmaineen takia. Hänen mielestään maantieteen tuli keskittyä vain aistein havaittavan ympäristön tutkimiseen ja jättää suosiolla ihmisyhteisöjen tutkiminen sosiologialle, uudelle nousevalle tieteelle, jolla oli siihen hyvät tieteelliset edellytykset ja jolla oli läheiset yhteydet psykologiaan. ${ }^{561}$

Granö oli miettinyt selkeän työnjaon maantieteen ja sosiologian välille: 
Niin kuin maantieteilijä alueyhteyksiä määrätessään ottaa huomioon vain aistittavat piirteet ja ottaa vasta selvityksessä tarkastettavikseen kaikki tutkimusobjektissa ilmentymiä aikaansaavat tekijät, mutta ei pidä asianaan käsitellä tuon tutkimusesineen vaikutusta ihmiseen ja ihmisyhteisöön, niin sopisi käsityksemme mukaan toisaalta sosiologian tehtäväksi määrätä henkiset ympäristöt henkisten piirteiden nojalla ja tutkia, millä tavalla m.m. meidän tutkimusobjektimme, aistittu kokonaisuus, tuohon henkiseen kompleksiin vaikuttaa. ${ }^{562}$

Maantieteilijöiden ja sosiologien yhteistyöllä olisi Granön mukaan mahdollista kytkeä tutkimuksen piirin muun muassa "luonnon kauneuden merkitys ihmistoimintaa suuntaavana ja aiheuttavana tekijänä" ja "aistiympäristöjen kaunokirjallisuuteen kohdistuva voimakas vaikutus". Jos työnjako toteutuisi, merkitsisi se hänen mukaansa samalla sitä, että

... maantiede ja sosiologia samalla tavalla "paikkaan sidottuina", paikan ja ajan mahdista todistavina tieteinä, joutuisivat yhdessä tutkimaan ihmisen kotiseutua tämän sanan laajimmassa merkityksessä; ne muodostaisivat yhdessä kotiseututieteen eli ihmisekologian. ${ }^{563}$

Eri tieteiden välisen yhteistyön avulla saavutettavissa oleva hyöty oli Granön mielestä hyvä osoitus siitä, että keskittyminen aistiympäristön tutkimiseen ei merkinnyt maantieteen köyhdyttämistä tai kuihduttamista, sillä sen,

... minkä siirrämme maantieteen rajojen ulkopuolelle, kehittävät erikoistutkijat itsenäistyneiden tieteiden suojissa varmaan syvemmälle ja kauemmas kuin mihin me olisimme pystyneet, hyödyttäen tarpeen tullen maantiedettäkin entistä enemmän; se mitä erikoisalaksemme on jäänyt, on keskeistä merkitystä oleva, täyteläinen ja ehyt kokonaisuus. ${ }^{564}$ 


\section{Iivari Leiviskän vastahyökkäys}

Tehtäväkentän tiukka rajaus oli osoitus siitä, että Granön teoreettisten ponnistelujen tavoitteena oli hahmottaa maantieteelle oma tieteellinen identiteetti, joka olisi antanut sille selkeän tehtäväkentän tieteiden piirissä ja lopettanut reviirikiistat lähitieteiden kanssa. Hän koki tämän tavoitteen niin tärkeäksi, että oli sen vuoksi valmis luopumaan itselleen ominaisesta varovaisesta ja diplomaattisesta suhtautumisesta muiden maantieteilijöiden töihin. Tämä näkyi Granön Terrassa 1926 julkaisemassa artikkelissa "Maantieteellisen muoto-opin tehtävät ja merkitys", jossa hän arvioi kriittisesti Iivari Leiviskän edellisenä vuonna ilmestyneen teoksen Maanpinnan muodot ja niiden synty. ${ }^{565}$

Granön mukaan Leiviskän teos ei tyydyttänyt kompleksia käsittelevän, kokonaisuuksia muodostavan maantieteen vaatimuksia. Kirja oli paitsi jäsentymätön myös hajanainen, mikä oli pääosin johtunut siitä, että kirjoittaja ei ollut noudattanut maantieteellisen tutkimuksen ja opetuksen kultaista sääntöä, ensin kuvaus, sitten vasta selvitys.

Granö ymmärsi hyvin, että tiukka arvostelu merkitsi varmaa vastahyökkäystä, sillä Leiviskä oli tottunut antamaan sanan sanasta. Hän katsoi kuitenkin olevansa pakotettu kritiikin esittämiseen, koska oli sekä yliopistollisessa opetuksessaan että julkaisuissaan esittänyt toisenlaista muoto-oppia kuin se, "jonka tulkitsijaksi Leiviskä uudessa oppikirjassaan on ruvennut" ${ }^{566}$

Leiviskä otti haasteen tapansa mukaan ärhäkkäästi vastaan. Nopeasti laatimassaan vastineessa "Geomorfologia ja ns. maisematiede" hän ei puuttunut niinkään Granön arviossa esittämiin kommentteihin vaan hyökkäsi ankarasti tämän maantieteelle antamaa uutta sisältöä vastaan. Leiviskän mukaan maantiede oli yleisesti jaettu yleismaantieteeseen ja erikois- eli aluemaantieteeseen. Yleinen maantiede oli taas jakautunut osa-alueisiin, joista maanpinnan muotoja käsittelevää osaa sanottiin yleisimmin geomorfologiaksi.

Granö puolestaan piti geomorfologiaa itsenäisenä tieteenä tai vain maantieteellisen muoto-opin osana, sillä maantieteen keskeisin lohko oli maisematiede eli ym- 
päristötiede. Maisematiede oli Leiviskän mukaan Granön itsensä kehittämä tiede, jonka kannattajia hänen lisäkseen ei juuri ollut, lukuun ottamatta eräitä nuorempia tutkijoita, jotka olivat koettaneet seurata hänen esimerkkiään. ${ }^{567}$

Leiviskä pyrki kirjoituksessaan esittämään monin esimerkein, että maisematiede oli sisällöltään epämääräinen ja ristiriitainen. Hän totesi, että vaikka Granö väitti, että hänen maanpinnanmuotoja koskeva "morfografinen järjestelmänsä" perustui hänen omiin tutkimuksiinsa, se oli vain Passargen esityksen jonkinlainen lyhennelmä, joka oli "teennäisiä määritelmiä lisäämällä saatu sangen monessa kohdin tosioloille vieraaksi ja on siis aivan tyypillinen keinotekoinen luokitus." ${ }^{\text {668 }}$

Leiviskä syytti Granötä myös maantieteen yliopisto-opetuksen laiminlyönnistä. Hänen mukaansa hän oli joutunut kantamaan päävastuun maantieteen opiskelijoiden laudaturkirjoitusten ohjaamisesta. Kun hän oli siten oppinut tuntemaan hyvin laitoksen opiskelijat, hän oli tahtomattaankin joutunut huomaamaan, minkälaiseksi maisematiede oli heidän päässään kehittynyt, ja kuinka sen hedelminä olivat aivan "pintapuoliset komplekseilla, vuorovaikutuksilla, ykseyksillä y.m. käsitteillä paiskomiset." ${ }^{\text {569 }}$

Leiviskä lopetti vastineensa toteamalla, että

Prof. Granön maisemaopista on moni minulle sanonut, ettei hän sitä ymmärrä. Minä olen sen jo hänen ensi kirjoituksistaan alkaen sikäli ymmärtänyt, että se "maisemaoppina" olisi käytännössä toteutettavissa vain epämääräisenä maisemallisena tunnelmoimisena (Landschaftseinfühlung), koska sen näennäisesti monipuoliselta filosofiselta perustelulta puuttuu loogillisuus, ja että se "morfografisena systeeminä" on heikko yritys sijoittaa geomorfologian tilalle pelkkää kaavamaisuutta ja muotoilua - samalla kun nämä molemmat puolet merkitsevät jonkunlaista säyseänalistuvaa pyrkimystä löytää maantieteelle vähäpätöinen ala, jota viljellessä ei joutuisi kahnaukseen toisten tieteiden kanssa. ${ }^{570}$

Koska Granö kuului Terran toimituskuntaan, hän sai tilaisuuden vastata Leiviskän kritiikkiin välittömästi. "Morfologia ja ympäristötiede" -kirjoituksessaan hän totesi, 
että Leiviskän "käsitteiden selvittelyssä" oli siksi paljon sekä tietoista että tiedotonta vär̈ristelyä, että hänen oli pakko vielä kerran tarttua kynään. Varsinkin, kun Leiviskä oli pitänyt sopivana ja tarkoituksenmukaisena kääntää lukijan huomion hänen oppikirjansa puutteiden sijasta eräisiin hänen tässä aikakauskirjassa julkaisemiin kirjoituksiinsa. ${ }^{571}$

Granön mukaan Leiviskän arvostelu oli yhtä keskeytymätöntä väärinymmärrysten sarjaa. Hän myönsi, että hänen kirjoituksensa eivät muodostaneet yhtenäistä kokonaisuutta vaan olivat "asteita edustamani tieteenhaaran kehityksessä". Leiviskän olisi kuitenkin tullut ottaa huomioon, että kysymys oli yhä jatkuvasta tieteellisestä prosessista, joka johti työn edetessä väistämättä maisematieteellisten menetelmien ja käsitteiden täsmällistymiseen. ${ }^{572}$

Granö totesi, että aistimusperäisen, antroposentrisen ympäristön ottaminen lähtökohdaksi sekä yleisessä että erikoismaantieteessä oli omaperäinen mutta välttämätön ratkaisu. Hän oli nimittäin huomannut tutkijana ja yliopiston opettajana, miten toivotonta oli saada yleisesti käytettyä menettelytapaa seuraamalla yhtenäistä ja selvää käsitystä maantieteellisen kokonaisuuden laadusta, muuttumisesta ja synnystä.

Granö puuttui myös Leiviskän esittämään käsitykseen, jonka mukaan maisematiede oli käytännössä toteutettavissa vain epämääräisenä "maisemallisena tunnelmoimisena”. Hän totesi, ettei voinut ymmärtää, miten hänen metodiset pohdintansa voisivat johtaa tunnelmoimiseen. Väitteisiin sekavuudesta, epämääräisyydestä ja loogillisuuden puutteesta hän ei halunnut ottaa kantaa mutta lausui puolustuksekseen, että hänen kirjoitustensa ymmärtäminen ei toki riippunut vain hänen taidostaan tai taitamattomuudestaan ajatustensa selvään ja loogiseen esittämiseen. Kysymys oli myös siitä, missä määrin lukijalla oli tarpeellisia edellytyksiä, kykyä ja halua tämänkaltaisia asioita ymmärtää:

Tosiasia on, ettei ainoakaan oppilaistani ole ympäristötieteen tarkoitusperiä niin väärin ymmärtänyt eikä sillä tavalla määrittelemiäni käsitteitä sotkenut ja "paiskonut" kuin prof. Leiviskä. ${ }^{573}$ 
Kirpeään sävyyn saattoi vaikuttaa se, että Leiviskä oli syyttänyt Granötä opetustehtävien huonosta hoidosta. Tämä oli kyllä tarkoituksellista panettelua, sillä Granö oli edelleen paneutunut huolellisesti opetustoimintaan. Hänen opetusvelvollisuutensa lievä pienentyminen 1924 ja 1925 oli johtunut vain Suomen Kartaston 1925 aiheuttamista työpaineista. ${ }^{574}$

Granön tarkoituksena ei myöskään ollut "löytää joku vähäpätöinen, rauhoitettu ala tieteellemme", vaan päinvastoin kehittää sitä maantieteen osaa, joka jotakuinkin yksimielisesti voitiin tunnustaa varsinaiseksi maantieteeksi. Hänen edustamansa maantieteen laadusta ja merkityksestä ei tietystikään ollut mahdollista saada oikeata käsitystä pelkkien metodisten artikkelien perusteella.

Granö toivoikin, että lopullinen arvostelu lausuttaisiin vasta sitten, kun "olemme varsinaisessa tutkimustyössä saaneet osoittaa, mitä tarkoitamme ja mihin pyrimme". Luottavaisten sanojen takana oli vankka usko siihen, että hänelle oli vihdoin avautumassa tilaisuus keskittyä oppirakennelmansa kehittämiseen ja testaamiseen. ${ }^{575}$ 


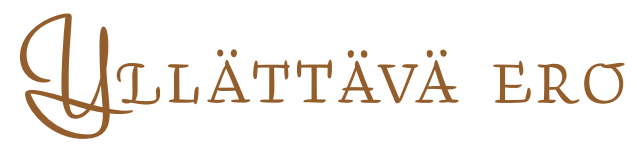

\section{Työntö}

Granö oli ehtinyt hoitaa maantieteen vakinaista professuuriaan vain runsaat kaksi vuotta, kun hän yllättäen pyysi keväällä 1926 eroa toimestaan saatuaan kutsun siirtyä Turun Suomalaisen Yliopiston maantieteen professoriksi. Konsistorin puollettua esitystä tasavallan presidentti Lauri Kr. Relander myönsi 3. elokuuta 1926 Granölle eron syyskuun alusta alkaen.

Ratkaisu herätti yleisesti suurta ihmetystä. Miksi valtion yliopiston professori siirtyi pieneen yksityiseen yliopistoon, joka kärsi taloudellisten resurssien niukkuudesta ja jonka tulevaisuus oli epävarma?576

Granön päätöksen taustalla oli useita tekijöitä, jotka kaikki vaikuttivat samaan suuntaan. Hän oli isänsä tavoin vapauttaan ja omaa pätäntävaltaa arvostanut henkilö, joka oli nauttinut Tarton ajastaan saadessaan perustaa maantieteen laitoksen ja ohjata sen toimintaa oman harkintansa perusteella. Helsingissä hän oli joutunut sopeutumaan 30 vuotta vanhaan laitostraditioon, professorikollegoiden erilaisiin näkemyksiin ja ison yliopiston hallintokoneistoon. ${ }^{577}$

Tartossa Granö oli tuntenut vanhan humboldtilaisen sivistysyliopiston henkeä, mutta Helsingin yliopisto oli hänen mielestään muuttunut suureksi maisteri-, lääkäri-, pappi- ja juristitehtaaksi, jossa kokeneet tiedemiehet eivät päässeet läheiseen ja henkilökohtaiseen kosketukseen oppilaidensa kanssa. Hänen mielestään vapaalla henkisellä työllä oli parhaat edellytykset menestyä pienessä, hyvin varustetussa yliopistossa, jossa professorit saivat työlleen innostusta vuorovaikutuksesta ja yhteistoiminnasta opiskelevan nuorison kanssa. ${ }^{578}$

Turun yliopisto tarjosi Granölle mahdollisuuden Tarton kokemusten toistamiseen ja soi samalla hänelle tilaisuuden toimintaan suomenkielisen sivistyksen hyväksi. Snellmanilaisessa kodissa kasvaneena hän oli usein osoittanut halunsa toimia suomenkielisen sivistyksen hyväksi, ja siihen Turun Suomalainen Yliopisto soveltui 
erinomaisesti. Granö katsoi, ettei suomalaisuutta edistetty pelkillä puheilla, symboleilla ja eleillä vaan se edellytti myös konkreettisia toimia. Siksi hän oli jo vuoden 1918 lopulla osallistunut rahankeruuseen yliopiston perustamiseksi. ${ }^{579}$

Työkumppanuus vanhan luottoystävän J. K. V. Tuomisen kanssa oli puolestaan pitkäaikainen haave, jonka hän olisi voinut toteuttaa Turun yliopiston maantieteen laitoksen johtajana. Myös puoliso Hilma Granö kannatti lämpimästi muuttoa. Hän oli kotoisin Turusta, jossa oli käynyt kaupungin tunnetun tyttölyseon eli Tipulan luokkatovereinaan muun muassa Granön ystävien A. E. Koskenniemen ja J. K. V. Tuomisen puolisot. Kun isä merikapteeni Isak Ekholm vietti eläkepäiviään Turussa ja veli hovioikeudenneuvos Aleksis Ekholm asui siellä, muutto Aurajoen rannoille olisi merkinnyt paluuta tutun sukulais- ja ystäväjoukon piiriin yli 13 vuotta kestäneiden reissuvuosien jälkeen.

Viimeisenä ja ehkä tärkeimpänä syynä muuttoon oli Granön halu keskittyä tutkimukseen. Jo ottaessaan vastaan Tarton yliopiston maantieteen professuurin hän oli päättänyt luoda maantieteelle uuden oppisisällön ja metodin. Hän oli saanut tämän kehitystyön hyvään käyntiin, mutta nyt se uhkasi pysähtyä kaikkiin niihin tehtäviin, joista hän joutui kantamaan vastuun professorina, Suomen Maantieteellisen Seuran sihteerinä ja Suomen Kartaston toimittajana. Granö tunsi, että Helsingissä hänen aikansa meni tieteellisen työn sijasta rutiinitehtävien pyörittämiseen.

\section{Veto}

Maantieteen professuurin perustamista Turkuun oli pohdittu 1919 sekä Turun Suomalaisessa Yliopistossa että Åbo Akademissa. Vuonna 1919 perustetussa Akademissa asia jäi pian pöydälle ja hautautui toteutumattomien suunnitelmien joukkoon, mutta suomenkielisessä yliopistossa se sai osakseen vastakaikua. Kun yliopiston toiminnan aloittamista valmisteltiin 1920-luvun alussa, Turun Suomalainen Yliopistoseura toivoi, että luonnontieteelliseen tiedekuntaan luotaisiin eläintieteen, kasvitieteen, kemian ja fysiikan professuurien ohella myös maantieteen professuuri. 
Maantieteen opetuksen aloittamista perusteltiin koulunopettajien tarpeella, maantieteen suurella kansallisella merkityksellä ja sen luonnontieteellisiä ja humanistisia tieteitä yhdistävällä luonteella. Taloudelliset syyt johtivat kuitenkin siihen, että maantieteen virkaa ei heti perustettu yliopiston aloittaessa tieteellisen toimintansa 1922.580

Asia nousi esille uudestaan keväällä 1923, jolloin yliopiston luonnontieteellinen tiedekunta ehdotti maantieteen professuurin perustamista seuraavan vuoden alusta alkaen. Tiedekunnan mukaan maantiede tulisi todennäköisesti houkuttelemaan huomattavasti enemmän miesylioppilaita kuin humanistien kannattama germaanisen filologian professuuri. Myös konsistori kannatti esitystä, mutta kun kansleri J. R. Danielson-Kalmari ei puoltanut vakinaisen oppituolin perustamista, maantieteen opetus päätettiin syksyllä 1924 käynnistää tilapäisin voimin..$^{581}$

Granön kieltäydyttyä kiireisiin vedoten tehtävästä opetuksen aloittamisen sai vastuulleen Iivari Leiviskä, jonka apulaiseksi määrättiin Granön suosituksesta hänen ystävänsä filosofian kandidaatti J. K. V. Tuominen. Opetus järjestettiin siten, että Leiviskä matkusti joka toinen viikko Helsingistä Turkuun ja vastasi maantieteen laitoksen johtajana approbatur-tason luennoista, seminaariharjoituksista ja kenttämittaustöistä Tuomisen huolehtiessa kartanpiirustustöiden ohjaamisesta. ${ }^{582}$

Maantieteen laitos perustettiin aivan Turun sydämessä Kauppatorin laidalla olleeseen yliopistorakennukseen, entiseen maineikkaaseen Phoenix-hotelliin. Maantieteilijät saivat käyttöönsä rakennuksen toisesta kerroksesta kaksi yhteensä noin 100 neliömetrin huonetta. Näistä suurempi kalustettiin 10-paikkaiseksi piirustussaliksi ja pienempi assistentin huoneeksi ja välineistön säilytyspaikaksi. Luennot pidettiin alakerrassa, yliopiston suuressa, 96-paikkaisessa luentosalissa. ${ }^{53}$

Opetuksen käynnistyttyä luonnontieteellinen tiedekunta esitti uudelleen maantieteen professuurin perustamista, sillä vain näin voitaisiin mahdollistaa opetus myös approbaturia korkeampia arvosanoja varten. Kanslerin katsottua, että asian ratkaisemiseksi oli välttämätöntä turvautua ulkopuoliseen asiantuntijaan, tiedekunta päätti pyytää Granöltä lausunnon maantieteellisen yliopisto-opetuksen laadusta ja tarkoitusperistä..$^{58}$ 
Granö laati nopeasti lausunnon, jossa hän korosti ympäristön merkitystä maantieteen keskeisenä tutkimuskohteena. Keskittymällä ympäristön tutkimiseen maantiede saattoi vapautua aine- ja aikatieteiden vaikutuksesta ja tarjota myös lähitieteiden edustajille, luonnontieteilijöille, historioitsijoille ja valtiotieteilijöille, monenlaista hyödyllistä aineistoa. Granön mielestä valtiollinenkin maantiede oli erotukseksi valtio-opista lähinnä luonnontiedettä, valtioiden luonnonoppia. Valtiolliseen maantieteeseen olisi Turussa mahdollista perehtyä opetusohjelman eri osissa. ${ }^{585}$

Granön myönteisen lausunnon jälkeen luonnontieteellinen tiedekunta päätti esittää, että yliopistoon perustettaisiin maantieteen professuuri syyslukukauden 1925 alusta alkaen. Ehdotus sai konsistorin yksimielisen kannatuksen ja kanslerin ehdollisen hyväksymisen, mutta se ei tälläkään kertaa johtanut myönteiseen tulokseen, sillä yliopistoon päätettiin perustaa vain germaanisen kielitieteen professuuri. Leiviskän jätettyä Turun maantieteen laitoksen opetuksen sai vastuulleen assistentti Tuominen, jota Granö parhaansa mukaan auttoi muun muassa opetusvälineiden hankinnassa. ${ }^{586}$

Luonnontieteellinen tiedekunta uskoi, että kolmas kerta toden sanoo. Biologisten aineiden opiskelijoiden määrän kasvuun vedoten se esitti konsistorille syyskuun lopulla 1925, että maantieteen professuuri perustettaisiin mahdollisimman nopeasti. Konsistori ja kansleri hyväksyivät esityksen loka-marraskuun vaihteessa, mutta aiemmat vastoinkäymiset olivat saaneet hankkeen puuhamiehet ymmärtämään, että asia ei ollut vielä sillä selvä. Esityksen lopullinen hyväksyminen piti varmistaa jollakin keinolla, joka lisäisi yliopiston tieteellistä arvovaltaa ja houkuttelisi yliopistoon uusia opiskelijoita. Tämä voitiin parhaiten toteuttaa yhdistämällä viran perustaminen Granön siirtymiseen Helsingistä Turkuun. ${ }^{57}$

Granön kutsumista Turkuun oli suunniteltu jo 1923, mutta ystäviensä suostutteluista huolimatta hän oli tuolloin suhtautunut asiaan kielteisesti otettuaan vastaan Suomen Kartaston toimittamisen. Syksyllä 1925 tilanne oli muuttunut täysin päinvastaiseksi, sillä juuri karttatöiden pitkittymisen ja Suomen Maantieteellisen Seuran sihteerin tehtävien paljouden vuoksi hän oli valmis harkitsemaan asiaa uudelleen. 
Turkulaiset olivat tietoisia asenteen muuttumisesta muun muassa Tuomisen ansiosta, minkä vuoksi yliopiston edustajat kävivät marraskuun alkupuolella eläintieteen professorin Walter M. Linnaniemen johdolla Helsingissä houkuttelemassa Granötä siirtymään Suomen vanhaan pääkaupunkiin. ${ }^{58}$

Granö suhtautui alustavasti myönteisesti ajatukseen, mutta totesi Linnaniemelle lähettämässään kirjeessä, ettei hän ollut ehtinyt vielä miettiä asiaa kunnolla. Jonkin verran hän oli kuitenkin jo kysymystä pohtinut, sillä hän kykeni nopeasti kertomaan, että siirtyminen Turkuun edellytti tiettyjen reunaehtojen täyttämistä. Erityisesti hän kiinnitti huomion neljään pääseikkaan, joihin kuhunkin liittyi joukko toisarvoisia kysymyksiä. ${ }^{589}$

Ensinnäkin Granö halusi saada mahdollisuuden rauhalliseen tutkimus- ja opetustyöhön. Helsingissä tähän ei ollut mahdollisuuksia, minkä vuoksi "aika ja voimat kuvaannollisesti puhuen pirstoutuvat sirpaleiksi, työn tulokset hupenevat olemattomiin”. Hän halusi mahdollisuuksia keskittyä, vetäytyä joskus hiljaisuuteen, syventyä tieteellisiin ongelmiin, täydentää itsekasvatusta, seurata tieteen kehitystä: "Ellei näitä mahdollisuuksia ole, muuttuu puisevaksi opetustyössä ja kiteytyy muotoihin ja elämänkatsomukseen, jotka homeelle haiskahtavat." ${ }^{90}$

Toiseksi Granö halusi, että Turun yliopiston maantieteen laitos voisi kilpailla tarkoituksenmukaisten järjestelyjen ja menestyksellisen opetustoiminnan suhteen ainakin minkä tahansa pohjoismaisen vastaavan instituutin kanssa. Tämä ei hänen mielestään ollut lainkaan mahdoton ajatus. Jos maantieteen professorin palkkaan varattaisiin varoja vuoden 1926 alusta alkaen ja viran haltija astuisi toimeensa ja alkaisi nostaa palkkaa vasta syyskuun alusta, varoja vapautuisi niin paljon, että laitos saataisiin täysin kuntoon ja professori voisi jopa tehdä pienen kiertomatkan Pohjoismaiden yliopistokaupunkeihin, joissa hän voisi oppia yhtä ja toista.

Maantieteen laitoksen ei Granön mukaan olisi pakko olla kovin suuri. Jos opiskelijoiden määrä pysyisi noin 30:n tuntumassa, laitos ei tarvitsisi kuin ison piirustussalin ja kolme pientä huonetta: Esimiehen ja assistentin huoneet sekä seminaarikirjaston, joka toimisi myös lukusalina ja pitkälle ehtineiden opiskelijoiden työskentely- 
tilana. Esimiehen huoneen tulisi soveltua paitsi rauhalliseen tutkimustyöhön myös tenttihuoneeksi ja opiskelijoiden lopputöiden ohjaamiseen.

Kolmantena tekijänä Granö mainitsi palkkauksen, sillä "perheellisen ja kapittaalittoman miehen" tuli toki taloudellista puolta harkita ennen kuin jättää sen tuen, minkä valtion yliopisto voi tässä suhteessa palvelijalleen tarjota. Hän uskoi tämän asian ratkeavan, varsinkin kun elämä Turussa tulisi hiukan halvemmaksi kuin Helsingissä. Hän torjui kuitenkin jyrkästi sen, että hänelle olisi maksettu parempaa palkkaa kuin muille professoreille, mikä olisi ollut mahdollista yksityisessä yliopistossa.

Neljäs mutta ei suinkaan vähäisin kysymys, oli sopivan asunnon löytäminen perheelle. Neljän lapsen perhe tarvitsisi viiden huoneen huoneistoa, josta maksettava vuokra ei saisi ylittää sitä summaa, jonka he saisivat vuokraamalla Pohjoisen Rautatiekadun asuntonsa Helsingissä. Asuntoasian myönteinen ratkaiseminen oli Granöille suorastaan "conditio sine qua non" eli kynnyskysymys, sillä perhe ei halunnut suin surminkaan joutua elämään samanlaista "kapsäkkielämää" kuin Tartossa..91

Granö kertoi Linnaniemelle, ettei hän halunnut asettaa suuria ehtoja ja vaatimuksia siirtymiselleen. Hän tekisi kuitenkin väärin sekä turkulaisia että perhettään kohtaan, ellei nostaisi avoimesti esiin niitä kysymyksiä, jotka ratkaisivat Turkuun siirtymisen. Lisäksi hän totesi, että hänen mielestään turkulaisten olisi pitänyt aluksi kysyä Iivari Leiviskän kantaa asiaan ja vasta sitten kääntyä hänen puoleensa. Hän kiitti Linnaniemeä kirjeen lähettämisestä tavalla, joka osoitti, kuinka sitoutunut hän oli Turun Suomalaisen Yliopiston tavoitteisiin: "Toivoisin hartaasti, että voisin edes rajoitetussa määrässä olla tämän luottamuksenne veroinen; ei ainoastaan tiedemiehenä ja yliopiston opettajana, vaan myös suomalaisena miehenä puheessa ja ennen kaikkea työssä.." ${ }^{92}$

Granö oli esittänyt Linnaniemelle toivomuksen, että joku turkulaisista pistäytyisi vielä hänen luonaan pääkaupungissa keskustelemassa asiasta. Linnaniemi katsoi parhaaksi täyttää pyynnön niin, ettei Granölle jäisi epäilyksiä siitä vakavuudesta, jolla kutsu oli esitetty. Koko Turun yliopiston luonnontieteellisen tiedekunnan saavuttua dekaaninsa M. H. Palomaan johdolla hatut käsissä Granön kotiin hänen viimeisin- 
kin vastarintansa murtui. Hän suostui henkisesti otettuna ja liikuttuneena turkulaisten kosintaan. ${ }^{593}$

Tiedekunta oli valinnut oikean taktiikan. Kun hoitokunta hyväksyi asian 28. joulukuuta 1925, myönteisen kannan syntymistä edisti ratkaisevimmin tieto siitä, että J. G. Granö oli yliopiston rehtorin V. A. Koskenniemen kanssa käymissään neuvotteluissa ilmaissut valmiutensa siirtyä Turkuun hoitamaan vakinaista professuuria. Hoitokunnassa pohdittiin jopa mahdollisuutta, että maantieteen oppituolin perustamisen ehdoksi pantaisiin, että sen ensimmäisen haltijan tuli olla Granö. Suunnitelmasta kuitenkin luovuttiin, koska sen katsottiin voivan nostattaa vastavoimia, jotka "tekisivät kaikkensa pidättääkseen Granön Helsingissä. .994

Hoitokunnan päätettyä perustaa maantieteen professuurin vuoden 1926 alusta asiat etenivät nopeasti Granön esittämän suunnitelman mukaisesti. Kun luonnontieteellinen tiedekunta ehdotti, että viran ensimmäiseksi haltijaksi kutsuttaisiin Granö, yliopiston kansleri Danielson-Kalmari nimitti hänet Turun Yliopiston maantieteen professoriksi heinäkuun 1926 alusta alkaen.995

\section{Ratkaisun jälkeen}

Vastaamalla myönteisesti turkulaisten kutsuun J. G. Granö otti saman askeleen kuin filosofi Edvard Westermarck, joka oli pari vuotta aiemmin siirtynyt Helsingin yliopistosta Åbo Akademiihin. He kumpikin arvostivat äidinkieltään kulttuurikielenä, mutta kunnioittivat samalla traditioita ja olivat tieteellisessä merkityksessä kosmopoliitteja.

Turussa Granön ratkaisu herätti yleistä tyytyväisyyttä. Uuden professuurin ja nimekkään tutkijan odotettiin tuovan yliopistoon uusia opiskelijoita ja siten vahvistavan sen asemaa. Granön uusi aluetieteellinen suuntautuminen ja tutkimukset olivat suomenkielisen yliopiston ja kansallisen leiman kannalta tervetulleita. Kielikysymykselläkin oli merkityksensä, sillä Granön rooli suomenkielisen maantieteellisen opetuksen pioneerina ja ammattikäsitteistön kehittäjänä tiedettiin merkittäväksi. ${ }^{996}$ 
Granön ystävistä erityisesti Tarton yliopiston aikainen kollega, matematiikan professori Kalle Väisälä, iloitsi suuresti tämän tulosta, sillä hän oli toivonut tätä hartaasti jo pitkään. Myös rehtori ja runoilijamestari V. A. Koskenniemi tervehti asiaa ilolla, sillä molemmat miehet olivat snellmanilaisen kielipolitiikan edustajia:

Siitä lähtien kuin Turun yliopisto aloitti toimintansa ei yliopiston vaiheissa ole tapahtunut mitään, joka siinä määrin kuin Sinun tänne tulosi vahvistaisi yliopistomme merkitystä ja asemaa tieteellisenä laitoksena. Tästä olemme kyllä kaikki tietoisia, ja voit olla vakuutettu siitä, että jos me kukin kohdaltamme voimme tehdä jotakin valmistaaksemme Sinulle täällä tieteellisen työn mahdollisuuksia, niin tulemme sen mielihyvin tekemään. ${ }^{597}$

Helsingissä tunnelmat olivat täysin päinvastaiset. Erityisesti yliopiston luonnontieteellisessä tiedekunnassa Granön ratkaisuun oltiin pettyneitä. Hänelle oli myönnetty suuria apurahoja ja hänen professorinimitystensä puolesta oli tehty paljon työtä, ja nyt hänen katsottiin mitätöineen tukijoidensa ponnistelut siirtymällä yksityisen yliopiston palvelukseen.

Eniten asia koski Granön vanhaan opettajaan J. E. Rosbergiin, mutta hän varoi luonteensa mukaisesti näyttämästä avoimesti tunteitaan. Sen sijaan kasvitieteen professori Fredrik Elfving katkeroitui Granön ratkaisusta syvästi, sillä hän oli fyysismatemaattisen osaston vaikutusvaltaisena dekaanina nähnyt paljon vaivaa tämän nimittämiseksi ylimääräiseksi professoriksi. Miesten aiemmin ystävälliset suhteet eivät palautuneet koskaan täysin ennalleen. ${ }^{598}$

Myös Suomen Kartaston toimitusvaliokunnassa Granön ratkaisu herätti arvostelua. Kyösti Haatajan johtamassa Maanmittaushallituksessa pidettiin jopa hätäkokous, jossa sekä isäntä että Geologisen toimikunnan johtaja J. J. Sederholm ja Metsähallituksen pääjohtaja A. K. Cajander ripittivät ankarasti Granötä todeten, ettei tällainen uskottomuus käynyt laatuun. Granö puolustautui tieteellisiin ja opetuksellisiin velvollisuuksiin vedoten. Hän ei raaskinut sanoa suoraan, että korkeat 


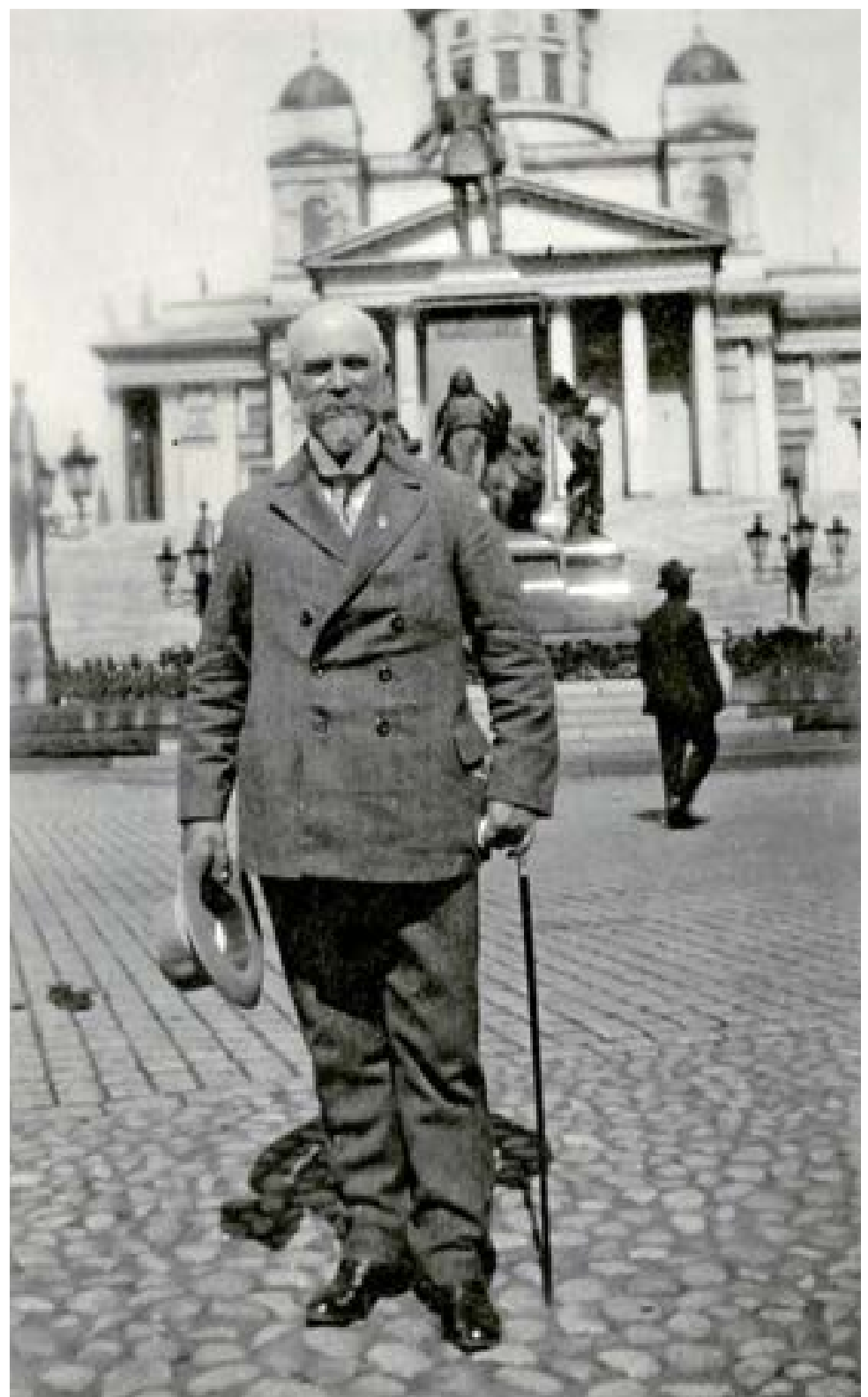

J. E. Rosberg

Senaatintorilla. 
herrat saivat osin syyttää itseään, kun olivat kasanneet yhden miehen harteille liian raskaan taakan.

Geologian professorit Wilhelm Ramsay ja Pentti Eskola pyrkivät vielä estämään Granön siirtymisen kääntymällä suoraan Turun Suomalaisen Yliopiston kanslerin J. R. Danielson-Kalmarin puoleen. Herrat totesivat Danielson-Kalmarille, ettei Granö ollut tehnyt oikein, sillä hänen velvollisuutensa olisi ollut pysyä Helsingissä palvelemassa maan pääyliopistoa. Vanha kansleri lopetti kuitenkin keskustelun lyhyeen. Sopimus oli tehty, ja siitä pidettäisiin kiinni..$^{599}$

Granö lähti Helsingin yliopistosta, mutta ei lopullisesti. 


\section{TURUN SUOMALAISEN YLIOPISTON PROFESSORI \\ VI}

"Jos tulkintani on oikea, ovat pyrkimyksemme, huolimatta heikkouksistamme ja hairahduksistamme samat: oikean ja hyvän puolesta pahaa ja alhaista vastaan, yhä syvemmälle ja kauemmas opin ja sivistyksen tiellä, yhä korkeammalle, sinne missä avarat näköalat aukeavat ja matalamielisyys hupenee mitättömyyteensä. Sikäli kun voimani ja kykyni riittävät, tahdon olla tukenanne ja apunanne näissä pyrkimyksissänne." ${ }^{600}$ 


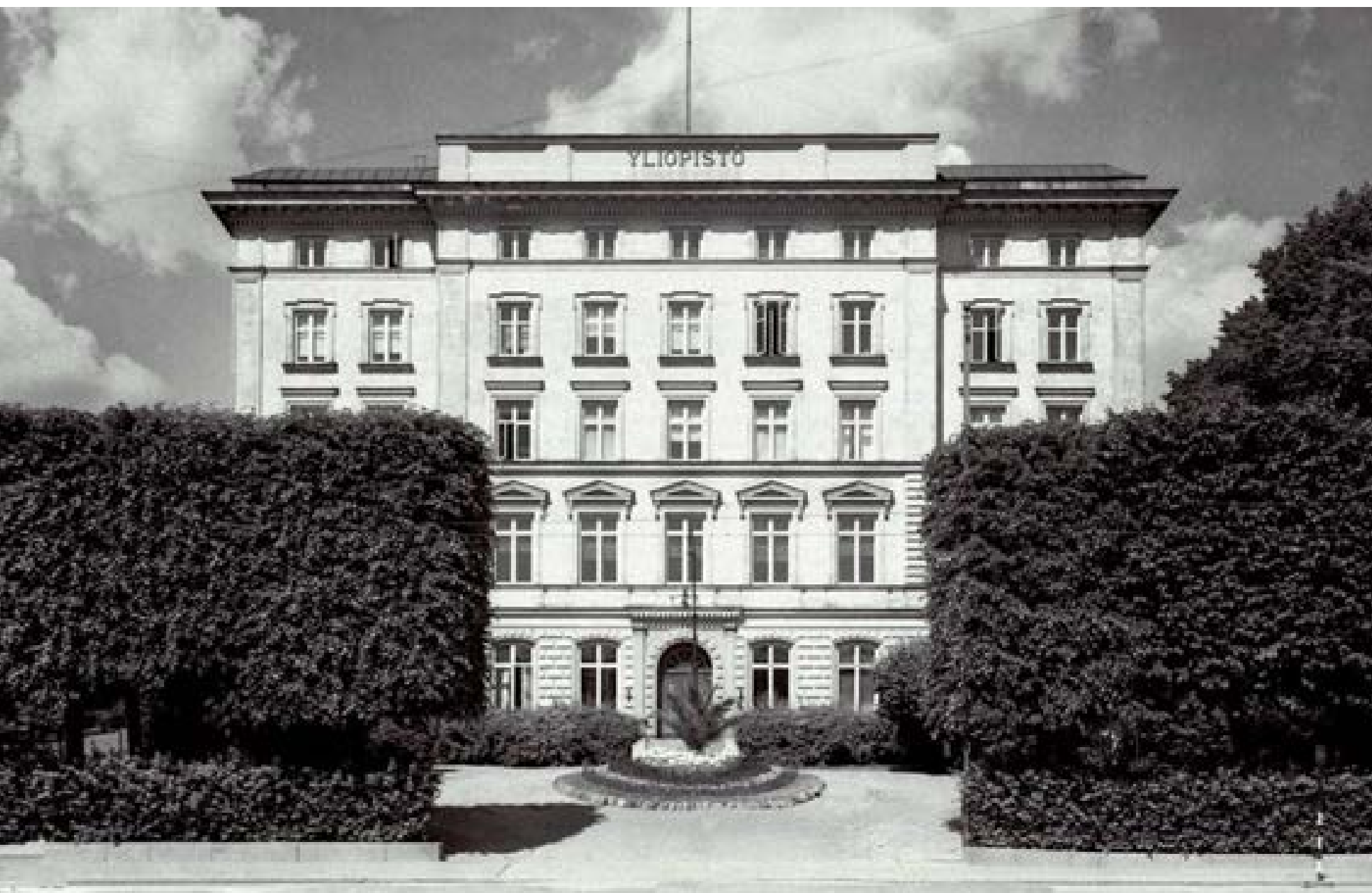

Turun Suomalaisen Yliopiston päärakennuksena toimi vuodesta 1922 lähtien alun perin hotelliksi 1878 rakennettu Phoenixin talo Kauppatorin laidassa. Uusien yliopistorakennusten valmistuttua nykyiselle Yliopistomäelle 1950-luvun puolivälissä talo jäi tyhjilleen ja purettiin huonokuntoisena 1959. 


\section{Aurajoen qarrelia}

\section{Kristiinankatu 1}

Granö oli asettanut yhdeksi Turkuun siirtymisen pääehdoksi sen, että hänelle järjestetään kunnollinen perheasunto. Kun sellaista ei ollut heti vapaana, Granöt asettuivat aluksi Suomalaisen Säästöpankin taloon Kauppiaskatu 9:ssä Kauppatorin laidassa. Kysymyksessä oli tilapäisratkaisu, sillä perheen tavoitteena oli löytää asunto jostakin puutalosta ydinkeskustan läheltä. ${ }^{601}$

Varsin nopeasti kävi kuitenkin ilmi, ettei sopivaa puutaloasuntoa ollut saatavilla. Siksi Granöt päätyivät lopulta muuttamaan vakuutusyhtiö Irtaimistopalon omistamaan Kristiinankatu 1:n jugend-linnaan Aurajoen varrelle. Vuonna 1909 valmistunut liike- ja asuinrakennus oli kaupunkikuvallisesti, rakennustaiteellisesti ja kulttuurihistoriallisesti Turun merkittävimpiä kivitaloja. Aurinkoisista huoneista avautuivat hienot näköalat Aurajoen yli Samppalinnanmäen vehmaisiin maisemiin.

Granöjen suuressa vuokra-asunnossa oli sali, ruokasali, isän työhuone, kaksi makuuhuonetta, keittiö ja kotiapulaisen huone. Siihen kuului myös lasitettu parveke. Tilaa oli riittävästi, sillä professorin äiti oli muuttanut Kauppiaskadulta asumaan Paavo Granön luokse Helsingin liepeille Oulunkylään. ${ }^{602}$

Ruotsin kielen asema oli Turussa 1920-luvulla edelleen vahva. Kaupungin kielellinen kahtiajako näkyi myös siinä, että muuttaessaan Kristiinankadulle Granöt olivat 


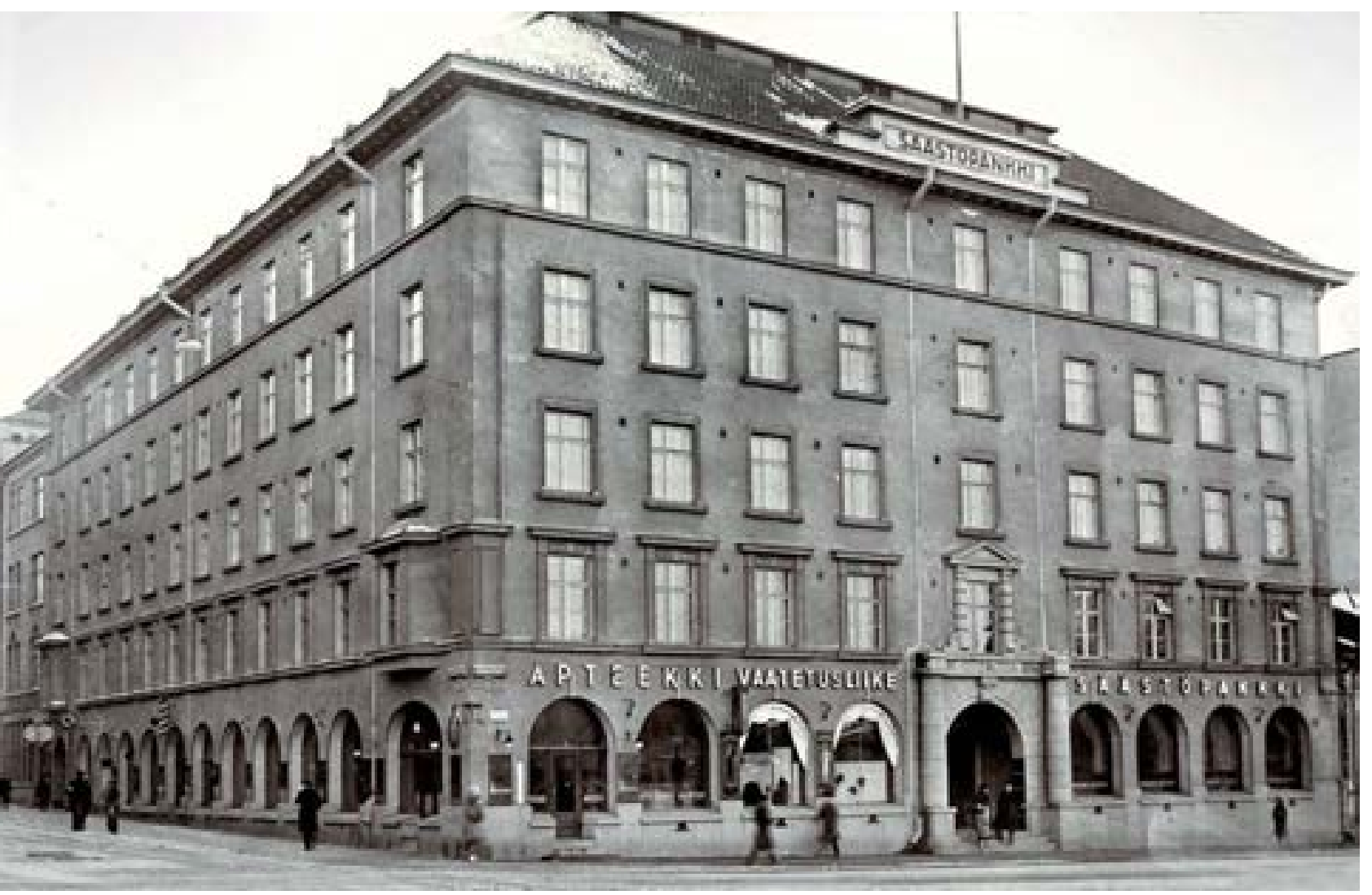

Apteekki, vaatetusliike ja Turun Suomalaisen Säästöpankin talo Kauppiaskatu 9:ssä Kauppatorin laidassa - Granön perheen ensimmäinen kotitalo Turussa.

talon ainoa suomenkielinen perhe. Lujana fennomaanina Granö piti kiinni suomen kielestä ja sijoitti lapsensa suomenkielisiin kouluihin, tyttäret äidin vanhaan kouluun tyttölyseoon eli Tipulaan ja kuopus Olavin Turun suomalaiseen klassilliseen lyseoon Linnankadun ja Eskelinkadun kulmaan. Suomen kieli sai lisää jalansijaa rakennuksessa vasta 1930-luvulla, jolloin suomalaiskansallinen suurliikemies Heikki Huhtamäki asettui sinne asumaan. ${ }^{603}$ 


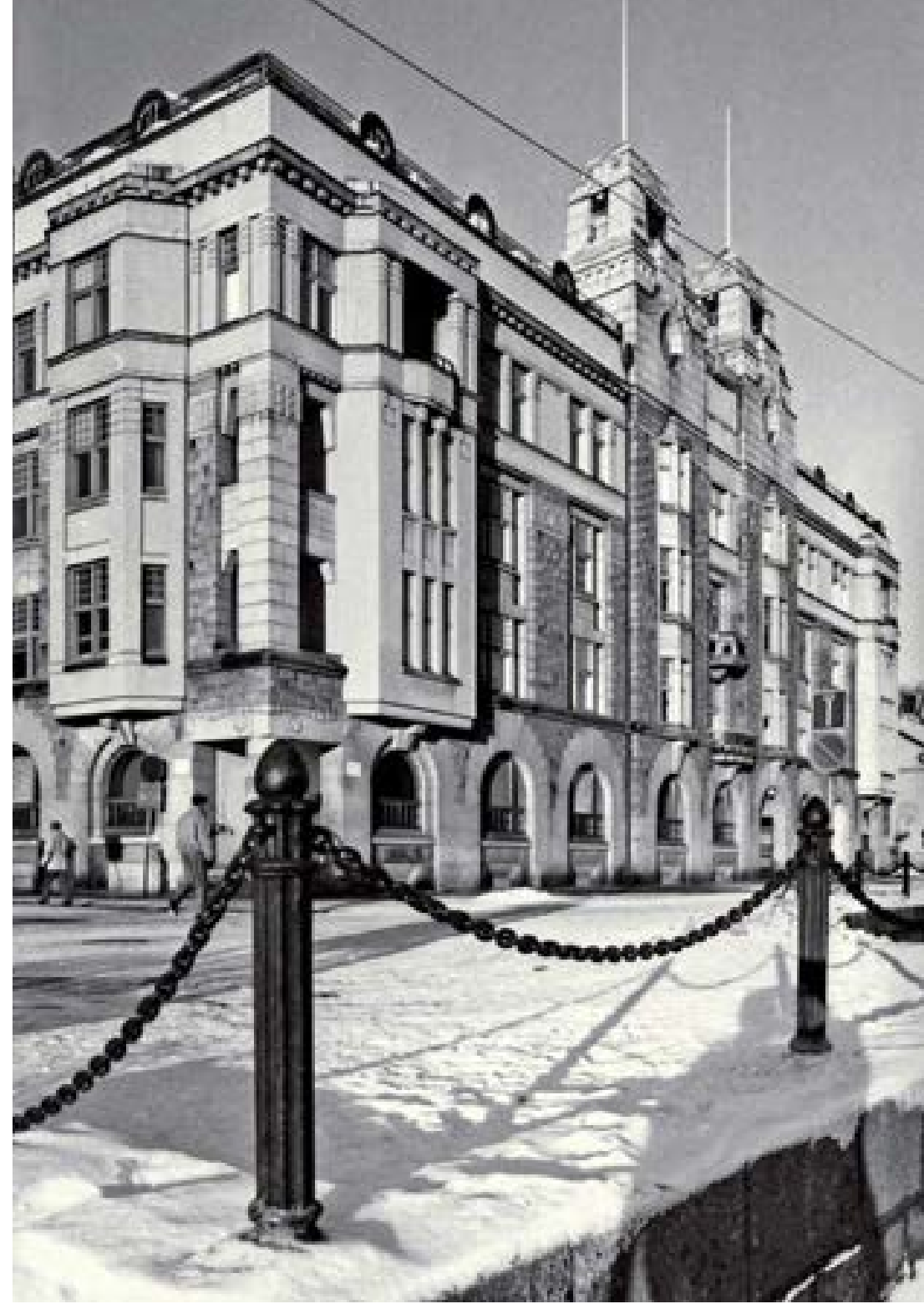

Granön perheen pitkäaikainen asunto Turussa oli Kristiinankadun ja Läntisen Rantakadun kulmaukseen 1909 valmistuneen jugend-rakennuksen kolmannessa kerroksessa Aurajoen rannalla. Kuva on 1940-luvulta.

Aurajoen ranta. Aurajoen ranta Granön Kristiinankadun asunnon edustalla toimi saaristosta saapuneiden veneiden satamana ennen joen alajuoksun siltojen rakentamista 1930-luvulla. Kuva on 1920-luvun silakkamarkkinoilta. Vastapäätä Granön asuntoa Kristiinankadulla olleet kaksi rakennusta purettiin 1950-luvulla.

Granön ajan dramaattisin tapahtuma Kristiinankadulla sattui talvisodan aikana, jolloin kaksi palopommia sujahti katon läpi ullakkokerrokseen. Pommit jäivät onneksi suutareiksi, joten talo säästyi tulipalolta. ${ }^{604}$ 


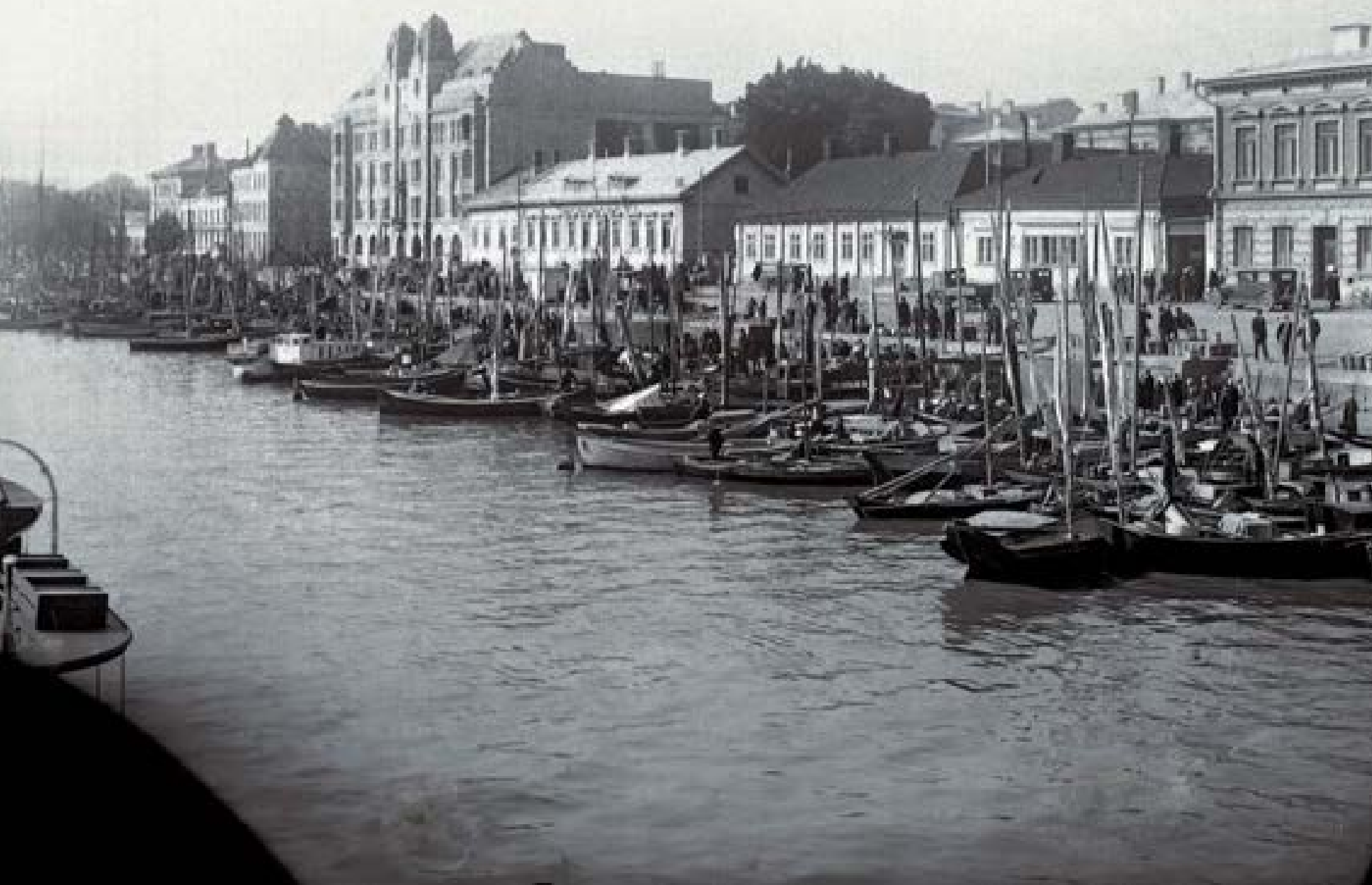

Granöt asuivat Kristiinankadulla vuoden 1944 syksyyn, jolloin he muuttivat takaisin Helsinkiin. Arvotalossa toimi pitkään Turun kaupunginkanslia, kunnes se muutti muualle. Turun kaupunki myi suojellun rakennuksen maaliskuussa 2010 yksityishenkilöille, joiden suunnitelmissa oli palauttaa se asuntokäyttöön. ${ }^{605}$ 


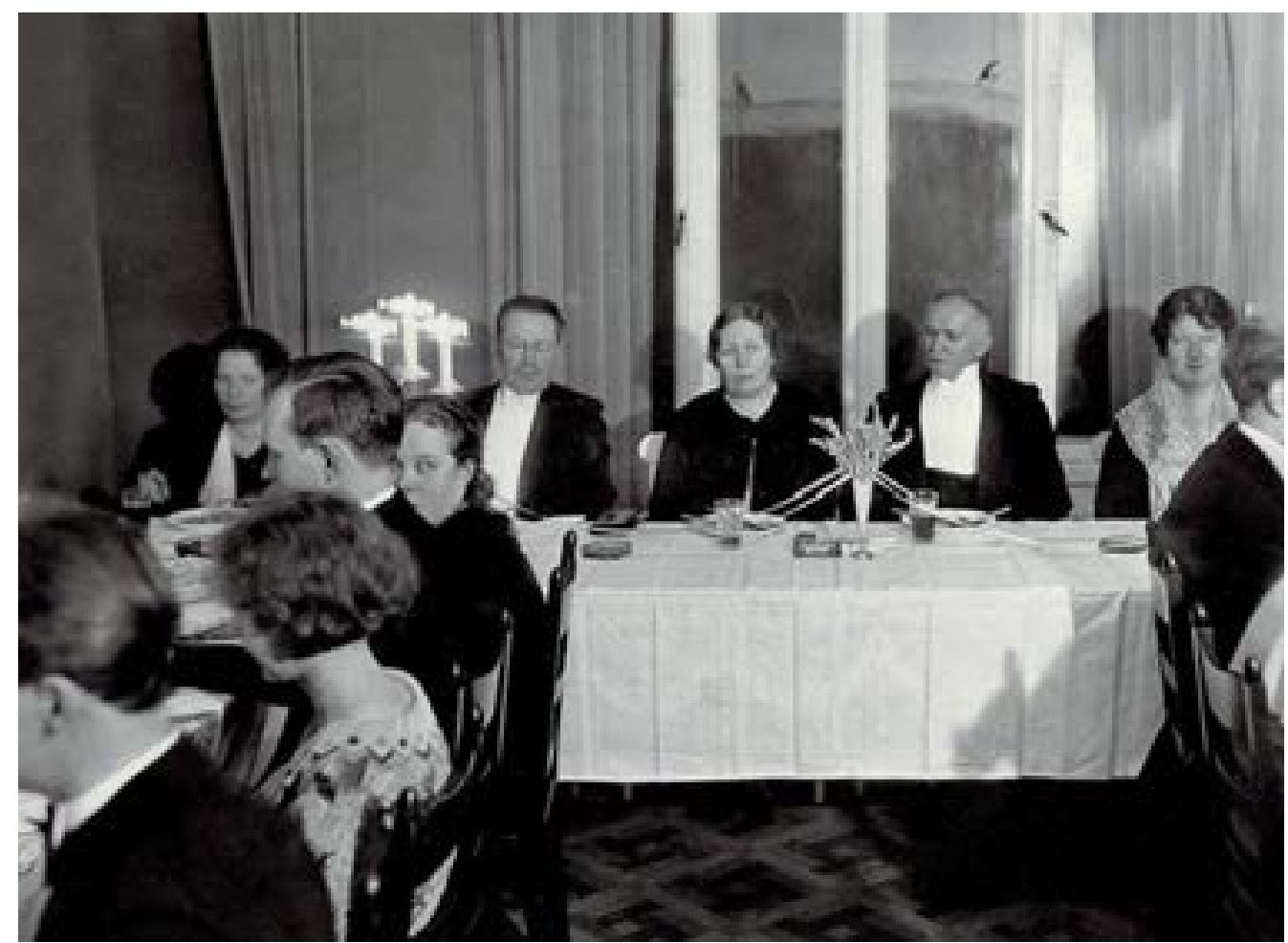

Granöt osallistuivat usein opiskelijoiden tilaisuuksiin, kuten Ylioppilaskunnan Pohjalaisen kerhon (osakunnan edeltäjän) vuosijuhlaan 28.1.1931. Pöydän takana vasemmalta Nanna Palomaa, J. G. ja Hilma Granö sekä professorikollega M. H. (Matti) Palomaa, läheinen ystävä jo Oulun kouluvuosilta.

\section{Seurapiirit}

Turun Suomalaisen Yliopiston ja Åbo Akademin perustamisen jälkeen Turusta tuli ainoa Suomen kaupunki, jossa toimi kaksi täysimittaista monitieteistä yliopistoa. Molemmat yliopistot olivat Helsingin yliopistoon verrattuna aluksi pieniä opinahjoja, sillä Granön ottaessa professuurin vastaan 1926 Åbo Akademissa professoreja oli 20 ja hänen uudessa yliopistossaan 13.606 


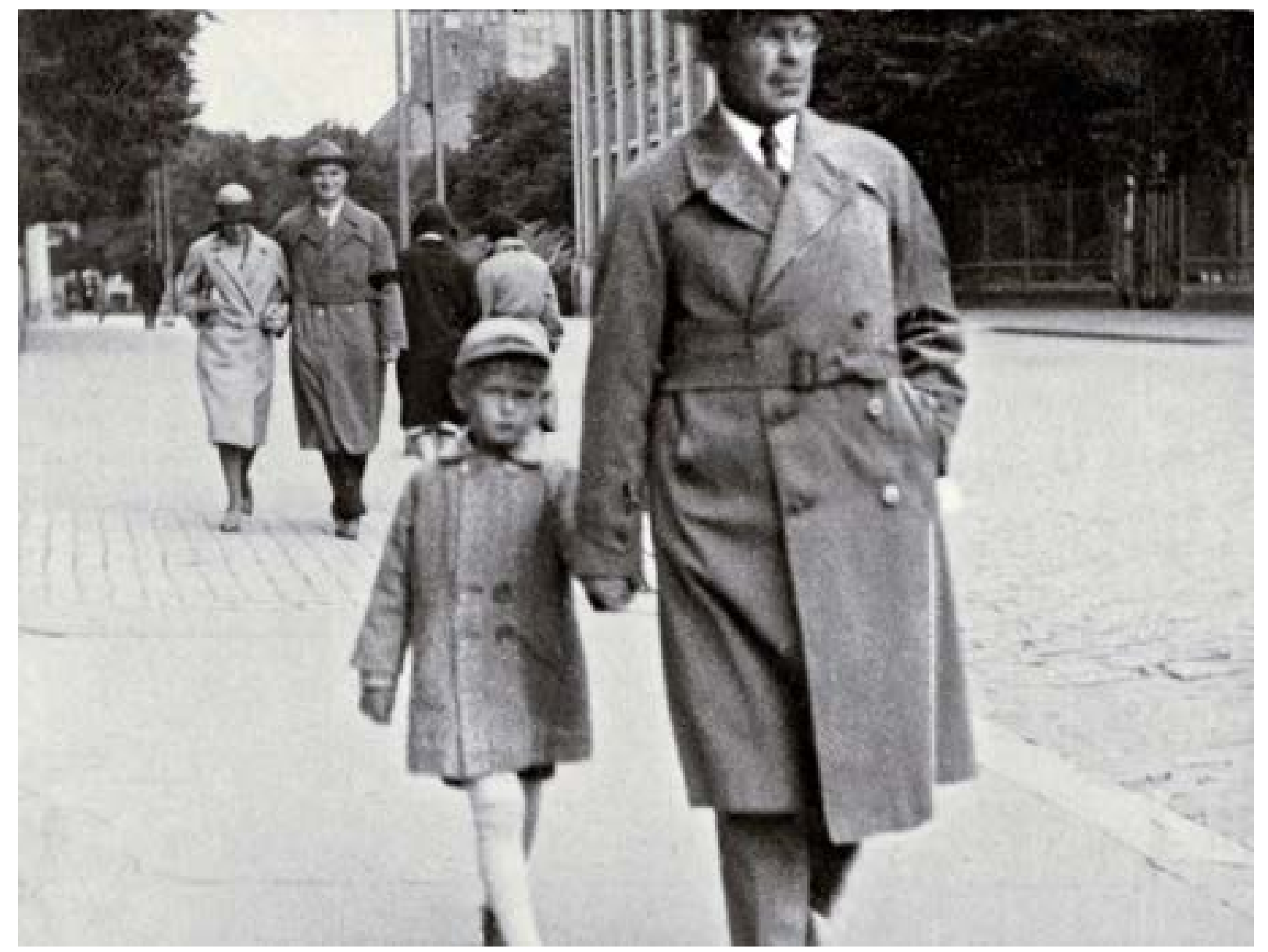

Yliopistojen pienuudesta huolimatta kielikiista piti huolen siitä, että niiden kesken oli vain vähän vuorovaikutusta. Saman alan kollegoiden välillä oli toki kanssakäymistä jo osin siksi, että J. G. ja Olavi Granö kävelevät Aurajoen rantakatua 1930-luvun alussa katuvalokuvaajan kuvaamana. Taustalla näkyy Tuomiokirkko. yliopistojen opiskelijat saattoivat tenttiä osan tenteistään toisessa yliopistossa, mutta kokonaisuudessaan yhteistyötä oli Granön mukaan valitettavan vähän. Ensimmäinen merkittävä yhteinen tapahtuma oli Turun vanhan akatemian 300 -vuotisjuhla, jonka Turun kaupunki järjesti 1940 vanhassa Akatemiatalossa. ${ }^{607}$ 
Turun Suomalaisen Yliopiston professorit muodostivat perheineen tiiviin yhteisön, jossa kaikki tunsivat toisensa ja kanssakäyminen oli vilkasta. Professorikollegoiden lisäksi Granön läheiseen ystäväpiiriin kuuluivat oman assistentin J. K. V. Tuomisen lisäksi muun muassa silloin Saaristosarjaansa suunnitellut yliopiston ylikirjastonhoitaja Volter Kilpi, jonka kanssa hän tunsi suurta henkistä yhteenkuuluvuutta, Turun Martin seurakunnan kappalainen A. E. Koskenniemi, johon hän oli tutustunut jo 1911 tämän toimiessa Japanissa lähetyssaarnaajana, sekä pikkuserkku, pankinjohtaja Edvard Solin. ${ }^{608}$

Yliopiston opettajien ja virkamiesten lisäksi Granö piti yhteyttä myös opiskelijoihin, sillä hän halusi välittää sekä tieteellistä että kansallista perintöä uusille tutkijapolville. Hän osallistui ylioppilaskunnan maakunta-, raittius- ja oppiainekerhojen toimintaan, ja niin pohjalainen kerho kuin maantieteen kerho kokoontuivat toisinaan hänen kotonaan.

Granö noudatti lukuvuosien aikana säännöllistä päivärytmiä. Hän nousi ylös yleensä kuuden aikaan aamulla ja laittoi itse aamukahvin. Yliopistolle hän saapui kello 8, ja mahdolliset luennot pidettiin heti aamulla 8-10. Kello 11 alkaneen, pari tuntia kestäneen lounaan jälkeen hän työskenteli kello 17:ään, jolloin hän lähti kotiin päivälliselle. Päivällisen jälkeen Granö meni vielä usein yliopistolle mutta palasi kotiin viimeistään siten, että saattoi kuunnella kymmenen uutiset. Yötöitä hän ei harrastanut koskaan. ${ }^{609}$

Tieteellinen työ ja erilaiset virkavelvollisuudet veivät niin suuren osan Granön ajasta, että hän ei juuri ehtinyt osallistua Turun kirjallis-taiteellisten piirien toimintaan. V. A. Koskenniemi kutsui hänet muutaman kerran kirjallisiin kutsuihinsa, joissa hän tapasi muun muassa runoilijat Kaarlo Sarkian ja Larin-Kyöstin. Ainoa kuvataiteilija, johon Granö piti Turussa yhteyttä, oli muotokuvamaalari Teodor Schalin, entinen luokkatoveri Oulun ajoilta. ${ }^{610}$

J. G. Granö ja J. K. V. Tuominen Kristiinankadun asunnossa. Seinällä Eetu Iston 1900-luvun alussa Alatorniolla maalaama taulu Johannes Granöstä. Nykyään maalaus on Alatornion pappilassa. 


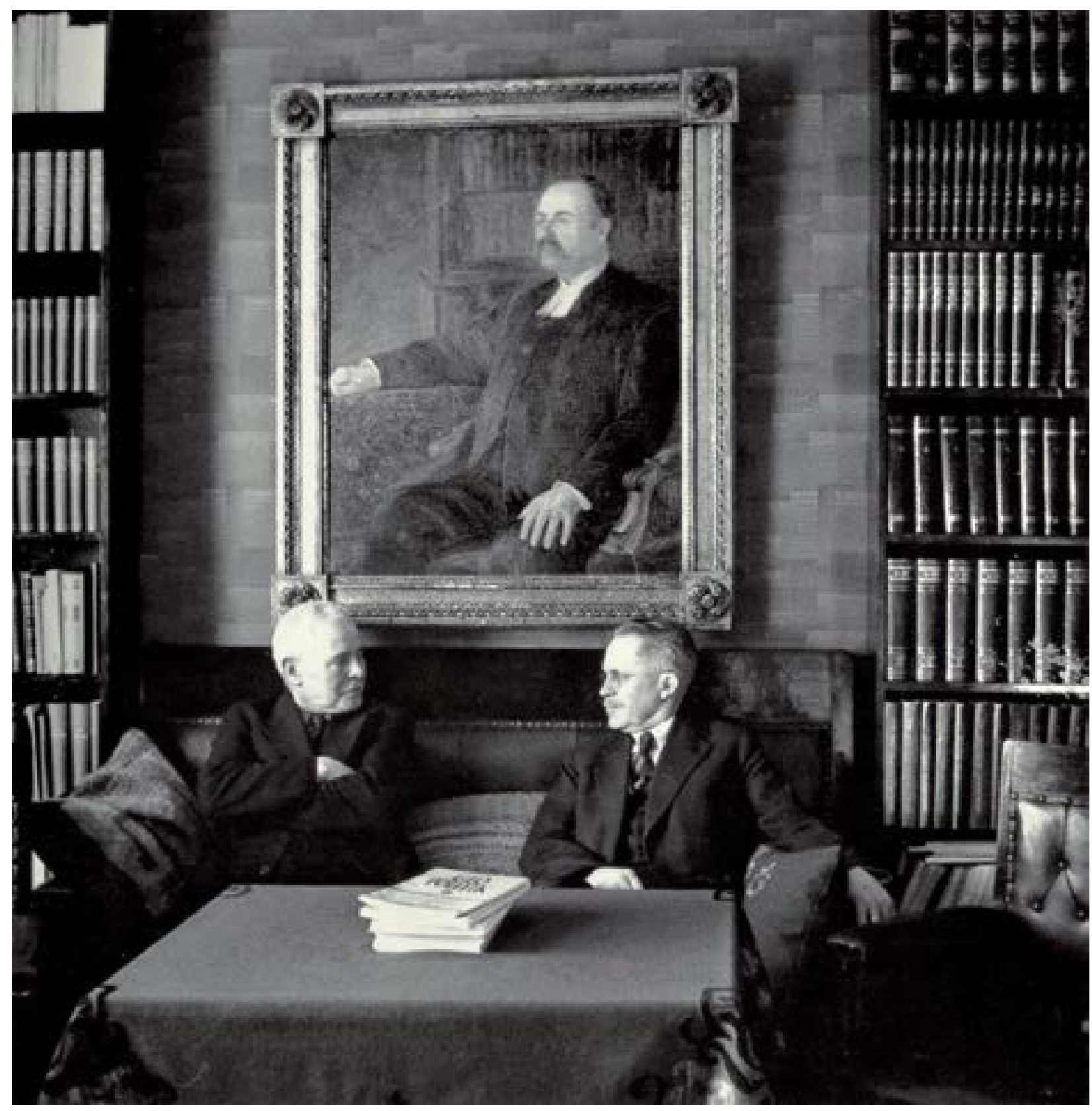


Granö oli omaksunut kansallisesti ajatteleville professoreille ominaisen elämäntyylin, joka perustui perinteisten arvojen kunnioittamiseen. Kaikenlaista komeilua ja hienostelua vieroksuttiin, mutta vanhoista tavoista ja käyttäytymissäännöistä pukeutumista myöten pidettiin tiukasti kiinni. Elämäntapojen tarkkuus näkyi myös ulkomuodossa. Hän käytti ajan muodin mukaisesti viiksiä, ja nuoruusaikojen taiteellisen kauden väistyttyä hän piti tuuhean mustan tukkansa visusti kuosissa.

Granön merkittävä asema kolmen yliopiston professorina ja kansainvälisesti arvostettuna tutkimusmatkailijana ja tiedemiehenä tuli parhaiten esiin hänen 50-vuotissyntymäpäivänään 14. maaliskuuta 1932. Tuolloin Kristiinankadun kotiin tulvi vieraita ja huomionosoituksia Suomesta ja ulkomailta. ${ }^{611}$

J. G. Granön 50-vuotissyntymäpäivät noteerattiin näyttävästi Suomen sanomalehdissä. Vuolaimmin päivänsankaria kehui J. K. V. Tuomisen sommittelemin sanoin kotikaupungin lehti Uusi Aura:
Suurinta ihmisessä on kuitenkin ihminen itse. Harvinaisen runsaasti ja tasasuh- taisesti ovat hyvät hengettäret suoneet professori Granölle ihmisen parhaimpia avuja, suuren työkyvyn, tyynen tarmon, kaiken inhimillisen hyvänsuovan ym- märtämisen säätyyn ja arvoon katsomatta, aurinkoisen optimismin ja huumo- rintajun ja - muita luettelematta - lopuksi senkin, mikä suurimmassakin ihmi- sessä on suurinta, vilpittömän sisäisen nöyryyden ja vaatimattomuuden. ${ }^{612}$

Vanha kiinnostus kasveihin synnytti Kristiinankadun tiloissa kaktuksiin kohdistuvan harrastuksen. Kaktuksen taimia oli tuolloin mahdollista tilata ulkomaiden puutarhoista. Talven ajaksi kaktukset tuotiin avaran asunnon ikkunalaudoille, mutta muuna aikana ne olivat lasiverannalla. Myöhemmin kuvaan tulivat mukaan orkideoiden eri lajit, joten asunnon koristeena oli usein kukkivia orkideoita.

Orkideaharrastus lujitti Granön suhdetta kasvitieteen professori Harry Warikseen (vuoteen 1935 Warén), joka Granön tapaan oli harrastanut ylioppilasaikanaan viulunsoittoa. Monien vuosien aikana he soittivat duettoja vuoroviikkoina toistensa 
kotona. Musiikki yhdisti Granötä myös vanhaan koulutoveriin kemian professori M. H. Palomaahan. Lähes jokaviikkoinen konserteissa käynti Palomaiden kanssa kuului Granön perheen ohjelmaan. ${ }^{613}$

Yksi uusi ajanviettotapa, jonka Granö Turussa omaksui, oli elokuvissakäynti. Hän piti elokuvien tarjoamasta mahdollisuudesta julkiseen yksityisyyteen, jossa hänen ei tarvinnut vastata ihmisten odotuksiin ja kysymyksiin. Hänen oppilaansa Paavo Kallio on kertonut menneensä kerran hieman häpeillen ja luimistellen nuorisolle tarkoitettuun Tarzan-elokuvaan ja istahdettuaan paikalleen tuntenut yhtäkkiä jonkun tarttuvan takaa hänen niskaansa. Pelästys taittui äkkiä, kun hän samalla kuuli Granön kysyvän, koska hän oli tulossa tenttiin. Kallio tunsi nyt olevansa riittävän arvokkaassa seurassa, joten hän saattoi keskittyä rauhassa seuraamaan komearaamisen ja -äänisen Johnny Weissmullerin seikkailuja sademetsässä vähäpukeisen Janen ja kumikrokotiilien kanssa. ${ }^{614}$ 


\section{AANTIETEEN LAITOKSEN JOHTAJA}

\section{Humboldtilainen maantieteen laitos}

Granön astuessa Turun yliopiston palvelukseen syyslukukauden 1926 alussa maantieteen laitos oli toiminut jo kaksi vuotta. Laitos oli hänelle tuttu, sillä hän oli opastanut neuvoin sen toiminnasta Iivari Leiviskän jälkeen vastannutta assistentti J. K. V. Tuomista ja hoitanut kevätlukukaudella tentit Helsingistä käsin. ${ }^{615}$

Tarton yliopiston maantieteen laitoksen perustaessaan Granö oli ollut vain 37-vuotias, mutta nyt seitsemän vuoden kuluttua siitä, hänelle oli professoritason kokemusta myös Helsingin yliopiston maantieteen laitokselta. Suunnitellessaan laitoksen toimintaa Granö otti silti lähtökohdakseen Viron ajan kokemukset, sillä yliopiston ei hänen mielestään tullut keskittyä vain tieteellisten tutkintojen myöntämiseen vaan myös ylioppilaiden kaikinpuoliseen henkiseen ja kansalliseen kasvattamiseen. Hänen tavoitteenaan oli humboldtilainen yliopisto, jossa tutkimuksen ohella arvostettiin opetusta ja kansallista kulttuuria. Hän ajatteli, että tieteen perinne voitiin parhaiten välittää uusille tutkijapolville kansallisissa yliopistoissa, jollaiseksi Turun yliopisto tulisi kehittää. ${ }^{616}$

Granön mielestä Turun yliopiston pienuus oli pikemminkin etu kuin haitta. Se mahdollisti professorien opetus- ja tutkimustyön sekä kansallisen kasvatuksen luontevan limittymisen toisiinsa. Opetuksen tuli olla tieteellisesti korkeatasoista ja kansallisesti innoittavaa. Lisäksi opiskelijat pääsivät pienessä yliopistossa välittömään kosketukseen eri alojen huippututkijoiden kanssa, sillä professori saattoi luennoida omasta alastaan ja tekeillä olevista tutkimuksistaan jo ensimmäisen vuoden opiskelijoille. ${ }^{617}$ 


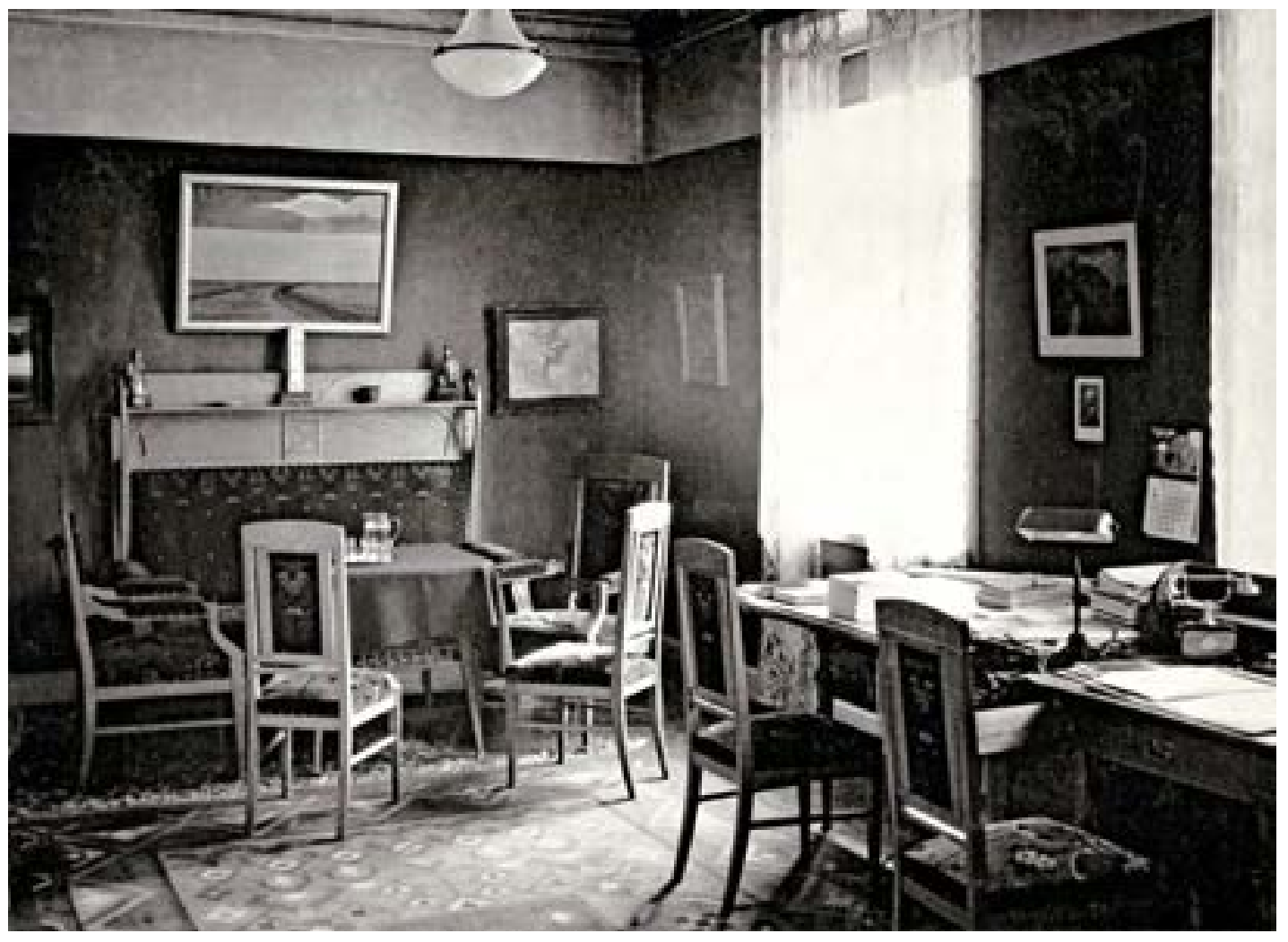

Turun Yliopiston maantieteen laitoksen johtajan huone Granön aikana. Jugend-huonekalut olivat peräisin Phoenix-hotellista. Seinällä oleva taulu on Paavo-veljen maalaama aromaisema Omskin ympäristöstä Siperiasta.

Ottaessaan vastaan professuurin Granö oli saanut lupauksen maantieteen laitoksen laajentamisesta. Vanhojen huoneiden lisäksi laitos sai 1926 käyttöönsä esimiehen huoneen ja kaksi pientä huonetta piirustustöitä ja seminaarikirjastoa varten. Granön saatua Wilhelm Ramsayn ja Pentti Eskolan laatiman lausunnon perusteella oikeuden antaa alkeisopetusta geologiassa ja mineralogiassa maantieteen opetuksen yhteyteen liitettiin tämän oppiaineen approbatur-arvosanaa vastaava kurssi. Kun laitos sai Au- 


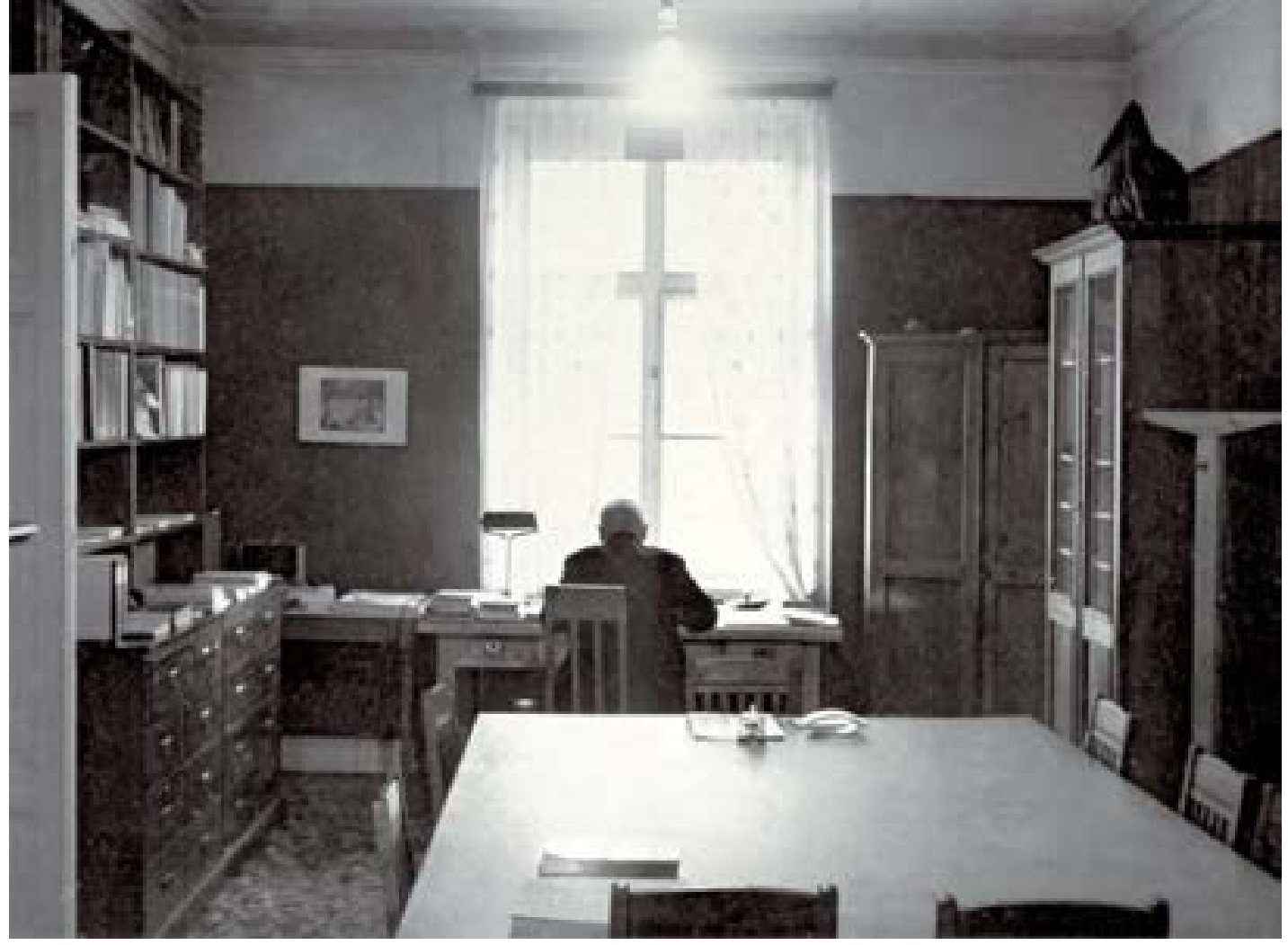

Maantieteen laitoksen kakkosmies oli kuvassa selin oleva J. K. V. Tuominen, osa-aikainen assistentti ja Granön pitkäaikainen luottoystävä.

rakadun puolelta neljä huonetta geologian opetuksen vaatimia kokoelmia ja harjoituksia varten, sen pinta-ala kasvoi kolminkertaiseksi aiempaan nähden. ${ }^{618}$

Suunnitellessaan laitoksen kalustamista sekä kokoelmien ja välineistön hankintaa Granö joutui noudattamaan ankaraa säästäväisyyttä ja harkintaa, sillä yksityisen yliopiston rahatilanne oli tukala. Laitoksen kalusto oli muodostunut pääosin Turun Keskusvankilassa eli Kakolassa teetetyistä erikoisvalmisteisista piirustuspöydistä ja Phoenix-hotellin vanhoista tuoleista, mutta tilojen kasvaessa kalusteita tarvittiin huomattavasti lisää. ${ }^{619}$

Granö pohti keväällä 1926 Billnäs-kalusteiden hankkimista, mutta luopui nopeasti ajatuksesta, koska pelkäsi niiden kalleuden herättävän puheita tuhlauksesta. 
Tilanne ratkaistiin siten, että paikallisilta valmistajilta tilattiin 21 uutta piirustuspöytää, kaksi suurta pantografipöytää sekä yksi valopöytä. Esimiehen ja assistentin huoneet sisustettiin pääosin yliopiston vanhoilla kalusteilla. ${ }^{620}$

Granö oli tuonut Tartosta Turkuun täydellisen sarjan Viron topografisia karttoja, joten kartastojen hankinnassa hän saattoi keskittyä keräämään mahdollisimman kattavan kokoelman Suomen karttoja. Vuonna 1928 laitos osti kaikki saatavissa olevat Suomesta tehdyn venäläisen topografikartan lehdet, ja hyvien suhteidensa ja Suomen Kartaston 1925 toimitustyön ansiosta Granö onnistui saamaan Maanmittaushallitukselta maksutta kaikki sen julkaisemat kartat. Lisäksi hankittiin muun muassa kotimaan merikarttoja sekä geologisia ja agrogeologisia karttoja. ${ }^{621}$

Opetuksen ja tutkimuksen vaatima kirjallisuus ostettiin pääasiassa laitoksen omilla määrärahoilla, mutta sitä saatiin myös lahjoituksina sekä laitoksilta että yksityisiltä henkilöiltä. Kun laitos perusti 1927 oman julkaisusarjan Turun Yliopiston Maantieteellisen Laitoksen Julkaisuja, se saattoi aloittaa julkaisujensa vaihdon kotimaisten ja ulkomaisten yliopistojen ja maantieteellisten organisaatioiden kanssa.

Granön tavoitteena oli elävöittää luento-opetustaan kuvilla, minkä vuoksi laitokseen hankittiin 1926-27 noin 650 diapositiivia. Seuraavan vuosikymmenen lopulla kuvia oli jo reilusti yli 3 000, mikä johti siihen, että diapositiivikokoelman hoito kävi työstä. Kuvien näyttämistä varten hankittua projektoria täydennettiin monin, erityisesti Tuomisen kehittämin lisälaittein. Kuultokuvia puolestaan näytettiin Granön omalla, varsin alkeellisella projektorilla. ${ }^{622}$

Kun Granö oli saanut maantieteen laitoksen toivomaansa kuntoon ja opetuksen alkuun, hän saattoi toteuttaa marras-joulukuun vaihteessa 1926 suunnittelemansa vierailun Ruotsin, Tanskan ja Norjan tärkeimpiin yliopistokaupunkeihin. Samalla kun hän tutustui pohjoismaisiin maantieteen laitoksiin ja maantieteellisiin seuroihin ja niiden toimintaan, hän piti joka paikassa luennon, jossa hän käsitteli sekä Altain tutkimustensa tuloksia että maisematieteen sisältöä ja metodiikkaa. Hän esitteli myös henkilökohtaisissa keskusteluissa näkemyksiään maantieteellisestä tutkimuksesta ja solmi useita tärkeitä suhteita skandinaavisiin tutkijoihin. ${ }^{623}$ 
Granön esitelmät maisematieteestä herättivät erityisesti Ruotsissa niin paljon huomiota, että häneltä pyydettiin artikkeli maantieteelliseen aikakauskirjaan Geografisk Årsbok. Vuonna 1927 ilmestyneessä kirjoituksessa esitetyt näkemykset poikkesivat kuitenkin niin paljon ruotsalaisesta tutkimusperinteestä, että ne eivät juuri saaneet vastakaikua sikäläisissä maantieteilijäpiireissä. Konkreettisimmin Granön Skandinavian kiertomatkasta hyötyi Turun yliopiston maantieteen laitos, sillä useat skandinaaviset yliopistot lahjoittivat sille julkaisujaan. ${ }^{624}$

Granön järjestämä maantieteen laitos veti puoleensa kiinnostuneita vierailijoita niin kotimaasta kuin ulkomailta. J. E. Rosberg kävi tutustumassa laitokseen jo vuoden 1927 alussa, ja pian siellä vierailivat myös muun muassa Hans Hausen Åbo Akademista, Iivari Leiviskä, Matti Sauramo ja Uunio Saalas Helsingin yliopistosta sekä Helge Backlund ja Otto Nordenskiöld Ruotsista. Vuoden 1928 lopulla laitoksessa käynyt Merentutkimuslaitoksen johtaja Rolf Witting oli niin tyytyväinen näkemäänsä, että suvaitsi kirjoittaa laitoksen vieraskirjaan armeijatyyliin: "Tarkastanut laitoksen päästä päähän ja havainnut sen olevan hyvässä kunnossa." ${ }^{25}$

Vuoden 1932 lopulla laitos sai osakseen myös kuninkaallista loistoa, kun Ruotsin kruununprinssi Kustaa Aadolf puolisoineen tutustui yliopistovierailun yhteydessä sen toimintaan. Ylhäisten vieraiden mutkaton esiintyminen sai J. K. V. Tuomisen kirjaamaan laitoksen Aikakirjaan seuraavan luonnehdinnan: "Tosisivistyneitten ihmisten koruton luonnollisuus antoi leimansa tälle vierailulle."26

\section{Opetus}

J. G. Granö määritteli tulevan opetusalansa 2. lokakuuta 1926 pitämässään virkaanastujaisesitelmässä "Suomalainen maisema". Taitavasti retoriikan mahdollisuuksia hyödyntäneen esitelmänsä aluksi hän esitti perinteisen tapaan laaditun kuvauksen suomalaisesta maisemasta:

Mitä kaikkea onkaan mielestämme suomalainen maisema! 
Kallioista ja soista metsämaata, kimmeltäviä järviä. Punaisia mökkeja ja sammaltuneita aitoja harmaiden teiden varsilla. Vihertävästä merestä kohoavia kallioluotoja ja metsäisiä saaria, kivikkoniemiä ja ruovikkopoukamia. Vuolaiden kymien välistä lakeutta, vauraita taloja, silmänkantamattomiin pelto- ja niittysarkoja. Aukeata tunturimaailmaa, kesäyön aurinkoa, mittaamattomia aappoja. Lumisia tantereita, hämärää, revontulia. Ehkäpä myös tuulen huminaa, kosken kohinaa, lintujen laulua saloilla ja ahomailla, hälinää pihoilla, teillä ja vainioilla, hellettä ja pakkasta, poutaa ja sadesäätä. Mahdollisesti sellaistakin suomalaiselle ympäristöllemme mielestämme oleellista, jota ei voida suoranaisesti aistimin havaita. ${ }^{627}$

Granö myönsi, että tutkija ottaa kovan riskin lähtiessään käsittelemään "näin laajaa, monivivahteista ja rajoiltaan epävarmaa aihetta”. Hän oli kuitenkin rohjennut näin tehdä, koska halusi ottaa maantieteilijänä selvää, oliko yleensä mahdollista puhua suomalaisesta maisemasta, ja jos oli, missä merkityksessä. ${ }^{628}$

Hyvään tutkimustapaan Granö aloitti esityksensä määrittelyillä. Hän ilmoitti käsittävänsä maiseman ihmiskeskeiseksi, havaitsijaan sidotuksi kokonaisuudeksi, jota rajoittaa vaakasuorassa tasossa näköpiiri ja ylhäällä taivaankansi. Se jakaantui noin 20 metrin päähän ihmisestä ulottuvaan lähinäkymään eli lähiöön, jonka ihminen aistii kaikilla aisteillaan, ja siitä aina taivaanrantaan asti ulottuvaan kaukonäkymään eli maisemaan, jonka ihminen hahmottaa vain näköaistin avulla.

Oliko sitten olemassa erityistä suomalaista maisemaa, siis ikään kuin jotakin kasvi- tai eläinlajia vastaavaa maisematyyppiä, joka olisi vain Suomessa edustettuna? Valaistuaan asiaa erityisesti suomalaisen maiseman pääluonnehtijoiden, maanpinnan muotojen ja vesistöjen, kannalta Granö päätyi toteamukseen, että suomalainen maisema oli erikoisena tyyppinä erotettavissa siitä syystä, ettei missään muualla ollut niin suurta maan ja veden vaihtelua kuin Suomessa. Missään muualla maankamara ei ollut niin veden pirstomaa kuin Sisä-Suomen järvialueella ja Saaristomeren alueella Turun ja Ahvenanmaan seudulla. ${ }^{629}$ 
Vaikka erityinen suomalainen maisematyyppi oli siis olemassa, kaikki Suomen maisemat eivät edustaneet tätä maisematyyppiä. Maankamaran korkokuva ja vesistöjen runsaus sekä kasvillisuuden ja tekoaineksen synnyttämät muodot vaihtelivat niin paljon, että Suomessa saattoi olla sellaisia maisemia, jotka erosivat selkeästi perustyypistä. Tutkittavaa siis riitti. ${ }^{630}$

Virkaanastujaisesitelmä oli lähtökohta Turun yliopiston maantieteen laitoksen opetus- ja tutkimusohjelmalle. Yliopiston luonnontieteelliselle tiedekunnalle antamansa lausunnon mukaisesti Granö suuntasi laitoksensa voimavarat ympäristön tutkimukseen.

Käytännössä tämä tapahtui siten, että opiskelijat käsittelivät erikoistöissään Lounais-Suomen maisemia ja rakennettua ympäristöä. Granö toi näin Tartosta Suomeen tutkimuslinjan, jossa luonto, mukaan luettuna ihmisen luontoon kohdistunut toiminta, oli tutkimuksen kohteena myös kokonaisuutena, maisemana. Samalla luotiin uusia menetelmiä maisemien tutkimiseksi. ${ }^{631}$

Granö saattoi suunnata laitoksen tutkimustoiminnan haluamallaan tavalla, sillä laitos toimi ensimmäiset vuosikymmenet kahden henkilön työpanoksen varassa. Granö vastasi professorina ja laitoksen johtajana pääosin opetuksesta ja harjoitustöiden johtamisesta, kun taas assistentti J. K. V. Tuominen osallistui opetukseen vain rajallisesti keskittyen amanuenssin tehtäviin, seminaarikirjaston ja kokoelmien hoitoon sekä yleensä kaikenlaisiin huolto- ja korjaustöihin. Tuomisen assistentuuri oli osa-aikainen, sillä hän hoiti edelleen Turun suomalaisen lyseon lehtorin virkaa. ${ }^{632}$

Granön maantieteen luento-opetuksen runkona olivat cum laude -tason luennot, jotka käsittivät yleis- ja erikoismaantieteen peruskurssit. Yleismaantieteen luentoihin kuulunut metodiikan luentokurssi oli johdatusta Granön maisematieteen perusnäkemyksiin ja käsitteisiin ja muodosti samalla pohjan aluetieteen opetukselle. Aluetieteen luennot käsittelivät puolestaan Eurooppaa ja muita maanosia sekä yksittäisiä maita, kuten Venäjä, Persiaa ja Afganistania sekä Turkkia. ${ }^{633}$

Granö katsoi, että hänen antamansa maantieteen luento-opetus vastasi laajuudeltaan Helsingin yliopiston maantieteen laitoksen tasoa, sillä hän ei luennoinut samoja 


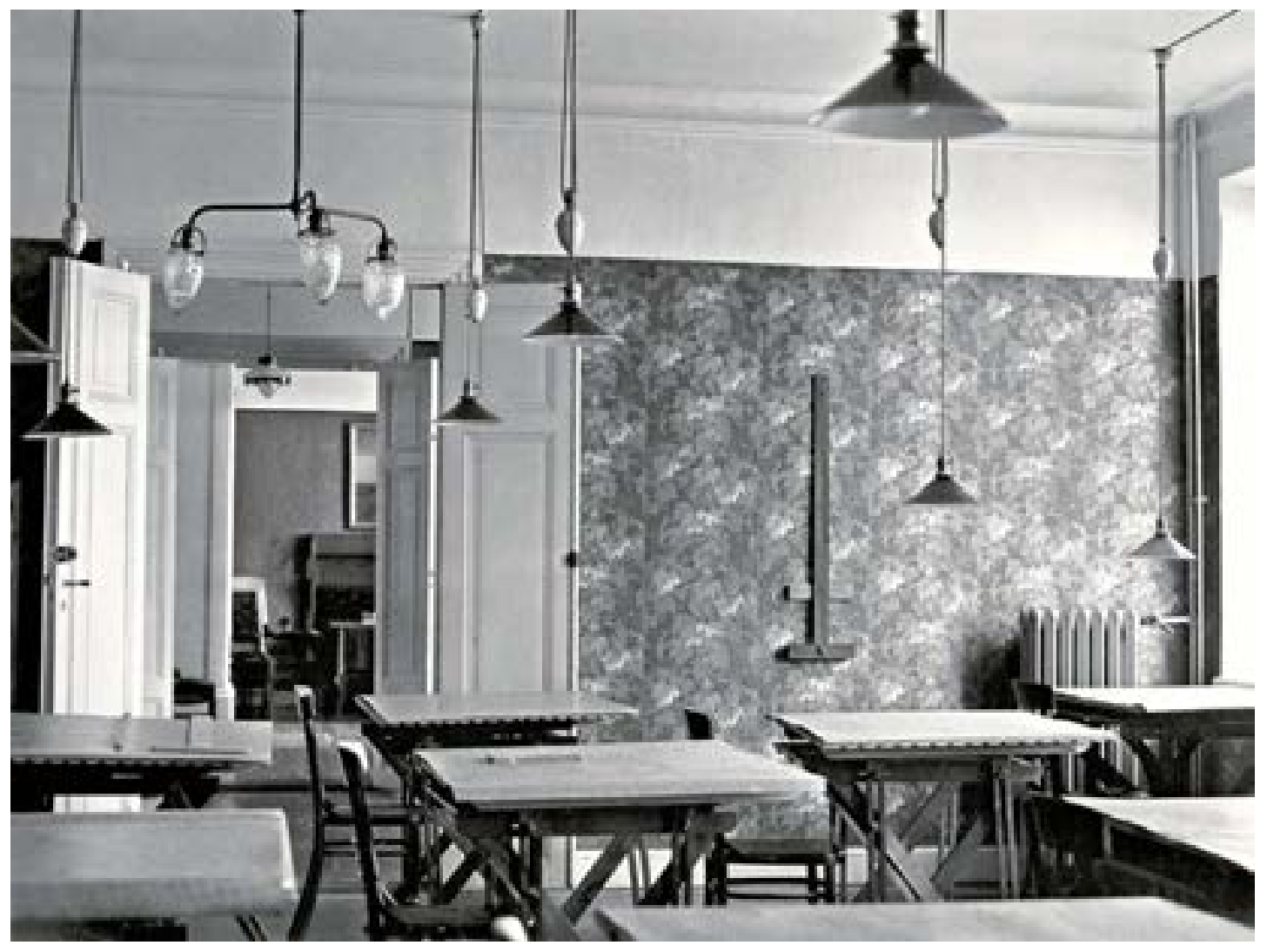

Turun Yliopiston maantieteen laitoksen piirustussali J. K. V. Tuomisen kuvaamana 1927.

peruskursseja joka vuosi. Koska useimmat opiskelijat osallistuivat myös biologisten aineiden opetukseen, eliömaantieteen luento-opetuksen saattoi jättää vähemmalle. Lisäksi opetusta monipuolisti se, että hän piti luentoja myös geologiassa ja mineralogiassa approbatur-arvosanaa varten. Granön ryhdyttyä hoitamaan yliopiston rehtorin tehtäviä geologian ja mineralogian opetuksesta vastasi pääosin Helsingin yliopiston geologian professori Matti Sauramo. ${ }^{634}$

Kaiken kaikkiaan Granön Turun vuosien luento-ohjelma oli monipuolinen. Eniten hän luennoi geomorfologiasta, aluetieteen perusteista ja klimatologiasta ja osea- 


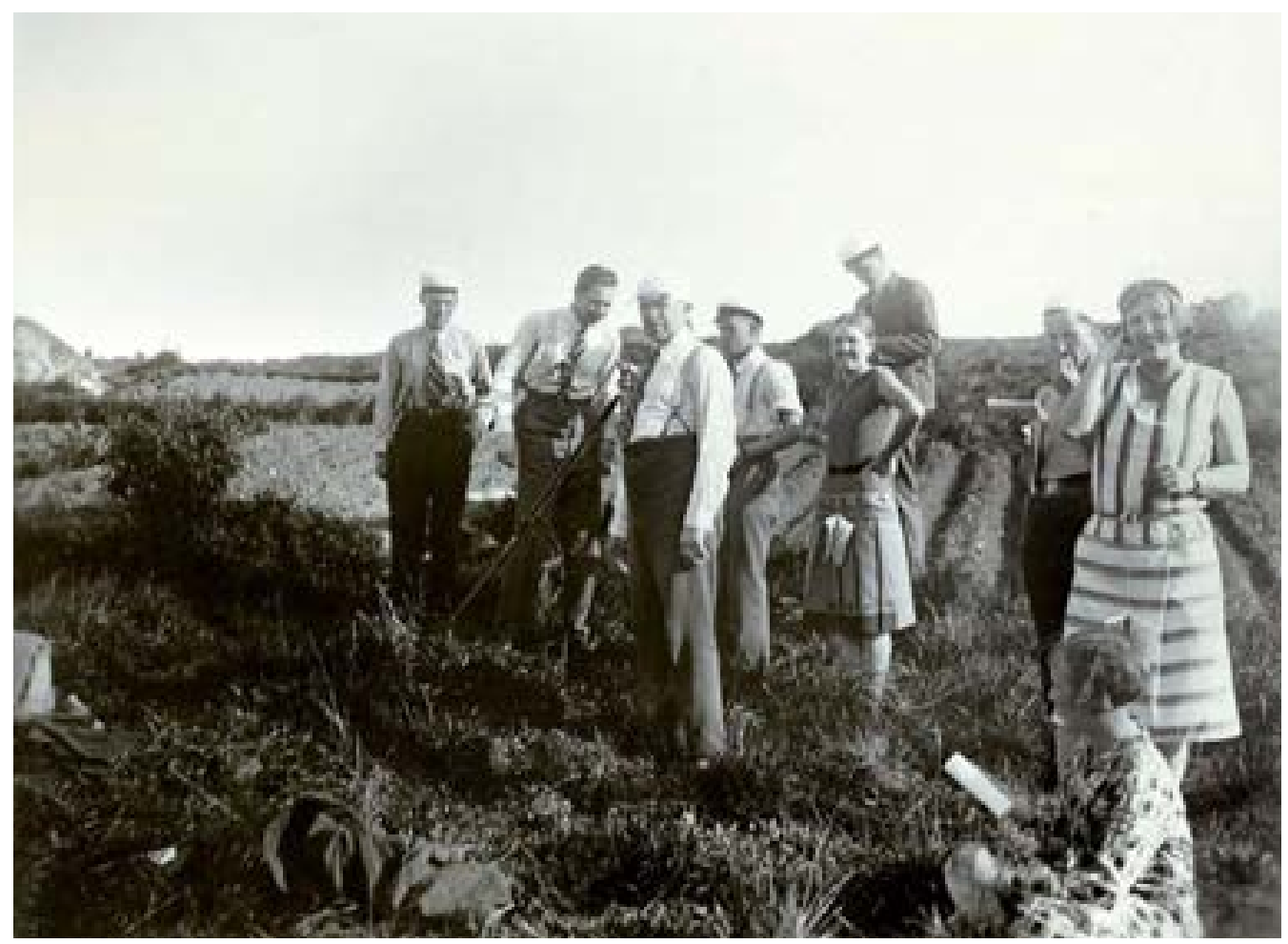

J. G. Granö johtaa kenttätöitä Turun-kaudella.

nografiasta, mutta myös ihmismaantiede ja maantieteen metodiikka kuuluivat useina vuosina ohjelmaan. Sen sijaan kartografiasta hän luennoi Turussa harvoin. ${ }^{635}$

Varsinaiset yleismaantieteen luennot alkoivat diakuvien elävöittämillä kuvailevilla jaksoilla, joita opiskelijoiden tuli vain keskittyneesti seurata. Sitten siirryttiin uusien käsitteiden selityksiin ja määritelmiin sekä muihin tärkeisiin asioihin, jotka opiskelijoiden oli kirjoitettava sanelusta muistiin. Näin opiskelijoille oli luentojen päättyessä syntynyt eräänlainen pieni oppikirja, joka sitten tentittiin.

Maantieteen harjoitustyöt olivat pääosin kartanpiirustustöitä, joita Granö oli teettänyt aiemmin Tarton ja Helsingin yliopistoissa. Töiden aiheena olivat muun 
muassa mittakaavat, kartanteon yleiset periaatteet sekä itse kerätyn tai yleisistä kartoista saadun tiedon saattaminen kartografiseen muotoon. Granön metodiikan mukaisissa maisematieteellisissä aluejakotöissä opiskelijoiden piti jakaa tietyt alueet topografisen kartan perusteella maisemallisesti yhtenäisiin alueisiin. Kartat oli valittu niin, että eri aineksien rajat eivät käyneet niin pahasti ristiin, että aluejako olisi ollut käytännössä lähes mahdoton tai ainakin hyvin vaikea toteuttaa. ${ }^{636}$

Toinen Granön suosima kartanpiirustustehtävä oli fyysisten karttojen piirtäminen värien ja liitujen avulla. Työt olivat varsin työläitä erityisesti silloin, kun kohdealueen kasvillisuus vaihteli paljon tai sen korkeuserot olivat suuret. Monet opiskelijat kuluttivat viikkokausia yksityiskohtaisten ja korkeatasoisten karttojensa laatimiseen, mutta 1927 laudatur-työnsä tehnyt Niilo Vikman selviytyi urakasta hämmästyttävän lyhyessä ajassa. Hänen kartassaan Länsi-Australia näyttäytyi lähinnä vaaleanruskealta tasaiselta laatalta. Muiden opiskelijoiden päivitellessä, miksei Vikman ollut piirtänyt karttaan minkäänlaisia yksityiskohtia, tämä selitti vuolaasti pää heiluen ja isot silmät levällään: ”Ei siell oo mittään. Se on yhtä aavikkoa ja autiomaata kaikki. Suola vaan kimalteloo."637

Maantiede oli Turun yliopiston alkuaikoina ainoa luonnontieteellisen tiedekunnan aine, johon sisältyi seminaariharjoituksia. Seminaarit olivat maantieteessä perinteinen opetusmuoto, ja niitä Granö oli vetänyt jo Helsingin ja Tarton yliopistoissa. Cum laude -opinnoista alkaen opiskelijoiden oli lukukausittain pidettävä esitelmä, joiden aiheet seminaarin vetäjä määräsi täysin diktatorisesti. Kukin opiskelija sai Granöltä juuri häntä varten valitun tutkimustehtävän, joka oli tehtävä omien havaintojen tai muun omatoimisesti kohdealueelta hankitun aineiston perusteella. Maantiedettä pääaineena opiskelevien opinnäytteet perustuivat enimmäkseen näihin esitelmiin, jotka tallennettiin laitoksen arkistoon. Helsingin ja Tarton yliopistoissa käytettyjä opiskelijoiden kesäretkeilyjä Granö ei ottanut Turussa ohjelmaan lukuun ottamatta kaupungin lähimaastossa tehtyjä kenttämittaustehtäviä. Hän kävi toisinaan eri puolilla Suomea seuraamassa joidenkin graduntekijöidensä kenttätöiden edistymistä. ${ }^{638}$

Granö suhtautui ennakkoluulottomasti opiskelijoiden sivuainevalintoihin. Hänen mielestään maantiede olisi sopinut hyvin yhteen eräiden humanistisen tiedekunnan 
aineiden, kuten sosiologian, etnografian tai taloustieteen, kanssa. Hän iloitsikin 1940-luvun alussa siitä, että yksi hänen oppilaistaan oli rohkeasti valinnut tällaisen uuden aineyhdistelmän. ${ }^{639}$

Saatuaan järjestää laitoksen toiminnan haluamallaan tavalla Granö pystyi keskittymään hyvin moniin tehtäviinsä. Vuonna 1927 opintonsa aloittanut Oiva Tuominen on antanut havainnollisen kuvauksen Granön määrätietoisesta työskentelytavasta:

Elävästi muistan kirjoituskoneen naputuksen Granön huoneessa. Niinä aamuina, jolloin hänellä ei ollut luentoja, tämä uutteran työskentelyn ääni kuului jo aamuvarhaiselta. Hänen työpöytänsä ääressä olevaan seinäkalenteriin oli kirjoitettu "Aika rientää, vuodet vierivät, tee työtä, pysy lestissäsi”. Granö oli harjaantunut järjestämään työnsä ja keskittymään tehtäviinsä niin, että hänen ei tarvinnut tehdä ylipitkiä päiviä eikä valvoa öitä. ${ }^{640}$

Työpaineiden lisäännyttyä opiskelijamäärän kasvun vuoksi Granö alkoi kaivata apua opetukseen mutta ei halunnut pyytää sitä yliopiston akuutin rahapulan vuoksi. Syksyllä 1930 hän viimein kertoi asiasta Turun yliopiston kanslerille E. N. Setälälle lähettämässään kirjeessä:

Minun on kuitenkin avoimesti tunnustettava, että tämä intensiivinen luentoja opetustoiminta on tehnyt varsinaisen tieteellisen työskentelyn lukukausien aikana miltei mahdottomaksi, ja että itse opetuskin on voinut tästä kärsiä. ${ }^{641}$

Kun yliopisto ei voinut myöntää varoja opettajien palkkaamiseen, tilanne alkoi helpottua vasta opiskelijoiden lukumäärän alkaessa vähentyä 1930-luvun alkupuolella. Granön ohella luentojen antamiseen osallistui vuosikymmenen aikana vain filosofian tohtori Johannes Kaikko, joka piti syyslukukaudella 1936 kahden viikkotunnin luentosarjan Euroopan maantieteestä. ${ }^{642}$ 


\section{Oppilaat}

Granön siirryttyä Turkuun maantieteen laitoksen opiskelijamäärä kasvoi nopeasti. Tämä johtui osin siitä, että osa hänen vanhoista Helsingin yliopiston opiskelijoistaan seurasi opettajaansa Aurajoen rannoille. Pääosin kasvu selittyi kuitenkin sillä, että uusi professorin virka antoi varmuuden maantieteen opintojen jatkomahdollisuuksista.

Syksyllä 1926 uusia ylioppilaita ilmoittautui kerralla 31, jolloin maantieteen opiskelijoiden kokonaismäärä nousi 46:een. Opiskelijoiden yhdyssiteeksi muodostettiin välittömästi maantieteellinen kerho, Turun Maantieteellisen Seuran edeltäjä, joka antoi aineelle omaa identiteettiä. Ensimmäisen pro gradu -työn valmistuttua 1929 seuraavan vuosikymmenen puoliväliin mennessä vanhemman lehtorin kelpoisuuden antaneen maantieteen laudaturin teki yli 30 opiskelijaa. ${ }^{643}$

Opiskelijamäärän kasvuvaihe taittui nopeasti. Vuonna 1932 uusien opiskelijoiden määrä laski 16:sta seitsemään ja seuraavana vuonna edelleen kolmeen. Vuosina 1934-44 uusia maantieteen opiskelijoita tuli keskimäärin vain yksi tai kaksi vuodessa, toisen maailmansodan aikana ei ainuttakaan. Kaikkiaan Granön Turunkaudella filosofiankandidaatin tutkinnon maantiede pääaineenaan suoritti runsaat 50 henkilöä.

Maantieteen laitoksen opiskelijamäärä laski suhteellisesti enemmän kuin koko yliopiston ja luonnontieteellisen tiedekunnan, joten sen taustalla oli muitakin kuin ajan poliittiseen tilanteeseen, lamakauteen ja yliopiston heikentyneeseen asemaan liittyneitä syitä. Akateemisen työttömyyden uhka koettiin 1930-luvun alusta alkaen suureksi juuri maantieteen alalla, sillä oppikoulujen opettajien paikat oli täytetty pitkäksi aikaa eikä juuri minkäänlaisia tutkijantoimia ollut olemassa ennen valtion tieteellisten toimikuntien aikaa 1950-luvulla. Asian oli tuonut esille professori Ilmari Välikankaan 1932 julkaisema kirjoitus "Biologisten tieteiden ja maantieteen opiskelijoiden tulevaisuuden mahdollisuuksista”, jossa hän ennakoi, että suurin osa alan opiskelijoista voi saada työpaikan vasta $15-20$ vuoden kuluttua. ${ }^{644}$

Osin maantieteen opiskelijoiden määrän kehitys kertoi myös siitä, että tieteenalan vetovoima oli alkanut hiipua 1930-luvun alusta alkaen. Tämä saattoi osin johtua siitä, 


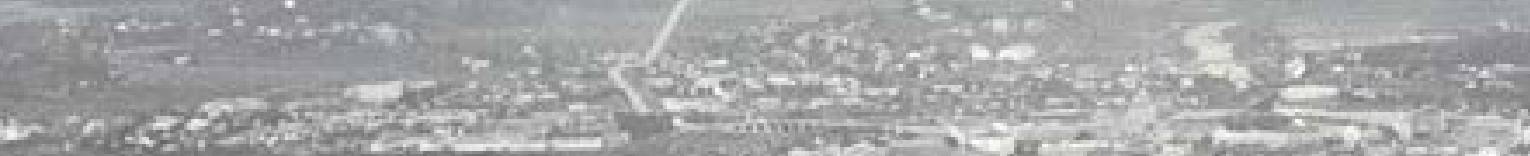
.

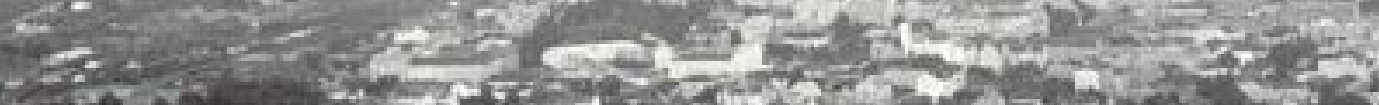

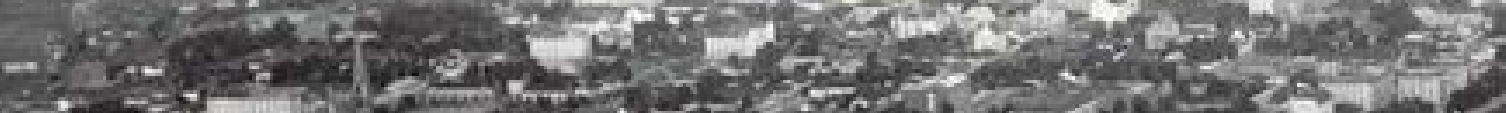

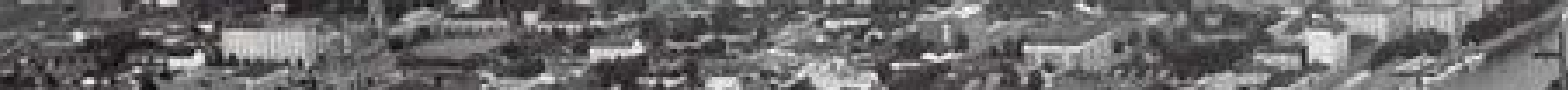
$-4.3^{2}$.

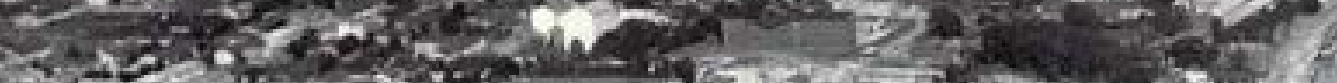

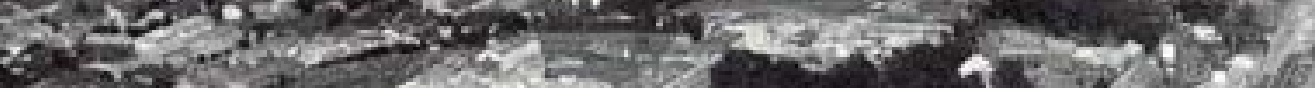
4.

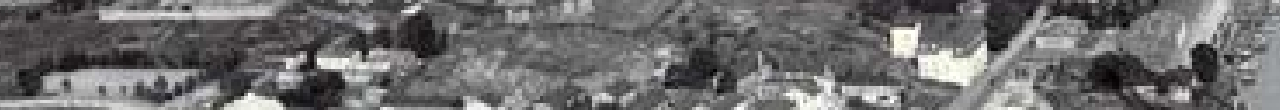
S.P.

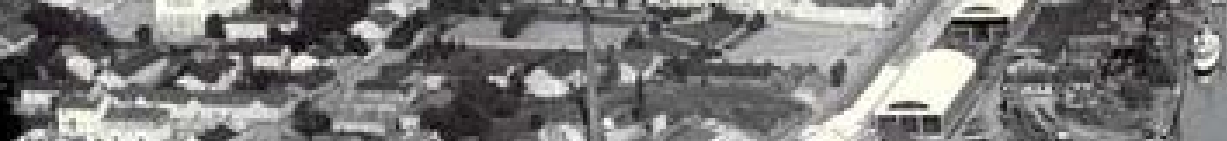

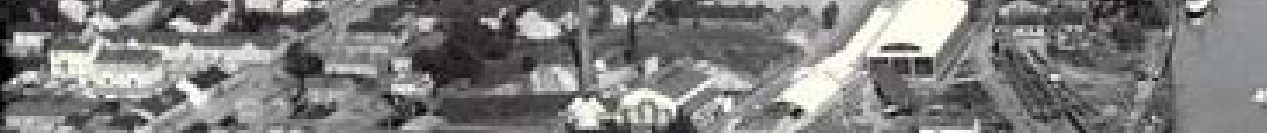

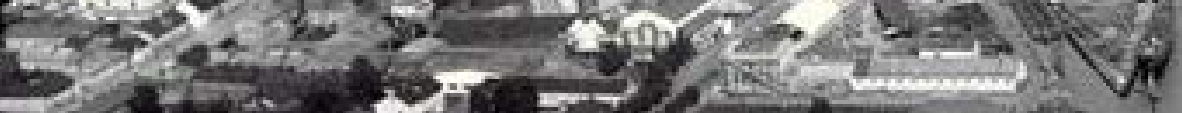

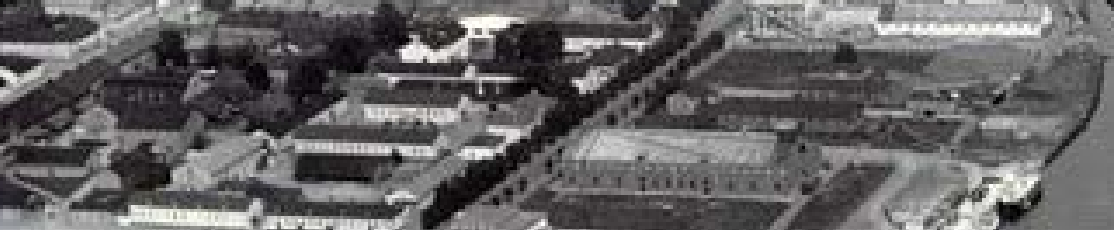

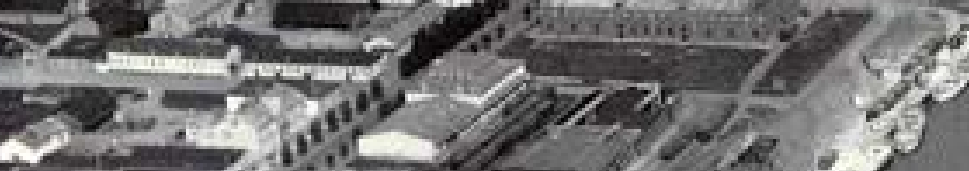

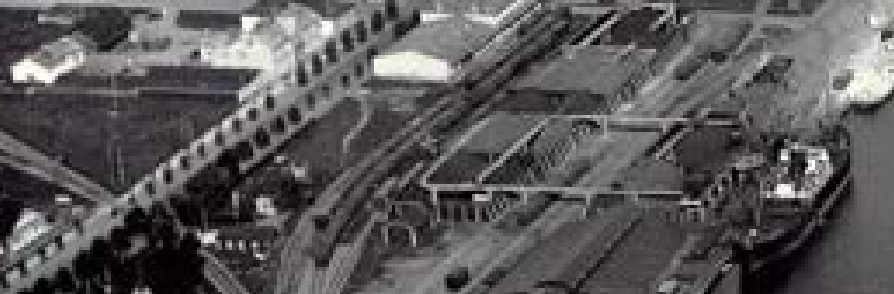

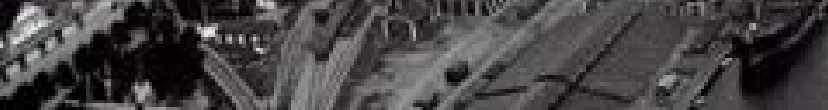

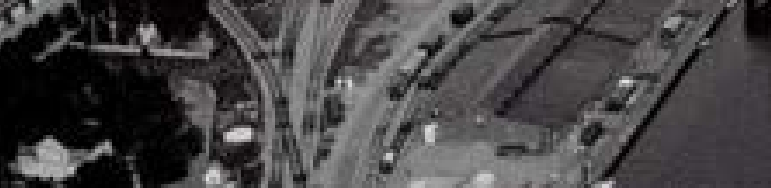
(1)
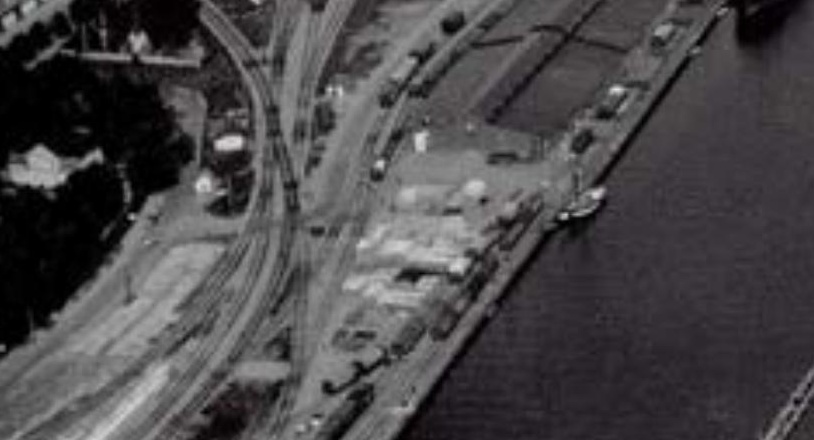

(1)

if
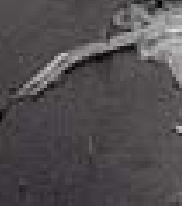


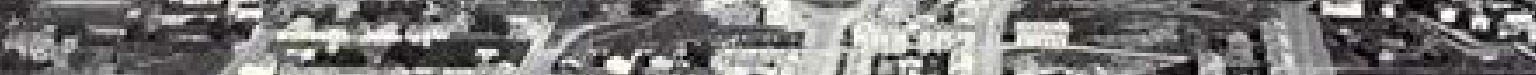
A.7. notes ज्ञा का -

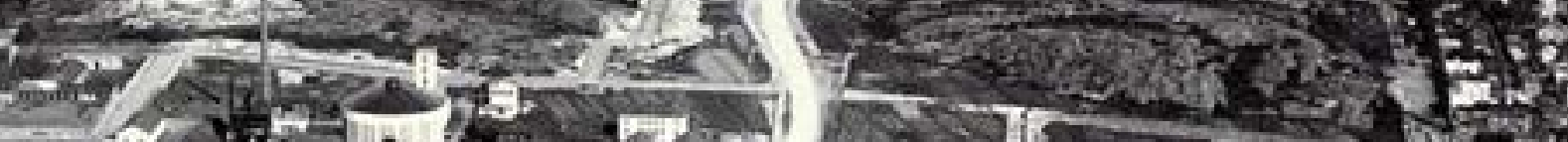

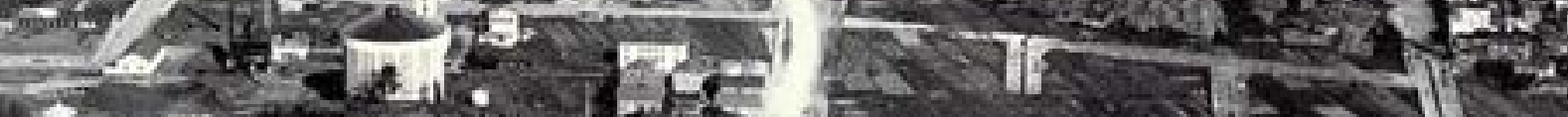

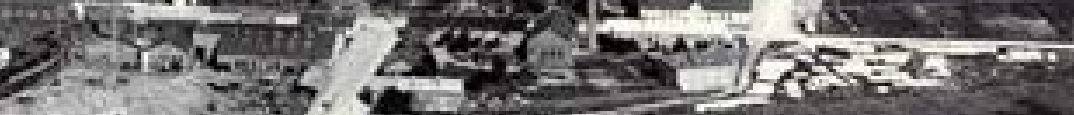
(11)

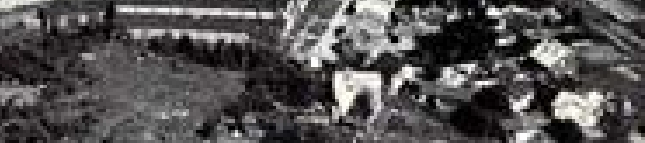

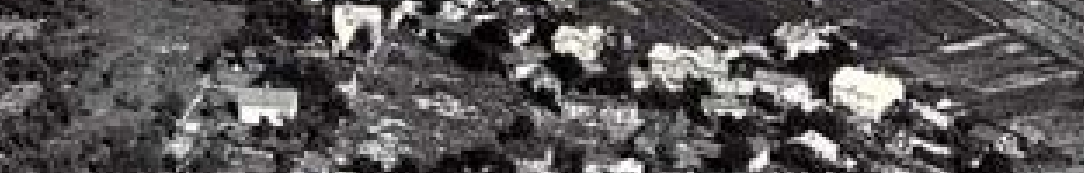

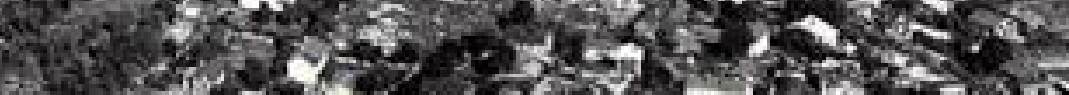

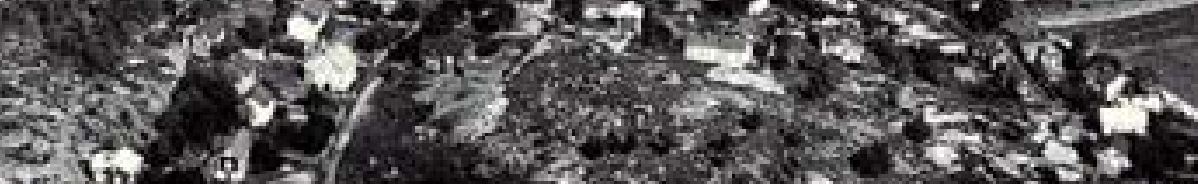

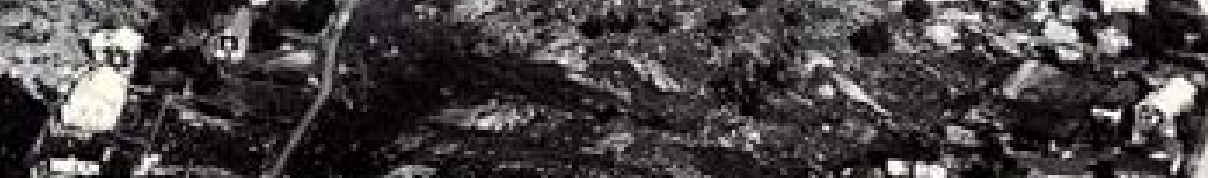
6. $3-3 \times+\cdots$ a. 20, 150 ,

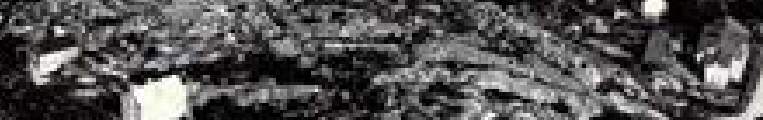
$4.135 \mathrm{~T}$ to Ging

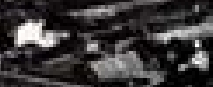

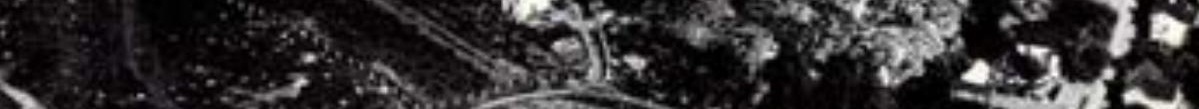


että Granö joutui yksin vastaamaan maantieteen varsinaisesta opettamisesta. Vaikka häntä pidettiin tiedekuntansa vaikuttavimpana opettajana ja vaikka hänen suhteensa oppilaisiinsa muodostui usein varsin läheiseksi, kynnys jatko-opintoihin oli korkea. Varsinkin saatettiin kokea liian haastavaksi se, että koko laitos personoitui yhteen henkilöön, joka vielä edusti yleislinjasta poikkeavaa käsitystä maantieteen olemuksesta. ${ }^{645}$

Ilmeisesti kuitenkin juuri tutkijanvakanssien puute vaikutti ratkaisevimmin siihen, ettei Granön ympärille muodostunut laajaa koulukuntaa jatkamaan ja kehittämään hänen työtään. Hänen Turun-kautensa opiskelijoista valtaosa oli suoraan koulualalle suuntautuneita naisia, ja myös miehistä lähes kaikki tähtäsivät oppikoulun luonnonhistorian tai maantieteen lehtoreiksi. Maantieteessä väitteli vain edellä mainittu Johannes Kaikko, jonka Laatokan rannikkovyöhykkeen maiseman juovaisuutta käsitellyt väitöskirja ilmestyi 1933. Kaikon väitöstilaisuus oli Tammekannin ohella ainoa, jossa Granö oli Suomessa virallisena vastaväittelijänä. ${ }^{646}$

Kaikko oli ollut alun perin Iivari Leiviskän oppilas, mutta hän oli siirtynyt Turkuun oppikoulun opettajaksi saadakseen väitöskirjatyönsä valmiiksi ja julkaistuksi. Hän jatkoi Granön ajatusten kehittelyä julkaisemalla 1940-luvulla useita maantieteelliseen rytmi-käsitteeseen liittyneitä artikkeleita. ${ }^{67}$

Granön jo muutettua pääkaupunkiin hänen Turun-kautensa oppilaista vielä kaksi väitteli maantieteessä. Aluksi Yläneen kunnan asutusmaantiedettä selvitellyt Oiva Tuominen siirtyi tutkimaan koulutoimensa ohessa Lounais-Suomen toiminnallista aluerakennetta Granön analyyttis-synteettisen metodin mukaisesti. Tuomisen väitöskirjan valmistuminen viivästyi kuitenkin niin paljon, että se ilmestyi vasta 1940-luvun lopulla Helsingin yliopistossa pääosin Walter Christallerin näkemyksiin tukeutuen. Koulualalle 1930-luvulla siirtyneen Kurt Enkolan 1953 julkaisemalla kulttuurimaantieteellisellä väitöskirjalla Lounais-Suomen väestön ke- 
hityksestä 1840-1940 oli puolestaan enää varsin vähän tekemistä Granön opetuksen kanssa. ${ }^{648}$

Muista Granön oppilaista pisimmälle akateemisella uralla etenivät luonnonsuojelutyössä ja Suomen luonnon kuvaajana kunnostautunut Reino Kalliola ja Turun yliopiston pitkäaikainen kasvitieteen professori Paavo Kallio, jotka molemmat väittelivät kasvitieteessä. Granö asetti suuria toiveita erityisesti opintonsa 1936 aloittaneeseen Kallioon, sillä tämä oli osoittautunut hyvin lahjakkaaksi oppilaaksi. Helsinkiin siirryttyään hän oli valmis ottamaan Kallion assistentikseen tarjotakseen tälle tilaisuuden väitöskirjan tekoon, joten Kallion päätös jäädä Turkuun ja suuntautua maantieteen sijasta kasvitieteeseen oli hänelle raskas pettymys. ${ }^{649}$

Granö kehitti erityisesti asutusmaantiedettä, jonka systemaattisen tutkimuksen hän aloitti Suomessa. Tällä alueella hänen pisimmälle opinnoissaan edenneitä oppilaita olivat filosofian kandidaatit Auvo Heikinheimo ja Paavo Niemelä, joiden tutkimukset Kustavin asutusmaantieteestä ja Salon seudun asutuksen jakautumisesta arvioitiin 1940 arvostetussa saksalaisessa sarjassa Petermanns Geographische Mitteilungenissa. Tutkimusrahoituksen puutteen vuoksi Heikinheimo ja Niemelä joutuivat kuitenkin muiden maantieteen pääaineopiskelijoiden tavoin hautaamaan akateemiset haaveensa ja siirtymään koulualalle. ${ }^{650}$

Granö toi Tartosta Turkuun siellä aloittamansa kaupunkitutkimuksen perinteen. J. E. Rosbergin poika Sigvald Rosberg oli julkaissut hänen ohjauksessaan jo 1923 tutkimuksen Helsingin sisäisestä erilaistumisesta. Varsinaisesti uuden tutkimussuunnan aloitti kuitenkin vasta J. K. V. Tuomisen 1930 ilmestynyt tutkimus Turun sisäisestä rakenteesta, Das Geschäftscentrum der Stadt Turku, joka oli Suomen ensimmäinen kaupungin sisäistä erilaistumista koskenut tutkimus. Sen ansiosta Tuominen voitti kilpailun kaupungin suomalaisen lyseon lehtorin vakinaisesta virasta. ${ }^{651}$

Granö suhtautui maantieteen jatko-opiskelijoiden vähyyteen maltillisesti. Hän katsoi, että miesopiskelijoiden paras aines oli hakeutunut Teknilliseen korkeakouluun ja lääketieteelliseen tiedekuntaan, joten huippulahjakkuuksista oli pulaa paitsi maantieteen myös muiden luonnontieteiden piirissä. Lukuisten naisylioppilaiden joukossa 


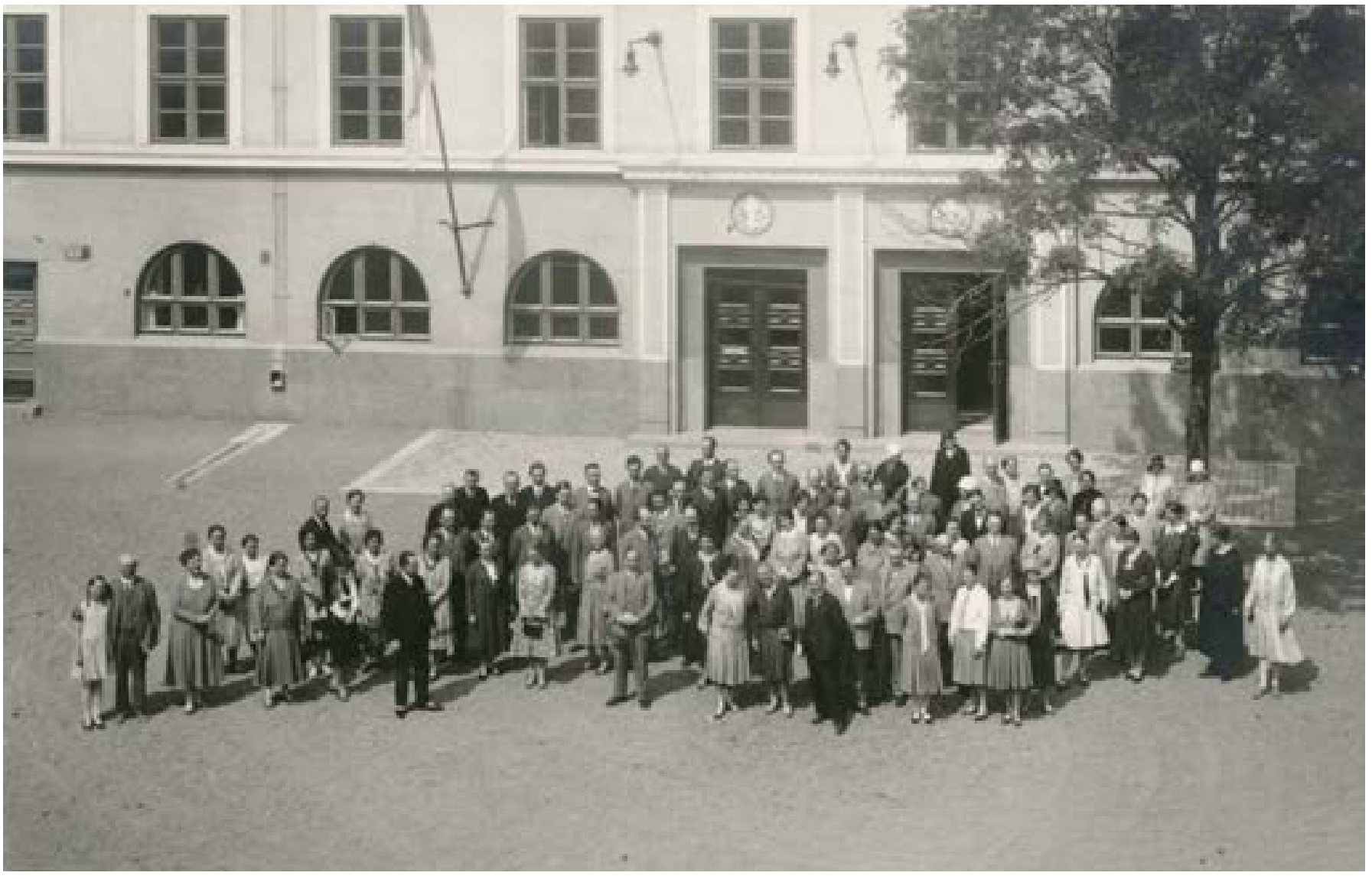

Maantieteen opettajien päivät Turussa 1930-Iuvun alussa. 
oli puolestaan ollut paljon lahjakkaita opiskelijoita, mutta heistä turhan monet olivat panostaneet ahkeraan istumiseen ja tunnolliseen lukemiseen enemmän kuin tieteellisen ajattelutavan kehittämiseen. ${ }^{652}$

Granö myös katsoi, että Suomessa oli liikaa korkeakouluopiskelijoita suhteessa niihin mahdollisuuksiin, joita opiskelijoilla oli hyvien työpaikkojen saamiseen. Erityisesti maantieteellisen tutkimuksen tilanne oli Suomessa sellainen, ettei tohtoriksi väitelleille ollut tarjolla heidän koulutustaan vastaavia tehtäviä. Tohtorit ansaitsivat pääosin elantonsa A. R. Helaakosken ja poikansa Aaro Hellaakosken tavoin opettajina tai muissa leipätöissä ja tekivät tiedettä sen verran minkä työkiireiltään ehtivät.

Granön mielestä yliopiston ei tullut keskittyä vain tieteellisen koulutuksen antamiseen vaan yhtä tärkeää oli kasvattaa ja ohjata valveutuneita ja kansallisesti sivistyneitä kansalaisia isänmaan palvelukseen heille soveltuville aloille. Tämän vuoksi hän sanoi muun muassa tulevalle Mannerheim-ristin ritarille Ilmari Honkaselle, ettei tämän kannattanut ryhtyä opiskelemaan luonnontieteitä vaan harkita kouluttautumista ekonomiksi. ${ }^{653}$

Turun yliopiston ylioppilaskunnan 10-vuotisjuhlassa pitämässään puheessa Granö totesi:

Ei riitä, että ylioppilas suorittaa tutkintonsa tai oppii tiedettä viljelemään, isänmaa tarvitsee kaikilla työn rintamilla ei ainoastaan oppineita ja taitavia palvelijoita, vaan myös avarakatseisia, tasapuolisesti arvostelevia, oikeamielisiä, hyviä kansalaisia. ${ }^{654}$ 


\section{Syventyminen maisematieteeseen}

Granön voi katsoa paenneen Helsingistä Turkuun tehdäkseen tieteellistä työtä. Pääkaupungissa hänen aikansa oli mennyt niin visusti professorin virkavelvollisuuksien hoitoon, Suomen Kartaston toimitustyöhön ja Suomen Maantieteellisen Seuran sihteerin moniin askareisiin, että hän ei ollut ehtinyt syventyä tutkimukseen haluamallaan tavalla.

Turussakaan Granö ei voinut heti keskittyä omaleimaisen alueteoriansa kehittämiseen, sillä hänen oli ensin tehtävä valmiiksi Suomen Kartaston kasvillisuuden ja asutuksen jakautumista sekä maantieteellisiä alueita kuvaavat kartat. Urakka ei ollut hänelle vain ikävää rästiin jääneiden töiden pakollista puurtamista, sillä molemmat kartat liittyivät läheisesti hänen teoreettisiin ja metodologisiin pohdintoihinsa. ${ }^{655}$

Neljä lehtiaukeamaa käsittänyt kasvillisuus- ja asutuskartta vaati Granöltä tuhansien tuntien työn. Kun se valmistui viimein elokuun lopulla 1927, hän jakoi heti ilonsa J. K. V. Tuomisen kanssa:

Olen ollut enimmäkseen Helsingissä. Piirtänyt - ja taasen piirtänyt... Tänän̈n, muutama tunti sitten, valmistui vihdoin kasvillisuuskartta, jonka kimpussa olen vapaahetkiäni kuluttanut jo kai kolmisen vuotta. Iloitse siis kanssani Sinä, joka työn määrän arvioida taidat!!656

Kartta oli kahdessa suhteessa uraauurtava. Se oli ensimmäinen koko maan käsittänyt kasvillisuuskartta, jossa oli esitetty eri väreillä pellot ja niityt, metsät, korvet, rämeet ja nevat, tunturikoivikot ja -paljakat, kalliot sekä pohjoisen havumetsän rajat. ${ }^{657}$ 
Kartassa pyrittiin myös ensimmäisen kerran hahmottamaan asutuksen jakautumista Suomen eri osissa. Tämä tapahtui siten, että asutuskeskusten ulkopuolisten haja-asutusalueiden väestön ryhmitystä kuvattiin mustilla pisteillä, jotka edustivat 100 asukasta. Vuoden 1920 henkiluettelojen pohjalta laadittu väentiheyden esitys paljasti suuria eroja maan eri alueiden välillä ja toi esiin Suomen kehittyneisyyden kahtiajaon, kaakkois-luoteissuunnassa kulkevan hyvinvointirajan, jonka linjaus osui varsin hyvin yhteen Ruotsin ja Novgorodin 1323 solmiman Pähkinäsaaren rauhan rajan kanssa. ${ }^{658}$

Suomen Kartasto 1925 tarjosi Granölle myös mahdollisuuden soveltaa Suomessa ensimmäisen kerran konkreettisesti Virossa kehittämäänsä aluejakometodia. Hän ei käyttänyt menetelmää sellaisenaan vaan otti nyt suuriakin aluekokonaisuuksia rajatessaan huomioon johdonmukaisesti kaikki maiseman neljä päätekijää (maankamara, vesistöt, kasvillisuus ja tekoaines) ja käytti niiden kuvaamiseen erilaisia värejä, symboleja, merkkejä, viivastoja, numeroita ja kirjaimia. Symbolien avulla hän saattoi merkitä karttoihin erityiset maisemakaavat, jotka luonnehtivat maiseman morfografian eli ulkonäön pääpiirteitä. ${ }^{659}$

Tuloksena oli uusi ja omaleimainen yhden kartta-aukeaman esitys, jossa kuvattiin aluksi neljän pienen kartan avulla Suomen jakautumista mahdollisimman yhtenäisiin alueisiin maisemallisten päätekijöiden perusteella. Maankamaran seitsemän tyyppiä vaihtelivat yli 200 metrin korkeusvaihtelujen ylhiömaasta vuori-, mäki-, kankaremaan ja lakeuden kautta tasankoon ja laakso- ja laakiomaahan. Veden tyyppejä oli kuusi, kasvillisuuden kuusi ja tekoaineksen neljä.

Analyyttisten karttojen "päällekkäin asettamisen" pohjalta laadittuun synteesiin nojautuen Granö esitti kahdella kartalla Suomen jakautumisen yleistämismäärän vaihdellessa ensin 19 laajaan maantieteelliseen maakuntaan, sitten 35 seutukuntaan ja lopulta isolla kartalla 105 pieneen maantieteelliseen seutuun. Maankamaran muotojen esittämisessä ja nimistön laadinnassa häntä avustivat dosentti Matti Sauramo (Etelä-Suomi) sekä filosofian kandidaatti Erkki Mikkola ja dosentti Väinö Auer (Pohjois-Suomi). 

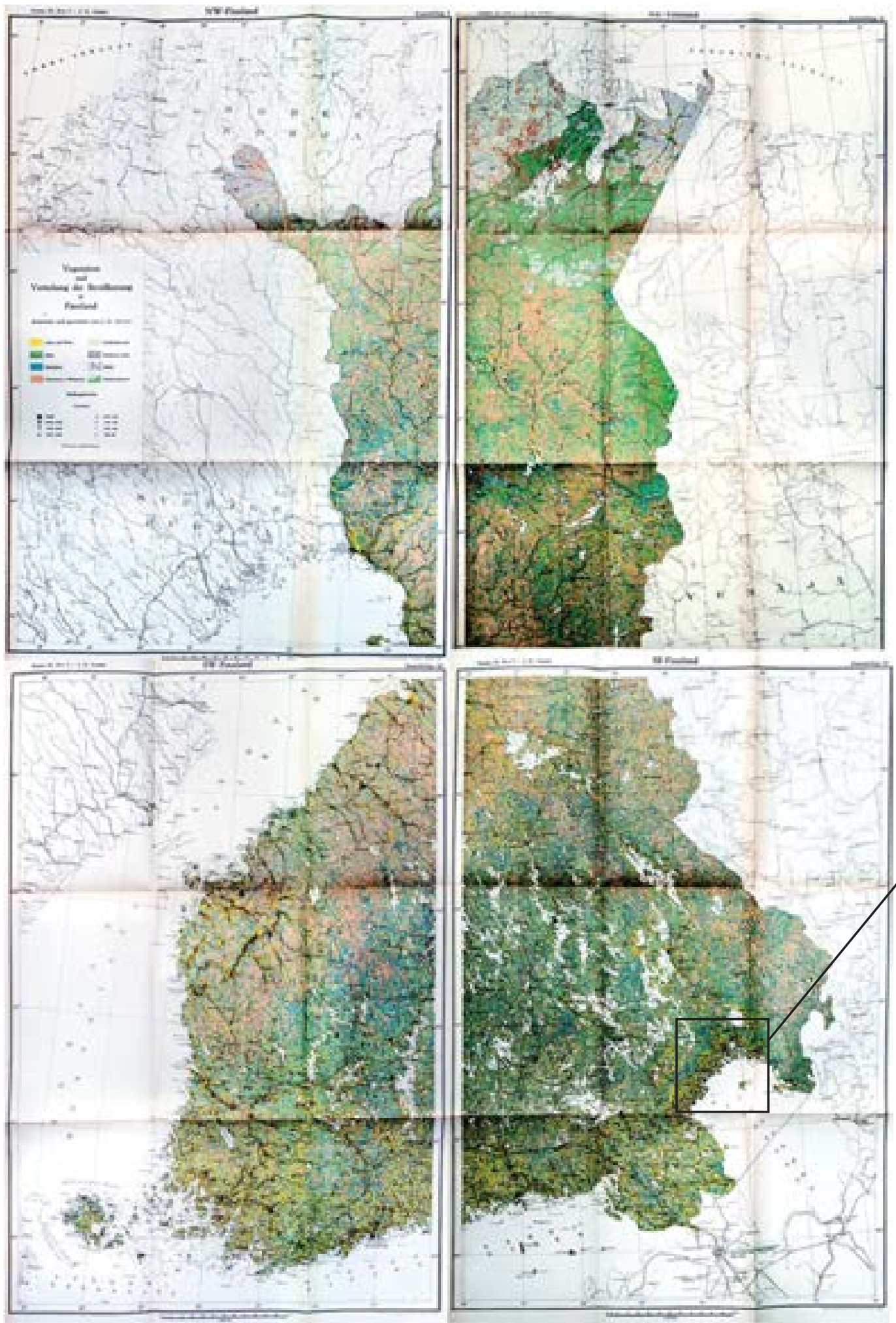


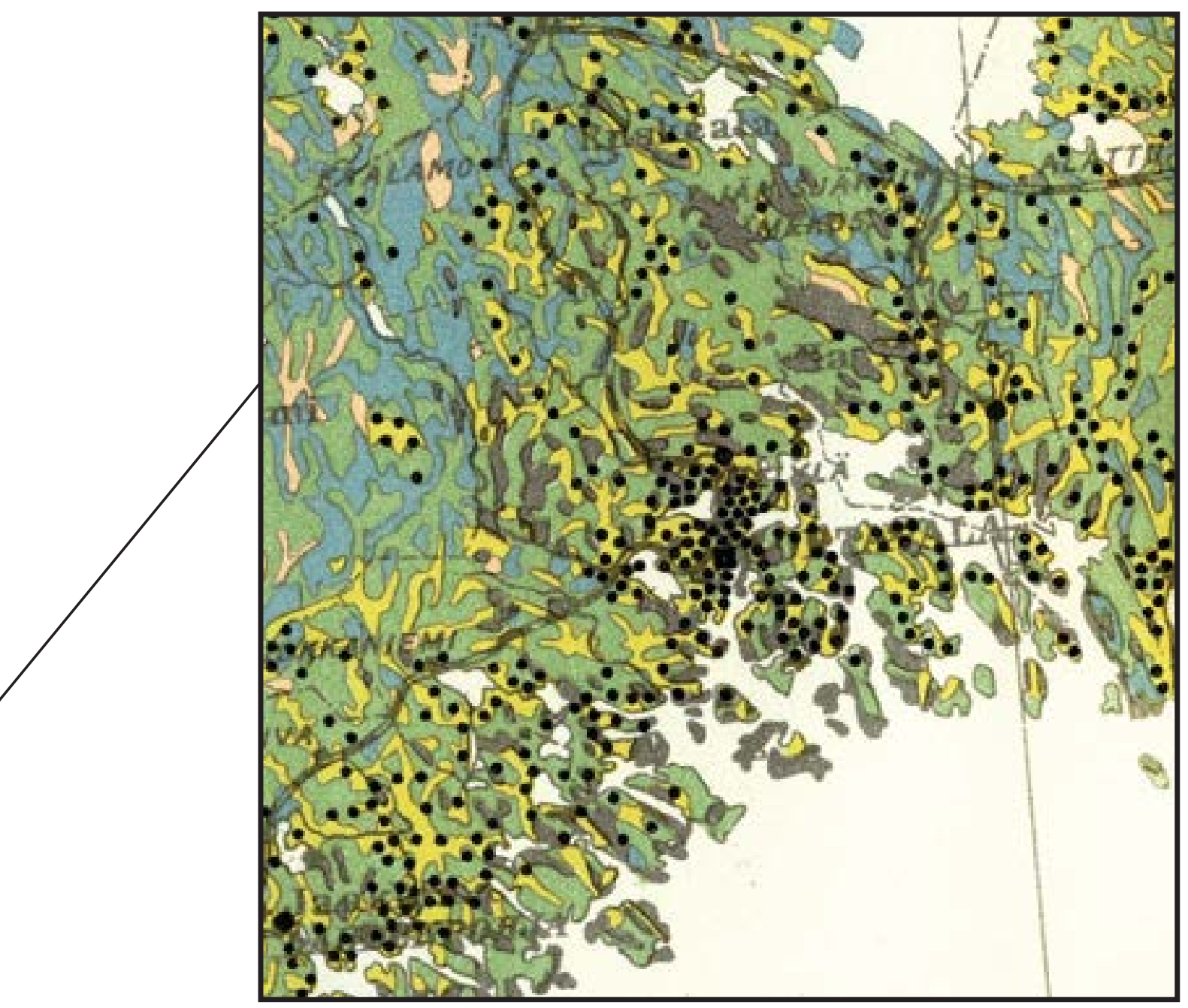

Neljässä osassa julkaistu Suomen kasvillisuus- ja väestökartta yhteen koottuna. Kasvillisuus on eri värein jaettu kahdeksaan tyyppiin, ja väestön määrä on esitetty erisuuruisin pistein, jotka vastaavat pienimmillään 400 henkilön väestökeskittymää ja suurimmillaan 200000 asukkaan kaupunkia. Sortavalan seutu on erotettu osoittamaan kartan suurta tarkkuutta. 
Kartastossa erotettiin ensimmäisen kerran johdonmukaisella metodilla suomalaiset maisema-alueet. Maan tyypillisimmiksi maisema-alueiksi nimeämiensä Järvi-Suomen ja Saaristo-Suomen ohella Granö erotti 17 muuta maantieteellistä maakuntaa, joista neljä sijaitsi etelärannikolla ja neljä Lapissa. Maakuntien sanallisen kuvaamisen sijasta hän tyytyi jo tilanpuutteenkin takia luonnehtimaan kutakin maakuntaa vain maisemakaavan avulla. ${ }^{660}$

Esimerkiksi Järvi-Suomen maisemakaava oli III IV 43 AC c, mikä tarkoitti aluetta, jota luonnehtivat mäki- ja kankaremaat (III IV), järvet ja järvireitistöt (4 3), metsät ja korvet (A C) sekä yksittäisasumukset (c). Saaristo-Suomen maisemakaava oli puolestaan III IV 5 AF bc, jonka mukaan alue oli rannikko- ja saaristovesien (5) halkomaa metsäistä ja kallioista (A F) mäki- ja kankaremaata (III IV), jossa oli yksittäisiä asumuksia ja asumusrykelmiä (b c). ${ }^{661}$

Kuvaustapa oli siten etääntynyt kovin kauas siitä suomalaisen maiseman perinteisestä luennehdinnasta, jonka Granö oli esittänyt virkaanastujaisluentonsa alussa pari vuotta aiemmin.

\section{Puhdas maantiede}

Granön Tarton yliopistossa toukokuussa 1923 pitämä jäähyväisluento osoitti, että hän oli päätynyt jo tuolloin siihen omaleimaiseen ratkaisuun, että maisematieteen rinnalle oli luotava toinen haara, lähiötiede, jonka tehtävänä oli tutkia maiseman ja ihmisen välillä olevaa, kaikin aistein havaittavaa ympäristön osaa. Hänen tavoitteenaan oli julkaista laaja tutkimus, joka sisältäisi sekä uuden aluetieteen teoreettisen perustan ja tutkimusmenetelmät että sovelluksia käytännön tutkimustyötä varten.

Granö päätti rakentaa teoksen pääosin Virossa ja Valosaaressa tehtyjen tutkimusten, Terrassa 1924-25 julkaistujen artikkelien ja Suomen Kartastoa varten tekemänsä työn varaan, joten uusien kartografisten esitysten laatimisen sijasta hän keskittyi teoriansa kehittämiseen ja erityisesti eri aistien alueellisten ulottuvaisuuk- 
sien pohdintaan. Tämä merkitsi perehtymistä sekä saksalaiseen Landschaft-kirjallisuuteen että muuhun maantieteellisiin alueisiin kohdistuneeseen tutkimukseen. ${ }^{662}$

Turun pienessä yliopistossa opiskelijat saattoivat seurata läheisesti Granön ponnisteluja teoriansa kehittämiseksi. Hänen luentojaan 1920-luvun lopulla kuunnelleen Reino Kalliolan mukaan opiskelijat saattoivat seurata uuden tieteen luomisprosessia:

Saimme kuulla uusia näkemyksiä, uusia käsitteitä ja menetelmiä, uutta mullistavaa oppia filosofisine perusteluineen suoraan keksijänsä suusta. Ymmärsimme tilanteen arvon ja ainutlaatuisuuden. Olimme luovan vallankumouksen syntysijoilla. Tunsimme saavamme murusia alati muuttuvan ja kehittyvän tieteen pöydältä. ${ }^{663}$

Granö sai Puhtaaksi maantieteeksi nimeämänsä teoksen suomenkielisen käsikirjoituksen valmiiksi varhaiskeväällä 1927. Työ oli suunnattu kansainvälistä tiedeyhteisöä varten, minkä vuoksi hän päätti julkaista sen ensiksi saksaksi. Kääntäjäksi valikoitui Helsingin yliopiston saksan kielen lehtori Heinrich Schlücking, joka oli muuttanut Saksasta Suomeen viisi vuotta aiemmin ja avioitunut tunnetun porvoolaisen paikallishistorioitsijan Anders Allardtin tyttären kanssa. Schlückingien huvila oli Porvoon saaristossa avomeren rannalla Tove Janssonin perheen kesäpaikan naapurina ja melko lähellä Tirmoa. ${ }^{664}$

Kirjoittajan ja kääntäjän tiiviin yhteistyön tuloksena Reine Geographie. Eine methodologische Studie, beleuchtet mit Beispielen aus Finnland und Estland ilmestyi syksyllä 1929. Julkaisutyö jatkui seuraavana keväänä, jolloin Puhdas maantiede. Tutkimusesimerkeillä Suomesta ja Virosta valaistu metodologinen selvitys valmistui WSOY:n kirjapainossa Porvoossa. ${ }^{665}$

Teoksen ilmestyminen saattoi loppuun Granön liki vuosikymmenen kestäneen maantieteen olemusta koskeneen kehittämistyön. Kun hän oli Altai-teoksessaan pyrkinyt korvaamaan perinteisen vapaamuotoisen ja monisanaisen aluekuvaustavan subjektiivisiin aistimuksiin ja tuntemuksiin perustuvalla metodilla, nyt hänen ta- 
voitteenaan oli ollut luoda tiukan looginen oppijärjestelmä, joka olisi vastannut ajan yleistä positivistista, empiirisiin menetelmiin, mittauksiin ja kokeisiin tukeutuvaa tiedekäsitystä ja vahvistanut näin maantieteen asemaa tiedeyhteisössä. ${ }^{666}$

Puhtaan maantieteen johdantoluvussa, joka oli Terrassa 1924 ilmestyneen "Ympäristö maantieteen tutkimusesineenä" -artikkelin hieman laajennettu ja muokattu versio, Granö antoi perustelut teoksen nimelle ja sisällölle. Ilmeisesti Emil Wisotzkin maantieteen oppihistoriaa käsittelevään teokseen Zeitströmungen in der Geographie tukeutuen hän totesi, että "n.s. puhtaan maantieteen edustajat" A. L. Bucher ja D. Wilhelmi olivat jo 1800-luvun alussa suosittaneet maanpinnan jakoa "luonnollisiin maihin", jotka eivät olisi olleet valtioiden tavoin riippuvaisia lyhyen ajan vaihteluista. ${ }^{67}$

Vaikka asia oli siten noussut esille jo sata vuotta aiemmin ja useat tutkijat olivat esittäneet omia ratkaisujaan, maantieteen ongelmana oli yhä se, ettei sillä ollut omaa yleispätevästi määriteltyä tutkimuskohdetta. Niin luonnollisilla mailla, alueellisilla yksiköillä kuin maisemilla tarkoitettiin milloin vain hallinnollista aluetta tai nähtyä kompleksia, milloin aistittua kokonaisuutta tai milloin aistitun ja henkisen ympäristön muodostamaa ykseyttä. Nyt Granö oli päättänyt poistaa tämän puutteen. Hänen mukaansa maantieteen tutkimuskohteena tuli olla vain aistiympäristö eli se ympäristö, jonka ihminen koki aisteillaan. ${ }^{668}$

Aistiympäristö oli maantieteessä yhtä määräävässä asemassa kuin kasvi kasvitieteessä, eläin eläintieteessä, ihminen antropologiassa tai kivilaji petrologiassa. Koska kysymys oli siitä, miten ihminen aisti ympäristönsä, maantieteilijä ei voinut tukeutua vain lähitieteiden tutkimuskohteisiin, kuten kiviin, ilmaan, veteen tai kasvillisuuteen. Näiden maiseman reaalisten ainesten lisäksi oli otettava huomioon niiden ilmentymät eli oli selvitettävä, miten ihminen aisti nämä ainekset. Ilmentymät saattoivat vaihdella vuorokauden osien ja vuodenaikojen mukaan reaalisten ainesten pysyessä muuttumattomina. Esimerkiksi rannan kivilohkareet eivät kadonneet sillä olemattomiin, että ne peittyivät nousuveteen, sumuun tai luminietoksiin, ja luonnonmaisema saattoi muuttua kulttuurimaisemaksi vain siksi, että syksyn saapuminen paljasti rantalehvistön suojaamat rakennukset. ${ }^{69}$ 
Maantieteilijöiden tuli ymmärtää, että kaikki se mitä ei ollut mahdollista aistein havaita jäi automaattisesti maantieteen ulkopuolelle. Siten esimerkiksi taide oli kaiken subjektiivisen ja henkisen kokemisen tavoin pidettävä erillään tieteellisestä tutkimuksesta:

Eiköhän olisi suorastaan anteeksiantamatonta, jos olevaista tutkiessamme ja työmme tuloksia muille esittäessämme asettaisimme etualalle esteettisten tunnevaikutusten herättämisen sekä kauniin ja ylevän palvonnan. Sillä näin menetellen raottaisimme tietoisesti ovea mielijohteille ja satunnaisuuksille. Älköön uskoteltako, että taiteen merkeissä saataisiin objektiivinen käsitys ympäristön harmonioista paikassa ja rytmeistä ajassa. ${ }^{670}$

Rajaus sulki maantieteen ulkopuolelle myös maisemaan sisältyvät taloudelliset ja henkiset tekijät, kuten metsän taloudellisen arvon, ja erilaiset ihanne- ja mielenmaisemat, jotka ihminen muodosti mielensä sopukoissa muistojensa tai toiveidensa siivittämänä. ${ }^{671}$

Ihmisellä ei muutenkaan ollut mitään erityisasemaa Granön oppirakennelmassa. Hänen mukaansa ihminen esiintyi maisemallisena tekijänä lähinnä siten, että

... että monenmoiset pukimet aikaansaavat suurta, tosin useammin värissä kuin muodossa ilmenevää vaihtelua. Paikoin ja ajoittain on ihmisiä maisemassa niin runsaasti, että voi puhua ihmismaisemasta. Mainittakoon esim. suurkaupunkien liikennekeskukset, suuret markkinat ja vilkas toriliikenne, uskonnolliset ja muut kansanjuhlat sekä sodan aiheuttamat sotaväen ja kansanjoukkojen liikehtimiset. ${ }^{672}$

Jos ihmisiä liikkui samalla alueella pysyvästi, heidät oli otettava huomioon vain alueellisen liikkuman muodostajina, ei yksilöinä. Granön tinkimättömyys - tässä tapauksessa tosin myös huumorintaju - tuli esiin siinä, että Valosaaren aluejakoa kuva- 
tessaan hän mainitsee pihamaalla aitan edessä seisovat nuorimmat tyttärensä Siinen ja Eevan vain "parina liikkuman edustajana”. ${ }^{673}$

Puhtaan maantieteen teoreettinen ja käsitteellinen alkuosa osoittaa, että Granö pyrki täyttämään kirjaimellisesti 1920 asettamansa vaatimuksen "tehtävän täsmällisestä määrittelystä”. Nimettyään ihmisen aistiympäristön maantieteen tutkimuskohteeksi Granö kuvaa, miten ihmisen ympäristöä koskevista havainnoista voidaan edetä aluejakoon ja maisemallisesti yhtenäisten alueiden hahmottamiseen. Samalla hän esittelee käyttämänsä peruskäsitteet ja työmetodit pyrkien samalla luomaan maantieteelle selkeän teoreettisen pohjan ja yleensä luonnontieteellisen tieteen kriteerit täyttävän oppisisällön. Tuloksena oli yksityiskohtainen, monimutkainen ja paikoin vaikeaselkoinen kokonaisuus. ${ }^{674}$

Granön aluetieteen perusta tuli saksalaisilta maantieteilijöiltä, erityisesti Siegfried Passargelta, Alfred Hettneriltä, Robert Gradmannilta, Karl Sapperilta, Hermann Wagnerilta ja Ewald Banselta. Maantieteilijöiden lisäksi Granö oli hakenut maisemakäsitykseensä aineksia psykologeilta ja filosofeilta. Hänen mukaansa saksalainen psykologi Willy Hellbach oli määritellyt maisema-käsitteen maantieteilijöitä täsmällisemmin todetessaan, että maisemalla on ymmärrettävä "sitä aisteilla tajuttavaa kokonaisvaikutusta, jonka pala maapallon pintaa ja siihen kuuluva taivaankupu meissä herättävät”. Saksalaiseen filosofiin F. Neeffiin tukeutuen hän katsoi, että aistiympäristöt oli käsitettävä ja kuvattava sellaisiksi kuin terve ihminen ne kokee pohtimatta, miten eri aistimukset ja yhteisaistimukset syntyvät. Nämä tehtävät kuuluvat psykologian ja ihmisfysiologian aihepiiriin. ${ }^{675}$

Uuskantilaiseen filosofiin Heinrich Rickertiin tukeutuen Granö totesi, että maapallon aistiympäristöjen ja alueyksiköiden täydellinen kuvaus on mahdoton tehtävä. Tämän vuoksi maantieteilijän oli keskityttävä ennen kaikkea siihen, mikä oli eri alueissa oleellista tai vaikuttavaa. Vaikka maantieteellinen kuvaus kykeni parhaimmillaankin esittämään vain muutamia harvoja piirteitä todellisuudesta, sen voi katsoa onnistuneen, jos se pystyi pätevästi hahmottelemaan ympäristöstään poikkeavan maantieteellisen alueen eli yksilön. ${ }^{676}$ 
Viitaten edelleen Rickertin näkemykseen, että yksilön selvittely oli tieteellisesti oikeutettua vain siinä tapauksessa, että se johtaa pätevään lopputulokseen ja sillä on määrätty "kulttuuriarvo", Granö katsoi maantieteellisen yksilön määrittämisen täyttävän nämä molemmat ehdot. Se auttoi ymmärtämään kokonaisuuksia, ja luonnossa ei ollut toista objektia, joka olisi yksikkönä ihmiselämään niin voimakkaasti vaikuttava ja yleiskulttuurin kannalta niin tärkeä kuin aistiympäristö. ${ }^{67}$

Granö toisti aiemmin esittämänsä näkemyksen vaeltavista lähiöistä ja maisemista. Hänen mielestään oli selvää, että maantiede ei voinut tyytyä vain näihin alati muuttuviin antroposentrisiin kokonaisuuksiin vaan tarvitsi rajoiltaan muuttumattomia, ilmentymiltään ja esineiltään määriteltäviä "maantieteellisiä yksilöitä". Tämän vuoksi maantieteilijöiden tuli keskittyä erottamaan maapallon pinnalta kahdentyyppisiä kohteita, lähiötä vastaavia, kaikkien aistien avulla koettavia paikkoja, sekä maisemia vastaavia, vain näköaistin avulla hahmotettavia alueita.

Paikkoja varten Granö loi uudissanan kohdake, joka on jän̈nt pois käytöstä. Maisemaa vastaavaa alueyksikköä hän kutsui seuduksi. Näiden aistiympäristöjensä puolesta tavalla tai toisella yhtenäisten alojen märäys, kuvaus ja kaikinpuolinen selvittäminen oli maantieteen varsinainen tehtävä. Vaadittavaan yhtenäisyyden kriteerit vaihtelivat, mutta yleissääntönä oli, että kohdakkeiden täytyi yleensä olla ympäristötekijöiltään yhtenäisempiä kuin seutujen. ${ }^{678}$

Koska maantieteellisessä tutkimuksessa tarvittiin myös suuria alueellisia kokonaisuuksia, samankaltaisia seutuja oli mahdollista yhdistää maantieteellisiksi seutukunniksi ja edelleen maantieteellisiksi maakunniksi, jopa maanosiksikin. Laajimpia maantieteellisiä kokonaisuuksia määritettäessä huomiota piti kiinnittää erityisesti usean ilmentymän yleiseen yhtenäisyyteen, ei niinkään harvojen ominaisuuksien mahdollisimman suureen homogeenisuuteen. ${ }^{679}$

Granö hyväksyi Alfred Hettnerin näkemyksen yleismaantieteestä korologisena, alueiden sisäistä rakennetta ja keskinäisiä eroja tutkivana tieteenä, mutta erikoismaantieteen eli aluetieteen oli hänen mukaansa keskityttävä tutkimaan maantieteellisiä yksilöitä ja niiden muodostamia yhteisöjä. Hän suuntasi päähuomionsa maisemien 


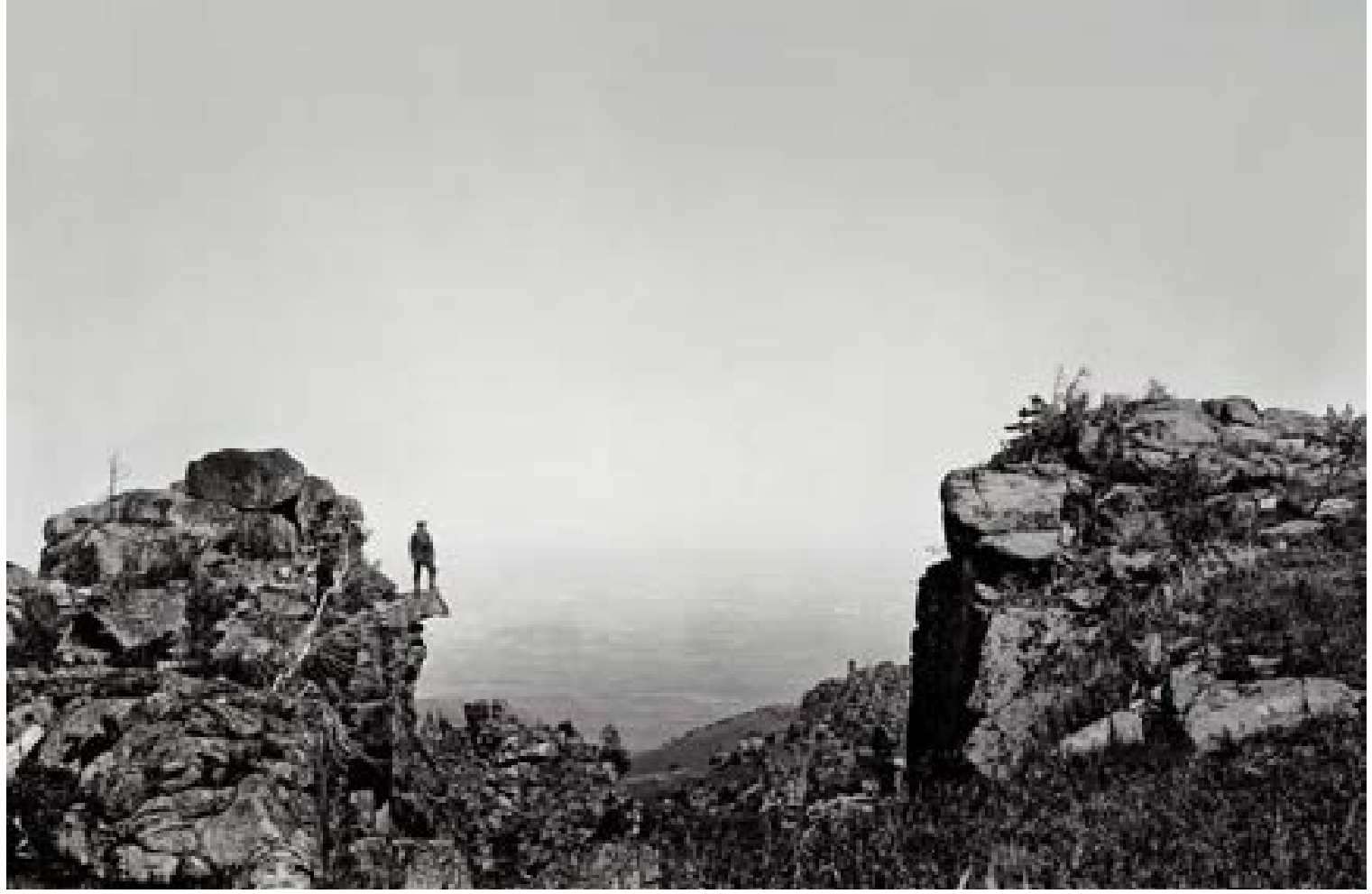

Puhtaassa maantieteessä Granö käytti tätä Altain pohjoisreunalta kohoavalta Bobyrganin vuorelta elokuussa 1914 ikuistamaansa näköalaa kuvaamaan "avointa luonnonlähiötä ja luonnonmaisemaa". Kielekkeellä keikkuu huimapäinen serkku Paavo Granö.

ulkonäköön mutta korosti, että tutkijan oli kiinnitettävä huomiota myös rajattujen maisemayksilöiden "elintoimintaan" eli hänen oli selvitettävä alueen sisäinen rakenne ja sen eri tekijöiden väliset vuorovaikutus- ja riippuvuussuhteet.

Tämä tutkimussuunta, jota Granö kutsui Passargen organismianalogian mukaan maantieteelliseksi fysiologiaksi, erosi selvästi muusta maisematieteestä, sillä siihen sisältyi sekä ilmiöiden tulkintaa että henkisten tekijöiden huomioonottamista. Aistiympäristöä voitiin pitää fysiologisena kokonaisuutena, jonka tutkimuksessa tarvittiin monipuolista, tieteiden rajoista riippumatonta aineistoa. Hän viittasi tässä yhteydessä Hans Spethmannin teokseen Dynamische Länderkunde, joka hänen mielestään sisälsi varteenotettavia näkökohtia. ${ }^{680}$ 
Puhtaan maantieteen luku "Maisema" perustui pääosin Granön Terrassa 1924 julkaisemaan artikkeliin "Maisematieteen tehtävät ja maiseman muotojen järjestelmä", mutta sen lopussa oli joitakin maisemateorian täydennyksiä. Kun hän oli aiemmin käsitellyt vain liikkumattomia muotoja, nyt hän otti huomioon muotoliikkumat eli pääosin taivaalla nähtävät ilmiöt, kuten kangastukset, pilvet, lentävien eläinten ryhmät sekä ilmalaivat ja lentokoneet. Maanpinnalla muotoliikkuma saattoi ilmetä muun muassa karjan liikkeinä tai ajoliikenteenä tiellä. Vuosittaista rytmiä noudattavaa muotomuuttumaa edusti parhaiten vesi, joka esiintyi kesäisin avovetenä ja talvisin jääpintana. ${ }^{61}$

Granö oli hyvin tietoinen siitä, kuinka voimakkaasti havaintopaikan korkeus maasta vaikutti maiseman kokemiseen. Siksi hän erotti toisistaan ihmissilmän perspektiivin, joka pääosin otti huomioon vain avoimen maiseman ja viipaleen taivasta, ja lintuperspektiivin, joka tarkasteli maanpintaa suljettuna systeeminä ilman taivasta. Granön mukaan maisema alkaa yleensä 100-200 metrin päässä katsojasta, mutta sen ulkoraja riippuu sekä havaintopaikan korkeudesta että maanpinnan korkokuvasta. Maisemaa vastaavan seudun minimisuuruudeksi Granö määritti noin 70 neliökilometriä eli sen alueen, jonka ihminen saattoi katseellaan hallita. ${ }^{682}$

Puhtaan maantieteen oppihistoriallisesti merkittävimpiin osiin kuului luku "Lähiö". Kuvaukset lähiön kokemisesta ja havaintopaikan korkeuden vaikutuksesta maiseman kokemiseen osoittivat, että Granö oli perehtynyt niihin tuloksiin, joita psykologit ja fysiologit olivat saavuttaneet ihmisen näkökyvyn olemusta selvittäneissä tutkimuksissaan. Hän katsoi, että lähiössä esineiden täytyy näyttäytyä niiden todellisessa koossa kolmiulotteisina. Esineistä saa kolmiulotteisen kuvan 20 metrin etäisyydelle saakka, mutta sen jälkeen ne muuttuvat kaksiulotteiseksi pinnaksi ja alkavat näyttää todellista pienemmiltä. Kun myös ilman väri ja sameus saavat aikaan sen, että esineet eivät näytä kauempana samanlaisilta kuin läheltä, lähiö loppuu noin 20 metrin päästä ihmisestä. Tämä merkitsi sitä, että avolähiön pinta-ala on noin 1500 neliömetriä. ${ }^{683}$

Lähiön tutkimusta tuli Granön mukaan tarkastella sen kolmen osan eli lähinäkymän, ympäreen ja alustan kannalta. Lähinäkymän tutkimisessa oli tärkeintä huomioon otettavien yksityiskohtien suuri määrä, oli sitten kysymys metsäholviston jäkälä- 
kuusista tai ihmisasunnon kirjaviin vaatteisiin pukeutuneista asukkaista. Merkittävänä rajoitteena oli kuitenkin se, että kohteiden tuli olla jollakin tavoin "määräävinä tai luonnehtivina näkyvässä kompleksissa", joten alle 1,5 metrin päässä havaitsijasta olevat pienet esineet tai piirteet eivät olleet "lähiötieteellisiä". ${ }^{684}$

Granö esitti Valosaaressa laatimiensa yksityiskohtaisten piirrosten ja profiilien avulla, minkälaisiin asioihin lähinäkymän tutkimuksessa oli keskityttävä ja mitä kaikkea esimerkiksi suomalaisessa lähinäkymässä saattoi esiintyä. Hän myönsi itsekin tutkimustyön vaativuuden toteamalla, että piirrokset oli laadittu havainnollistamaan alueen tyypillisiä piirteitä ja käytettyä työmetodia ja että erotetuilla pienaloilla ei ollut maisema-alueisiin verrattavaa merkitystä. ${ }^{65}$

Ympäreen muodostivat kuulo- ja haju- sekä eräät tuntoilmentymät. Ympäreen tutkimisen aluksi oli turvauduttava näköaistiin, jonka avulla voitiin selvittää, minkälaisesta ympäreestä oli kysymys. Esimerkiksi asunnon tapaiseen umpiympäreeseen välittyi huomattavasti vähemmän aistittavia asioita kuin avoimella hiekkarannalla olevaan avoympäreeseen. Lehtimetsien avonaisuus vaihteli vuodenaikojen mukaan, ja kallioseinämät puolestaan olivat pysyviä esteitä. ${ }^{686}$

Paikallisilmasto kuului pääosin meteorologian ja klimatologian piiriin. Koska ne eivät kuitenkaan harjoittaneet sisälähiöiden eli sisätilojen tutkimista, lähiötieteen tuli keskittyä juuri pienimpien alojen ilmaston selvittämiseen. Tuntoilmentymistä tärkeimpiä olivat ympäristöjen mikroilmastoon liittyvät piirteet, kuten asuntojen tasalämpöisyys ja avointen ruohostojen ja vesialueiden vaihtolämpöisyys. ${ }^{67}$

Granö oli pohtinut vakavasti myös kuuloaistin ja "kuuluman" ottamista mukaan yhdeksi aistiympäristön keskeiseksi osaksi. Tämän vuoksi hänen johdollaan Helsingin yliopiston maantieteen laitoksella opiskellut harrastelijalintutieteilijä Jussi Seppä ryhtyi tutkimaan uuden aluetieteen metodien soveltamista ornitologian havaintomaailmaan. Vuonna 1922 suuren suosion saaneen teoksen Lintujen äänet julkaisut Seppä sai 1928 valmiiksi teoksen Luonnon löytöjä: lintunäkymiä ja kuulumia, mutta Granö päätti lopulta olla nostamatta "kuulumaa" näkyvän ympäristön ja ilman sekä veden rinnalle. ${ }^{688}$ 


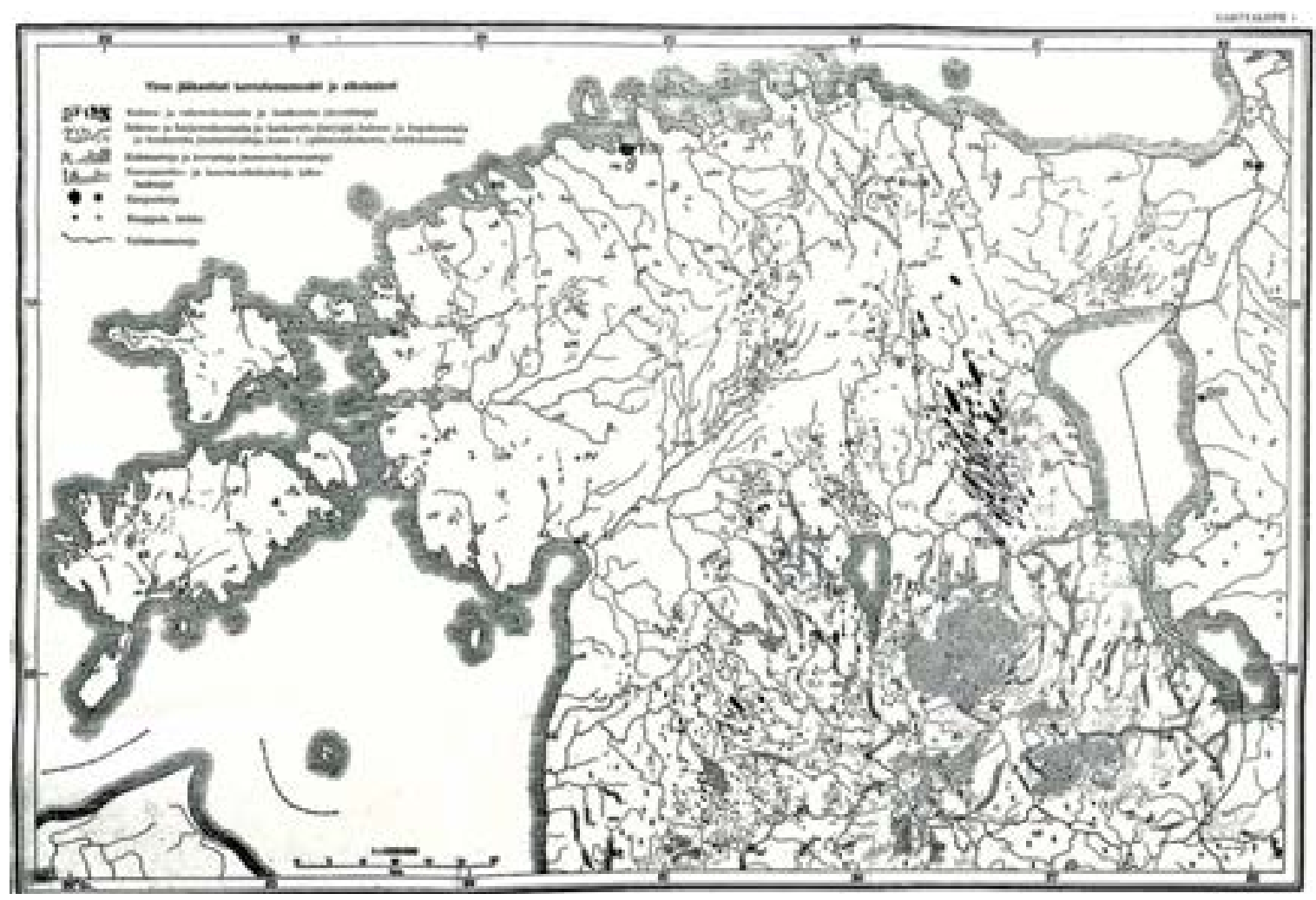

Granö havainnollisti Puhtaan maantieteen teoreettista sisältöä tutkimusesimerkeillä Suomesta ja Virosta, tässä tapauksessa Viron jääkautisten kerrostumamuotojen ja alkulaaksojen kartalla.

Kuuloilmentymien tutkiminen oli Granön mielestä kuitenkin olennainen osa lähiötutkimusta. Luonnonlähiöitä saattoi hallita täydellinen "kuolonhiljaisuus", mutta niiden yleisimpiä kuuloilmentymiä olivat muun muassa tyrskyjen pauhu, metsien humina, karjan mölinä ja lintujen laulu. Tekomuotojen leimaamien lähiöiden kuulumaa puolestaan useimmiten hallitsivat ihmisäänet sekä liikenteen ja teollisuuden aiheuttama hälinä ja meteli. Oleellista oli oivaltaa, että kuulolla sai muita aisteja 


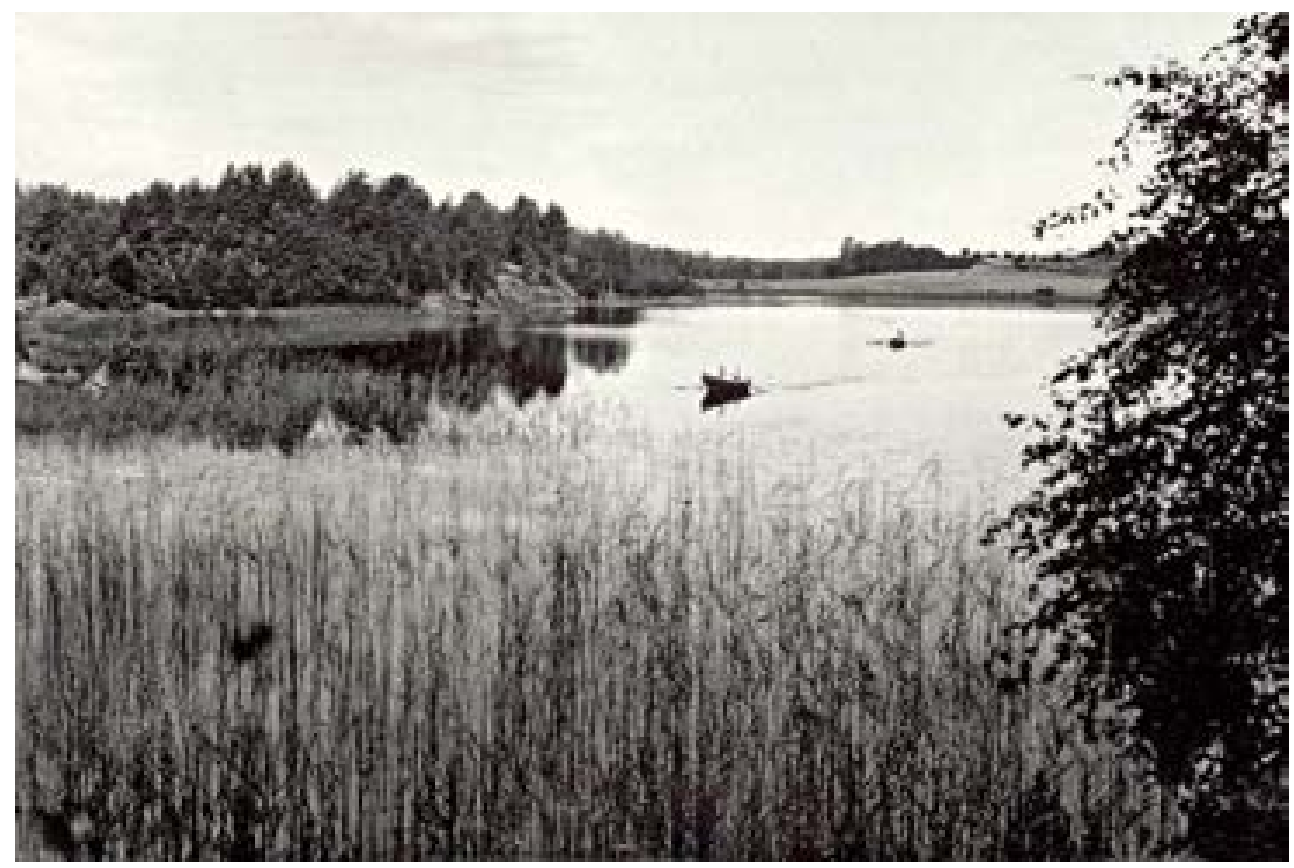

Granö kuvasi Puhtaassa maantieteessä lähinäkymän ja kaukonäkymän eli maiseman välistä vaihettumisvyöhykettä piirtämällä alkuperäiseen järvimaiseman valokuvaan 20 metrin, 50 metrin, 100 metrin ja 700 metrin etäisyydet.

selvemmin käsityksen ajasta, minkä vuoksi kuuloa oli nimitetty aika-aistiksi. Kuuluvassa kompleksissa eli kuulumassa tapahtuvalla oli siten suurempi merkitys kuin olevalla: "kaikki, mikä kuuluu, on tapahtuvaa: sointi, sävel, häly, sointu, epäsointu."689

Maantieteilijöiden piirissä oli Granön mukaan yleisesti vastustettu hajuilmentymien ottamista tutkimuksen piiriin. Tämä oli johtunut osin siitä perustellusta syystä, että ihmisten hajuaistit erosivat toisistaan selvästi. Osin vastustuksen taustalla oli kuitenkin ollut myös naiivi vetoaminen niihin käytännön vaikeuksiin, joihin jouduttaisiin, jos erilaiset "alemman kehitystason" ja "vähemmän hienot" hajuilmentymät otettaisiin huomioon. Karl Sapperiin ja Robert Gradmannin tukeutuen hän esitti, että erilaiset hajut, kuten kukkaniittyjen tuoksu ja lannan lemu, olivat olennainen 


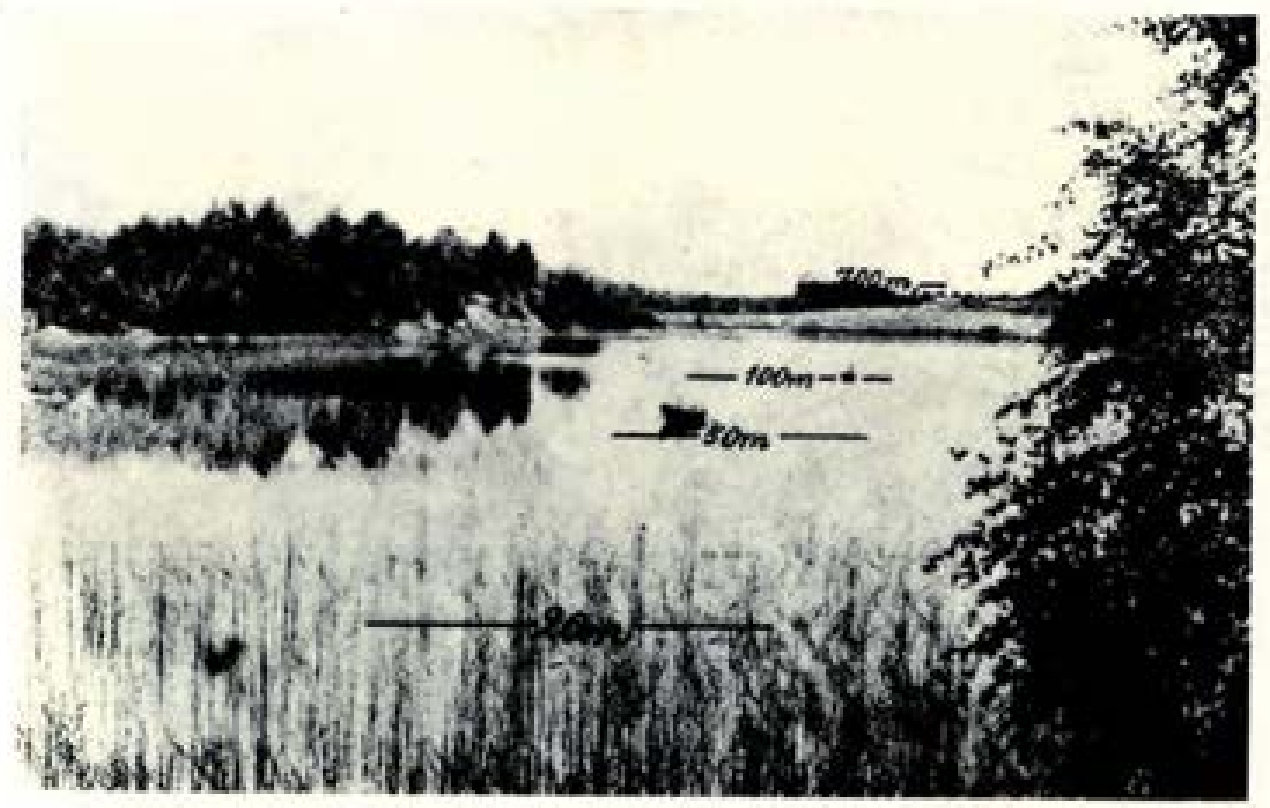

(Nukoula Valosasen eraalta Iabes 4 in jerven pinasn ylipoolella kobouvalta katliolta pobjoiseen.) Kuvassa on

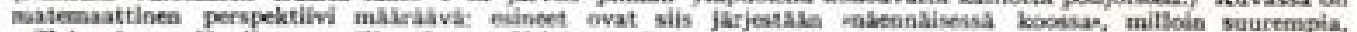

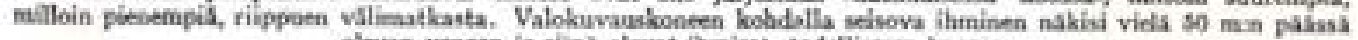

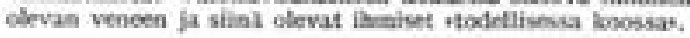

osa maisemakokemusta. Visuaalisen maiseman ohella oli siis muun muassa ääni-, tuoksu- ja värimaisema. ${ }^{690}$

Alusta muodostui luonnollisesta maankamarasta tai tekoaineksesta. Sen ilmentymismuotoja olivat muun muassa kaltevuus, kuoppaisuus, pehmeys ja särkyvyys, jotka ihminen aisti pelkän tuntoaistin avulla. Sitä olisi voinut pitää vain ympäreen osana, ellei ihminen olisi ollut painovoiman vuoksi täysin riippuvainen siitä. ${ }^{691}$

Granön mukaan uusi aluetiede muodosti kokonaisuuksia hajottamalla alueita, sillä "yhdistäminen toisaalla johtaa erottamiseen toisaalla". Muodostamalla keskeisten ominaisuuksiensa perusteella yhtenäisen alueellisen kokonaisuuden maantieteilijä sai aikaan määrätyn maantieteellisen tyypin edustajan. Kun hän sitten veti tämän 
kokonaisuuden ympärille rajan, hän samalla erotti maantieteellisen yksilön ympäristöstään. Päämääränä tuli olla yhtenäisten alueiden etsiminen, ei niinkään mahdollisimman selvien rajojen vetäminen. ${ }^{692}$

Granö kuvasi maantieteellisten kokonaisuuksien muodostamista esittelemällä sekä Viron aluejakonsa että ensimmäisen kerran painetussa tekstissä myös Valosaaressa tekemänsä seuduke- ja kohdakejaot, joissa hän osoitti, miten lähiötieteellinen aluejako tapahtui käytännössä. ${ }^{63}$

Lähiötieteellinen aluejako poikkesi Granön mukaan maisematieteellisestä aluejaosta siinä, että lähinäkymää analysoitaessa edettiin katsojan lähimmästä ympäristöstä kohti näkymän ulkorajaa, kun taas maisematieteellisessä aluejaossa suunta oli päinvastainen, "ulkoa sisälle päin". Monet maisemassa hyvin huomaamattomat piirteet saattoivat olla lähinäkymässä hyvinkin hallitsevia: "Katseen siirtyessä maisemasta lähiöön, avautuu kokonainen uusi maailma muotoja ja värejä, jotka mitä olennaisimmin kuuluvat aistiympäristöön ja joiden selvittelyä tämän vuoksi ei voida laiminlyödä."'694

Puhtaan maantieteen viimeinen luku "Maantieteen rajat" perustui Terrassa 1925 julkaistuun samannimiseen artikkeliin. Luku osoittaa, että Granö oli jo varhain vakuuttunut siitä, että maantiede saattoi vain loogisena ja monipuolisena aluetieteenä saavuttaa itsenäisen ja selvärajaisen tieteen aseman ja vaikuttaa samalla inhimillisen tiedon lisääntymiseen ja yhteiskunnan kehittämiseen. ${ }^{695}$

\section{Ristiriitainen vastaanotto}

Puhdas maantiede ilmestyi aikana, jolloin maantieteen olemuksesta keskusteltiin vilkkaasti Euroopassa ja Yhdysvalloissa. Vaikka teos liittyi saumattomasti useiden johtavien maantieteilijöiden, kuten Siegfried Passargen, Otto Schlüterin ja Carl Sauerin, edustamaan Landschaft-traditioon, se poikkesi teoreettisen sisältönsä puolesta suuresti useimmista tutkimussuunnan tutkimuksista.

Granön lähtökohtana ei ollut maisema alueena vaan ihmisen ympäristönä. Kun alan tutkijat keskittyivät yleensä käytännöllisiin tutkimuskysymyksiin, Granö pyrki 
ennen kaikkea luomaan maantieteelle tieteellisen itsenäisyyden takaavan teoreettisen sisällön sekä työmetodin, joka mahdollisti maisemien ja lähiöiden täsmällisen ja systemaattisen hahmottamisen kartografisten esitysten perusteella. ${ }^{696}$

Ajatus maantieteestä maisematieteenä ei ollut uusi, mutta Granö oli ensimmäinen tutkija, joka asetti aistiympäristön maantieteen tutkimuskohteeksi. Hänen oppirakennelmansa perusta oli luonnontieteissä, mutta se tukeutui myös psykologiaan ja filosofiaan. Havaitsevan ihmisen ottaminen mukaan tutkimuskohteen määrittelyyn edusti ajan tieteen valtalinjasta poikkeavaa avaraa tieteidenvälisyyttä, pyrkimystä ylittää luonnon- ja ihmistieteen rajalinja. Tämä näkyi myös suhtautumisessa ihmisen toimintaan. Alueyksikköjä rajattaessa ihminen sai roolin vain aistittavien tekijöiden muodostajana, mutta alueiden toimintaa tarkasteltaessa oli pohdittava myös sellaisia henkisiä tekijöitä, jotka eivät olleet välittömästi aistittavia. ${ }^{697}$

Ihmisen aineettoman toiminnan jättäminen alueiden rajaamisen ulkopuolelle synnytti paljon kritiikkiä, sillä monet tutkijat korostivat, että alueet erosivat toisistaan muun muassa sosioekonomisten tekijöiden perusteella. Ratkaisu osoittautui Granölle siinä mielessä onnelliseksi, että häntä ei kyetty mitenkään yhdistämään Saksan surullisenkuuluisaan "Lebensraum"-ajatteluun. Useat muut Landschaft-suuntauksen tutkijat, erityisesti Siegfried Passarge, Ewald Banse ja osittain myös Hermann Lautensach, kytkettiin eri tavoin natsien tiedepolitiikkaan, vaikka he kaikki eivät natseja varsinaisesti olleetkaan. ${ }^{698}$

Puhtaan madntieteen vastaanottoa leimasi ristiriitaisuus. Hänen professuurinsa Helsingin yliopistossa saanut Väinö Auer laati teoksesta vuoden 1930 lopulla Uuteen Suomeen melko pinnallisen arvostelun, jossa hän muodollisten kehujen ohella paljasti, että hän piti teoksen tavoitetta arvokkaampana kuin sen sisältöä. ${ }^{699}$

Luottoystävä Kaarlo Hildén ei "rohjennut" lausua teoksesta mitään, ei myöskään vanha opettaja J. E. Rosberg. Suorasukainen ja sovinnaisuuksia kaihtanut Aaro Hellaakoski sentään totesi, että Puhdas maantiede eteni teorian muodostuksen osalta johdonmukaisesti ja täsmällisesti kuin kone, mutta muuten hän piti teosta "vaikeatajuisena ja ikävyyteen asti perusteellisena” ${ }^{700}$ 
August Tammekann kehui tutkimusta Virossa julkaisemassaan arvostelussa todeten muun muassa, että "tuskin koskaan on maantieteessä esitetty niin loogillisen johdonmukaista ja eleganttia metodologista järjestelmää”. Sen sijaan Edgar Kant, Granön oppilaista teoreettisesti lahjakkain, jolla olisi ollut kansainvälisesti arvostettuna tutkijana hyvät edellytykset tehdä uutta teosta tunnetuksi, vaikeni täysin. Myöhemmin hän viittasi tosin arvostavasti Pubtaassa maantieteessä esitettyyn ajatukseen maantieteen ja juuri muotoutumassa olevan sosiologian läheisestä yhteydestä..01

Suomen suppeissa maantieteilijäpiireissä ei ollut harjoitettu juuri lainkaan muuta kuin vanhaan yleismaantieteeseen liittyvää empiiristä tutkimusta, joten Puhtaan maantieteen sisältö jäi vieraaksi valtaosalle alan tutkijoista. Muutamat tutkijat arvostelivat Iivari Leiviskän tapaan teosta ankarasti, mutta pääosin se sivuutettiin lähes kokonaan. Vieroksuva suhtautumistapa oli sinänsä ymmärrettävä, sillä teos edusti täysin muusta tutkimuksesta poikkeavaa linjaa. Lisäksi Granön käsitysten tiukka hyväksyminen olisi periaatteessa pakottanut valtaosan alan tutkijoista myöntämään, että heidän edustamansa tutkimussuunnat, kuten geomorfologia, kasvimaantiede ja talousmaantiede, eivät kokonaisuudessaan enää kuuluneet maantieteen alaan. ${ }^{702}$

Maantieteilijöiden ohella teos kiinnosti joitakin psykologeja ja filosofeja, kuten suomalaisen hahmopsykologian pioneeria Eino Kailaa, joka toimi Turun yliopiston professorina 1926-30 samaan aikaan Granön kanssa. Georg Henrik von Wrightin mukaan Helsingin yliopistoon siirtynyt Kaila oli luennoillaan 1930-luvun puolivälissä todennut, että vain Granö oli pohtinut aistifysiologiaan liittyviä asioita sekä teorian että käytännön kannalta. Kaila myös mainitsi myöhemmissä tutkimuksissaan muutamia Granön käyttämiä käsitteitä, kuten näkymä, kuuluma, tuntuma, lähi- ja kaukoavaruus. ${ }^{703}$

Psykologeista Puhtaan maantieteen teemoja käsitteli muun muassa kognitiiviseen lähestymistapaan suuntautunut Johan von Wright. Hän julkaisi 1947 artikkelin "Terrae incognitae", jossa hän kuitenkin irtaantui Granön ajatuksista esittäen ihmisten ajatusten ja mielikuvien ottamista maantieteellisen tutkimuksen kohteiksi. ${ }^{704}$

Muutamista myönteisistä ja kielteisistä kommenteista huolimatta yleisin suhtautumistapa teokseen oli vaikeneminen, mikä johtui joko halusta olla lausumatta jul- 
kista mielipidettä teoksesta tai sitten siitä, että sen sisältö koettiin niin vieraaksi, ettei siihen osattu tai haluttu ottaa kantaa. Tämä näkyi myös kansainvälisesti siinä, että vuoden 1930 tienoilla teoksesta julkaistiin kaikkiaan vain vajaat parikymmentä arviota, joista suurin osa ilmestyi Saksassa ja muissa Keski-Euroopan maissa. ${ }^{705}$

Tieteellisen maantieteen johtavassa maassa Saksassa Puhdas maantiede otettiin osittain yllättyneesti vastaan. Granö nautti maassa Altain tutkimustensa vuoksi suurta arvostusta, mitä osoitti se, että Albrecht Penck, yksi maailman tunnetuimmista maantieteilijöistä, piti häntä 1920-luvun lopulla "eurooppalaisen tason maantieteilijänä”. Kun isossa maassa riitti virkoja usean tutkimussuunnan edustajalle, monen oli vaikea ymmärtää, miksi perinteisestä luonnonmaantieteilijästä oli yhtäkkiä tullut vaikeaselkoinen teoreetikko. ${ }^{706}$

Granön tutkimusprofiilin muutos johti siihen, että Puhdasta maantiedettä arvostelivat pääosin henkilöt, joilla ei ollut mielikuvaa hänestä aiempien tutkimusten perusteella ja jotka eivät tunteneet Altai-kirjaa. Arvioissa tulivat esiin kaikki sävyt kehuista kovaan kritiikkiin. Petermanns Geographische Mitteilungenissa 1933 julkaisemassaan arvostelussa Fritz Jaeger piti teosta runsassisältöisenä ja omaleimaisena mutta myös varsin vaikeaselkoisena monimutkaisen kielen ja filosofisesti ja psykologisesti painottuneen sisällön vuoksi. Hän ei hyväksynyt Granön metodologiaa ja tuomitsi esimerkiksi värien ja äänien kartoituksen turhana puuhana. ${ }^{707}$

Geographische Zeitschriftiin arvostelun kirjoittaneen Hugo Hassingerin mukaan Puhtaalla maantieteelle oli paljon ansioita, mutta se ei kyennyt täyttämään kaikkia niitä tavoitteita, joita Granö oli kirjalleen asettanut. Teos tarjosi kuitenkin arvokasta kartografista materiaalia synteesin tekoa varten ja hahmotti ansiokkaasti maanpinnan käsittelyyn liittyviä seikkoja. ${ }^{708}$

Vaikka saksalaiset maantieteilijät torjuivat lähes yksimielisesti ihmisen havaintoympäristön asettamisen maantieteellisen tutkimuksen perustaksi ja vierastivat Granön psykologista otetta, Puhdas maantiede sai osakseen paljon myös arvostavaa huomiota. Myönteisimmin suhtauduttiin teoksen loogiseen rakenteeseen, ympäristön monipuoliseen tutkimiseen ja taitavaan karttojen käyttöön. ${ }^{709}$ 
Arvostus tuli näkyviin monin tavoin. Kun useat maantieteelliset seurat kutsuivat Granön kunniajäsenekseen, ne esittivät perusteluina Altain tutkimusten ohella hänen ansionsa Suomen maantieteen tutkijana ja maantieteen metodikkona. Monet tutkijat esittelivät Granön ajatuksia luennoillaan ja julkaisuissaan. Hans Schrepferin kirjoittaman maantieteellisen suurteoksen Suomi-osassa hänen todettiin nauttivan Puhtaan maantieteen kirjoittajana arvonantoa koko maantieteellisessä maailmassa, ja Hanno Beckin 1964 julkaisemassa luettelossa maantieteen historian tärkeimmistä tapahtumista ajalta 1859-1945 Suomen kohdalla mainitaan vain Suomen Kartaston julkaiseminen 1899 ja Reine Geographien ilmestyminen 1929.710

Granö oli vaikuttanut ratkaisevasti siihen, että Suomen Kartasto 1925 julkaistiin kotimaisten kielten lisäksi englanniksi eikä ranskaksi edellisten laitosten tapaan. Hän ei ollut kuitenkaan pyrkinyt itse rakentamaan suhteita Englannin tieteelliseen maailmaan, mikä osaltaan vaikutti siihen, että anglosaksisissa maissa saksankielistä teosta ei noteerattu juuri lainkaan. Huomattavimman arvostelun laati Ohion valtionyliopiston professori Eugene Van Cleef, joka vuoden 1930 Geographical Reviewissä totesi Granön nostaneen esiin lukuisia kiehtovia uusia käsitteitä, jotka tulivat varmasti herättämään keskustelua maantieteilijöiden piirissä. Arvostelun sävy oli varsin myönteinen, mihin ehkä osittain vaikutti se, että Van Cleef oli yksi Granön pitkäaikaisimmista kirjeenvaihtokumppaneista. ${ }^{71}$

Pohjois-Amerikkaan tieto Puhtaan maantieteen sisällöstä levisi hitaasti. Yhdysvalloissa suurin osa maantieteilijöistä lienee tutustunut teokseen vasta Richard Hartshornen alun perin 1939 ilmestyneen The Nature of Geography -teoksen kautta. Hartshornen useina painoksina ilmestynyt teos oli ehkä 1900-luvun alkupuoliskon tärkein maantieteen olemusta ja teoriaa käsitellyt teos, sillä se välitti anglosaksisen maailman tietoisuuteen kirjoittajansa erityisesti Alfred Hettnerin käsityksiin nojautuneen näkemyksen saksankielisen maantieteellisen tutkimuksen kehittymisestä. Kun saksan taito romahti toisen maailmansodan jälkeen maailmanlaajuisesti, Hartshornen tulkinta sivuutti usein saksalaisten tutkijoiden alkuperäiset käsitykset. 
Hartshorne kiinnitti teoksessaan merkittävästi huomiota Granön näkemyksiin, sillä tämä kuului muun muassa Alexander von Humboldtin ja Alfred Hettnerin ohella sen kymmenen eniten viitatun tutkijan joukkoon. Kokonaisuudessaan Hartshornen Puhtaasta maantieteestä antama kuva oli kriittinen, sillä hänen mukaansa Granö korosti liian paljon maiseman näkyvien piirteiden merkitystä henkisten ja toiminnallisten tekijöiden kustannuksella. ${ }^{712}$

Hartshornen mielestä maantieteen ei tullut keskittyä oman tutkimusreviirinsä merkitsemiseen vaan käyttää hyväksi kaikkia niitä metodeja ja ilmiöitä, jotka olivat oleellisia tutkittavan asian selvittämisen kannalta. Eiväthän historioitsijatkaan tukeutuneet vain kirjallisiin lähteisiin vaan hyödynsivät kaikkea menneisyydestä kertovaa ainesta, suullista perinnettä, karttoja, maalauksia ja yleensä kaikkea materiaalia, joka oli todisteena ihmisen toiminnasta. ${ }^{713}$

Kriittisistä kommenteista huolimatta Hartshorne arvosti Granön tutkimusta. Hänen mukaansa tämä oli ilmeisesti ainoa maantieteilijä, "joka oli todella käyttänyt korviaan ja nenäänsä kentällä”, ja oli alan tutkijoista ehkä kaikkein loogisimmin pohtinut maiseman olemusta. Granön Valosaaressa tekemät yksityiskohtaiset tutkimukset sademäärien ja tuulen voimakkuuden ja linnunlaulun kuuluvuuden pienistä paikallisista vaihteluista osoittivat havainnollisesti, kuinka voimakkaasti pienten alueiden tutkiminen poikkesi suurten alueiden tutkimisesta. ${ }^{714}$

Hartshornen mukaan Granön kehittämä systeemi oli monipuolisuudessaan niin vaativa, että "harvat, jos kukaan", oli sitä seurannut, ja tulevaisuudessa tulee seuraamaan. Aivan ehdoton hän ei kuitenkaan vakaumuksessaan ollut, sillä myöhemmin hän kirjoitti, että J. O. M. Broekin väitöskirja Santa Claran laaksosta lienee jossakin määrin tehty Carl Sauerin näkemysten mukaisesti, mutta "on saanut vaikutteita varsin huomattavasti myös Granöltä”. ${ }^{715}$

Väinö Auer totesi omassa arviossaan, että Puhdas maantiede oli herättänyt maantieteilijäpiireissä ihailun ja varovaisen pidättyväisyyden lisäksi osin jopa suoranaista pahansuopaisuutta. Näin oli käynyt varsinkin Ruotsissa, jossa mielipiteet teoksesta vaihtelivat suuresti. Esimerkiksi professori Sten De Geer, Granön ajatusten keskei- 
sin tukija länsinaapurissa, katsoi, että teos oli kansainvälisen tason tutkimus, joka syvensi käsityksiä maantieteellisistä maisemista ja niiden muodostumisesta. Granön ankaran loogisen järjestelmän mukainen, yksityiskohtaisen tarkka ja omaperäisillä kartografisilla ratkaisuilla toteuttama tutkimus oli nostanut pienen Valosaaren edustamaan koko maailmalle pohjoista maalaismaisemaa. De Geerin mielestä Granön ajatukset maantieteellisistä maisemista ja alueista olivat maantieteelle yhtä tärkeitä kuin aikanaan oli ollut Albrecht Penckin teoria maankuoren muodostumisesta. ${ }^{716}$

Göteborgin korkeakoulun professorina pitkään toiminut De Geer arvosti Granön tutkimusmatkoja, tutkimuksia ja karttajulkaisuja niin paljon, että ehdotti marraskuussa 1929 Svenska Sällskapet för Antropologi och Geografin -seuran hallitukselle, että tälle myönnettäisiin seuran korkein kunnianosoitus, kultainen Vega-mitali. Ehdotus kaatui kuitenkin tiukkaan vastustukseen, jonka kärjessä olivat professorit John Frödin ja Hans W:son Ahlmann. ${ }^{717}$

John Frödinin mielestä Granön tutkimusmatkat olivat tapahtuneet kauan aikaa sitten eivätkä niiden tulokset olleet nousseet keskinkertaista paremmiksi, ehkä pikemminkin päinvastoin. Jyrkkään sävyyn vaikutti ilmeisesti se, että Ruotsissa kaikkia tutkimusmatkailijoita verrattiin A. E. Nordenskiöldiin ja Sven Hediniin, joiden saavutuksia oli vaikea ylittää. Frödin ulotti arvostelun kuitenkin koskemaan myös Puhdasta maantiedettä, joka ei ollut hänen mukaansa saanut kansainvälistä hyväksyntää, eikä sitä todennäköisesti tulisi saamaankaan. Vaikka hän oli Granölle lähettämässään kirjeessä todennut teoksen käsittelevän aiheita, jotka olivat merkittäviä kaikille maantieteilijöille, De Geerille hän kertoi sen olevan liian kuvaileva ja jossakin kohdin niin naiivi, ettei se voinut nousta suureen suosioon. ${ }^{718}$

Hans W:son Ahlmann suhtautui Pubtaaseen maantieteeseen vielä Frödiniäkin jyrkemmin. Hän ei voinut hyväksyä sitä, että nuoret maantieteilijät pakotettiin luopumaan geneettisten kausaliteettisuhteiden analysoinnista ja ohjattiin maastoon rekisteröimään maiseman aineksia kuuliaisesti kuin kypäräpäiset preussilaiset sotilaat. Hänen mukaansa Granö ei ollut luonut mitään uutta oppia vaan ottanut suoria vaikutteita saksalaisilta maantieteilijöiltä, mikä näkyi siinä, ettei hän viitanut juuri 
lainkaan ranskalaisiin tutkijoihin. Ahlmann vastusti tiukasti Granön pyrkimystä rajata maantieteelle täysin muista tieteistä poikkeava tehtäväkenttä. Hänen mukaansa tiede kokonaisuudessaan kehittyi parhaiten siten, että samalla kun eri tieteenalat erikoistuivat ne lisäsivät yhteistyötään lähitieteiden kanssa. ${ }^{79}$

Kun De Geer vakuuttui siitä, että Frödin ja Ahlmann eivät tulisi kantaansa muuttamaan, hän katsoi parhaaksi luopua suosiolla ponnisteluistaan Granön hyväksi. Vuoden 1930 kultainen Vega-mitali myönnettiin norjalaiselle merentutkijalle Harald Sverdrupille. ${ }^{720}$

Puhtaan maantieteen vastaanoton ristiriitaisuus johtui osin siitä, että arvostelijat eivät olleet ymmärtäneet oikein kirjan luonnetta. Alaotsikon mukaisesti Granön tavoitteena oli ollut selvittää tutkimusesimerkkien avulla, voitaisiinko maantieteelle kehittää oma tutkimuskohde ja metodologia. Hän oli pohtinut asiaa koko 1920-luvun, mutta teos oli ensimmäinen yritys saattaa uudet ajatukset kokonaisteorian muotoon. Teos oli siis hänellekin eräänlainen koe, teesi, jonka avulla hän pyrki selvittämään, toimisivatko hänen kaavailemansa asiat käytännössä.

Kirjalle kävi niin kuin monelle uusiin aluevaltauksiin pyrkivälle teokselle käy. Vaikka kysymyksessä oli nimenomaan metodologinen selvitys, päähuomio kiinnitettiin joko teoksen johdonmukaisuuteen ja loogisuuteen tai sitten sen huonoiksi katsottuihin puoliin. Koska maantieteilijäkunnan ylivoimainen enemmistö työskenteli kokonaan toisenlaisten, pääasiassa empiiristen aiheiden parissa, teoksen sisältämiin tuoreisiin ajatuksiin ja sen tarjoamiin uusiin tutkimusmahdollisuuksiin ei juurikaan kiinnitetty huomiota. ${ }^{21}$

Toki syitä huonoon vastaanottoon voi hakea myös Puhtaan maantieteen sisällöstä. Granön tinkimätön ja lähes pakonomainen pyrkimys tieteellisesti omaleimaisen sisällön luomiseen maantieteelle synnytti paljon uusia näkemyksiä, mutta muodosti samalla myös teoksen heikkouden. Se oli liian ristiriitainen, vaikeaselkoinen, yksityiskohtiin tukehtuva ja kaavamainen, jotta se olisi kyennyt tarjoamaan hedelmällisen lähtökohdan uusille tutkimuksille tuolloisten tiedonkeruuvälineiden avulla. Lisäksi teoksen linjaus oli niin ehdoton, että se olisi sysännyt suurimman osan maantieteen 
yliopistoprofessoreista tieteenalan ulkopuolelle, geomorfologeiksi, geologeiksi, historioitsijoiksi, taloustieteilijöiksi, arkeologeiksi ja sosiologeiksi. ${ }^{722}$

\section{Suomen maantieteelliset alueet}

Puhtaan maantieteen saama kritiikki oli Granölle pettymys. Hän itse uskoi luomaansa oppirakennelmaan ja katsoi vastustuksen johtuneen pääosin siitä, että arvostelijat eivät olleet perehtyneet siihen riittävän syvällisesti. Siksi hän pyrki levittämään tietoa siitä jatkotutkimusten, esitelmätilaisuuksien ja kirjeenvaihdon avulla.

Vaikka Granö korosti kotimaan tutkimuksen ja maantieteen opetuksen merkitystä, tutkijana hän tavoitteli ennen kaikkea kansainvälisen tiedeyhteisön hyväksyntää. Siksi hän oli julkaissut Pubtaan maantieteen ensin saksaksi, ja siksi hän pyrki nyt tekemään tutkimustaan tunnetuksi Euroopassa. Ensimmäinen markkinointitilaisuus tapahtui elokuun 1929 lopulla Kööpenhaminassa, jossa hän valaisi runsaslukuiselle, mutta ilmeisesti varsin heikosti vastaanottavaiselle kuuulijakunnalle aluetieteensä sisältöä. Hän matkusti Kööpenhaminasta Turkuun Berliinin, Kaunaksen ja Riikan kautta, mutta paluumatka oli luonteeltaan turistimatka eikä sisältänyt esitelmätilaisuuksia. ${ }^{723}$

Kööpenhaminan esitelmätilaisuuden suhteen Granö ei ollut asettanut suuria odotuksia, mutta helmikuun 1930 lopulla tilanne oli kokonaan toinen. Tuolloin hän matkusti Siegfried Passargen kutsusta Hampuriin pitämään paikallisen maantieteellisen seuran kokouksessa esitelmän maantieteellisistä tyypeistä ja yksilöistä. Helmikuun 28. päivänä pidetty esitelmä maisematieteen sisällöstä sai sankan ja tarkkaavaisen kuulijakunnan, sillä Granö oli jo tunnettu nimi saksalaisissa maantieteilijäpiireissä. ${ }^{724}$

Esitelmä sai Granön peloista huolimatta hyvän vastaanoton. Varsinkin nuoret kuulijat tuntuivat hyväksyvän hänen näkemyksensä maantieteen uusista tehtävistä. Minkäänlaista väittelyä tai keskustelua ei kuitenkaan syntynyt, sillä mahtipontisen Passargen esitettyä lyhyen puheenvuoron kukaan läsnäolijoista ei rohjennut lausua 
mielipidettään. Tilaisuus päättyi sopuisassa ja myötämielisessä ilmapiirissä, jonka syntyä Granö oli avittanut kehumalla esitelmänsä alussa vuolaasti isäntänsä panosta maisematieteen kehittämisessä:

Selvemmin kuin missään muualla on täällä tunnustettu maantieteellisen kompleksin, maiseman merkitys, ja ehkä määrätietoisemmin kuin muualla on täällä viljelty maantieteellistä synteesiä. Ja ennen kaikkea: jyrkemmin kuin kukaan muu on prof. Passarge tehostanut tunnollisen ja perinpohjaisen induktion ja täsmällisen kuvauksen merkitystä ainoana oikeana lähtökohtana vakavassa maantieteellisessä tutkimustyössä. ${ }^{725}$

Saman matkan aikana Granö piti myös esitelmät Altaista sekä Hampurin yliopistossa että Greifswaldissa paikallisen Suomi-instituutin ja Pommernin maantieteellisen seuran järjestämässä tilaisuudessa. Kun Altain tutkimusten kuvaukset saivat hyvän vastaanoton, hän saattoi olla tyytyväinen matkan antiin ja palata Suomeen "ilman vihan kaunaa”. ${ }^{726}$

Onnistunut matka sai Granön jatkamaan työtään aluetieteensä tunnetuksi tekemiseksi. Hän oli huomannut, että sen teoreettisen sisällön hahmottaminen oli osoittautunut monelle ylivoimaiseksi, joten hän päätti keskittyä tuomaan esille käytännön sovelluksia. Julkaistuaan Terrassa maisematieteellistä aluejakoa selventävän artikkelin hän laajensi Suomen Kartastossa 1925 olleen Suomen maantieteellisiä alueita koskevan kirjoituksen itsenäiseksi tutkimukseksi, joka ilmestyi 1930-luvun alussa sekä saksaksi (Die geographischen Gebiete Finnlands) että suomeksi. ${ }^{727}$

Teoksen metodisessa johdannossa Granö totesi, että lähinnä näkyvien muotojen perusteella rajattavat maisemat oli huomattavasti helpompi hahmottaa kuin lähiöt, joiden rajauksessa oli otettava huomioon näkyvien muotojen lisäksi myös kuulo-, haju- ja tuntoilmentymät. Koska maisematieteellisen aluejaon avulla saatiin selville ympäristön tärkeimmät piirteet, hän päätti käsitellä nyt vain maisemiensa puolesta yhtenäisiä kokonaisuuksia. ${ }^{728}$ 


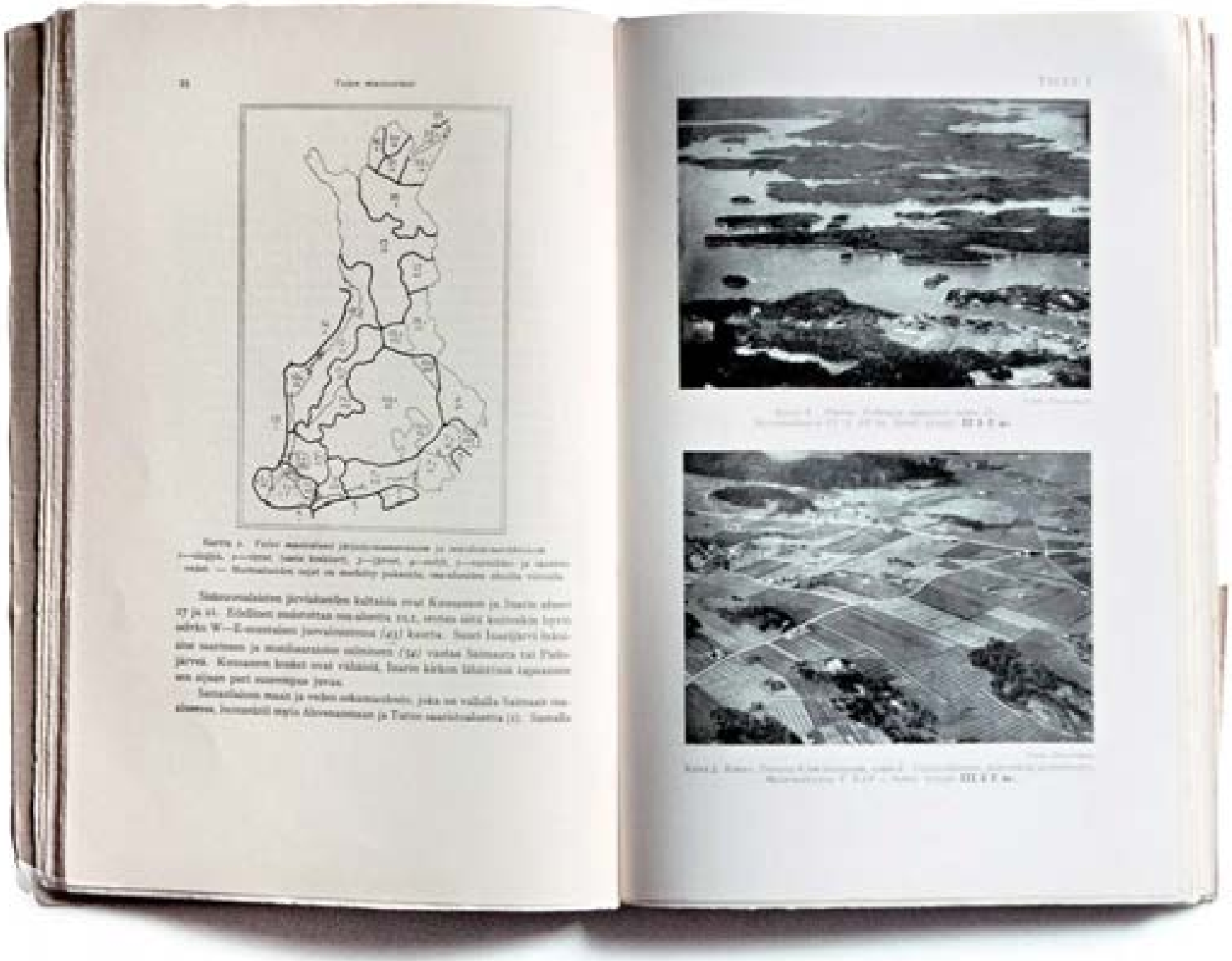

Granö esitteli Suomen maantieteellisiä alueita kartoin sekä viisto- ja panoraamakuvin. Kartta veden muotoalueista, viistokuvat Porvoon Pellingin saaristosta ja Raisiosta. 
Vaikka Granö seurasi toisen maailmansodan jälkeiseen aikaan asti ympäristöpsykologista ja aistifysiologista tutkimusta, tämä päätös johti käytännössä siihen, että hän luopui 1930-luvun alussa lähiötieteelliseen aluejaon kehittämisestä. Ratkaisun taustalla olivat sekä käytännölliset että teoreettiset syyt. Aluejakojen avulla oli yleensä tarkoitus kuvata pinta-alaltaan suuria alueita, joten isojen alueiden erottamisessa jouduttiin joka tapauksessa turvautumaan sellaisiin yleistämisratkaisuihin, että ne peittivät alleen pienten alueiden rajaamisessa käytetyt kriteerit.

Ja jos kaiken sen maisemallisesti tärkeän aineksen määrittäminen ja luokitteleminen, minkä ihminen maapallolla liikkuessaan saattoi nähdä, oli vaikea tehtävä, suorastaan mahdotonta oli kyetä kuvaamaan kaikki ihmisen lähiympäristöstään aistimat asiat siten, että ne voitaisiin sijoittaa johonkin luokittelujärjestelmään. ${ }^{729}$

Ratkaisu oli Granön kannalta ymmärrettävä, mutta lähiympäristön tutkimuksen kannalta harmillinen. Hänen Valosaaressa tekemänsä tutkimustyö oli niin ainutlaatuista, että se tarjosi ihmisten arkiympäristön tutkijoille ja suunnittelijoille erinomaista aineistoa vielä 2000-luvulla, jolloin tutkimuksen edellytykset olivat parantuneet ratkaisevasti kehittyneiden tietojenkeruulaitteiden ja paikkatietojärjestelmien ansiosta. ${ }^{730}$

Rajauksesta huolimatta Suomen maantieteelliset alueet oli suuritöinen teos. Vaikka Granö pitäytyi kartastossa esittämässään aluejaossa, hän esitti sekä käyttämänsä aluejakomenetelmän että sen tuloksena syntyneet alueet huomattavasti aiempaa laajemmin ja yksityiskohtaisemmin. Esimerkiksi ihmisen rakentamia tekomuotoja hän käsitteli nyt perusteellisesti, ja lisäksi hän tarkensi aluekuvaustaan merkitsemällä aluekaavojen yhteyteen alueen yksilöllisyyden astetta kuvaavia symboleja.

Kun kartaston aluekuvaus oli käsittänyt vain 12 sivua ja yhden kartta-aukeaman, Die Geographischen Gebiete Finnlands -teoksen laajuus oli yli 170 sivua. Tekstin lisäksi teoksessa oli karttapiirroksia, valokuvia ja yksityiskohtaisia tilastotaulukkoja. Erityisesti valokuvien suhteen uusi teos oli huomattavasti Puhdasta maantiedettä laadukkaampi, sillä siinä oli useita erikoispaperille painettuja maisemakuvia, joihin liittyi 
lyhyt kuvaus, maisemakaava ja fysiologisen tyypin kaava. Päöosan kuvista Granö oli saanut Ilmavoimilta, mutta myös Erkki Mikkola ja Matti Sauramo olivat luovuttaneet valokuvia hänen käyttöönsä. ${ }^{31}$

Granö tarkasteli yksityiskohtaisesti käyttämäänsä aluejakomenetelmää ja esitti, miten erilaisista rajausongelmista selvittiin. Määritellessään tyyppejä hänen pääkriteerinään oli se, kuinka leimaa-antava tietty aines oli maisemassa. Lopputuloksena oli, että maisematyyppi, jossa vesi oli määräävimmässä asemassa, kattoi lähes puolet Suomen pinta-alasta. Noin kolmannes pinta-alasta kuului korkokuvan hallitsemiin alueisiin, ja kasvillisuus oli määräävässä asemassa alueilla, jotka käsittivät runsaan viidenneksen pinta-alasta. ${ }^{732}$

Maantieteellisestä fysiologiasta Granö esitti yksityiskohtaisen kuvauksen, jota ei ollut Puhtaassa maantieteessä. Hänen mukaan ulkoiset luonnonvaikuttajat, lämpövaihtelut, tuuli, vesi ja eliöt, vaikuttivat monin eri tavoin Suomen maisemiin riippuen siitä, minkälainen niiden maankamara oli korkokuvaltaan, rakenteeltaan ja koostumukseltaan. Korkokuvalla oli suurin merkitys, sillä mitä suuremmat korkeuserot olivat, sitä enemmän ja nopeammin painovoiman aiheuttamat tekijät muuttivat maisemia. ${ }^{733}$

Granö totesi, että harvaan asutussa Suomessa luonnonfysiologialla oli luonnollisesti suurempi vaikutus maisemiin kuin kulttuurifysiologialla. Ilmeisesti Keski-Euroopan oloja ajatellen hän käsitteli kuitenkin kulttuurifysiologian vaikutuksia huomattavasti luonnonfysiologiaa laajemmin. Hän kuvasi väestön ryhmitystä, väestöntiheyttä, rakennustoimintaa, maanviljelyä, karjataloutta ja teollisuutta Suomen eri osissa kiinnittäen huomiota myös alueiden väliseen liikenteelliseen vuorovaikutukseen ja jopa Suomen ulkomaankauppaan. Jo Suomen Kartaston 1925 kasvillisuus- ja väestökartta oli paljastanut Suomen alueelliset kehittyneisyyserot, mutta vasta nyt Granö osoitti selkeästi, kuinka voimakkaasti Pohjanlahden perukan ja Laatokan välisen linjan lounaispuolella oleva Viljely- eli Kulttuuri-Suomi poikkesi sen koillis- ja pohjoispuolella olevasta Luonnon-Suomesta. ${ }^{734}$

Uhrattuaan paljon tilaa kulttuurifysiologian tarkasteluun Granö totesi, että se kuitenkin aina perustui luonnonfysiologiaan. Koko ihmisen maatieteellinen toiminta oli 


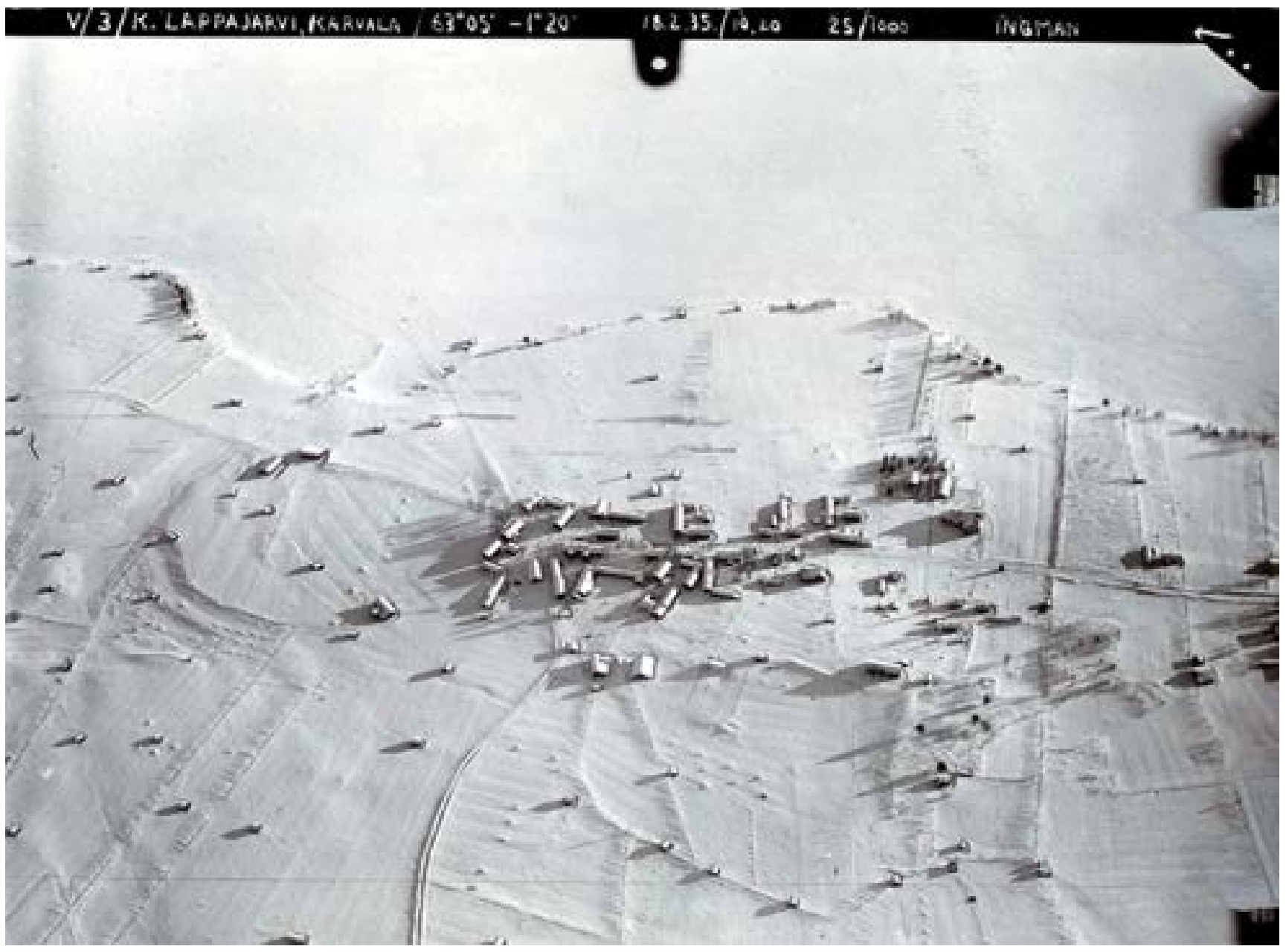

Etelä-Pohjanmaalla tekomuodot koostuivat 1920-luvulla pääosin rakennuksista ja teistä. Ilmavoimien viistokuva Karvalan kylästä Lappajärven meteoriittikraatterin rantamailta.

joko luonnonoloihin sopeutumista tai pyrkimystä niiden muuttamiseen. Tämän vuoksi maantieteellisten alueiden sisäisen toiminnan ryhmittelyssä oli kiinnitettävä päähuomio luonnonmaisemassa esiintyviin fysiologisiin eroavaisuuksiin. Kaltevuusenergian suhteen hän erotti neljä päätyyppiä (I-IV), samoin kasvillisuuden ja rapautumisen (A-D) kun taas veden (1-5) ja, ihmisen toiminnan (a-e) suhteen päätyyppejä oli viisi. ${ }^{735}$ 
Tutkittuaan Suomen seutuja tämän luokittelun avulla Granö päätyi siihen, että maan kaikkiaan 105 seudusta kulttuuriseutuja oli 62 ja luonnonseutuja 43. Kulttuuriseudut olivat lähinnä maatalousseutuja, teollisuudella ja liikenteellä oli huomattavaa merkitystä pääosin vain etelärannikolla ja Tampereen seudulla. Hän huomautti kuitenkin, että saatu lopputulos oli vain osapuilleen oikea, koska maisemiensa puolesta yhtenäiset alueet eivät välttämättä olleet sitä myös fysiologisesti. ${ }^{736}$

Käytännössä maantieteellisen fysiologian käsittely toi Puhtaassa maantieteessä esiteltyyn oppirakennelmaan lisää vain yhden luokitteluun perustuvan työmetodin. Vaikka Granö analysoi kulttuurifysiologiassa alueiden dynaamisuutta ja toiminnallisuutta varsin laajasti, työ tähtäsi vain jo luotujen alueyksikköjen ryhmittelyyn eri tekijöiden perusteella. Aluejaon perustana olivat edelleen maisemien näkyvät piirteet, eivät niiden toiminnalliset erot. Alueiden toiminnallisuutta ja dynaamisuutta Granö pyrki tosin selvittämään liikkuman avulla, mutta 1930-luvun vaihteessa pääosassa Suomea ihmisten, karjan ja liikennevälineiden merkitys maisemassa oli vähäinen. ${ }^{737}$

Suomen maantieteelliset alueet oli korkeatasoinen teos. Granö kykeni esittämään teoreettiset ja metodologiset näkemyksensä selkeämmin kuin Pubtaassa maantieteessä ja myös laajentamaan huomattavasti sen fysiognomisten ja fysiologisten tyyppien kuvausta. Pääosan kirjasta kattoi Suomen maisemien ja olojen monipuolinen kuvaus, joka osoitti Granön taidon ytimekkääseen ja täsmälliseen aluekuvaukseen. ${ }^{738}$

Teos otettiin Suomessa hyvin vastaan, mihin osittain vaikutti luonnollisesti se, että se perustui tieteellisten piirien yhteisvoimin julkaisemaan Suomen Kartasto 1925 -teokseen sisältyneeseen aluejakoon. Sitä vastaan hyökkäsi oikeastaan vain vanha tieteellinen kiistakumppani Iivari Leiviskä, joka sivuutti sen täysin 1934 julkaisemassaan teoksessa Suomen maa ja kansa. Hänen mielestään sitä olisi pitänyt "pitkin matkaa oikoa" muun muassa siksi, että se perustui omakohtaisen maastotuntemuksen sijasta pääosin kartoista saatuihin tietoihin, sivuutti monia maisematekijöitä ja sisälsi epäjohdonmukaisuuksia alueiden nimityksissä ja luonnehdinnoissa. ${ }^{739}$

Leiviskän kritiikin tehoa pienensi se, että hän ei esittänyt oman 16 maakuntaan perustuvan aluejakonsa tueksi minkäänlaista selvitystä vaan totesi sen pohjautuvan 


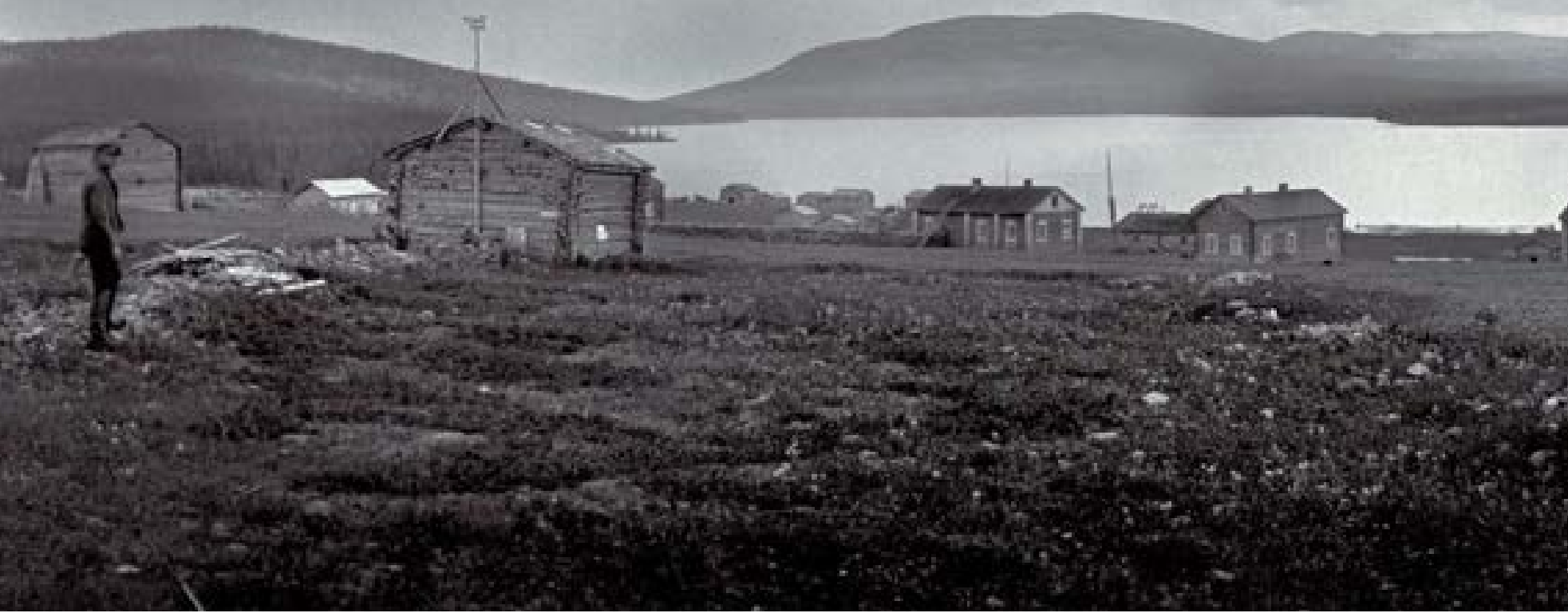

Vielä 1930-luvulla Suomi oli pääosin luonnonmaisemaa. Granön oppilaan ja ystävän Erkki Mikkolan valokuva Pelkosenniemeltä: Pyhäjärven kylä ja Pyhäjärvi taustanaan Pyhätunturi.

sin keinoin voitiin pienentää suuri alueyksikkö ja erilaisten karttaesitysten avulla oli mahdollista selvittää "sen erilaiset leimaa-antavat ominaisuudet" ${ }^{741}$

Leiviskä ei yleensä jäänyt tieteellisissä kiistoissa saamapuolelle. Hän vastasi Granölle julkaisemalla Suomalaisen Tiedeakatemian julkaisusarjassa 1937 kirjoituksen, jossa hän arvosteli edelleen ankarasti Granön aluejakoa ja esitti oman perustellun luonnoksensa Suomen jakautumisesta 19 alueeseen. Hän oli kuitenkin ehtinyt kriittisillä kirjoituksillaan ärsyttää niin paljon alan johtavia tutkijoita, ettei hänen aluejakonsa kiinnostanut juuri ketään. ${ }^{742}$ 
geographischen Gebieten”, jossa hän esitti tiiviisti ja johdonmukaisesti maisematieteensä ydinkohdat. ${ }^{743}$

Oikukas kohtalo puuttui kuitenkin jälleen Granön elämään samalla tavoin kuin syksyllä 1916, jolloin hän oli joutunut rahoituksen loppumisen vuoksi jättämään Altai-tutkimuksensa kesken. Nyt matkan Varsovaan esti salaperäinen sairaus, johon ei heti löydetty syytä.

Granön oli pakko katkerin mielin perua Varsovan-matkansa. Esitelmätilaisuus olisi tarjonnut mahdollisuuden suureen kansainväliseen läpimurtoon, sillä loistavana esiintyjänä ja asioiden havainnollistajana hän olisi kyennyt paremmin kuin kukaan muu avaamaan oppinsa salat laajalle yleisölle. Lukuisat oppilaat samoin kuin useat häntä haastatelleet toimittajat ovat todenneet, että hän kykeni henkilökohtaisessa kanssakäymisessä esittämään vaikeaselkoiset asiat helposti ymmärrettävällä tavalla.

Matkan peruuntuminen oli sitäkin harmillisempaa, koska Varsovan konferenssiin osallistunut suuri saksalainen valtuuskunta oli vielä täysin vailla kansallissosialismin vaikutusta. Sen sijaan seuraavassa kansainvälisessä maantieteilijäkongressissa Amsterdamissa 1938 Saksan valtuuskunnan osanottajien valinta oli tapahtunut jo niin selvästi Hitlerin oppien merkeissä, ettei Granö halunnut osallistua koko tapahtumaan.

Varsovan-kokousta varten laadittu esitelmä ei jäänyt täysin käyttämättä, sillä Granö laati sen pohjalta Petermanns Geographische Mitteilungenin 80-vuotisjuhlaniteessä 1935 ilmestyneen artikkelin Geographische Ganzheiten (1935). Tässä artikkelissa, johon liittyi kuudesta kartakkeesta koostunut kartografinen esitys Järvi-Suomen rajaamisesta, hän esitti tiiviissä muodossa maisematieteensä filosofisen taustan, teorian ja metodiikan pääpiirteet. ${ }^{74}$

Artikkelin ilmestyminen maantieteen kansainvälisesti ehkä arvostetuimman julkaisusarjan juhlanumerossa oli suuri huomionosoitus Granön tutkijantyölle. Hänen näkemyksensä maantieteen olemuksesta, maantieteellisistä tyypeistä ja yksilöistä sekä maantieteellisten tyyppien hahmottamisesta aluejaon avulla levisivät näin koko maailman maantieteilijäkunnan tietoisuuteen. Arvostuksesta kertoivat muun 
muassa Stefano Renierin ja Hans Schrepferin arvioinnit, joissa kehuttiin Granön koulukunnan metodologisia ja terminologisia saavutuksia. ${ }^{75}$

Geographische Ganzheiten -artikkeli oli viimeinen tärkeä metodinen kirjoitus, jonka Granö suuntasi kansainväliselle tiedeyhteisölle. Suomessa hän palasi maantieteen ja erityisesti maisema- ja aluetieteen olemukseen vielä Suomalaisen Tiedeakatemian vuosikokouksessa huhtikuussa 1946 pitämässään esitelmässä "Aluemaantieteellisestä tutkimuksesta ja sen tehtävistä maassamme", jossa hän pohti aluemaantieteen uutta roolia soveltavassa tutkimuksessa mutta kuvasi myös maantieteen sisältöä ja tavoitteita. Hänen mukaan useimmille nykypolven maantieteilijöistä maantiede oli

... ennen kaikkea maapallon alueiden ja maiden tutkimista. Vähän lienee keskuudessamme enää niitä, jotka eivät pidä aluemaantiedettä eli erikoismaantiedettä tieteemme pääosana. Yleismaantiede, joka jäsentää tehtävänsä ilmiöiden eikä alueiden mukaan, kiinnostaa meitä, nykyisin ehkä yhtä paljon maantieteen propedeutiikkana kuin maapallon eri ilmiökehiä tai joitakin maantieteellistä erikoiskysymystä selvittävänä tieteenä. ${ }^{746}$

Granön mukaan maantiede oli niin hänen itsensä kuin erityisesti saksalaisten Norbert Krebsin, Robert Gradmannin ja Albrecht Penckin sekä venäläisten L. S. Bergin ja P. P. Semjonov Tjan-Shanskin mielestä nimenomaan paikallisuustiedettä. Sen oli pyrittävä muodostamaan maantieteellisistä alueista kokonaisuuksia, joiden eri osat, ilmiöt ja tekijät olivat sopeutuneet toisiinsa niin hyvin, että tasapaino häiriintyi, jos yksikin tekijä muuttui. Kysymys oli samanlaisesta vuorovaikutuksesta kuin elävässä organismissa:

Keskeytymätön syiden ja seurausten sarja kulkee pinnamuodoista ja maaperästä ilmaston kautta kasvipeitteeseen ja eläinmaailmaan, asutukseen, talouselämään, liikenneoloihin, valtionmuodostukseen, henkiseen kulttuuriin ja kansojen historiaan. Miltei loputon määrä korrelaatioita liittää - suoranaisesti 
tai välillisesti - eri ilmiöryhmät toisiinsa, ja näin syntyy meissä käsitys jakamattomasta kokonaisuudesta. ${ }^{77}$

Granö korosti, että aluejako oli vain välttämätön alkuvaihe, jonka jälkeen alkoi tutkimuksen pääosa, saatujen alueiden "erikoisselvittely". Jokainen ympäristöstään erottuva alue oli kaikessa monivivahteisuudessaan kokonaisuus, maantieteellinen yksilö, jollaista ei ollut missään muualla, ja sen ulkoasu eli fysiognomia, sen esiintymispaikka ja esiintymistapa samoin kuin siinä vaikuttava toiminta, fysiologia, olivat ainutlaatuisuudestaan huolimatta yhtä vakavan tieteellisen huomion arvoisia kuin siinä vaikuttavat luonnonlait. ${ }^{748}$

Maantieteilijät liikkuivat Granön mukaan metodologisesti samoilla linjoilla kuin biologit. He selvittivät yksilöllisiä piirteitä, määrittelivät tyypillistä ja tyyppejä, näkivät lainmukaisuutta ja etsivät lakeja. Laajoilla ja ihmisille tärkeillä aluekokonaisuuksilla oli tietenkin verrattomasti suurempi merkitys kuin jollakin yksityisellä kasvilla tai eläimellä. Maantiede oli siten selvemmin individualisoiva eli idiografinen kuin biologiset tieteet; sen lainmukaisuutta ja lakeja toteava puoli, eli nomoteettinen osa, oli heikompi kuin noiden sitä lähellä olevien tieteiden mutta toisaalta vahvempi kuin henkitieteiden. ${ }^{749}$

Granön mielestä uusi käsitys maantieteen olemuksesta ja tehtävistä oli vain hyvin rajoitetussa määrin päässyt hedelmöittämään aluetieteellistä tutkimusta. Suomalaisten maantieteilijöiden olisi vihdoin otettava päämääräkseen kaikkien Suomen alueiden maantieteellinen selvitys. Hanke olisi toteutettava siten, että sen tulokset olisivat kansainvälistä luokkaa, joten se vaatisi koulutettuja tutkijoita ja valtiollista rahoitusta. Hän ei kuitenkaan tahtonut pitää pelkkänä utopiana ajatusta, että maamme aluetieteellistä tutkimusta tehtäisiin vielä joskus samaan tapaan kuin geologit tekivät nyt alueellista kartoitusta omalta sektoriltaan..$^{750}$ 


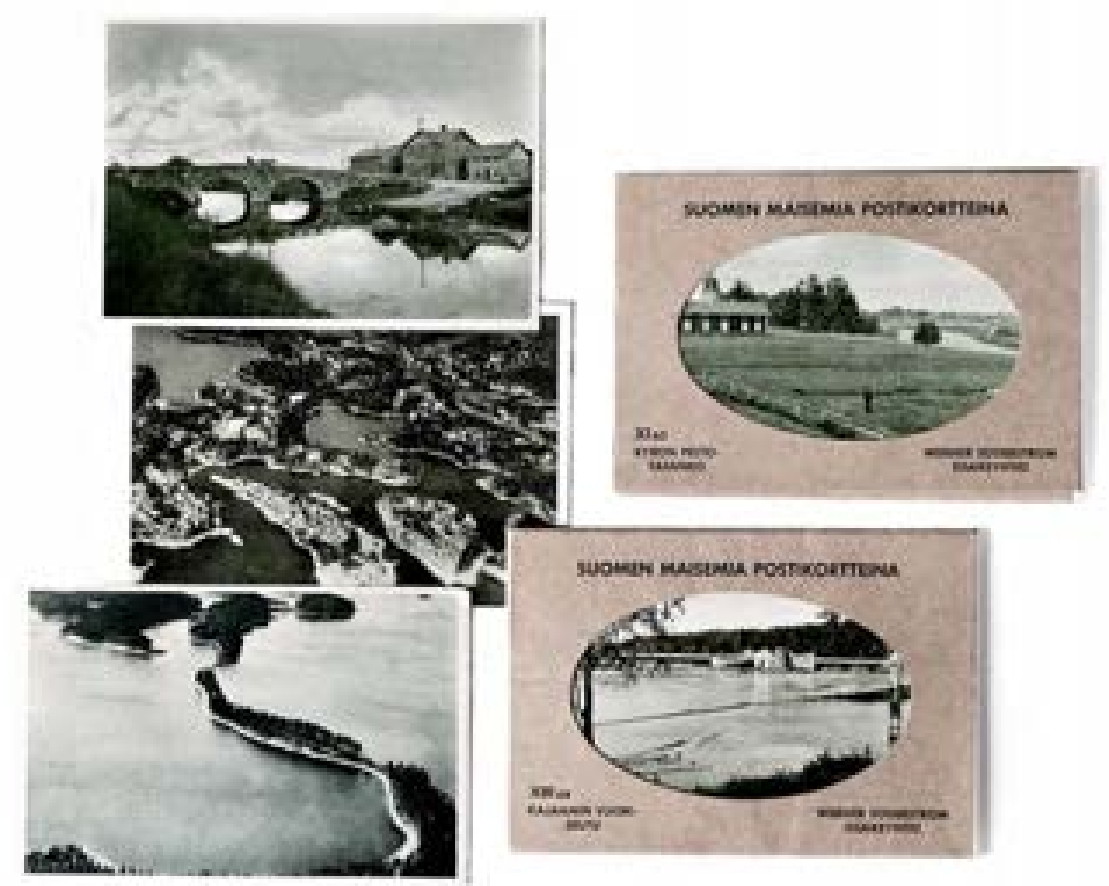

Suomen maisemia postikortteina on J. E. Rosbergin 1930-luvun alussa WSOY:Ile toimittama postikorttisarja. Erilliset kortit jaoteltiin ja numeroitiin Granön maisema-aluejaon mukaisiksi maakunniksi, seutukunniksi ja seuduiksi.

\section{Formaalisista alueista toiminnallisiin alueisiin}

Granön oli tarkoitus julkaista uusi esitys kotimaan maisema-alueista ensimmäisessä Suomen maantieteen käsikirjassa, mutta hänen sairastumisensa esti suunnitelman toteutumisen. Hän ehti laatia 1936 ilmestyneeseen, voimakkaasti kansallishenkiseen käsikirjaan vain Suomen asutusta kuvaavan luvun, jossa tuotiin esiin uusia näkökohtia väestön sijoittumisesta. Kirjoitus julkaistiin seuraavana vuonna lähes sellaisenaan saksaksi teoksena Gehöfte und Siedlungen in Finnland. ${ }^{751}$

Suomen Kartastossa 1925 alun perin ilmestynyt aluejako muodosti perustan Granön Suomen maantieteen käsikirjan toisessa laitoksessa 1951 julkaisemalle maantieteellisten alueiden kuvaukselle. Hänen näkemyksensä Suomesta oli edelleen selkeän kaksijakoinen: 
Suomenniemimaan mannerraja, joka voidaan vetää Laatokan koillisrannikolta Pielisen ja Oulujärven koillispuolitse Pohjanlahden perukkaan, on samalla tiheämmin asutun maamme osan, Viljelys-Suomen eli Kulttuuri-Suomen raja enimmäkseen asumatonta Luonnon-Suomea vastaan, joskin tietysti poikkeusaloja on rajan molemmin puolin. Kuvaavaa on, että kaikki vähänkin huomattavammat asutuskeskuksemme, yhtä - Rovanientä - lukuunottamatta, ja rautatiemme, paitsi paria yksinäistä linjaa, ovat mainitulla tavalla määritetyn Viljelys-Suomen rajojen sisäpuolella. ${ }^{752}$

Käsikirjassa Granö otti aiempaa enemmän huomioon ihmisen toimintaan liittyvät tekijät, minkä vuoksi hän erotti nyt paitsi Kulttuuri-Suomen ja Luonnon-Suomen myös Rannikko-Suomen ja Sisä-Suomen. Rannikko-Suomi oli maan vilja-aitta ja varsinainen teollisuuden ja kaupan alue, kun taas Sisä-Suomi oli metsätalousmaata, joka tuotti maan tärkeintä raaka-ainetta, puuta. Näiden suuralueiden välissä oli vaihettumisalueena Lounais-Hämeen viljelysmaa, jossa oli varsin kehittynyttä maanviljelyä ja muutakin teollisuutta kuin metsäteollisuutta. ${ }^{753}$

Kokonaisuudessaan käsikirjassa esitetty aluejako poikkesi aiemmista pääasiassa vain siinä, että Granö käytti nyt jonkin verran voimakkaampaa yleistystä ja antoi suuremman merkityksen eri muotojen esiintymismäärälle. Lisäksi hän saattoi hyödyntää vuosina 1921-24 ja 1936-38 toteutettujen valtakunnan metsien inventointien tuloksia, jotka eivät olleet käytettävissä Suomen Kartaston kasvillisuuskarttaa laadittaessa. Toisaalta esityksen merkitystä pienensi se, että rajallisen tekstitilan vuoksi Granö ei voinut kuvata yksilöllisesti muodostamiaan alueita ja että sillä ei ollut yhteyttä teoksen muihin lukuihin ja niissä esitettyihin aluejakoihin. ${ }^{754}$

Viimeisen kerran Granö kuvasi maantieteellisiä alueita 1955, jolloin hän julkaisi Suomen yleiskuvauksen Kaarlo Hildénin toimittaman yleistajuisen Maat ja kansat -teossarjan neljännessä osassa ja Suomen maisema-alueiden kuvauksen saksalaisessa Geographische Rundschau-aikakauskirjassa. Saksankielinen kirjoitus oli vain tiivistel- 
mä suomenkielisistä kuvauksista. Maat ja kansat -teoksessa hän tarkasteli asiallisella mutta elegantilla tyylillään Suomen maisemien syntyyn vaikuttaneita ja yhä vaikuttavia tekijöitä ja niiden alueellisten vaihteluiden synnyttämiä maantieteellisiä maakuntia. Näkemys maan kahtiajakautumisesta oli pelkistynyt entisestään, sillä nyt hän jakoi Suomen suoraan Kulttuuri-Suomeen (saaristoalueet, eteläiset maakunnat, järviseudut, Karjalan vaaramaat ja Pohjanmaa) ja Luonnon-Suomeen (KajaaninKuusamon vaaramaat, Ylä-Kainuu, Peräpohjola ja Lappi). ${ }^{755}$

Granön yli 25 vuoden aikana laatimia ja kehittämiä aluejakoja käytettiin pitkään Suomen maisema-alueiden hahmottamiseen. Hänen näkemyksensä Suomen kahtiajakautumisesta antoi tieteellisen vahvistuksen Henrik Gabriel Porthanin jo 1780-luvulla esittämälle ja sittemmin sitkeästi vaikuttaneelle näkemykselle, jonka mukaan Suomi jakautui sivistyksellisesti ja taloudellisesti kahteen osaan, Kulttuuri-Suomeen ja Luonnon-Suomeen. Porthanin mukaan Uudenmaan, Varsinais-Suomen, Satakunnan, Hämeen ja Pohjanmaan pääosan asukkaat muodostivat ruotsalaisen sivistyneen Suomen, joka oli osa Eurooppaa, kun taas Karjalan, Savon, Rautalammin pitäjän ja Pohjanmaasta Kajaaninlinnan asukkaat elivät vielä villissä ja sivistymättömässä tilassa ja olivat sen vuoksi rannikkoväestöä ennakkoluuloisempia, harvalukuisempia ja hitaampia sekä ulosanniltaan että olemukseltaan. ${ }^{756}$

Granö myös todisti oikeaksi J. L. Runebergin ja Z. Topeliuksen kirjallisesti hahmottaman ja 1800-luvun taidemaalarien kuvien muotoon saattaman näkemyksen, että Suomelle tyypillisin maisema oli korkealta mäeltä avautuva avara näkymä yli järvien, merenselkien, saarien ja metsien. Granön mukaan Suomi oli paitsi tuhansien järvien, myös tuhansien saarien maa, sillä "ei löydy toista aluetta maapallolla, missä olisi niin runsaasti järviä ja reittejä kuin Järvi-Suomessa". ${ }^{757}$

Granön näkemys Suomen maisemien olennaisimmista piirteistä osoittautui kestäväksi, sillä se perustui pysyviin luonnontieteellisiin tekijöihin, kuten kallioperään, maaston korkeussuhteisiin, vesistöihin, jääkauden jälkiin ja kasvillisuuteen, jotka puolestaan olivat ohjanneet ihmisen toiminnan sijoittumista. Myös osa hänen kehittämästään maisematutkimuksellisesta erityissanastosta jäi pysyvään käyttöön, mutta 
sen sijaan monet hänen muista aluejaoistaan vanhenivat nopeasti. Tämä näkyi jo Suomen Kartaston vuoden 1960 painoksessa. Vain hänen esityksensä pinnanmuotojen jakautumisesta kelpasi pienin korjauksin, kaikista muista aluejakokartoista vastasi ensi sijassa teoksen toimittaja Leo Aario. ${ }^{758}$

Suomalaisen yhteiskunnan rajun rakennemuutoksen seurauksena maantieteilijöiden huomio kohdistui 1940-luvun lopulta alkaen aiempaa voimakkaammin ihmisen toimintaan, minkä vuoksi Granön pääosin maiseman ulkonaisiin piirteisiin perustuva formaalinen aluejakometodi joutui vähitellen syrjään. Sen tilalle nousi Granön arvostaman Hans Spethmannin teoksessaan Dynamische Länderkunde (1928) hahmottama dynaaminen suunta, jonka mukaan tutkittava alue oli selitettävä yksinomaan siinä vaikuttavien voimien funktiona. Oli siis löydettävä, kuvattava ja selitettävä aluetta muovaavat ydintekijät ja ymmärrettävä alue niiden tulokseksi. $^{759}$

Kuvaavaa on, että Granön vanhaan professuurin Helsingissä nimitetty Leo Aario totesi virkaanastujaisesitelmässään 1953, että maisemaa siinä vaikuttavine voimineen voidaan verrata "useiden magneettien ja sähkövirtojen muodostamaan voimakenttään, jossa rautaviilajauho asettuu tietyllä tavalla näkymättömien voimaviivojen mukaisesti”. Siirtymän vei loppuun suomalaisen kulttuurimaantieteen vahvimmaksi alaksi pian noussut keskus- ja vaikutusaluetutkimus. ${ }^{760}$

\section{Uusi nousu}

Granön aluetieteellisten näkemysten kohtalona oli vaipua 1930-luvun jälkeen unohduksiin, kunnes niihin ryhdyttiin kolmen vuosikymmenen kuluttua kiinnittämään huomiota ensin maantieteen ulkopuolella, muun muassa arkkitehtuurin, taidehistoriallisen maisematutkimuksen, äänimaisematutkimuksen, ympäristöpsykologian ja ympäristönsuunnittelun piirissä. Yhtenä ensimmäisistä teoksen "uudelleen löytäjistä" oli Oulun yliopiston arkkitehtuurin professori Reima Pietilä, 


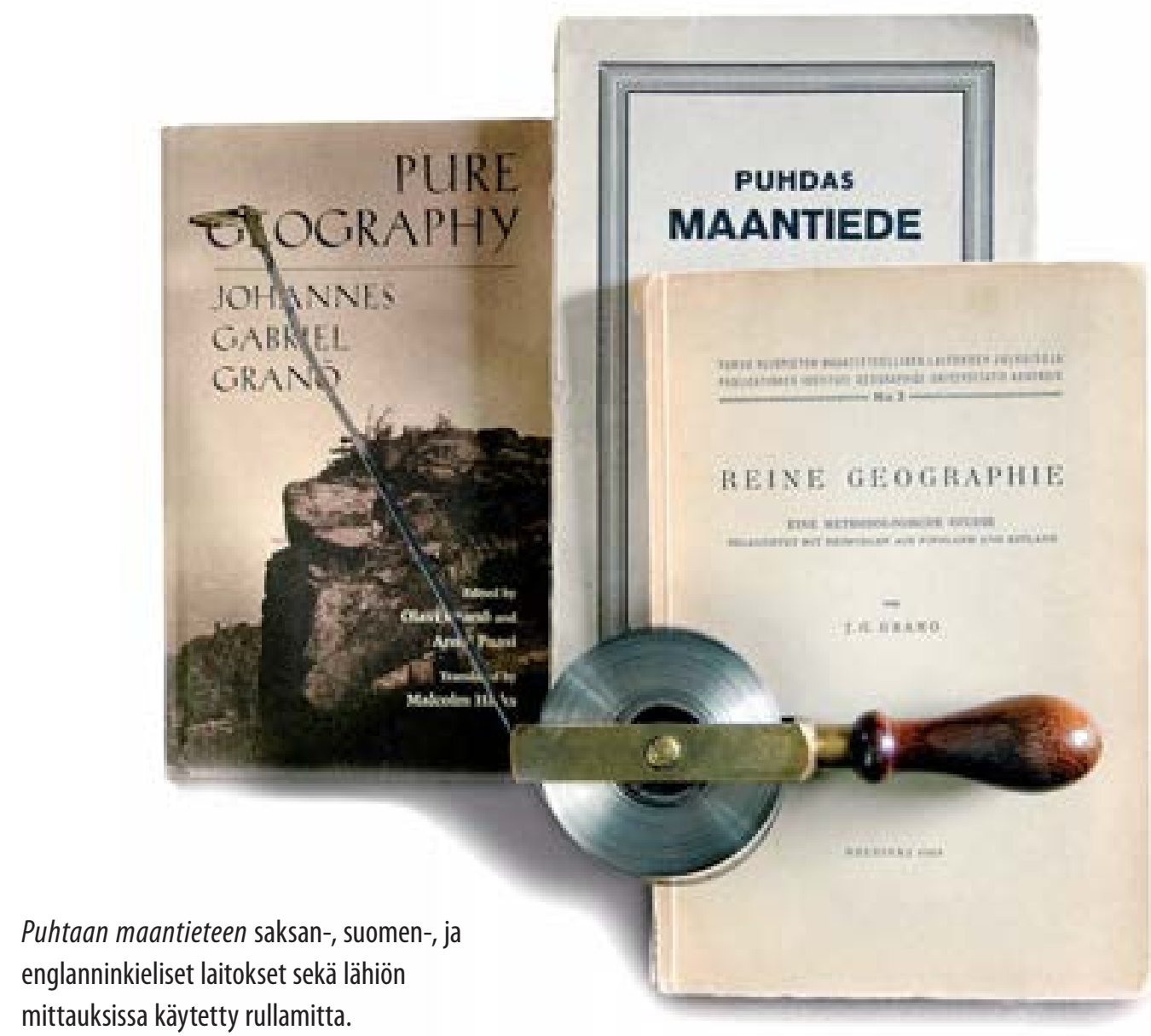

joka 1968 ilmestyneessä kirjoituksessaan "Maisema ja rakentamismuodot" piti sitä "maisema-arkkitehtuurin ainoana suomenkielisenä käsikirjana". ${ }^{761}$

Pietilää miellytti Puhdas maantiede -teoksessa erinomaisen morfologisen kuvauksen lisäksi sen monipuolinen pyrkimys luonnonelämysten hahmottamiseen, sillä erityisesti metsät tuottivat hänelle itselleen voimakkaita tilallisia kokemuksia. Hän pyrki omissa töissään kulttuurin, luonnon ja ihmisen rinnakkaiseloon häivyttämällä rajan luonnon ja rakennuksen väliltä. Luonto ikään kuin jatkui arkkitehtuurissa. Tämä pyrkimys näkyi niin asuinalueiden, kuten Espoon Suvikummun, kuin yksit- 
täisten rakennusten suunnittelussakin. Timo Keinäsen mukaan Pietilä puhui arkkitehtuurinsa yhteydessä mielellään luonnon morfologiasta ja kirvoitti myös keskustelun käsitteestä genius loci, paikan luonteen ilmenemisestä rakennuksessa. ${ }^{762}$

Opetuksessaan Pietilä kuvasi Puhdasta maantiedettä ja Suomen maantieteelliset alueet -teosta "uudistavien näkemysten varastoina". Hän uskoi, että Oulun koulukunnan piiristä olisi saattanut kasvaa voimia, jotka olisivat voineet jatkaa "maantieteellisen arkkitehtuurin" linjaa käytännön sovelluksiin saakka. Tämä olisi kuitenkin edellyttänyt sitä, että maantieteessä olisi ryhdytty jatkamaan Granön aloittamaa maisematieteen perustutkimusta. ${ }^{763}$

Asemakaavaopin professorien Otto-Iivari Meurmanin ja Olli Kivisen ansiosta myös Teknillisen korkeakoulun opiskelijat perehtyivät 1960-luvulta alkaen Granön teoksiin. Varsinkin arkkitehdit Martti I. Jaatinen, Tom Simons ja Leena Iisakkila käyttivät töissään ja opetuksessaan hyväksi tämän ajatuksia. Myös taidehistorian piirissä tunnettiin kiinnostusta Granön näkemyksiin, mistä oli osoituksena muun muassa Kai Linnilän 1968 julkaisema artikkeli maisematieteen soveltamisesta taidehistorialliseen maisematutkimukseen. ${ }^{764}$

Maantieteessä Granö keksittiin ikään kuin uudelleen 1970-luvulla, jolloin kiinnostus ihmisen ja ympäristön suhdetta kohtaan lisääntyi ja huomiota ryhdyttiin kiinnittämään niihin tekijöihin, jotka vaikuttivat ihmisten maisemakokemuksiin. Hänen näkemystensä tärkeimpiä puolestapuhujia olivat Josef Schmithüsen, Karlheinz Paffen ja Ernst Winkler, jotka antoivat Granölle suuren merkityksen maisematieteen kehittäjänä.

Paffen valitsi Granön Geographische Ganzheiten -kirjoituksen johdantotekstiksi 1973 ilmestyneeseen teokseensa Das Wesen der Landschaft, jossa esitellään maailman tunnetuimpien maisemamaantieteen tutkijoiden, kuten Hermann Lautensachin, Otto Schlüterin ja Carl Trollin, käsityksiä tieteenalan olemuksesta ja metodiikasta. Myös Winklerin pari vuotta myöhemmin toimittamassa Probleme der allgemeinen Geographie -teoksessa, jossa pohditaan yleis- ja aluemaantieteen keskinäisten suhteiden kehitystä, Granö on sijoitettu maantieteelle uutta suuntaa antaneiden tutkijoiden ketjuun, joka alkaa Carl Ritteristä ja päättyy David Harveyhin. ${ }^{765}$ 
Aluksi Granötä tulkittiin niin ylimalkaisesti, että häntä alettiin pitää perseptiomaantieteen ja jopa humanistisen maantieteen pioneerina. Tämä perustui kuitenkin täydelliseen väärinkäsitykseen. Kun Granö oli sulkenut maisematieteestään pois subjektiivisen kokemuksen tutkimisen ja maisemaan liittyvät erilaiset ideologiset, psykologiset ja poliittiset kytkennät, uusien suuntien tutkijat paneutuivat nimenomaan ympäristön synnyttämien tuntemusten ja mielikuvien selvittämiseen. Heille paikka ei ollut tärkeä kartografisessa mielessä, vaan ihmisten kokemuksista ja inhimillisestä tulkinnasta merkityssisältönsä saavana ilmiönä. ${ }^{76}$

Vaikka Granö ei siten ollut perseptiomaantieteen edelläkävijä, hänen merkityksensä huomattiin, kun humanistisen maantieteen edustajat ryhtyivät kiinnittämään monipuolisesti huomiota maiseman havaitsemisen ja kokemisen eri puoliin. Toisin kuin pelkästään visuaalisia havaintoja korostavassa maisemamaantieteessä Pubtaassa maantieteessä painotettiin näön ohella myös kuulo-, haju-, maku- ja tuntoaistin merkitystä ja esitettiin menetelmiä niiden avulla saatujen havaintojen kirjaamiseksi. ${ }^{767}$

Erityisesti äänimaisemien tutkimuksessa Granö oli Heikki Uimosen mukaan yksi alan uranuurtajista, joka paitsi pohti kuuloaistin ominaispiirteitä, myös loi uutta ja esteettisesti korkeatasoista terminologiaa. Turkulainen maantieteilijä Birger Ohlson jatkoi 1970-luvulla hänen linjoillaan tutkien muun muassa kaupunkien ja maaseudun äänimaisemia ja niiden muuttumista, mutta varsinaisesti äänimaisematutkimuksen Suomessa 1980-luvun lopulla aloittaneet Tampereen yliopiston kansanperinteen laitoksen etnomusikologit saivat virikkeensä alan kanadalaisesta tutkimuksesta. ${ }^{768}$

Maisematutkimus nousi osittain saksalaisten Landschaft-tutkijoiden synkän natsimaineen vuoksi uudelleen voimakkaasti esille vasta 1980 -luvulta alkaen. Tuolloin se omaksuttiin nimenomaan ihmisen aistiympäristöä tarkoittavassa englanninkielisessä muodossa landscape, eikä Landschaft-käsitteen mukaisessa sekä maisemaympäristöä että tiettyä aluetta osoittavassa kaksoismerkityksessä. Kun landscape- tai maisemakäsitteen käyttö yleistyi yhtäältä luonnonmaantieteessä, ekologiassa ja kulttuurimaisemien tutkimuksessa sekä toisaalta kulttuurimaantieteessä ja eräillä kulttuurintut- 
kimuksen aloilla, Pubtaan maantieteen teemat nousivat jälleen ajankohtaisiksi useilla tieteenaloilla, ympäristönsuunnittelussa, arkkitehtuurissa ja taiteiden piirissä. ${ }^{79}$

Uudessa tutkimuksessa maisema-käsitettä ei käytetty niinkään sellaisenaan luonnontieteellispohjaisen tutkimuskohteen osoittajana kuin kokoavana yleisterminä. Maiseman tutkimuksellinen käsittely oli laajentunut tutkijan ja ympäristön välisestä suhteesta koskemaan yleensä maiseman kokemista, sen symboleja, arvoa ja merkitystä eri aikoina unohtamatta silti kaiken perustana olevaa konkreettista ympäristöä. Kun tieteen ja taiteen maisemat kohtasivat, kumpikin suunta sai uutta sisältöä, kuten Taneli Eskolan J. G. Granötä valokuvaajana koskevat tutkimukset osoittavat.. ${ }^{70}$

Granön maantieteellisen ajattelun yhtenä päämääränä oli kehittää systemaattinen ja miltei matemaattisen tarkka kaava maantieteellisten alueiden määrittelemiselle. Tämän pyrkimyksen vuoksi hänet liitettiin 1970- ja 1980-luvulla kvantitatiivisen maantieteen pioneereihin. Kuten Anssi Paasi on todennut, Granö ei kuitenkaan osallistunut maantieteen "matematisoimiseen" vaan hänen ansionsa tällä saralla liittyivät formaalisen kielen luomiseen ja päällekkäin asetettavien karttojen käyttöön perustuvaan aluejakomenetelmään, joka hyväksyttiin 1900-luvun lopulla keskeiseksi analyysitavaksi paikkatietojärjestelmässä eli GIS-järjestelmässä (Geographical Information System)..$^{771}$

Granö pohti Puhtaan maantieteen teoreettisissa osissa myös useita muita teemoja, jotka nousivat uudelleen tutkimuksen kohteeksi 1900-luvun lopulla ja 2000-luvun alussa. Tällaisia aiheita olivat muun muassa ihmisekologia, ilmaston vaikutus ympäristöön, mittakaavan merkitys maiseman kokemisessa, visuaalisen havaitsemiseen liittyvät psykologiset tekijät ja ihmisten lähiympäristöön liittyvien kokemusten tutkiminen. Hänen teoreettinen työnsä alueanalyysin kehittämiseksi ennakoi puolestaan Walter Isardin käynnistämää laajaa tutkimustyötä, jonka tavoitteena oli alueen teoreettinen ja metodologinen käsitteellistäminen. ${ }^{772}$

Anglosaksissa maissa virinneen kiinnostuksen ansiosta Granön ajatukset alkoivat 1980-luvulla myös Suomessa kiinnostaa uudelleen maantieteilijöitä. Samalla ajatus Puhtaan maantieteen kääntämisestä englanniksi alkoi saada yhä suurempaa kanna- 
tusta. Hankkeen arvovaltaisimmaksi puolestapuhujaksi nousi ruotsalainen Torsten Hägerstrand, innovaatiotutkimuksen ja aikamaantieteen uranuurtaja, joka oli esittänyt ensimmäisen kerran jo 1976, että teos käännettäisiin myös englanniksi. ${ }^{773}$

Torsten Hägerstrand perusteli ajatustaan seuraavasti:

Puhdas maantiede on osoittautunut olevan ajatusmaailmansa puolesta puoli vuosisataa aikaansa edellä. Ilmestyessään se herätti ristiriitaista huomiota. Monet saivat siitä vaikutteita, mutta Granön ajatusten syvin sisällys jäi kuitenkin vieraaksi, koska siihen aikaan tutkimuksen näkökulmat olivat kokonaan toiset. Viime aikoina kiinnostuksen kohdistuessa kompleksiin ihminen/ympäristö on tutkimus maantieteessä, arkkitehtuurissa, ympäristöpsykologiassa, kognitiotieteessä ym. lähestynyt Puhtaassa maantieteessä käsiteltyä kysymystä ihmisen ympäristön luonteesta. Granö oli poikkeuksellinen metodologi myös siinä suhteessa, että hän todella itse suoritti tutkimuksia käytännössä esittämiensä teoreettisten periaatteiden mukaisesti. ${ }^{774}$

Hägerstrandin toive toteutui 1997, jolloin Pure Geography ilmestyi suuren yhdysvaltalaisen tiedekustantamon The Johns Hopkins University Pressin kustantamana lähes 70 vuotta saksankielisen painoksen ilmestymisen jälkeen. Kääntäjänä oli kokenut tieteellisten tekstien taitaja Malcolm Hicks, jonka tukena olivat teoksen toimittajat Olavi Granö ja Oulun yliopiston maantieteen professori Anssi Paasi. Turun Yliopistosäätiön rahoittama vaativa käännösurakka vei kaikkine esitöineen noin kolme vuotta. $^{775}$

Puhtaan maantieteen englanninkielisen laitoksen saama laaja myönteinen vastaanotto osoitti, että Granö koettiin edelläkävijäksi monella nykymaantieteen alalla. Erityistä huomiota kiinnitettiin hänen innovatiivisuuteensa, tinkimättömyyteensä ja johdonmukaisuuteensa tieteellisten tavoitteiden määrittelyssä ja tavoittelussa. Yhdysvalloissa uuden aluetieteen johtohahmoksi noussut Reginald G. Golledge nimesi teoksen 1998 yhdeksi maantieteen klassikoista. ${ }^{776}$ 


\section{Vaikea ratkaisu}

Ensimmäiset Turun vuodet olivat olleet Granölle tutkimuksellisesti ja henkisesti antoisia. Kun erilaiset ylimääräiset työt loppuivat ja oppilaita ei ollut liikaa, hän saattoi keskittyä kartastotöiden loppuun saattamiseen, maisemateoriansa kehittämiseen ja muuhun tieteelliseen toimintaan. Työrauhansa varmistamiseksi hän ei hankkinut kotiinsa edes puhelinta. ${ }^{77}$

Granö nautti pienen yliopiston vapaamuotoisuudesta ja rauhallisesta henkisestä ilmapiiristä. Luonnontieteellisen tiedekunnan professorit, kemisti M. H. Palomaa, eläintieteilijä Walter M. Linnaniemi, matemaatikko Kalle Väisälä, fyysikko Yrjö Väisälä ja kasvitieteilijä Harry Waris muodostivat Granölle läheisen ystäväpiirin, jossa kanssakäyminen oli läheistä ja jatkui myös yliopiston ulkopuolella perheenjäsenten kesken. ${ }^{778}$

Pientä luonnontieteilijäjoukkoa yhdistivät suomenmielinen aatteellisuus ja pyrkimys kehittää Turun yliopistoa niukoista voimavaroista huolimatta. Pyöreän pöydän ääressä pidetyt tiedekunnan kokoukset sujuivat leppoisasti ja rakentavasti, ja yhdessäoloa tiivisti päivittäin kokoontunut kahviklubi. Humanistisessa tiedekunnassa ei ollut vastaavaa henkeä, minkä vuoksi sitä kaivannut historian professori Einar W. Juva (vuoteen 1935 Juvelius) hakeutui usein seuraan. Kun vierailu oli toistunut riittävän monesti, alettiin hyväntahtoisesti puhua "lisätystä luonnontieteellisestä tiedekunnasta".779

Granö saavutti tiedekunnan kokouksissa niin keskeisen aseman, että siitä aiheutui myöhemmin paineita hänen seuraajakseen 1945 Helsingistä tulleelle Leo Aariolle, joka peri myös hänen paikkansa kokouspöydässä. Kun keskustelun jälkeen ryhdyttiin sorvaamaan päätöstä kaikkien katseet kääntyivät kuin itsestään Aarioon, tiedekunta kun oli tottunut kuulemaan siltä paikalta päätösesityksen. ${ }^{80}$ 
Myönteisistä kokemuksista huolimatta Granö mietti 1930-luvun vaihteessa vakavasti paluuta pääkaupunkiin. Helsingin yliopistossa haettiin sekä maantieteen vaihtuvan että kiinteän professuurin haltijaa, ja hän olisi vaikutusvaltaisten tukijoidensa ansiosta todennäköisesti saanut jommankumman viran. Houkuttelijoihin kuului muun muassa kasvitieteen professori Kaarlo Linkola, joka kirjoitti Granölle 5.11.1929:

Nyt kun maantieteen täkäläisen professorinviran hakuaika on päättymäisillään, rohkenen kääntyä puoleesi ilmoittaakseni omasta ja monien muiden hartaista toiveista saada Sinun hakupaperisi tänne Helsinkiin. Tiedän, että virka Sinun käsissäsi tulisi hoidetuksi tavalla, joka olisi erikoisen suureksi siunaukseksi tieteelle ja opetukselle. Muista nyt mahdollisista käsistä ei ole läheskään yhtä hyviä takeita. ${ }^{781}$

Granön olisi siis tarvinnut vain ilmoittaa suostumuksensa, mutta hän päätti pysyä Turussa. Asiaan vaikuttivat monet syyt, joista ehkä tärkeimmät liittyivät hänen haluunsa keskittyä tutkimustyöhön ja välttää Helsingissä odotettavissa olevia työkiireitä ja arvovalta- ja henkilöristiriitoja. Sen verran tarkkaan hän oli kuitenkin muuttoa harkinnut, että oli ehtinyt pohtia vuoden 1929 alussa seuraavaa ongelmaa:

Jos siirtymisestäni päkaupunkiin tulisi tosi, olisikohan minun pidettävä uudelleen virkaanastujaisesitelmä ja juhlallisesti astuttava konsistorin ovien sisäpuolelle, vai voitaisiinko kaikki muodollisuudet sivuuttaa? Tuntuisi puolittain koomilliselta nousta uudelleen juhlasalin kateederiin vasta leivottuna tai oikeammin leivottavana. ${ }^{782}$

Kun Granö ei ottanut osaa viranhakuihin, Helsingin professuurit menivät Väinö Auerille ja Väinö Tannerille. Erityisesti suotutkijana ansioitunut Auer nimitettiin 
1929 Iivari Leiviskän kanssa käydyn kovan kilpailun jälkeen Granöltä vapautuneen vaihtuvan professuurin haltijaksi, ja pääasiassa kvartäärigeologiaa mutta myös alue- ja ihmismaantiedettä tutkinut Tanner sai Rosbergin jäätyä eläkkeelle 1931 maantieteen vakinaisen professuurin. Nyt molemmat virat olivat pätevien ja tuotteliaiden tutkijoiden hallussa. ${ }^{783}$

Granön tavoite välttyä yliopistopolitikoinnilta ja -hallinnolta jäämällä Turkuun epäonnistui surkeasti. Tämä johtui siitä, että Turun yliopisto joutui 1920-luvun lopulla kriisiin, joka haittasi pahoin sen kehittämistoimia ja uhkasi lopulta lakkauttaa sen kokonaan.

Kriisin taustalla oli kielitieteilijän ja poliitikon E. N. Setälän valinta Turun yliopiston kansleriksi helmikuussa 1926. Hän oli kuulunut yliopiston perustajiin, mutta sitten monet vastuulliset tehtävät olivat vieneet hänen aikansa niin, ettei hän ollut ehtinyt paneutua yliopiston kehitykseen. Tilanne jatkui samanlaisena myös ensimmäisinä kanslerivuosina 1927-29, jolloin hän oleskeli pääosin ulkomailla toimiessaan Suomen lähettiläänä Kööpenhaminassa ja Budapestissa. ${ }^{74}$

Setälä oli jo alusta alkaen suhtautunut varauksellisesti yksityisen yliopiston mahdollisuuksiin kilpailla maan parhaista kyvyistä valtion voimakasta tukea nauttivan Helsingin yliopiston kanssa. 1920-luvun lopulla yliopisto oli lähes 90 varsinaisella professuurillaan suurempi kuin Suomen kaikki muut yliopistot ja korkeakoulut yhteensä. Seuraavaksi suurin oli Teknillinen korkeakoulu, jossa oli 28 professoria. Turun yliopistoista Åbo Akademissa oli 25 ja Turun Yliopistossa 15 professuuria. Helsingin Kauppakorkeakoulussa oli kuusi professoria. ${ }^{785}$

Ennakkoasenne saattoi olla syynä siihen, että Setälä odotti Turun yliopistolta nopeita tieteellisiä näyttöjä, vaikka yleinen sääntö oli, että uudelta yliopistolta meni useita vuosia, tai jopa vuosikymmeniä, oman tieteellisen tutkimustradition kehittämiseen. Kun tieteellisiä läpimurtoja ei oitis tullut, Turun Suomalainen Yliopisto alkoi näyttää Setälän silmissä lähinnä mitättömältä kandidaattileipomolta, jonka ainoa mahdollisuus selkeään tasonnostoon olisi ollut täydellinen keskittyminen korkeatasoiseen tutkimustyöhön. ${ }^{786}$ 


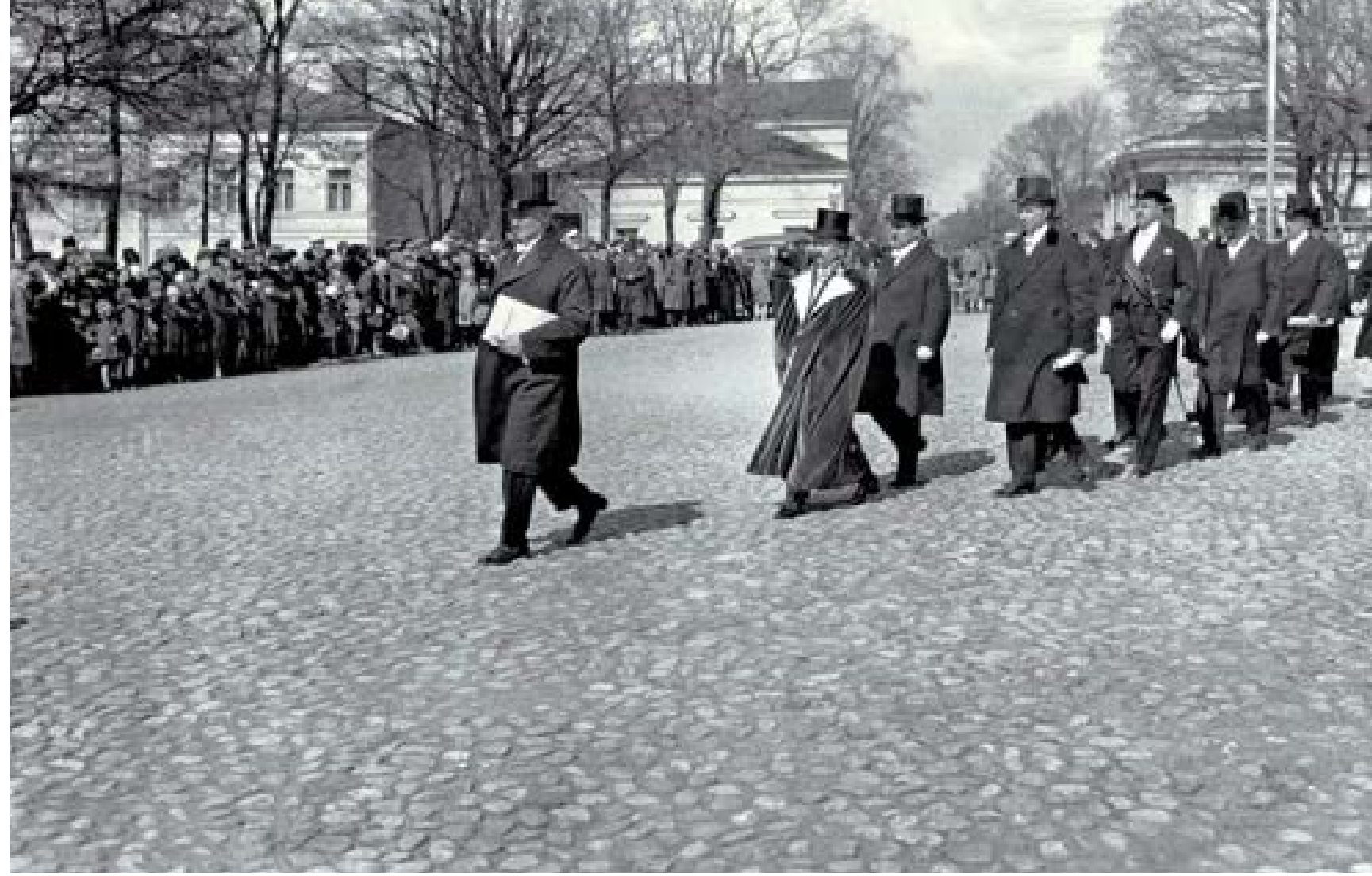

Turun Suomalaisen Yliopiston ensimmäinen promootio järjestettiin 12.5.1927. Promootioväki marssi kansleri E. N. Setälän ja rehtori V. A. Koskenniemen johdolla kulkueena yliopiston päärakennukseksi hankitusta Phoenix-hotellista tuomiokirkkoon.

Yliopiston tilanne huononi edelleen 1920-luvun lopulla, jolloin alkanut yleismaailmallinen talouspula lopetti uusien lahjoitusten tulon ja laski jo kertyneiden varojen tuottoa. Kun yliopiston oli pakko keskeyttää kaikki kehittämissuunnitelmansa ja ryhtyä harkitsemaan jo aloitetun toiminnan supistamista, Setälä esitti julkisuudessa epäilyksen, tarvittiinko yliopistoa enää.

Ylimmän edusmiehen jyrkkä lausunto sai valtaosan yliopiston professoreista nousemaan vastarintaan. Yhden voimakkaimmista puheenvuoroista käytti J. G. Granö, joka tuomitsi Suomen Kartaston 1925 julkistamistilaisuudessa 22. maaliskuuta 1929 
ankarasti Setälän väitteen Turun yliopiston tarpeettomuudesta. Hänen mielestään yliopiston oli jatkettava entiseen tapaan toimintaansa kahteen tiedekuntaan jakaantuneena opinahjona. ${ }^{787}$

Setälä ei perääntynyt, sillä hän oli päättänyt yhdistää Turun yliopiston toiminnan supistamisen ja 1929 perustamansa suomen kielen ja sen sukukielten tutkimiseen keskittyneen Suomen suku -tutkimuslaitoksen kehittämisen. Tutkimuslaitos sai toimintansa käynnistämiseen valtion ja yksityistä rahoitusta, mutta siitä tuli käytännössä Setälän yksityinen instituutti, jonka päätavoitteena oli suomen kielen etymologisen sanakirjan laatiminen. ${ }^{788}$

Setälä pyrki uutterasti vahvistamaan instituuttinsa asemaa yliopistoon nähden. Jo syksyllä 1930 hän tiedusteli kaikilta professoreilta, millä edellytyksillä heidän laitoksensa saataisiin täyskelpoisiksi opetus- ja tutkimuslaitoksiksi. Toivomuslistat saatuaan hän tulkitsi niitä omiin tarkoitusperiinsä soveltuvalla tavalla. Hänen mukaansa oli käynyt selväksi, ettei yliopisto voinut jatkaa entiseen tapaan opetuksen ja tutkimuksen alalla vaan sen voimavaroja oli suunnattava erityisesti Suomen suku -tutkimuslaitoksen tukemiseen. ${ }^{789}$

Setälän toiminta sai aluksi erityisesti humanistisen tiedekunnan piirissä niin paljon kannatusta, että hänen toimikauttaan pidennettiin keväällä 1931. Vähitellen tyytymättömyys häntä kohtaan lisääntyi, ja kansleria alettiin syyttää vallanhimosta ja pyrkimyksestä supistaa yliopiston toimintaa. Rehtori V. A. Koskenniemen johtama yliopiston hallitus pyrki selviytymään vaikeasta taloudellisesta tilanteesta supistamalla toiminnallisia määrärahoja ja pidättymällä kaikista uusista viroista ja hankinnoista. ${ }^{700}$

Kanslerin yritys vahvistaa tutkimuslaitoksensa asemaa kiristi yliopiston johdon välit äärimmilleen. Tilanteen laukaisemiseksi Setälä ja Koskenniemi laativat kanslerin luottomiesten J. E. Salomaan ja Uno Harvan välityksellä herrasmiessopimuksen, joka voitiin tulkita siten, että molemmat olisivat eronneet tietyn ajan kuluessa. Koskenniemi lähettikin kanslerille vuoden 1931 lopulla kirjeen, jossa hän anoi eroa tehtävästään rehtorina. Setälä hyväksyi eronpyynnön oitis, mutta jäi itse tyynesti 


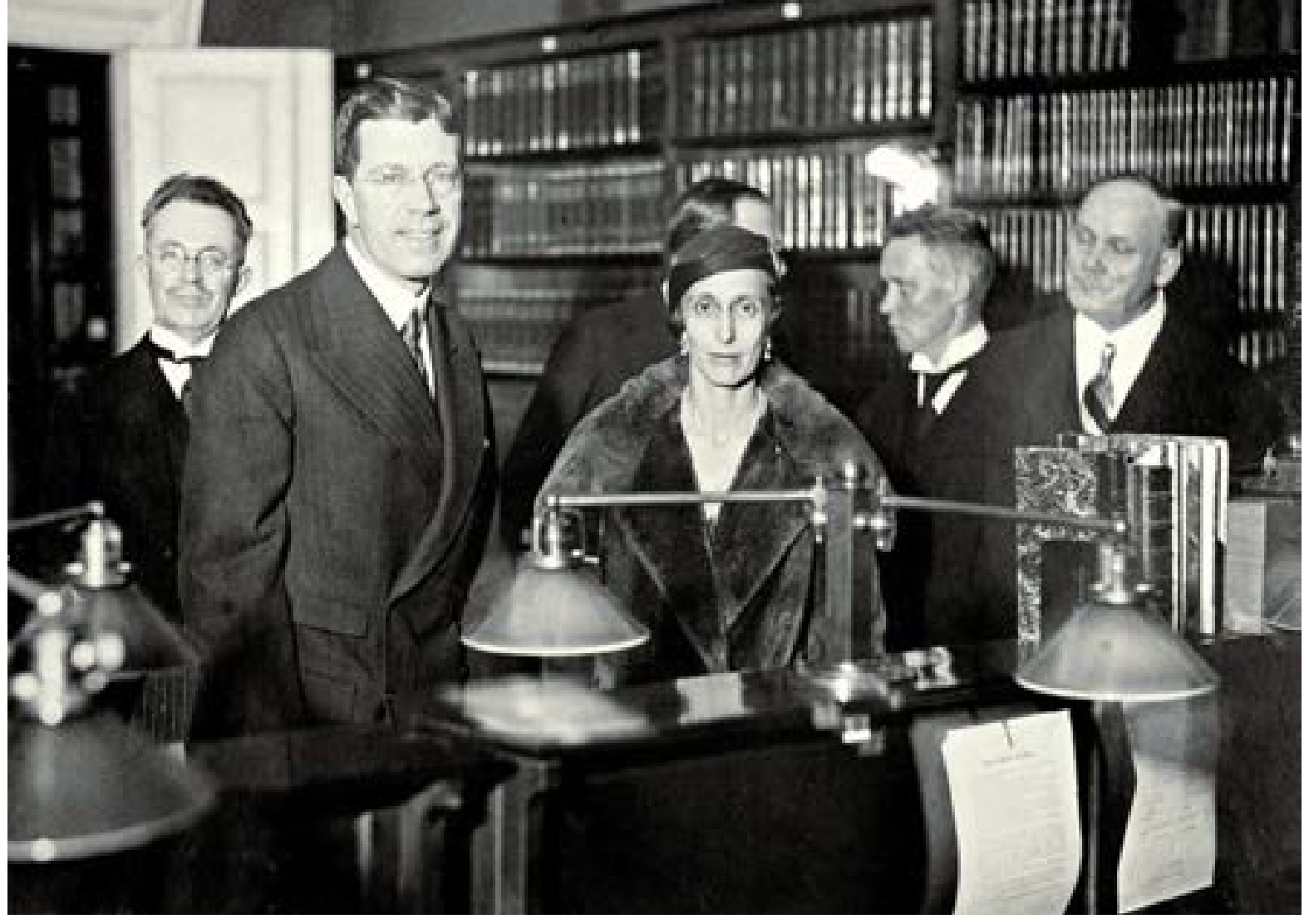

Ruotsin kruununprinssipari vieraili Turun Yliopistossa 6.12.1932. Yliopiston kirjastossa vasemmalta yliopiston rehtori J. G. Granö, Ruotsin kruununprinssi Kustaa Aadolf, professori Emil Öhmann, prinsessa Louise, Turun tuomiorovasti Einar Candolin ja yliopiston kansleri E. N. Setälä.

paikalleen aikomattakaan erota. Yllättävä käänne sydämistytti Koskenniemen ohella vararehtori Kalle Väisälää niin paljon, että hän katsoi Koskenniemen kantaa edustaneena velvollisuudekseen erota tehtävästään. ${ }^{791}$

Setälän suunnitelmia vastustavat professorit olivat nyt tilanteessa, että heidän oli nopeasti löydettävä rehtoriksi mies, joka kykeni asettumaan vastustamaan voimakastahtoista ja keinoja kaihtamatonta kansleria. Katseet kääntyivät J. G. Granöhön, joka oli saavuttanut arvostetun aseman professorien keskuudessa ja kuului yliopiston hallitukseen. Hän oli jo paljastanut, mitä hän ajatteli Setälän suunnitelmista ja oli 
lisäksi osoittanut yliopiston hallintoon liittyvissä kysymyksissä tulevansa ainakin muodollisesti toimeen kaikkien kanssa ja kykenevänsä säilyttämään viileän harkintakykynsä tilanteessa kuin tilanteessa. ${ }^{792}$

Granö torjui aluksi tiukasti professorien suunnitelmat ilmoittamalla yksikantaan, ettei hänestä ole hallintomieheksi. Hän oli tullut Turkuun voidakseen keskittyä tutkimukseen ja opetukseen, ja tämä päätös piti edelleen. Hilma-puoliso tuki lujasti miestään, sillä hän tiesi, minkälaisiin paineisiin tämä hallintotehtävissä velvollisuudentunnossaan joutuisi. ${ }^{73}$

Mikään ei kuitenkaan auttanut, sillä professorikollegio esitti vetoomuksen, joka asetti Granön lähes yhtä mahdottomaan tilanteeseen kuin Kyösti Kallio Risto Rytin talvisodan sytyttyä 1939: "Joka ei vaarallisessa tilanteessa suorita velvollisuuttaan sillä paikalla, johon hänet katsotaan sopivaksi, on moraalisesti rintamakarkuri." ${ }^{794}$

Granö oli saman liiton miehiä kuin Ryti, eikä enää vastustellut. Tammikuisena iltana 1932 ylioppilaiden soihtukulkue saapui Kristiinankadulle tervehtimään uutta rehtoria jätettyään sitä ennen jäähyväiset vanhalle rehtorille Koskenniemelle. Granö kiitti ylioppilaita muun muassa seuraavin sanoin: "Olkaa vakuutetut siitä, että uudella rehtorillanne on oleva yksi pyrkimys kaiken muun yläpuolella: sen kansallisen yliopiston palveleminen, jonka Suomen kansan rakkaus on pystyttänyt tänne Auran rannoille."795

\section{Puolustustaistelu kansleria vastaan}

Granö joutui yliopiston johtoon vaikeana ajankohtana. Taloudellinen tilanne aiheutti yhä suurta huolta pula-ajan otteen kiristyessä, ja kansleri Setälä kehitti jatkuvasti uusia suunnitelmia yliopiston toiminnan supistamiseksi. Hän sanoi suoraan, että Suomi ei tarvinnut toista yliopistoa Helsingin yliopiston rinnalle.

Granö päätti kuitenkin taistella itsenäisen Turun Suomalaisen Yliopiston puolesta. Hän lähetti Setälälle toukokuussa 1932 sairasvuoteeltaan kirjeen, jossa hän 


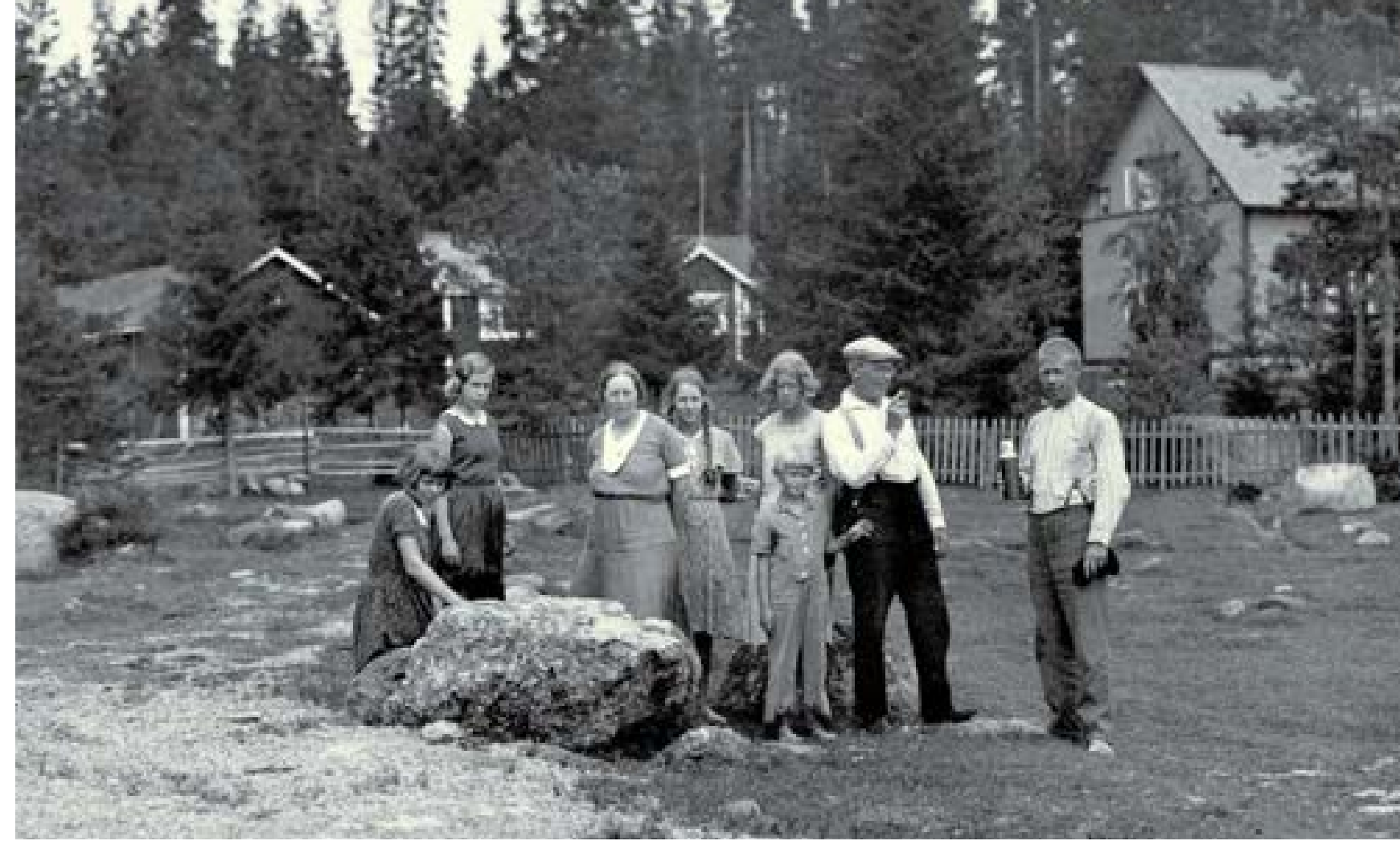

Fyysikko Yrjö Väisälä kävi kesällä 1933 tyttärensä kanssa Turusta aloittamansa purjehdusmatkan aikana tapamassa Granön perhettä Porvoon saaristossa. Seurue asettui ryhmäkuvaan Tirmon huvilan rannalle. Oikealta Yrjö Väisälä, J. G. Granö, Marja Väisälä ja Aune, Hilma, Siine sekä Eeva Granö. Isän vieressä Olavi Granö, joka oli syntynyt perheen kuopuksena toukokuussa 1925.

syytti tätä petturuudesta, kun ei ollut eronnut lupauksensa mukaisesti. Setälä sivuutti kuitenkin syytöksen ylimielisesti:

Olen suuresti pahoillani siitä, että olet joutunut vaivautumaan kirjeen kirjoittamiseen tautivuoteelta. Puhumatta siitä, että kylmä harkinta kuumeisessa tilassa pettää, on mielenliikutus sellaisessa tilassa terveydelle vaarallista. Varmaan et olisikaan terveenä miehenä käynyt käsiksi asiaan, jossa aloite kaiken lain ja kohtuuden mukaan on oleva minun. ${ }^{796}$ 
Granö ei jättänyt asiaa tähän. Avatessaan rehtorina yliopiston yhdennentoista lukuvuoden 5. syyskuuta 1932 hän ilmoitti, ettei taloudellisten huolten tullut lannistaa luottamusta opinahjon tulevaisuuteen. Hän uskoi, että Suomen kansan tuki tuli kantamaan sen vaikeiden aikojen yli. ${ }^{797}$

Hengen nostatuksen ohella Granö keskittyi sekä yliopiston hallinnon kehittämiseen että erityisesti sen rahoituksen turvaamiseen, sillä Turun yliopistossa rehtori oli myös laitoksen tärkein talousviranomainen. Yliopiston itsenäisyyden puolustaminen jäi pitkälti Granön vastuulle, sillä vararehtoriksi valitun suomen ja sen sukukielten professorin Niilo Ikolan asema kielitieteilijänä oli vaikea Setälän ja luonnontieteilijöiden välissä.

Vuoden tiiviin työurakan jälkeen Granö katsoi, että hän oli täyttänyt velvollisuutensa ja pyysi eroa rehtorin toimesta vuoden 1933 alusta lukien. Hän esitti syyksi mahdottomuuden hoitaa kauemmin yhtä aikaa sekä rehtorin että professorin tehtäviä, mutta tärkeimpänä syynä olivat ristiriidat Setälän kanssa. Tämä myönsi hänelle eron, vaikka valittikin asiaa todeten, että Granö oli hoitanut rehtorin tehtävät "aivan erinomaisella taidolla". ${ }^{798}$

Ratkaisu ei kuitenkaan vapauttanut Granötä hankalasta tehtävästä, sillä yliopiston järjestysmuodon mukaan rehtori voitiin pyynnöstään huolimatta valita uudelleen, jos hän ei ollut vielä toiminut rehtorina kolmea vuotta. Yliopiston professorit valitsivat hänet uudelleen rehtorikauden jäljellä olevaksi ajaksi ja vielä seuraavaksi kolmivuotiskaudeksi. ${ }^{799}$

Näin Granö joutui ottamaan etulinjassa vastaan Setälän uuden rynnistyksen, jonka lähtölaukauksena oli kanslerin rehtorille huhtikuun lopulla 1933 lähettämä kirjelmä. Siinä suositettiin "kandidaattileipomon" lakkauttamista tai ainakin voimakasta supistamista Helsingin suuren valtionyliopiston hallitsevan aseman ja taloudellisten vaikeuksien vuoksi. Operaatio olisi paras toteuttaa siten, että tietyn siirtymäajan jälkeen liian kalliiksi osoittautunut luonnontieteellinen tiedekunta lakkautettaisiin ja humanistinen tiedekunta muutettaisiin tutkimuslaitoksiksi tai yhdeksi tieteelliseksi instituutiksi, jolla ei olisi opetustehtäviä. ${ }^{800}$ 


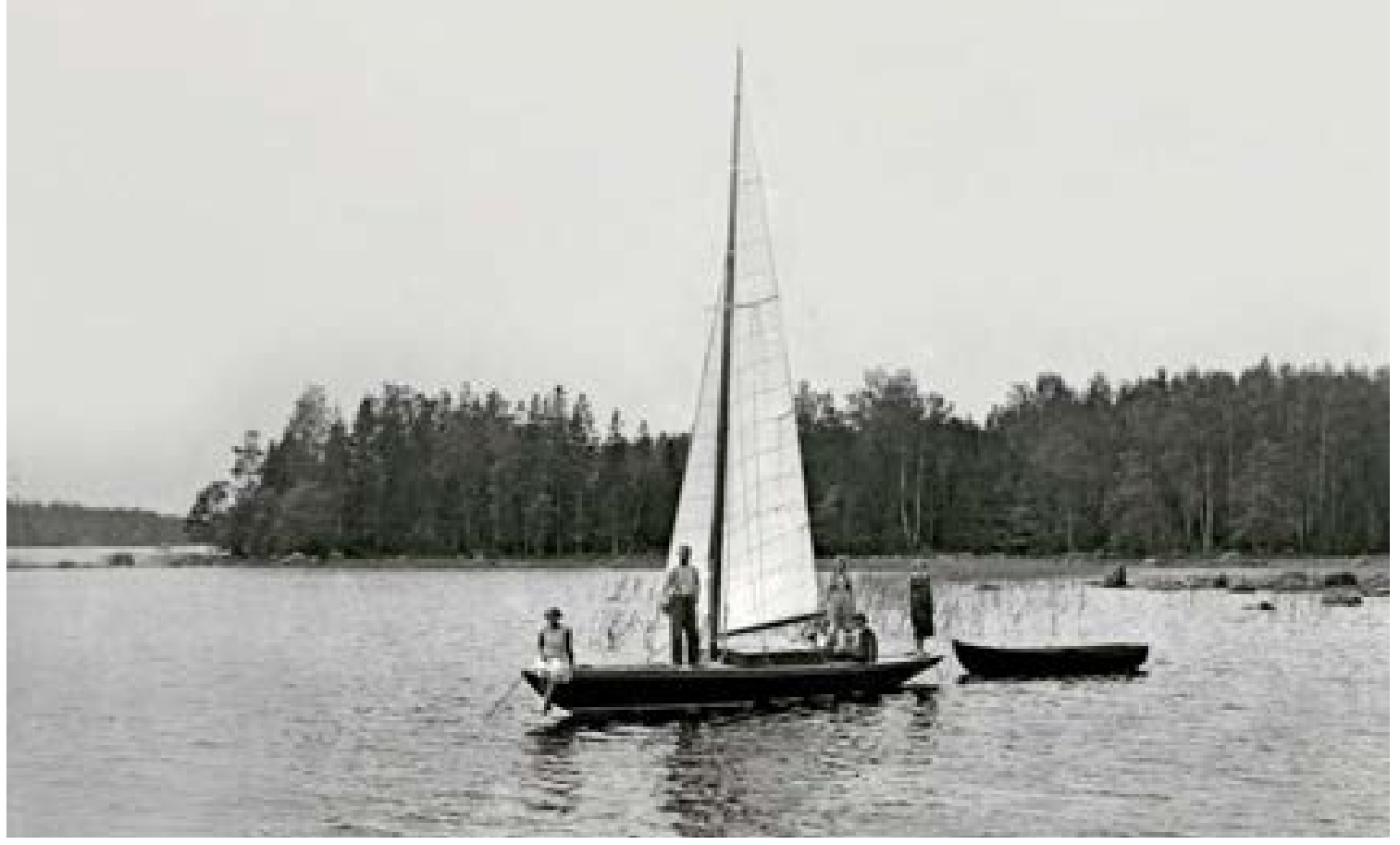

Yrjö Väisälän hai-vene Mira Tirmon edustalla 1933.

Kysymys ei ollut salaisesta manööveristä, sillä ilmeisesti Setälä itse toimitti kirjelmän Aika-lehden välityksellä julkisuuteen. Asiasta nousi suuri kohu, sillä harvoin oli kuultu tapauksesta, jossa kansleri ei pitänyt omaa yliopistoaan minkään arvoisena vaan vaati sen lopettamista. Sanomalehti Uusi Aura julkaisi asiasta pitkän artikkelin ”Turun Yliopisto oudon hyökkäyksen kohteena”, jossa tuettiin yliopiston itsenäisyyttä. ${ }^{801}$

Granön johtama hallitus oli päättänyt aluksi olla välittämättä Setälän kirjelmästä, mutta asian tultua julkisuuteen sen oli pakko ottaa siihen kantaa. Osa professoreista katsoi, että kanslerin olisi tullut erota tehtävästään, mutta hallitus päätti toimittaa julkisuuteen vain oman vastineensa. Sen mukaan yliopiston rakennetta ei tullut muuttaa, sillä sen talous oli kestävällä pohjalla. Lisäksi kirjelmässä moitittiin Setälää virheellisten ja harhaanjohtavien tietojen levittämisestä. ${ }^{802}$

Granö ilmaisi oman kantansa asiaan lukuvuoden 1933-34 avajaispuheessaan. Palautettuaan kuulijoiden mieleen Setälän esityksen Turun Yliopiston muuttamisesta 
tutkimuslaitoksiksi Granö osoitti kohta kohdalta tämän perustelut virheellisiksi sekä Suomen että Turun kannalta. Hänen mukaansa valtakunnan koko sivistyselämää ei tullut keskittää pääkaupunkiin, sillä maakuntakeskukset saattoivat monipuolistaa ja rikastaa sitä huomattavasti. Ja vaikka Turun Yliopiston säteily ei ollut koko valtakunnassa yhtä voimakasta kuin Helsingin yliopiston, se oli kuitenkin "sitä lämpimämpää omalla alueellaan”. ${ }^{803}$

Samalla Granö kiteytti jälleen kerran käsityksensä yliopiston tehtävästä:

\begin{abstract}
Niin suuria eroavaisuuksia kuin onkin eri maiden ja eri aikojen yliopistojen välillä, on niillä yhteisenä leiman antavana piirteenä kahtaalle suuntautuva toiminta, tieteellinen tutkimus ja opetus. Yliopistojen kahtaalle tähtäävästä toiminnasta johtuu, että niiden saavutuksia arvioitaessa on otettava huomioon myös opetus- ja kasvatustoiminta. Kansallisen sivistyksen kannalta on tämä työ ehkäpä tieteellistä tutkimustoimintaa tärkeämpi. Ei riitä, että yliopiston opettajat ovat kykeneviä tiedemiehiä, tuotteliaita spesialisteja, on tärkeätä, että yliopistossa on monipuolisesti valistuneita persoonallisuuksia, jotka kykenevät esittämään tieteen saavutuksia laajemmiltakin aloilta, opettajia, joilla on avarampaa synteettistä tajua, eikä vain analyytikon syventyneisyyttä ahtaaseen erikoisalaan, opettajia, jotka ovat kosketuksissa elävän elämän kanssa ja joille ne toimialat eivät ole vieraita, joille ylioppilaista useimmat tulevat antautumaan... ${ }^{804}$
\end{abstract}

Granön voimakas puhe herätti suurta huomiota. Setälän tukijat hermostuivat kanslerin suorasukaisesta arvostelusta niin paljon, että jopa eräät rehtorin ystävät katsoivat, että tilanteen rauhoittamiseksi hänen olisi pitänyt vetäytyä syrjään. Suurin osa yliopiston opettajista ja opiskelijoista asettui kuitenkin samalla kannalle kuin puhetta Granölle lähetetyssä sähkösanomassa ylistäneet yliopiston merkkimiesten lesket Jenny Danielson-Kalmari, Helmi Virkkunen, Ilta Ojansuu ja Katri Lehtonen sekä Turun Ylioppilaslehden toimittaja, joka kaunopuheisesti kuvaili sen merkitystä: 
Ja voimme olla vakuutettuja, että tämä puhe on vakuuttanut sekä kuulijansa että lukijansakin. Se on taittanut kärjen mahdollisilta takana puhumisilta, se on kuin uudelleen koonnut yliopiston ystävät yliopistonsa ympärille, ja tämä kaikki merkitsee myös velvoitusta yliopiston kasvateille, opiskelijoille. Uskomme, että rehtorin vakuuttavat sanat ovat merkinneet heillekin tulevaisuudenuskoa ja tulevaisuudentahtoa. ${ }^{805}$

Granö pyrki parantamaan Turun yliopiston asemaa neuvottelemalla muun muassa Kansallis-Osake-Pankin pääjohtajan J. K. Paasikiven kanssa, mutta talousongelmat eivät hellittäneet. Kovat paineet saattoivat osaltaan vaikuttaa siihen, että Granön terveys heikkeni vuoden 1934 alussa niin paljon, että hän joutui vuoteenomaksi. Kun sairaus ei hellittänyt, hän joutui olemaan virkavapaalla suurimman osan kevätlukukautta. Vaikean ajan synkeyttä lisäsi Granön Alma-äidin kuolema Helsingin liepeillä Oulunkylän pappilassa, jossa hän oli asunut viimeiset elinvuotensa Paavo-poikansa luona.

Vararehtori Niilo Ikola oli päättänyt jo syksyllä palata entiseen virkaansa Turun kauppaopiston rehtoriksi, joten hänen tehtävänsä tammikuussa 1934 perinyt Granön ystävä Einar W. Juva sai kantaa päävastuun Turun yliopiston pelastamisesta. Hän otti tehtävän vastaan, vaikka se merkitsi lupaavasti alkaneen oman tieteellisen uran uhraamista. Hänellä olisi ollut hyvät mahdollisuudet saada Helsingin yliopiston Suomen ja Skandinavian historian professuuri, mutta hän veti hakemuksensa pois. ${ }^{806}$

Granölle myönnettiin ero rehtorin toimesta syyskuun alusta 1934 alkaen. Hän osallistui kuitenkin seuraajansa Juvan kanssa Setälän vastaiseen kamppailuun, jonka tuloksena muun muassa yliopiston taloudenhoito siirtyi Kansallis-Osake-Pankilta sen varta vasten palkatulle omalle taloudenhoitajalle Toivo Lehtikunnaalle. Juva onnistui myös saamaan turkulaisilta yliopiston ystäviltä varat lukuvuoden välittömän vajauksen kattamiseen ja luomaan suunnitelman valtakunnallisen kansalaiskeräyksen järjestämisestä yliopiston toiminnan tukemiseksi. ${ }^{807}$

Kun yliopiston johto ei taipunut kanslerin edessä, tämä kiristi otettaan. Setälä kieltäytyi vahvistamasta vuoden 1934-35 talousarviota kiinnittäen huomiota erityi- 
sesti siihen, että eräitä professorinvirkoja oli jätetty täyttämättä, että muutamat professorit huolehtivat myös muiden kuin omien oppiaineidensa virkatehtävistä ja että päätoimisen taloudenhoitajan virka oli perustettu vastoin kanslerin tahtoa.

Osa Setälän huomautuksista oli aiheellisia, mutta osin ne kertoivat myös siitä, kuinka tiukasti hän ajoi omia tarkoitusperiään. Hän ei edes pyrkinyt ymmärtämään, että monet Granön ja Juvan johdolla tehdyistä ratkaisuista olivat luonteeltaan kompromisseja, joihin oli jouduttu niukkojen taloudellisten olojen synnyttämästä pakosta. ${ }^{808}$

Talousarviosta ja muista kiistakysymyksistä päästiin sopuun syksyllä 1934, mutta tilanne pysyi vaikeana koko loppuvuoden Setälän asettauduttua vastustamaan Juvan Turun yliopiston pelastamiseksi suunnittelemaa kansalaiskeräystä. Tämä päätti tällöin sivuuttaa Setälän kokonaan ja ryhtyä kokoamaan tiedemaailman avainhenkilöitä uuden rahankeräyksen ydinryhmäksi. Joukkoon tulivat muun muassa Helsingin yliopiston kansleri Hugo Suolahti, ylipormestari Antti Tulenheimo ja kansainvälisesti ansioitunut kemisti Gustaf Komppa, joka kuului Suomalaisen Tiedeakatemian perustajiin ja oli toiminut Turun yliopiston sijaiskanslerina 1928-29. ${ }^{809}$

Operaation toteutuminen varmistui dramaattisesti helmikuun 8. päivän iltana 1935, jolloin kiistan osapuolet olivat kokoontuneet toisistaan tietämättä Helsingin keskustaan. Setälän illastaessa uppsalalaisen emeritusprofessorin J. A. Lundellin kanssa yksityisesti ravintola Seurahuoneella Juvan hotelli Kämpiin kutsumat pääkaupungin kulttuuri- ja talouselämän vaikuttajat lupasivat turvata Turun Suomalaisen Yliopiston toiminnan jatkuvuuden.

Ratkaisusta täysin tietämätön Setälä oli viihtynyt niin hyvin vanhan ystävänsä kanssa, että oli jättänyt tapansa mukaan lähdön kotimatkalle Järvenpään Toimelaan aivan viime tinkaan. Kipeine jalkoineen viimeiset sadat metrit puolijuoksua konkaten hän ehti juuri ja juuri Rautatieasemalla jo lähdössä olleeseen junaan ja lysähti huokaisten penkilleen. Kovien työpaineiden rasittama sydän ei kestänyt äkillistä ponnistusta, ja vanha professori menehtyi sydänhalvaukseen jo ennen Ristinummen seisaketta. Setälän viimeinen matka kotiin Toimelaan taittui lopulta liina silmillä tilan pehtorin ohjaaman hevosen kyydissä. ${ }^{810}$ 
Setälän kuolema päätti Turun Suomalaisen Yliopiston historian pahimman kriisin. Uudeksi kansleriksi valittu Gustaf Komppa ja rehtori Juva kykenivät talousongelmista huolimatta vähitellen vakiinnuttamaan yliopiston toiminnan vuoteen 1945 mennessä, jolloin molemmat luopuivat tehtävistään. ${ }^{811}$ 


\section{GUTKIMUSTYYö JATKUUU}

\section{Salaperäinen sairaus}

Granön terveys oli ollut koko elämän ajan hyvä, kunnes hän sairastui vuoden 1934 vaihteessa vakavasti. Hänen vatsaansa ilmaantui outo punainen läiskä, joka paisui pian isoksi pahkuraksi. Turkulaiset lääkärit kokoontuivat perhelääkärin johdolla hänen vuoteensa ääreen oikein miehissä pohtimaan, mistä oli kysymys. Kun luotettavaa diagnoosia ei kyetty tekemään, Granö passitettiin tammikuun lopulla jatkotutkimuksiin Helsinkiin Mehiläisen sairaalaan. ${ }^{812}$

Mehiläisessä Granö pääsi opiskelutoverinsa professori A. J. Palménin, historian professori E. G. Palménin pojan, potilaaksi. Palmén päätteli, että kysymys oli todennäköisesti sädesienestä. Bakteerin aiheuttaman taudin äkillinen puhkeaminen saattoi liittyä siihen henkisen stressiin, johon Granö oli ajautunut yliopiston kanslerin E. N. Setälän kanssa syntyneen arvovaltakiistan vuoksi. ${ }^{813}$

Koska kysymys oli ilmeisesti sädesienestä, Palmén päätti, ettei pahkuraa saanut leikata, vaan sitä oli hoidettava voimakkaan röntgen- ja ultralyhytaaltokäsittelyn avulla. Todennäköisesti Granön hengen pelastaneen diagnoosin oikeellisuus varmistui vuoden 1952 alussa, jolloin professori Väinö Seiro totesi syöpäleikkauksen yhteydessä kysymyksessä olleen sädesienen. ${ }^{814}$

Palattuaan takaisin Turkuun Granö siirtyi lääketieteen tohtori A. K. Vuoren potilaaksi. Koska sädesieneen ei vielä ollut mitään tehokasta lääkitystä, pahkuraa ryhdyttiin hoitamaan monitaitoisen J. K. V. Tuomisen rakentamalla jodihoito-laitteella, jonka synnyttämällä radioaktiivisella jodilla pyrittiin hillitsemään tulehdusta. Hoitomenetelmä oli Suomessa uusi, minkä vuoksi Vuori ja Granö hankkivat siitä tietoa Saksasta erään hammaslääkärin välityksellä. Menetelmän ymmärrettiin voivan aiheuttaa syöpää, mutta se päätettiin ottaa käyttöön, koska sairaus oli vakava ja potilas oli yli 50 -vuotias. ${ }^{815}$ 


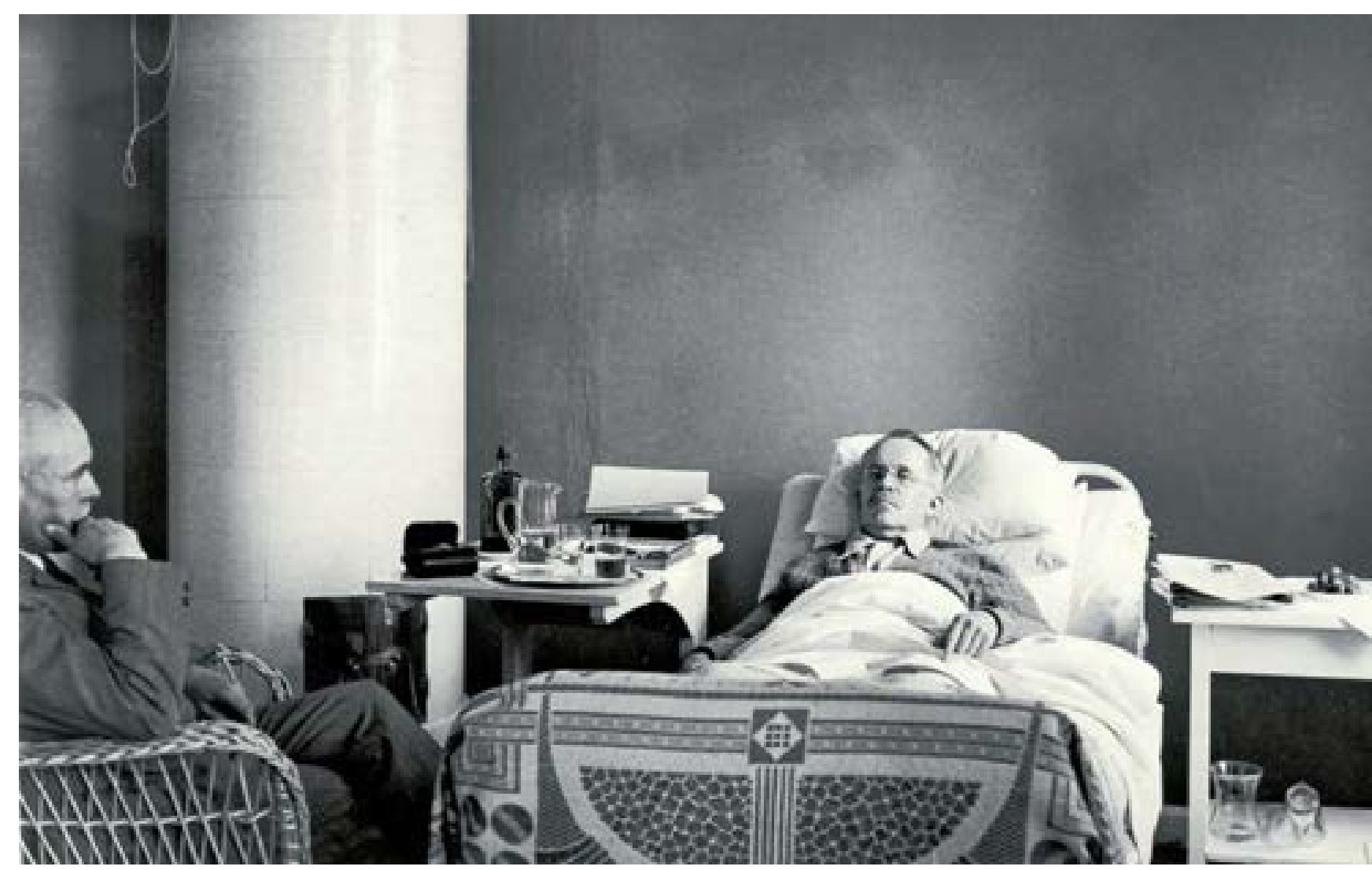

Granö oli osan kevätlukukautta 1936 vuoteeseen "kahlehdittuna"

Turun kunnallissairaalan sisätautiosastolla. Assistentti J. K. V. Tuominen

kävi lähes päivittäin katsomassa esimiestään ja ystäväänsä.

Sädesienen paraneminen tapahtui hitaasti. Aina välillä tauti tuntui hellittävän, mutta sitten Granön "belsebubiksi", vanhaksi "pääpahaksi" ja "kehnoksi” nimittämä pahkura äityi jälleen pahaksi, kipeytyi ja alkoi märkiä. Esimerkiksi kesällä 1936 hän lähetti J. K. V. Tuomiselle seuraavan tilannetiedotuksen: 
Parempaan päin on näihin asti oltu menossa. Yleisvointi jatkuvasti hyvä, lämpö hyvin konstantti... Sille "kehnolle" on syötetty iooneja, Hilma "konemestarina”. Kaikki käynyt hyvin; koje jatkuvasti moitteettomassa kunnossa... ”Kehno" on tällä haavaa hyvin mitättömän näköinen, mutta märkää näkyy riittävän. ${ }^{816}$

Tilannetta pahensi se, että joko itse tauti tai sitten sen kovat parannuskeinot synnyttivät pahan nivelreuman, joka vei ajoittain Granön täysin vuodepotilaaksi ja jopa sairaalaan. Pahimmat vaiheet olivat talvet 1935-36 ja 1936-37, jolloin hän joutui olemaan suurimman aikaa vuoteenomana. Potilaan pitkiin sairauspäiviin toivat pääosin vaihtelua vain lääkärin, sairaanhoitajien, hierojien ja muun lääkintähenkilökunnan käynnit. ${ }^{817}$

Perheenjäsenten ja sukulaisten lisäksi Granö päästi vuoteensa viereen pääasiassa vain lähimmät ystävänsä ja työtoverinsa J. K. V. Tuomisen ja A. K. Merisuon, mutta myös opiskelijat saattoivat tarvittaessa käydä hänen puheillaan. Tuominen pistäytyi lähes päivittäin kyselemässä potilaan vointia ja samalla hoituivat myös maantieteen laitoksen toimintaan liittyvät tehtävät. Granö kykeni hoitamaan luentotehtävät syyslukukautta 1936 lukuun ottamatta. Filosofian maisteri Merisuo oli Granön entinen oppilas ja luottokartanpiirtäjä, joka kävi usein kysymässä neuvoja ja esittelemässä uusimpia töitään. ${ }^{818}$

Granön haluttomuus ottaa vieraita vastaan oli yleisesti tiedossa, ja sitä myös kunnioitettiin. Yksi poikkeus vahvisti säännön. Kerran eräs tuntematon henkilö sivuutti tyynesti Olavi Granön estely-yritykset Kristiinankadun kodin ulko-ovella toteamalla yksikantaan, että potilas ei kai nyt niin sairas ole, ettei voisi ottaa vastaan kaukaa Helsingistä tullutta vierasta.

Olavi ponkaisi salamana ilmoittamaan isälleen tuntemattomasta tunkeilijasta, jolloin potilas vain virkkoi, että kyseessä oli varmaankin Hellaakoski, sillä hän oli nähnyt sanomalehdestä, että runoilijalla oli lausuntatilaisuus Turussa. Samassa vieras jo astui makuuhuoneeseen jäyhäilmeisenä ja mykän pelottavana kuin Pääsiäissaaren kivimies, istuutui muitta mutkitta sängynreunalle ja alkoi Olavin hämmästykseksi vilkkaan ja ystävällisen keskustelun Granön kanssa. ${ }^{819}$ 
Mies oli maantieteilijä ja runoilija Aaro Hellaakoski, joka oli seurannut isänsä A. R. Helaakosken esimerkkiä ja valinnut maantieteen pääaineekseen. Hellaakosken väitöskirja Puulan järviryhmän kehityshistoriasta oli hyväksytty 1928, vaikka vastaväittäjä Iivari Leiviskä oli tehnyt parhaansa nostaakseen esiin kaikki sen virheet ja heikkoudet. Moiteryöppy oli saanut muutenkin helposti kuohahtavan Hellaakosken menettämään malttinsa niin tyystin, että hän oli alkanut julkeasti sättiä Leiviskää, joka onnistui tyyneydellään nipin napin pelastamaan väitöstilaisuuden täydeltä katastrofilta. ${ }^{820}$

Helsingin yliopiston maantieteen dosenttina 1930-45 toiminut Hellaakoski ja Granö tulivat hyvin toimeen keskenään, sillä Leiviskän-vastaisuuden lisäksi miehiä yhdisti tietojen systemaattiseen keräämiseen, käsittelyyn ja luokitteluun perustunut tutkimustapa ja käsitys maantieteestä analyyttisenä tieteenä. Helsingin tyttönormaalikoulun pitkäaikaisena yliopettajana toiminut Hellaakoski - oppilaiden kesken vain Koukku - vaati myös maantiedon kouluopetukselle Granön tapaan tieteellistä runkoa, jottei jouduttaisi "epäjärjestykseen ja hämmennykseen" ja jottei luokkahuone muuttuisi Granön sanoin " 'juttutuvaksi', missä kerrotaan maista ja kansoista, mitä milloinkin mieleen juolahtaa." ${ }^{21}$

Kesällä 1937 tauti helpotti sen verran, että Granö päätti lääkärin kanssa neuvoteltuaan luopua jodi-hoidosta ja lääkkeistä. "Belsebubi” antoi aina silloin tällöin merkkejä olemassa olostaan ja liikkumiskyky oli heikentynyt pysyvästi, mutta potilas päätti, että vaivojen kanssa oli vain opittava elämään. Ratkaisua auttoi se, että Granö saattoi jälleen harjoittaa lempipuuhaansa kalastusta kuin "vanhaan hyvään aikaan”. Jo heinäkuun loppuun mennessä saaliiksi oli kertynyt lähes 50 haukea ja satoja ahvenia. ${ }^{822}$

Granön tervehtyminen sattui sopivaan saumaan, sillä Suomen Maantieteellinen Seura oli juuri valmistautumassa 50-vuotisjuhliinsa tammikuun 22. päivänä 1938. Granö oli valittu hyvissä ajoissa seuran puheenjohtajaksi, sillä juhlavuonna tehtävään tarvittiin arvovaltaista ja maineikasta tutkijaa. Tieteellisillä seuroilla oli 1930-luvulla suuri merkitys Suomen tieteen kehittämisessä ja etujen valvojana. Maantieteellisen Seuran rooli oli erityisen suuri, sillä se oli osallistunut tiiviissä yhteistyössä valtio- 
vallan kanssa Suomen aseman tunnetuksi tekemiseen niin autonomian ajan lopulla kuin itsenäisyyden ajan alkuvuosikymmeninä. ${ }^{823}$

Juhlista tuli komea tilaisuus, jota kunnioitti läsnäololla koko Suomen valtio- ja kulttuurielämän kerma. Seuran läheisiä yhteyksiä valtakunnan ylimpään johtoon kuvasti se, että paikalla olivat presidentti Kyösti Kallio, sotamarsalkka Gustaf Mannerheim, eduskunnan puhemies Väinö Hakkila, pääministeri A. K. Cajander, ulkoasiainministeri Rudolf Holsti ja opetusministeri Uuno Hannula yhdessä diplomaattikunnan sekä korkeakoulujen ja valtion tutkimuslaitosten edustajien kanssa. Hilma Granö istui eturivissä presidenttiparin ja sotamarsalkka Mannerheimin kanssa.

Avattuaan tilaisuuden sujuvasti suomen-, ranskan-, ruotsin-, saksan- ja vironkielillä pitämällään tervehdyspuheella Granö käsitteli pääpuheessaan sekä maantieteen yleistä historiaa Strabonista ja Ptolemaioksesta Carl Ritteriin ja Alexander von Humboldtiin että alan tutkimuksen juurtumista Suomeen. Hänen mukaansa 1921 syntynyt uusi Suomen Maantieteellinen Seura oli osoitus siitä, että yleismaantieteellinen ja aluemaantieteellinen linja nivoutuivat hyvin yhteen. Hän päätti puheensa seuraaviin sanoihin, jotka korostivat seuraan vaakunaan kaiverrettujen sanojen, Viribus unitis, yhteisin voimin, merkitystä:

\footnotetext{
Tieteen perusolemukseen kuuluu jatkuva kehitys. Myös maantieteessä on uusia näköaloja avautuva, uusia menetelmiä tullaan kehittämään. Tässä herkeämättömässä kehityksessä kuvastuva totuuden etsiminen tuo mukanaan myös taistelua, taistelua siksi, että näemme vain puolittain, että yksityisen tutkijan kyky parhaimmillaankin on vähäinen ja inhimillisten heikkouksien rajoittama. Mutta yhteistyössä täydentävät yksilöiden sellaisinaan pienet saavutukset toisiaan ja tieteen kirkas totuus vapautuu häiritsevästä kuonasta. ${ }^{824}$
}

Pääjuhlan jälkeen järjestetyillä illallisilla puhunut opetusministeri Uuno Hannula mainitsi heti aluksi, että hänen oli kiittäminen Granötä siitä, että oli yleensä lähtenyt opintielle. Asuessaan Alatorniossa mäkitupalaisen poikana hänen alkeisopetukses- 
taan oli vastannut lukiolainen Kaapo Granö. Hannula totesi muistavansa vieläkin hyvin, kuinka elävästi tuleva Suomen Maantieteellisen Seuran puheenjohtaja oli opettanut hänelle ilmansuuntia pappilan avarassa salissa. Tällöin Hilma Granön vieressä istunut Mannerheim huudahti spontaanisti kuuluvalla äänellä, "Bravo!"825

\section{Paluu Keski-Aasian aineistoihin}

Granö olisi halunnut ryhtyä muokkaamaan Altain tutkimusmatkoiltaan kokoamaansa aineistoa heti palattuaan Siperiasta Suomeen vuoden 1916 lopulla. Tieteellisen tutkimuksen asema oli maassa kuitenkin niin huono, ettei edes huippututkijalle löytynyt tehtävää, joka olisi mahdollistanut keskittymisen tutkimustyöhön. Perheensä toimeentulon varmistaakseen Granö joutui keskittymään aluksi erilaisiin tilapäistöihin ja vuodesta 1919 alkaen maantieteen professuurin hoitoon ensin Tartossa, sitten Helsingissä ja Turussa. Kun hän lisäksi katsoi velvollisuudekseen luoda maantieteelle itsenäisen oppirakennelman, hän joutui sysäämään syrjään ne työt, jotka olisivat loppujen lopuksi ehkä kiinnostaneet häntä eniten.

Julkaistuaan Pubtaan maantieteen Granö alkoi vähitellen kallistua sille kannalle, että hänen olisi syytä luopua maisematieteen teorian kehittämisestä. Kaarlo Linkolalle vuoden 1930 lopulla lähettämässään kirjeessä hän totesi:

Olen vihdoin päässyt tieteellisessä askartelussani niin pitkälle, että voin palata Altain aineksien ääreen - aivan anteeksiantamattoman pitkän tauon jälkeen. Viron puuhat, Suomen maantiede, metoodiset kysymykset ovat vieneet kuluneen vuosikymmenen, ja Altain maantiede ja geologia ovat saaneet odottaa. Nyt aion pyytää osittaista virkavapautta kevätlukukaudeksi, ja toivon voivani jo joululoman aikana ryhtyä käsittelemään vanhaa, rakasta työmaatani. ${ }^{826}$

Granö jatkoi vielä muutaman vuoden teoreettista työtään, kunnes hän joutui 1934 peruuttamaan osallistumisensa Varsovan maantieteilijäkongressiin. Tuolloin hän 


\section{A.GEOGR. 6, N:o 1 ULĀN-DABĀ - KOBBDOFLUS}

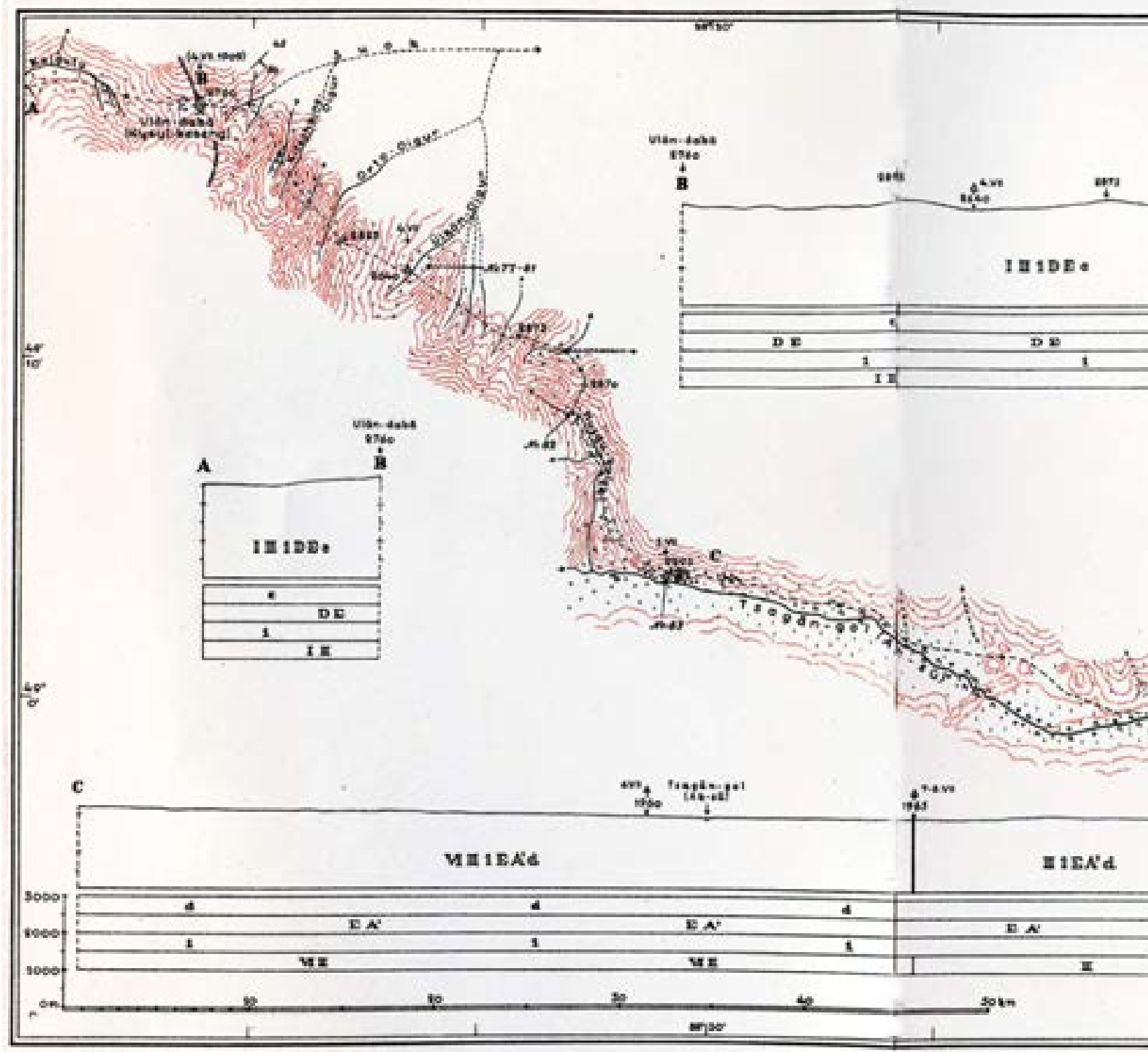

400 VI TURUN SUOMALAISEN YLIOPISTON PROFESSORI 


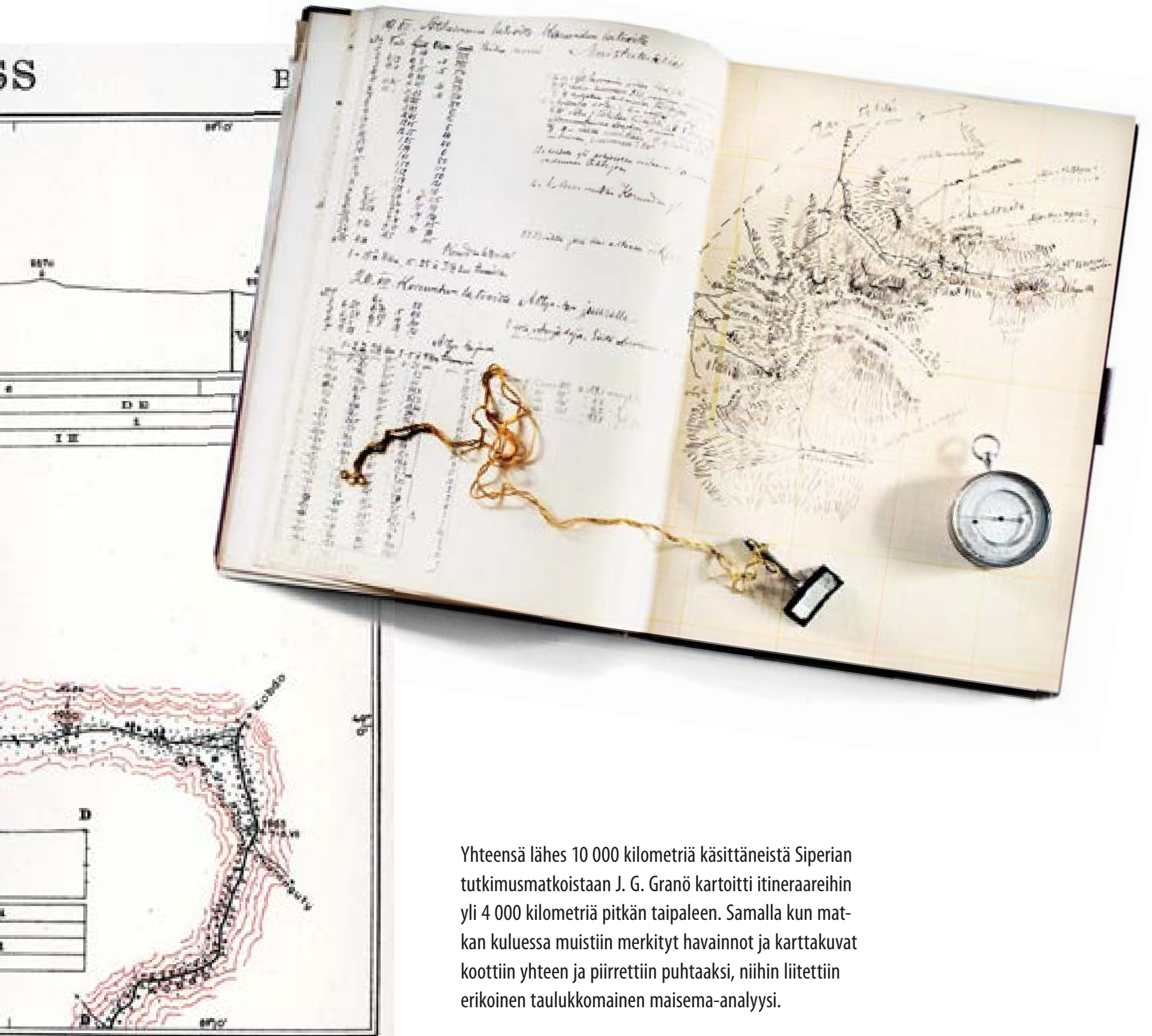

Tutкimustyö jatkuU V| 401 
Sairauden osoittauduttua pitkäaikaiseksi Granö keskittyi suunnittelu- ja tarkastustehtäviin ja antoi kartaston puhtaaksi piirtämisen Merisuon tehtäväksi. Samalla hän päätti, että koko aineistoa ei käsitellä mutta että karttoihin lisätään maisemaprofiilit, joihin merkittiin ikään kuin pystyleikkauksena maanpinnan ja veden muodot, kasvillisuus ja ihmisasumukset. Näin Granö yhdisti perinteiseen itineraariin oman maisemakuvausmetodinsa, joka perustui luonnon- ja kulttuurimaiseman määräävien näkyvien piirteiden huomioon ottamiseen. Hän itse piti maisemaprofiilimenetelmän kehittämistä yhtenä uransa merkittävimmistä saavutuksista. ${ }^{828}$

Hilma Granön saatua alkuperäiskartat järjestykseen työ eteni nopeasti vuodesta 1936 alkaen. Merisuo piirsi taitavasti karttoja ja profiileja puhtaaksi, ja Granö tarkasti työn jokaisen yksityiskohdan. Vuonna 1938 ilmestyneen Itinerarien und Landschaftsprofile J. G. Granös aus Uranchai (Tannu-Tuwa) und der Nordmongolei -teoksen kuvaamien reittien yhteispituus oli 4400 kilometriä. ${ }^{829}$

Granö arvosti Merisuon taitoja niin paljon, että järjesti tämän piirtämään Turussa puhtaaksi Mannerheimin alkuperäiset matkakartat tämän Aasian-ratsastusretkeä 1906-08 kuvaavaan englanninkieliseen teokseen Across Asia from West to East. Järjestely oli mahdollista siksi, että teoksen toimitussihteerinä toiminut Kaarlo Hildén luotti täysin vanhan opettajansa vakuutukseen Merisuon taidoista. ${ }^{830}$

Granö oli suunnitellut itineraarin Mongolian aluemaantiedettä kuvaavan teoksen karttaosaksi, joten hän aloitti nyt tämän teoksen kirjoittamisen. Hän tunsi alueen hyvin tutkimusmatkojensa ansiosta, mutta oli myös jatkuvasti kartuttanut tietojaan uusien tutkimusten avulla. Monipuolinen Mongolian-tuntemus oli tullut esiin Granön kevälllä 1935 pitämästä radioesitelmässä, jonka alku osoitti hänen erinomaiset havainnollistajan taitonsa:

Keski-Aasia, maapallon laajin ja korkein ylämaa, on kuin suunnaton linnoitus, jota reunavuoristot moniosaisina muureina ympäröivät. Korkeimmalle linnoituksen muurit ja pihamaa kohoavat etelässä. Täällä aukeaa, Himalaijan jättiläisseinämän takana, neljäntuhannen metrin korkeudella, linnoituksen sisäpiha, 

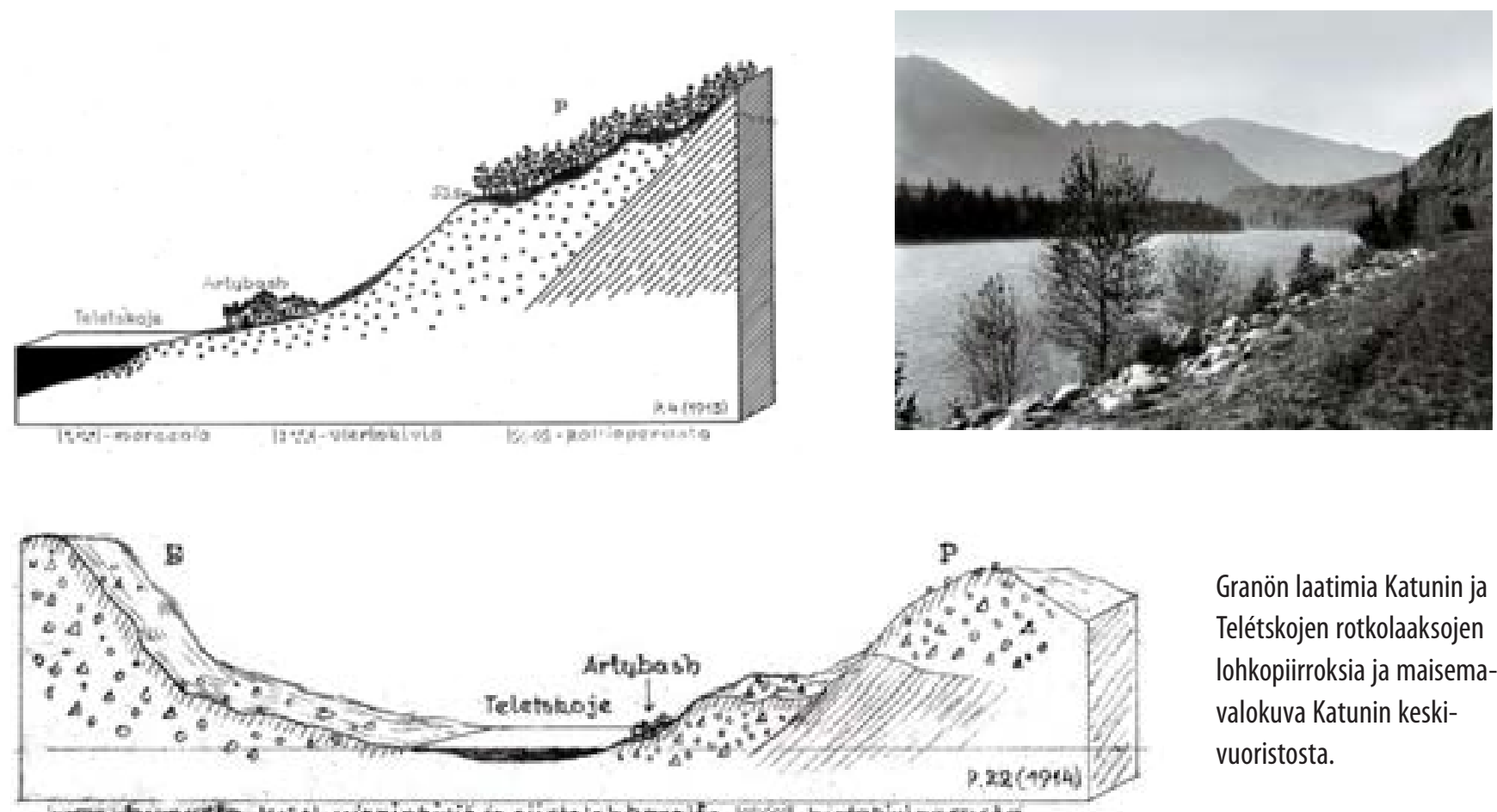

Granön laatimia Katunin ja Telétskojen rotkolaaksojen lohkopiirroksia ja maisemavalokuva Katunin keskivuoristosta.

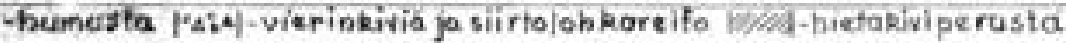

Tibet. Pohjoisempana, pari kolme tuhatta metriä alempana, seuraa avarampi ulkopiha, lähes Euroopan Venäjän kokoinen alue, jonka muodostavat Itä-Turkestan ja Mongolia. Tämä viimeksi mainittu maa jakaantuu puolestaan kahteen osaan, nimittäin eteläisempään Sisä-Mongoliaan, jonka rajana varsinaista Kiinaa vastaan on tunnettu Kiinan muuri, ja pohjoisempaan Ulko-Mongoliaan. ${ }^{831}$

Esitelmä sai niin suuren suosion, että Granö julkaisi sen pohjalta Terrassa 1939 artikkelin Ulko-Mongolia. Päätarmonsa hän suuntasi kuitenkin Mongoliaa kuvaavan moniosaisen teossarjan julkaisemiseen. Työ eteni hitaasti, sillä eri syistä kirjoittamismotivaatio oli kadoksissa. Lopulta sota sotki suunnitelmat niin, että alkuperäissuunnitelman mukaisesta neliosaisesta teoksesta valmistui vain johdannoksi tarkoitettu ensimmäinen osa. ${ }^{832}$ 


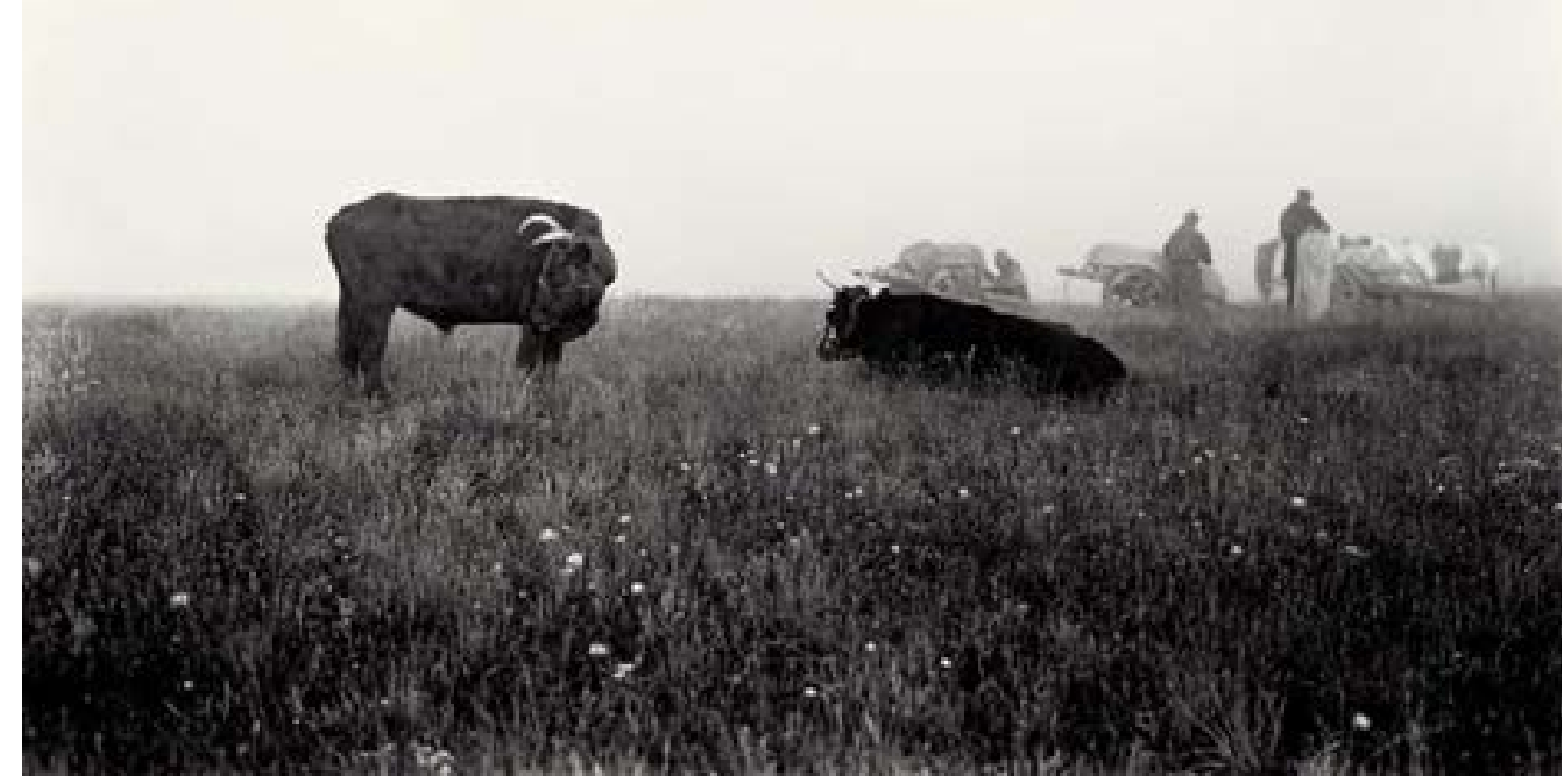

Mongolialainen maisema: Syksyllä 1909 Granö kuvasi härkien kuormaamista aamun sarastaessa Botogonjoen varrella Hangaivuorten maastossa.

Vuoden 1941 lopulla ilmestynyt Mongolische Landschaften und Örtlichkeiten kuului samaan sarjaan kuin Viron ja Suomen aluejakoja hahmottavat teokset. Teos antaa tietoja Mongoliaa käsittelevistä lähdeteoksista, esittelee sen maantieteelliset ja maisemalliset pääpiirteet ja kuvaa lopuksi sen jakautumista 29 erilaiseen maantieteelliseen alueeseen. Edgar Kantin mukaan teos "on samalla kertaa monipuolinen ja esikuvallinen Mongoliaa kuvaava aluemonografia, joka ottaa huomioon kaiken sitä aiemmin käsitelleen”. ${ }^{833}$ 


\section{Suur-Suomi-kysymys ja tutkijan rooli}

Maantiede kytkeytyi 1900-luvun vaihteessa kiinteästi Suomen kansalliseen ja valtiolliseen kehitykseen. Maantieteilijöiden isänmaallista työtä johti Suomen Maantieteellinen Seura, jonka yhtenä keskeisenä tavoitteena oli Suomen luonnollisen alueen - siis myös Kuolan niemimaan sekä Vienan ja Aunuksen Karjalan - kaikinpuolinen tutkimus. ${ }^{834}$

Suomen itsenäistyminen ei päättänyt luonnontieteellisiä haaveiluja Suur-Suomesta. Pyrkimys itärajan siirtämiseen tuli esiin muun muassa maantieteellisesti suuntautuneen historiantutkijan Väinö Voionmaan 1919 julkaisemassa teoksessa Suomen uusi asema, jossa pohdittiin laajasti "Suur-Suomen" luonnetta ja sen luonnontieteellistä perustaa. Kirjoittaja totesi ruotsalaiseen geopolitiikka-käsitteen luojaan Rudolf Kjélleniin vedoten, miten "Suomi ilman Venäjän Karjalaa ja Kuollan niemimaata on kuin leipä ilman kantaa". ${ }^{835}$

Vaikka elokuussa 1920 solmittu Tarton rauhansopimus lopetti viralliset vaatimukset Itä-Karjalan liittämisestä Suomeen, Suur-Suomen-aatteen kannattajia löytyi edelleen niin armeijan kuin sivistyneistön ja tiedemiesten piirissä. Tätä osoittaa, että ruotsiksi 1920 käännetty Theodor Homénin toimittama Itä-Karjala ja Kuollan Lappi julkaistiin seuraavana vuonna myös englanniksi nimellä East Carelia and Kola Lapmark. Saksan ajauduttua antautumisensa jälkeen sekasortoon englanninkielisen teoksen avulla pyrittiin viemään kansainvälisen tiedeyhteisön piiriin perusteluita, jotka oikeuttaisivat Suomen saamaan Kuolan niemimaan, Itä-Karjalan ja osan Jäämeren rannikosta. ${ }^{836}$

Hyvä valmius itärajan uuteen määrittelyyn nousi esiin huhtikuussa 1941, jolloin presidentti Risto Ryti pyysi Väinö Aueria laatimaan tutkimuksen, jonka avulla voitaisiin esittää tieteellisiä perusteita Suomen alueen laajentamiselle. Tavoite oli kahta- 
lainen. Tutkimuksen tuli osoittaa, että Itä-Karjala ja Kuola kuuluivat historiallisesti ja maantieteellisesti Suomelle, mutta samalla sen oli todistettava, että alueet eivät kuulunut millekään muulle maalle, eivät ainakaan Saksalle tai Norjalle. ${ }^{837}$

Toukokuun puolivälissä hankkeeseen kytkettiin mukaan tunnettu historiantutkija Eino Jutikkala, ja kirjoitustyö päätettiin aloittaa kesäkuun lopulla. Nopeasti muuttunut sotilaallinen tilanne johti kuitenkin siihen, että maan poliittinen johto katsoi välttämättömäksi saada kaipaamiaan perusteluja jo aiemmin. Siksi presidentti Ryti pyysi historioitsija Jalmari Jaakkolaa kirjoittamaan pikaisesti esityksen Suomen itärajaan liittyvistä ongelmista ja kokoamaan samalla yhteen asiaan liittyvän tieteellisen aineiston. Sitä tarvittiin Saksan ja Suomen välisiin neuvotteluihin, jotka koskivat rajajärjestelyjä voittoisan sodan jälkeen. ${ }^{838}$

Jaakkola pestasi avukseen muutamia AKS:n johtomiehiä, joiden tuella hän saattoi alkukesästä julkaista suppeahkon teoksen Suomen idänkysymys. Se ilmestyi ensin heinäkuussa 1941 saksaksi nimellä Die Ostfrage Finnlands, ja myöhemmin myös ruotsiksi, ranskaksi ja englanniksi. Teoksessa tuotiin korostetusti esille Itä-Karjalaan liittyvät taloudelliset mahdollisuudet ja korostettiin, että alueliitoksen avulla voimistunut Suomi voisi muodostaa aiempaa tehokkaamman turvan itää vastaan. ${ }^{839}$

Samaa asiaa todisti myös Auerin ja Jutikkalan loppusyksystä 1941 ilmestynyt tutkimus Finnlands Lebensraum. Teos perusteli laajojen itäisten alueiden liittämistä Suomeen muun muassa sillä, että Suomella ennen vuotta 1940 ollut itäraja "ei ollut sen paremmin maantieteellisesti luonnollinen, väestöllisesti asianmukainen, taloudellisesti mielekäs kuin Euroopan puolustuksen kannalta strategisesti edullinen..." ${ }^{\prime 80}$

Jaakkolan, Auerin ja Jutikkalan teokset ohjasivat tieteellistä valloitusretkeä, johon maantieteilijät osallistuivat historioitsijoiden, kasvi- ja eläintieteilijöiden sekä monien muiden tieteenalojen edustajien tapaan. Suomen Maantieteellisen Seuran esityksestä opetusministeriö perusti syksyllä 1941 erityisen Valtion tieteellisen Itä-Karjalan toimikunnan, jonka tehtävänä oli löytää poliitikoille todisteita Suomen ja Itä-Karjalan läheisestä yhteydestä. Seura oli jo edellisenä vuonna kutsunut Mannerheimin ensimmäiseksi kunniajäsenekseen, ja lokakuun alussa se myönsi marsalkalle ensimmäisen 
kultaisen Fennia-mitalinsa erityisesti Aasian ratsastusmatkan tuottamista ansioista maantieteellisen tutkimuksen alalla. ${ }^{841}$

Seuran aikakauskirjan Terran vuoden 1941 viimeinen numero oli suorastaan pyhitetty Itä-Karjalalle. Julkaisun geopoliittisesti painavimpaan antiin kuuluivat presidentti Risto Rytin asiantuntijaksi "Suomen elintilakysymyksissä" nousseen Väinö Auerin artikkeli "Tuleva Suomi talousmaantieteellisenä kokonaisuutena" ja Leo Aarion aluekuvaus, joissa geopolitiikan strateginen terminologia ja organismiajattelu saavuttivat huippuunsa suomalaisen maantieteen historiassa. ${ }^{842}$

Syksyllä 1941 seuran hallitus päätti julkaista Fenniassa katsauksen, jossa kuvattiin suomalaisten osuutta Kuolan niemimaan ja Itä-Karjalan tutkimuksessa. Kahden vuoden kuluttua ilmestyneessä kirjoituksessa muun muassa Pentti Eskola, Matti Sauramo, Kaarlo Linkola, Lauri Hakulinen, A. M. Tallgren ja Erkki K. Osmonsalo valottivat suomalaisten luonnontieteilijöiden ja humanistien työtä itärajan takana. Työtä johtanut päätoimittaja Väinö Auer totesi omassa yhteenvedossaan, että paljon tutkimusta oli tehty mutta paljon oli myös tekemättä:

On ainutlaatuista maailman maantieteellisessä tutkimuksessa, että Euroopan yhden kaikkein selvimmän maantieteellisen kokonaisuuden toinen osa on jäänyt selvitystä vaille eikä ole saanut sitä käsittelyä, minkä se ominaisuuksiensa perusteella olisi vaatinut. ${ }^{843}$

Kasvimaantieteilijä ja valtion luonnonsuojeluvalvoja Reino Kalliola yltyi puolestaan Valvoja-Aika-lehdessä painottamaan, että luonnontieteellisen Suomen - ja samalla koko Fennoskandian - itäraja oli todennäköisesti jyrkin luonnonmaantieteellinen raja koko pohjoisessa Euraasiassa. Hänen mukaansa Itä-Karjalassa avautuivat Suomen ja Fennoskandian "alkuperäiset luonnonkasvot, joten sinne tulisi perustaa "Suomen Yellowstone", joka olisi ainutlaatuinen koko Euroopassa. ${ }^{844}$

Valtion tieteellinen Itä-Karjalan toimikunta alkoi vuodesta 1942 lähtien koordinoida ja tukea itäisiä alueita koskevaa tutkimusta. Se kartoitti tutkittavia kohteita 
ja värväsi halukkaita tutkijoita, joita kertyi kaikkiaan noin sata. Yksi tuen piiriin päässeistä tutkijoista oli Granön oppilas August Tammekann, joka oli siirtynyt Neuvostoliiton miehitettyä Viron Suomeen heinäkuussa 1940. Kun Tarton yliopisto peruutti syyskuussa sapattivuoden ja Tammekann kieltäytyi palaamasta Tarttoon, hän menetti työpaikkansa ja Viroon jääneen omaisuutensa. Hän sai Suomen kansalaisuuden $1941 .{ }^{845}$

Saksalaisten miehitettyä Viron he vaativat Tammekannia palaamaan maahan kartoituksen asiantuntijana, mutta tämä katsoi parhaaksi jäädä Suomeen. Hän työskenteli sotavuosina geodeettina, Suomen geologisen komission apulaisgeologina ja Werner Söderström Oy:n kartografisten töiden johtajana. Saatuaan osin Granön avulla Helsingin yliopiston dosentuurin Tammekann osoitti kiinnostustaan Itä-Karjalan tutkimukseen kirjoittamalla muun muassa helmikuussa 1942 Uuteen Suomeen historiallisen katsauksen "Euroopan itäraja. Mihin historia on piirtänyt sen lujimman jakson?”. Artikkelissa korostettiin Suomen ja Viron kohtalonyhteyttä ja merkitystä taistelussa idän hirmuvaltaa vastaan. ${ }^{846}$

Saatuaan Itä-Karjalan toimikunnalta suuren apurahan Tammekann ryhtyi kesällä 1943 suunnittelemaan kartografisen esityksen laatimista Itä-Karjalan ja muiden itärajan takaisten alueiden asutuksesta ja kansallisuussuhteista. Työ jäi pahasti kesken, sillä sotilaallisen tilanteen heikentyminen johti jo vuoden lopulla siihen, että Itä-Karjalan kehittämisen sijasta ryhdyttiin suunnittelemaan sen evakuointia. Suomalaiset vetäytyivät Syvärin varsilta kesällä 1944, ja syyskuussa solmittu Moskovan välirauhansopimus mursi haaveen "luonnonhistoriallisesta Suur-Suomesta". ${ }^{847}$

Isänmaallisena ihmisenä Granö koki talvisodan hyvin raskaasti. Hän ymmärsi, ettei Suomella ollut pienenä maana mitään mahdollisuuksia selviytyä yksin Neuvostoliittoa vastaan, joten parempi oli taipua kuin taittua. Suurvaltasuhteissa 1940 tapahtunut käänne ja Saksan hyökkäys itään, operaatio Barbarossa, kesäkuussa 1941 herättivät hänessä toiveita siitä, että Suomi voisi selviytyä hyvin uudesta sodasta. Juhannuksen alla $1941 \mathrm{~J}$. K. V. Tuomiselle lähettämässään kirjeessä hän totesi: 
Olemme siis taas joutuneet suurten tapahtumain pyörteeseen. Miehet mennä vilistivät "ylimääräisiin", ja nyt olemme vain me vanhukset kotiasioita ja kotirintamaa hoitelemassa... Katselemme kuitenkin toivorikkain mielin tulevaisuutta. Asiat taitavat kehittyä tälläkin kerralla salamavauhtia, mutta tällä kertaa hyvään päin.

Saa nyt sitten nähdä, milloin Venäjä saadaan kukistetuksi ja milloin me, viheliäiset siviilit ja hengen viljelijät, saamme palata tehtäviimme. Kyllä elämme ihmeellisiä aikoja. Suokoon Jumala, että raskaat uhrit johtavat pysyvään rauhaan. ${ }^{848}$

J. G. Granön merkittävä asema suomalaisessa maantieteessä sai julkisen tunnustuksen hänen täyttäessään 60 vuotta 14. maaliskuuta 1942. Suomen Maantieteellinen Seura valitsi hänet Mannerheimin jälkeen toiseksi kunniajäsenekseen, ja Terran vuoden kaksi ensimmäistä nidettä sisältänyt kaksoisnumero omistettiin hänelle. Vaikka hän kuului seuran hallitukseen vuoteen 1942 ja aikakauslehden toimituskuntaan vuoteen 1943 asti, hän ei osallistunut monen oppilaansa ja kollegansa tavoin Suur-Suomi-kaavailuihin ja Suomen sodanpäämäärien tieteellisen puolustamiseen. Oikeastaan ainoa esiintyminen yhteisten etujen ajajana tapahtui syksyllä 1941, jolloin hän kirjoitti Terraan arvion Mannerheimin Across Asia from West to East -teoksesta. ${ }^{849}$

Arvostelun yleissävy oli ylistävä, mutta asiallinen; huomio kohdistui itse tutkimusretkeen ja sen tuloksiin. Sotapäällikön sijasta Granö piirsi Mannerheimista kuvan tyylillisesti taitavana tutkijana, joka sopi hyvin myös Puhtaan maantieteen mannekiinin tai puolestapuhujan rooliin:

Mannerheimin matkateoksen merkitys ei kuitenkaan tieteen kannalta ole yksinomaan siinä, että erikoistutkijat ovat siitä saaneet ja saavat uutta arvokasta materiaalia puutteellisesti tunnetusta maapallon osasta. Tahtoisin väittää, että sillä on ainakin yhtä suuri arvo synteettis-maantieteellisenä aikaansaannoksena, koko ihmisen ympäristöön kohdistuvana kuvauksena, missä maisema ja siinä liikkuva, asuva ja elinkeinojaan harjoittava ihminen saavat rinnan ja oikeassa suhteessa huomiota osakseen. ${ }^{850}$

410 VI Turun suomalaisen yliopiston professori 
Granön pidättyvä asenne johtui ilmeisesti useasta syystä. Ensinnäkin hän tunsi itsensä ennen kaikkea tiedemieheksi ja halusi siksi pysyä täysin politiikan ulkopuolella. Tämän vuoksi hän oli kesällä 1920 vastannut kielteisesti J. K. Paasikiven pyyntöön ryhtyä Suomen ja Venäjän välisten rauhanneuvottelujen tulkiksi sekä torjunut 1920-luvulla pyynnön asettua kokoomuksen ehdokkaaksi eduskuntavaaleissa. Samasta syystä hän torjui maaliskuussa 1940 ehdotuksen siirtyä Tukholman lähettilään tehtävään, jota hänelle tarjottiin Paasikiven matkustettua lähettilääksi Moskovaan. ${ }^{851}$

Granö suhtautui vieroksuvasti myös akateemisessa maailmassa suosittuun aitosuomalaisuuteen, jota hän piti liian jyrkkänä. Lähinnä tämän vuoksi hän kieltäytyi marraskuussa 1923 hänelle tarjotusta Akateemisen Karjala-Seuran seniorijäsenyydestä, vaikka monet hänen arvostamistaan tutkijoista, kuten J. R. Danielson-Kalmari, Rafael Erich, Kustavi Grotenfelt, Gustaf Komppa, Carolus Lindberg, Kaarlo Linkola, Otto Manninen, Martti Rapola, Matti Sauramo ja E. N. Setälä, liittyivät seuran johtohenkilöiden Iivari Leiviskän ja Väinö Auerin tavoin yli 30 seniorijäsenen joukkoon. Granö hyväksyi AKS:n päämärän, "häpeällisesti sorrettujen heimokansojemme" kohottamisen ja vapauttamisen, mutta hänen käsityskantansa erosi eräissä keskeisissä kysymyksissä niin paljon seuran edustamasta suunnasta, että hän ei katsonut voivansa ottaa vastaan jäsenyyttä. 852

Granö oli omaksunut isältään varovaisuuden elämänasenteekseen, ja riskien karttaminen ja pragmaattisuus värittivät myös hänen suhtautumistaan Venäjän ja Neuvostoliittoon. Maltillisena konservatiivina hän vastusti kommunismia mutta kannatti K. J. Ståhlbergin edustamaa politiikkaa, jonka mukaan Tarton rauhassa saavutettua yhteisymmärrystä itänaapurin kanssa ei tullut järkyttää. Suomeen verrattuna itänaapuri oli jättiläisvaltakunta, jonka heikkous oli paikallista ja hetkellistä mutta voimavarat yhtä loputtomat kuin hänen hyvin tuntemansa Siperian arot ja metsät. ${ }^{853}$

Granö ei myöskään jakanut Suomessa yleistä venäläisiin kohdistuvaa väheksyvää tai kielteistä suhtautumista. Kun esimerkiksi historiantutkija ja huomattava poliitikko Väinö Voionmaa katsoi, että Suomen tuli saada yhteyteensä laajoja alueita idästä ja Venäjään oli suhtauduttava kuin periviholliseen, Granön kanta oli toinen. Tutki- 
musmatkavuosinaan hän oli retkeillyt "suuressa isänmaassa", ja Suomen itsenäistyttyä hän piti itänaapuria "toisena kotimaanaan". Myönteinen suhtautuminen perustui omiin kokemuksiin. Hän oli oppinut arvostamaan venäläisiä, jotka olivat muun muassa pyyteettömästi pelastaneet hänet jos ei nyt nälkäkuolemalta niin ainakin pahasta pulasta kesän 1906 veneonnettomuuden jälkeen. Tämä näkyi jo Altai-teoksessa, jossa annettu kuvaus poikkesi selvästi 1920-luvun vaihteen julkisuutta hallinneesta venäläiskielteisestä linjasta: "Urjanhaissa asuvien venäläisten ystävällisyyttä ja erinomaista avuliaisuutta on minun kiittäminen siitä, että saatoin, huolimatta onnettomuuden aiheuttamista vaikeuksista, jatkaa matkaani ja suorittaa minulle uskotut tehtävät." ${ }_{854}$

Granön kannan ehdottomuus tuli esiin kesällä 1942. Tuolloin kansanedustaja Antti Hackzell saapui tulisella kiireellä Tirmoon pyytäen, että hän matkustaisi Suomen edustajana Saksaan. Granön tehtävänä olisi ollut esitellä isännille suomalaisten käsityksiä Itä-Karjalan kansallisuuskysymyksistä ja samalla valottaa Hackzellin Saksan aseiden voittoon tukeutuvaa väestösuunnitelmaa. Sen mukaan Itä-Karjalan venäläinen väestö olisi tullut siirrättää Volgan mutkaan ja tuoda sieltä tilalle suomensukuista väestöä ikään kuin turvallisuusvyöhykkeeksi Suomen ja Venäjän väliin. Granö kieltäytyi jyrkästi tarjouksesta pitäen sitä täysin epärealistisena. Koko suunnitelma hautautui pian, kun suomalaiset alkoivat ymmärtää, ettei sota tulisi päättymään Saksan kannalta hyvin. ${ }^{855}$

Granön keskittyminen politiikan sijasta tieteellisiin kysymyksiin näkyi myös siinä, että hänen suhteensa saksalaisiin kollegoihin säilyivät sodan aikana ja sen jälkeen, samoin kuin ne säilyivät joihinkin venäläisiin tutkijoihin lokakuun vallankumouksen, Suomen itsenäistymisen ja toisen maailmansodan jälkeen. Hän suhtautui kielteisesti sekä idän että Keski-Euroopan totalitaarisiin järjestelmiin, osin siksi, että molemmat polkivat törkeästi pienten kansojen oikeuksia.

Granö otti hyvin penseästi vastaan Hitlerin hänelle 13. maaliskuuta 1943 myöntämän Saksan Kotkan ritarikunnan ensimmäisen luokan ansioristin. Korkean kunniamerkin myöntäminen johtui ilmeisesti sekä Suomen Maantieteellisen 
Seuran läheisistä yhteyksistä Saksaan että Granön korkeasta asemasta Suomen tiedehierarkiassa. ${ }^{856}$

Suursodassa vuoden vaihteessa 1943 tapahtunut käänne ei jäänyt Granöltä huomaamatta. Usko Saksan aseiden voittoon oli mennyt, ja Suomen ja maailman tulevaisuus alkoi näyttää hänen silmissään murheelliselta. Hän oli seurannut koko ajan tarkoin Viron asioita ja oli syvästi huolissaan eteläisen veljeskansan kohtalosta Neuvostoliiton ja Saksan puserruksessa.

Keväällä 1944 Granö oli yksi kahdeksasta suomalaisesta tiedemiehestä, jotka pyrkivät Viron saksalaiselle miehityshallinnolle osoittamallaan kirjelmällä estämään suunnitelman Tarton yliopiston kokoelmien evakuoimisesta Königsbergiin (nykyiseen Venäjän Kaliningradiin) Saksaan. Allekirjoittajat, Granön ohella professorit Kaarlo Blomstedt, A. R. Cederberg, V. A. Heiskanen, Lauri Kettunen, Martti Rapola, Väinö Salminen ja A. M. Tallgren, vertasivat operaatiota venäläisten vastaaviin toimiin ensimmäisen maailmansodan vuosina. ${ }^{857}$

Kirjelmä olisi todennäköisesti haudattu kaikessa hiljaisuudessa arkistojen syövereihin, mutta sen päästäminen julkisuuteen synnytti vaikean konfliktin Suomen ja Saksan välille. Huhtikuun 16. päivänä 1944 Uuden Suomen takaosassa vaatimattomasti yhdellä palstalla julkaistu mielipidekirjoitus "Viron kulttuurilaitosten evakuointi" sai saksalaiset ylimpää sotilasjohtoa myöten raivoihinsa. Syynä oli se, että lehden toimitussihteeri oli tahattomasti tai tarkoitukselle sijoittanut artikkelin viereen pikku-uutisen Suomalais-saksalaisen seuran vuosikokouksesta.

Kun tieto kirjoituksesta tuli näin kaikkien Suomen ja Saksan suhteiden vaalijoiden tietoon, sen viesti kiiri jo seuraavana päivänä Berliiniin asti. Vanhaan kulttuuri-Saksaan myönteisesti suhtautuneet professorit olivat tuskin osanneet kuvitella, minkälaisen myrskyn heidän epäpoliittiseksi tarkoitettu kirjoituksensa maan pääkaupungissa synnytti. Itse Suur-Saksan johtaja Adolf Hitler sai kirjelmän takia yhden kuuluisista raivokohtauksistaan. Häntä, Euroopan kulttuurin suojelijaa "idän raakalaisuutta" vastaan, suvaittiin syyttää keskeisten kulttuuriaarteiden ryöstämisestä. 858 


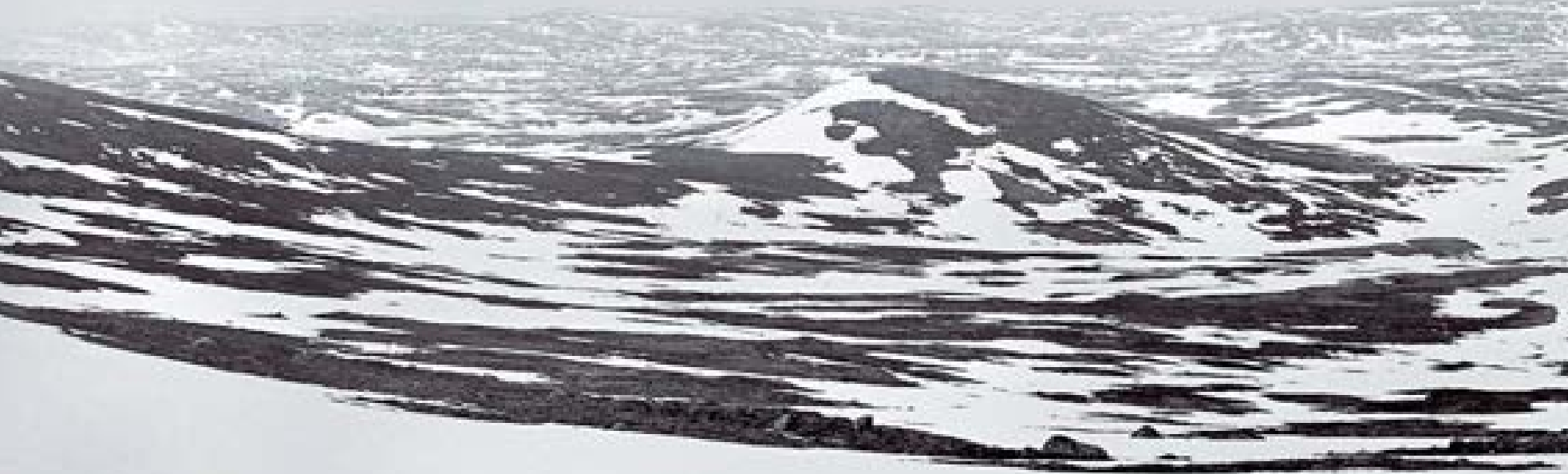




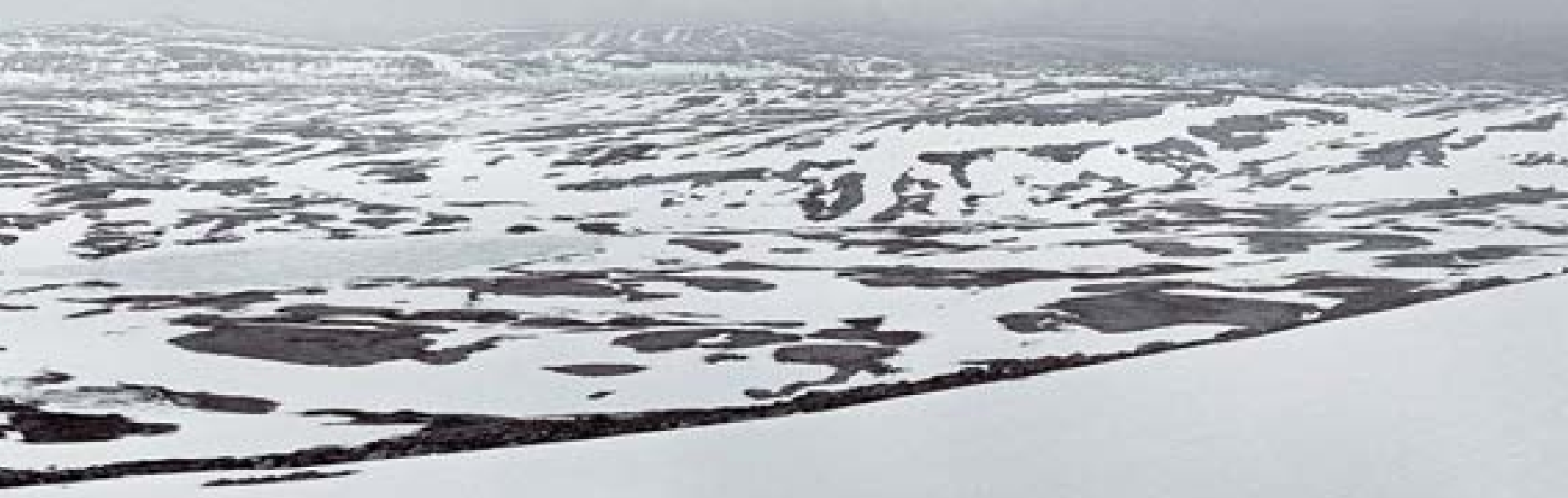

Granö kävi Petsamossa ja Jäämeren rannikolla 1924 toimiessaan kreivi Pál Telekin johtaman unkarilaisen maantieteilijäretkikunnan Suomen-vierailun tieteellisenä oppaana. Jäättömän satamansa ja rikkaiden nikkelimalmiesiintymiensä ansiosta alue kiinnosti suomalaisten lisäksi myös saksalaisia ja neuvostoliittolaisia, minkä vuoksi siitä tuli yksi toisen maailmansodan keskeisistä sotanäyttämöistä. Erkki Mikkolan valokuva 1930-luvun alkupuolelta. 
Hitler määräsi välittömästi keskeyttämään kaiken Suomeen suuntautuvan aseviennin. Kiellon ulkopuolelle jäi vain sellainen materiaali, joka katsottiin ehdottoman välttämättömäksi Suomen rintaman kestämisen kannalta. Lisäksi hän määräsi ulkoministeri Joachim von Ribbentropin ottamaan Saksan Helsingin-lähettiläältä Wipert von Blücheriltä selville yksityiskohtaisia tietoja protestista ja siitä, miten se oli päässyt sensuurin läpi julkisuuteen ilmentämään "takapajuisuuden ja typeryyden huippua, joka saattoi palvella vain Neuvostoliiton intressejä". ${ }^{859}$

Suurlähettiläs von Blücher välitti edelleen 18. huhtikuuta Hitlerin terveiset Suomen ulkoministeri Henrik Ramsaylle ja vaati tätä ryhtymään toimenpiteisiin, jotta kyseiset professorit tunnustaisivat julkisesti joutuneensa propagandan uhreiksi ja saattaisivat asian myös lehdistön tietoon. Ramsay pyrki parhaansa mukaan saamaan herrat toimimaan toivotulla tavalla, mutta hänen hyvät yrityksensä kilpistyivät "suomalaiseen paksupäisyyteen". Von Blücherin uhkailuista huolimatta professorit pysyivät tiukasti kannassaan eivätkä peruuttaneet kirjoitustaan. ${ }^{860}$

Professorien kirjelmä ei sellaisenaan ollut sen synnyttämän messun arvoinen. Saksan johto oli kuitenkin tehnyt kevään 1944 aikana selväksi suomalaisille muun muassa elintarvikekuljetukset lopettamalla, että Suomen osoittama halukkuus irrottautua aseveljeydestä ja ryhtyä neuvottelemaan rauhasta Neuvostoliiton kanssa ei voinut olla vaikuttamatta asetoimituksiin. Saattaa hyvin olla, että huonoon ajankohtaan sattunut protesti oli se kuuluisa viimeinen pisara, joka sai diktaattorin sapen kiehumaan yli äyräiden. ${ }^{861}$

Suomen puolustuksen kannalta Hitlerin raivonpuuskalla oli ikävät seuraukset. Päämajan toiveet tykistön modernisoinnista ja yhdenmukaistamisesta sekä uuden hyökkäysvaunukaluston ja muun sotamateriaalin hankkimisesta valuivat tyhjiin. Onneksi maahan oli ehtinyt saapua vajaata viikkoa ennen kirjelmän julkistamista 1700 panssarinyrkin ja 300 panssarikauhun aselasti, joka voitiin jakaa rintamamiehille kättä pitemmäksi puna-armeijan suurhyökkäyksen käynnistyttyä kesäkuun 9. päivänä. Rintamatilanteen huononnuttua nopeasti Hitler kumosi asevientikiellon kolmen päivän kuluttua, ja panssarintorjunta-aseita ryhdyttiin välittömästi toimitta- 
maan lentokoneilla ja moottoritorpedoveneillä. Samalla Saksa lopetti vihoittelunsa kahdeksan suomalaisen professorin kanssa. ${ }^{862}$

Granö oli suhtautunut tyynesti Saksan kovisteluun, sillä hän ei ollut niinkään huolissaan omasta turvallisuudestaan kuin koko Suomen kohtalosta. Kesän 1944 kiivaiden torjuntataistelujen aikana hän oli Tirmossa, jossa kauniista kesästä ei voinut nauttia, kun etäinen jylinä ja talon perustan vavahtelut kertoivat maan kohtalon olevan vaakalaudalla. Granö tunsi itsensä joutavaksi ja tarpeettomaksi tekijäksi yhteiskunnassa, kun ei voinut antaa isänmaalle mitään, millä olisi ollut siinä tilanteessa jotakin arvoa. ${ }^{863}$

Suomalaisten kyettyä torjumaan saksalaisten tuella puna-armeijan rynnistystä niin pitkään, että Stalinille tuli kiire ehtiä Berliiniin, Suomelle avautui mahdollisuus rauhaan. Maan poliittinen johto vaihtui, ja uudet miehet aloittivat aseleponeuvottelut Neuvostoliiton kanssa. Syyskuun 13. päivänä eli päivää ennen kuin Suomi aloitti rauhanneuvottelut Moskovassa, Granö purki tuntojaan J. K. V. Tuomiselle:

Niin, Veljeni, nyt voimme sanoa jo tietävämme enemmän kuin viime keväänä. Mutta sitä emme vieläkään tiedä, sitä pääasiaa, mikä on oleva muodoltaan ja resursseiltaan rauhaan astuva Suomi. Mielestäni siirryttiin mahdollisimman viisaasti uusille linjoille. Oliko sitten tämä siirtyminen yhtä tyylikästä kuin se oli järkevää, on toinen kysymys. Pelko ja vapistus mielessä odottaa tietoja Moskovasta. Kun olemme pieniä, niin olemme pieniä... ${ }^{864}$

Kun välirauhansopimus oli allekirjoitettu, valvontakomission ensimmäiset jäsenet olivat saapuneet maahan ja sota saksalaisia vastaan oli aloitettu Lapissa, Suomi oli onnistunut pääsemään eroon tuhoon ajautuvasta Saksasta ja turvaamaan valtiollisen olemassaolonsa. Tarkoin tilannetta seurannut Granö kirjoitti lokakuun 14. päivänä Oiva Tuomiselle: 
Kaksi kuukautta on siitäkin kulunut, siitä ystävällisen kirjeesi saapumisesta. Myöhäinen kiitokseni!

Paljon on sen jälkeen tapahtunut, paljon muuttunut. Kovasti on purtemme heilunut suurpolitiikan ristiaallokossa. Täyskäännös on tehty. ${ }^{865}$

Granö oli realisti parhaasta päästä. Hänen mielestään nyt ei kannattanut esittää mielipiteitä sitä, mitä suomalaiset olivat kokeneet ja mihin he joutuivat nyt sopeutumaan, vaan tärkeintä oli suunnata katseet tulevaisuuteen. Aseiden vaiettua suomalaisten oli pyrittävä palaamaan mahdollisimman nopeasti arkiseen toimintaan ja tulevaisuuden rakentamiseen.

\section{Inhimillinen huoli}

Granö toimi talvisodan aikana tammikuusta huhtikuuhun 1940 sotasensuurin palveluksessa, mutta sen jälkeen hän vapautui lähes 60-vuoden ikäisenä kaikista sotilastehtävistä. Useimmat hänen nuoremmista kollegoistaan ja oppilaistaan joutuivat sen sijaan astumaan armeijan harmaisiin puolustamaan ase kädessä isänmaataan. Hän ymmärsi heti talvisodan sytyttyä, että nyt oli tosi kysymyksessä, ja oli hyvin huolissaan miesten selviytymisestä ylivoimaista vihollista vastaan. ${ }^{866}$

Huoli ei ollut turha, sillä Granö sai ensimmäisen suruviestin työtoverin sankarikuolemasta jo joulukuun lopulla 1939. Suomen Kartaston kolmannen painoksen aputoimittajana Granön kanssa tiiviissä kirjeenvaihdossa ollut Osmo H. Porkka oli kaatunut kuun puolivälissä vartiopaikalleen Karjalan kannaksella. ${ }^{867}$

Helmikuun puolivälissä tuli tieto, että Granön oppilas ja ystävä, geologi ja maantieteilijä Erkki Mikkola oli kuollut luutnanttina Taipaleenjoen verisissä taisteluissa. Erinomaisesti Lapin maankamaran ja nimistön tuntenut Mikkola oli avustanut professoriaan Suomen Kartaston kolmannen painoksen ja Suomen maantieteelliset alueet -teoksen laadinnassa ja luovuttanut tämän käyttöön useita valokuvia Lapista. Mikkola oli ollut erinomainen valokuvaaja, jonka pyörähtäväobjektiivisella 
panoraamakameralla ottamat maisemakuvat kuuluvat suomalaisen valokuvataiteen parhaimmistoon. ${ }^{868}$

Granö ymmärsi, että sodan oloissa maan tulevaisuus oli väistämättä nuorten miesten ja nuorukaisten harteilla. Hän ei kuitenkaan tyytynyt vain kotona istujan passiiviseen rooliin vaan katsoi, että hänen velvollisuutensa oli pyrkiä tukemaan sotilaita henkisesti ja käytännöllisesti. Heti talvisodan sytyttyä Granö aloitti kirjeenvaihdon monen rintamalle joutuneen oppilaansa ja työtoverinsa kanssa. Arvostusta osoittaen, kuulumisia kysellen ja tutkimustyöstään kertoen hän yritti paitsi auttaa heitä saattamaan "suuren tehtävänsä onnelliseen loppupisteeseen myös tarjoamaan heille tuokioita, jotka veivät ajatukset pois sodan melskeistä". Vilkkainta kirjeenvaihto oli A. K. Merisuon, Oiva Tuomisen ja Paavo Kallion kanssa. ${ }^{869}$

Elokuun 1941 nopean hyökkäysvaiheen aikana Granö kirjoitti Oiva Tuomiselle kannustavan kirjeen, jossa hän omien kuulumistensa ohella välitti aitoa yhteenkuuluvuuden tunnetta:

Sinä ja te kaikki muut "poikani" siellä kaukana olette aina ajatuksissani, mutta eipä vain kynään tule tartuttua. Syy on kai perimmältään se, että tämä meidän siviilien elämä ja meidän hommamme tuntuvat tällä kertaa teidän edesottamisienne ja päämäärienne rinnalla kerrassaan niin jonnin joutavilta, ettei niistä viitsisi kirjoittaakaan. Ja onttoja sanoja ei haluaisi myöskään panna paperille, niitä on ilma muutenkin täynnä...

Te työnnytte sellaista vauhtia eteenpäin siellä Karjalan ja Aunuksen rintamilla, että siviilimiehen päätä huimaa. ${ }^{870}$

Vuoden kuluttua Granön optimismi oli hieman vähentynyt, mutta hän jaksoi yhä uskoa Saksan aseiden voittoon:

Hiukan pyrkii tämä loputon sodankäynti käymään hermoille. Sen huomaa siitä, ettei tieteellinen työ tahdo nyt oikein luistaa. Olin elänyt siinä toivossa, että 
Pietari jo nyt olisi otettu, mutta näin ei ole käynyt. Ja kun asia pitkistyy, niin se usein mutkistuu. Toisaalta on lohdullista, että etelämpänä syntyy kaikesta päättäen jotakin aivan ratkaisevaa. Uskaltaisiko nyt ruveta odottamaan, että ensi talvi vihdoin tuo lopullisen ratkaisun. ${ }^{871}$

Asemasotavaiheen aikana sotilaallisen paineen hieman vähennettyä Granö pyrki edistämään opiskelijoidensa mahdollisuuksia tutkimustyön jatkamiseen. Esimerkiksi Paavo Kallio onnistui osin Granön tuella täydentämään opintojaan jatkosodan vuosina. Pro gradu -tutkielma "Eurooppalaisen karjamajatalouden maantieteelliset päätyypit" hyväksyttiin keväällä 1944 korkeimmalla arvolauseella laudatur. Kiitokseksi avusta Kallio vei erään lomamatkan aluksi rintamalla ammutun metson Granölle tietäen hyvin, että kotirintamalla elintarvikkeista oli pulaa. ${ }^{872}$

Monien sotarintamalta tulleiden suru-uutisten ohella Tirmoon tuli elokuun alussa 1942 murheviesti myös siviilimaailmasta. Granön Paavo-veli kuoli monivuotisen sairastelun jälkeen aivohalvauskohtaukseen kesähuvilassaan Karjalohjan Pipolassa:

Vihdoin vapautti Jumala väsyneen hengen. Kahdeksan pitkää vuotta kesti kamppailua ja kiihkeää vapautuksen odottelua. Pari viikkoa sitten tuli uusi halvauskohtaus, ja, kun hetki tuli, sammui mainen elämä hiljaa ja ilmeisesti tuskattomasti. Päättyi useistakin syistä erikoinen luku perheemme historiassa. ${ }^{873}$

\section{Pako tutkimukseen}

Turun yliopiston toiminta keskeytettiin lokakuun alussa 1939 ja käynnistettiin uudelleen vasta toukokuussa 1940. Kaikki palveluskelpoiset miehet komennettiin armeijaan, ja yliopiston muu henkilökunta osallistui kotirintaman ponnistuksiin kykyjensä mukaan. Yliopistorakennukseen sijoitettiin sotilasvarastoja ja juhlasalissa toimi Suomen Punaisen Ristin Varsinais-Suomen kaasunaamaritehdas. Arvokkaita kokoelmia evakuoitiin kaupungin ulkopuolelle. ${ }^{874}$ 
Maantieteen laitos käynnisti muiden laitosten tapaan opetuksen huhtikuussa 1940, mutta yksikään opiskelija ei suorittanut tutkintoja. Lukuvuosi 1940-41 oli periaatteessa normaali, mutta - kuten aiemmin on todettu - opiskelijoita oli erittäin vähän. Jatkosodan sytyttyä laitos oli kiinni kokonaan lukuvuoden 1941-42. Seuraavina sotavuosina opetustoimintaa pyrittiin jatkamaan, mutta käytännössä se tyrehtyi lähes kokonaan oppilaiden puutteeseen. ${ }^{875}$

Saatuaan terveytensä kuntoon Granö olisi ohjannut mielellään suurempia opiskelijamääriä, sillä maantieteen opetukseen liittyvät kysymykset kiinnostivat häntä jatkuvasti. Hän ymmärsi kuitenkin, että sotaoloissa ei voinut odottaa normaalin akateemisen elämän palautuvan ennalleen. Turun jouduttua pommitusten kohteeksi hän oli huolissaan keskellä kaupunkia olevan laitoksen kokoelmien kohtaloista. Erityisesti hän toivoi, että amanuenssi J. K. V. Tuominen veisi turvaan sekä hänen Suomen Kartastoa 1925 varten tekemänsä kartat sekä Mannerheimin piirtämät Aasian-retken alkuperäiskartat, jotka olisi hänen mielestään tullut pikaisesti toimittaa Valtionarkistoon. ${ }^{876}$

Kun yliopiston toiminta oli pysähdyksissä, Granö saattoi keskittyä tutkimustyöhön. Saatuaan Ulko-Mongoliaan koskeneen kirjoituksensa valmiiksi loppuvuonna 1941 hän paneutui uudelleen Altain pinnanmuotoja käsittelevään materiaaliinsa, jonka pohjalta hän oli 1910-luvulla julkaissut Les formes du relief dans l'Altaï russe et leur genèse -tutkielman ohella vain suomen-, venäjän- ja saksankielisiä ennakkoselvityksiä. Granön näkemyksiin Altain pinnanmuodoista ja niiden synnystä viitattiin ajan kirjallisuudessa yleisesti, varsinkin L. S. Bergin Venäjän maantieteellisiä vyöhykkeitä käsitelleen suurteoksen ja S. P. Suslovin Siperian luonnonmaantiedettä kuvanneen tutkimuksen ilmestyttyä englanniksi. ${ }^{877}$

Työtä helpotti Emil Aaltosen Säätiön 1942 hakemuksetta myöntämä 100000 markan tieteellinen apuraha, joka oli tarkoitettu juuri Altain-tutkimusten loppuunsaattamiseen. Granö oli myönteisen yllättynyt palkinnosta, sillä hän ymmärsi sen merkitsevän tunnustusta hänen suorittamastaan tieteellisestä työstä. Siirtyminen aluetieteellisten tutkimusten jälkeen puhtaasti geomorfologisiin kysymyksiin osoit- 
tautui vaikeammaksi kuin hän oli otaksunut. Varhaisissa Altain-tutkimuksissaan hän oli pääosin soveltanut W. M. Davisin eroosiosyklioppia, mutta neljännesvuosisadan aikana geomorfologinen tietämys oli lisääntynyt niin paljon, että yhdysvaltalaisen tutkijan näkemykset eivät enää täysin tyydyttäneet häntä. ${ }^{878}$

Erityisesti Walther Penckin tutkimukset ohjasivat Granön ajatuksia uusiin suuntiin. Lahjakas Penck oli kuollut vain 35-vuotiaana 1923, mutta hänen isänsä oli toimittanut painokuntoon hänen seuraavana vuonna ilmestyneen pääteoksensa Morphological Analysis of Landforms. Granö oli hyvin perehtynyt Penckien näkemyksiin, sillä hän oli isä-Penckin kanssa säännöllisessä kirjeenvaihdossa 1911-40, ja tapasi hänet henkilökohtaisesti saksalaisen vieraillessa Tartossa ja Helsingissä 1922. ${ }^{879}$

Professoreiden hyviä suhteita kuvasti se, että Granö saattoi 1922 kutsua Penckin lounaalle kotiinsa Pohjoiselle Rautatiekadulle. Kun vieras saapui paljon sovitusta ajasta myöhässä, isäntä kysyi huolestuneena, oliko matkalla kenties sattunut jotakin yllättävää. Mistään sellaisesta ei kuitenkaan ollut kysymys. Penck oli vain sattumalta huomannut asuinrakennuksen vieressä olevalla rakentamattomalla tontilla olevassa silokalliossa merkkejä sekä jäkakautisen jäätikön että rantavoimien toiminnasta. Kun hän oli vain harvoin nähnyt näin selviä jälkiä kahden eri prosessin toiminnasta, hänen oli ollut suorastaan pakko silmäillä niitä lähemmin. Nykyisin paikalla ovat Sibelius-Akatemia ja Eduskuntatalo. 880

Granön alkuperäisenä tavoitteena oli laatia koko Altaita käsittelevä tutkimus mutta perehdyttyään materiaaliin hän päätti keskittyä tutkimaan parhaiten tuntemansa Koillis-Altain eli Venäjän Altain pinnamuotojen syntyhistoriaa. Tehtävä osoittautui työlääksi. Sota-aikana työmotivaatio oli ajoittain kadoksissa, ja kaikki tekijät huomioon ottavien johtopäätösten teko vaati ankaraa pohdintaa. Hän joutui kirjoittamaan joitakin lukuja kolme, neljäkin kertaa uudelleen ennen kuin pääsi itseään tyydyttävään lopputulokseen. Oiva Tuomiselle lähettämässään kirjeessä Granö kuvasi hänelle tyypillisellä realistis-humoristisella tavalla työn etenemistä kesällä 1944: ”... eräät probleemat mielestäni eivät ole vielä lopullisesti kirkastuneita. Työ on ollut vaikea; tuntuupa usein siltä, että tehtävä on "pääknupilleni” ylivoimainen." ${ }^{881}$ 
Loppukesällä 1944 urakka oli vihdoin valmis. Granö lähetti osittain saksaksi kirjoittamansa käsikirjoituksen uudelle saksan kielen kääntäjälleen filosofian tohtori Marta Römerille ja ryhtyi etsimään teokselle julkaisukanavaa. Tämä osoittautui vaikeaksi tehtäväksi, sillä sodan jälkeisessä talousahdingossa valtion varoja ei juuri riittänyt tieteellisen kirjallisuuden kustantamiseen. Teos olisi saattaa jädä pitkäksi aikaa käsikirjoitusasteelle, ellei Turun Sanomien kustantaja Arvo Ketonen olisi myöntänyt varat sen julkaisemiseen Turun yliopiston maantieteen laitoksen julkaisusarjassa. ${ }^{882}$

Kun suomalainen tiede-elämä alkoi palautua sodan jälkeen normaaleihin uomiin, Granö pääsi esittämään uusimpia tutkimustuloksiaan kahdella tärkeimmällä tieteen yleisfoorumilla. Joulukuun alussa 1944 hän piti Suomalaisen Tiedeakatemian kokouksessa esitelmän aiheesta "Altain vuorimaan muotovyöhykkeistä ja tasaantumispinnoista". Seuraavan vuoden alussa esiintymispaikkana oli Suomen Tiedeseuran kokous, jossa hänen teemanaan oli "Jäätiköityminen ja pinnanmuodosto. Havaintoja ja päätelmiä Altain vuorimaasta”. ${ }^{883}$

Vuonna 1945 ilmestynyt Das Formengebäude des nordöstlichen Altai oli Granön yhteenveto pitkäaikaisen tutkimustyön tuloksista. Hänen mukaansa Altain pinnanmuodot olivat syntyneet maankuoren jatkuvan kohoamisen ja jätiköiden yhteisvaikutuksen tuloksena siten, että jäätikköeroosion voima vaihteli korkeuden mukaan. Altaille luonteenomaiset tunturitasangot olivat osia tertiaarikauden lopulla kupolimaisesti kohonneesta peneplaanista, jota Granö kutsui Walther Penckin mukaan alkupinnaksi. ${ }^{884}$

Noin neljänneksen vuoriston pinta-alasta käsittäneet tunturitasangot olivat pysyneet tasaisina lähes liikkumattoman jäätikön suojaamana. Sen sijaan vanhan alkupinnan lumirajan yläpuolelle kohonnut vuoriston korkein keskusosa oli joutunut voimakkaan jäätikkötoiminnan kohteeksi. Tuloksena oli lumeen ja jäähän peittynyt alppimainen ylävuoristo, Valkoinen Altai, joka oli Granön mukaan vuoriston kehityshistorian nuorin osa. ${ }^{885}$

Granö oli osoittanut jo väitöskirjassaan, että Altain tunturilakeuksia halkovien, mahtavan Objoen kahden suuren lähdejoen Bijan ja Katunin vanhat jokieroosion 


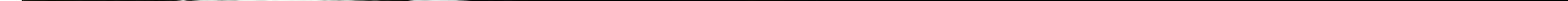




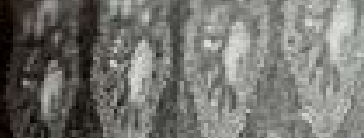

Nay

14)

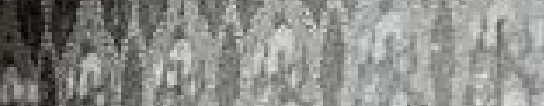

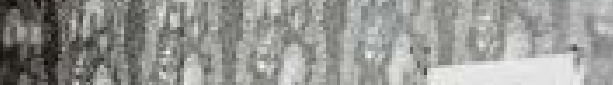
atisy as:

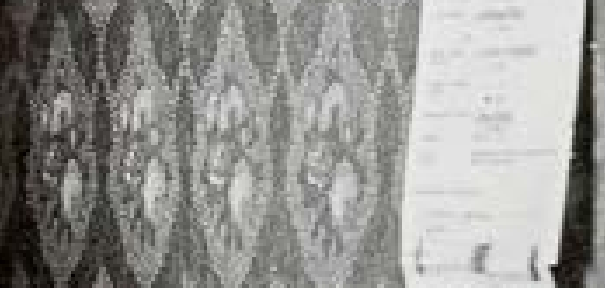

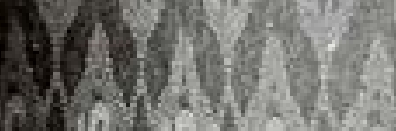

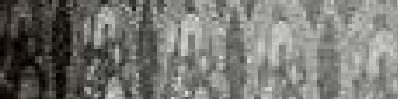
7.
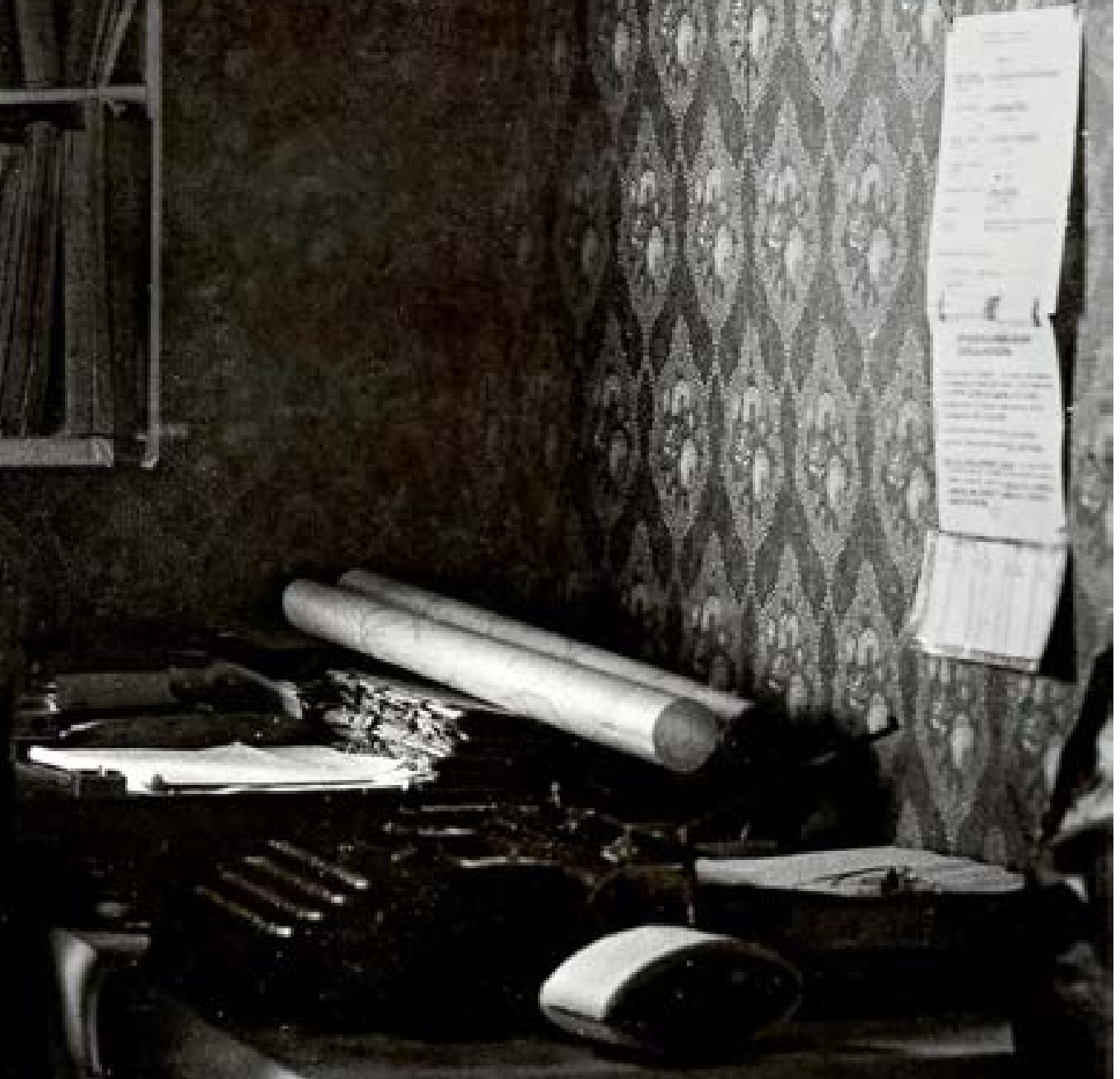

$\sqrt{10}$
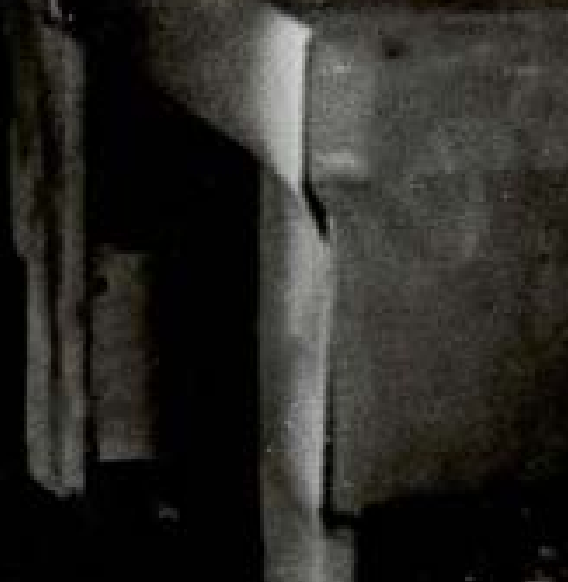
synnyttämät laaksot olivat jäätikkövirtojen muovaamia ja syventämiä ruuhilaaksoja eivätkä maankuoren pystysuorien liikuntojen aiheuttamia rotkolaaksoja. Päävirtojen reunustalla oli Granön arvoituksellisina pitämiä laajoja arotasankoja, joista esimerkiksi Katunin sivujoen Tšujan aro oli noin 70 kilometriä pitkä ja 40 kilometriä leveä.

Koska Granöllä oli nyt käytössään edellisiä töitä laajempi tutkimusaineisto, hän saattoi tulkinnassaan kiinnittää aiempaa enemmän huomiota päälaakson rinteillä olevien penkereiden korkeustasoihin. Uuden tulkinnan mukaan penkereillä oli ollut suuri merkitys virtaavan laaksojäätikön toiminnan osoittajana jokilaaksojen muotoutumisessa viimeisen jääkauden aikana. Sen sijaan niillä ei ollut merkitystä varhaisempien jäätiköitymisvaiheiden selvittämisessä, kuten hän oli aiemmin arvellut. ${ }^{886}$

Das Formengebäude des nordöstlichen Altai-teoksen avulla Granö sai yhteyden vanhaan tutkijakollegaansa V. A. Obrutševiin, joka julkaisi teoksesta pitkän arvostelun Neuvostoliiton Tiedeakatemian sarjassa. Obrutšev yhtyi pääosin Granön näkemyksiin Altain kehityksestä. ${ }^{887}$

Vaikka teos herätti huomiota Neuvostoliitossa, muualla se jäi pääosin kahdesta syystä vaille ansaitsemaansa huomiota. Ensinnäkin se ilmestyi saksaksi, joka oli väistymässä englannin tieltä luonnontieteiden johtavana kielenä. Toiseksi se julkaistiin taloudellisten vaikeuksien vuoksi vain Turun yliopiston julkaisusarjassa, minkä vuoksi sen levikki jäi pieneksi. Tämän vuoksi siitä ilmestyi vain kaksi laajaa arviota, joista toisen julkaisi Puhdasta maantiedettä ankarasti arvostellut Hans W:son Ahlmann Ruotsissa 1946 ja toisen George B. Cressey Yhdysvalloissa 1948. Cressey oli tuolloin Kansainvälisen maantieteellisen unionin presidentti. ${ }^{888}$

Geomorfologisen pääteoksen kohtalo osoitti, että vanha ilmaus "Ei kahta ilman kolmatta" piti Granön suhteen valitettavan hyvin paikkansa. Vuonna 1916 tieteellinen läpimurto geomorfologina pysähtyi tutkimusrahoituksen päättymiseen ja loka- 
kuun vallankumoukseen, 1934 sairastuminen esti Pubtaan maantieteen esittelemisen kansainvälisille maantieteellisille piireille ja 1945 Das Formengebäude des nordöstlichen Altai -teos jäi toisen maailmansodan seurausten vuoksi tyystin vaille ansaitsemaansa huomiota.

Oppihistoriallisesti kysymys ei ollut kuitenkaan kohtalokkaasta menetyksestä, sillä 1960-luvulla vuorijonojen synnyn selittäjäksi noussut laattateknoniikka siirsi niin Granön kuin Penckin ja Davisin näkemykset osaksi tieteen historiaa. Altain vuoriston, samoin kuin Himalajan, synnyn taustalla on Aasian ja Intian mannerlaatan törmäys, jonka vuoksi molemmat vuoristot kohoavat yhä. ${ }^{889}$

Altain suuret jokilaaksot ja niiden syntyhistoria nousivat uudelleen kansainvälisen tieteen valokeilaan Neuvostoliiton romahtamisen jälkeen 1990-luvulla. Tuolloin myös länsimaiset tutkijat pääsivät tutkimaan neuvostoliittolaisten geologien jo kauan tuntemia Euraasian ja Altain muinaisia valtavia jääjärviä, jotka olivat samantapaisia kuin Pohjois-Amerikan monivaiheinen Agassiz jääjärvi. Uudessa tutkimuksessa on esitetty teorioita, joiden mukaan jääkauden päättymisvaiheessa Altaille muodostui suuri jäätikköjärvi vuorilta valuvien jäävirtojen tukittua pohjoiseen virtaavat vedet. Kun jääeste lopulta murtui, järvestä olisi purkautunut puoli kilometriä korkea tulva-aalto, joka maksimissaan olisi edennyt 160 kilometriä tunnissa purkausmäärän ollessa suurimmillaan 18 miljoonaa kuutiometriä sekunnissa. Tämä jättiläismäinen purkaus olisi synnyttänyt myös Granön arvoituksellisena pitämän Tšujan laajan laaksotasangon. ${ }^{890}$

Vaikka laattatektoniikan läpimurto osoitti Granön tulkinnan puutteelliseksi, se ei vienyt siltä arvoa tieteellisenä suorituksena. Hyvän tutkimuksen tavoitteena on vastata pätevästi vanhoihin kysymyksiin ja suunnata mielenkiinto uusiin kysymyksiin, joihin annetut vastaukset tekevät sen tuoreen tiedon ja uusien tulkintojen ansiosta vääjäämättä vanhentuneeksi. Lisäksi Granön hyvin dokumentoidulla havaintoaineistolla on pysyvää tieteellistä arvoa. 


\title{
VASTUUNKANTAJA
}

\author{
VII
}

"Meitä ympäröi vyörynä kasvava teknillisten saavutusten maailma. Se on luonut ympärillemme myös henkisen miljöön, joka on monessa suhteessa toinen kuin muutamia vuosikymmeniä sitten. Kehitys vie kai pian siihen, että lennetään tuokiossa mihin maahan tahansa, otetaan silmänräpäyksessä yhteys keneen tahansa missä tahansa, istutaan kongresseja ja järjestetään neuvonpitoja miltei yhtä vaivattomasti kaukaisimmissa maissa kuin kotona tai naapurissa." ${ }_{991}$ 


\section{GaKAISIN PÄ̈̈KAUPUNKIIN}

\section{Maantiede tuuliajolla}

Suomalaisten elämää hallitsi Moskovan välirauhan jälkeen alakulo. Aseet olivat vaienneet itärintamalla, mutta Lapissa alkoi uusi sota entistä liittolaista Saksaa vastaan. Maassa piti poliittista valtaa liittoutuneiden valvontakomissio, joka koostui pääosin neuvostoliittolaisista sotilaista. Yhteiskunnan voimavarat oli suunnattava sodan tuhojen korjaamiseen, siirtoväen asuttamiseen ja sotakorvausten maksamiseen, joten kaikille jaettavaksi riitti vain niukkuutta. Sisäpoliittinen ilmapiiri kiristyi pitkään vangittuina olleiden kommunistien noustessa nopeasti merkittäväksi voimatekijäksi. ${ }^{92}$

Sota oli aiheuttanut kovat menetykset myös Helsingin yliopiston maantieteen laitokselle. Talvisodassa ruotsalaisen vapaaehtoisjoukon kartografina toimineen Väinö Tannerin ainoa poika oli kaatunut jatkosodan alkuvaiheessa, mikä oli ajanut hänet synkkään masennukseen. Hän jätti syyskuussa 1944 professuurinsa, muutti asumaan Ruotsiin, hankki maan kansalaisuuden ja alkoi katkeroituneena syyttää Suomen hallitusta ja erityisesti Väinö Aueria natsimyönteisestä politiikasta. ${ }^{893}$

Laitoksen toinen professori Väinö Auer oli puolestaan ollut näkyvimpiä SuurSuomen rajojen vetäjiä. Tämän vuoksi hän oli syksyllä 1944 niin huolissaan henkilökohtaisesta turvallisuudestaan, että oli Matti Sauramon mukaan kysellyt "myrkkyjä paremmille päiville päästäkseen". Heti Moskovan välirauhansopimuksen ehtojen julkistamisen jälkeen hän lähti sairauteen vedoten Pohjois-Ruotsiin jäämättä katsomaan, miten Suomeen asettunut valvontakomissio tulisi suhtautumaan hänen so- 
danaikaiseen toimintaansa Itä-Karjalan toimikunnan puheenjohtajana ja saksalaissuuntauksen keskeisenä edustajana. ${ }^{894}$

Maantieteen dosentti August Tammekann siirtyi entisenä virolaisena syksyllä 1944 virkavapauden turvin Ruotsin puolelle, ja toinen dosentti Aaro Hellaakoski luopui yliopistourastaan sodan aiheuttaman masennuksen vuoksi. Hellaakosken lähtö oli suuri tappio maantieteen laitokselle, sillä Leo Aarion mukaan hänen "geomorfologian ja aluemaantieteen luentosarjansa kuuluvat epäilemättä parhaisiin, mitä yliopisto voi tarjota." ${ }^{995}$

Ylimääräisen professorin Iivari Leiviskän ollessa 68-vuotiaana jäämässä eläkkeelle Helsingin yliopiston maantieteen laitoksen toiminta uhkasi lamaantua opettajapulaan. Väliaikaisratkaisuna kasvillisuuden ja soiden kehitystä tutkinut dosentti Leo Aario määrättiin hoitamaan toistaiseksi Tannerin virkaa, kun taas Leiviskä otti tilapäisesti vastuulleen Väinö Auerin professuurin.

Pian tilanne paheni entisestään, kun kävi ilmi, että Auer saattaisi jättää professuurinsa kokonaan. Nyt matemaattis-luonnontieteellinen osasto ryhtyi pohtimaan dekaaninsa Matti Sauramon johdolla mahdollisuuksia yhden maantieteen professuurin siirtämisestä tarpeettomana meteorologialle, teoreettiselle fysiikalle tai perinnöllisyysopille. Yliopiston rehtorin Rolf Nevanlinnan asettauduttua vastustamaan suunnitelmaa heräsi ajatus Granön kutsumisesta takaisin Helsinkiin. ${ }^{896}$

Granö oli hyvien suhteittensa ansiosta tietoinen maantieteen uhanalaisesta asemasta Helsingin yliopistossa. Kun Sauramo tiedusteli häneltä marraskuun puolivälissä kirjeitse yksimielisen matemaattis-luonnontieteellisen osaston nimissä, olisiko hän valmis tässä vakavassa tilanteessa ottamaan kutsusta vastaan Tannerilta vapautuneen professuurin, hän ilmoitti suostuvansa pyyntöön "siinä tapauksessa, että Osasto menettää molemmat vakinaiset maantieteen edustajat, sillä tässä tapauksessa katsoisin voivani olla Helsingin Yliopistolle vaikeana ajankohtana hyödyksi. ${ }^{{ }^{997}}$ 
Kun Granön asettama ehto herätti osastossa vastustusta, hän päätti parin viikon miettimisen jälkeen suostua ottamaan kutsun ehdoitta vastaan. Ratkaisuun vaikutti se, että hän kantoi suurta huolta maantieteen tulevaisuudesta maan pääyliopistossa, joka oli kouluttanut myös hänet itsensä tutkijaksi. Hänellä oli ollut viimeisinä vuosina Turussa vähän opiskelijoita, joten hän katsoi voivansa olla suomalaiselle maantieteelle suuremmaksi hyödyksi Helsingissä, jossa opiskelijoita oli paljon. Lisäksi hän tunsi henkistä mielihyvää siitä, että matemaattis-luonnontieteellinen osasto oli ilmoittanut pitävänsä joka tapauksessa hänen tuloaan tärkeänä. ${ }^{898}$

Helsingin yliopiston maantieteen laitoksella iloittiin Granön ratkaisusta. Leo Aario välitti tunnelmat heti tuoreeltaan hänen tietoonsa:

Laitoksellamme on täysi syy olla kiitollinen siitä. että olet suostunut uhraamaan jäljellä olevat opettajavuodet Helsingin Yliopistolle. Toivomme, että auktoriteettisi kykenisi myös täällä kohottamaan maantieteen arvovaltaa tieteiden suuressa orkesterissa, missä se on tähän asti pikku poikana pyritty sysäämään syrjemmälle. ${ }^{899}$

Kun osasto oli saanut tietoonsa Granön valmiuden palata Helsinkiin, se pyysi asiasta lausunnot Sauramolta ja geologian ja mineralogian professorilta Pentti Eskolalta. Sauramo kehui omassa lausunnossaan Granön ansioita tutkijana ja opettajana ja totesi, että tämän paluu olisi "voitoksi sekä osastollemme että yliopistolle”. .00

Eskolan mukaan Granö oli luonut maisematieteen käsitteistön, kehittänyt sille erinomaisen suomenkielisen terminologian ja soveltanut sitä aluetutkimukseen. Vaikka Pubtaan maantieteen perustana olevan morfologian oli todettu olevan jossakin määrin keinotekoisen, se oli Granön itsensä ja hänen oppilaittensa hänen johdollaan soveltamana johtanut kauniisiin ja sopusuhtaisiin tuloksiin. Granö kuului Eskolan mukaan "maantieteilijöiden ensimmäisiin koko maailmassa", ja Suomessa hänellä oli "ensimmäinen sija maantieteen tutkijana ja opettajana, ja hän on ehdottomasti kaikkien muiden kysymykseen tulevien edellä otettava huomioon avoimeksi tullutta maantieteen professorinvirkaa täytettäessä". ${ }^{901}$ 
Sauramon ja Eskolan vakuuttavien lausuntojen jälkeen matemaattis-luonnontieteellinen osasto päätti yksimielisesti kutsua Granön hoitamaan maantieteen varsinaisen professorin virkaa. Saatuaan Mannerheimin tasavallan presidenttinä 9. helmikuuta 1945 allekirjoittaman nimityskirjan hän astui virkaansa runsaan kuukauden kuluttua pitämättä virkaanastujaisesitelmäänsä ja vannomatta säädettyä virka- ja tuomarinvalaa, koska oli vannonut ne jo 1924. Näin hänestä tuli heti virkaiältään yliopiston viidenneksi pitkäikäisin professori Rafael Karstenin, Edwin Linkomiehen, Pentti Eskolan ja Viljo Tarkiaisen jälkeen. ${ }^{902}$

Granö erosi maaliskuun 1945 alusta Turun yliopiston professuurista mutta vei keväällä loppuun syyslukukaudella aloittamansa luennot ja muun opetustoiminnan. Hänen seuraajakseen nimitettiin Leo Aario, joka oli hoitanut hänen virkaansa Helsingissä kevätlukukauden ajan. Tehtävän vaihdos tapahtui toukokuun lopulla erityisessä katsastustilaisuudessa, johon osallistuivat maantieteen professorien lisäksi Turun yliopiston rehtori Einar W. Juva ja laitoksen amanuenssi J. K. V. Tuominen.. ${ }^{903}$

\section{Paluu Vihreään taloon}

Granön paluu Helsinkiin oli siinä mielessä helppo, että hän ei ollut Turun vuosinaan myynyt Pohjoisen Rautatiekadun Vihreässä talossa ollutta asuntoaan vaan oli antanut sen vuokralle eräälle leskirouvalle. Muutto vanhaan kotiin ei kuitenkaan käynyt niin vain, sillä toisen maailmansodan jälkeisen ankaran huoneenvuokrasäännöstelyn takia vuokralaisten saaminen pois asunnosta oli vaikeata. Koska muuttokuorma Turusta saapui ennen asunnon vapautumista kesäkuun 1945 alussa, tavarat jouduttiin sijoittamaan väliaikaisesti viereisen Konservatorion varastotiloihin. ${ }^{904}$

Puolison Hilman lisäksi kaikki lapset muuttivat Helsinkiin. Filosofian maisteri Siine siirtyi kodista pois 1950-luvun alussa mentyään naimisiin kirjastonhoitajan, myöhemmän eduskunnan ylikirjastonhoitajan Henrik Schaumanin kanssa ja Olavi 1953 avioiduttuaan filosofian maisteri Eeva Kalevan kanssa. Vain naimattomiksi 
jääneet tyttäret proviisori Aune ja käsityön lehtori Eeva jäivät asumaan pitkäksi aikaa vanhempiensa asuntoon. Pisimpään siellä viihtyi Aune, joka kuoli 92-vuotiaana 2006.905

Muut lapset jäivät Helsinkiin, mutta Olavi Granö palasi vanhaan kotikaupunkiinsa 1959, jolloin hän ryhtyi hoitamaan Turun yliopiston maantieteen apulaisprofessuuria. Toimittuaan apulaisprofessorina vuoteen 1961 hän hoiti maantieteen professuuria vuosina 1962-88. Tiedehallinnon keskeisissä tehtävissä monin tavoin ansioitunut ja akateemikon arvonimen 1980 saanut Granö oli isänsä tavoin myös 10 vuotta Turun yliopiston kanslerina 1984-94.906 


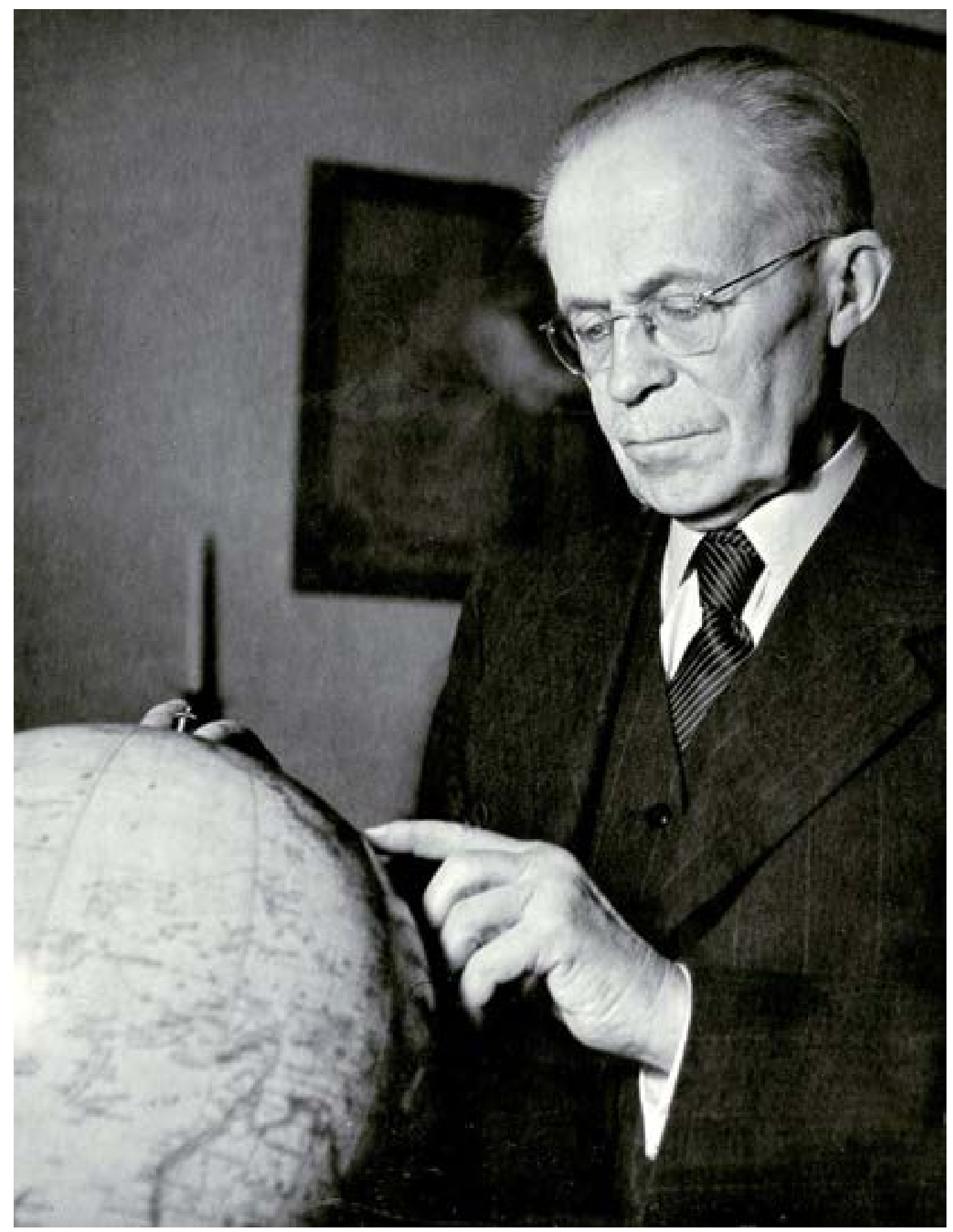




\section{サtiopisto-opet'Uksen t'AKAaja}

\section{Professori ja laitoksen esimies}

J. G. Granö palasi nuoruutensa yliopistoon kevään virkavapauden jälkeen syksyllä 1945. Siltasaarenkadulla lähellä Pitkääsiltaa sijainneen maantieteen laitoksen esimiehenä toimi Väinö Auer, joka oli palannut hoitamaan virkaansa helmikuussa 1945. Tuolloin oli käynyt selväksi, että valvontakomissio ei rankaisisi häntä sodanaikaisesta toiminnasta ylimääräisellä Siperian-matkalla. Professorien lisäksi laitoksen henkilökuntaan kuuluivat muun muassa dosentti Helmer Smeds, assistentti Jorma Mattila sekä amanuenssi Igor Svento. ${ }^{907}$

Laitoksen kirjasto saatiin sotavuosien evakuoinnin jälkeen järjestettyä nopeasti, mutta sen kokoelmat olivat kokeneet suuria menetyksiä. Se joutui Suomen Maantieteellisen Seuran sekä muiden virastojen, laitosten ja yhteisöjen tavoin toimittamaan luovutettuja alueita kuvaavat kartat valvontakomissiolle ja edelleen Neuvostoliittoon. Suomesta kuljetettiin heinäkuun puoliväliin 1945 mennessä itärajan taakse yli 16 miljoonaa karttalehteä, Täysin valvontakomissio ei kuitenkaan tavoitteissaan onnistunut. Esimerkiksi Granö siirsi vähin äänin Turun yliopiston maantieteen laitoksella olleet Viron kartat kotiinsa, josta suku lahjoitti ne Neuvostoliiton romahdettua Suomalaisen Kirjallisuuden Seuran arkistoon..$^{908}$

Granön työpaineet kasvoivat syksyllä 1946. Kun Argentiinan hallitus oli kutsunut Väinö Auerin tekemään tieteellistä tutkimusta ja johtamaan agrogeologista kartoitusta Patagoniassa, Helsingin yliopisto myönsi hänelle kahden vuoden virkavapauden syyslukukauden 1946 alusta. Granön saatua vastuulleen myös laitoksen esimiehen tehtävät hän oli jälleen Tarton ja Turun yliopiston tapaan laitoksensa esimies ja ainoa vakituinen professori. Nyt tilanne oli kuitenkin siinä mielessä parempi kuin ennen, että hän kykeni pestaamaan aiempaa enemmän apuvoimia. 


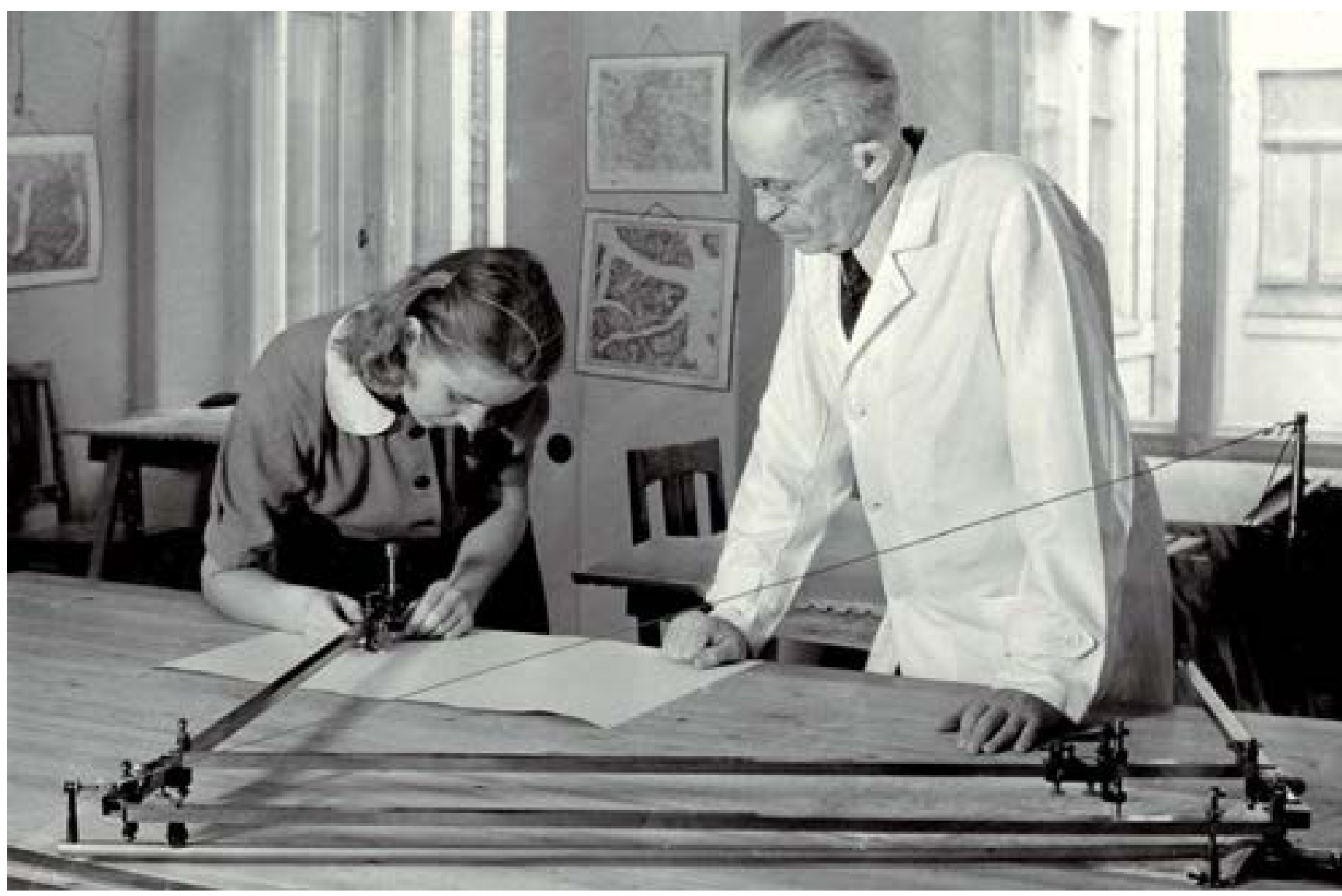

Granö johti kartanpiirustustöitä

Helsingin yliopiston maantieteen laitoksella 1947.

Helsingin kauppakorkeakoulun talousmaantieteen professori ja vararehtori Kaarlo Hildén suostui hoitamaan toistaiseksi virkaatekevänä Auerin professuuria, kun Granö lupautui auttamaan häntä opetuksen järjestämisessä. Vuosikymmenen lopulla opettajavoimat vahvistuivat, kun laitos sai maantieteen ruotsinkielisen professuurin, jota ryhtyi aluksi virkaatekevänä hoitamaan dosentti Helmer Smeds. Granö 
oli tutustunut Smedsiin jo 1930-luvulla, jolloin tämä oli ollessaan Turussa oppikoulunopettajana asunut Granöitten kanssa samassa Kristiinankatu 1:n talossa. ${ }^{909}$

Laitoksen johtajuus tuotti Granölle paljon epämieluisia hallinnollisia tehtäviä mutta soi myös tilaisuuden tarjota oppilailleen mahdollisuuksia tieteelliseen pätevöitymiseen. Hän pyrki aluksi houkuttelemaan Paavo Kallion jatkamaan maantieteen opintoja, mutta kun tämä ei onnistunut, hän päätti yrittää pelastaa ystävänsä J. K. V. Tuomisen pojan Oivan takaisin tieteen pariin.

Oiva Tuominen oli saanut väitöskirjansa hyvään alkuun 1930-luvun lopulla, mutta ensin leipätyöt Turun kauppaopiston tuntiopettajana ja sitten sotavuodet sekä Arkadian yhteislyseon opettajan pesti Helsingissä uhkasivat saattaa sen yhdeksi luvuksi kesken jääneiden töiden kirjaan. Granö uskoi, että assistentuuri voisi sytyttää poika-Tuomisessa vimman, joka veisi tutkimuksen päätökseen. J. K. V. Tuomiselle lähettämässään kirjeessä hän esitteli tuumaansa:

Uskon kuitenkin olevani oikeassa, sillä väitöskirjan teko on pelottavan kuolleessa pisteessä minun mielestäni. Tuo assistentintoimi (muutama harva tunti viikossa) voi ehkä tempaista miehen ylös raiteille, iloisempiin luomisyrityksiin. Koetetaan siis tällaista keinoa... Pianhan toivottavasti näemme, mitä "kuuri" vaikuttaa. Älä vielä tukista vanhaa veljeäsi, mutta älä myöskään kiitä.910

Granön suunnitelma onnistui. Ryhdyttyään hoitamaan maantieteen assistentin tehtäviä Tuominen sai jälleen kiinni väitöskirjan teosta ja sai sen valmiiksi kesän 1948 aikana. Tuomisen 1949 Granön tuella Fenniassa julkaisema väitöskirja Lounais-Suomen toiminnallisesta aluerakenteesta toi Walter Christallerin keskus- ja vaikutusalueteorian Suomeen. Pääosin Christallerin näkemyksiin perustunut mutta alueiden rajaamisessa Granön analyyttis-synteettiseen metodiin tukeutunut tutkimus vaikutti huomattavasti Suomen keskus- ja vaikutusaluetutkimuksen kehitykseen. Tuominen oli ensimmäinen suomalainen tutkija, joka tarkasteli kokonaista keskusten ja vaikutusalueiden järjestelmää ja teki jaon absoluuttiseen ja relatiiviseen vaikutusalueeseen. 
Tuomisen lisäksi laitoksen ylimääräisinä assistentteina toimivat lyhyen aikaa myös tulevat maantieteen professorit Veikko Okko ja Olavi Granö. ${ }^{912}$

Esimiehenä Granö saattoi liittää maantieteen laitoksen Ruotsiin siirtyneen Edgar Kantin Lundin yliopistossa käynnistämään maantieteen kansainväliseen hankkeeseen, jonka tavoitteena oli koota maantieteen ja siihen läheisesti liittyvien tieteiden termistö kymmenellä Euroopan kielellä. Toukokuun 1948 loppuun mennessä laitoksen sanastoon oli kertynyt jo noin 3500 sanalippua. Samoihin aikoihin laitos ryhtyi myös kokoamaan Suomen maantieteellistä paikannimiluetteloa, johon kerättiin tietoa taloudellisen kartan sisältämästä nimistöstä. ${ }^{913}$

\section{Opetuksen sisältö}

Jos Granö oli Turussa harmitellut maantieteen vähäisiä opiskelijamääriä, Helsingissä tähän ei ollut aihetta. Viimeisenä sotavuonna 1945 opiskelijoita oli vain runsaat 30, mutta vuosikymmenen loppuun mennessä heidän määränsä kohosi yli 70:een. Tämä merkitsi sitä, että luennoilla oli paljon kuulijoita, harjoitussaleissa ja seminaareissa riitti ohjattavaa sekä pro gradu -töissä tarkastettavaa. ${ }^{914}$

Suurista opiskelijamääristä huolimatta Granön viimeiset Helsingin-vuodet eivät johtaneet varsinaisten opettaja-oppilas-suhteiden syntymiseen. Pääosa jatko-opintoja harkinneista maantieteen luentojen kuulijoista luopui eri syistä väitöskirjan tekemisestä tai suuntautui Kari Lagerspetzin ja Yrjö Vasarin tavoin lähitieteisiin. Tämä johtui edelleen pääosin maantieteen yliopistovirkojen vähäisyydesta, ei Granön opetuksen tasosta. Syksyllä 1948 maantieteen opiskelun aloittaneen Lagerspetzin mukaan Granö oli luennoitsijana harvinaisen hyvä: Syvämietteinen, selkeä ja inhimillisesti koskettava. ${ }^{915}$

Ainoa maantieteestä väitellyt Granön toisen Helsingin-kauden opiskelija oli Ritva Ruotsalo-Aario, joka perehtyi syvällisesti tämän maisematieteellisiin näkemyksiin. Vuonna 1967 ilmestyneessä väitöskirjassaan Naturlandschaft und Siedlung in 
der Gegend der Stadt Kuopio auf der Finnischen Seenplatte ja muissa vuosikymmenen lopun tutkimuksissaan Ruotsalo-Aario pyrki yhdistämään Granön formalistisen metodin maiseman dynaamisiin puoliin keskittyneisiin tutkimussuuntiin siten, että hän kiinnitti huomiota myös maisemassa näkymättömiin tekijöihin. ${ }^{916}$

Granö kantoi 1940-luvun jälkipuoliskolla raskaan vastuun maantieteen laitoksen opetuksesta. Hän veti joka lukukausi yleismaantieteen peruskurssin eli yhteensä 10 kurssia, ja aluemaantieteestä hän piti sekä johdanto- että tyyppialueluentoja. Luennot olivat monipuolisia ja havainnollisia, ja niiden punaisena lankana oli maantieteen alueellisen roolin korostaminen. Kartografian harjoitustyöt hän uudisti samoin kuin 40 vuotta aiemmin tultuaan laitoksen ensimmäiseksi assistentiksi ja seurasi harjoitustöitä hän seurasi edelleen tiiviisti. ${ }^{917}$

Vaikka Granö oli kokenut luennoitsija, tiivis työtahti kävi voimille. Vuoden 1947 lopulla hän kirjoitti J. K. V. Tuomiselle:

Tehtävää on liiankin paljon, ja pyrkii usein väsyttämään, mutta asiat on kerta kaikkiaan hoidettava. Onneksi ja iloksi päättyy lukukausi pian, niin että saa hiukan rentoutua ja tehdä virkistyksekseen sitä, mitä oikein haluaa tehdä. ${ }^{918}$

Maantieteen laitoksen ohjelmaan kuuluivat yhä opiskelijoiden kesäretket. Ehkä runsaat 50 vuotta aiemmin Pallastunturille tekemänsä retken muistoksi Granö päätti suunnata esimieskautensa viimeisen kesäretken Lappiin. Professori Helmer Smedsin, dosentti Oiva Tuomisen ja poikansa Olavin avustamana Granö johdatti heinäkuussa 1950 opiskelijansa ja seurueeseen liittyneen portugalilaisen professorin Mariano Feijon tutustumaan muun muassa Inarijärven, Tenojoen, Pallastunturin ja Tornionjoen maisemiin. Retken aikana osanottajat kävivät myös Alatornion vanhassa pappilassa, mutta Granö jätti ilmeisesti tunnesyistä tämän vierailun väliin. ${ }^{119}$ 


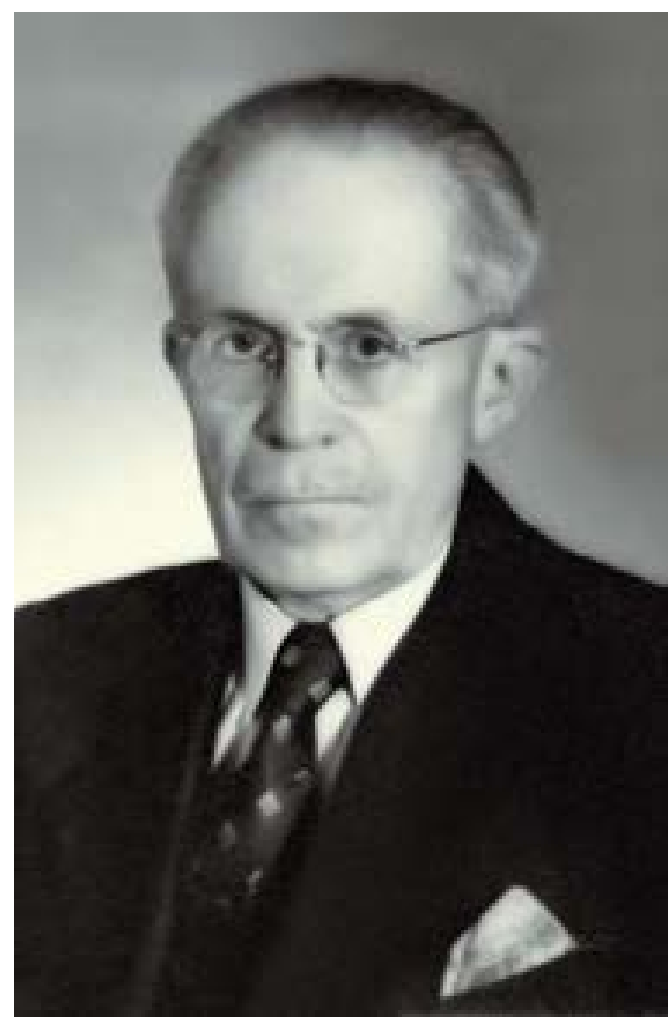

Johannes Gabriel Granö 70-vuotiaana maaliskuussa 1952.

\section{Ero yliopistosta}

Granö hoiti maantieteen varsinaisen professorin ja maantieteen laitoksen esimiehen tehtäviä elokuun 1950 loppuun, jolloin hän erosi yliopiston palveluksesta. Ero ei ollut yhtäkkinen, sillä hän piti konsistorin määräyksellä virkaan kuuluneet seminaariharjoitukset syyslukukauden loppuun asti. ${ }^{920}$

Granön pyydettyä eroa Helsingin yliopiston matemaattis-luonnontieteellinen osasto päätti hänen esityksestään kutsua August Tammekannin hoitamaan toistaiseksi hänen virkaansa. Tammekann oli sodan jälkeen siirtynyt turvallisuussyistä Ruotsiin ja menettänyt Helsingin yliopiston dosentuurin. Hän oli toiminut muun muassa maan puolustusvoimien yleisesikunnassa karttatoimittajana ja Zürichin yliopiston maantieteen vierailevana professorina, kunnes oli siirtynyt 1949 ruotsalaisen geologin Lennart von Postin avustajaksi. Kun Suomen ulkopoliittinen tilanne oli vakiintunut, Tammekann otti mielihyvin vastaan vanhan opettajansa järjestämän kutsun. ${ }^{921}$

Tammekann hoiti Granön professuuria viransijaisena vuoteen 1953. Tuolloin hän sai Väinö Auerilta vapautuneen professuurin, jota hän hoiti kuolemaansa 1959 saakka. Hän vaikutti suomalaisen maantieteen kehityksen myös Suomen Maantieteellisen Seuran puheenjohtajana ja Terran toimittajana. ${ }^{922}$

Toista maantieteen professuuria hoiti muutaman vuoden ajan Kaarlo Hildénin jälkeen dosentiksi 1950 nimitetty Oiva Tuominen, kunnes Leo Aario nimitettiin 1953 vakinaiseksi professoriksi. Väinö Auerin palattua Suomeen hänet nimitettiin 
1953 presidentti J. K. Paasikiven tuella maantieteen henkilökohtaiseksi ylimääräiseksi professoriksi. ${ }^{923}$

Granön ratkaisu siirtyä 1945 Turusta pääkaupunkiin osoittautui ratkaisevaksi Helsingin yliopiston maantieteen laitoksen toiminnan kannalta. Hänen arvovaltansa ansiosta maantiede ei menettänyt yhtä professuuria sen paremmin heti sodan jälkeen kuin 1950-luvun vaihteessa, jolloin laitos sai uuden ruotsinkielisen professuurin. Ilman Granön panosta maan pääyliopiston maantieteen opetuksen jatkuvuus olisi ollut entisessä laajuudessaan uhattuna tilanteessa, jossa sekä tieteen kehitys että yhteiskunnan muuttuneet tarpeet edellyttivät taitavaa johtajuutta. 


\section{Akateeminen qaikut'taja}

\section{Kanslerin monet tehtävät}

Muutto pääkaupunkiin ei merkinnyt Granön yhteyksien katkeamista Turun ylipistoon, sillä hänet nimitettiin Gustaf Kompan jälkeen yliopiston kansleriksi helmikuussa 1945. Valinnan ratkaisivat matemaattis-luonnontieteellisen tiedekunnan professorit tukenaan historian professori Einar W. Juva ja vaikutusvaltainen suomen kielen ja sen sukukielien professori Paavo Ravila. Ravilan mielestä Granö oli ruotsinkielisestä nimestään huolimatta sopivin mies suomalaisen yliopiston johtoon sodanjälkeisissä poikkeuksellisissa oloissa. ${ }^{924}$

Granön akateemisissa piireissä nauttima luottamus ei rajoittunut vain Turkuun, sillä häntä kohtaan tunnettiin yleisesti suurta arvonantoa tutkijana, opettajana, organisatorisena kykynä ja kokoavana persoonallisuutena. Hänet tunnettiin miehenä, joka ei kysellyt oman erinomaisuutensa perään, vaan keskittyi omien töidensä tekemiseen ja muiden tukemiseen ja innostamiseen. ${ }^{925}$

Luja usko Granön taitoihin tuli esiin syksyllä 1945, jolloin Helsingin yliopistossa järjestettiin rehtorin vaali Rolf Nevanlinnan jouduttua eroamaan tehtävästä suomalaisten kommunistien painostuksen vuoksi. Suuri konsistori asettui koevaalissa Nevanlinnaa myöten lähes yksimielisesti Granön valinnan kannalle, mutta operaatio pysähtyi alkuunsa tämän jyrkän kieltäytymisen vuoksi. Hän ilmoitti, ettei tulisi ottamaan tehtävää vastaan vaan eroaisi mieluummin professorin virasta ja keskittyisi johtamaan kanslerina Turun yliopistoa. Rehtoriksi valittiin toinen natsimielistä saksalaissuuntausta vieroksunut tutkija, romaanisen filologian professori, vararehtori Arthur Långfors, Granön vanha kilpailija Rosenbergin apurahoista. ${ }^{926}$ 
Granön jyrkkä kieltäytyminen rehtorin virasta ei katkaissut professorien luottamusta hänen kykyihinsä. Kun hän suostui asettumaan ehdolle Helsingin yliopiston kanslerin vaalissa 1949, hänet sijoitettiin toiselle ehdokassijalle ennen vararehtori Erik Lönnrothia. Ensimmäisellä sijalla ollut Antti Tulenheimo valittiin kuitenkin toiselle viisivuotiskaudelle. ${ }^{927}$

Granön aloittaessa kanslerinkautensa Turun yliopiston luonne alkoi muuttua ratkaisevasti kahdesta syystä. Jo 1930-luvulla alkanut kielipolitiikan painoarvon pienentyminen voimistui toisen maailmansodan vuosina, jolloin ymmärrettiin, että maan molemmat kansanosat, suomenkieliset ja ruotsinkieliset, taistelivat yhteisen isänmaan puolesta. Tämä yhteisymmärrys näkyi rauhan palattua siten, että Turun Suomalaisen Yliopiston ja Åbo Akademin kanssakäyminen lisääntyi. ${ }^{928}$

Vaikeat taloudelliset ongelmat olivat puolestaan jo pitkään nakertaneet uskoa sii-

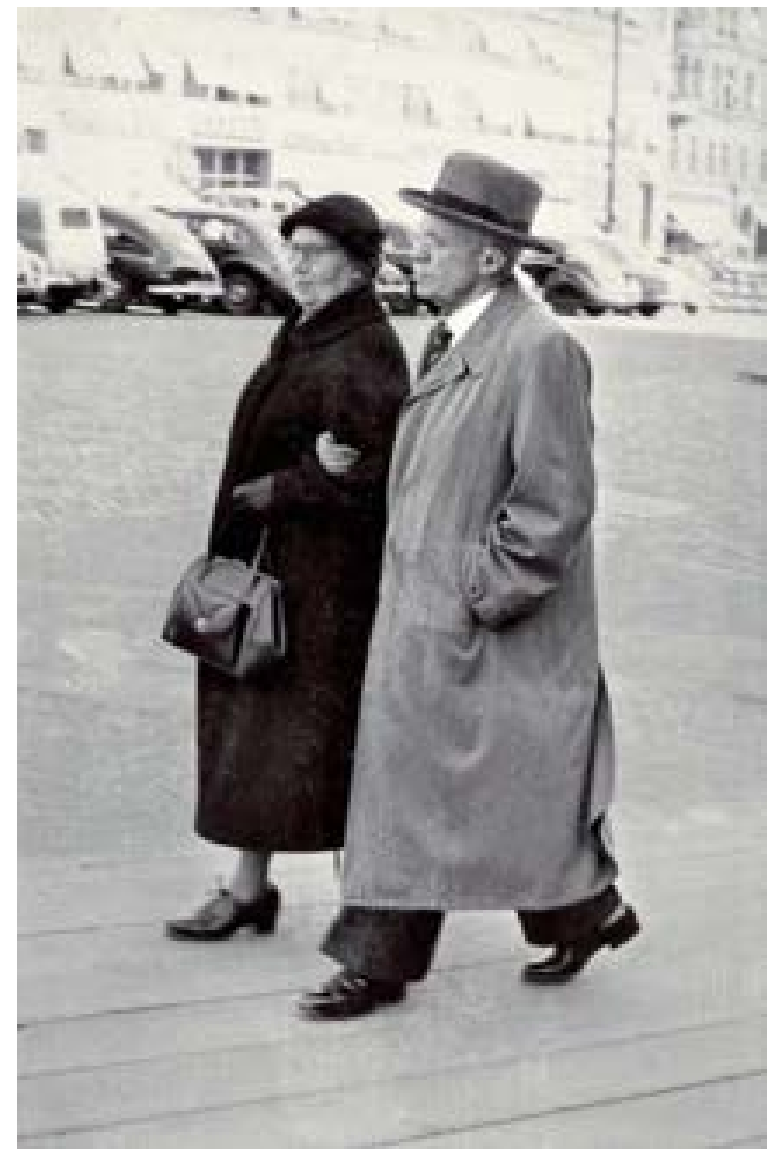

Hilma ja J. G. Granö palaavat Keski-Suomeen tehdyltä matkalta 1950-luvun alussa. Granö laati tuolloin kirjoitusta Suomen aluemaantieteestä. hen yliopiston perustajien näkemykseen, että opinahjon tuli olla yksityinen, valtiovallan holhouksesta riippumaton korkeakoulu. Viimeistään sotavuodet olivat osoittaneet, että se ei tullut toimeen omin voimin. Valtio oli sitoutunut kantamaan vastuun 1943 perustetun uuden lääketieteellisen tiedekunnan menoista, mutta sen varoja tarvittiin myös yhä enemmän peittämään niin vanhojen tiedekuntien kuin kirjaston ja hallinnon kustannuksia. Rehtorina vuoteen 
1945 toiminut Einar W. Juva näki yliopiston ainoaksi mahdolliseksi kehittämisvaihtoehdoksi valtiollistamisen, minkä toteuttamiseksi hän laati 1948 erityisen toimintasuunnitelman. ${ }^{929}$

Juvan kanssa läheisessä yhteistyössä toiminut Granö tuki sekä yhteistyön lisäämistä Åbo Akademin kanssa että yliopiston valtiollistamista toiminnan jatkuvuuden turvaamiseksi. Hän ei yliopiston korkeimpana hallintoviranomaisena osallistunut käytännön kehittämistyöhön vaan tyytyi pääosin vahvistamaan hallinnon valmistelemat asiat ja toimimaan edunvalvojana, taustavaikuttajana ja neuvonantajana. Yliopiston operatiivisesta johtamisesta hänen kanslerikaudellaan vastasivat rehtorit Harry Waris (1945-48), Toivo Olin (1948-54) ja Osmo Järvi (1954-60).930

Granön johdolla Turun yliopisto pyrki tehostamaan toimintaansa ja teki opetusministeriölle toistuvasti esityksiä valtionapunsa kasvattamisesta. Toimet tuottivat myös tuloksia. Yliopiston professuurien lukumäärä kasvoi vuoden 1945 runsaasta paristakymmenestä 1950-luvun alkuvuosiin mennessä yli 30:een opiskelijamäärän lisääntyessä suunnilleen samassa suhteessa vajaasta 370:stä runsaaseen 570:een. ${ }^{931}$

Suotuisa kehitys katkesi 1952, jolloin opiskelijoiden lukumäärä jatkoi nopeaa kasvuaan virkojen määrän pysyessä ennallaan. Tämä johtui siitä, että opetusministeriö siirsi yliopiston kehittämissuunnitelmien käsittelyn tuolloin perustetulle korkeakoulukomitealle, jonka tehtävänä oli valmistella koko maata koskeva korkeakouluohjelma. Komitean puheenjohtajuutta tarjottiin Granölle, mutta hän kieltäytyi siitä korkeaan ikäänsä vedoten. Puheenjohtajaksi nousi matemaatikko, tieteellisen keskustoimikunnan puheenjohtaja ja Helsingin yliopiston tuore kansleri P. J. Myrberg. ${ }^{932}$

Myrbergin komitean kokoonpano oli akateemisesti mahdollisimman arvovaltainen, sillä sen jäsenet edustivat kaikkien korkeakoulujen johtavia piirejä. Turun yliopiston edustajina olivat Osmo Järvi ja Einar W. Juva, jotka muiden jäsenten tavoin pyrkivät tiukasti pitämään oman opinahjonsa puolta. Eri osapuolten etujen yhteensovittaminen osoittautui niin työlääksi ja näköalattomaksi, että komitean 1956 valmistunut mietintö osoittautui pian vanhentuneeksi. ${ }^{933}$ 
Kun valtion toimet korkeakoulujen kehittämiseksi pääosin pysähtyivät Myrbergin komitean työskentelyn ajaksi, Granön kansleriajan viimeiset vuodet olivat tietynlaista valmistautumista niihin suuriin muutoksiin, jotka väistämättä olivat edessä. Hänen kautensa tärkein ratkaisu oli päätös keskittää yliopiston toiminta Vesilinnanmäelle, tulevalle Yliopistonmäelle, jonka juurelle myös ylioppilaskunnan rakennukset sijoitettiin. Ensimmäisten uusien rakennusten peruskivi laskettiin keväällä 1953, ja syksyllä 1954 sekä kirjasto että kemian laitos saattoivat muuttaa uusiin tiloihin.934

Helmikuun lopulla 1955 Granö luovutti Turun yliopiston kanslerin tehtävät Toivo Olinille, joka oli yllättäen voittanut kanslerinvaalissa Einar W. Juvan. Yliopiston 35. vuotisjuhlista 28. helmikuuta 1955 muodostui siten myös Granön erojuhla yliopiston palveluksesta. Rehtori Osmo Järvi korosti lämminhenkisessä puheessaan Granön merkitystä yliopistolle:

Kymmenen vuoden ajan on yliopistolla ollut onni pitää prof. Granö korkeimpana hallitusmiehenään. Tänä aikana häntä kohtaan tunnettu kunnioitus on mikäli mahdollista, yhä vain kasvanut. Lukemattomissa vaikeissa, väliin arkaluontoisissakin kysymyksissä on hänen puoleensa kuluneina vuosina käännytty. Monessa kysymyksessä, joista yliopiston eläessä parhaillaan uutta kehitysvaihetta ei ole ollut puutetta, on kansleri arvovallallaan edustanut yliopistoa auttaen sille edullisten päätösten syntymistä. Hänen päätöksissään on ennen kaikkea säteillyt oikeudenmukaisuus ja muodon lakien noudattaminen. Tämä on omiaan edelleen lisäämään luottamusta yksityisiin korkeakouluihin ja lisäämään niiden arvovaltaa. ${ }^{935}$

Vuosijuhlan päätyttyä Turun yliopisto järjesti Granön kunniaksi illalliset Hamburger Börsissä. Tilaisuudessa olivat läsnä yliopiston professorikunnan ja muiden opettajien ja kaupungin merkkihenkilöiden lisäksi entiset professorit ja silloiset Suomen Akatemian jäsenet V. A. Koskenniemi ja Yrjö Väisälä. Akateemikkojen läsnäolo oli siinä mielessä luontevaa, että Granö oli Turun yliopiston kanslerina kuulunut vuodesta 1947 lähtien akateemikkojen valinnasta vastanneeseen akatemialautakuntaan 
ja osallistunut siten niin Koskenniemen ja Väisälän kuin yhdeksän muun akateemikon valintaan. ${ }^{936}$

Granön Suomen tiede-elämässä saavuttama keskeinen asema tuli esiin monin tavoin. Vuonna 1945 hänet kutsuttiin Kustannusosakeyhtiö Otavan perustaman Tiedekirjasto-nimisen kurssikirjasarjan toimituskuntaan vastaamaan maantieteen alaan kuuluvan kirjallisuuden julkaisemisesta, ja 1954 hänet valittiin Tieteen päivien puheenjohtajaksi.

Tieteen päivien tapaisia tilaisuuksia oli järjestetty jo 1922 ja 1926 Tutkijainkokouksen nimellä, mutta perinne oli katkennut. Nyt tiedetapahtuman ideoijana oli vaikeasta pääministerikaudesta ja sotasyyllisyystuomiosta roimasti lisää henkistä arvovaltaa kehittänyt latinan kielen ja kirjallisuuden professori Edwin Linkomies, jonka mielestä suurelle yleisölle tarkoitettujen tilaisuuksien avulla voitiin lisätä poliitikkojen ymmärrystä korkeinta opetusta ja tutkimusta kohtaan. Päivien järjestäjiin kuuluivat kaikki yliopistot ja korkeakoulut sekä tärkeimmät tiedeyhteisöt ja tutkimuslaitokset. ${ }^{937}$

Granö otti mielihyvin vastaan Tieteen päivien puheenjohtajan tehtävän. Hän oli koko tiedemiesuransa aikana edustanut näkemystä, että tiede ei saanut olla erillinen saareke, vaan sen oli toimittava läheisessä kosketuksessa siihen yhteiskuntaan, jonka varoilla se toimi ja jonka hyväksi se teki työnsä. Granö avasi puheellaan Tieteen päivät Helsingin yliopiston juhlasalissa tammikuun alussa 1954 pidetyssä tilaisuudessa, jota kunnioitti läsnäolollaan tasavallan presidentti J. K. Paasikivi. ${ }^{938}$

Puheessaan Granö puuttui muun muassa akateemiseen aivovuotoon, lahjakkaiden tutkijoiden siirtymiseen ulkomaille. Asiasta oli Suomessa keskusteltu koko sodanjälkeinen aika, mutta se kiinnosti häntä myös omien kokemusten takia:

Suureen maailmaan vievä oikotie avaa tosin meillekin, täällä ennen syrjäisessä maassa, arvaamattomia mahdollisuuksia, mutta sen seuraamisella on, tieteen kannalta katsoen, myös tietty tragiikka. Sen lumoihin joutuvat näet ymmärrettävistä syistä keskuudessamme ennen kaikkea lahjakkaimmat ja elävimmät, 
vaikutteille herkimmät yksilöt, jollaisia jo ennen olemme kotoisissa oloissamme menettäneet milloin minnekin. ${ }^{939}$

Tieteen päivillä pidetty puhe oli Granön viimeinen julkinen esiintyminen, ja seuraavana vuonna Maat ja kansat -teoksessa ilmestynyt Suomi-kuvaus päätti hänen 1901 alkaneen julkaisutoimintansa. Yli 50 vuoden aikana hän oli julkaissut monografioita ja artikkeleita kaikkiaan kahdeksalla eri kielellä, joista käytetyimmät olivat suomi, saksa ja ruotsi. ${ }^{940}$

\section{Tärkeät aloitteet}

Toisen maailmansodan jälkeen Granö keskittyi tutkimuksen sijasta opetukseen ja tärkeiksi kokemiensa hankkeiden ja asioiden edistämiseen. Tultuaan Suomalaisen Tiedeakatemian esimieheksi hän ehdotti maaliskuussa 1946 tarkoin punnittuun lausuntoon nojautuen, että Suomen Maantieteellinen Seura julkaisisi uudet painokset Suomen maantieteen käsikirjasta ja Suomen Kartastosta. ${ }^{941}$

Granö perusteli esitystään tieteen nopealla kehityksellä ja maan rajojen muuttumisella toisen maailmansodan jälkeen. Suomen Kartasto 1925 oli tarkoitettu esittelemään uutta itsenäistä valtiota, mutta sen antama kuva ei enää vastannut sodanjälkeistä todellisuutta. Samoin 1936 ilmestynyt Suomen maantieteen käsikirja oli ollut huomattava tieto- ja lähdeteos, mutta se oli ilmestynyt vain suomeksi ja oli nyt auttamatta vanhentunut.

Koska Suomen Maantieteellisen Seuran voimavarat eivät riittäneet kahden suuren hankkeen samanaikaiseen toteuttamiseen, sen tuli Granön mukaan aluksi suunnata voimavaransa englannin- ja venäjänkielisen käsikirjan julkaisemiseen. Kun tämä työ oli saatettu päätökseen, ohjelmaan tuli ottaa Suomen Kartaston neljännen laitoksen laatiminen. Teosten avulla Suomi voisi jälleen kerran näyttää maailmalle, millainen se oli ja mikä oli sen tieteen taso. ${ }^{942}$ 


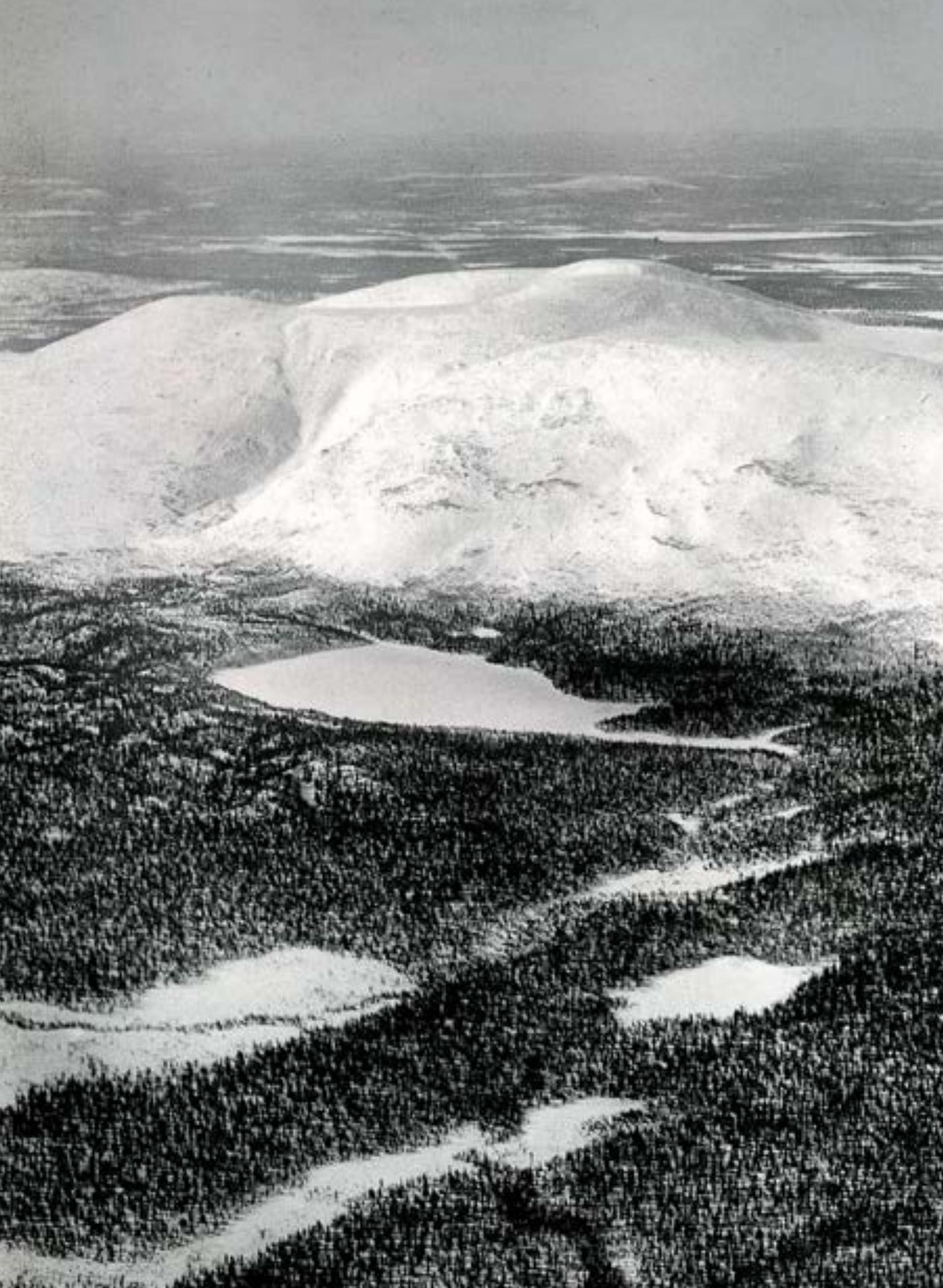



Suomen Maantieteellisen Seuran hallitus hyväksyi yksimielisesti esityksen ja valitsi Granön käsikirjan toimituskunnan puheenjohtajaksi. Toimituskunnan jäseneksi kutsuttiin hänen esityksestään professorit Risto Jurva, Jaakko Keränen, Viljo Kujala,
Edellinen aukeama: Granö laati 1951 ilmestyneeseen Suomen maantieteen käsikirjaan asutusta, maantieteellisiä alueita sekä korkeussuhteita ja pinnanmuotoja kuvaavat luvut. Pallastuntureita esittävä kuva sai tuekseen kuvatekstin: "Kuperarinteisiä kupukohoumia ja rinteisiin syöpyneitä vakolaaksoja (kuruja)". Aarne Laitakari ja Uuno Pesonen. Toimitussihteerinä oli ensin Erkki Kanervo ja teoksen viimeistelyvaiheessa Pentti Kalaja. ${ }^{943}$

Toimituskunnan puheenjohtajana Granö joutui kirjan suunnittelun ja toimittamisen valvonnan ohella hankkimaan varat työn toteuttamiseen. Hän tunsi hyvin opetusministeriön vaikutusvaltaisen kansliapäällikön Arvo Salmisen, jonka avulla hän pääsi keskustelemaan asiasta SKDL:ään kuuluneen opetusministeri Eino Kilven kanssa. Ilmeisesti Granön ratkaisu julkaista teos myös venäjäksi oli tärkein syy siihen, että Neuvostoliittoon myönteisesti suhtautunut ministeri myönsi valtiontalouden kireästä tilanteesta huolimatta miljoonaa markkaa käsikirjoituksen julkaisemista varten. ${ }^{944}$

Saatuaan käsikirjan perusrahoituksen turvatuksi Granö ryhtyi neuvottelemaan yksityisten kustantamoiden kanssa sen julkaisemisesta myös kotimaisilla kielillä. Neuvottelut johtivat nopeasti myönteiseen päätökseen, sillä hän saattoi ilmoittaa jo syyskuussa, että Kustannusosakeyhtiö Otava oli valmis julkaisemaan suomenkielisen ja Söderström \& Co ruotsinkielisen painoksen. ${ }^{945}$

Kun alkurahoitus oli saatu kuntoon, teoksen valmistaminen aloitettiin nopeasti. Se päätettiin julkaista ensimmäisen painoksen suuntaviivojen mukaisesti mutta sitä tiivistetympänä laitoksena. Työ eteni aluksi hyvin, mutta 1940-luvun lopulla jouduttiin toteamaan, että ilman lisärahoitusta hanketta ei ollut mahdollista viedä päätökseen. Ongelman ratkaisi jälleen rahankeruumatkalle usutettu Granö, jonka neuvottelutaitojen ansiosta opetusministeriö myönsi käsikirjaa varten 1949 1,7 miljoonaa markkaa. ${ }^{946}$

Uusi suomenkielinen Suomen maantieteen käsikirja ilmestyi 1951 yli 500 sivun laajuisena. Vaikka sen sivumäärä oli viidenneksen pienempi kuin edellisen laitoksen, sen aihepiiriä oli laajennettu seitsemällä uudella luvulla: geodeettiset työt, luonnonsuo- 
jelu, kansankulttuurin maantieteelliset alueet, siirtoväki, maanmittaus ja maanjaot, maantieteelliset alueet ja seutukaavoitus. Käsikirjassa tarkasteltiin monipuolisesti ja analyyttisesti Suomen olosuhteita lähinnä yleismaantieteelliseltä näkökannalta. Kirjoittajakunta koostui eri alojen parhaista asiantuntijoista, joista mainittakoon Aarne Laitakari, Matti Sauramo, K. Järnefelt, Väinö Auer, Reino Kalliola, Aarne Äyräpää, Yrjö Ilvessalo, Eino Jutikkala, Kustaa Vilkuna ja vanha presidentti K. J. Ståhlberg. ${ }^{947}$

Granö oli ajatellut kirjoittaa teokseen vain asutusta ja maantieteellisiä alueita käsittelevät luvut, mutta edelliseen käsikirjaan maan korkeussuhteita ja pinnanmuotoja kuvaavan luvun laatineen Väinö Tannerin siirryttyä Ruotsiin hän otti vastuulleen myös tämän osuuden. Kirjoitus oli hänen ainoa geomorfologinen tutkimuksensa, jonka kohteena ei ollut Altai. Se perustui suuressa määrin Suomen maantieteelliset alueet -teoksen lukuun maakamaran muotoalueista. Uutta kirjoituksessa oli kallioperän ja korkokuvan välisten suhteiden pohdinta ja geneettinen tulkinta, jossa kuvastui hänen viimeisessä Altain geomorfologiassaan esittämänsä Walther Penckin mukainen näkemys peneplaanin muodostumisesta. Hän piti todennäköisenä, että Suomen maisemille luonteenomaiset tasaantumispinnat olivat saaneet muotonsa vasta tertiäärikaudella, siis paljon myöhemmin kuin aiemmin oli otaksuttu. ${ }^{948}$

Käsikirjan ruotsinkielisen painoksen julkaiseminen kaatui taloudellisiin ongelmiin, mutta englanninkielinen painos ilmestyi 1952 Fennia-sarjan niteenä 72. Kirjan merkitys oli suuri kylmän sodan aikana. Se kertoi ulkomaisille lukijoille, että sodassa kärsimistään aluemenetyksistä ja mittavista siirtoväen asuttamiseen liittyvistä ongelmista huolimatta Suomi oli säilyttänyt itsenäisyytensä ja demokraattisen poliittisen järjestelmänsä. Sanomaa tuki American Geographical Societyn omassa sarjassaan 1955 julkaisema Finland and Its Geography -teos, jonka Raye R. Platt oli toimittanut suurelta osin käsikirjan ja Granön sekä muiden suomalaisten maantieteilijöiden tutkimusten pohjalta. ${ }^{94}$

Venäjänkielinen laitos valmistui hakemistoa lukuun ottamatta painokuntoon vuoden 1951 alkupuolella, jolloin seura jäi odottamaan työn loppuun saattamisen mahdollistavaa valtionapupäätöstä. Sen saaminen viipyi kuitenkin niin kauan, että 
työn jatkaminen tuli tarpeettomaksi. Moskovassa ilmestyi 1953 täysin yllättäen piraattipainos, jonka neuvostoliittolaiset olivat kääntäneet itse. Teos oli asiasisällöltään korkeatasoinen ja alamuistutuksia lukuun ottamatta korrekti, vaikka siitä puuttui kolme lukua eli siirtoväkeä, maanmittausta ja maanjakoja sekä seutukaavoitusta käsittelevät tekstit. ${ }^{950}$

Niukkojen taloudellisten olojen vuoksi Suomen Kartaston neljännen painoksen valmistelut voitiin käynnistää vasta 1953. Tuolloin perustetun kartastotoimikunnan puheenjohtajaksi valittiin Granö, joka onnistui jälleen hankkimaan opetusministeriöltä varmuuden rahallisesta avustuksesta ja teki Kustannusyhtiö Otavan kanssa teoksen julkaisemisesta samankaltaisen sopimuksen kuin edellisen kartaston suhteen. ${ }^{951}$

Kun Granön terveys murtui, hän erosi toimikunnasta vuoden 1955 lopulla. Kartastotoimikunnan uudeksi puheenjohtajaksi nimitettiin professori Väinö Auer. Kartaston toimittajaksi valittiin Leo Aario ja toimitussihteeriksi juuri väitellyt Olavi Granö, jonka tehtävänä oli pääosin huolehtia puhtaaksi piirtämisen ja painatuksen valvonnasta. Granön saatua 1958 nimityksen Turun yliopiston apulaisprofessoriksi Aario otti vastuulleen myös hänen tehtävänsä. 952

Aarion ja Helsingin yliopiston maantieteen laitoksen henkilökunnan yhteisponnistuksen ansiosta kartasto ja sen tekstiosa ilmestyivät lopulta 1961. Kartasto oli edellisten painosten laajuinen, mutta sitä oli uudistettu niin esitysteknisesti kuin aiheenkäsittelyltään. Siinä pyrittiin staattisen yleiskuvan ohella esittämään myös alueiden dynamiikkaa, mistä syystä karttoihin liitettiin usein kehityksen suuntaa osoittavia diagrammeja.. .53

J. G. Granö ryhtyi 1940-luvun lopulla luomaan edellytyksiä soveltavan maantieteellisen tutkimuksen lisäämiselle. Suomalaisen Tiedeakatemian vuosijuhlassa 1946 pitämässään esitelmässä "Aluemaantieteellisestä tutkimuksesta ja sen tehtävistä maassamme" hän korosti, että maantiede ei ollut vain akateeminen tiede vaan sillä oli vanhastaan läheiset suhteet käytännölliseen elämään. Talous- ja liikennemaantiedettä oli harjoitettu jo kauan, mutta nyt niiden rinnalle oli nousemassa uusi ala eli aluesuunnittelu, joka oli saanut ulkomailla merkittävän aseman. ${ }^{954}$ 
Aluesuunnittelu liittyi maantieteeseen Granön mukaan siten, että maantiede oli omalla tavallaan ihmisen ekologiaa. Sen tavoitteena oli antaa tieteellinen kokonaiskäsitys ihmisen ympäristöstä, johon kohdistui monenlaisia paineita yhteiskunnallisen ja teknisen kehityksen seurauksena. Paine saattoi olla niin verkkaista ja vähittäistä, että luonnonympäristö pystyi mukautumaan siihen, mutta myös niin voimakasta, että siitä aiheutui suuria ongelmia. Nopeat väkiluvun muutokset, teollisuuslaitosten sijoittamiset vääriin paikkoihin ja muut taloudellisten etujen vuoksi tehdyt häikäilemättömät virheratkaisut saattoivat johtaa luonnon kannalta kohtalokkaisiin seurauksiin. ${ }^{955}$

Aluesuunnittelun avulla olisi Granön mukaan mahdollista toisaalta estää pahimmat virheet ja toisaalta suunnata toimintaa sellaisiin paikkoihin, joihin ne soveltuivat parhaiten. Tavoitteena ei siis ollut lyhyen ajanjakson suunnitelma mahdollisimman suuren ja nopean hyödyn saavuttamiseksi, ei myöskään suunnitelmatalous laajemmalla pohjalla, vaan nimenomaan alueiden jatkuva kehittäminen. Päämääränä oli taata "alueen sopusuhtainen kulttuurimaantieteellinen kehitys sanan parhaassa merkityksessä". .56

Aluesuunnittelu oli Granön mukaan lähtenyt liikkeelle ensimmäisen maailmansodan jälkeen Englannin ja Saksan kaltaisissa isoissa maissa, joissa suuri väkiluku ja tehokas elinkeinotoiminta olivat pakottaneet aloittamaan jo varhain toimet luonnonympäristön suojelemiseksi. Vähitellen myös pienissä maissa oli ryhdytty kiinnittämään asiaan vakavaa huomiota, ja esimerkiksi Sveitsissä tehtiin 1940-luvun alussa seikkaperäisesti perusteltu ehdotus yleisvaltakunnallisen aluesuunnittelun aikaansaamiseksi. ${ }^{957}$

Suomalaiset asuivat Granön mukaan kulttuurimaailman karussa ja vähäväkisessä rajavyöhykkeessä, jossa oli ollut niin paljon tilaa ekstensiiviselle taloudelle, ettei "meillä ole vielä ollut aihetta selvittää itsellemme, miten meidän olisi tarkoituksenmukaisimmin käytettävä elintilaamme". Tilanne oli kuitenkin muuttumassa, varsinkin kun Neuvostoliitolle luovutetuilta alueilta siirtyneelle 400000 suomalaiselle oli löydettävä uusi asuinsija ja toimeentulon edellytykset. Siksi olisi syytä käynnistää 
yleisvaltakunnallinen aluesuunnittelu, jonka ensimmäisenä tehtävänä olisi selvittää ja kartografisesti esittää niin eri elinkeinoille ja asutukselle kuin yhteiskunnan muihin tarpeisiin soveltuvat alueet. Korostaessaan näin maantieteen tarjoamia valmiuksia hän pyrki tietoisesti myös luomaan maantieteilijöille uusia työtilaisuuksia koulumaailman ulkopuolelta. ${ }^{958}$

Granön esitys perustui vankkaan asiantuntemukseen. Kuten aiemmin on todettu, hän oli havainnut 1930-luvun alussa, että Suomi jakautui kehittyneeseen Kulttuuri-Suomeen ja luonnontilaiseen Luonnon-Suomeen. Tämä näkemys oli vain vahvistunut seuraavien vuosien aikana, jolloin hän oli perehtynyt uuteen aluetieteelliseen tutkimukseen niin Suomessa kuin ulkomailla ja alueelliset erot alkoivat voimistua maan talouselämän päästyä jälleen vauhtiin suuren talouslaman jälkeen.

Väinö Auer oli käynnistänyt jo 1930-luvulla Helsingin yliopistossa asutuskeskuksiin ja niiden talousalueisiin liittyvän tutkimussarjan, joihin liittyi Oiva Tuomisen pitkään vireillä ollut tutkimus Lounais-Suomen toiminnallisesta aluerakenteesta. Myös Auerin langon, 1945 yliopiston liikenne- ja asutusmaantieteen dosentiksi nimitetyn Reino Ajon heti sodan jälkeen ilmestyneet tutkimukset Tampereen liikennealueesta ja liikennealueiden kehittymisestä Suomessa nostivat esiin kysymyksen alueellisen suunnittelun tarpeesta ja vaikuttivat myös Granön ajattelun kehittymiseen. Granö myös auttoi Ajoa saamaan Englannista W. R. Meadin välityksellä uutta aluesuunnittelua käsittävää kirjallisuutta. ${ }^{959}$

Granö ei jäänyt vain odottelemaan aluesuunnittelun käynnistymistä vaan tilasi suunnittelemansa Suomen maantieteen käsikirjan uuteen painokseen artikkelin seutukaavoituksesta Teknillisen korkeakoulun asemakaavaopin professorilta Otto-Iivari Meurmanilta. Hän oli juuri 1947 ilmestyneessä Asemakaavaopissa vaatinut seutukaavoituksen aseman vahvistamista ja antanut muun muassa lähiö-käsitteelle kaupungin tai taajaman osaa tarkoittavan merkityksen, joka viimeistään 1960-luvun aikana sivuutti Granön luoman, aistiympäristöä tarkoittavan merkityksen. ${ }^{960}$

Käsikirjaan laatimassaan monipuolisessa ja humaanissa kirjoituksessa Meurman vaati voimakkaasti seutukaavoituksen edistämistä Suomessa. Se oli hänen mukaansa 
nyt entistäkin tärkeämpää, koska Suomen pinta-ala oli pienentynyt sodan vuoksi huomattavasti ja koska siirtoväen asuttaminen vaati erityistoimia. Maahan olisi tullut viipymättä perustaa valtakunnallinen suunnitteluelin yhdenmukaistamaan eri seutujen suunnittelua. ${ }^{961}$

Granön ja Meurmanin toivomukset aluesuunnittelun käynnistämisestä saivat uutta vauhtia, kun pääministeri Urho Kekkosen 1952 ilmestynyt kirjanen Onko maallamme malttia vaurastua käynnisti voimakkaan aluepoliittisen keskustelun. Sen tuloksena virisi teollistamispolitiikka, joka suuntasi tukirahat Pohjois-Suomeen, suunnilleen Granön Luonnon-Suomeksi kutsumalle alueelle, ja laaja alueelliseen erilaistumiseen ja kehittyneisyyseroihin keskittynyt tutkimustoiminta. Ilmari Hustich ja monet muut maantieteilijät osallistuivat voimakkaasti suomalaisen aluepolitiikan muotoutumiseen. ${ }^{962}$

Granö toimi viimeisenä professorivuotenaan 1950 Suomen Maantieteellisen Seuran puheenjohtajana. Puheenjohtajakauden jälkeen hän palveli suomalaista maantieteilijäyhteisöä vielä vuoden seuran hallituksen jäsenenä tehden esityksen, jonka perusteella Seura päätti liittyä 1951 Kansainvälisen maantieteellisen unionin IGU:n jäseneksi. Esityksen taustalla olivat Granön keskustelut unionin johtohenkilöiden kanssa Lissabonissa 1949 pidetyn maantieteilijäkongressin aikana ja sen presidentin George B. Cresseyn kirjeitse lähettämät kehotukset. Maantieteilijöiden pääsy maailmanlaajuiseen järjestöön oli tärkeä päänavaus aikana, jolloin Suomessa suhtauduttiin hyvin epäilevästi kaikkeen, minkä saattoi tulkita pyrkimykseksi lähentyä länsimaita. ${ }^{963}$

\section{Kansainväliset suhteet}

Toinen maailmansota ravisteli yhteiskunnallisia rakenteita ja arvoja niin Suomessa kuin koko maailmassa. Sodan aikana tiede oli valjastettu palvelemaan sotaponnistuksia, ja tutkijat työskentelivät täysin voimin maidensa sodanpäämäärien hyväksi. Aseiden vaiettua vallitsi uusi järjestys, johon myös tiede joutui sopeutumaan. Tämä merkitsi vanhojen tutkimusperinteiden katkeamista ja uusien syntyä. Suomen tieteen 
vanha suunnannäyttäjä Saksa menetti asemansa, ja Yhdysvallat nousi maailman tieteen johtomaaksi. ${ }^{964}$

Kun Suomi ryhtyi elvyttämään ja rakentamaan kansainvälisiä tiedesuhteita, Granö soveltui erinomaisesti näihin tehtäviin. Hän ei ollut sitoutunut saksalaissuuntaukseen ja omasi ennestään hyvät suhteet eri puolille maailmaa, mistä olivat osoituksena useat työ-, kirjeenvaihtaja- ja kunniajäsenyydet eri maiden maantieteellisissä seuroissa. Hyvä kielitaito teki mahdolliseksi laajan kirjeenvaihdon ulkomaalaisten tutkijoiden kanssa, mutta Granö kärsi monen muun suomalaisen huippututkijan kanssa siitä, että hän ei hallinnut riittävän hyvin englantia, tieteen uutta valtakieltä. Hänen englanniksi julkaistujen tutkimustensa määrä jäi vähäiseksi, mutta Puhtaan maantieteen herättämän kiinnostuksen vuoksi häneen alettiin 1900-luvun lopulla viitata englanninkielisissä sarjoissa enemmän kuin saksankielisissä sarjoissa. ${ }^{965}$

Granö sai 1940-luvun jälkipuolella kirjeitä sellaisilta neuvostoliittolaisilta kollegoilta, jotka olivat kirjoitelleet harvakseltaan jo ennen sotaa. Valvontakomissioon hänellä ei ollut muita yhteyksiä kuin että hän sai sen varsinaiselta puheenjohtajalta G. M. Savonenkovilta ja erikoislähettiläs A. N. Abramovilta kutsun osallistua 7. marraskuuta 1946 pidettyyn lokakuun vallankumouksen vuosijuhlaan Neuvostoliiton lähetystössä Kaivopuistossa. ${ }^{966}$

Valvontakomissionin poistuttua maasta Neuvostoliiton suurlähetystöstä otettiin Granöön yhteyttä ja tarjottiin muun muassa vierailukäyntiä itänaapuriin. Vierailu ei toteutunut, mutta vaikutusvaltainen akateemikko I. P. Gerasimov kävi syksyllä 1954 tapahtuneen Suomen-matkansa aikana hänen kotonaan. Käynti oli sikäli poikkeuksellinen, että Gerasimov saapui vierailulle yksin, ilman yleensä häntä varjon lailla seurannutta politrukkia. ${ }^{967}$

Gerasimovin mukaan parin tunnin tapaamisen ilmapiiri oli slaavilaisen lämmin:

J. G. Granö oli säilyttänyt hyvän venäjän kielen taidon ja pyysi kutsumaan itseään venäläiseen tapaan nimeltä ja isännimeltä. Hän puhui siitä, että oli viettänyt elämänsä parhaat vuodet Venäjällä tehdessään maantieteellisiä kent- 
tätutkimuksia Siperiassa ja että oli säilyttänyt ikiajoiksi suuren kiinnostuksen ja rakkauden maahamme, jota pitää toisena kotimaanaan. Hän kyseli minulta monista henkilökohtaisesti tuntemistaan venäläisistä maantieteilijöistä ja geologeista. Erityiset ystävyyssuhteet J. G. Granö oli säilyttänyt V. A. Obrucheviin, jonka kanssa hän oli jatkuvassa kirjeenvaihdossa. ${ }^{968}$

Virossa Granön nimi painui hieman unhoon 1940-luvulta alkaen osittain sen vuoksi, että hänen Neuvostoliiton miehityksen alta maasta poistuneisiin oppilaisiinsa August Tammekanniin ja Edgar Kantiin suunnattiin sodan jälkeen parjauskampanja, joka alkoi hellittää vasta 1960-luvun lopulla. Tämän jälkeen Virossa kiinnitettiin paljon huomiota Granön tutkimuksiin. ${ }^{969}$

Granön suhteet Ruotsiin pysyivät tiiviinä, sillä hänet tunnettiin maassa hyvin Altain vuoristoa ja Suomen maantieteellisiä alueita koskevien tutkimustensa ansiosta. Monien virolaisten maantieteilijöiden siirryttyä sodan jälkeen Ruotsiin pakolaisina hän pyrki parantamaan heidän asemaansa henkilökohtaisten viestien ja heidän ansioitaan korostavien lausuntojen avulla. Esimerkiksi August Tammekann ja Edgar Kant olivat aluksi lähes puilla paljailla jouduttuaan jättämään omaisuutensa Viroon. ${ }^{970}$

\section{Tieteellisen vuorovaikutuksen monet tiet}

Edgar Kant eli koko 1940-luvun lopun Ruotsissa hyvin ahtaissa taloudellisissa oloissa. Hänen tutkimuksiinsa parhaiten Ruotsissa perehtynyt professori Sten De Geer oli juuri kuollut, minkä vuoksi hän joutui hankkimaan toimeentulonsa Lundin yliopiston maantieteen laitoksen tarjoamista pienistä arkistojärjestelijän ja tutkimusapulaisen tehtävistä. Tilanne alkoi helpottua 1950, jolloin hän osin Granön lähettämien suositusten ansiosta sai nimityksen talousmaantieteen lehtoriksi. Vähitellen 
hänen asemansa parani niin, että hän sai 1964 hoitaakseen talousmaantieteen professuurin, josta hän jäi eläkkeelle 1967.

Saatuaan asemansa vakiinnutettua Lundin yliopistossa Kant saattoi jatkaa tutkimustyötään. Hän syventyi aluksi erityisesti keskus- ja vaikutusalue- ja muuttoliiketutkimuksiin mutta keskittyi myöhemmin pääosin monikielisen maantieteellisen sanaston laadintaan. Työ sopi hyvin kansainväliselle kielinerolle: Kant hallitsi kahtatoista kieltä.

Siirtämällä Tartossa luodun tutkimusperinteen Lundiin Kant vaikutti huomattavasti ruotsalaiseen aluetutkimukseen käytännön ja teorian tasolla. Hän esitteli Tartossa toteutettuja käytännöllisiä ratkaisuja, joita Ruotsissa voitiin käyttää hyväksi 1960-luvulla toteutetussa suuressa kuntauudistuksessa. Samalla hän perehdytti ruotsalaiset kollegansa ja apulaisensa niin Walter Christallerin keskusteoriaan, alueellisten mallien muodostamiseen ja kvantitatiiviseen pelkistämiseen kuin sosiologisiin kysymyksiin ja muuttoliiketutkimukseen.

Kantin alueteoreettiset näkemykset olivat kansainvälisesti niin merkittäviä, että Harvardin yliopiston professori ja sen arvostetun kansainvälisen seminaarin johtaja Henry Kissinger tarjosi hänelle tilaisuutta siirtyä Yhdysvaltoihin. Kant ei kuitenkaan ottanut tarjousta vastaan, koska hän ei halunnut vaihtaa jälleen maata ja koska englanti kuului hänen heikoimmin hallitsemiinsa kieliin.

Kant edusti näkemystä, jonka mukaan matemaattisten menetel-

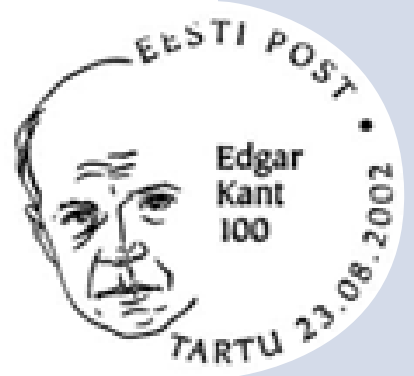
mien käyttö oli tutkimustyössä pelkkä apuneuvo. Tärkeintä oli ihmisen ja ympäristön tutkiminen sekä tiedollisessa että sosiaalisessa kontekstissa. Aika ei kuitenkaan ollut vielä kypsä tällaiselle näkemykselle, vaan pääpaino annettiin tiedon matemaattistamiselle. Kvantitatiivisen maantieteen keskeiseksi hahmoksi nousi varsinkin Yhdysvalloissa ja Isossa-Britanniassa Lundin yliopiston maantieteen professorina 195771 toiminut Torsten Hägerstrand, joka Kantin assistenttina sai omaan 
ajatteluunsa paljon vaikutteita tämän muuttoliike-, diffuusio- ja sijaintiteorioista.

Hägerstrandin, joka sai suomalaisen akateemikon arvonimen 1980, innovaatiotutkimukset ja kvantitatiiviseen simulointiin perustuvat tutkimukset loivat perustan niin sanotun Lundin koulukunnan synnylle. Hägerstrandin ja koulukunnan muiden tutkijoiden, erityisesti William Bungen, Peter Gouldin, Allan Predin ja Richard Morrillin, kehittämät diffuusio-, muuttoliike-, sijainti- ja muut teoriat ja mallit vaikuttivat maantieteelliseen tutkimukseen kaikkialla maailmassa.

Kant oli Tarton-vuosinaan 1930-luvulla vaikuttanut Suomen maantieteen kehitykseen suoraan J. G. Granön ja tämän oppilaitten J. K. V. ja Oiva Tuomisen välityksellä, mutta kolmen vuosikymmenen kuluttua hänen vaikutuksensa kanavoitui Suomeen myös Ruotsin

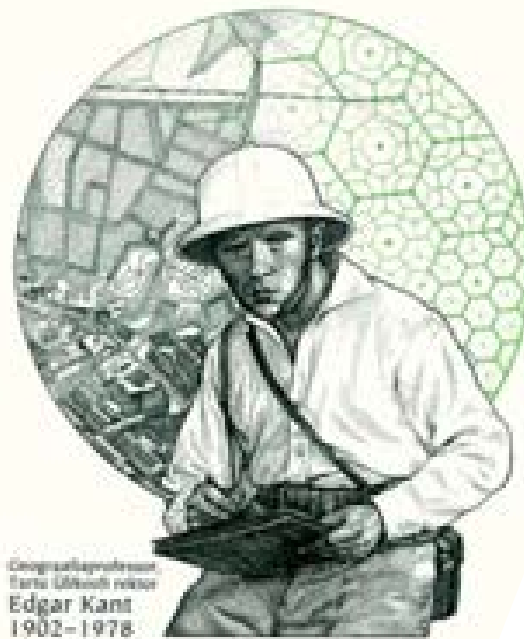

Viron postilaitos julkaisi Kantin satavuotissyntymäpäivän kunniaksi kortin ja otti käyttöön juhlaleiman 2002. ja Yhdysvaltojen kautta. Suomessa seurattiin Ruotsin esimerkkiä ja tehtiin kuntauudistus, jossa noudatettiin Virosta alun perin lähteneitä ideoita. Kvantitatiivinen vallankumous puolestaan toteutettiin suomalaisessa maantieteessä hyvin anglosaksisessa hengessä, joten Kantin ja Hägerstrandin opit saatiin ikään kuin pesuveden mukana.

Suomalaisen keskus- ja vaikutusaluetutkimuksen tärkeimmäksi kehittäjäksi nousi 1960-luvulla Mauri Palomäki, joka tunsi sekä suomalaisen että virolaisen keskus- ja vaikutusaluetutkimuksen perinteen mutta joka haki tärkeimmät vaikutteensa teorian kansainvälisiltä kehittäjiltä. Palomäki vakiinnutti Christallerin teorian aseman suomalaisen keskus- ja vaikutusaluetutkimuksen johtavana paradigmana ja loi uudenlaisen menetelmän, enumeratiivisen luokittelun, keskusten luokittelemiseksi. Myös nyt tieteellinen työ johti käytännön sovellutuksiin. Kyseistä menetelmää ryhdyttiin soveltamaan seutusuunnittelussa ja monissa muissa suunnittelutehtävissä. ${ }^{971}$ 
Saksalaiseen tiedemaailmaan Granön yhteydet taantuivat toisen maailmansodan jälkeen, vaikka joihinkin tutkijoihin, kuten Erich Obstiin ja Carl Trolliin, hän oli kirjeenvaihtoyhteydessä 1950-luvulle saakka. Vanhoja saksankielisiä suhteita täydensi nyt Sveitsi, jonne monien suomalaisten tiedemiesten tavoin myös Granön huomio suuntautui. Asiaan vaikutti se, että alppimaahan oli siirtynyt jo 1930-luvun puolivälissä saksalaisia tutkijoita, jotka myöhemmin tarjosivat sekä maanmiehilleen että muille kollegoilleen mahdollisuuden esiintyä kansainvälisissä konferensseissa ja symposiumeissa. Granölle läheisiä alue- ja maisematutkijoita Sveitsissä olivat Hans Boesch, Ernst Winkler, Hans Carol ja Heinrich Gutersohn, ja esimerkiksi A. Captin ja Werner Schaffnerin väitöskirjat Zürichissä perustuivat hänen metodologiaansa.972

Granön oli tarkoitus pitää Suomalaisen Tiedeakatemian edustajana syksyllä 1947 päëesitelmä Altaista Zürichissä suuressa vuoristotutkijoiden kongressissa, jossa hän oli toivonut voivansa uudistaa sodan takia katkenneita suhteitaan vanhoihin tutkijakollegoihinsa. Näihin lukeutui ranskalainen Alppien tutkija André Allix, joka oli käsitellyt hänen geomorfologisia tutkimuksiaan useissa kirjoituksissa 1910-luvulta alkaen.973

Katkerien vastoinkäymisten pitkä lista sai kuitenkin jatkoa, kun Granö joutui suureksi pettymyksekseen perumaan viime tingassa matkansa Väinö Auerin lähdettyä yllättäen Argentiinaan. Velvollisuudentuntoinen Granö piti sopimattomana sitä, että molemmat maantieteen professorit olisivat olleet poissa juuri lukuvuoden alkaessa. ${ }^{974}$

Granö osallistui keväällä 1949 Suomen Tiedeseuran, Suomalaisen Tiedeakatemian ja Suomen Maantieteellisen Seuran edustajana Lissabonin maantieteilijäkongressiin. Lentomatka Helsingistä Lissaboniin, yli hiljalleen sodasta toipuvan Euroopan, oli vaikuttava kokemus:

Lentomatka tänne oli todella elämys. Helsingistä Tukholmaan olivat kylläkin pilvet kiusana, ja hiukan satelikin, niin että myöhästyin siitä koneesta, jolla olisi pitänyt jatkaa, mutta koneesta oli sähkötetty, että tällainenkin ukkeli on menossa Lontooseen, ja niin sattui varsin sopivasti nopeamenoinen hollantilainen kone lähtemään Kööpenhaminaan ja sieltä pitemmittä viivytyksittä toinen 
Lontooseen. Etelä-Ruotsin yllä oli vielä pilveilyä, mutta Kööpenhaminasta Lontooseen näin jo koko maailman ihanuudet allani, enimmäkseen n. 2000 m korkeudelta. Siellä täällä oli "kuoppaista”, mutta ei siitä haittaa ollut. Lontoossa yötä, aamupäivällä matka jatkui, pysähdys Bordeauxissa, sieltä edelleen Pyreneitten niemimaan poikki Lissaboniin. ${ }^{975}$

Granö piti kongressissa kaksi ranskankielistä esitelmää, Altain jääkautisista laaksoterasseista ja maantieteellisistä aluejakomenetelmistä, ja osallistui eri puolille Portugalia tehtyihin retkiin, muun muassa viikon kestäneelle matkalle Madeiralle. Kongressin osanottajalista oli kylmän sodan rintamalinjojen mukainen: Paikalla oli 600 osanottajaa, joista yksikään ei ollut Neuvostoliitosta. Saksaa, kongressien vanhaa mahtimaata, edusti vain Hermann Lautensach, tunnettu Portugalin-tutkija, joka aloitti pian kirjeenvaihdon Granön kanssa ja omisti myös tälle yhden tutkielmistaan. ${ }^{976}$

Keväällä 1953 Granö osallistui Suomalaisen Tiedeakatemian ja Suomen Maantieteellisen Seuran edustajana Berliinin maantieteellisen seuran 125-vuotisjuhliin Länsi-Berliinissä. Hän oli nähnyt Berliinin vanhassa loistossaan 1920-luvun lopulla mutta ei ollut käynyt Saksassa vuoden 1930 jälkeen, ja muutenkin hänen tietämyksensä maan muuttuneista oloista oli vähäinen. Vastaavasti myös eräiden läsnäolijoiden tieto Granön tutkijaprofiilin muutoksista osoittautui huonoksi. Tämä näkyi konkreettisesti siten, että maantieteellisen seuran puheenjohtaja E. Fels katsoi aiheelliseksi esitellä juhlakokouksessa kunniajäseneksi valitun Granön kaksi kertaa, kahtena toisistaan poikkeavana tutkijahahmona: toisaalta arkeologina, geologina ja geomorfologina sekä toisaalta aluetieteen teoreetikkona. ${ }^{977}$

Granö oli lähtenyt Hilma-rouvansa kanssa matkaan hyvissä ajoin, joten hän saattoi ennen Berliiniin saapumista tutustua viiden päivän ajan Pariisin nähtävyyksiin. Ranskan pääkaupunki oli selvinnyt miehityksestä huolimatta hyvin sodasta, mutta Saksan vanha ykkösmetropoli oli saanut maksaa hirvittävän hinnan Hitlerin politiikasta. Erityisesti keskikaupungilla näkyi kaikkialla merkkejä lentopommituksista ja tulipaloista, ja laajat tyhjät aukiot todistivat yhä hävityksen laajuudesta ja perin- 
pohjaisuudesta. Kokeneena matkahavaintojen tekijänä Granö osasi kuitenkin katsoa raunioiden taakse: "Toisaalta saimme kuitenkin vakuuttavan kuvan määrätietoisesta eteenpäin pyrkivästä, kohti aikaisempaa mahtiasemaansa nopeasti kehittyvästä suuresta maailmankaupungista." ${ }^{978}$

\section{Palkintoja ja kunnianosoituksia}

Granön nousu yhdeksi Suomen tieteen johtohahmoksi 1940-luvun lopulla näkyi myös siten, että hänelle myönnettiin monenlaisia kunnianosoituksia ja palkintoja. Vuonna 1950 hän sai tieteellisistä ansioistaan korkean Suomen Valkoisen Ruusun Ritarikunnan 1 luokan komentajamerkin. Presidentinlinnan itsenäisyysjuhliin hänet oli kutsuttu Turun yliopiston rehtorina 1930-luvulla kahdesti, ja sodan jälkeen kanslerina kutsu tuli useita kertoja. Toukokuun lopulla 1952 hän osallistui kutsuttuna vieraana sekä presidentti J. K. Paasikiven Ruotsin kuninkaalle Kustaa VI Aadolfille ja tämän puolisolle Louiselle tarjoamille juhlapäivällisille että Helsingin yliopiston juhlasalissa pidettyyn tilaisuuteen, jossa kuningas promovoitiin filosofisen tiedekunnan kunniatohtoriksi. ${ }^{779}$

Suomen Maantieteellinen Seura myönsi Säätytalossa pitämässään juhlakokouksessa 18. huhtikuuta 1947 Granölle Mannerheimin jälkeen toisen kultaisen Fenniamitalinsa. Palkinnon perusteena olivat tämän ansiot Sisä-Aasian vuoristojen pitkäaikaisena tutkijana ja nykyaikaisen maisematieteen luojana. Kahden ensimmäisen kultaisen Fennia-mitalin saajan tiet kohtasivat viimeisen kerran 1951, jolloin Granö sai kunniatehtävän kirjoittaa Terraan marsalkka Mannerheimin nekrologin. ${ }^{980}$

Seuran järjestämässä juhlavassa palkinnonjakotilaisuudessa Granötä kiitettiin muun muassa siitä, että hän oli yltänyt suuriin saavutuksiin vaatimattomista resursseista huolimatta. Hän otti palkinnon kiitollisena vastaan mutta ei malttanut olla keventämättä tilaisuuden ylevää tunnelmaa. Hän totesi, että seura oli ollut oikeassa todetessaan, että hän oli tehnyt tutkimusmatkansa Etelä-Siperian vuorimaassa ja Mongoliassa ilman hyvin varustettujen karavaanien tukea. Seura oli kuitenkin unohtanut 
yhden mainitsemisen arvoisen asian: Myös henkiset edellytykset olivat olleet varsin vaatimattomat. ${ }^{981}$

Juhlakokouksen päätteeksi Granö piti esitelmän "Tunturilakeuksista ja ruuhilaaksoista Keski-Aasian pohjoisosassa", jossa hän kuvasi monipuolisesti ja tarkasti Neuvostoliiton ja Mongolian rajaseutujen maantieteellisiä oloja. Aihetta valitessaan hän ei ollut tiedemiehenä ilmeisesti ottanut lainkaan huomioon sitä, että maassa piti valtaa valvontakomissio, jonka yhtenä keskeisenä tavoitteena oli pitää huolta siitä, että Suomessa olisi mahdollisimman vähän kartografista tietoa itärajan takana olevista strategisista alueista. ${ }^{982}$

Vuonna 1948 Granö sai Suomalaisen Tiedeakatemian kunniapalkinnon tunnustukseksi suurista ansioista maantieteen alalla. Tieteellisten seikkojen ohella palkinnon perusteissa kiinnitettiin huomiota hänen ilmaisurikkauteensa:

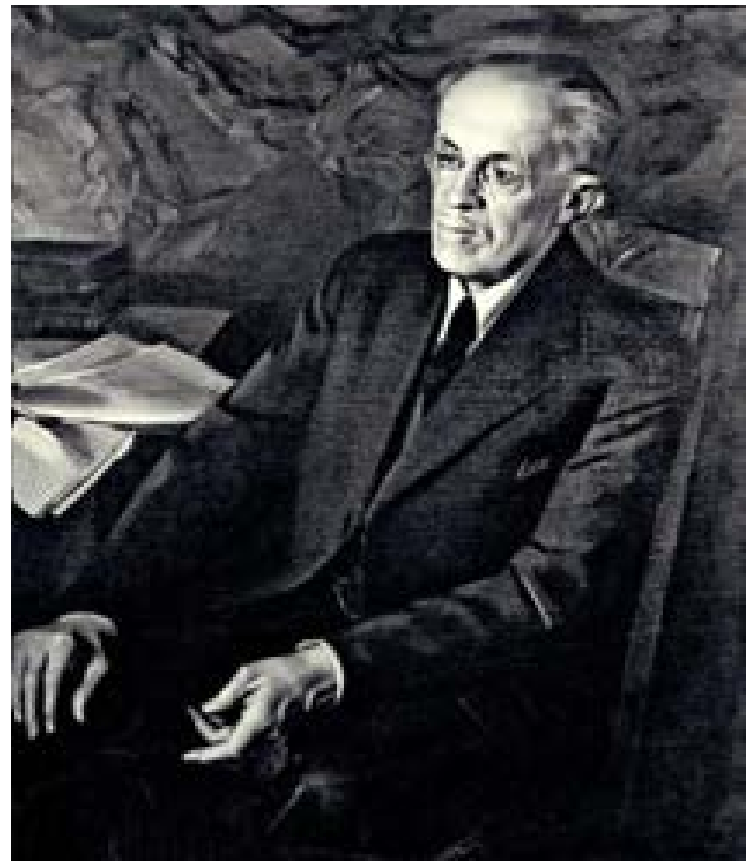

Valokuvajäljennös taiteilija Emil Rautalan maalaamasta J. G. Granön muotokuvasta. Maaliskuun 26. päivänä 1945 paljastetun muotokuvan lahjoittivat Turun Yliopistolle kauppaneuvokset Heikki Kestilä ja J. G. Nordström.

Kaikille Granön tutkimuksille, tieteellisille ja kansantajuisille, antavat leimansa syvällinen eläytyminen esitettäviin kysymyksiin, laajat tiedot, johdonmukainen käsittely, selkeä esitystapa ja hiottu kielellinen muoto. ${ }^{983}$

Alfred Kordelinin säätiö oli myöntänyt Granölle kunniapalkintonsa jo 1934, mutta se myönsi palkinnon toistamiseen vuosijuhlassaan 1949. Vuonna 1952 Granö kutsuttiin Suomen Kulttuurirahaston Kannatusyhdistyksen kunniajäseneksi, ja täyttäessään 70 vuotta 14. maaliskuuta 1952 hänen kunniakseen lyötiin juhlamitali. Mitalin suunnitellut kuvanveistäjä Essi Renvall oli aluksi ajatellut ikuistaa siihen suurmiestyyliin sopivan pitkäkoipisen uljaan ratsun, mutta tutustuttuaan Granön kuviin mongo- 


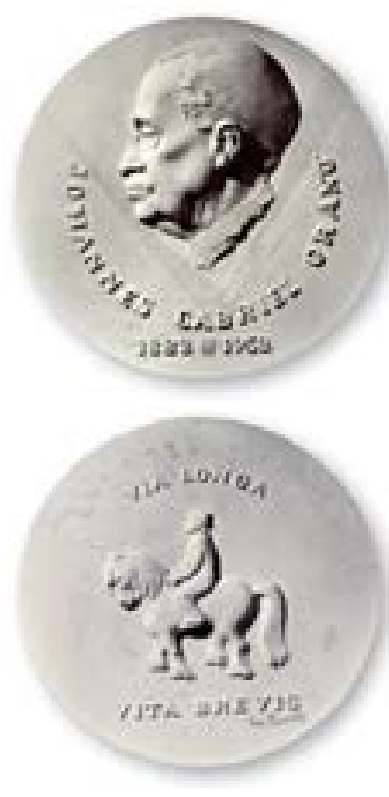

lialaisista pienikokoisista hevosista hän tuli toisiin aatoksiin. Mitaliin tuli pieni työjuhdan oloinen hepo, ja sen takapuolta koristaa Granön valitsema tunnuslause, jossa perinteinen ars oli muutettu via-sanaksi: Via longa, vita brevis (Tie pitkä, elämä lyhyt). ${ }^{984}$

Mitalia lyötiin kolme suurta kappaletta: Helsingin ja Turun yliopistoihin sekä Granön kotiin. Renvall viimeisteli mitalinsa yleensä huolellisesti, mutta nyt hänelle sattui pieni lipsahdus. Toisen etunimen alkukirjain meni väärin, ja niin Gabrielista tuli Cabriel.985

Turun yliopisto muisti monin tavoin pitkäaikaista professoriaan, rehtoriaan ja kansleriaan. Yliopiston juhlasalissa paljastettiin 26. maaliskuuta 1945 Granön muotokuva, jossa taiteilija Emil Rautala toi esiin hänen tutkimusmatkailijataustansa maalaamalle taustalle himmeän punaisin ja lämpimän ruskein värisävyin Aasian ja Altain kartan. Maalauksen kustansivat Turun yliopiston vanhat tukijat, kauppaneuvokset Heikki Kestilä ja J. G. Nordström. Erotessaan kanslerin virasta hän sai yliopiston suuren muistomitalin, ja kevään 1955 promootiossa hänet vihittiin yliopiston kunniatohtoriksi..$^{986}$

Granön tutkimusmatkailijan maine näkyy maasto- ja tähtikartoissa. Altain vuoristossa lähellä Mongolian rajaa on nimetty yksi jäätikkö Granön mukaan ja useita pikkuplaneettoja suomalaisten mukaan 1935-53 ristinyt Yrjö Väisälä antoi planeetta numero 1451:lle nimen Grano. ${ }^{987}$

Granö oli saanut Emil Aaltosen säätiöltä sen kunniapalkintoon rinnastuvan suuren apurahan 1943. Koska nimitys kunniapalkinto otettiin virallisesti käyttöön vasta 1950, hänelle voitiin myöntää palkinto vielä toistamiseen maaliskuussa 1955. Vastaanottaessaan palkinnon Granö iloitsi siitä, että palkintoon ei liittynyt minkäänlaisia velvoitteita:

Olenhan jo siirtymässä siihen ikään, jolloin varsinainen aktiivinen toiminta lähentelee luonnonlakien mukaan päättymisvaihettaan. Älköön kuitenkaan tätä vii- 


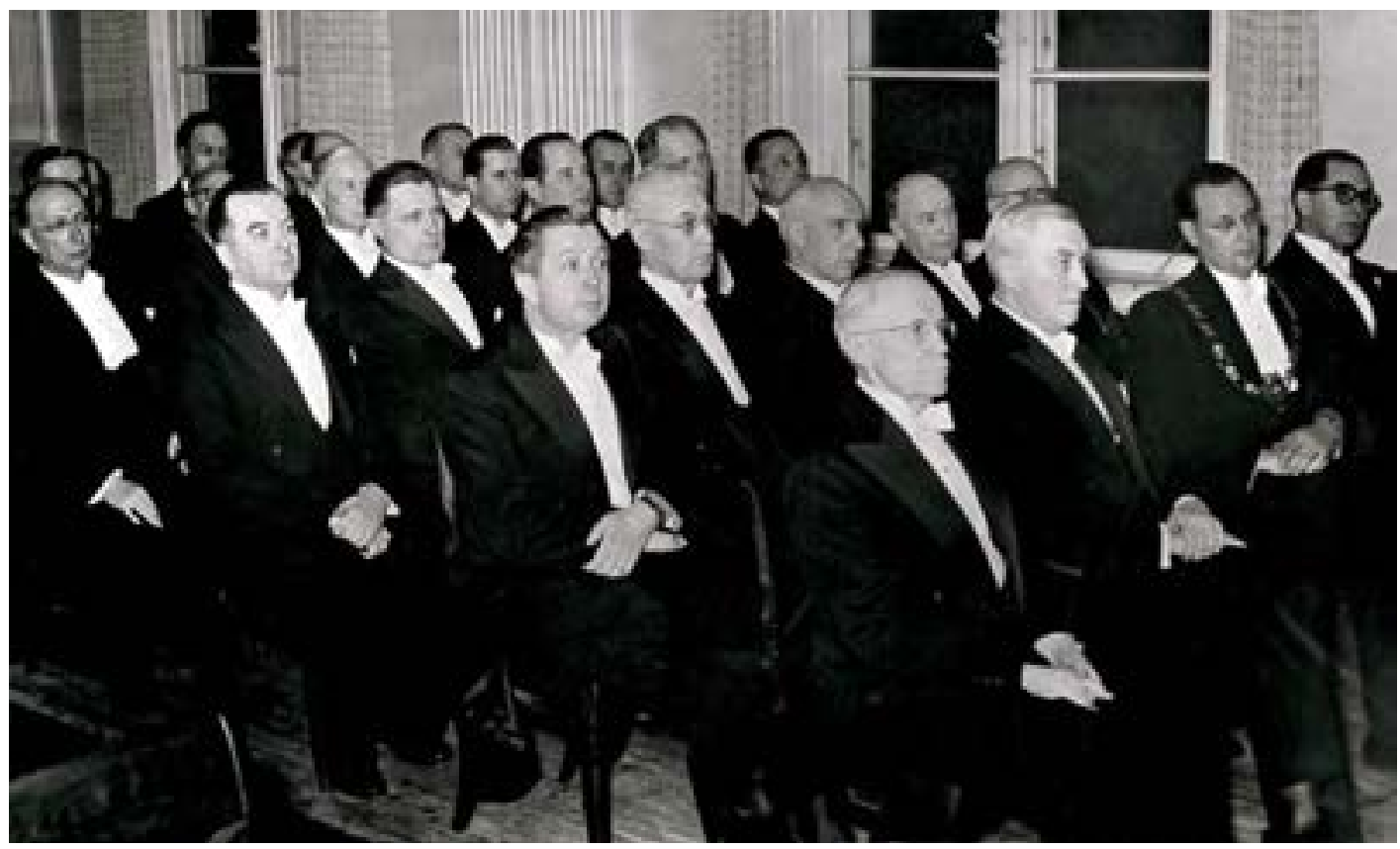

Turun Yliopiston vuosijuhla 28.2.1955. Ensimmäisessä rivissä vasemmalta oikealle eroava kansleri J. G. Granö, uusi kansleri T. E. Olin, rehtori Osmo Järvi, vararehtori Tauno Nurmela.

Toinen rivi: professorit Toivo Salmi, A. S. Rosenqvist, A. R. Klossner ja Einar W. Juva.

Vuoden 1954 Tieteen päivien johtoryhmä.

Vasemmalta Paavo Ravila, P. J. Myrberg, J. G. Granö ja Edwin Linkomies, päivien varsinainen ideoija.

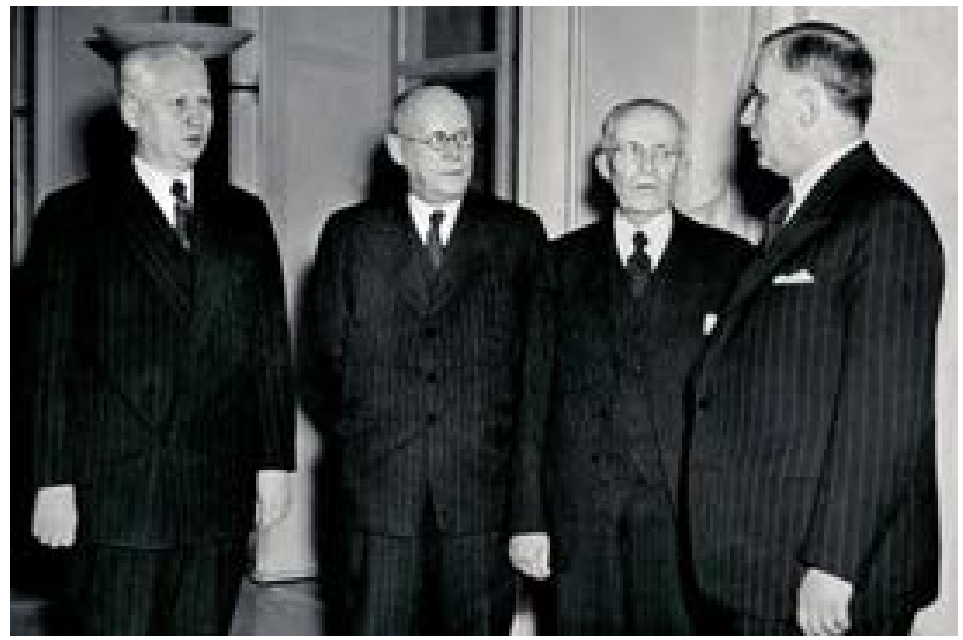

meksi mainittua toteamusta ymmärrettäkö väärin. Elän päinvastoin edelleen siinä valoisassa toivossa, että saan mahdollisuuden saattaa julkaisukuntoon tutkimusmatkoilla Keski-Aasiassa keräämäni materiaalit, jotka vielä ovat muokkaamatta. ${ }^{98}$ 


\section{Kuolema}

\section{Vakava sairaus}

Granölle ei suotu tilaisuutta tutkimustensa täydentämiseen, sillä hänen terveytensä alkoi nopeasti heikentyä maaliskuussa 1955. Kunnon huononeminen tuli pienoisena yllätyksenä. Hänen oli todettu sairastavan vatsasyöpää vuoden 1952 alussa, mutta professori Väinö Seiron tekemä leikkaus oli onnistunut niin hyvin, että hän pystyi pitämään maaliskuussa 70-vuotisvastaanoton ja palaamaan hoitamaan kanslerin tehtäviä.

Selviydyttyään vaikeasta sairaudesta Granö katsoi luottavaisena tulevaisuuteen. Tämä näkyi muun muassa siinä, että hän suostui ottamaan vastaan Suomen Syöpäyhdistyksen puheenjohtajuuden, kun "minulla nyt on kokemusta asiasta". Tämä tehtävä vei hänet Tarton-vuosien ja Turun rehtorikauden tapaan yhteyteen J. K. Paasikiven kanssa, sillä vanhimman tyttärensä Annikin kuoltua syöpään presidentti oli perustanut 1950 rahaston syöpätautien tieteellistä tutkimustyötä varten. ${ }^{989}$

Kesät 1952-54 sujuivat totuttuun tapaan Tirmossa. Lapset pitivät lomillaan seuraa vanhemmilleen, ja kansleri vastasi tieteellisten ja virkaan liittyneiden asioiden hoidon ohella edelleen siitä, että veden vilja ei loppunut ruokapöydästä. Loppukesällä 1954, viimeistellessään Maat ja kansat -teossarjassa julkaistua kirjoitustaan Suomesta, Granö teki puolisonsa kanssa Uudenmaan itäisiin rannikkokaupunkeihin, Karjalaan ja Järvi-Suomeen ulottuneen linja-automatkan, jonka aikana hän saattoi ensimmäisen kerran ihailla Kolilta avautuvia maisemia. Paluumatka Kuopiosta Helsinkiin tapahtui lentokoneella, yli "tuhansien järvien" maisemamosaiikin. Granö olisi mielellään pistäytynyt vielä kerran Valosaaressa Puhtaan maantieteen "syntymäsijoilla", mutta Mikkelissä samoihin aikoihin järjestetty maanviljelynäyttely oli täyttänyt majapaikat niin tyystin, ettei sinne ollut menemistä. ${ }^{990}$ 
vain ruotsia. Granö ei halunnut paljastaa erehdystä vaan keskusteli hoitajan kanssa hiljaisella äänellä ruotsiksi sen minkä jaksoi.

Mehiläisen sairaalassa Granön kunto heikkeni tasaisesti, kunnes hän nukkui rauhallisesti pois helmikuun 23. päivän illalla 1956. Hän olisi täyttänyt vajaan kolmen viikon kuluttua 74 vuotta. Tieto Granön kuolemasta levisi nopeasti, sillä useat kotimaiset ja ulkomaiset sanomalehdet julkaisivat vainajasta muistokirjoituksen muutaman päivän sisällä. Nekrologeissa tuotiin esiin hänen monipuoliset tieteelliset saavutuksensa ja korostettiin hänen merkitystään kulttuurielämän edustajana ja vaikuttajana. ${ }^{911}$

Tieteellisissä aikakauskirjoissa nekrologeja julkaistiin Suomen lisäksi muun muassa Ruotsissa, Ranskassa, Neuvostoliitossa, Italiassa ja Virossa. Neuvostoliiton Tiedeakatemian julkaisuun laatimassaan muistokirjoituksessa L. G. Serebrjyannyj totesi Granön olleen laajalti tunnettu neuvostomaantieteilijöiden keskuudessa:

Hänen työnsä tuovat merkittävän panoksen Altain, Tuvan, Eestin, Karjalan, Kuolan niemimaan ja maamme muiden alueiden maantieteelliseen tutkimukseen. Hänen tutkimustensa arvokkaimpia ominaisuuksia ovat laaja eruditio, loogisuus ja esityksen selkeys, omaleimaisuus sekä maantieteen eri ongelmien tarkastelun laaja-alaisuus. ${ }^{992}$

Kaarlo Hildénin ohella Granön työtä arvosti syvällisimmin Edgar Kant, joka Svensk Geografisk Årsbokissa julkaisemassaan nekrologissa totesi, että

Granössä Suomi, Pohjola ja kansainvälinen maantieteilijäyhteisö menettivät yhden uudenaikaisen maisematieteen perustajista, johtavan persoonallisuuden metodologian alalla ja samalla miehen, jota kaikki hänet tunteneet arvostivat korkean kulttuurin aidoksi edustajaksi. ${ }^{993}$ 


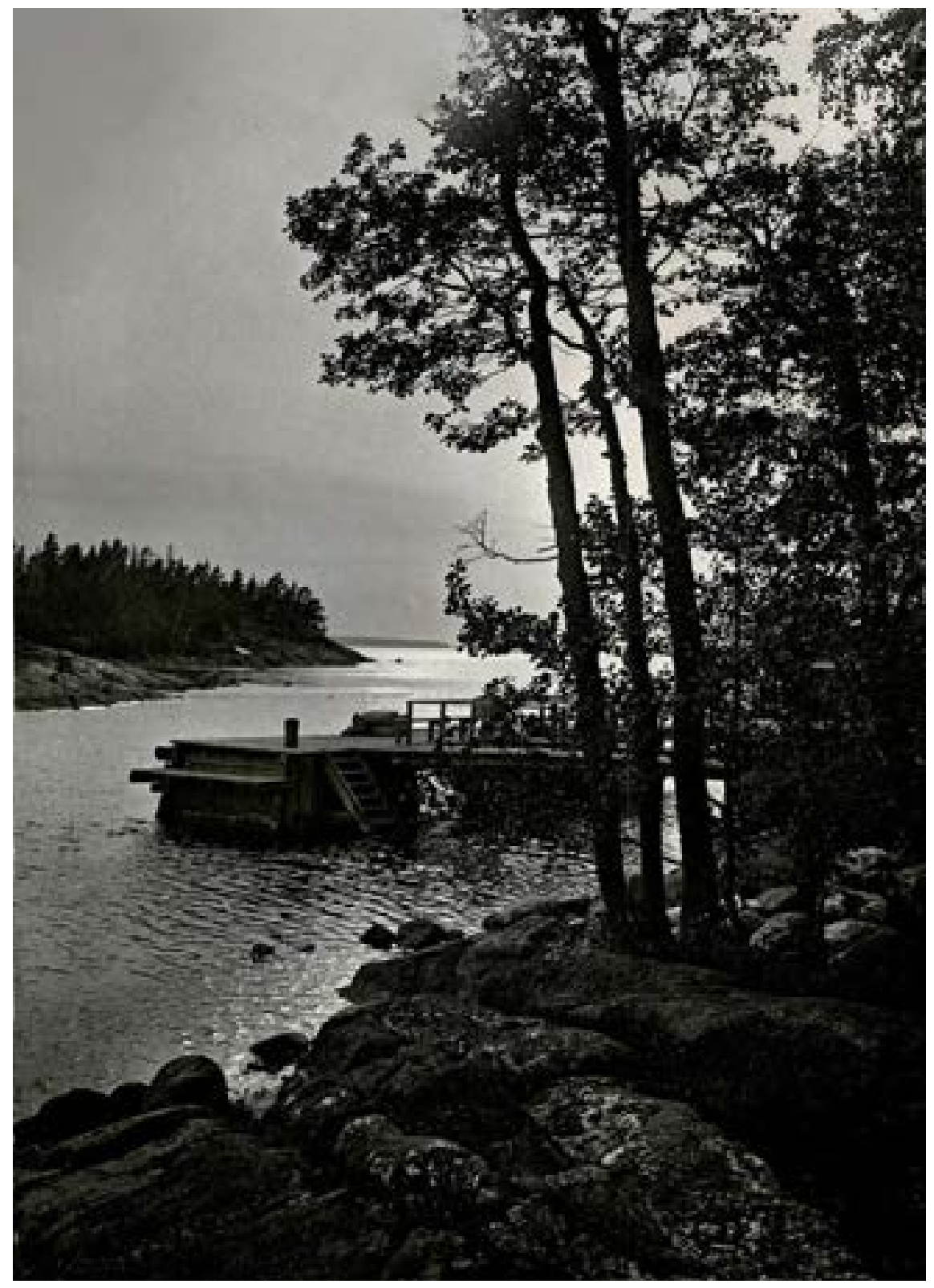

Hyvästijättö Uudenmaan saaristolle.

Kuva J. E. Rosbergin Suomen maisemia postikortteina -sarjasta. 


\section{Hiljaiset hautajaiset}

J. G. Granön hautajaiset järjestettiin hänen toivomuksensa mukaisesti hiljaisin menoin Hietaniemen krematorion kappelissa Helsingissä. Ruumiinsiunauksen toimitti Töölön kirkkoherra, rovasti Väinö Forsman, joka oli ikään kuin perhepappi. Hautausvirreksi lapset olivat valinneet isän mielivirren 622, "Minä vaivainen, vain mato, matkamies maan, monet vaellan vaikeat retket".

Hautajaistilaisuudesta tuli vielä pienimuotoisempi kuin Granö oli itse ajatellut. Maaliskuun alussa yhtä aikaa uuden presidentin Urho Kekkosen virkakauden kanssa alkanut yleislakko aiheutti sen, että pääkaupungin ulkopuolella asuvat sukulaiset ja ystävät joutuivat jäämään kotiin, kun junat ja linja-autot eivät kulkeneet ja polttoaineen puute esti yksityisautoilun. Murheellisinta oli, että Granön sielunveli J. K. V. Tuominen ei voinut saapua Turusta jättämään viimeistä tervehdystään vanhalle ystävälleen. ${ }^{994}$

Krematorioon kokoontuneeseen viimeiseen saattojoukkoon kuuluivat Helsingissä asuvien perheenjäsenten ja lähimpien sukulaisten lisäksi vain vanha oppilas, ystävä ja tutkijakumppani Kaarlo Hildén puolisoineen. Siunaustilaisuuden jälkeen hautajaisvieraat kokoontuivat pieneen kahvi- ja muistelutilaisuuteen Pohjoisen Rautatiekadun asuntoon.

Granön tuhka sijoitettiin aluksi Krematorion uurnalehtoon, josta se myöhemmin siirrettiin perhehautaan Hietaniemen vanhalle hautausmaalle. Tirmon kesähuvilassa Pellingissä 83-vuotiaana heinäkuun 20. päivänä 1965 kuollut Hilma Granö haudattiin viimeiseen lepoon puolisonsa rinnalle.

Granön lähipiiri sai vastaanottaa vielä vuosien ajan kotimaasta ja eri puolilta maailmaa saapuneita surunvalitteluja arvostetun tutkijan poismenon vuoksi. Mies oli poissa mutta jäljellä oli elämäntyö, jota tutkijakollega Pentti Eskola oli kuvannut taitavasti Alfred Kordelinin säätiön vuosijuhlassa 1949 palkinnonsaajan kunniaksi esittämässään heksametrisessa runossa: 
Altain taigoja tutkit ja Mongolian pölymaita,

Röykkiömaita ja ouruja, miss oli jäätiköt muinoin;

Aasian autiomaat samosit, näit temppelit Urgan;

Tuttuja sull' oli tunguusit, oli noidat ja laamat.

Eestin maisemat vielä kun selvitit, sai sinut Suomi,

rakkain syntymämaa sekä Auran rantamaat armaat.

Loit lähiöt, kerot, luusuat, laakiot, onsilot, ourut,

kaikkien muotojen maan nimet, loit koko maisematieteen.

Suur' oli vihdoin meill' ilo kun toki vuosien jälkeen

Entinen Alma Mater peri sun ja sä taas tulit Töölöön,

Mainehikas mies, tahdikas, kanslerin arvoa kantain.

Ansainnut hyvin oot tämän illan kunniapalkan.

Kauan jaksaos jatkaa ain' osas onnekas olkoon.995 


\title{
EHEÄN IHMISEN ELÄMÄ
}

\author{
VIII
}

Erno Paasilinna määritteli Yksinäisyys ja uhma -teoksessaan kirjailijan olemusta siten, että kirjailijaksi ei synnytä vaan "on elettävä sellainen elämä, josta syntyy kirjailija" ja että hyvä kirjailija on aina ihmisen puolella. Näkemys sopii J. G. Granön arvioimiseen tutkijana sillä lisäyksellä, että hän sai kiittää tutkijan ominaisuuksistaan myös syntymälahjojaan.

Hyvät hoksottimet, kielipää ja suuri tarmo olivat perustana elämäntyölle, joka ulottui monelle alalle. Granöstä tuli tutkimusmatkailija, tietokirjailija ja valokuvaaja, yliopisto-opettaja, geomorfologi, aluetieteen teorian, käsitteistön ja metodien kehittäjä, maisematutkija ja tärkeä kansallinen vaikuttaja.

Granön elämän suuntautumiseen vaikuttivat ratkaisevasti syntymäkodin arvot ja lapsuusvuodet Siperiassa. Isä-Johannekselta hän peri uskonnollisuuden, isänmaan- ja lähimmäisenrakkauden ja suomenmielisyyden. Isän peruja olivat myös käytännöllisyys ja varovaisuus, samoin toimeliaisuus, kunnianhimo ja rohkeus omien rajojen koettelemiseen, kun taas äiti-Almalta hän omaksui hienotunteisuuden, herkkyyden, sosiaalisuuden ja vaatimattomuuden.

Monien kansojen asuttamassa avarassa Siperiassa vietetty aika avasi Granön silmät luonnon, kansojen ja ihmisten moninaisuudelle. Suomi oli hänelle rakas isänmaa mutta samalla vain yksi palsta maapallon pinnalla ja siellä asuva kansa yksi kansa kansojen joukossa. Suomella kuten millään muuallakaan maalla ei ollut erityisoikeutta kansalliseen ylemmyydentuntoon ja asettumiseen muiden yläpuolelle.

Näkemys kansojen tasavertaisuudesta ei estänyt Granötä toimimasta määrätietoisesti suomalaisuuden ja suomen kielen kehittämiseksi. Päinvastoin, hän uskoi, että työ suomalaisen kulttuurin hyväksi loi edellytyksiä osallistua kansainväliseen toimintaan ja koitui koko ihmiskunnan hyväksi. Sen sijaan kaikenlaista kansallista 

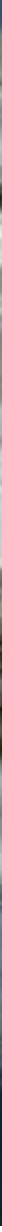

J. G. Granön mukaan nimetty jäätikkö on osa Tabun- Bogdo-uulan, "viiden pyhän vuoren", jäätiköitynyttä vuorijonosolmua Venäjän ja Mongolian rajalla. Kuva on otettu 2004, jolloin Rauli Virtanen valmisteli Suomen TV-1:ssä esitettyä tutkimusmatkailijasarjaa.

kiihkoilua hän vierasti, eikä osallistunut Suomen tiedepiireissä yleiseen Suur-Suomiintoiluun.

Opiskelun aloittaminen 1900-luvun alussa osoittautui ratkaisevan tärkeäksi Granön elämän kannalta. Aivan kuten isä oli vienyt vastoin suvun tahtoa perheensä 
Siperiaan, hän valitsi nyt oman tiensä vastoin tämän toivomusta ja opiskeluvuosien tärkeän auktoriteetin J. A. Palménin neuvoa. J. G. Granö päätti ryhtyä maantieteilijäksi.

Tämä pätös johti siihen, että kolme 1900-luvun alussa Siperiaan ja Mongoliaan tehtyä muinaistieteellistä tutkimusmatkaa eivät tehneet Granöstä arkeologia vaan maanpinnan muotojen tutkijan, geomorfologin. Havaittuaan matkojen aikana runsaasti merkkejä muinaisista jääkausista hän päätti ensin todistaa, että Altain alue oli muinoin peittynyt jätiköiden alle, ja sitten laatia kokonaisesityksen vuoriston rakenteesta ja synnystä.

Työ jäi kesken, kun Granön oli tutkimusrahoituksen loputtua palattava Suomeen. Lopullisesti paluun Siperiaan esti lokakuun vallankumous, jonka seurauksena länsimaisten tutkijoiden pääsy Aasian keskiosien rajaseuduille katkesi lähes kokonaan 70 vuodeksi. Granö palasi 1930-luvulla Altain seudulta keräämänsä geomorfologisen aineiston käsittelyyn ja julkaisi pitkäaikaisen tutkimustyön tuloksista yhteenvedon 1945. Teos jatkoi Granön Altain tutkimusten epäonnekasta historiaa, sillä se jäi toisen maailmansodan seurausten vuoksi tyystin vaille ansaitsemaansa huomiota.

Granölle ei löytynyt poliittisten murrosvuosien Suomesta hänen koulutustaan ja taitojaan vastaavaa tehtävää, joten hän joutui hankkimaan elantonsa erinäisistä tilapäistöistä. Ehkä juuri vastuullisten tehtävien puute vapautti hänen luomisvoimansa kaksiosaisen Altai-teoksen vaatimaan suureen henkiseen ponnistukseen. Teoksesta tuli suomalaisen matkakirjallisuuden klassikko, joka yhdisti ainutlaatuisella tavalla tiedon popularisoinnin kaunokirjalliseen ja runolliseen kuvaukseen.

Teos osoitti, että Granö oli paitsi erinomainen kirjoittaja myös taitava valokuvaaja. Hän hallitsi niin hyvin tieteellisen valokuvauksen, että pystyi kehittämään valokuvien käyttöä maanpinnan muotojen tutkimuksessa. Samalla hän oli myös luova kuvaaja, joka osasi ikuistaa ajattomasti ja taiteellisesti matkoillaan näkemiä maisemia ja tilanteita.

Granön elämä sai 1919 uuden käänteen, kun hänet nimitettiin Tarton yliopiston maantieteen professoriksi. Kansainvälisesti tunnettuna geomorfologina hän olisi voinut keskittyä opetuksessaan ja tutkimuksessaan maanpinnan muotoihin. Näin ei 
kuitenkaan käynyt, sillä hän oli jo Suomessa päättänyt pyrkiä luomaan maantieteelle sisällön, joka takaisi sille itsenäisen yliopistotieteen aseman. Tämä merkitsi keskittymistä oman maan kuvaukseen ja aluetieteen teorian kehittämiseen.

Pari vuotta kestänyt Viron aika oli Granölle yhtä työn myllyä. Hän perusti Tarton yliopiston maantieteen laitoksen, aloitti maisema- ja lähiötieteen teorian ja metodiikan kehittämisen ja käynnisti virolaisen kotiseudun- ja kaupunkitutkimuksen. Hyvän kielipäänsä ja intensiivisen opiskelun ansiosta hän saattoi aloittaa vuoden 1920 alussa maantieteen vironkielisen opetuksen ja ammattisanaston laatimisen.

Nopea siirtyminen viron kielen käyttöön liittyi hänen uskoonsa siihen, että tieteellisen koulutuksen tuli tapahtua opiskelijan äidinkielellä kansallisissa yliopistoissa. Samalla kun uudet tutkijasukupolvet oppivat ymmärtämään, että tiede oli kansainvälistä, heidän tuli tiedostaa oman isänmaansa ja kielensä merkityksen. Siksi hän oli jo Helsingissä ryhtynyt luennoimaan suomeksi ja aloittanut suomenkielisen maantieteellisen nimistön kokoamisen.

Granö oli Altai-tutkimuksillaan noussut kansainvälisesti arvostetuksi tutkijaksi, joten hänen siirtymisensä eteläiseen naapurimaahan koettiin Suomen tiedepiireissä harmilliseksi aivovuodoksi. Välittömästi alkanut työ hänen kutsumisekseen takaisin kotimaahan johti tulokseen vuoden 1923 alussa, jolloin hänet nimitettiin kovan kilpailun jälkeen Helsingin yliopiston maantieteen ylimääräiseksi professoriksi.

Vaikka virka vaihtui pian maantieteen vaihtuvaksi professuuriksi, Granö ei viihtynyt Helsingissä kuin runsaat kolme vuotta ennen kuin siirtyi yksityisen Turun Suomalaisen Yliopiston professoriksi. Ratkaisun taustalla oli tyytymättömyys ison yliopiston hallinnon raskauteen, henkilöiden välisiin ristiriitoihin ja yleiseen ilmapiiriin, joka poikkesi hänen mielestään liikaa humboldtilaisen sivistysyliopiston ihanteista. Hän katsoi, että Helsingissä hänen ajastaan oli mennyt liian paljon hallinto- ja opetuskäytäntöjen noudattamiseen ja erilaisiin Suomen Kartaston toimittajan ja Suomen Maantieteellisen Seuran sihteerin rutiinitehtävien pyörittämiseen. Päätös herätti pääkaupungin tieteellisissä piireissä suurta ärtymystä, mutta Granö ei siitä piitannut. Hän halusi isänsä tavoin päättää itse elämästään ja seurata sitä tietä, jonka tunsi oikeaksi. 
Granö ryhtyi kehittämään runsaat pari vuotta toiminutta Turun Suomalaisen Yliopiston maantieteen laitosta niin määrätietoisesti, että käytännössä voi puhua sen toisesta perustamisesta. Hän pyrki luomaan laitokselle samat olosuhteet kuin Tarton yliopistossa, jossa hän oli voinut keskittyä tutkimukseen ja opiskelijoiden henkilökohtaiseen tieteelliseen ja kansalliseen kouluttamiseen. Tarton kaltainen menestys lahjakkaiden jatko-opiskelijoiden kouluttamisessa ei toistunut enää Suomessa, mutta Granö valmensi suuren määrän päteviä maantieteen opettajia koululaitoksen palvelukseen.

Opetuksen ohella Granö suuntasi voimansa Suomen Kartastoon 1925 liittyviin karttojen valmistamiseen ja maisemateoriansa viimeistelemiseen. Vuonna 1929 ensin saksaksi ja seuraavana vuonna suomeksi ilmestynyt Puhdas maantiede kokosi yhteen hänen Tartossa aloittamansa ja Helsingissä jatkamansa aluetieteen teoriaan ja metodeihin keskittyneen kehittämistyön.

Granön mukaan maantieteen tutkimuskohteena tulisivat olla alueet, jotka olivat maanpinnan muotojen, kasvillisuuden, vesistöjen ja ihmisen synnyttämien tekomuotojen puolesta mahdollisimman yhtenäisiä. Hän kehitti maiseman eri elementtien yksityiskohtaisen luokittelujärjestelmän, joka mahdollisti alueiden systemaattisen rajaamisen kartografisten esitysten perusteella.

Granö poikkesi muista maisematieteilijöistä siinä, että hänen lähtökohtanaan ei ollut maisema alueena vaan ihmisen aistiympäristönä. Sen hän jakoi vain näköaistin avulla havaittavaan maisemaan ja ihmisestä noin 20 metrin päähän ulottuvaan lähiympäristöön eli lähiöön, joka koettiin kaikilla aisteilla. Teoksen oppihistoriallisesti merkittävimpään antiin kuuluivat kuvaukset mittakaavan ja havaintopaikan korkeuden vaikutuksesta maiseman kokemiseen ja Granön Valosaaressa tekemän lähiötieteellisen tutkimustyön tulokset.

Puhdas maantiede sai ristiriitaisen vastaanoton. Sitä kiitettiin monipuolisuudesta, loogisesta johdonmukaisuudesta ja täsmällisyydestä, mutta monet arvostelijat pitivät sitä liian vaikeaselkoisena, kaavamaisena ja yksityiskohtiin takertuvana. Ongelmat johtuivat ainakin osin siitä, että teos oli syntynyt pakottavasta tarpeesta saada aikaan 
maantieteelle sellainen sisältö, joka takaisi sille itsenäisen yliopistotieteen aseman. Kun vertaa Altai-teosta Puhtaaseen maantieteeseen, huomaa selvästi, kuinka ankarasti pakko oli kahlehtinut Granön luovuutta.

Teos sai 1930-luvun alussa niin vähän tieteellistä vastakaikua, että Granö pyrki syventämään jatkotutkimuksillaan sen sisältöä. Hän lisäsi hieman alueiden toiminnallisen puolen tarkastelua mutta vastaavasti luopui lähiötieteellisen aluejaon kehittämisestä. Päätös kertoi ennen kaikkea siitä, että hän antoi pääpainon suurten maisemallisten alueiden rajaamiselle, mutta asiaan saattoi vaikuttaa myös kasvanut ymmärrys siitä, kuinka mahdotonta oli kyetä ottamaan huomioon kaikki ihmisen lähiympäristöstään aistimat asiat ja ilmiöt.

Granölle tarjoutui 1934 tilaisuus esitellä aluetiedettään koko tieteenalan eliitille Varsovan maantieteilijäkongressissa, mutta hän joutui peruuttamaan esiintymisensä sairauden vuoksi. Tilaisuutta varten laadittu esitelmä loi perustan myöhemmin julkaistulle Granön arvostetuimmalle tieteelliselle artikkelille Geographische Ganzheiten, mutta se ei estänyt Puhtaan maantieteen joutumista unohduksiin vuosikymmeniksi. Teoksen uusi tuleminen alkoi 1960-luvulla, jolloin sen teemoihin alettiin kiinnittää huomiota muun muassa arkkitehtuurin, äänimaisematutkimuksen ja ympäristönsuunnittelun piirissä ja seuraavalla vuosikymmenellä myös maantieteessä, jossa ryhdyttiin pohtimaan aiempaa monipuolisemmin ihmisen suhdetta ympäristöönsä.

Sädesieneksi osoittanut sairaus katkaisi lyhyeen Granön uran Turun Suomalaisen Yliopiston rehtorina. Granön aika opinahjon johdossa kuului suomalaisen yliopistohistorian merkillisimpiin. Rehtori joutui tekemään kaikkensa estääkseen yliopiston korkeinta hallintomiestä eli kansleria toteuttamasta suunnitelmaansa sen muuttamiseksi tieteelliseksi tutkimuslaitokseksi.

Tervehdyttyään Granö keskittyi professorin tehtävien hoitoon ja tieteelliseen työskentelyyn, joita sotavuodet 1939-44 rasittivat ankarasti. Rauhan palattua hän katsoi parhaaksi palata Helsingin yliopistoon, jossa maantiede oli ajautunut uhanalaiseen tilaan opettajakadon vuoksi. Granö onnistui arvovallallaan vakiinnuttamaan tieteenalan aseman maan pääyliopistossa. 
Helsingissä Granö nousi keskeiseen asemaan maan tieteellisessä elämässä. Hän oli Turun yliopiston kansleri, monien tieteellisten elinten jäsen ja tärkeä vaikuttaja ja aloitteentekijä. Hänelle annettiin useita merkittäviä palkintoja ja luottamustehtäviä, jotka hän hoiti tavoilleen uskollisesti vähäeleisen tehokkaasti.

Granö koki itsensä nimenomaan yliopistotutkijaksi ja -opettajaksi, minkä vuoksi hän kieltäytyi poliittisluonteisista tehtävistä, kuten kansanedustajaehdokkuudesta ja Suomen Tukholman-lähettilään pestistä. Keskittymistä tutkijanuralle tuki puoliso Hilma Granö, joka oli itsekin saanut maantieteilijän koulutuksen. Tieteelliset teoriansa ja metodinsa Granö kehitti pääosin työhuoneessaan yliopistossa, sillä koti oli pääosin rauhoitettu työelämän ongelmilta.

Granön saavuttaman menestyksen taustalla ei ollut kova pyrkimys näyttäviin asemiin vaan suuri tarmo, saavutetut tulokset ja eri tehtävissä osoitettu taito. Häntä arvostettiin tutkijana, opettajana, organisaattorina sekä rakentavana ja innostavana ihmisenä. Hän suhtautui ihmisiin tasapuolisesti rotuun, kansallisuuteen, säätyyn tai arvoon katsomatta ja tavoitteli ratkaisuja, joissa otettiin huomioon muutkin kuin vain tieteelliset näkökohdat.

Suuresta menestyksestä huolimatta Granön uraan mahtui niin kovia pettymyksiä ja takaiskuja, että ne olisivat voineet lannistaa hänet rutiinitöiden tekijäksi. Näin ei kuitenkaan käynyt, sillä vastuulliseen ja tavoitteelliseen elämänasenteeseen yhdistyi syvä uskonnollisuus, optimismi ja huumorintaju, joiden avulla hän säilytti sisäisen nöyryyden ja vaatimattomuuden sekä kyvyn uudistua.

Granö oli eheä ja tasapainoinen persoona, joka uskoi siihen mitä teki. 


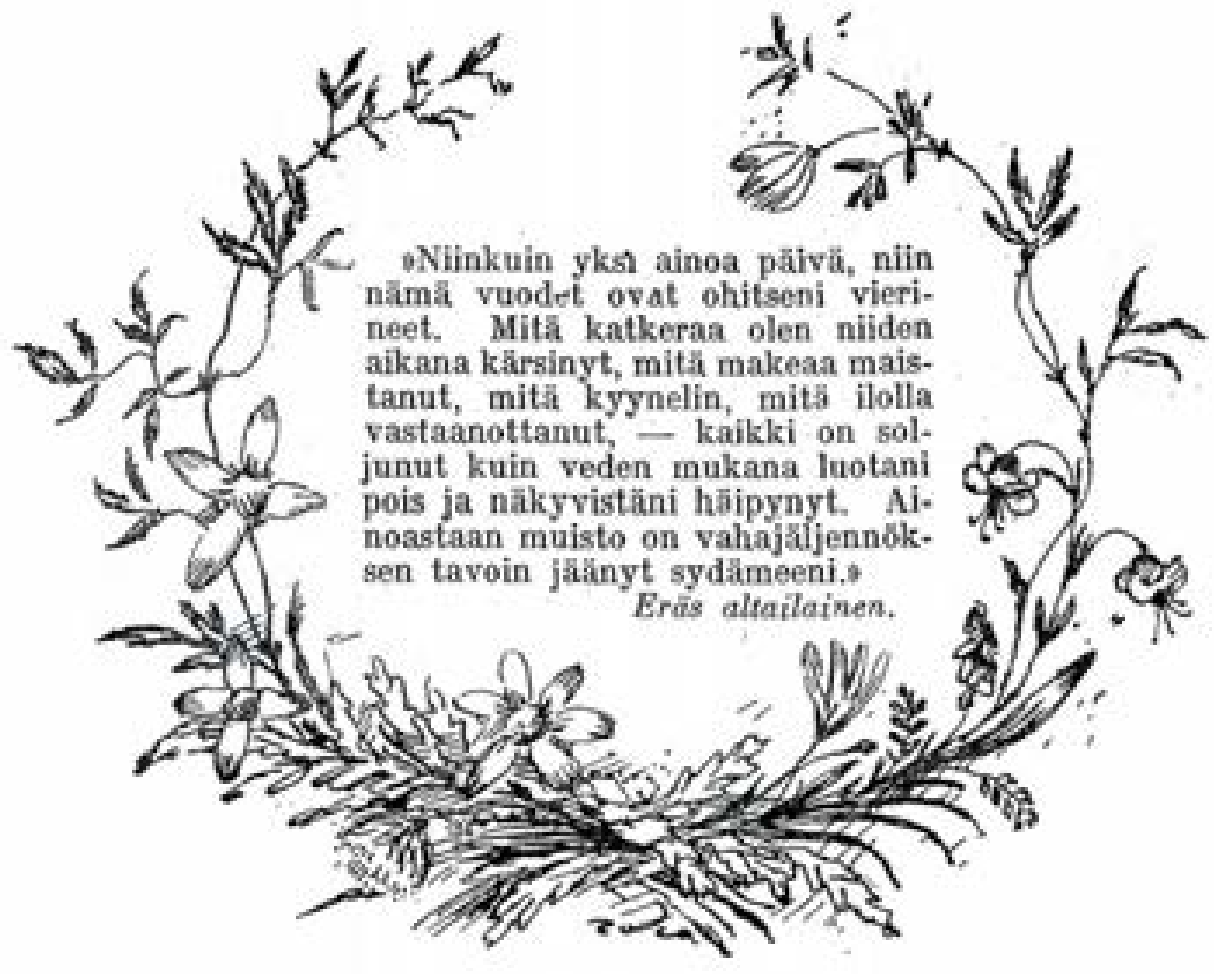




\section{Viitteet}

1 J. G. Granön kirje J. K. V. Tuomiselle 1.3.1914 JGGA. SKS, KiA.

2 J. E. Rosbergin kirje J. G. Granölle 16.1.1927. JGGA. SKS, KiA; Granö 1982a ja 1988, 11.

3 Tirranen 1951, 2. HYKA; Granö, P. 1921, 40-41.

4 Wilskman 1918; Hildén 1938, 227; Kovero 1938; Tommila 1989, 142-143.

5 Koskenniemi 1980; Granö 1982a, Dahlbacka 1987, 90; Tommila 1989, 70-78, 102.

6 Granö, P. 1921, 41-47; Sandvik 1975; Strömberg 1989, 784-790.

7 Skyttä 1967, 1-10, 83-88; Granö 1995, 146.

8 Tirranen 1951, 5. HYKA; Rossi 1995, 148.

9 Johannes Granön kirje Josef Simeliukselle 18.2.1904. JGGA. SKS, KiA.

10 Ylikangas 1974; Granö 1995, 146.

11 Skyttä 1967, 10-21.

12 F. G. Hedbergin kirje Johannes Granölle 24.12.1880. JGGA. SKS, KiA; Granö 1982a.

13 Granö, P. 1921, 42-44; Skyttä 1967, 22-27; Huovinen 1987, 163-166.

14 Engman 2005, 37-52; Tiitta 2009, 30-32.

15 Granö 1893, 1; Granö, P. 1921, 44-45; Dahlbacka 1987, 98.

16 Granö 1893, 2-3; Skyttä 1967, 27-28.

17 Granö 1905, 4-6; Skyttä 1967, 29-48; Amerikan Uutiset 6.2.1973; Herlin 1980, 8; Granö 1982a; Juntunen 1982, 357, 1983, 35-57 ja 1985, 265267; Kotimaa 25.8.1983; Heikkilä 1985, 175-176; Saari 1993, 37-38 ja 1994, 28; Engman 1997, 540, 2004, 64-65 ja 2005, 338-348; Tiitta 2009, 4647.

18 Granö 1893, 1-3; Juntunen 1983, 114; Heikkilä 1985, 177.

19 Skyttä 1967, 48-52.

20 Granö 1893, 4-21; Tuominen 1982, 4; Saari 1994, 28.

21 Skyttä 1967, 52-53; Saari 1993, 38.

22 Granö 1893, 22-23; Wrede 1918, 206-207; Mihailov 1967, 11-13; Juntunen 1993, 148.
23 Granö 1988, 13 ja 2002b; Mead 1988.

24 J. G. Granön kirjeet Henry S. Heimoselle 13.4.1938 ja André Froehlichelle 5.5.1948. JGGA. SKS, KiA; Granö 1982a; Olavi Granön haastattelu 14.5.2010.

25 Betty Fontellin kortti Selma Charlotta Solinille 22.3.1903. JGGA. SKS, KiA; Saari 1993, 38-39; Granö 2009, 22.

26 Granö 1982a; Juntunen 1983, 116.

27 Skyttä 1967, 54-56; Heikkilä 1970; Saari 1994, 28; Granö 2003b.

28 Granö 1893, 33-37; Granö, P. 1921, 49-50; Skyttä 1967, 56-57, 72-76.

29 Herlin 1980, 8; Juntunen 1983, 87-94, 115.

30 Skyttä 1967, 57-71; Heikkilä 1970; Herlin 1980, 8; Saari 1993, 38-39; Granö 1995, 147 ja 2004, 275.

31 Granö 1905, 39-40; Skyttä 1967, 72-76; Juntunen 1983, 115-116 ja 1994; Kotimaa 25.8.1983; Saari 1993, 38; Engman 2005, 345.

32 Skyttä 1967, 77-82; Granö 2004, 275; Verhne Suetukin kirkko korjattiin 106 vuotta myöhemmin alkuperäiseen asuunsa ja vihittiin uudelleen 8.7.1994.

33 Granö 1893; Skyttä 1967, 83-91; Granö 1995, 147 ja 2004, 275.

34 Juntunen 1982, 359-360.

35 Tallgren 1942, 188-191; Janhunen 1984, 26; Halén 1989, 180-183; Salminen 2003, 115-116, 238-239.

36 Kurs 1995, 580; Salminen 2003, 100.

37 Granö, P. 1921, 51-53; Skyttä 1967, 94-99.

38 Simojoki 1983, 91-92; Rantatupa 1988, 333.

39 Johannes Granön kirje Josef Simeliukselle 22.12.1896. JGGA. SKS, KiA; Granö 1995, 147.

40 Skyttä 1967, 100-113; Rantatupa 1988, 333; Granö 2004, 275.

41 Granö, P. 1921, 53; Granö 1995, 147.

42 Johannes Granön kirjeet Josef Simeliukselle 11.2. ja 1.5.1902, 7.9.1907. JGGA. SKS, KiA; Simojoki 1983, 115-116. 
43 Koulutodistukset. Aa. JGGA. SKS, KiA; Tirranen 1951, 6. HYKA; Granö 1982a.

44 Kant 1956b, 164; Hildén 1957a, 193; Granö 1982a.

45 J. G. Granön kirje J. K. V. Tuomiselle 10.11.1920, Koulutodistukset. Aa. JGGA. SKS, KiA; Granö 1988, 11; Klinge 1990, 395.

46 Koulutodistukset. Aa. JGGA. SKS, KiA.

47 Tirranen 1951, 16. HYKA; Granö 1982a ja 1988, 14.

48 Hildén 1956c, 77.

49 Rikkinen 1980; Leikola 1996b; Lagerspetz 2000, 198-201; Tiitta 2000a, 310-314; Vallisaari 2006.

50 Oulun lyseo 1883-1933 1933, 178; Herlin 1980, 8; Saari 1994, 81.

51 Granö, P. 1921, 46-47; Skyttä 1967, 153-155.

52 Johannes Granön kortti Alma Granölle 19.4.1902 ja kirje Josef Simeliukselle 15.10.1902. JGGA. SKS, KiA; Heikkilä 1985, 325-326; Saari 1993; Granö 1995, 147; Engman 1997, 541.

53 Granö 1993b, 535; Juntunen 1993, 148-149; Saari 1993, 39; Luntinen 2000, 264-272.

54 Herlin 1980, 8; Juntunen 1982, 360; Saari 1993, 39.

55 Kinnunen 1991b; Saari 1994, 111-113; Herlin 1980, 8.

56 Eetu Iston kirjeet Paavo Granölle 3.5. ja 15.6.1902, Johannes Granön kirje J. G. Granölle 4.11.1905. JGGA. SKS, KiA; Tirranen 1951, 13. HYKA; Helsingin Sanomat 31.1.1935; Jussila 1979, 38-41; Kurs 1983; Phoenix 1990, 9; Rönkko 1990; Reitala 2004, 347-348; Risto Jaakkolan haastattelu 18.9.2008

57 Skyttä 1967, 155-168.

58 Opintokirja. Aa. JGGA. SKS, KiA; Tirranen 1951, 16-17. HYKA; Heinonen 1943, 23; Rikkinen 1988, 145.

59 Berg 1930; Granö 1931a; Kant 1956b, 164; Granö 1982a; Granön laaja kasvikokoelma on nykyisin Helsingin ja Turun yliopistojen kasvimuseoissa.

60 Granö 1980, 109, ja 1992; Rikkinen 1988, 145.

61 Granö 1932a; Hildén 1932; Jaatinen 1985 ja 1988; Rikkinen 2006.
62 Davis 1912; Granö 1990, 39-40; Haapala 2000, 272.

63 Granö 1901 ja 1932a; Kaskimies 1947, 54; Granö $1982 \mathrm{a}$

64 Tiitta 1994, 320-399, ja 2000a, 308-310.

65 Granö 1982a; Rikkinen 1988, 36-60, 124-144.

66 Tiitta 2000a, 309 ja 200b.

67 Redogörelse.... under läseåren 1899-1902, 22; Mereste 1985, 177; Rikkinen 1993; Tiitta 1994, 336-338.

68 Fyysis-matem. os. ptk:t 8.3. ja 22.3.1900, Tirranen 1951. HYKA; Kihlman 1900; Schulman \& Nordenstreng 1912, 631; Juntunen 1993, 148.

69 Fyysis-matem. os. ptk 9.5.1900. HYKA.

70 Fyysis-matem. os. ptk 22.9.1900. HYKA; Redogörelse.... under läseåren 1899-1902, 22; Rikkinen 1988, 145; Tiitta 2000a, 312-313.

71 Fyysis-matem. os. ptk 29.1.1902. HYKA.

72 Granö 1920b, 20.

73 Kertomus HY:n toiminnasta 1902-05, 92, 99, 231; Hildén 1956c, 84.

74 Granö 1979, 75; Rikkinen 1988, 145; Granö 1989, 203; Haapala 2009, 120-128; Tiitta 2009; Vares 2010.

75 Granö 1911b; Olsoni 1920.

76 Saalas 1963, 148-149.

77 Kertomus HY:n toiminnasta 1902-05, 231.

78 Tommila 1989, 151-154; Vares 2010, 49-50; Olavi Granön haastattelu 14.5.2010.

79 Granö 1920b, 22.

80 J. G. Granön kirje J. K. V. Tuomiselle 31.7.1955. JGGA. SKS, KiA.

81 A. R. Cederbergin kirje J. G. Granölle 2.12.1935. JGGA. SKS, KiA; Tirranen 1951, 1-2. HYKA.

82 Hanna Lignellin kirje J. G. Granölle 18.10.1901. JGGA. SKS, KiA; Immonen 1987, 427.

83 Kolmisoinnun jäsenten kirje J. G. Granölle 10.12. 1909, J. G. Granön puhe Vanamon juhlapäivällisillä 24.3.1946. JGGA. SKS, KiA; Oulun lyseo 1883-1933, 176.

84 Alma ja Johannes Granön kortit ja kirjeet J. G. Granölle 1905-13. JGGA. SKS, KiA.

VitTteET || 483 
85 Torsten Aminoffin kirje J. G. Granölle 4.6.1901, Hanna Lignellin kirje J. G. Granölle 13.12.1901. JGGA. SKS, KiA; Granö 1982a.

86 Koulutodistukset. Aa. JGGA. SKS, KiA; Uusi Aura 1943/18, 752.

87 Tirranen 1951, 23. HYKA; Heinonen 1943, 23; Tammekann 1955a.

88 Granö 1982a ja 2002b.

89 Mpk 3.-9.6. JGGA. KA; Salminen 2003, 28.

90 Konsistorin ptk 23.3.1911, Fyysis-matem. os; YliJokipii 1988.ptk 31.3.1921. HYKA; Herlin 1980, 8; Juntunen 1983, 169.

91 Granö 1905, 3.

92 Mpk 10.8.-9.9.1905. JGGA. KA.

93 Mpk 1905. JGGA. KA; Kertomus HY:n toiminnasta 1902-05, 99; Granö 1906; Kurs 1983.

94 Kurs 1995, 581; Buttimer 2010, 11.

95 Granö 1919a, 5; Tammekann 1955a; Hildén 1956b, 4; Granö 1989, 204 ja 2002b.

96 Heinonen 1943, 23; Granö 1988, 15; Salminen 2003, 115-116.

97 Halén 1989, 188; Juntunen 1993, 149-150; Granö 2002b.

98 Opintokirja. Aa. JGGA. SKS, KiA; Tirranen 1951, 17. HYKA; Granö 1982a.

99 Granö 1941; Granö 1990, 530; Juntunen 1993, 152; Mannerheim 2007.

100 Granö 1919a, 6.

101 Mpk 9.-10.6.1906. JGGA. KA.

102 Mpk 10.-14.6.1906. JGGA. KA. Tämän jälkeen Granö siirtyi käyttämään päiväkirjoissaan Venäjällä tuolloin noudatettua juliaanista kalenteria, joka oli 13 vuorokautta Suomessa ja Euroopassa käytettyä gregoriaanista kalenteria jäljessä. Neuvosto-Venäjällä siirryttiin gregoriaaniseen kalenteriin tammikuussa 1918; Juntunen 1993, 150; Granö 2002b.

103 Mpk 24.6.1906. JGGA. KA; Granö 1980, 108.

104 Mpk 30.6.-1.7.1906. JGGA. KA; Granö 1989, 205 ja 2009, 23.

105 Tirranen 1951, 38-39. HYKA; Salminen 2003, 115.
106 Mpk 2.-28.7.1906. JGGA. KA; J. G. Granön radioesitelmä 18.5.1935. JGGA. SKS, KiA; Granö 1980, 111.

107 Mpk 29.-30.7.1906. JGGA. KA; Granö 1982a. 108 Mpk 30.7.1906. JGGA. KA.

109 Mpk 21.8.1906. JGGA. KA; Granö 1921a, 652653.

110 Mpk 31.7.-1.8.1906. JGGA. KA.

111 Mpk 21.8. ja 10.-11.9.1906. JGGA. KA.

112 Mpk 9.8.-4.9.1906. JGGA. KA.

113 Mpk 5.-22.9.1906. JGGA. KA; J. G. Granön kirje J. K. V. Tuomiselle 10.11.1920. JGGA. SKS, KiA; Granö 1989, 205.

114 Mpk 23.9.-2.10.1906. JGGA. KA; J. G. Granön kirje J. K. V. Tuomiselle 10.11.1920. JGGA. SKS, KiA.

115 Halén 1989, 188.

116 Heinonen 1943, 23; Granö 1980, 120-121.

117 Heinonen 1943, 23; Granö 1989, 205-206; Juntunen 1993, 150.

118 Vilhelm Thomsenin kirjeet J. G. Granölle 190708, E. N. Setälän kirje J. G. Granölle 25.6.1910. JGGA. SKS, KiA.

119 Granö 1912b, 6; Anonymous 1946, 9; Eskola 2002, 74-75; Granö 2009, 24.

$120 \mathrm{Mpk}$ 30.4.-1.5.1907. JGGA. KA.

$121 \mathrm{Mpk}$ 2.5.-15.6.1907. JGGA. KA; Granö J. G. Granön kirje J. K. V. Tuomiselle 10.11.1920. JGGA. SKS, KiA; Granö 1980, 114-115 ja 1989, 206; Halén 1989, 188.

122 Mpk 16.-28.6.1907. JGGA. KA.

123 Mpk 29.6-3.7.1907. JGGA. KA; Granö 1989, 206.

124 Mpk 4.-19.7.1907. JGGA. KA; Salminen 2003, 80.

125 Mpk 20.-24.7.1907. JGGA. KA; Tirranen 1951, 28. HYKA.

126 Phoenix 1990, 9; Salminen 2003, 80.

127 Halén 1989, 188.

128 Tirranen 1951, 23. HYKA.

129 Konsistorin ptk 23.3.1911. HYKA; Granö 1909d; Granö 1982a; Tiitta 2006. 
130 Granö 1912b, 1-2; Salminen 2003, 215-216.

131 Mpk 8.-31.5.1909. JGGA. KA; Granö 1910a, 1-3 ja 1912b, 2-5; Granö 1980, 115-117.

132 Mpk 11.-15.5.1909. JGGA. KA; J. G. Granön kortti Alma Ganölle 30.5.1909. JGGA. SKS, KiA; Hasselblatt 1917, 126-127; Granö 1993b, 531 ja 2009, 23-24; Lahti-Argutina 2001, 547; Engman $2005,347$.

133 Mpk 1.6.-8.7.1909. JGGA. KA.

134 Mpk 30.6.-2.7.1909. JGGA. KA; Granö 1912b, 5.

135 Mpk 11.7.-28.8.1909. JGGA. KA.

136 J. G. Granön radioesitelmä 25.5.1935. JGGA. SKS, KiA; Granö 1912b, 40-47; Eskola 2002, 150.

137 Gregoriaanisen kalenterin mukaan tapaaminen tapahtui 24.8.1909. Mpk 10.-12.8.1909. JGGA. KA; Granö 1912b, 22-47; Halén 1989, 188.

138 Mpk 9.8.1909. JGGA. KA; J. G. Granön radioesitelmä 25.5.1935. JGGA. SKS, KiA; Granö 1989, 208-209; Eskola 2002, 61.

139 Mpk 29.8.1909. JGGA. KA.

140 Mpk 30.8.-14.9.1909. JGGA. KA; Granö 1912b, 50-51.

141 Fyysis-matem. os, ptk 2.3.1911, Konsistorin ptk 20.4.1921. HYKA; Salminen 2003, 116.

142 Fyysis-matem. os. ptk 2.3.1911, Konsistorin ptk 20.4.1921. HYKA; Granö 1909a, 1910a ja 1910g; Tallgren 1942, 188; Aalto 1958, 1989, 1991; Jacobson-Tepfer, Kubarev \& Tseveendorj 2008.

143 Kurs 1995, 580; Buttimer 2010, 12-17.

144 Kertomus HY:n toiminnasta 1908-11, 28; Granö 1989, 199, 210; Haapala 2009, 121-128.

145 Granö 1990, 37-39.

146 Granö 1979, 75, 1982a, 1992, 42-43.

147 Kertomus HY:n toiminnasta 1908-11, 28; Granö 1910b ja 1912b, 52; Granö 1988, 11.

148 Konsistorin ptk 13.3.1911. HYKA; Granö 1979, 75.

149 Konsistorin ptk 20.4.1921. HYKA; Allix 1912 ja 1923; Edelstein 1912, 51-53; Reznichenko 1914; Anonymus 1915a ja 1915b; Tammekann 1955a; Hildén 1956c, 79; Granö 1993b, 535-537; Juntunen 1993, 149-153.

150 Konsistorin ptk 20.4.1921. HYKA.
151 Kertomukset HY:n toiminnasta 1905-08, 37-38, 89-90, 1908-11, 71-72.

152 Konsistorin ptk 29.3.1911, Fyysis-matem. os. ptk:t 10.4. ja 23.5., 30.9.-21.12.1911, Tirranen 1951, 62. HYKA; Granö 1979, 77-78 ja 1993b, 528-529.

153 Konsistorin ptk:t 29.3., 8.4. ja 17.5.1911, Fyysismatem. os. ptk:t 6., 20. ja 28.2., 2.3.1911. HYKA; Kertomus HY:n toiminnasta 1908-11, 21; Paaskoski 2008, 310.

154 Kertomukset HY:n 1905-08, 37, 89, 1908-11, 7174; Selonteko HY:n ... 1908-12; Rosberg 1919, 6; Tiitta 2000a, 313.

155 Tirranen 1951, 39-40, 62. HYKA.

156 Kertomus HY:n toiminnasta 1908-11, 19, 1911-14, 19, 127 ja 1914-17, 149.

157 Konsistorin ptk 29.3.1911. HYKA; Selonteko HY:n... 1911-13.

158 J. K. V. Tuomisen kirjeet (116) ja kortit (8) J. G. Granölle 1913-55, J. G. Granön kirjeet (63) ja kortit (67) J. K. V. Tuomiselle 1913-55. JGGA. SKS, KiA; Tuominen 1988, 130.

159 Kertomus HY:n toiminnasta $1908-11,139$ ja $1911-$ 14, 148-149; Oulun lyseo 1883-1933 1933, 175178 .

160 J. G. Granön kirje J. K. V. Tuomiselle 7.11.1915. JGGA. SKS, KiA; Granö 1908b.

161 Granö 1910f ja 1911c; Tiitta 2000b.

162 Konsistorin ptk 29.3.1911. HYKA; Granö 1910c ja 1910d; Hildén 1956c, 84.

163 Granö 1910e.

164 Granö 1910e.

165 Granö 1910e.

166 Hettner 1927, 124-125; May 1970, 90-92, 132-134; Büttner \& Hoheisel 1980, 60; Vartiainen 1980, 15.

167 Granö 1990, 19 ja 1998, 18.

168 Konsistorin ptk 20.4.1921. HYKA; Granö 1911a ja 1912a; Juntunen 1993, 152-153.

169 Mpk 7.5.-21.6.1911 ja 21.6.-21.7.1911. JGGA. KA; Granö 1912b, 53-104; Anonymous 1946, 8-9; Granö 1982a.

170 Granö 1912b, 11; Tuominen 1982, 6; Saari 1994, 82; Engman 2005, 353. 
171 J. G. Granön kirje Kurt Lübenille 6.6.1932. JGGA. SKS, KiA.

172 J. G. Granön kirje Kurt Lübenille 6.6.1932. JGGA. SKS, KiA.

173 Heinonen 1943, 23-24; Yli-Jokipii 1982; Granö 1990, 39-41 ja 1992, 44.

174 Fyysis-matem. os. ptk:t 10.2.1912, 30.11.1912, Konsistorin ptk 18.1.1913. HYKA; Tammekann 1955a, Granö 1979, 75 ja 1989, 203; Juntunen 1993, 149; Tommila 2002, 66, 72.

175 Konsistorin ptk 13.3.1911, Fyysis-matem. os. ptk 10.2.1912. HYKA.

176 Konsistorin ptk 13.3.1911. HYKA.

177 Konsistorin ptk 13.3.1912, Fyysis-matem. os. ptk 10.2.1912. HYKA; Lagerspetz 2000, 215-218.

178 Fyysis-matem. os. ptk 30.11.1912. HYKA.

179 Fyysis-matem. os. ptk 30.11.1912, Konsistorin ptk:t 11.12.1912 ja 18.1.1913. HYKA.

180 Vuoden 2010 rahanarvoon saatettuna vuosittainen apuraha vastasi noin 23000 euroa; Konsistorin ptk 14.5.1913. HYKA.

181 Johannes Granön kortit J. G. Granölle 13. ja 19.3.1908. JGGA. SKS, KiA; Oulun lyseo 18831933 1933, 178; Herlin 1980, 8; Saari 1994, 81.

182 Paavo Granön kirje Olavi Granölle 12.12.1999. JGGA. SKS, KiA; Hildén 1956c, 77; Skyttä 1967, 189-191; Saari 1994, 82-83; Hautausmaasta ei ole nykyisin mitään jäljellä, sillä sen paikalle rakennettiin myöhemmin iso kivirakennus.

183 J. G. Granön kirje J. K. V. Tuomiselle 19.-24. 10.1913. JGGA. SKS, KiA.

184 J. G. Granön kirje J. K. V. Tuomiselle 19.-24. 10.1913, J. G. Granön kirje J. K. V. Tuomiselle 19.-24.10.1913. JGGA. SKS, KiA; Tirranen 1951, 10. HYKA; Granö 1910b.

185 Mpk 2.7.-2.8.1913. JGGA. KA.

186 J. G. Granön kirje J. K. V. Tuomiselle 19.-24. 10.1913. JGGA. SKS, KiA; Granö 1919a, 9-10; Granö 1989, 208-209.

187 Olavi Granön haastattelu 15.5.2011.

188 Mpk 6.8.1913. JGGA. KA; Kaskimies 1947, 5657.

486
189 Kertomus HY:n toiminnasta 1911-14, 128; Davis 1912; Heinonen 1943, 23; Granö 1982a, 1990, 37-39 ja 2002b; Beck 1982, 196-198; Juntunen 1993, 153.

190 Mpk 10.-21.8.1913. JGGA. KA; J. G. Granön kirje J. K. V. Tuomiselle 19.-24.10.1913. JGGA. SKS, KiA.

191 J. G. Granön kirje J. K. V. Tuomiselle 19.-24. 10.1913. JGGA. SKS, KiA.

192 Mpk 22.8-1.9.1913. JGGA. KA; J. G. Granön kirje J. K. V. Tuomiselle 19.-24.10.1913. JGGA. SKS, KiA.

193 Mpk 2.9-29.9.1913. JGGA. KA; J. G. Granön kirje J. K. V. Tuomiselle 19.-24.10.1913. JGGA. SKS, KiA.

194 J. G. Granön ja J. E. Rosbergin kortti J. K. V. Tuomiselle 31.8.1913. JGGA. SKS, KiA.

195 Granö 1919a, 9 ja 1921a, 633-634.

196 Konsistorin ptk 13.3.1911. HYKA; Granö 1921a, 441-442; Granö 1989, 208.

197 Mpk 15.-16.4.1914. JGGA. KA.

198 Hildén 1956c, 82-83.

199 Mpk 17.-28.5.1914. JGGA. KA; J. G. Granön kortti Alma Ganölle 16.5.1914, J. G. Granön kirje J. K. V. Tuomiselle 10.1.1915. JGGA. SKS, KiA; Granö 1919a, 168-173; Granö 1982a.

200 Mpk 2.-12.6.1914. JGGA. KA; Konsistorin ptk 13.3.1911. HYKA; Granö 1919a, 9-10.

201 Mpk 13.-21.6.1914. JGGA. KA.

202 Granö 1919a, 11.

203 Mpk 22.6.-11.7.1914. JGGA. KA; Kaarlo Hildénin kirjeet (84) ja kortit (68) J. G. Granölle 1913-54, erityisesti 13.8.1914. JGGA. SKS, KiA; Granö 1919a, 11-12.

204 Mpk 12.7.-1.8.1914. JGGA. KA; J. G. Granön kirje J. K. V. Tuomiselle 10.1.1915. JGGA. SKS, $\mathrm{KiA}$.

205 J. G. Granön kirje J. K. V. Tuomiselle 10.1.1915. JGGA. SKS, KiA.

206 Mpk 2.-29.8.1914. JGGA. KA; Granö 1919a, $12-13$. 
207 Anonymus 1946, 9.

208 Mpk 6.-11.5.1915. JGGA. KA; J. G. Granön kirje J. K. V. Tuomiselle 16.5.1915. JGGA. SKS, KiA; Granö 1919a, 13-14.

209 Mpk 12.-24.5.1915. JGGA. KA.

210 Mpk 26.5.-28.6.1915. JGGA. KA; Granö 1919a, 14-15; Granö 1921a, 371-379.

211 Mpk 29.6-10.7.1915. JGGA. KA; J. G. Granön kortti J. K. V. Tuomiselle 26.7.1915. JGGA. SKS, KiA.

212 Granö 1919a, 173.

213 Mpk 13.-25.7.1915. JGGA. KA.

214 Mpk 26.7.-5.8.1915. JGGA. KA.

215 Mpk 6.8.-10.9.1915. JGGA. KA; J. G. Granön kortti J. K. V. Tuomiselle 13.7.1915, J. G. Granön kirje J. K. V. Tuomiselle 7.11.1915. JGGA. SKS, KiA; Granö 1919a, 14-16.

216 J. G. Granön kirje J. K. V. Tuomiselle 7.11.1915. JGGA. SKS, KiA.

217 Mpk 1.6.-11.7.1916. JGGA. KA.

218 Mpk 12.7.-28.7.1916. JGGA. KA; Granö 1919a, 16-18: Granö 1989, 209.

219 Konsistorin ptk 13.3.1911. HYKA.

220 J. G. Granön kirje J. K. V. Tuomiselle 19.24.10.1913. JGGA. SKS, KiA.

221 Granö 1938; Kant 1956b, 165; Granö 1989, 209.

222 J. G. Granön kirjeet J. K. V. Tuomiselle 1.3.1914 ja 7.11.1915. JGGA. SKS, KiA; Granö 1914a ja $1914 b$.

223 J. G. Granön kirje J. K. V. Tuomiselle 1.3.1914. JGGA. SKS, KiA; Kertomus HY:n toiminnasta 1911-14, 42; Granö 1915 ja 1916c; Kurs 1983; Juntunen 1993, 153.

224 J. G. Granön kirje J. K. V. Tuomiselle 10.1.1915. JGGA. SKS, KiA.

225 J. G. Granön kirje J. K. V. Tuomiselle 7.11.1915. JGGA. SKS, KiA.

226 J. G. Granön kirje J. K. V. Tuomiselle 16.5.1915. JGGA. SKS, KiA; Zetterberg 2000, 329-332.

227 Kant 1956b, 165; Granö 1938; Granö 1989, 209.

228 Granö 1980, 121-122.
229 J. G. Granön kirje J. K. V. Tuomiselle 25.5.1916. JGGA. SKS, KiA; Granö 1916a ja 1916b.

230 Konsistorin ptk 20.4.1921. HYKA; Granö 1917; Heinonen 1943, 24; Kant 1956b, 166; Granö 1993b, 536-537.

231 Davis 1921, 155-156 ja 1923; Friederichsen 1922; Fickeler 1925; Granö 1990, 37-41 ja 1992, 44.

232 J. G. Granön kirjeet W. M. Davisille 14. ja 30.10.1920, 15. ja 27.2.1921 ja HLHU; W. M. Davisin kirjeet J. G. Granölle 1920-23. JGGA. SKS, KiA; Granö 1926a, 50.

233 Granö 1979, 77 ja 1989, 210.

234 Granö 1926a, 51 ja 1990, 536-537.

235 J. G. Granön kortit J. K. V. Tuomiselle 9.4. ja 16.4.1916, J. G. Granön kirje J. K. V. Tuomiselle 25.5.1916, JGGA. SKS, KiA; Konsistorin ptk 24.5.1916. HYKA.

236 HY:n ohjelma 1912-13, 92; Tommila 2002, 73-74.

237 J. G. Granön kirje J. K. V. Tuomiselle 25.5.1916, Iivari leiviskän kirje J. G. Ganölle 16.9.1916, Kaarlo Hildénin kirje J. G. Ganölle 3.10.1916. JGGA. SKS, KiA; Fyysis-matem. os. ptk 5.5.1916, Konsistorin ptk 24.5.1916. HYKA.

238 Fyysis-matem. os. ptk 16.9.1916, Konsistorin ptk 21.10.1916. HYKA; Felix Jonassonin kirje J. G. Granölle 6.11.1916. Kaarlo Hildénin kirje J. G. Granölle 15.11.1916. JGGA. SKS, KiA; Haapala 2000, 271300; Vares 2010, 48-49, 56.

239 J. G. Granön kortit J. K. V. Tuomiselle 19. ja 16.4., 28.11.1916. JGGA. SKS, KiA; Granö 1989, 212; Juntunen 1993, 154.

240 Granö 1992, 44-45; Granö 2003b.

241 J. G. Granön kirje J. K. V. Tuomiselle 25.9.1919. JGGA. SKS, KiA.

242 Granö 1990, 39-40 ja 1993b, 537.

243 Kertomus HY:n toiminnasta 1914-17, 149.

244 Laati 1955, 153-157; Siipi 1962, 224-239.

245 J. G. Granön kortit J. K. V. Tuomiselle 10.1. ja 8.2.1917. JGGA. SKS, KiA; Tirranen 1951, 67. HYKA; Vetre 1976, 39-58; Olavi Granön kirjallinen tiedonanto 15.11.2010. 
246 J. G. Granön kortti J. K. V. Tuomiselle 8.2.1917. JGGA. SKS, KiA.

247 J. G. Granön kirje J. K. V. Tuomiselle 8.7.1917. JGGA. SKS, KiA.

248 J. G. Granön kirje J. K. V. Tuomiselle 23.11.1918. JGGA. SKS, KiA; Oulun lyseo 1883-1933 1933, 175-178.

249 K. Oksalan kirje J. G. Granölle 12.5.1917, J. G. Granön kortti J. K. V. Tuomiselle 22.4.1917. JGGA. SKS, KiA.

250 J. G. Granön kortti J. K. V. Tuomiselle 24.6.1917. JGGA. SKS, KiA.

251 Polvinen 1967, 16-27.

252 Laati 1955, 162-172; Polvinen 1967, 101-131.

253 Polvinen 1967, 155-311.

254 J. G. Granön kirje J. K. V. Tuomiselle 14.10.1917. JGGA. SKS, KiA; Kertomus HY:n toiminnasta 1914-17, 174-176; Klinge 1990, 15-16, 396.

255 Konsistorin ptk 20.4.1921. HYKA; Granö 1919b; Tarkka 1980, 82.

256 J. G. Granön kirje Akateemiselle Karjala-Seuralle 4.11.1923. JGGA. SKS, KiA; Tirranen 1951, 4041. HYKA; Vares 2010, 47-50.

257 Homén 1918, VIII-IX.

258 Viljanen 1955, 193-194; Klinge 1990, 15-23.

259 J. G. Granön kirje J. K. V. Tuomiselle 14.10.1917. JGGA. SKS, KiA.

260 Olavi Granön haastattelu 14.5.2010.

261 J. G. Granön kortti J. K. V. Tuomiselle 18.5.1918. JGGA. SKS, KiA.

262 J. G. Granön kortti J. K. V. Tuomiselle 18.5.1918, J. G. Granön kirje Akateemiselle Karjala-Seuralle 4.11.1923. JGGA. SKS, KiA.

263 Paavolainen 1971, 169-206.

264 J. G. Granön kortit J. K. V. Tuomiselle 18.5. ja 21.8.1918. JGGA. SKS, KiA.

265 J. G. Granön kortti J. K. V. Tuomiselle 21.8.1918. JGGA. SKS, KiA; Rosberg 1922, 15-20.

266 Tirranen 1951, 67. HYKA.

267 J. G. Granön kirje J. K. V. Tuomiselle 28.3.1919. JGGA. SKS, KiA.

488
268 J. G. Granön kirje J. K. V. Tuomiselle 2.11.1918. JGGA. SKS, KiA.

269 J. G. Granön kirje J. K. V. Tuomiselle 23.11.1918. JGGA. SKS, KiA.

270 J. G. Granön kirjeet J. K. V. Tuomiselle 23.11.1918 ja 28.3.1919. JGGA. SKS, KiA; Jäntti 1928, 386-387; Oulun lyseo 1883-1933 1933, 175-178; Tiitta 1996, 77.

271 J. G. Granön kirje J. K. V. Tuomiselle 23.11.1918. JGGA. SKS, KiA; Uusi Suometar 14.12.1917.

272 J. G. Granön kirje J. K. V. Tuomiselle 25.9.1919. JGGA. SKS, KiA; Kertomus HY:n toiminnasta 1917-20, 16.

273 J. G. Granön kirje J. K. V. Tuomiselle 28.3.1919. JGGA. SKS, KiA.

274 Zetterberg 2007, 504-514.

275 Nuorteva 2001, 102-103, 109-110; 375-vuotias Tarton yliopisto, 4 .

276 Zetterberg 2007, 241-244, 322-325, 404-412, 580-583.

277 375-vuotias Tarton yliopisto, 4-5.

278 J. G. Granön kirje André Froehlichelle 5.5.1948; J. G. Granön kirje Henry S. Heimoselle 13.4.1938. JGGA. SKS, KiA; Paatsi 2000, 3; Jauhiainen 2001, 32.

279 Paatsi 2000, 4; Zetterberg 2007, 580-583.

280 Kettunen 1948, 66-69; Paatsi \& Paatsi 1982, 357-362; Paatsi 2000, 3-4; Kurs \& Granö 2004, 2.

281 Kurs 1982 ja 2005, 405; Paatsi 1997, 5; Hildén 2002.

282 Johannes Piiperin kirje J. G. Granölle 12.8.1919, Peeter Pöldin sähkösanoma J. G. Granölle 18.9.1919. JGGA. SKS, KiA: Paatsi 2000, 4; Kurs 2005, 405.

283 J. G. Granön kirje J. K. V. Tuomiselle 25.9.1919. JGGA. SKS, KiA; Hildén 1956c, 83; Granö 1988.

284 J. G. Granön kirje J. K. V. Tuomiselle 25.9.1919. JGGA. SKS, KiA; Tirranen 1951, 62. HYKA; Granö 1993b, 528-529 ja 2003 b. 
285 Rosberg 1919; Granö 1988, 2003b ja 2005 a.

286 Lauri Hendellin kirjeet J. G. Granölle 1., 3. ja 4.9.1919. JGGA. SKS, KiA; Konsistorin ptk 20.4.1921. HYKA; Olsoni 1920.

287 Setälä 1919.

288 Rosberg 1919.

289 Tirranen 1951, 43. HYKA.

290 J. G. Granön kirje J. K. V. Tuomiselle 25.9.1919. JGGA. SKS, KiA.

291 J. G. Granön opetuksessaan käyttämä kirgiisiläinen sanonta.

292 Tirranen 1951, 62. HYKA; Granö 1979, 77-78 ja 1993b, 528-529; Jaatinen 1988.

293 Buttimer 2010, 13-20.

294 Tirranen 1951, 7. HYKA; Granö 1909b, 33-35.

295 Fyysis-matem. os. ptk 2.3.1911. HYKA; Granö 1907a, 1907b, 1908a ja 1908c ja 1909c.

296 J. G. Granön radioesitelmä 25.5.1935. JGGA. SKS, KiA.

297 J. G. Granön kortti J. K. V. Tuomiselle 24.6.1917; J. G. Granön kirje J. K. V. Tuomiselle 14.10.1917. JGGA. SKS, KiA; Granö 1993b, 524.

298 Uusi Suometar 14.12.1917.

299 Eskola 2002, 28-31.

300 Felix Jonasson kirjeet ja kortit J. G. Granölle 1913-30. JGGA. SKS, KiA; Rikkinen 1988, 117; Eskola 2005, 95.

301 Eskola 2002, 30-41.

302 Granö 1930b ja 1932b; Eskola 2002, 21-22.

303 Olavi Granön haastattelu 14.5.2010.

304 Eskola 2002 ja 2005; Jones 2003, 92-94.

305 Granö 1919a ja 1921a.

306 Granö 1921a, 600-601.

307 Granö 1919a, 203, 211-212.

308 Eskola 2002, 22, 38.

309 Granö 1919a, 304; Eskola 2002, 32-33.

310 Granö 1916b, 210.

311 Eskola 2002, 5, 37.

312 Tirranen 1951, 38-39. HYKA.

313 Eskola 2002, 95; Buttimer 2010.

314 J. G. Granön kirje J. K. V. Tuomiselle 10.11.1920. JGGA. SKS, KiA; Granö 1993b, 524.
315 Rosberg 1919; Tolvanen 1920, 108; Granö 1997b, 50 ja $2003 a$.

316 Granö 1919a, 18; Buttimer 2010.

317 Granö 1919a, 18; Granö 1998, 19.

318 J. G. Granön kirjeet J. K. V. Tuomiselle 8.7. ja 14.10.1917. JGGA. SKS, KiA; Tirranen 1951, 3839. HYKA.

319 J. G. Granön kirje J. K. V. Tuomiselle 10.11.1920. JGGA. SKS, KiA; Granö 1921a.

320 J. G. Granön kirje J. K. V. Tuomiselle 10.11.1920. JGGA. SKS, KiA.

321 Granö 2003b.

322 Jones 2003, 86-97.

323 Granö 1919a, 18; Olavi Granön haastattelu 14.5.2010.

324 Toivo Vikstedtin kirje J. G. Granölle 1.8.1919. JGGA. SKS, KiA.

325 Granö 1919a, 34-35; Granö 1992, 48-49.

326 Granö 1919a, 37; Suutala 1993.

327 Granö 1919a, 289; Rosberg 1919, Eskola 2002, 120-124.

328 Granö 1919a, 47.

329 Granö 1919a, 258-273; Rosberg 1919.

330 Granö 1919a, 54; Eskola 2002, 107-108.

331 Granö 1921a, 510.

332 Granö 1919a, 53; Buttimer 2010, 27-28.

333 Eskola 2002, 72-74.

334 Granö 1919a, 59-60; Kuitunen 1993.

335 Granö 1919a, 262, 301.

336 Granö 1919a, 161 ja 1921a, 529-531; Suutala 1993.

337 Granö 1919a, 219-220; Eskola 2002, 111-113.

338 Granö 1919a, 171.

339 J. G. Granön kirje J. K. V. Tuomiselle 7.6.1920. JGGA. SKS, KiA.

340 Granö 1921a, 431.

341 Aamulehti 27.12.1942; Jones 2003, 90-96; Buttimer 2010, 32.

342 Hintikka 1919; I. 1921, Tolvanen 1919; Jäntti 1928, 389.

343 Konsistorin ptk 20.4.1921. HYKA; Rosberg 1919; Valkonen 2002. 
344 Aarne Anttilan kirje J. G. Granölle 18.3.1931. JGGA. SKS, KiA; Hintikka 1919; Tolvanen 1920, 107.

345 Hjalmar Appelgren-Kivalon kirje J. G. Granölle 28.2.1921. JGGA. SKS, KiA; Granö 1993a.

346 Olavi Granön haastattelu 14.5.2010.

347 Kuitunen 1993; Eskola 2002, 121-123.

348 Lehtola 1993.

349 Granö 1993a.

350 Lehtola 1993.

351 Eskola 2002, 5-7; Granö 2002a; Magnusson 2002; Uimonen 2002.

352 Salokorpi 2002.

353 Harvilahti 2002; Koskela 2002, 114; Uimonen 2002; Vauras 2002; Raento 2005, 16.

354 Myllykangas 2005.

355 Granö 2005b, 9; Tiitta 2005a; Linkola 2007 ja 2008.

356 Clarke 1997, 55-74; Hanson 2005; Uimonen 2005a; Buttimer 2010, 32.

357 Eskola 2002, 133-137; Pälviranta 2002; Jones 2003, 97-98.

358 J. G. Granön kirje J. K. V. Tuomiselle 10.11.1920. JGGA. SKS, KiA.

359 Polvinen 1971, 275-313; Zetterberg 2000, 361 ja 2007, 508-510.

360 Lauri Kettusen kirje J. G. Granölle 11.9.1919. JGGA. SKS, KiA; Kettunen 1948, 70-72

361 Paatsi 1997, 7.

362 Kettunen 1948, 70-71.

363 J. G. Granön kirje J. K. V. Tuomiselle 25.9.1919. JGGA. SKS, KiA; Zetterberg 2007, 324.

364 J. G. Granön kirje J. K. V. Tuomiselle 25.9.1919, J. G. Granön kortti J. K. V. Tuomiselle 19.10. 1919. JGGA. SKS, KiA; Kettunen 1948, 84-85.

365 J. G. Granön kirje J. K. V. Tuomiselle 20.12.1919. JGGA. SKS, KiA; Kurs \& Granö 2004, 5.

366 J. G. Granön kirjeet J. K. V. Tuomiselle 7.6.1920, 20.12.1919 ja 2.8.1921. JGGA. SKS, KiA; Tirranen 1951, 45. HYKA.

367 J. G. Granön kirje J. K. V. Tuomiselle 7.6.1920. JGGA. SKS, KiA.
368 J. G. Granön kirje J. K. V. Tuomiselle 2.8.1921. JGGA. SKS, KiA; Paatsi 2000, 14.

369 Kurs 2001b, 89-90; Granö 2005a, 168; Buttimer 2010, 14-16.

370 J. G. Granön kirje J. K. V. Tuomiselle 20.12.1919. JGGA. SKS, KiA.

371 J. G. Granön kirje J. K. V. Tuomiselle 20.12.1919. JGGA. SKS, KiA; Uusi Suomi 29.8.1919; Kurs 2001a, 4-6.

372 Paatsi 2000, 4-5.

373 J. G. Granön kirje André Froehlichelle 5.5. 1948; J. G. Granön kirje Henry S. Heimoselle 13.4.1938. JGGA. SKS, KiA.

374 J. G. Granön kirje J. K. V. Tuomiselle 20.12.1919. JGGA. SKS, KiA; Kurs 2005, 405.

375 Paavo Granön kirjeet J. G. Granölle 4.10. ja 13.11.1917 ja 27.3., 8.7. ja 1.8.1920, Paavo Granön sähkösanoma J. G. Granölle 1921. JGGA. SKS, KiA; Oulun lyseo 1883-1933 1933, 178; Hasselblatt 1917, 125-126; Paavolainen 1966, 140-144; Aaltonen 1967, 101; Heikkilä 1970; Amerikan Uutiset 6.2.1973; Herlin 1967, 159 ja 1980, 8; Kiiskinen 1977; Janhunen 1982, 11-13; Juntunen 1982, 361-363; Kotimaa 25.8.1983, Granö 1995, 147; Kinnunen 1991a ja 1991b; Saari 1993, 39 ja 1994, 111-113; Nevalainen 2002, 171-172; Zetterberg 2000, 359-361; Ahonen 2006; Tuuri 2009, 197-201.

376 Kettunen 1948, 219; Polvinen 1971, 348-370.

377 J. G. Granön kirje J. K. V. Tuomiselle 2.2.1922. JGGA. SKS, KiA; Granö 1998, 21; Paatsi 2000, 11; Zetterberg 2007, 532-534.

378 J. G. Granön kortti J. K. V. Tuomiselle 31.3.1921. JGGA. SKS, KiA; Roosaare 1994, 30.

379 Paatsi 2000, 11-12.

380 Hildén 1956b, 5; Mereste 1985, 182.

381 Kaskimies 1947, 58; Granö 1992, 38; Paatsi 2000, 5; Jauhiainen 2001, 31-33.

382 Granö 1920a.

383 Granö 1979, 75-76 ja 2003, 24.

384 Granö 1998, 19.

385 Jessen 1936, 196; Leiviskä 1949，280-304;

490

\section{Vittteet}


Granö 1982, 8-10; Muir 1990; Raivo 1997, $194-195$.

386 Granö 1920a, 9; Granö 1982b, 8-10 ja 1998, 19; Mereste 1985, 179; Muir 1990; Raivo 1997, 94-195.

387 J. G. Granön kirje W.M. Davisille 15.2.1921. HLHU; Heinonen 1943, 24; Granö 2003c, 13 15.

388 Lev S. Bergin kortit J. G. Granölle 1914-46. JGGA. SKS, KiA; Berg 1930; Granö 1997b, 50; Granö \& Paasi 1997, xv-xvi.

389 Granö 2003c, 13-23.

390 J. G. Granön kirje J. K. V. Tuomiselle 20.12.1919, Kalle Väisälän kirjeet J. G. Granölle 1919-23. JGGA. SKS, KiA; Postimees 25.2. ja 10.4.1920; Paatsi \& Paatsi 1982; Kurs 1992a; Paatsi 2000, 5; Lehto 2004, 345-347.

391 J. G. Granön kirje J. K. V. Tuomiselle 20.12.1919. JGGA. SKS, KiA; Kurs 1982; Granö 2003a ja 2005b.

392 J. G. Granön kirjeenvaihto 1901-55. JGGA. SKS, KiA; Tirranen 1951, 66. HYKA; Tarmio 2000, 63; Oksanen 2010; Buttimer 2010; Olavi Granön haastattelu 21.10.2004.

393 J. G. Granön kirje J. K. V. Tuomiselle 7.6.1920. JGGA. SKS, KiA; Kurs, Paatsi \& Tammiksaar 1999, 16.

394 Hildén 1956a, 5; Mereste 1985, 182; Paatsi 2000, 11; Raig 2007, 7.

395 Jauhiainen 2001, 35; Granö 2005a, 169-172.

396 Granö 2003b.

397 Granö 1997b, 51; Buttimer 2010, 19-20.

398 J. G. Granön kirje J. K. V. Tuomiselle 25.9.1919. JGGA. SKS, KiA.

399 J. G. Granön kirje J. K. V. Tuomiselle 20.12.1919. JGGA. SKS, KiA; Paatsi 2000, 4-5.

400 Granö 1988, 2003b ja 2005a; Tarmio 2000, 64; Linkola 2005b; Zetterberg 2007, 406-410, 580-583.

401 Granö 1921b, 31-38; Paatsi 2000, 5.

402 Paatsi 1997, 9; Pae \& Mardiste 2009, 20-22.

403 Granö 1921b, 32; Paatsi 2000, 5; Granö 2000b;
Jauhiainen 2001, 32-35.

404 J. G. Granön kirje J. K. V. Tuomiselle 2.8.1921. JGGA. SKS, KiA; Kurs 1988; Kurs, Paatsi \& Tammiksaar 1999, 17-18.

405 Tammekann 1955a; Paatsi 2000, 5-8.

406 J. G. Granön kirje J. K. V. Tuomiselle 2.2.1922. JGGA. SKS, KiA; Kurs, Paatsi \& Tammiksaar 1999, 17-18.

407 August Tammekannin kirjeet (64) ja kortit (4) J. G. Granölle 1922-53. JGGA. SKS, KiA; Kertomus HY:n toiminnasta 1925-26, 15; Granö 1927c; Kurs 1994, 1731-1732.

408 Roosaare 1994, 30; Palang, Mander, Kurs \& Sepp 2000, 157.

409 Tammekann 2000; Jauhiainen 2001, 34-39.

410 Edgar Kantin kirjeet (64) ja kortit (25) J. G. Granölle 1922-54. JGGA. SKS, KiA; Paatsi 2000, 7-8; Granö 2005a, 169-170; Schough 2008, 186-201.

411 Kant 1926; Granö 1927d; Mead 1977, 369.

412 Tuominen 1930; Tiitta 2000a, 318; Jauhiainen 2001, 35.

413 Buttimer 1994; Paasi 1995, 38; Vares 2010, 5657.

414 J. G. Granön kirje Erik Ljungnerille 28.9.1949. JGGA. SKS, KiA; Kant 1935; Kurs 1992 b ja 2007 , 13; Schough 2008, 189-190.

415 J. G. Granön kirje The Rockefeller Foundationille 18.6.1931. JGGA. SKS, KiA; Granö 2005a, 170172; Kurs 2007, 14.

416 Jauhiainen 1991, 35.

417 Schough 2008, 190-194.

418 Kurs 1992; Granö 2005a, 170-172.

419 Leiviskä 1926, 128-131; Jaeger 1933; Hellaakoski 1936, 18-19; Kant 1956b, 167.

420 Jessen 1936, 195-196; Granö 1982b, 10.

421 Granö 1920a, 9; Mereste 1985, 179; Granö 1992, 45 ja 1998,19

422 Granö 1922, 106-109, 280-281; Buttimer 2010.

423 Helsingin Sanomat 20.12.1922.

424 Granö 1922, 266-270; Granö 1923 ja 1924a; Hildén 1956c, 83; Paatsi 2002, 8-11.

425 Granö 1922, 271-280. 
426 Nuuja \& Palokangas 1987, 2.

427 Kurs 1988; Raig 1997, 7; Kurs, Paatsi \& Tammiksaar $1999,17$.

428 Paatsi 2002, 8-11.

429 Granö 1923, 179; Tiitta 2007.

430 Jäntti 1928, 386-387; Tiitta 2005b.

431 Granö 1923, 179; Kurs 1998, 212.

432 Kaarlo Hildénin kortti J. G. Granölle 29.3.1920. JGGA. SKS, KiA.

433 Granö 1923, 179; Paatsi 2000, 14; Kurs 2007, 8.

434 Paatsi 2000, 15-16.

435 Granö 1923, 179.

436 Granö 2005a, 169-170; Kurs 2007, 2008.

437 Granö 1923, 179-180; Kurs 1992b; Paatsi 2000, 14; Jauhiainen 2001, 33.

438 J. G. Granön kirjeet J. K. V. Tuomiselle 2.8 .1921 ja 2.2.1922. JGGA. SKS, KiA; Kurs 2007, 8.

439 Granö 1923, 180.

440 J. G. Granön kirje J. K. V. Tuomiselle 2.2.1922. JGGA. SKS, KiA.

441 Granö 1923, 180-181.

442 J. G. Granön kirje J. K. V. Tuomiselle 2.2.1922,

J. G. Granön kortit Aune Granölle 13.6.1922 ja 8.7.1922. JGGA. SKS, KiA; Granö 1923, 181; Granö 2003c, 21; Kurs 2007, 8-9.

443 Granö 1923, 181-182; Paatsi 2000, 12-14.

444 Granö 1923, 182; Paatsi 2000, 12-14.

445 Buttimer 2010, 20-21.

446 Granö 1923, 181; Kurs 1988; Kurs \& Paatsi 1990; Kurs, Paatsi \& Tammiksaar 1999, 17.

447 Kurs 1998, 214.

448 Granö 1923, 181.

449 Granö 1992, 49 ja 1999, 19; Kurs 1992b; Jauhiainen 2001, 33.

450 Granö 1923, 181-182.

451 Edgar Kantin kirjeet J. G. Granölle 1922-29. JGGA. SKS, KiA; Granö 1923, 182.

452 Kurs \& Paatsi 1990; Paatsi 2000, 8-11; Kurs 2007, $10-12$.

453 Sederholm 1912; Rosberg 1919, 1-6; Tiitta 2000a, 309-315.

454 Rosberg 1918 ja 1919, 18.

\section{VittTeEt}

455 Granö 1920b, 45; Witting 1921, 33-42, 61-83.

456 Granö 1920b; Linkola 2005b.

457 Granö 1920b, 13-19, 46-48.

458 Granö 1920b, 15.

459 Granö 1921b, 31-38.

460 Granö 1920b, 28-29.

461 Granö 1920b, 16; Granö 1998, 18.

462 Granö 1920b, 16-22.

463 Granö 1920b, 23-33.

464 J. G. Granön kirje J. K. V. Tuomiselle 7.6.1920. JGGA. SKS, KiA.

465 J. G. Granön kirje J. K. V. Tuomiselle 10.11.1920. JGGA. SKS, KiA.

466 Tiitta 2000a, 312-321.

467 Tammekann 1953a; Hildén 2002; Eskelinen 2004, 96; Löytönen 2005, 52-53.

468 Kertomus HY:n toiminnasta 1920-23, 21; Perälä 1970, 68; Tuominen 1978, 6-9.

469 Konsistorin ptk:t 3. ja 10.11.1920, 9.3. ja 20.4.1921, 19.1.1924. HYKA.

470 Tuominen 1988, 131-132.

471 Kaarlo Hildénin kirjeet J. G. Granölle 14.4., 18.5. ja $28.10 .1920,30.4$. ja 22.8.1921, Wäinö Bonsdorffin kirje J. G. Granölle 2.4.1921. JGGA. SKS, KiA.

472 Konsistorin ptk:t 20. ja 27.4.1921. HYKA.

473 Tiitta 2000a, 314-315.

474 Tiitta 2000a, 310-311.

475 Kaarlo Hildénin kortti J. G. Granölle 20.1.1922; J. G. Granön kirje J. K. V. Tuomiselle 2.2.1922. JGGA. SKS, KiA; SMS:n ptk 12.5.1922. Terra 34/1922, 196.

476 J. G. Granön kirje J. K. V. Tuomiselle 2.2.1922. JGGA. SKS, KiA; Tirranen 1951, 49. HYKA.

477 Konsistorin ptk 7.12.1921. HYKA; Kaarlo Hildénin kortti J. G. Granölle 31.5.1922. JGGA. SKS, KiA; Kertomus HY:n toiminnasta 1920-23, 156.

478 Konsistorin ptk 25.4.1923. HYKA; Kertomus HY:n toiminnasta 1920-23, 22.

479 J. G. Granön kirje J. K. V. Tuomiselle 2.2.1922, J. G. Granön kortti Aune Granölle 13.6.1922. JGGA. SKS, KiA. 
480 Henrik Koppelin kirje J. G. Granölle 8.6.1922. JGGA. SKS, KiA; Paatsi 2000, 14.

481 J. G. Granön kortti J. K. V. Tuomiselle 19.10.1922. JGGA. SKS, KiA; SMS:n ptk 29.9.1922. Terra 34/1922, 251.

482 Konsistorin ptk:t 24. ja 31.1.1923. HYKA, J. G. Granön kirje J. K. V. Tuomiselle 2.3.1923. JGGA. SKS, KiA; Klinge 1990, 46-47; Lagerspetz 2000, 229-230; Tommila 2002, 73-74.

483 Konsistorin ptk 31.1.1923. HYKA.

484 Klinge 1990, 47-49.

485 J. G. Granön kirje J. K. V. Tuomiselle 2.3.1923. JGGA. SKS, KiA.

486 Valtioneuvoston ptk:t 19.1. ja 22.2.1923. KA; Konsistorin ptk 7.3.1923. HYKA.

487 Kurs 1988.

488 J. G. Granön kirje J. K. V. Tuomiselle 2.2.1922. JGGA. SKS, KiA; Kettunen 1948, 85.

489 Granö 1997b, 50.

490 V. A. Heiskasen kirje J. G. Granölle 8.1.1950, J. G. Granön kirje V. A. Heiskaselle 13.1.1951. JGGA. SKS, KiA; Roosesaare 1994, 31-32; Granö 2001, 17; Granö 2003c, 31; Kurs \& Granö 2004, 17; Olavi Granön haastattelu 14.5.2010.

491 J. G. Granön kortti Aune Granölle 8.5.1923; Granö \& Kant 1923, 321, julkaisu perustuu Edgar Kantin pikakirjoituksella tekemiin muistiinpanoihin Granön luennosta.

492 Granö \& Kant 1923, 321-322; May 1970, 10, 74125; Beck 1973: 320.

493 Granö \& Kant 1923, 322.

494 Granö 1982b, 10, 1997b, 50 ja 2002c; Aartolahti 1982, 33; Tiitta 1996, 280-312; Granö \& Paasi 1997, xviii; Jones 2003, 85; Kalliola 2007, 42.

495 Granö \& Kant 1923, 322.

496 Granö \& Kant 1923, 323-324.

497 Granö \& Kant 1923, 324-325.

498 Granö \& Kant 1923, 326.

499 Granö \& Kant 1923, 326-327.

500 Granö \& Kant 1923, 327.

501 Granö 1930b, 111; Jessen 1936, 195; Mead 1977, 369; Paasi 1982, 149-150; Golledge 1998, 681682.
502 Paatsi 2000, 14.

503 Rauhala 2002, 433; Granö 2005a, 171; Jauhiainen 2010.

504 J. G. Granön kirje J. K. V. Tuomiselle 23.2.1924. JGGA. SKS, KiA.

505 HY:n ohjelmat 1923-24, 46-52, 77, 1924-25, 50-56, 85, 1925-26, 52-60, 87; Kertomus HY:n toiminnasta 1920-23, 21; Granö 1932a; Jaatinen 1988; Tiitta 1996, 72-73; Alhonen \& Alhonen 2006, 26-46.

506 Löytönen 1986, 227; Lagerspetz 2000, 209, 240; Hildén 2002.

507 HY:n ohjelmat 1923-24，46，1924-25， 50 ja 1925-26, 52; Kertomus HY:n toiminnasta 192023,110 .

508 HY:n ohjelmat 1923-24, 48-52, 1924-25, 52-56 ja 1925-26, 54-58; Kertomus HY:n toiminnasta 1925-26, 50; Alhonen \& Alhonen 2006, 26-39.

509 Tirranen 1951, 49. HYKA; Klinge 1990, 49-58.

510 Konsistorin ptk:t 7.6.1923, 19. ja 30.1., 20.2.1924. HYKA; Kertomus HY:n toiminnasta 1923-24, 3, 13.

511 Konsistorin ptk 19.1.1924. HYKA; Paaskoski 2008, 310, 389.

512 J. G. Granön kirje J. K. V. Tuomiselle 23.2.1924. JGGA. SKS, KiA; Tirranen 1951, 49. HYKA; Leiviskä 1951, 4; Löytönen 1986, 227.

513 J. G. Granön kirje J. K. V. Tuomiselle 23.2.1924. JGGA. SKS, KiA; Tirranen 1951, 49. HYKA.

514 Konsistorin ptk 7.5.1924. HYKA; Granö 1924c; Terra 36/24, 295-296.

515 Pál Telekin kirjeet ja kortit J. G. Granölle 1924-28, Aladár Paasosen kirje J. G. Granölle 10.11.1938. JGGA. SKS, KiA; Tirranen 1951, 58-59. HYKA.

516 J. G. Granön kirje J. K. V. Tuomiselle 26.6.1925. JGGA. SKS, KiA.

517 J. G. Granön kirje J. K. V. Tuomiselle 31.7.1955. JGGA. SKS, KiA.

518 J. G. Granön kirje J. K. V. Tuomiselle 26.6.1925. JGGA. SKS, KiA.

519 J. G. Granön kirje J. K. V. Tuomiselle 26.6.1925, J. G. Granön kortit J. K. V. Tuomiselle 11.7.1930 ja 11.8.1930. JGGA. SKS, KiA.

\section{VittTeET}


520 J. G. Granön kirje J. K. V. Tuomiselle 30.7.1944. JGGA. SKS, KiA.

521 Olavi Granön haastattelu 23.2.2006.

522 J. G. Granön kirje J. K. V. Tuomiselle 29.8.1954. JGGA. SKS, KiA; Tirranen 1951, 67. HYKA; Olavi Granön kirjallinen tiedonanto 26.2.2010.

523 Granö 1955d.

524 SMS:n ptk 26.1.1923. Terra 35/1923, 85.

525 SMS:n ptk 21.2.1924. Terra 36/1924, 309-310; Suomen Kartasto 1925.

526 J. G. Granön kirje J. K. V. Tuomiselle 23.2.1924. JGGA. SKS, KiA; SMS:n ptk 27.3.1923. Terra 35/1923, 96.

527 Vuoden 2010 rahanarvoon saatettuna vuoden 1923 valtionapu vastasi runsasta 18000 euroa; SMS:n ptk:t 26.1.1923 ja 21.2.1924. Terra 35/1923, 85 ja /1924, 310.

528 Suomen Kartasto 1925.

529 Konsistorin ptk:t 19.12.1923 ja 30.9.1925. HYKA; Kertomus HY:n toiminnasta 1923-24, 14; SMS:n ptk 8.10.1924. Terra 37/1925, 46-47; Tirranen 1951, 49. HYKA.

530 SMS:n ptk 28.11.1925. Terra 38/1926, 72.

531 SMS:n ptk:t 28.11.1925 ja 26.1.1926. Terra 38/1926, 72-73, 145-147.

532 Osmo H. Porkan kirjeet J. G. Granölle 1926-30. JGGA. SKS, KiA; SMS:n ptk:t 4.1. ja 6.10.1926, 25.1.1927. Terra 38/1926, 144 ja 39/1927, 33, 132133.

533 Suomen Kartasto 1925; Suomen Kartasto 1925. Teksti.

534 SMS:n ptk:t 27.1.1927 ja 29.1.1929. Terra 40/1928, 181-182 ja 41/1929, 125; Suomen Kartasto 1925.

535 Hans Schrepferin arvio Suomen kartastosta 1925. Cd. JGGA. SKS, KiA; Eskola 1929; Linkola 1929; Uusi Suomi 23.3.1929; Åbo Underrättelser 1929; De Geer 1930; Juntunen 1993, 156.

536 SMS:n ptk 17.11.1922. Terra 34/1922, 257.

537 Granö 1924b, 1.

538 Granö 1924b, 1-2; Karlsson \& Enkvist 2000, 249.
539 Granö 1924b, 2; Toivonen 1924, 37.

540 Granö \& Paasi 1997, xi-xx.

541 J. G. Granön kirje J. K. V. Tuomiselle 29.8.1954. JGGA. SKS, KiA; SMS:n ptk 14.12.1923. Terra 36/1924, 86; Granö 1929a, 17-18, 111-114; van der Vaart 1975, 93-94; Granö 1982a ja 1988.

542 J. G. Granön kirje J. K. V. Tuomiselle 2.1.1924. JGGA. SKS, KiA; SMS:n ptk 14.12.1923. Terra 36/1924, 86; Hautamäki 1987, 13.

543 J. G. Granön kirje J. K. V. Tuomiselle 2.1.1924. JGGA. SKS, KiA.

544 J. G. Granön kirje J. K. V. Tuomiselle 2.1.1924. JGGA. SKS, KiA.

545 Granö 1924a, 1 ja 1924b, 1.

546 Granö 1924b, 3-4; Auer 1930; Hildén 1956c, 85; Granö 1992, 46.

547 Granö 1924b, 3.

548 Granö 1924b, 3-4.

549 Granö 1924b, 4.

550 Granö 1924b, 4-5; van der Vaart 1975, 92.

551 Granö 1924b, 8-35; Hautamäki 1987, 13.

552 Granö 1924b, 35-36.

553 Konsistorin ptk 7.5.1924. HYKA; Granö 1924c, 102; Tarmio 2000, 69-70.

554 Banse 1920; Younghusband 1920 ja 1921; Granö 1924c, 100; Kalliola 1982, 29-30.

555 Granö 1924c, 100.

556 Granö 1924c, 105-106; Banse 1928; Paasi 1982, 146-147.

557 Sauer 1925, 344.

558 Granö 1925; Hettner 1927, 110-130.

559 Granö 1925, 152-156; Hartshorne 1951, 213-214; van der Vaart 1975, 92.

560 Hettner 1927, 121-122; Granö 1963, 20 ja 1982b; Paasi 1982, 140.

561 Kant 1956b, 168; Allardt 2000, 489-490.

562 Granö 1925, 158-159; Paasi 1982, 147; Mereste 1985, 181; Granö 1992, 46.

563 Granö 1925, 159.

564 Granö 1925, 154-158.

565 Granö 1926a, 56. 
566 Granö 1926a, 56-58.

567 Leiviskä 1926, 120-121.

568 Leiviskä 1926, 128-131.

569 Leiviskä 1926, 131.

570 Leiviskä 1926, 123-132.

571 Granö 1926b, 133.

572 Granö 1926b, 135.

573 Granö 1926b, 135.

574 Matem-luonnont. os. ptk 14.12.1944. HYKA; Tuominen 1988, 133-134.

575 Granö 1926b, 139-140.

576 Konsistorin ptk:t 26.5. ja 17.8.1926. HYKA; Kertomus HY:n toiminnasta 1925-26, 10.

577 J. G. Granön puhe Ylioppilaskunnan toimihenkilöille. Ce. JGGA. SKS, KiA; Tiitta 2000a, 309.

578 Perälä 1970, 170-171, 200.

579 J. G. Granön kirjeet J. K. V. Tuomiselle 2.11.1918 ja 2.3.1923. JGGA. SKS, KiA.

580 Jäntere 1942; Tuominen 1978, 6-9; Tommila 2002, 115-120.

581 Turun Yliopiston Maantieteellisen Laitoksen Aikakirja 1924-48. JGGA. SKS, KiA; Perälä 1970, 68-69.

582 J. G. Granön kirje J. K. V. Tuomiselle 23.2.1924. JGGA. SKS, KiA; Kutsu kuulemaan.... 1926, 4; Tuominen 1978, 16-17.

583 Kalliola 1981, 111; Tommila 2002, 119-120.

584 Turun Yliopiston Maantieteellisen Laitoksen Aikakirja 1924-48. JGGA. SKS, KiA; Tarmio 2000, 65.

585 Tuominen 1978, 16-18.

586 Kutsu kuulemaan.... 1926, 4; Perälä 1970, 70.

587 Tuominen 1978, 18-22; Tarmio 2000, 65-66.

588 Kalle Väisälän kirje J. G. Granölle 24.2.1923; J. G. Granön kirjeet Artturi H. Virkkuselle s.a., J. K. V. Tuomiselle 2.3.1923 ja Walter M. Linnaniemelle 15.11.1925. JGGA. SKS, KiA.

589 J. G. Granön kirje Walter M. Linnaniemelle 15.11.1925. JGGA. SKS, KiA.

590 J. G. Granön kirje Walter M. Linnaniemelle 15.11.1925. JGGA. SKS, KiA.
591 J. G. Granön kirje Walter M. Linnaniemelle 15.11.1925. JGGA. SKS, KiA.

592 J. G. Granön kirje Walter M. Linnaniemelle 15.11.1925. JGGA. SKS, KiA; Tirranen 1951, 49-50. HYKA.

593 Walter M. Linnaniemen kirje J. G. Granölle 3.12.1925. JGGA. SKS, KiA; Tirranen 1951, 50. HYKA.

594 Tarmio 2000, 65.

595 Kutsu kuulemaan.... 1926, 3-4; Perälä 1970, 7071; Tuominen 1978, 24.

596 Turun Yliopiston Maantieteellisen Laitoksen Aikakirja 1924-48. JGGA. SKS, KiA; Raivo 1999c; Tarmio 2000, 65-66.

597 Kalle Väisälän kirje J. G. Granölle 24.2.1923, V. A. Koskenniemen kirje J. G. Granölle 3.1.1926. JGGA. SKS, KiA; Sandvik 1986.

598 Tirranen 1951, 50. HYKA; Paasi 2004, 277.

599 Tirranen 1951, 50. HYKA.

600 J. G. Granön puhe soihtukulkueen ylioppilaille Turussa tammikuussa 1932. Ce. JGGA. SKS, KiA.

601 Tirranen 1951, 51. HYKA; Olavi Granön haastattelu 21.10.2004.

602 Olavi Granön haastattelu 21.10.2004.

603 Tommila 2002, 120-124.

604 Olavi Granön haastattelu 21.10.2004.

605 Helsingin Sanomat 18.3.2010.

606 Tommila 2002, 124.

607 Tirranen 1951, 52. HYKA; Rossi 1995, 150.

608 A. E. Koskenniemen kirjeet ja kortit J. G. Granölle 1911. JGGA. SKS, KiA; Tirranen 1951, 51. HYKA; Granö 1912b, 98-100.

609 Rossi 1995, 144-145; Olavi Granön haastattelu 23.2.2006.

610 Tirranen 1951, 51. HYKA; Häikiö 2010, 379.

611 Uusi Aura 14.3.1932; Uusi Suomi 14.3.1932.

612 Uusi Aura 14.3.1932.

613 Olavi Granön kirjallinen tiedonanto 26.2.2010.

614 Olavi Granön haastattelu 23.2.2006.

615 J. G. Granön kirje J. K. V. Tuomiselle 26.6.1925. JGGA. SKS, KiA; Tuominen 1978, 24-33 ja 1982, 8 .

VittтеET || 495 
616 Tarmio 2000, 65-66; Granö 2003a ja 2003 b.

617 Rossi 1995, 144-146.

618 Wilhelm Ramsayn ja Pentti Eskolan antama todistus 25.2.1927. Aa. JGGA. SKS, KiA; Perälä 1970, 71; Tuominen 1978, 16-17, 57.

619 Turun Yliopiston Maantieteellisen Laitoksen Aikakirja 1924-48. JGGA. SKS, KiA.

620 J. G. Granön kirje J. K. V. Tuomiselle 2.3.1926. JGGA. SKS, KiA.

621 Tuominen 1978, 59-60.

622 Tuominen 1978, 60-61.

623 J. G. Granön kortit J. K. V. Tuomiselle 26.11.1926 ja 5.12.1926, Turun Yliopiston Maantieteellisen Laitoksen Aikakirja 1924-48, JGGA. SKS, KiA; Lunds Dagblad 22.11.1926; Sydsvenska Dagbladet Snällposten 23.11.1926; Göteborgs Morgonpost 30.11.1926; Aftonposten 3.12.1926; StockholmsTidningen 5.12.1926; Perälä 1970, 71.

624 Tuominen 1978, 29, 61; Hägerstrand 1984, 1621.

625 Turun Yliopiston Maantieteellisen Laitoksen Aikakirja 1924-48. JGGA. SKS, KiA.

626 Turun Yliopiston Maantieteellisen Laitoksen Aikakirja 1924-48. JGGA. SKS, KiA.

627 Granö 1927b, 73.

628 Granö 1927b, 73; Tuominen 1978, 29.

629 Granö 1927b, 73-86; Granö 1997b, 51.

630 Granö 1927b, 74.

631 Granö 2000a, 39 ja 2003c, 27-28; Käyhkö, Granö \& Häyrinen 2004, 246.

632 Tuominen 1978, 24-33.

633 Tuominen 1978, 48.

634 J. G. Granön kirje Turun yliopiston kanslerille E. N. Setälälle 22.10.1930, Matti Sauramon kirje J. G. Granölle 19.12.1930. JGGA. SKS, KiA; Perälä 1970, 199.

635 Turun Yliopiston Maantieteellisen Laitoksen Aikakirja 1924-48. JGGA. SKS, KiA.

636 Kalliola 1981, 112.

637 Kalliola 1981, 113.

638 Tirranen 1951, 51, 63. HYKA; Tuominen 1978, 51; Rossi 1995, 145.

496 VIITteET
639 Heinonen 1943, 25.

640 Kalliola 1981, 111; Tuominen 1982, 10; Rossi 1995, 144.

641 J. G. Granön kirje E. N. Setälälle 22.10.1930. JGGA. SKS, KiA.

642 Perälä 1970, 199.

643 Tuominen 1978, 25-36, 41-47; Granö 2000a, 39.

644 Perälä 1970, 227-228; Tuominen 1978, 25-26, 36; Tiitta 2004, 390-391.

645 Rossi 1995, 144-145; Granö 2000a, 37; Soikkeli 2000; Reino Alavan haastattelu 5.5.2010.

646 Kaikko 1933; Tuominen 1978, 41-42; Hägerstrand 1984, 21; Paasi 1984b; Paaskoski 2008, 69.

647 Johannes Kaikon kirje J. G. Granölle 8.2.1931, J. G. Granön kirje Johannes Kaikolle 9.3.1932, J. G. Granön kirje Väinö Auerille 12.12.1941. JGGA. SKS, KiA; Tirranen 1951, 65. HYKA; Kaikko 1942, 1944 ja 1945.

648 Leo Aarion kirje J. G. Granölle 22.1.1952, J. G. Granön kirjeet Kurt Enkolalle 10. ja 15.4.1953. JGGA. SKS, KiA; Tuominen 1939 ja 1988, 138145.

649 J. G. Granön kirje J. K. V. Tuomiselle 23.10.1945. JGGA. SKS, KiA; Soikkeli 2000; Haahtela 2001, 26.

650 Heikinheimo 1939; Niemelä 1939; Schrepfer 1940; Käyhkö, Granö \& Häyrinen 2004, 246.

651 J. G. Granön kirje J. K. V. Tuomiselle 4.11.1930. JGGA. SKS, KiA; Tuominen 1988, 132; Tiitta 2000a, 318; Jauhiainen 2001, 35; Granö 2003c, 22.

652 Tirranen 1951, 64-65. HYKA.

653 J. G. Granön vastaus Säästöpankkilehden kyselyyn 15.6.1933. Cb., Ilmari Honkasen kirje J. G. Granölle 12.8.1940. JGGA. SKS, KiA.

654 Turun Ylioppilaslehti 13/1932, 97; Tuominen 1988, 134-141; Tiitta 2000a, 316.

655 Kaskimies 1947, 58.

656 J. G. Granön kortti J. K. V. Tuomiselle 25.8.1927. JGGA. SKS, KiA.

657 Tarmio 2000, 71-72; Granö 2003c, 28

658 Väinö Auerin kirje J. G. Granölle 8.9.1927. JGGA. SKS, KiA; Tirranen 1951, 49. HYKA; Cajander 1929; Eskola 1929; Granö 1998, 23; Viitala 1999. 
659 Granö 1929b, 112; Raivo 1999a, 74-75.

660 Suomen Kartasto 1925; Granö 1997b, 51.

661 Suomen Kartasto 1925; Granö 1927b, 73.

662 Granö 1930b, 111; Jessen 1936, 195; Mead 1977, 369; Paasi 1982, 149-150; Golledge 1998, 681682.

663 Kalliola 1981, 111.

664 Tommila 1989, 143-144, 163; Olavi Granön kirjallinen tiedonanto 26.2.2010.

665 Heinrich Schlückingin kirjeet J. G. Granölle 192729. JGGA. SKS, KiA; Granö 1929a ja 1930b.

666 Granö 1930b, III-IV, 2; Jessen 1936, 195, 200; Niiniluoto 2002, 616-618.

667 Wisotzki 1897, 154-159, 193-206, 250; Granö 1924c ja 1930b, 1-32; James 1972, 140-141; Schmithüsen 1976, 104, 107; Granö 1992, 47 ja 2003, 16.

668 Granö 1930b, 1-2, 31-32; Jessen 1936, 196; Kaskimies 1947, 58-59; Tarmio 2000, 61; Granö 1993, 16

669 Granö 1930b, 8-10; Aartolahti 1982, 35; Granö 1982b, 10; Jones 2003, 79-81.

670 Granö 1924b, 101 ja 1930b, 5-6.

671 Granö 1930b, 42-43; Raivo 1999a, 72.

672 Granö 1930b, 33, 88, 115; Paasi 1982, 145.

673 Granö 1930b, 88, 96, 161.

674 Auer 1930; Granö 1930b, 4-52; Tarmio 2000, 67.

675 Hellbach 1923, 3, 348; Granö 1930b, 22, 34-35, 58-59, 125-136; Hartshorne 1951, 152; Schultz 1980, 161; Granö 2003c, 25; Jones 2003, 81-82.

676 Rickert 1902; Granö 1930b, 36-39; Paasi 1982, 145-15; Mereste 1985, 181.

677 Granö 1930b, 40-41; Tarmio 2000, 67-68.

678 Granö 1930b, 27-29; Hautamäki 1987, 13.

679 Granö 1930b, 29.

680 Granö 1930b, 25, 42-43; Tammekann 1953b, 121; Granö \& Paasi 1997, ixx-xx.

681 Granö 1930b, 96-99; Hautamäki 1987, 12-13.

682 Granö 1930b, 56-57.

683 Granö 1930b, 113-114; Golledge 1998, 679; Jones 2003, 82-83.

684 Granö 1930b, 114-117.
685 Granö 1930b, 117-121; Granö 2003c, 29.

686 Granö 1930b, 121-124.

687 Granö 1930b, 124-125; Jones 2003, 82-83.

688 Seppä 1922, 1928 ja 1945; Jäntti 1928, 382-383;

Granö 1930a, 16; Jessen 1936, 195-196.

689 Granö 1930b, 125-126.

690 Granö 1930b, 127-129; Jessen 1936, 195-196; Raivo 1999a, 70-74; Österman 2005.

691 Granö 1930b, 129-131.

692 Granö 1930b, 133-134.

693 Granö 1930b, 135-153.

694 Granö 1930b, 114-115, 157-163.

695 Granö 1925 ja 1930 b, 164-170.

696 Jessen 1936, 198; van der Vaart 1975, 92-93; Granö 1992, 45, 1997b, 50-51 ja 1998, 19; Golledge 1998, 677-678.

697 von Fieandt 1972, 292-295; Schramke 1975, 6162; Paasi 1982, 148-151; Hägerstrand 1984, 17; Käyhkö, Granö \& Häyrinen 2004, 247.

698 Hartshorne 1951, 205; Granö 2003c, 22.

699 Väinö Auerin kirje J. G. Granölle 20.9.1930. JGGA. SKS, KiA; Auer 1930.

700 Kaarlo Hildénin kortti J. G. Granölle 2.5.1930. JGGA. SKS, KiA; Hellaakoski 1936, 18-19; Tuominen 1988, 134-136.

701 Kaarlo Hildénin kortti J. G. Granölle 2.5.1930. JGGA. SKS, KiA; Tammekann 1930 ja 1955a; Kant 1933.

702 Väinö Auerin kirje J. G. Granölle 4.11.1935. JGGA. SKS, KiA; Granö 1990, 38.

703 Paasi 1982, 148-149 ja 1984b, 27-28; Kaila 1944 ja 1960; Olavi Granön haastattelu 21.10.2004.

704 von Wright 1947; Ihanus 2000, 466-467.

705 Granö 1927d; Granö 2005b.

706 Maantieteen vaihtuvan professorinviran täyttäminen. Asiakirjoja yliopistoasioissa 1929:1, 39; Olavi Granön haastattelu 21.10.2004.

707 Jaeger 1933; James 1972, 140-141; van der Vaart 1975, 94.

708 Hassinger 1930, 296.

709 Lautensach 1933; Bürger 1935; Westermanns Lexikon der Geographie 1969-70, 987-988; Granö 1979, 78 .

Vistteet || 497 
710 Geographische Gesellschaft zu Hannoverin kirje J. G. Granölle 4.11.1938, Die Geographische Gesellschaft in Münchenin J. G. Granölle 1938 lähettämä nimityskirja, H. Schlengerin kortti Kaarlo Hildénille 10.10.1958. JGGA. SKS, KiA; Kaikko 1938, 358; Schrepfer 1938; Beck 1964.

711 Eugene Van Cleefin kirjeet J. G. Granölle 1931-53. JGGA. SKS, KiA; Tirranen 1951, 60. HYKA; Van Cleef 1930 ja 1932; van der Vaart 1975, 94.

712 Hartshorne 1951, 191-195, 214, 224, 445.

713 Hartshorne 1951, 197-201.

714 Hartshorne 1951, 197, 244.

715 Hartshorne 1951, 161, 178; Paasi 1998, 28.

716 Sten De Geerin kirje Svenska Sällskapet för Antropologi och Geografin hallitukselle 8.11.1929. JGGA. SKS, KiA; Auer 1930.

717 Sten De Geerin kortit ja kirjeet J. G. Granölle 1923-30 ja kirje Svenska Sällskapet för Antropologi och Geografin hallitukselle 8.11.1929. JGGA. SKS, KiA.

718 John Frödinin kirjeet J. G. Granölle 8.9.1929 ja Sten De Geerille 9.12.1929. JGGA. SKS, KiA; Wennerholm 1978.

719 Väinö Auerin kirje J. G. Granölle 8.9.1927, Hans W:son Ahlmannin kirje Sten De Geerille 12.12.1929, Matti Sauramon kirje J. G. Granölle 29.9.1930. JGGA. SKS, KiA; Ahlmann 1930.

720 Sten De Geerin kirjeet John Frödinille 10.12.1929 ja Hans W:son Ahlmannille 13.12.1929. JGGA. SKS, KiA.

721 Granö \& Paasi 1997, xxiv-xxv.

722 Granö 1930b, 164-170; Jessen 1936, 198; Paasi 1982, 150; Mereste 1985, 179-183.

723 J. G. Granön kirje J. K. V. Tuomiselle 24.8.1929; J. G. Granön kortit J. K. V. Tuomiselle 30.8., 2.4. ja 6.9.1929 JGGA. SKS, KiA.

724 Turun Yliopiston Maantieteellisen Laitoksen Aikakirja 1924-48, Siegried Passargen kirjeet J. G. Granölle 1930. JGGA. SKS, KiA.

725 Geographische Individuen und Typen. Ce. JGGA. SKS, KiA.
726 J. G. Granön kortit J. K. V. Tuomiselle 25. ja 27.2.1930 sekä 2. ja 4.3.1930. JGGA. SKS, KiA.

727 Granö 1930a, 1931b ja 1932b.

728 Granö 1932b, 1; Jessen 1936, 199.

729 Granö 1930b, 136, 154.

730 Tiainen 2011.

731 Jessen 1936, 199.

732 Granö 1932b, 104-109; Tarmio 2000, 71.

733 Granö 1932b, 110-113; Granö 2003c, 31.

734 Granö 1932b, 113-133; Jessen 1936, 199; Granö 1998, 23 ja 2003 b.

735 Granö 1932b, 133-134; Jessen 1936, 199.

736 Granö 1932b, 133-136.

737 Granö 1932b, 60, 95; Rikkinen 1977, 41-50.

738 Waibel 1933; Jessen 1936, 198-199; Granö 1992, 49-50.

739 Hellaakoski 1934; Leiviskä 1934a ja 1934b.

740 Granö 1935b.

741 Kaskimies 1947, 60.

742 Matti Sauramon kirje J. G. Granölle 7.5.1929. JGGA. SKS, KiA; Leiviskä 1937; Löytönen 1986, 227-228.

743 Der Begriff des geographischen Gebietes. Die Grundlagen der Bildung von geographischen Gebieten. Ce. JGGA. SKS, KiA.

744 J. G. Granön kirje Beulah Reifelille 4.2.1952. JGGA. SKS, KiA; Granö 1935a; Granö 1979, 77 ja 1992, 47.

745 Renier 1935; Schrepfer 1940.

746 Granö 1947b, 25-30; Granö 1998, 23.

747 Granö 1947b, 26; Paasi 1982, 145.

748 Granö 1947b, 26.

749 Granö 1947b, 26-27.

750 Granö 1947b, 29.

751 Granö 1936 ja 1937; Kalliola 1963, 75; Vares 2010, $52-53$.

752 Granö 1951b, 302; Tuominen 1956; Viitala 1999, 86-87.

753 Granö 1951e, 391-392.

754 Kalliola 1963, 75.

755 Granö 1955b ja 1955c; Tammekann 1955b.

756 Tiitta 2007, xxvi-xxx. 
757 Granö 1951d, 368; Tiitta 1999, 22.

758 Suomen Kartasto 1960; Suomen Kartasto 1960. Teksti; Aario 1961, 119-123; Paasi 1998, 28; Raivo 1999 b ja 1999 c.

759 Spethmann 1928; Granö 1930b, 25; Palomäki 1982, 72; Yli-Jokipii 2003, 74-75.

760 Aario 1953b, 220; Tammekann 1953b, 121-122.

761 Pietilä 1968.

762 Arkkitehti 1970, 34; Quantrill 1987, 56; BronerBauer 1997; Keinänen 2006, 687.

763 Reima Pietilän kirje Olavi Granölle 15.3.1970. JGGA. SKS, KiA.

764 Linnilä 1968; Ristkok 1975/1976; Jaatinen 1976; Iisakkila 1978; Hautamäki 1987, 16-17; Olavi Granön haastattelu 23.2.2006 ja kirjallinen tiedonanto 31.3.2011.

765 Paffen 1973; Tuan 1974; Winkler 1975; Schmithüsen 1976; Jones 2003; Buttimer 2010, 21-22.

766 van der Vaart 1975, 93-95; Mead 1977, 369-370; Tuomi 1978; Holt-Jensen 1980, 71; Tarasti 1981, 58-69; Hautamäki 1987, 15; Golledge 1998, 678680; Jones 2003, 85-86.

767 Peltonen 1976; Paasi 1982, 140-150, 1983 ja 1998, 28-29; Raivo 1996, 1997, 1999b ja 2002; Granö 2003c, 31; Buttimer 2010, 12.

768 Ohlson 1975, 1976 ja 1982; Järviluoma 1998, 164165; Uimonen 2005b, 34-35; 92-95; Järviluoma, Koivumäki, Kytö \& Uimonen 2006.

769 Granö \& Paasi 1997, xxvi-xxviii; Buttimer 2010, 21-22.

770 Granö 2002c.

771 Steiner 1975; Ristkok 1975/1976; Schmithüsen 1976, 139-140; Mead 1977; Bennett 1981, 9; Paasi 1982, 152 ja 1984a; Mereste 1985, 182-183; Golledge 1998, 679-682; Granö 1998, 19-20.

772 Gilbert 1960, 162; Karjalainen \& Raivo 1995; Jones 2003, 71-73; Linkola 2005a; Helama ja Holopainen 2010; Tiainen 2011.

773 Torsten Hägestrandin kirje J. C. A. Daveylle 31.8.1976, J. C. A. Daveyn kirje Torsten Hägestrandille 3.9.1976. JGGA. SKS, KiA; Hägestrand 1977; Raivo 2002; Granö 2005b, 8-10.
774 Hägerstrand 1977 ja 1995; Granö \& Paasi 1997, viii-xiv; Granö 2005b, 8-10.

775 Olavi Granön kirjeet Turun Yliopistosäätiön hallitukselle 20.5.1991 ja 9.11.1995. JGGA; Granö 1997a; Itkonen 1998; Tuhkanen 1998.

776 Golledge 1998, 681-682; Raivo 1999c; Unwin 1999; Granö 2005b, 10.

777 Tirranen 1951, 50-51. HYKA; Rossi 1995, 152; Olavi Granön haastattelu 26.8.2004.

778 Perälä 1970, 188-200.

779 Juva 1998, 301-336; Lehto 2004, 370-371.

780 Pentti Yli-Jokipiin haastattelu 23.2.2006

781 Kaarlo Linkolan kirje J. G. Granölle 5.11.1929. JGGA. SKS, KiA.

782 J. G. Granön kirje Kaarle Linkolalle 11.2.1929. JGGA. SKS, KiA.

783 Susiluoto 2000, 12-16; Alhonen 2003; Alhonen \& Alhonen 2006, 142-146; Rikkinen 2007.

784 Perälä 1970, 159-169, 232-239; Vares \& Häkkinen 2001, 402-411, 453-462, 498.

785 E. N. Setälän kirje J. G. Granölle 7.12.1933 JGGA. SKS, KiA; Michelsen 2002, 153-157.

786 Autio 1986, 386; Juva 1998, 316-317.

787 Uusi Suomi 23.3.1929.

788 Perälä 1970, 161-174; Autio 1986, 386-387; Koukkunen 2008.

789 E. N. Setälän kirje J. G. Granölle 23.9.1930. JGGA. SKS, KiA.

790 V. A. Koskenniemen kirje J. G. Granölle 17.8.1931. JGGA. SKS, KiA; Autio 1986, 387; Juva 1998, 316.

791 V. A. Koskenniemen kirje J. G. Granölle 9.9.1932, E. N. Setälän kirjeet J. G. Granölle 9.3. ja 22.5.1932, J. G. Granön kirje E. N. Setälälle 17.5.1932. JGGA. SKS, KiA; Tirranen 1951, 53. HYKA; Turun Sanomat 1.1.1932; Vares \& Häkkinen 2001, 498-499; Häkkinen 2002; Lehto 2004, 382; Häikiö 2010, 302-303.

792 Åland 20.1.1932.

793 Olavi Granön haastattelu 14.5.2010.

794 Hokkanen 1986, 285; Turtola 1994, 200. 
795 Granön puhe soihtukulkueen ylioppilaille tammikuussa 1932. Ce. JGGA. SKS, KiA; Uusi Suomi 16.1.1932; Uusi Aura 24.1.1932; Perälä 1970, 170; Vares \& Häkkinen 2001, 499.

796 J. G. Granön kirje E. N. Setälälle 17.5.1932, E. N. Setälän kirje J. G. Granölle 22.5.1932. JGGA. SKS, KiA.

797 J. G. Granön puhe avajaispuhe 5.9.1932. Ce. JGGA. SKS, KiA.

798 Tirranen 1951, 54. HYKA; Turun Ylioppilaslehti 14/1932, 109.

799 Turun Sanomat 12.11.1932; Turun Ylioppilaslehti 15/1932, 12; Tuominen 1982, 9.

800 Perälä 1970, 163-165; Vares \& Häkkinen 2001, 499.

801 E. N. Setälän kirje J. G. Granölle 9.6.1933 JGGA. SKS, KiA; Uusi Aura 27.5.1933; Lehto 2004, 383.

802 Uusi Aura 29.5.1933; Perälä 1970, 165-166; Vares \& Häkkinen 2001, 499.

803 Turun Ylioppilaslehti 9/1933, 78.

804 Turun Ylioppilaslehti 13/1932, 97.

805 Jenny Danielson-Kalmarin, Helmi Virkkusen, Ilta Ojsansuun ja Katri Lehtosen sähkösanoma J. G. Granölle 7.9.1933. JGGA. SKS, KiA; Tirranen 1951, 54. HYKA; Turun Ylioppilaslehti 9/1933, 77; Vares \& Häkkinen 2001, 499.

806 Juva 1998, 315-326.

807 E. N. Setälän kirjeet J. G. Granölle 3.-4,7.1934, Einar W. Juvan kirje J. G. Granölle 17.7.1934. JGGA. SKS, KiA; Tuominen 1982, 9; Vares \& Häkkinen 2001, 500.

808 Perälä 1970, 167-169.

809 Vares \& Häkkinen 2002, 410, 500; Lehto 2004, 383-384.

810 Itkonen 1976, 32-33.

811 Einar W. Juvan kirje J. G. Granölle 13.4.1945. JGGA. SKS, KiA; Tirranen 1951, 54. HYKA; Perälä 1977, 161-162; Autio 1986, 386-387; Juva 1998, 325-326; Michelson 2002, 157.

812 J. G. Granön kortti J. K. V. Tuomiselle 23.8.1932, Turun Yliopiston Maantieteellisen Laitoksen Aikakirja 1924-48. JGGA. SKS, KiA.
813 Olavi Granön haastattelu 14.5.2010.

814 J. G. Granön kirje J. K. V. Tuomiselle 3.2.1934, J. G. Granön kirje Kerttu Airanteelle 10.6.1953. JGGA. SKS, KiA.

815 J. G. Granön kirje Kerttu Airanteelle 10.6.1953. JGGA. SKS, KiA; Granö 1988; Arno Forsiuksen haastattelu 13.5.2011.

816 J. G. Granön kortti J. K. V. Tuomiselle 25.7.1936. JGGA. SKS, KiA.

817 J. G. Granön kortit J. K. V. Tuomiselle 18., 21. ja 26.6.1936, Turun Yliopiston Maantieteellisen Laitoksen Aikakirja 1924-48. JGGA. SKS, KiA.

818 A. K. Merisuon kirje J. G. Granölle 17.9.1935. JGGA. SKS, KiA.

819 Olavi Granön haastattelu 14.5.2010.

820 Kupiainen 1953, 238-241; Leikola 1996a, 4950.

821 Granö 1930b, 166; Tuominen 1988, 134-135; Tikkanen 1993; Majamaa 2004, 720-721; Alhonen \& Alhonen 2006, 53.

822 J. G. Granön kirjeet J. K. V. Tuomiselle 26.7.1937 ja 19.8.1938, J. G. Granön kirje Väinö Auerille 10.10.1942. JGGA. SKS, KiA.

823 Yrjö Ilvessalon kirje J. G. Granölle 22.1.1939. JGGA. SKS, KiA; Tiitta 2000a, 310-325.

824 Hildén 1938, 226-230.

825 Tirranen 1951, 14. HYKA; Olavi Granön kirjallinen tiedonanto 26.2.2010.

826 J. G. Granön kirje Kaarlo Linkolalle 13.12.1930. JGGA. SKS, KiA.

827 Granö 1926a, 56-58, 1935b, 66-67 ja 1938, 3

828 Kaskimies 1947, 61.

829 J. G. Granön kortti J. K. V. Tuomiselle 24.8.1936. JGGA. SKS, KiA; Heinonen 1943, 24-25; Kant 1956b, 165.

830 Screen 2001, 69-70; Olavi Granön haastattelu 14.5.2010

831 J. G. Granön radioesitelmä 25.5.1935, Pentti Eskolan kirje J. G. Granölle 16.8.1937. JGGA. SKS, $\mathrm{KiA}$.

832 J. G. Granön kirje Oiva Tuomiselle 7.7.1940. JGGA. SKS, KiA; Granö 1939. 
833 J. G. Granön kirjeet Oiva Tuomiselle 8.8. ja 12.11.1941. JGGA. SKS, KiA; Granö 1941; Heinonen 1943, 25; Kant 1956b, 166-167; Granö 1979, 77 ja 2003 b.

834 Paasi 1995, 40.

835 Voionmaa 1919, 371-374; Tommila 1989, 151-155; Paasi 1995, 38-43; Harle \& Moisio 2000, 22-23; Tiitta 2000a, 323-324.

836 Homén 1920 ja 1921; Alhonen \& Alhonen 2006, 233-236.

837 Manninen 1980, 49; Laine 1993, 97-98; Kosonen 2000, 298-301.

838 Nygård 1978, 238 ja 1979, 202-208; Manninen 1980, 44-52, 107-116; Laine 1982, 36-41; Leikola $1986,137-138$.

839 Jaakkola 1941a ja 1941b; Jokipii 1987, 294-296, 518-519; Tommila 1989, 199.

840 Auer \& Jutikkala 1941; Alhonen \& Alhonen 2006, 229-231, 251-266.

841 SMS:n ptk:t 3.12.1940, 26.9. ja 30.10.1941. Terra 52/1940, 124, 53/1941, 263-264, 292-293; Laine 1993, 97-105.

842 Paasi 1990; Alhonen \& Alhonen 2006, 238-248; Jokisipilä 2009, 55-67; Vares 2010, 51-55.

843 Auer 1942, 20 ja 1943, 135-136.

844 Kalliola 1942.

845 Tammekann 2000, 34; Kaarninen 2009, 45.

846 Uusi Suomi 24.2.1942; Kosonen 2000, 319-320; Jauhiainen 2001, 34; Rui 2006, 318-324; Olavi Granön kirjallinen tiedonanto 26.2.2010.

847 Laine 1982, 115, 350-353.

848 J. G. Granön kirjeet J. K. V. Tuomiselle 21.6. ja 8.8.1941. JGGA. SKS, KiA.

849 SMS:n ptk:t 30.12.1940 ja 25.2.1942. Terra 52/1940, 124 ja 54/1942, 273.

850 Granö 1941, 75-76.

851 Valtioneuvoston ptk:t 8.4. ja 25.5.1940. KA; Hildén 1956c, 82; Nevakivi 1988, 214-216; Granö 1992, 50; Polvinen 1995, 169; Olavi Granön kirjallinen tiedonanto 26.2.2010.

852 J. G. Granön kirje Akateemiselle Karjala-Seuralle 4.11.1923. JGGA. SKS, KiA; Laine 1993, 129;
Eskelinen 2004, 130-131; Alhonen \& Alhonen 2006, 62; Paaskoski 2008, 95-97.

853 Immonen 1987, 427.

854 Mpk 30.4.-1.5.1907. JGGA. KA; Granö 1919a, 8; Serebrjyannyj \& Gerasimov 1956, 127; Klinge 1972, 57-131; Luostarinen 1986, 154-177; Immonen 1987, 280; Vares 2010, 50, 52, 57-58.

855 Antti Hackzellin kirje J. G. Granölle 16.7.1942. JGGA. SKS, KiA; von Blücher 1951, 287; Manninen 1980, 13, 148, 295-298 ja 1993, 112-114; Uola 2004, 457.

856 J. G. Granön kirje J. K. V. Tuomiselle 5.8.1943. JGGA. SKS, KiA; Laine 1993, 104-130.

857 Vesikansa 1964; Olavi Granön kirjallinen tiedonanto 26.2.2010.

858 Polvinen 1964, 255-256.

859 Myllyniemi 1982, 361.

860 Vesikansa 1964.

861 Polvinen 1964, 257-259.

862 Manninen 1993, 136-137.

863 J. G. Granön kirje J. K. V. Tuomiselle 30.7.1944. JGGA. SKS, KiA.

864 J. G. Granön kirje J. K. V. Tuomiselle 13.9.1944. JGGA. SKS, KiA.

865 J. G. Granön kirje Oiva Tuomiselle 14.10.1944. JGGA. SKS, KiA.

866 Palvelutodistus 18.4.1940. Ab. JGGA. SKS, KiA.

867 Osmo H. Porkan kirjeet ja kortit J. G. Granölle 1926-38. JGGA. SKS, KiA; Hildén 1940.

868 Sauramo 1940; Mäkelä 2008.

869 Paavo Kallion kirjeet J. G. Granölle 1940-44, A. K. Merisuon kirjeet J. G. Granölle 1940-44, J. G. Granön kirje J. K. V. Tuomiselle 8.8.1941, J. G. Granön kirje Oiva Tuomiselle 18.7.1943. JGGA. SKS, KiA; Tuominen 1988, 137; Soikkeli 2000; Haahtela 2001, 26.

870 J. G. Granön kirje Oiva Tuomiselle 8.8.1941. JGGA. SKS, KiA.

871 J. G. Granön kirje J. K. V. Tuomiselle 20.7.1942. JGGA. SKS, KiA.

872 J. G. Granön kirje Paavo Kalliolle 25.2.1942, Paavo Kallion kirje J. G. Granölle 28.12.1942. JGGA. 
SKS, KiA; Soikkeli 2000, 5; Martti Soikkelin kirjallinen tiedonanto 1.9.2005.

873 J. G. Granön kirje J. K. V. Tuomiselle 8.8.1942. JGGA. SKS, KiA.

874 Turun Yliopiston Maantieteellisen Laitoksen Aikakirja 1924-48. JGGA. SKS, KiA; Perälä 1977, 11-14; Michelsen 2002, 185-186; Kaarninen 2009, 26.

875 J. G. Granön kortti J. K. V. Tuomiselle 10.9.1941, J. G. Granön kirje Oiva Tuomiselle 17.3.1943. JGGA. SKS, KiA; Perälä 1977, 15-20; Tuominen 1978, 26, 36 ja 1982, 9, 72-73.

876 J. G. Granön kirjeet J. K. V. Tuomiselle 21.6.1941 ja 23.5.1942, J. G. Granön kirjeet Oiva Tuomiselle 8.8.1941 ja 17.3.1943, Turun Yliopiston Maantieteellisen Laitoksen Aikakirja 1924-48. JGGA. SKS, KiA; Granö 1943; Olavi Granön haastattelu 14.5.2010; vuonna 1940 ilmestyneen Across Asia from West to East-teoksen alkuperäiskäsikirjoitus on tallennettu Kansallisarkistoon, mutta Mannerheimin piirtämät alkuperäiskartat ovat hävinneet.

877 Berg 1930; Granö 1945, 3; Suslov 1961, 71-105; Granö 2003b.

878 Vuoden 2010 rahanarvoon saatettuna apuraha vastasi noin 19000 euroa; Heinonen 1943, 22-23; Seppälä 1987, 28; Granö 1990, 39-40.

879 Albrecht Penckin kirjeet ja kortit J. G. Granölle 1911-40, Walther Penckin kortti J. G. Granölle 1920, J. G. Granön kirjeet Albrecht Penckille 1923-40. JGGA. SKS, KiA; Penck 1924; Granö 1947a; Granö 1979, 75.

880 Olavi Granön haastattelu 14.5.2010.

881 J. G. Granön kirjeet Oiva Tuomiselle 18.7.1943 ja 16.7.1944. JGGA. SKS, KiA; Heinonen 1943, 22-23; Granö 1945, 3.

882 J. G. Granön kirje J. K. V. Tuomiselle 30.7.1944. JGGA. SKS, KiA; Hietala 2002, 494-495.

883 Paaskoski 2008, 176-181; Olavi Granön kirjallinen tiedonanto 26.2.2010.

884 Tammekann 1955a; Granö 1990, 39-42, 1992, 44 ja 2003 b.
885 Olavi Granön kirjallinen tiedonanto 26.2.2010.

886 Olavi Granön kirjallinen tiedonanto 26.2.2010.

887 Granö 1945; Obruchev 1947; Granö 1980, 122 123; Juntunen 1993, 154.

888 Hans W:son Ahlmannin kortti J. G. Granölle 28.2.1946. JGGA. SKS, KiA; Ahlman 1946; Cressey 1948.

889 Matti Saarniston kirjallinen tiedonanto 14.4.2011.

890 Kakkuri 2003, 111; Herget 2004; Svendsen et al. 2004; Alho 2005, 10.

891 Granö 1955a, 9.

892 Rentola 1994, 462-538; Meinander 2006, 189190.

893 Matem.-luonnont. os. ptk 19.10.1944. HYKA; Kertomus HY:n toiminnasta 1944-45, 14; Hustich 1963, 32; Susiluoto 2000, 24; Rikkinen 2007b.

894 Matti Sauramon kirje J. G. Granölle 22.10.1944. JGGA. SKS, KiA; Matem.-luonnont. os. ptk:t 19. ja 26.10, 9.11.1944. HYKA; Kertomus HY:n toiminnasta 1944-45, 15; Alhonen \& Alhonen 2006, 266-267.

895 Aario 1953a, 1-2; Kupiainen 1953, 293-295; Leikola 1996a, 51.

896 Matem.-luonnont. os. ptk:t 19. ja 26.10.1944. HYKA; Matti Sauramon kirje J. G. Granölle 22.10.1944, Leo Aarion kirje J. G. Granölle 6.12.1944. JGGA. SKS, KiA.

897 Matti Sauramon kirjeet J. G. Granölle 16.11. ja 1.12.1944, J. G. Granön kirje Matti Sauramolle 26.11.1944, J. G. Granön kirje Leo Aariolle 26.11.1944. JGGA. SKS, KiA.

898 J. G. Granön kirje Matti Sauramolle 12.12.1944. JGGA. SKS, KiA; Matem.-luonnont. os. ptk 14.12.1944. HYKA.

899 Leo Aarion kirje J. G. Granölle 6.12.1944. JGGA. SKS, KiA.

900 Matem.-luonnont. os. ptk 14.12.1944. HYKA.

901 Matem.-luonnont. os. ptk 14.12.1944. HYKA.

902 Matem.-luonnont. os. ptk:t 19.12.1944, 31.1., 
14.2. ja 21.3.1945. HYKA; Matti Sauramon kirje J. G. Granölle 12.2.1945. JGGA. SKS, KiA.

903 J. G. Granön kirjeet Leo Aariolle 17.12.1944 ja 7.2.1945, Leo Aarion kirjeet J. G. Granölle 4. ja 19.2. sekä 5.4.1945, Pöytäkirja Turun Yliopiston maantieteen laitoksella 28.5.1945 pidetystä katsastustilaisuudesta. JGGA. SKS, KiA; Kertomus HY:n toiminnasta 1944-45, 15; Perälä 1977, 66.

904 J. G. Granön kirje Leo Aariolle 7.2.1945. JGGA. SKS, KiA; Olavi Granön kirjallinen tiedonanto 15.11.2010.

905 Olavi Granön haastattelu 14.5.2010.

906 Tiitta 2000a, 336.

907 Kertomus HY:n toiminnasta 1944-45, 72; Granö 2003b; Alhonen \& Alhonen 2006, 267-268.

908 SMS:n ptk 18.5.1945. Terra 57/1945, 170; Syrjö 2006, 9-12; Olavi Granön haastattelu 14.5.2010.

909 J. G. Granön kirjeet Kaarlo Hildénille 24.6. ja 12.7., 22. ja 30.7.1946, Kaarlo Hildénin kirjeet J. G. Granölle 3., 16. ja 26.7.1946. JGGA. SKS, KiA; HY:n ohjelmat 1948-49, 39, 1949-50, 40; Tuominen 1982, 9; Alhonen \& Alhonen 2006, 267-271, 309; Fogelberg 2008, 246.

910 J. G. Granön kirje J. K. V. Tuomiselle 23.10.1945. JGGA. SKS, KiA; Kertomus HY:n toiminnasta 1946-47, 58; Tuominen 1988, 137-138.

911 J. G. Granön kirje J. K. V. Tuomiselle 18.6.1948, Walter Christallerin kirje Oiva Tuomiselle 31.3.1950. JGGA. SKS, KiA; Katajamäki 1977; Tuominen 1988, 138-145; Tiitta 2000a, 327.

912 Kertomukset HY:n toiminnasta 1946-47, 58, 1947-48, 57, 1948-49, 72-73, 1949-50, 78.

913 SMS:n ptk 26.5.1948. Terra 61/1949, 178 ja 62/1950, 168-169.

914 Kertomukset HY:n toiminnasta 1944-50; Granö 1982a.

915 Kari Lagespetzin haastattelu 11.11.2002.

916 Ruotsalo 1967; Ruotsalo-Aario 1969; Lagerspetz 2000, 237, 240-241, 250.

917 HY:n ohjelmat 1944-45, 30-31, 1946-47, 31, 1947-48, 32, 1948-49, 35, 1949-50, 30; Granö
1990, 19 ja 1998, 18.

918 J. G. Granön kirje J. K. V. Tuomiselle 24.11.1947. JGGA. SKS, KiA.

919 J. G. Granön kirje J. K. V. Tuomiselle 24.7.1950. JGGA. SKS, KiA; Tirranen 1951, 64. HYKA; Tuominen 1988, 142; Olavi Granön haastattelu 14.5.2010.

920 Kertomukset HY:n toiminnasta 1949-50, 9 ja 1950-51, 10.

921 J. G. Granön kirjeet August Tammekannille 1950. JGGA. SKS, KiA; Matem.-luonnont. os. ptk 11.5.1950. HYKA; Tammekann 2000, 34-35; Ruin 2006, 342; Rikkinen 2007a, 616.

922 Jauhiainen 2001, 34.

923 Tuominen 1988, 141-142; Tiitta 2000, 324-332; Alhonen \& Alhonen 2006, 349-351.

924 Uusi Suomi 21.2.1945; Uusi Aura 22.2.1945; Perälä 1977, 161-162; Tuominen 1978, 29-30; Olavi Granön haastattelu 14.5.2010.

925 Lehtola 1993

926 J. G. Granön kirje Matti Sauramolle 12.9.1945. JGGA. SKS, KiA; Hildén 1956b, 5; Klinge 1990 156-161, Lehto 2001, 188; Olavi Granön kirjallinen tiedonanto 26.2.2010.

927 Autio 1990, 261-264; Klinge 1990, 216.

928 Perälä 1977, 5.

929 Einar W. Juvan kirje J. G. Granölle 16.9.1948. JGGA. SKS, KiA; Perälä 1977, 33-36; Autio 1990 228; Juva 1998, 408-409.

930 Einar W. Juvan kirjeet J. G. Granölle 1950-50. JGGA. SKS, KiA; Perälä 1977, 161-164; Eskola S. 2002, 377; Olavi Granön kirjallinen tiedonanto 15.11.2010.

931 Perälä 1977, 36-46, 389-393.

932 Hildén 1956b, 6; Perälä 1977, 102-103.

933 Eskola S. 2002, 224-226, 377.

934 Perälä 1977, 110-111.

935 Uusi Aura 1.3.1955; Turun Sanomat 1.3.1955.

936 Uusi Suomi 2.3.1955; Tiitta 2004, 73-96.

937 Lassila 1990, 69; Paaskoski 2008, 287-288.

938 Granö 1955a; Hildén 1956b, 6.

939 Granö 1955a; 9; Tiitta 2004, 45-58. 
940 Granö 1955c; Granö 2005b, 8-10.

941 SMS:n ptk 13.3.1946. Terra 58/1946, 150; Paaskoski 2008, 181.

942 Tirranen 1951, 60-61. HYKA; Granö 1951a, V; Granö 1982a.

943 SMS:n ptk:t 12.4. ja 13.3.1946. Terra 58/1946, 150; Tuominen 1951.

944 SMS:n ptk:t 17.5. ja 20.9.1946. Terra 58/1946, 151-153; Autio 1990, 46-47.

945 SMS:n ptk 20.9.1946. Terra 58/1946, 151-153 ja 59/1947, 46.

946 Vuoden 2010 rahanarvoon saatettuna vuoden 1949 valtionapu oli noin 68000 euroa; SMS:n ptk:t 21.5.1947 ja 16.9.1949. Terra 62/1950, 163, 174.

947 Tuominen 1951; Väänänen 1951; Kalliola 1963, 75.

948 Granö 1951d, 85; Olavi Granön kirjallinen tiedonanto 26.2.2010.

949 Platt 1955; Freeman 1965, 137-139.

950 Kalliola 1963, 72; Terra 63/1951, 70; Olavi Granön kirjallinen tiedonanto 26.2.2010.

951 Granö 1982a.

952 J. G. Granön kirje Leo Aariolle 24.10.1955. JGGA. SKS, KiA; Aario 1963.

953 Tiitta 2000a, 310-311.

954 Granö 1947b, 30; Granö 1998, 23.

955 Granö 1947b, 30.

956 Granö 1947b, 30; Granö 1998, 23.

957 Granö 1947b, 31.

958 J. G. Granön kirjeenvaihto Reino Ajon kanssa 1947-48. JGGA. SKS, KiA; Granö 1947b, 30-31; Freeman 1965, 139-140.

959 Reino Ajon kirjeet J. G. Granölle 1947-48, J. G. Granön kirje Reino Ajolle 16.5.1948, J. G. Granön kirjeet W. M. Meadille 25.4. ja 16.5.1948. JGGA. SKS, KiA; Tuominen 1988, 138-139; Tiitta 1996, 77; Granö 1998, 23.

960 Meurman 1947, 415, 422-423; Nykysuomen sanakirja 1954, 299; Tiitta 2000a, 326-327; Rossi 2005, 24.

961 Meurman 1951; Koskinen 2005, 687.

962 Meurman 1951, 403; Suomi 1990, 200-210; Granö
1998, 23; Viitala 1999, 86-88; Tiitta 2000a, 328330.

963 George B. Cresseyn kirjeet J. G. Granölle 194954, erityisesti 2.4.1949, J. G. Granön kirje George B. Cresseylle 20.4.1949, George H. T. Kimblen kirje J. G. Granölle 28.9.1949. JGGA. SKS, KiA; SMS:n ptk:t 16.3. ja 14.12.1951. Terra 64/1952, 28-33; Tiitta 2004, 423-425.

964 Saxén 2002, 21-25.

965 Yli-Jokipii 1982; Granö 2005b, 8-10.

966 J. G. Granön kirjeenvaihto 1946-55, A. N. Abramovin kutsukirje J. G. Granölle. JGGA. SKS, KiA.

967 Olavi Granön kirjallinen tiedonanto 26.2.2010.

968 V. A. Obrutševin kirjeet J. G. Granölle 1926-48. JGGA. SKS, KiA; Serebrjyannyj \& Gerasimov 1956, 127, käännös: Risto Rönkä.

969 Jauhiainen 2001, 28-32; Granö 2005b, 8-10.

970 Edgar Kantin kirjeet J. G. Granölle 1944-54, Erik Ljungerin kirjeet J. G. Granölle 20.9.1949 ja 2.1.1950, Hans W:son Ahlmannin kirje J. G. Granölle 23.1.1950. JGGA. SKS, KiA.

971 Buttimer 1987, 1994, 2000 ja 2005; Kurs 1992, 596-597; Tiitta 2000a, 327-329; Jauhiainen 2001, 35 ja 2005; Wärneryd 2004-2005, 32-33; Granö 2005a, 170-173; Schough 2008, 189-201; Olavi Granön haastattelu 14.5.2010.

972 Erich Obstin kirjeet J. G. Granölle 1929-52, J. G. Granön kirjeet Erich Obstille 1930-50, J. G. Granön kirjeet Carl Trollille 1938-51, Ernst Winklerin kirjeet J. G. Granölle 1929-55. JGGA. SKS, KiA; Carol 1956, 112; Olavi Granön kirjallinen tiedonanto 26.2.2010.

973 Allix 1912 ja 1923; Granö 2005b, 11.

974 J. G. Granön kirje Kaarlo Hildénille 30.7.1946. JGGA. SKS, KiA; Alhonen \& Alhonen 2006, 267-268; Paaskoski 2008, 185.

975 J. G. Granön kirjeet J. K. V. Tuomiselle 27.3. ja 13.4.1949. JGGA. SKS, KiA.

976 Divisions Géographiques et une méthode de les Determiner. Ce. JGGA. SKS, KiA; J. G. Granön kirjeet Hermann Lautensachille 1949-53, 
Hermann Lautensachin kirjeet J. G. Granölle 1949-50. JGGA. SKS, KiA; Granö 1950a, 1950b ja 1952; Lautensach 1952a ja 1952b; Hildén 1956c, 85-86.

977 Gesellschaft für Erdkunde zu Berlinin kirje J. G. Granölle 10.5.1954. JGGA. SKS, KiA; Granö 2003c, 16-17; Olavi Granön kirjallinen tiedonanto 26.2 .2010 .

978 J. G. Granön kortti J. K V. Tuomiselle 22.3.1952. JGGA. SKS, KiA; Granö 1953, 108.

979 J. G. Granön osallistuminen Ruotsin kuninkaan ja kuningattaren vierailuun Helsingissä 24.26.5.1952. Da. JGGA. SKS, KiA.

980 Kanervo 1947; Granö 1951c; Yli-Jokipii 1982.

981 Terra 59/1947, 44.

982 Granö 1949.

983 Eskola 2002, 37.

984 Eskola 2002, 68; Paaskoski 2008, 310, 389.

985 Ars Universitaria 1640-1990, 76-77.

986 Uusi Aura 27.3.1945; Perälä 1977, 123; Tuominen 1982,11

987 Granö 1979, 77 ja 2003, 17-18; Oja 2003, 66, 70, 101

988 Aamulehti, Helsingin Sanomat ja Suomen Sosiaalidemokraatti 21.3.1955; Seppälä 1987, 28, 37-50, 86.

989 Olavi Granön haastattelu 14.5.2010.

990 J. G. Granön kirje J. K. V. Tuomiselle 29.8.1954. JGGA. SKS, KiA.

991 Ilta-Sanomat 24.2.1956; Helsingin Sanomat 25.2.1956; Hufvudstadsbladet 25.2.1956; Turun Sanomat 25.2.1956; Uusi Aura 25.2.1956; Uusi Suomi 25.2.1956; Åbo Underrättelser 25.2.1956; Dagens Nyheter 26.2.1956.

992 Serebrjyannyj \& Gerasimov 1956, 127, käännös: Risto Rönkä.

993 Kant 1956a, 1956b ja 1957; Chabot 1956, Hildén 1956a, 1956b, 1956c, 1957a ja 1957b; Sauramo \& Eskola 1956; Serebrjyannyj \& Gerasimov 1956; Hang 1957.

994 Olavi Granön haastattelu 14.5.2010.

995 Pentti Eskolan runo 1949. JGGA. SKS, KiA.

\section{Kuvaluettelo}

Kirjan kuvituksena on käytetty Suomalaisen

Kirjallisuuden Seuran Granö-kokoelman aineistoa alla mainituin poikkeuksin:

s. 41, 266-267 ja 414-415 Museovirasto

s. $73,77,82,83,93,123,137,164,172,201$, 222 (alla), 260, 371, 375 ja 401 Taneli Eskola

s. 135 Jukka Käyhkö

s. 167 ja 168 Antti Huittinen

s. 198 Kansanrunousarkisto, SKS

s. 220 ja 222 Turun yliopistosäätiö

s, 261 Helsingin yliopiston museo

s. 305, 308 ja 309 Turun Sanomien arkisto

s. 329-330, 363, 450-451 Ilmavoimien Maantieteen laitokselle tutkimuskäyttöön luovuttamia viistokuvia

s. 429 Veljekset Karhumäki Oy

s. 460 ja 461 yksityiskokoelma

s. 475 Rauno Ekholm 


\title{
$\mathscr{L} \ddot{\text { ÄTEET }}$
}

\section{ARKISTOT}

\section{Helsingin yliopisto keskusarkisto (HYKA)}

Hertta Tirrasen tekemä J. G. Granön haastattelu 1951. (Tirranen 1951)

Konsistorin pöytäkirjat 1911-26. (Konsistorin ptk)

Matemaattis-luonnontieteellisen (vuoteen 1924 fyysis-matemaattisen) osaston pöytäkirjat 1920-45, 1950. (Matem.-luonnont. os. ptk, Fyysis-matem. os. ptk)

\section{Houghton Library. Harvard University (HLHU)}

J. G. Granön kirjeet W. M. Davisille

\section{Suomalaisen Kirjallisuuden Seura, Kirjallisuusarkisto (SKS, KiA)}

J. G. Granön arkisto (JGGA)

\section{Kansallisarkisto (KA)}

J. G. Granön matkapäiväkirjat (Mpk)

Valtioneuvoston pöytäkirjat 1923, 1940

\begin{abstract}
Allan Tiitan arkisto (ATA)
Granö, Olavi, J. G. Granö. Puhe valokuvanäyttelyn avajaistilaisuudessa Helsingin kaupungin taidemuseossa Meilahdessa 14.3.2002. Painamaton käsikirjoitus. (Granö 2002a)
\end{abstract}


Granö, Olavi, J. G. Granö Siperian ja Pohjois-Mongolian tutkijana. Tervehdyssanat J. G. Granön valokuvanäyttelyn avajaistilaisuudessa 24.10.2002 Pietarissa Venäjän Maantieteellisen Seuran rakennuksessa. Painamaton käsikirjoitus. (Granö 2002b)

Granö, Olavi, J. G. Granön elämänvaiheet. J. G. Granö -seminaari Tartossa 9.5.2003. Painamaton käsikirjoitus (Granö 2003a)

Granö, Olavi, Suomalainen maisema. Näyttelyn avaussanat 23.9.2003 Liedon Vanhalinnassa. Painamaton käsikirjoitus (Granö 2003b)

Leiviskä, Iivari, Valtion luonnontieteelliselle toimikunnalle, Suomen Akatemian jäsenille ja Opetusministerille. Iivari Leiviskän elokuussa 1951 päiväämä kirjoitus. (Leiviskä 1951)

\section{Painetut lähteet}

Helsingin yliopiston (vuoteen 1918 Keisarillisen Aleksanterin-yliopiston) ohjelmat lukuvuosille 1902-26 ja 1945-50. Helsinki 1902-26 ja 1945-50. (HY:n ohjelmat...)

Kertomus Helsingin yliopiston (vuoteen 1918 Keisarillisen Aleksanterin-yliopiston) toiminnasta lukuvuosina 1902-26 ja 1944-54. Helsinki 1905-54. (Kertomus HY:n toiminnasta...)

Kutsu kuulemaan sitä julkista esitelmää, jonka Turun Suomalaisen yliopiston maantieteen professori filosofian tohtori Johannes Gabriel Granö pitää virkaanastujaisissaan lokakuun 2 p:nä 1926. Turku 1926. (Kutsu kuulemaan.... 1926)

Maantieteen vaihtuvan professorinviran täyttäminen. Asiakirjoja yliopistoasioissa 1929:1. 
Redogörelse för Kejserliga Alexansers-Universitet i Finland under läseåren 18931902. Helsingfors. (Redogörelse... under läseåren)

Selonteko Helsingin yliopiston (vuoteen 1918 Keisarillisen Aleksanterin-yliopiston) opettajain toiminnasta 1908-20. Helsinki 1909-22. (Selonteko HY:n...)

Suomen Maantieteellisen Seuran pöytäkirjat 1922-51. Terra 1922-52. (SMS:n ptk)

\section{Haastattelut ja kirjalliset tiedonannot}

Reino Alavan haastattelu 5.5.2010

Arno Forsiuksen haastattelu 5.5.2010

Olavi Granön haastattelut 21.10.2004, 23.2.2006, 14.5.2010 ja 15.5.2011

Olavi Granön kirjalliset tiedonannot 26.2.2010, 15.11.2010 ja 31.3.2011

Risto Jaakkolan haastattelu 18.9.2008

Kari Lagerspetzin haastattelu 11.11.2002

Matti Saarniston kirjallinen tiedonanto 14.4.2011

Martti Soikkelin kirjallinen tiedonanto 1.9.2005

Pentti Yli-Jokipiin haastattelu 23.2.2006 


\section{Kirjallisuus}

Aalto, Pentri, Materialen zu den Alttürkischen Inskriften der Mongolei. Gesammelt von G. J. Ramstedt, J. G. Granö und Pentti Aalto. Journal de la Sociéte Finno-ougrienne 60/1958.

, Skandinavier und Finnen in der Mongolei. Heissig, Walter \& Claudius E. Müller (hrsg.), Die Mongolen II, 95-100. Zell am See 1989.

Old Turkic epigraphic materials, gathered by J. G. Granö. Journal de la Societe FinnoOugrienne 83/1991.

Aaltonen, Olavi, Antti Oskari Tokoi. Teoksessa Soikkanen, Hannu (toim.), Tiennäyttäjät 2. Suomen työväenliikkeen merkkimiehiä Ursinista Tanneriin, 63-110. Rauma 1967.

Aario, Leo, Aaro Hellaakoski kuollut. Terra 65/1953, 1-4. (Aario 1953a)

—_, Maantieteen tehtävästä ja sen rajoittamisesta. Suomalainen Suomi 21/1953, 218-222. (Aario 1953b)

—- Maantieteelliset alueet. Teoksessa Suomen Kartasto 1960. Teksti, 119-123. Helsinki 1961.

- Suomen Kartasto 1960. Terra 75/1963, 67-69.

Aartolahti, Toive, Suomen luonnonmaisemien kehitys. Terra 94/1982, 33-42.

Ahlmann, Hans W:son, J. G. Granö: Reine Geographie. Ymer 50/1930, 358-361.

_ J. G. Granö: Das Formengebäude des nordöstlichen Altai. Ymer 67/1946, 233-235.

Ahonen, Hanna, Granön miesten Siperia. Satakunnan Kansa 26.3.2006.

Alho, Petteri, Reconstruction and inundation estimation of glacial outburst floods. Turun Yliopiston Julkaisuja AII (182)/2005, 1-38.

Alhonen, Pentti, Auer, Väınö (1895-1981) geologian ja paleontologian professori. Suomen kansallisbiografia 1, 442-443. Hämeenlinna 2003.
Alhonen, Pentti \& Antero Alhonen, Vaakavarren ratsastaja. Tutkimusmatkailija Väinö Auerin elämä. Turenki 2006.

Allardt, Erik, Yhteiskuntatieteet. Teoksessa Suomen tieteen historia 2. Humanistiset ja yhteiskuntatieteet, 476-535. Porvoo 2000.

Allix, A., Les glaciations quaternaires dans la Sibérie méridionale et la Mongolie occidentale. La Géorgaphie 25/1912, 431-437.

_ L L'Altai Russe. Revue Géographique Alpine 11/1923, 759-799.

Anonymous, G. I. Granë. (J. G. Granö). Sibirskaja zhizn'4. III.1915. (Anonymous 1915a)

Anonymous, Finljandskij uchenyj. Sibirskaja zhizn'4.III.1915. (Anonymous 1915b)

Anonymous, Altaivuorten kulkija. Tieteen matkamiehiä. Kodin Kuvalehti 49/1946, 8-9.

Ars Universitaria 1640-1990. Mitaleita Helsingin yliopiston kokoelmista. Näyttelyluettelo. Espoo 1990.

AuER, VÄInÖ, Maantieteellinen merkkiteos. Uusi Suomi 28.12.1930.

— Suomalaisten tutkijain Kuolassa, ItäKarjalassa ja Inkerissä suorittaman tutkimustyön merkityksestä. Terra 54/1942, 15-20.

- (hrsg.), Anteil der finnischen Forscher an der Erforschung von Kola, Ostkarelien und Ingermanland. Fennia 67/1943:3.

Auer, Väinö \& Eino Jutikkala, Finnlands Lebensraum: das geographische und geschichliche Finnland. Berlin 1941.

Autio, Veli-Matti, Ensimmäisen tasavallan kulttuuripolitiikka 1917-1944. Opetusministeriön historia 4. Pieksämäki 1986.

— tuksen tielle. Teoksessa Autio, Veli-Matti \& Markku Heikkilä, Jälleenrakennuksen ja kasvun kulttuuripolitiikkaa 1945-1965. Opetusministeriön historia 5, 224-282. Pieksämäki 1990. 
BAnse, Ewald, Expressionismus und Geographie. Braunschweig 1920.

- Landschaft und Seele. Neue Wege der Untersuchung und Gestaltung. München 1928.

Beck, Hanno, Zeittafel der Geographie von 1905 bis 1945. Wiesbaden 1964.

—-, Geographie. Europäische Entwicklung in Texten und Erkläuterungen. München 1973.

- Grosse Geographen. Pioniere-Aussenseiter-Gelehrte. Berlin 1982.

Bennett, R. J., Quantitative and theoretical geography in Western Europe. In Bennett, R. J. (ed.), European progress in spatial analysis. London 1981.

BERG, L. S., Landshaftnye zony SSSR, 374-376. (Also in English: Landscape zones of USSR). Sel'khozgiz, Moscow-Leningrad 1930.

von Blücher, Wibert, Suomen kohtalonaikoja. Muistelmia vuosilta 1935-44. Porvoo 1951.

Broner-Bauer, Kaisa, Reima Pietilä (19231993) Arkkitehtuurin šamaani. Kansallisgalleria. Suuret suomalaiset 5, 92-99. Porvoo 1997.

Buttimer, Anne, Edgar Kant 1902-1978. Geographers: Bibliographical Studies 11/1987, 71-82.

Buttimer, Anne, Edgar Kant and Balto-Skandia: Heimatkunde and regional identity. In Hooson, David (ed.), Geography and national identity, 162-183. Oxford 1994.

_- Edgar Kant and the modernist turn in Swedish geography. Forskningsrapporter frä Kulturgeografiska Institutionen Uppsala Universitet 110/2000, 39-61.

— Edgar Kant (1902-1978) - A Baltic pioneer. Geografiska Annaler B 878/2005:3, 176.

-, Humboldt, Granö and Geo-poetics of the Altai. Fennia 188/2010. (http://ojs. tsv.fi/index.php/fennia/article/view/2838, 3.12.2010)

Bürger, K, Der Landschaftsbegriff. Dresdener Geographische Studien 17/1935.

Büttner, Manfred \& Karl Hoheisel, Imma- nuel Kant 1724-1804. In Freeman, T.W. \& Philippe Pinchemel (eds). Geographers. Biobibliographical Studies 1980/4, 55-68.

Cajander, A. K., Kasvillisuus. Teoksessa Suomen Kartasto 1925. Teksti, 78-83. Helsinki 1929.

Carol, Hans, Zur Diskussion um Landschaft und Geographie. Geographica Helvetica 2/1956, 111-132.

Сhabot, Georges, J. G. Granö. Nécrologie. Annales de Géographie 65/1956, 361.

Clarke, Graham, The Photograph. Oxford History of Art. Hong Kong 1997.

Cressey, George B., Das Formengebäude des nordöstlichen Altai by J. G. Granö. Geographical Review 38/1948, 160-161.

Dahlbacka, Ingvar, Den Evangeliska rörelsen $i$ Svenska Österbotten 1845-1910. Åbo 1987.

Davis, W. M., Die erklärande Beschreibung der Landformen. Leipzig 1912.

Davis, W. M., Morphology of the Altai Mountains. Geographical Review 11/1921, 155-156.

, The Cycle of Erosion and the Summit Level of The Alps. The Journal of Geology 31/1923, 1-41.

De Geer, Sten, Den tredje atlasen över Finland. Ymer 1930.

Edelstein, J., Geologicheskiya izledovaniya proizvedenniya v yugo-vostocnoi chasti Minusinskago uyezda. S.-Peterburg 1912.

Engman, Max, Pastor Erikssons berättelse från Sibirien 1892. Historisk Tidskrift för Finland 82/1997: 4, 537-542.

__, Suomalaiset Venäjällä. Lähdeopas. Helsinki 2004.

— Suureen itään. Suomalaiset Venäjällä ja Aasiassa. Suomalaisen siirtolaisuuden historia 5. Jyväskylä 2005.

Eskelinen, Heikni, Me tahdoimme suureksi Suomenmaan. Akateemisen Karjala-Seuran historia I. Juva 2004.

Eskola, Pentti, Maantieteellinen suurtyö. Helsingin Sanomat 7.4.1929. 
Esкоla, Seıкко, Tiedepolitiikka ja korkeakoulut. Teoksessa Suomen tieteen historia 4. Tieteen ja tutkimuksen yleinen historia 1880-luvulta lähtien, 220-391. Porvoo 2002. (Eskola S. 2002)

Eskola, TAneli, Sininen Altai. J. G. Granö Siperian valokuvaajana 1902-1916. Helsinki 2002.

—, Rajanylityksï̈-Boundary Crossings. Ajan ja paikan vuoropuhelu suomalaisessa maisemavalokuvauksessa. Temporal Dialogues in Finnish Landscape Photography. Hämeenlinna 2005.

Fickeler, Paul, Der Altai. Petermanns Geographisches Mitteilungen. Ergänzungsheft $187 / 1925$.

von Fieandt, K., Havaitsemisen maailma. Porvoo 1972.

Fogelberg, Paul, Sata vuotta Helmer Smedsin syntymästä. Terra 120/2008, 243-247.

Freeman, T. W., A Hundred Years of Geography. University Paperbacks 147. London 1965.

Friederichsen, Max, Granö, J. G.: Les formes du relief dans l'Altai Russe et leur genèse. Petermanns Mitteilungen 68/1922, 92-93.

Gilbert, E. W., The Idea of the Region. Geography XLV/1960, 157-175.

Golledge, Reginald G., Pure Geography. Journal of Regional Science 38/1998:4, 677-682.

Granö, Johannes, Kuusi vuotta Siperiassa. Helsinki 1893.

Granö, J. G., Uusi Guinea. Geografiska Föreningens Tidskrift 13/1901, 334-344.

- Siperian suomalaiset siirtolat. Fennia 22/1905:4, 3-86.

—, Maralinhoito Etelä-Siperiassa. Luonnon Ystävä 10/1906, 9-13.

—_ Kobdo. Luonnon Ystävä 11/1907, 31-39. (Granö 1907a)

—_, Matkamuistelmia Länsi-Siperiasta ja Mongoliasta I. Matkustus Altai-vuoristossa ja Kulunda-arolla kesällä vuonna 1905. Maan- tieteellisen Yhdistyksen Aikakauskirja 19/1907, 257-278. (Granö 1907b)

—, Eurooppalaista betsoaaria Mongoliassa. Luonnon Ystävä 11/1907, 31-39. (Granö 1908a)

—, Koulukomitea ja maantieteen opetus tyttökoulun jatkoluokalla. Maantieteellisen Yhdistyksen Aikakauskirja 20/1908, 269-271. (Granö 1908b)

—, Matkamuistelmia Länsi-Siperiasta ja Mongoliasta II. Matkustus Uranhaissa, Luoteis-Mongoliassa ja Dzhungariassa vuonna 1906. Maantieteellisen Yhdistyksen Aikakauskirja 20/1908, 1-16, 281-308. (Granö 1908c)

-, Archäologische Beobachtungen von meinen Reisen in den nördlichen Grenzgegenden Chinas in den Jahren 1906 und 1907. Mémoires de la Société Finno-Ougrienne 26:3. Helsingfors 1909. (Granö 1909a)

Ch. Darwin maantieteilijänä ja geologina. Luonnon Ystävä 1909 13/1909, 33-38. (Granö 1909b)

—, Matkamuistelmia Länsi-Siperiasta ja Mongoliasta III. Matkustus Altai-vuoristossa, Luoteis-Mongoliassa ja Uranhaissa vuonna 1907. Maantieteellisen Yhdistyksen Aikakauskirja 21/1908, 9-46 (Granö 1909c)

—, Piirteitä eläinmaantieteen historiasta, etenkin aluejakokysymystä silmällä pitäen. Suomen Maantieteellisen Yhdistyksen Julkaisuja 8/1909, 1-93. (Granö 1909d)

Archäologische Beobachtungen von meiner Reise in Südsibirien und der Nordwestmongolei im Jahre 1909. Journal de la Sociéte Finno-ougrienne XXVIII. Helsingfors 1910. (Granö 1910a)

, Beiträge zur Kenntnis der Eiszeit in der nordwestlichen Mongolei und einigen ihrer südsibirischen Grenzgebirge. Geomorphologische Studien aus den Jahren 1905, 1906, 1907 und 1909. Fennia 28/1910: 5. (Granö 1910b) 
Granö, J. G., Maantieteellinen kirjallisuutemme. Uusi Suometar 6.11.1910. (Granö 1910c)

_, Maantieteellisen maakuntajaon perusteista. Maantieteellisen Yhdistyksen Aikakauskirja 22/1910, 309-314. (Granö 1910d)

_- Maantieteellistä kirjallisuutta. Uusi Suometar 20.10.1910. (Granö 1910e)

—, Tärkeä isänmaallinen teos. Uusi Suometar 1910. (Granö 1910f)

—, Über die geographische Verbreitung und die Formen der Altertümer in der Nordwestmongolei. Journal Sociéte Finno-Ougrinne 28/1910:2, 1-55. (Granö 1910g)

- Die Eiszeitfrage in der nordwestlichen Mongolei I. Petermanns Geographische Mitteilungen 57/1911, 330-331. (Granö 1911a)

_, Matematis-maantieteellisiä ohjeita ja tauluja. Maantieteellisen Yhdistyksen Aikakauskirja 23/1911, 187-222. (Granö 1911b)

— Uusi kartasto. Uusi Suometar 5.10.1911. (Granö 1911c)

- - Die Nordwest-Mongolei. Eine geographische Skizze. Zeitschrift für Gesellschaft für Erdkunde zu Berlin 8/1912, 1-28. (Granö 1912a)

_-, Matkoiltani Keski-ja Itä-Aasiassa vuosina 1909 ja 1911. Helsinki 1912. (Granö 1912b)

_, Die Forschungen Fritz Machatscheks im westlichen Tienschan. Petermanns Geographische Mitteilungen 60/1914, 260-261. (Granö 1914a)

- Morphologische Forschungen im östlichen Altai. Zeitschrift der Gesellschaft für Erdkunde zu Berlin 10/1914, 1-13. (Granö 1914b)

Granö, G. I., O lednikovom periode v Russkom Altaye. Izv. Zap. Sib. Otd. Russ. Geogrf. Obshch. III:I. Omsk 1915.

Granö, J. G., Jääkauden geomorfologisesta vaikutuksesta Venäjän Altain Bija-alueeseen. Terra 28/1916, 33-55. (Granö 1916a)

—, Jääkausitutkimukseni Venäjän Altais- sa. Muutamia edeltäviä tiedonantoja. Terra 28/1916, 179-239. (Granö 1916b)

Granö, G. I., O znachenii lednikovago perioda dlya morfologii sev.-vost. Altaya s fot. I kartoi. Zapiski Zap. Sib. otd. russ. Geogrf. Geogrf. obshch. XXXVIII. Omsk 1916. (Granö 1916c)

Granö, J. G., Les formes du relief dans l'Altaï russe et leur genèse. Etude morphologique. Fennia 40/1917: 42. Altai, vaellusvuosina nähtyä ja elettyä. Osa 1. Porvoo 1919. (Granö 1919a) , Venäjä. Tietosanakirja X, 849-875. Helsinki 1919. (Granö 1919b)

-, Geograafia kui teadus ja ülikooli aine. Tartu 1920. (Granö 1920a)

- Maantieteestä, sen asemasta ja sitä meillä edustavista seuroista. Terra 32/1920, 13-50. (Granö 1920b)

—_, Altai, vaellusvuosina nähtyä ja elettyä.

Osa 2. Porvoo 1921. (Granö 1921a)

, Geografien vid universitetet i Dorpat. Terra 33/1921, 29-38. (Granö 1921b)

—, Eesti maastikulised üksused. Loodus 2, 4 ja 5/1922, 105-123, 193-214, 257-281.

- Viron kotiseutututkimus. Suomen Heimo 1923, 179-182.

_- Maastikuteaduse ülesanded ja maastiku vormide süsteem. Loodus 4-5/1924, 171-190, 233-247. (Granö 1924a)

—, Maisematieteen tehtävät ja maiseman muotojen järjestelmä. Terra 36/1924:1, 1-36. (Granö 1924b)

_ nä. Terra 36/1924:1, 97-107. (Granö 1924c)

, Maantieteen rajat. Terra 37/1925:4, 152-159.

—, Maantieteellisen muoto-opin tehtävät ja merkitys. Terra 38/1926, 49-59. (Granö 1926)

-, Morfologia ja ympäristötiede. Terra 38/1926, 133-140. (Granö 1926b) 
_, Geografiens forskningsobjekt. Svensk Geografisk Årsbok 1927, 34-46. (Granö 1927a)

_- Suomalainen maisema. Terra 39/1927, 72-87. (Granö 1927b)

, A. Tammekann, Die Oberflächengestaltung des nordostestländischen küstentafellandes. Terra 39/1927, 126-128. (Granö 1927c)

— Edg. Kant, Tartu linn kui ümbrus ja organism. Terra 39/1927, 128-129. (Granö 1927d)

—_, Reine Geographie. Eine methodologische Studie, beleuchtet mit Beispielen aus Finland und Estland. Acta Geographie 2/1929:2. (Granö 1929a)

—_, Väestön ryhmitys ja Maantieteelliset alueet. Teoksessa Suomen Kartasto 1925. Teksti, 83-87; 111-122. Helsinki 1929. (Granö 1929b)

—, Maisematieteellinen aluejako. Terra 42/1930, 1-26. (Granö 1930a)

—, Puhdas maantiede. Tutkimusesimerkeillä Suomesta ja Virosta valaistu metodologinen selvitys. Porvoo 1930 (Granö 1930b)

—_ Altain kasvillisuus. Terra 43/1931, 1-20. (Granö 1931a)

- Die geographischen Gebiete Finnlands. Eine vergleichende Übersicht nebst methodischen Erörterungen. Helsinki 1931. (Granö 1931b)

—-, Johan Evert Rosberg. Terra 44/1932, 73-75. (Granö 1932a)

- Suomen maantieteelliset alueet. Porvoo

1932. (Granö 1932b)

—, Geographische Ganzheiten. Petermanns Geographische Mitteilungen 81/1935, 295-302. (Granö 1935a)

—_, Maisematieteellinen aluejako vielä kerran. Terra 47/1935, 66-74. (Granö 1935b)

_- Asutus. Teoksessa Suomen Maantieteen Käsikirja, 451-510. Helsinki 1936.
Gehöfte und Siedlungen in Finnland. Helsinki 1937.

— , Vorwort und einleitendem Text. Teoksessa Merisuo, A. K., Itinerarien und Landschaftsprofile J. G. Granös aus Uranchai (Tannu-Tuwa) und der Nordmongolei. Turun Yliopiston maantieteellisen laitoksen julkaisuja 16. Helsinki 1938.

—, Ulko-Mongolia. Terra 51/1939, 179198.

- Mongolische Landschaften und Örtlickeiten. Helsinki 1941.

, Sotamarsalkka Mannerheimin matkateos. Terra 53/1941, 70-78.

-, Maantiede ja sen aputieteet filosofiankandidaatin tutkinnossa. Terra 55/1943:1.

, Das Formengebäude des nordöstlichen Altai. Turun Yliopiston maantieteellisen laitoksen julkaisuja 20. Helsinki 1945.

— Albrecht Penck kuollut. Terra 59/1947:1, 19-20. (Granö 1947a)

, Aluemaantieteellisestä tutkimuksesta ja sen tehtävistä maassamme. Terra 59/1947:2, 25-32. (Granö 1947b)

— , Tunturilakeuksista ja ruuhilaaksoista Keski-Aasian pohjoisosassa. Terra 61/1949, 149-161.

— Les terrasses dans les vallées de l'Altaï nord-est, témoins de l'évolution morphologique de ces montagnes. Compte rendu du XVIe Congrès international de Géographie. Lisbonne 1949, 482-486. Lisbonne 1950. (Granö 1950a)

—_, Lissabonin maantieteilijäkongressi 1949. Terra 62/1950, 1-5. (Granö 1950b)

, Alkulause. Teoksessa Suomen maantieteen käsikirja, V-VI. Helsinki 1951. (Granö 1951a)

- Asutus. Teoksessa Suomen maantieteen käsikirja, 302-340. Helsinki 1951. (Granö 1951b) 
Granö, J. G., Carl Gustaf Emil Mannerheim 4.6.1867-28.1.1951. Terra 63/1951, 2-3. (Granö 1951c)

—_ Korkeussuhteet ja pinnanmuodot. Teoksessa Suomen maantieteen käsikirja, 65-87. Helsinki 1951. (Granö 1951d)

_, Maantieteelliset alueet. Teoksessa Suomen maantieteen käsikirja, 364-394. Helsinki 1951. (Granö 1951e)

—- Régions géographiques et une méthode pour les délimiter. Compte rendu du XVIe Congrès international de Géographie. Lisbonne 1949, 322-331. Lisbonne 1952.

_- Berliinin maantieteellinen seura ja sen 125-vuotisjuhlallisuudet. Terra 65/1953, 105108.

—-, Avajaispuhe. Tieteen päivät Helsingissä 7. -9. tammikuuta 1954, 7-13. Helsinki 1955. (Granö 1955a)

—, Die geographischen Provinzen Finnlands. Geographische Rundschau 7/1955, 8194. (Granö 1955b)

—- Oma maamme. Maat ja kansa IV, 246288. Keuruu 1955. (Granö 1955c)

—, Altai. Vaellusvuosina nähtyä ja elettyä. Tampere 1993. (Granö 1993a)

—, Pure Geography. Baltimore 1997. (Granö 1997a)

Granö, J. G. \& Edgar Kant, Maastik ja ümbrus. Loodus 2/1923, 321-327.

Granö, Olavi, Natur und Wirtschaft an der Schärenkuste vor Porvoo in Südfinnland. Helsinki 1955. (Granö 1955d)

—, Piirteitä J. G. Granöstä tutkimusmatkailijana ja maantieteilijänä. Kaistale maantieteellisen tutkimuksen historiaa. Terra 75/1963, 11-27.

- Johannes Gabriel Granö 1882-1956. In Freeman, T.W., Oughton, M. \& P. Pinchemal (eds.), Geographers, biobibliographical studies 3/1979, 73-84.
Granö, Olavi, Granö - vuoristojen tutkija. Teoksessa Hakulinen, Kerkko \& Olavi Heikkinen, Suomalaiset Aasian-kävijät, 108-125. Rauma 1980.

—, J. G. Granön tutkijapersoonallisuuden muotoutuminen. Eesti Loodus 1982. (Olavi Granö 1982a)

—, Maisematutkimus maantieteen traditiona. Terra 94/1982, 7-12. (Olavi Granö 1982b)

—, J. G. Granön tutkijantie Oulusta KeskiAasiaan. Nordia Tiedonantoja 2/1988, 11-25.

—, Johannes Gabriel Granö Aasian tutkijana. Teoksessa Löytönen, Markku (toim.), Matka-arkku. Suomalaisia tutkimusmatkailijoita, 198-215. Hämeenlinna 1989.

, The Spread of the Peneplain Concept to Finland. An Example of a Paradigm's Relation to an Institutional Structure. Striae 31/1990, 37-42.

— Johannes Gabriel Granö (1882-1956) och regionalgeografin. Svensk Geografisk Arsbok 68/1992, 37-54.

—, J. G. Granö - Altai-teoksen kirjoittaja. Teoksessa Granö, J. G., Altai. Vaellusvuosina nähtyä ja elettyä, 523-548. Tampere 1993. (Granö 1993b)

—, Johannes Granö, Siperian suomalaisten pappi. Keskipohjalaisia elämäkertoja, 146-147. Kokkola 1995.

—, Tieteellisen maisemakäsityksen muodostuminen ja tulo Suomeen. Turun Yliopiston maantieteen laitoksen julkaisuja 154/1997, 15-26. (Granö 1997b)

_ Puhdas maantiede aikansa kuvastimessa. Teoksessa Tuhkanen, Sakari (toim.), J. G. Granön Puhdas maantiede ja sen uusi tuleminen englanninkielisen käännöksen muodossa. Turun yliopiston maantieteen laitoksen julkaisuja 157/1998, 15-25.

—, Maantiede Turussa - vanhasta perin- 
teestä uuteen yliopistoon. Terra 112/2000: 1, 37-40. (Granö 2000a)

, Soome kodu-uurimise kogemuse tulek Eestisse. Raamatulooline Eesti Kodumaa Tundmise Allikade, 54-56. (Granö 2000b)

, Saaristorannikko vaihettumisalueena ulapan ja mantereen välillä - luonnonympäristöön perustuvan tutkimusperinteen synty ja kehitys. Teoksessa Tuhkanen, Sakari, Lahti, Mikko, Tantarimäki, Sami \& Ville Karjalainen (toim.), Tutkimusretkistä paikkatietojärjestelmiin - matkalla kulttuurimaantieteen maailmoissa. Juhlakirja professori Pentti Yli-Jokipiin 60-vuotispäivän kunniaksi. Turun yliopiston maantieteen laitoksen julkaisuja 164/2001, 11-25.

_- Suomalaisen maiseman tutkiminen. Teoksessa Suomalainen maisema. Maisemantutkimuksen näkökulmia, 9-12. Helsinki 2002. (Granö 2002c)

, The radical reorientation of J. G. Granö's research work at the University of Tartu, Estonia, in 1919-1923. In Granö, Olavi (ed.), Origin of Landscape Science. Turun yliopiston maantieteen laitoksen julkaisuja 167/2003, 13-34. (Granö 2003c)

, Granö, Johannes (1850-1913) Siperian suomalaisten pappi. Suomen kansallisbiografia 3, 275-276. Hämeenlinna 2004.

, J. G. Granö and Edgar Kant: Teacher and pupil, colleagues and friends. Geografiska Annaler 87B/2005:3, 167-173. (Olavi Granö 2005a)

(ed.), References to the Work of J. G. Granö. Turun yliopiston maantieteen laitoksen julkaisuja A 170. Turku 2005. (Olavi Granö 2005b)

, Käynti Omskin alueella Siperiassa kesällä 1992. Siirtolaisuus - Migration 4/2009, 22-24.
Granö, Olavi \& PaAsi, Anssi, The Intellectual and Social Contexts of J. G. Granö's Pure Geography. In Granö, J. G., Pure Geography, xi-xxxii. Baltimore 1997.

Granö, PaAvo, Johannes Granö. Joulukirja. Suomen Kirkon Pappisliiton Joulutervehdys Suomen Kirkkokansalle III, 40-56. Porvoo 1921. (Granö, P. 1921)

Haahtela, Ilpo, Paavo Kallion henkilökuva ja sotahistoriaa. Luonnon Tutkija 1/2001, 26.

HaApala, Ilmari, Geologia. Teoksessa Suomen tieteen historia 3. Luonnontieteet, lääketieteet ja tekniset tieteet, 268-305. Porvoo 2000.

—, Maankamaran tutkijat maailmalla. Teoksessa Löytönen, Markku (toim.), Uusi matka-arkku, 119-188. Hämeenlinna 2009.

Halén, Harry, Altain huiput siintelee. Teoksessa Löytönen, Markku (toim.), Matka-arkku. Suomalaisia tutkimusmatkailijoita, 148-197. Hämeenlinna 1989.

Hang, E., J. G. Granö 1882-1956. Eesti Geograafia Seltsi Aastaraamat 1957, 257-258.

Hanson, Doug, Finnish photographers celebrate expanses and culture. The Star Tribune 9.9.2005.

Harle, Vilho \& Sami Moisio, Missä on Suomi. Kansallisen identiteettipolitiikan historia ja geopolitiikka. Tampere 2000.

Hartshorne, Richard, The Nature of Geography. A Critical Survey of Current Thought in the Light of the Past. Annals of the Association of American Geographers 29/1939. Fourth Printing. Lancaster 1951.

Harvilahti, Lauri, Altai - kuvia ja mielikuvia. Hiidenkivi 2002:3, 26-27. Helsinki.

Hasselblatt, Ivar, Siperiaan karkoitettuna. Helsinki 1917.

Hassinger, H., Zur Methode der Landschaftsbeschreibung und Landschaftsgliederung. Geographische Zeitschrift 36/1930, 293-296.

HAUTAMÄKI, LAURI, Ympäristön havainnointi eri 
aistien avulla - miten eri aistien avulla tehtyjä havaintoja voidaan kuvata tutkimuksen ja taiteen keinoin. Tampereen yliopisto. Aluetieteen laitos. Tutkimuksia. Sarja B 42/1987.

Heikinheimo, A., Siedlungsgeographie des Kirchspiels Kustavi in Südwestfinnland. Turun yliopiston maantieteen laitoksen julkaisuja 17/1939, 1-88.

Heikкilä, Hillevi, Lapsuuden vuosia Siperiassa. Kotimaa 1.9.1970.

Heikкilä, Markкu, Kielitaistelusta sortovuosiin 1869-1917. Opetusministeriön historia 3. Pieksämäki 1985.

Heinonen, Helka, ”Altain rinteillä on pilvien koti...”. Prof. Granö kertoo tutkimusmatkoistaan. Turun Ylioppilaslehti 1943, 22-25.

Helama, Samuli \& Jari Holopainen, Ilmastonmuutos ja puhdas maantiede: lähiö, maisema ja kartografia J. G. Granön teorian kontekstissa. Alue ja ympäristö 1/2010, 3-14.

Hellbach, Willy, Die geopsychischen Erscheinungen. Leipzig 1923.

H.(EllaAkoski), A. A.; Iivari Leiviskä. Suomen maa ja kansa. Terra 46/1934, 177-181.

HellaAkoski, Aaro, Kuvan käytöstä maantieteen opetuksessa. Luonnonhistorian ja Maantieteen Opettajain päivät. Suomen luonnonhistorian ja maantieteen opettajien liiton julkaisuja 1/1936, 6-42.

Herget, Jürgen, Reconstruction of Ice-Dammed Lake Outburst Floods in the Altai Mountains. Siberia - A Review. Journal Geological Society of India 64/2004: October, 561-574.

Herlin, Heikкi H., Suomalaiset Siperiassa. Teoksessa Mihailov, Nikolai, Siperia. Suurten mahdollisuuksien maa, 146-161. Helsinki 1967.

Herlin, Heikкi H., Siperiassakin suomalaisia. Suomen Silta 5/1980, 8-9.

Hettner, A., Die Geographie, ihre Geschichte, ihr Wesen und ihre Methoden. Breslau 1927.

Hietala, Marjatta, Tutkimuksen julkinen rahoitus. Teoksessa Suomen tieteen historia 4. Tieteen ja tutkimuksen yleinen historia 1880-luvulta lähtien, 492-509. Porvoo 2002.

Hildén, Jukka, Taistelevat Gabrielit: Johannes Gabriel Granö ja Iivari Gabriel Leiviskä. $N a$ tura 2002:3, 44-45.

Hildén, KaArlo, Rosberg, Johan Evert. Kansallinen elämäkerrasto. IV, 515-517. Porvoo 1932.

Hildén, KaArlo (toim.), Suomen Maantieteellisen Seuran 50-vuotissjuhla 22.1.1938. Terra 50/1938. 221-332.

Hildén, KaArlo, Osmo H. Porkka kuollut. Terra 52/1940, 34.

—, Hommage à la mémoire de J. G. Granö. Terra 68/1956, 2-13. (Hildén 1956a)

- J. G. Granö. Muistosanoja. Valvoja 1/1956, 4-7. (Hildén 1956b)

—, Johannes Gabriel Granö. Muistopuhe. Suomalainen Tiedeakatemia. Esitelmät ja Pöytäkirjat 1956, 77-87. (Hildén 1956c)

_- Johannes Gabriel Granö. Muistosanoja. Memoranda Societatis pro Fauna et Flora Fennica 32/1957, 192-194. (Hildén 1957a)

—, Nechrologi. J. G. Granö. Bollettino della Società Geografica Italiana 93/1956, 601-602. (Hildén 1957b)

H(ıмтікка), T. J., J. G. Granö. Altai I. Taide ja kirjallisuus. Iltalehti 26.11.1919.

HokKanen, Kari, Kyösti Kallio 2. 1930-40. Juva 1986.

Holt-Jensen, A., Geography, its history and concepts. London 1980.

Homén, Theodor (toim.), Itä-Karjala ja Kuollan Lappi suomalaisten luonnon- ja kielentutkijain kuvaamana. Helsinki 1918.

Homén, Theodor (red.), Östkarelen och Kola lappmark: skildrade av finska natur-och språkforskare. Helsingfors 1920.

Homén, Theodor (ed.), East Carelia and Kola Lapmark. Described by Finnish Scientist and Philologists. Fennia 42/1921:3. 
Huovinen, Lauri, Varsinais-Suomen seurakuntaelämä autonomian ajalla (1809-1917). Varsinais-Suomen historia 8, 5. Turku 1987.

Hustich, Ilmari, Väinö Tanner. Minnesord. Terra 75/1963, 29-30.

Hägerstrand, Torsten, Utlåtande angående medel till engelsk översättning av "Reine Geographie”. Turun yliopisto 1977.

- Kulturgeografien i Svensk Geografisk Årsbok. Svensk Geografisk Årsbok 60/1984, 18, 21.

The landscape as overlapping neighbourhoods. Carl Sauer Memorial Lecture. In Benko, G. \& Strohmayer, U. (eds), Geography, history, and social sciences. The Geojournal Library 27/1995, 83-96.

Häıкї, Martтı, V. A. Koskenniemi: suomalainen klassikko 2. Taisteleva kirjallinen patriarkka 1939-62. Porvoo 2010.

HäKkinen, Kaisa, E. N. Setälä ja kansallisten tieteiden tutkimuslaitos. Teoksessa Suomen tieteen historia 4 . Tieteen ja tutkimuksen yleinen historia 1880-luvulta lähtien, 179. Porvoo 2002.

I., W. F., J. G. Granö: Altai I-II. Maaseudun Sanomat 15.5.1921.

Ihanus, Juhani, Psykologia. Teoksessa Suomen tieteen historia 2. Humanistiset ja yhteiskuntatieteet, 438-475. Porvoo 2000.

IIsakkila, L., Perustietoa maisemaan vaikuttavista luonnontekijöistä. Espoo 1978.

Immonen, Kari, Ryssästä saa puhua... Neuvostoliitto suomalaisessa julkisuudessa ja kirjat julkisuuden muotona 1918-39. Keuruu 1987.

Itкоnen, ERKкi, Toimelasta Hallituskadulle. Teoksessa Tuomi, Tuomo (toim.), Sanojen taivalta. Puoli vuosisataa Sanakirjasäätiön toimintaa. Suomi 121: 2. Helsinki 1976.

Itronen, Pertti, Puhdasta maantiedettä vihdoinkin englanniksi. Yliopistotiedot, Turun yliopisto 6/1998, 10-11.
JaAkкola, Jalmari, Suomen idänkysymys. Helsinki 1941. (Jaakkola 1941a)

—, Die Ostfrage Finnlands. Helsinki 1941. (Jaakkola 1941b)

Jahtinen, Martti I., Tie suomalaisessa maisemassa. Porvoo 1967.

JaAtinen, Stig, John Evert Rosberg 1864-1932. Geographers. Biobibliographical Studies 9. London 1985.

, John Evert Rosberg - Liv och gärning. Terra 100/1988, 13-31.

Jaeger, Fritz, Granös Reine Geographie. Petermanns Geographische Mitteilungen 76/1933, 67-68.

Jacobson-Tepfer, E. \& Kubarev, V. \& D. TseveEndorJ, Mongolie du Nord-Ouest: Haut Tsagaan Gol, Répertoire des Pétroglyphs d'Asie centrale. Sous la direction de Henri-Paul Francfort et Yakov Sher. Paris 2008.

Janhunen, Juha, Suomesta Siperiaan. Bibliophilos 2/1982, 11-17.

—, Minusinskin kattila. Siperian arojen muinaisuus. Öljyposti 1/1984, 22-26.

James, Preston E., All possible worlds. A history of geographical ideas. New York 1972.

Jauhiainen, Jussi S., Suomen ja Viron maantieteen yhtymäkohtia. Teoksessa Tuhkanen, Sakari, Lahti, Mikko, Tantarimäki, Sami \& Ville Karjalainen (toim.), Tutkimusretkistä paikkatietojärjestelmiin - matkalla kulttuurimaantieteen maailmoissa. Juhlakirja professori Pentti Yli-Jokipiin 60-vuotispäivän kunniaksi. Turun yliopiston maantieteen laitoksen julkaisuja 164/2001, 27-53.

_, Edgar Kant and the rise of modern urban geography. Geografiska Annaler B: Human Geography 87/2005:B:3, 193-203.

_ , J. G. Granölle nimikkoluentosali Tarton yliopistoon. Terra 122/2010, 221.

Jessen, J., A Finnish Geographer. Baltic Countries II/1936:2, 195-200. 
JokipiI, Mauno, Jatkosodan synty. Tutkimuksia Saksan ja Suomen sotilaallisesta yhteistyöstä 1940-41. Keuruu 1987.

Jokisipilä, Markku, Suur-Suomi-aate ja ItäKarjalan miehiys jatkosodassa. Teoksessa Turtola, Martti (toim.), Sodassa koettua. Yhdessä eteenpäin, 54-75. Porvoo 2009.

Jones, Michael, Human geographical landscapes: J. G. Granö's approach to landscapes as scientist and artist. In Granö, Olavi (ed.), Origin of Landscape Science. Turun yliopiston maantieteen laitoksen julkaisuja 167/2003, 71-98.

Juntunen, Alpo, Länsi-Siperian inkeriläiset siirtolat. Turun Historiallinen Arkisto 38/1982, 350-367.

— Suomalaisten karkottaminen Siperiaan autonomian aikana ja karkotetut Siperiassa. Suomen vankeinhoidon historiaa 3. Helsinki 1983.

_, Förvisningarna av finländare tilli Siberien under autonomin och de förvisade I Siberien. Nordisk Tidskrift för kriminalvidenskap 72/1985: 4, 263-273.

— Impact of the Russian Empire on geography in Finland. Fennia 171/1993:2, 137-158.

- Siperia on opettanut meitä liikaakin. Turun Sanomat 26.8.1994.

Jussila, Osmo, Nationalismi ja vallankumous venäläis-suomalaisissa subteissa 1899-1914. Helsinki 1979.

Juva, Мıкко, Aika etsiä ja aika löytää. Sukuni vaiheita sadan vuoden ajalta. Keuruu 1998.

Jäntere, KaArlo, Turun yliopiston perustaminen. Turku 1942.

JäntTI, YRjö A., Werner Söderström Osakeyhtiö. Viisikymmenvuotinen kustannustoiminta 1878-1928. II osa. Porvoo 1928.

Järviluoma, Helmi, J. Granö's "Pure Geography" now available in English. Northern Soundscapes 1/1998, 164-165.
Järviluoma, Helmi, KoivumäKi, Ari, Kytö, Meri \& Heikki Uimonen (toim.), Sata suomalaista äänimaisemaa. Suomalaisen Kirjallisuuden Seuran Toimituksia 1100. Tampere 2006.

Kaarninen, Merja, Yliopisto ja tiede sodassa. Teoksessa Turtola, Martti (toim.), Sodassa koettua. Yhdessä eteenpäin, 24-53. Porvoo 2009.

Kалкко, Jон., Streifigkeit der Landschaft in Ladoga-Karelien. Fennia 58/1933:4, 18-45.

—- Suomi saksalaisessa maantieteen suurteoksessa. Terra 50/1938, 357-360.

_- Suomen maantieteellisten alueiden maisematieteelliset vuodenajat ja maiseman rytmikaavat. Terra 54/1942, 229-248.

— Maantieteellisten liikkuman vuodenaikainen rytmi. Terra 56/1944, 3, 9.

—_, Maiseman vuodenaikainen rytmi Suomen kasvipeitteessä ja tekomuodostossa. Terra 57/1945, 69 .

KaILA, E., Hahmoprobleemasta ynnä muutamista muista teoreettisen psykologian ongelmista. Ajatus 13/1944.

—_, Arkikokemuksen perseptuaalinen ja konseptuaalinen aines. Ajatus 23/1960.

Kaкkuri, Juhani, Tulevaisuuden uhkakuvat. Helsinki 2003.

Kalliola, Reino, Itä-Karjalan suomalaiset luonnonkasvot. Valvoja-Aika 20/1942.

— Suomen Maantieteen Käsikirja. Terra 75/1963, 70-76.

— Suolan kimallus. Terra 93/1981, 111112.

— maisemakuvauksesta. Terra 94/1982, 27-32.

Kalliola, Risto, Luonto ja maisemat. Teoksessa Tiitta, Allan (toim.), Maamme Suomi, 30-43. Porvoo 2007.

Kanervo, Erkki, Kansleri, professori J. G. Granö toinen Fennia-mitalin saaja. Terra 59/1947, 42-44.

Kant, Edgar, Tartu: Linn kui ümbrus ja or- 
ganism: Linnageograafiline vaatlus, ühtlasi lisang kultuurmaastiku morfoloogiale. Tartu 1926.

, Géographie, sociographie et l'écologie humaine. Publicationes Seminarii Universitatis Tartuensis Oeconomico-Geographici 4/1933, $1-61$.

, Bevölkerung und Lebensraum Estlands: Ein anthropoökologischer Beitrag zur Kunde Baltoskandias. Tartu 1935.

, Johannes G. Granö. Tulimuld 7/1956, 254-260. (Kant 1956a)

, Johannes Gabriel Granö 14.3.1882-

23.2.1956. Några minnesord. Svensk Geografisk Årsbok 1956, 163-172. (Kant 1956b)

, J. G. Granö in memoriam. Commentationes Balticae 1957.

Karjalainen, P. T. \& Petri J. Raivo, Johdatusta kulttuurimaantieteelliseen maisematutkimukseen. Oulun yliopiston maantieteen laitoksen opetusmoniste 21. Oulu 1995.

Karlsson, Fred \& Nils Erik Enkvist, Kielitieteet. Teoksessa Suomen tieteen historia 2. Humanistiset ja yhteiskuntatieteet, 224-296. Porvoo 2000.

Kaskimies, Einari, Altai-vuoriston tutkija. Turun Yliopiston kansleri ja Helsingin Yliopiston maantieteen professori J. G. Granö. Teoksessa Suuria suomalaisia tiedemiehiä, 53-64. Pieksämäki 1947.

Katajamäкi, Hannu, Keskus- ja vaikutusaluetutkimus. Tampereen yliopisto. Aluetiede. Tiedonantoja 1977.

Keinänen, Timo, Pietilä, Reima (1923-1993) arkkitehti, arkkitehtuurin professori, akateemikko. Suomen kansallisbiografia 7, 685-688. Hämeenlinna 2006.

Kettunen, Lauri, Tieteen matkamiehen uusia elämyksiä. Murrosvuodet 1918-1924. Porvoo 1948.

Kihlman, A. Osw., Maantieteen opetus meillä ja muualla. Valvoja 20/1900, 157-166, 247-257.

Kiıskinen, Kyösti, Tähden Yrjön Siperian reissu. Uusi nainen 10/1977.

Kinnunen, Helena, Suomalaisia kaukaa menneisyydestä. Helsingin Sanomat 29.9.1991. (Kinnunen 1991a)

- Omskin pappila kaipaa remonttia. Helsingin Sanomat 2.10.1991. (Kinnunen 1991b)

Klinge, Matti, Vihan veljistä valtiososialismiin. Porvoo 1972.

—, Vallankumouksesta talvisotaan, Sodan ja muutosten aika sekä Politiikka ja korkeakoulupolitiikka. Teoksessa Klinge, Matti sekä Knapas, Rainer, Leikola, Anto \& John Strömberg, Helsingin Yliopisto 1917-1990. Helsingin Yliopisto 1640-1990. Kolmas osa, 9-349. Keuruu 1990.

3236 suomalaista Siperiassa 1800-luvulla. Amerikan Uutiset 6.2.1973.

375-vuotias Tarton yliopisto. Viro.nyt 3/2007, 4-7.

Koskela, Hille, J. G. Granö valokuvaajana mustan todellisuuden toisella puolen. Terra 114/2002, 104-105.

Koskenniemi, Lauri, Pohjanmaan hengellinen herättäjä. Stavuotismuisto. Sanansaattaja 28.2.1980.

Koskinen, Tuulikki, Meurman, Otto-Iivari (1890-1994) asemakaava-arkkitehti, asemakaavaopin professori. Suomen kansallisbiografia 6, 686-688. Hämeenlinna 2005.

Kosonen, Katarimna, Kartta ja kansakunta. Suomalainen lehdistökartografia sortovuosien protesteista Suur-Suomen kuviin 1899-1942. Suomalaisen kirjallisuuden Seuran Toimituksia 793. Helsinki 2000.

Kouknunen, Kalevi, Suomen suku on saanut ansaitsemansa ja ansiokkaan historian. Hiidenkivi 4/2008, 39.

Kovero, Martti, August Gideon Fontell kuollut. Terra 50/1938, 378-384. 
Kuitunen, Kalevi, J. G. Granö: Altai. Vaellusvuosina nähtyä ja elettyä. Bibliophilos 1993.

Kupiainen, Unto, Aaro Hellaakoski: ihminen ja runoilija. Porvoo 1953.

Kurs, Отт, Granön syntymän 100-vuotispäiväksi. Neuvosto-Karjala 26.3.1982.

-, Granö ja Altai. Neuvosto-Karjala 18.9.1983.

- - Geographers in research of administrative units and administrative division of Estonia. Geographical Research 1988, 93-100.

_- Eesti rahvasliku maateaduse algusaastaist. Eesti Geograafia Seltsi aastaraamat 271992, 149-154. (Kurs 1992a)

- Scientific heritage of Edgar Kant. Estonia. Man and Nature. Tallinn 1992. (Kurs 1992b)

—, Granö, J. G.: Altai. GeoJournal 37/1995, 580-581.

- Die ersten Jahrzehnte der estnischen Stadtgeographie. Mitteilungen der Österreichischen Geographischen Gesellschaft 140/1998, 211-234.

- Johannes Gabriel Granös Eestis. Turu 2001. (Kurs 2001a)

— Suomen ja Viron maantieteen yhtymäkohtia. Teoksessa Tuhkanen, Sakari, Lahti, Mikko, Tantarimäki, Sami \& Ville Karjalainen (toim.), Tutkimusretkistä paikkatietojärjestelmiin - matkalla kulttuurimaantieteen maailmoissa. Juhlakirja professori Pentti Yli-Jokipiin 60-vuotispäivän kunniaksi. Turun yliopiston maantieteen laitoksen julkaisuja 164/2001, 89-106. (Kurs 2001b)

— Eesti rahvastiku ja asustuse uurimisest 1920. ja 1930. aastail. Teoksessa Kant, Edgar, Eesti rahvastik ja asustus, 7-20. Tartu 2007.

Kurs, Otт \& Granö, Olavi, Johannes Gabriel Granö as a founder of modern geography in Estonia. Turku 2004.

Kurs, Ott, PaAtsi, Vello \& Tammiksaar, ERKI, Institutions of geography in Estonia,
1632-1999. Publicationes Instituti Geographici Universitatis Tartuensis 83/1999, 7-25.

KäYнкӧ, Niına, Olavi Granö \& Maunu Häyrinen, Finnish landscape studies - a mixture of traditions and recent trends in the analysis of nature-human interactions. Belgeo 2004/2-3, 245-256.

LAATI, IIsAKKI, Helsinki valtiollisten tapahtumien näyttämönä. Teoksessa Helsingin kaupungin historia IV:1, 105-180. Helsinki 1955.

Lagerspetz, Kari, Biologiset tieteet. Teoksessa Suomen tieteen historia 3. Luonnontieteet, lääketieteet ja tekniset tieteet, 190-267. Porvoo 2000.

Lahti-Argutina, Eila, Olimme joukko vieras vaan. Venäjänsuomalaiset vainonuhrit Neuvostoliitossa 1930-luvun alusta 1950-luvun alkuun. Vammala 2001.

LAine, Antti, Suur-Suomen kahdet kasvot. ItäKarjalan siviiliväestön asema suomalaisessa miehityshallinnossa 1941-1944. Keuruu 1982.

—, Tiedemiesten Suur-Suomi - Itä-Karjalan tutkimus jatkosodan aikana. Historiallinen Arkisto 1993, 91-202.

Lassila, Pertti, Otavan historia. Kolmas osa 1941-1975. Keuruu 1990.

Lautensach, Hermann, Wesen und Methoden der geographischen Wissenschaft. In Klute, F. (ed.), Handbuch der Geographischen Wissenschaft I/1933, 23-56.

$\longrightarrow$, Der Geographische Formenwandel. Colloquium Geographicum 3/1952, 84-85. (Lautensach 1952a)

_- Otto Schlüters Bedeutung für die methodische Entwicklung der Geographie. Petermanns Geographische Mitteilungen 96/1952, 219-231. (Lautensach 1952b)

Lehto, Olli, Korkeat maailmat. Rolf Nevanlinnan elämä. Keuruu 2001.

, Oman tien kulkijat. Veljekset Vilho, Yrjö ja Kalle Väisälä. Keuruu 2004. 
Lehtola, Erkкa, Oliko Siperiassa elämää. Tutkimusmatkailun klassikko nousi unohduksen yöstä. Aamulehti 8.9.1993.

Leikola, Anto, Kotilokabinetti. Juva 1986. -, Aaro Hellaakoski (1893-1952) Runoilija ja tiedemies. Kansallisgalleria. Suuret suomalaiset 4, 48-55. Porvoo 1996. (Leikola 1996a) , Johan Axel Palmén (1845-1919) Suomen eläintieteen isähahmo. Kansallisgalleria. Suuret suomalaiset 2, 130-132. Porvoo 1996. (Leikola 1996b)

LeIVISKÄ, IIVARI, Geomorfologia ja ns. maisematiede. Terra 38/1926, 120-132.

_- Suomen maa ja kansa. Porvoo 1934. (Leiviskä 1934a)

— Vähän selitystä nimimerkki A.A.H:n arvosteluun teoksestani "Suomen maa ja kansa". Terra 46/1034, 202-204. (Leiviskä 1934b)

—, Suomen maantieteellisestä aluejaosta. Suomalainen Tiedeakatemia. Esitelmät ja pöytäkirjat 1936, 91-111. Helsinki 1937.

_- Maantiede, sen historia, olemus ja tehtävät. Porvoo 1949.

Linkola, Hannu, Hajonnut maisema. J. G. Granön maisematiede aikansa kuvana ja osana nykyistä maisemamaantiedettä. Julkaisematon pro gradu -työ. Helsingin yliopiston matemaattis-luonnontieteellisen tiedekunnan opinnäytteet. Helsinki 2005. (Linkola 2005a)

- Puhtaan maantieteen alkujuurilla. Terra 117/2005, 238-240. (Linkola 2005b)

_ Rajanylityksiä Gallen-Kallelan museossa. Terra 119/2007, 277.

—_, Rajanylityksiä-näyttelyssä yli 1800 vierasta. Terra 120/2008, 48.

Linkola, KaARlo, Suuri isänmaallinen tietokirja. Uusi Suomi 7.9.1929.

Linnilä, KaI, J. G. Granön maisematieteen soveltaminen taidehistorialliseen maisematutkimukseen. Arkkitehti 1968/4.

Luntinen, Pertti, Uudenaikuistumisen paine.
Teoksessa Kirkinen, Heikki (toim.), Venäjän historia, 261-298. Keuruu 2000.

Luostarinen, Heikni, Perivihollinen. Suomen oikeistolehdistön Neuvostoliittoa koskeva viholliskuva sodassa 1941-44: tausta ja sisältö. Jyväskylä 1986.

Löytönen, Markкu, Miehen kunnia - romaani Iivari Leiviskästä. Terra 98/1986, 225-239.

, Leiviskä, Iivari (1876-1953) maantieteen professori. Suomen kansallisbiografia 6, 52-53. Hämeenlinna 2005.

Magnusson, Rauni. J. G. Granön Siperian valokuvaajana. Länsi-Suomi 17.3.2002.

MajamaA, Raija, Hellaakoski, Aaro (1893-1952) runoilija, maantieteen dosentti, maantieteen ja luonnonhistorian opettaja. Suomen kansallisbiografia 3, 718-722. Hämeenlinna 2004

Mannerheim, C. G., Ratsain halki Aasian 190608. Uusi lyhennetty laitos. Matkapäiväkirjasta valikoiden suomentanut Harry Halén. Otava, Keuruu 2007.

Manninen, Онто, Suur-Suomen ä̈riviivat. Jyväskylä 1980 .

— Asemasodan poliittinen tausta. Teoksessa Jatkosodan historia 4, 111-138. Porvoo 1993.

MaY, J. A., Kant's concept of geography and it's relation to recent geographical thought. University of Toronto. Department of Geography. Research Publications 4. Toronto 1970.

Mead, W. R., Recent developments in human geography in Finland. Progress in Human Geography 1977/1, 361-375.

$\longrightarrow$, A generation of geographers. Teoksessa Torsten Hägerstrand \& Anne Buttimer (eds), Geographers of norden. Reflections on career experiences. Lund studies in geography. Series B. Human geography 1988, 11-34.

Mereste, Uno, Johannes Gabriel Granö ja teoreettinen maantiede. Terra 97/1985:3, 176183. 
Meurman, Otto-Iivari, Asemakaavaoppi. Helsinki 1947.

-, Seutukaavoitus. Teoksessa Suomen maantieteen käsikirja, 395-403. Helsinki 1951.

Meinander, Henrik, Suomen historia. Linjat, rakenteet, käännekohdat. Porvoo 2006.

Michelsen, Karl-Erik, Tiede rauhan ja sodan vuosina. Teoksessa Suomen tieteen historia 4. Tieteen ja tutkimuksen yleinen historia 1880-luvulta lähtien, 146-219. Porvoo 2002.

Minailov, Nikolai, Siperia. Suurten mahdollisuuksien maa. Helsinki 1967.

Myllykangas, Maija, J. G. Granö. Keskipohjanmad 16.10.2005.

Myllyniemi, Seppo, Suomi sodassa 1939-1945. Keuruu 1982.

Mäkelä, Riıtta, Maantieteilijä ja geologi Erkki Mikkola tutki ja kuvasi Pohjois-Suomea. Kaleva 5.1.2008.

Nevakivi, Jukкa, Ulkoasiainhallinnon historia 1918-1956. Helsinki 1988.

Nevalainen, Pekka, Punaisen myrskyn suomalaiset. Suomalaisten paot ja paluumuutot idästä 1917-1939. Vammala 2002.

Niemelä, PaAvo, Verteilung der Bevölkerung im Hügelland von Salo in Südwestfinnland. Turun yliopiston maantieteellisen laitoksen julkaisuja 18. Turku 1939.

Niıniluoto, Ilkka, Suomalaisen tutkimuksen suunnat. Teoksessa Suomen tieteen historia 4. Tieteen ja tutkimuksen yleinen historia 1880-luvulta lähtien, 602-637. Porvoo 2002.

Nuorteva, Jussi, Suurvaltakauden tiede Suomessa. Teoksessa Suomen tieteen historia 1. Tieteen ja tutkimuksen yleinen historia 1880-luvulle, 98-167. Porvoo 2001.

Nuuja, Ismo \& Risto Palokangas, Eesti etsii ratkaisua ympäristöongelmiinsa. Yhteishyvä 83/1987, 2-3, 8.

Nyg̊̊rd, ToIvo, Suur-Suomi vai lähiheimolaisten auttaminen. Keuruu 1978.
NygÅRD, ToIvo, Henkisin voimin vai aseellisin toimin. Heimojärjestöjen Suur-Suomen luomiskeinoista esittämiä käsityksiä. Historiallinen Aikakauskirja 1979, 201-208.

Nykysuomen sanakirja. Kolmas osa. L-N. Porvoo 1954.

Obruchev, V. A., Geologie von Sibirien. Fortschritte der Geologie und Palaeontologie 15. Berlin 1926.

Obruchev, V. A., Retzensija. Iu. G. Grane, Geologicheskoe stroenie severo-vostochnogo Altaia. (Review. J. G. Grane. Geological structure of northeastern Altai). Izvestiia Akademii Nauk SSSR, Seriia Geologicheskaia 3/1947, 142-144.

Ohlson, Birger, Landsbygdens och stadens ljudlandskap. Nordenskiöld-samfundets Tidskrift 35/1975, 36-50.

$\longrightarrow$, Sound fields and sonic landscapes in rural environments. Fennia 148/1976, 34-44.

—, Muuttuva äänimaisema. Terra 94/1982, $78-81$.

Oja, Heıккi, Sibeliuksesta Tuonelaan. Aurinkokuntamme kiehtova nimistö. Ursan julkaisuja 85. Jyväskylä 2003.

OKsAnen, SoFi, Miksi et kirjoittaisi englanniksi? Helsingin Sanomat 4.8.2010.

O(Lsoni), B(ÖRJE), J. G. Granö. Altai I. Studentbladet 10.5.1920.

Oulun lyseo 1883-1933. Oulu 1933.

PAAsi, Anssi, Subjektiivisen elementin merkityksestä J. G. Granön maantieteellisessä ajattelussa. Terra 94/1982, 140-156.

__, Maantieteen subjekti? Tie humanistisen ja behavioraalisen maantieteen nykytematiikkaan. Joensuun korkeakoulu. Historian, maantieteen ja muiden aluetieteiden osaston julkaisuja 34. Joensuu 1983.

_- Aluetietoisuus ja alueellinen identiteetti ihmisen spatiaalisen sidoksen osana. Suunnittelumaantieteen yhdistyksen julkaisuja 13. Helsinki 1984. (Paasi 1984a) 
Connections between J. G. Granö’s geographical thinking and bevioural and humanistic geography. Fennia 162/1984:1, 21-31. (Paasi 1984b)

- The rise and fall of Finnish geopolitics. Political Geography Quarterly 1990, 53-65.

_ Maantiede, geopolitiikka ja Suomen itärajan muuttuvat representaatiot. Alue ja ympäristö 1995, 28-49

, J. G. Granön Puhdas maantiede ja nykyaika. Teoksessa Tuhkanen, Sakari (toim.), J. G. Granön Puhdas maantiede ja sen uusi tuleminen englanninkielisen käännöksen muodossa. Turun yliopiston maantieteen laitoksen julkaisuja 157/1998, 27-30.

- Granö, Johannes Gabriel (1883-1956) maantieteen professori, Turun yliopiston kansleri. Suomen kansallisbiografia 3, 276-278. Hämeenlinna 2004.

Paasilinna, Erno, Yksinäisyys ja uhma. Keuruu 1984.

Paaskoski, Jyrki, Oppineiden yhteisö. Suomalainen Tiedeakatemia 1908-2008. Keuruu 2008.

Paatsi, A. \& Paatsi, Vello, J. G. Granö Tartu Ülikoolis. Eesti Loodus 1982, 357-362

Paatsi, Vello, Johannes Gabriel Granö Virossa. Salo 1997.

PaAtsi, Vello, Johannes Gabriel Granö Virossa. Turku 2000.

Paavolainen, JaAkкo, Poliittiset väkivaltaisuudet Suomessa 1918. I. Punainen terrori. Helsinki 1966.

—, Vankileirit Suomessa 1918. Helsinki 1971.

Pae, Taavi \& Heino Mardiste, Moningaid täiendusi eestikeelse geograafia algusaegadesse. Publicationes Instituti Geographici Universitatis Tartuensis 108/2009, 20-28.

Paffen, Karlheinz (hrsG), Das Wesen der
Landschaft. Wege der Forschung XXXIX. Darmstadt 1973.

Palang, Hannes, Mander, Ülo, Kurs, Ott \& Kalev Sepp, The concept of landscape in Estonian Geography. Estonia, Geographical Studies 8/2000, 154-169.

PAlomäKI, MaURI, Suomen kaupunkimaiseman muuttuminen. Terra 94/1982, 72-74.

Peltonen, Arvo, Äänimaisema - ympäristöasiaa oppilastyönä. Natura 13/1976, 135-139.

Penck, Walter, Die morphologische Analyse. Stuttgart 1924.

Perälä, Tauno, Turun yliopisto 1920-1939. Turku 1970.

—, Turun yliopisto 1939-1974. Turku 1977.

Pietilë, Reima, Maisema ja rakentamismuodot. Arkkitehti 65/1968, 30-31.

Platt, Raye R. (ed.), Finland and Its Geography. New York 1955.

Polvinen, Tuomo, Suomi suurvaltojen politiikassa 1941-1944. Jatkosodan tausta. Porvoo 1964.

—, Venäjän vallankumous ja Suomi 1. Helmikuu 1917-joulukuu 1918. Porvoo 1967.

—_, Venäjän vallankumous ja Suomi 2. Toukokuu 1918-joulukuu 1920. Porvoo 1971.

—_, Jaltasta Pariisin raubaan. Suomi kansainvälisessä politiikassa III: 1945-47. Juva 1981.

_ J. J. Paasikivi. Valtiomiehen elämäntyö 3 1939-1944. Juva 1995.

Pälviranta, Harri, Maantieteilijän valokuvataide. Turun Sanomat 3.7.2002.

Quantrill, Malcolm, Reima Pietilä. Keuruu 1987.

Raento, Elina, Lukijalle. Teoksessa Eskola, Taneli, Rajanylityksiä - Boundary Crossings. Ajan ja paikan vuoropuhelu suomalaisessa maisemavalokuvauksessa. Temporal Dialogues in Finnish Landscape Photography, 15-17. Hämeenlinna 2005.

Raig, Kulle, Tarton yliopisto ja suomalaiset. Viro.nyt 3/2007, 6-7. 
Raivo, Petri, Maiseman kulttuurinen transformaatio. Ortodoksinen kirkko suomalaisessa kulttuurimaisemassa. Nordic Geographical Publications 25:1, 15-46. Oulu 1996.

—, Kulttuurimaisema: alue, näkymä vai tapa nähdä. Teoksessa Haarni, Turkka, Karvinen, Marko, Koskela, Hille \& Sirpa Tani (toim.), Tila, paikka ja maisema, 193-209. Tampere 1997.

—_, Maisema ja mielikuvat. Teoksessa Löytönen, Markku \& Laura Kolbe (toim.), Suomi. Maa, kansa, kulttuurit, 70-87. Helsinki 1999. (Raivo 1999a)

—, Maisema ja suomalaisuus. Teoksessa Westerholm, John \& Pauliina Raento (toim.), Suomen Kartasto 1999, 104-107. Porvoo 1999. (Raivo 1999b)

—, Suomalainen maisematutkija J. G. Granö. Teoksessa Löytönen, Markku \& Laura Kolbe (toim.), Suomi. Maa, kansa, kulttuurit, 73-74. Helsinki 1999. (Raivo 1999c)

- The Finnish landscape and its meanings. Fennia 180/2002: 1-2, 89-98.

Rantatupa, Heikкi, Alatornion historia. Jyväskylä 1988.

Rauhala, Pirkкo-Lissa, Havaintoja Suomen ja Viron sillalta. Yhteiskuntapolitiikka 67/2002: 5, 430-444.

Reitala, Aimo, Isto, Eetu (1865-1913) taidemaalari, koristemaalari. Suomen kansallisbiografia 4, 347-348. Hämeenlinna 2004.

Renier, Stefano, Un maestro e una scuola: J. G. Granö e l'Instituto geografico dell'Università di Abo. Rivista Geografica Italiana 42/1935, 24-28.

Rentola, Kimmo, Kenen joukoissa seisot? Suomalainen kommunismi ja sota 1937-1945. Juva 1994.

Reznichenko, V., Yuznyi Altai i yego oledeniniye (predvaritelnyi ocherk). Petrograd 1914.

Rickert, H., Die Grenzen der Naturwissenschaftlichen Begriffsbildung. Tübingen 1902.
Rikkinen, Kalevi, Suomen asutusmaantiede. Keuruu 1977. , Suuri Kuolan retki 1887. Keuruu 1980. , Ragnar Hult and the emergence of geography in Finland. Fennia 166/1988, 3-192.

- Maantieteen laitoksen alkuvaiheet Helsingin yliopistossa. Publicationes instituti geographici universitatis Helsingiensis C 7. Helsinki 1993.

—, Rosberg, Johan, Evert (1864-1932) maantieteen professori. Suomen kansallisbiografia 8, 342. Hämeenlinna 2006.

- Tammekann, August (1894-1959) maantieteen professori. Suomen kansallisbiografia 9, 615-616. Hämeenlinna 2007. (Rikkinen 2007a)

, Tanner, Väinö (1881-1948) maantieteen professori, valtiongeologi, lähettiläs. Suomen kansallisbiografia 9, 631-632. Hämeenlinna 2007. (Rikkinen 2007b)

Ristкок, A., Maastike puhkeomaduste hindamise teoreetilistest alustest J. G. Granö maastikuteadusliku pärandi valgusel. Eesti Geograafia Seltsi Aastraamat 1975/1976.

Roosanre, JürI, Physical Geography of Estonia: Bridging Western and Eastern Schools of Landscape Synthesis. GeoJournal 33/1994:1, 27-36.

Rosberg, J. E., Geografin och dess studium i Finland, särskilt i Åbo. Abo Akademis Årskrift 1918.

-, Mitä on maantiede? Terra 31/1919, $1-26$.

— Piirteitä yliopistokomppanian historiasta joulukuusta 1918 joulukuuhun 1922. Teoksessa Yliopistokomppania. Universitets kompaniet, 13-20. Helsinki 1922.

Rossi, Leena, Kaksi sukupolvea Turun yliopistossa. Teoksessa Perinteitä ja persoonia. Juhlakirja Turun yliopiston täyttäessä 75 vuotta, 143-156. Turku 1995.

\section{LёнтеЕT}


Tietotekniikan soveltaminen Maankäyttöja rakennuslain kaavojen toteutuksen ohjelmointiin. Tampereen teknillinen yliopisto. Julkaisu 525. Tampere 2005.

Rui, Timo, Tiedemiehet sodan jaloissa. Näkökulmia suomalais-virolaisiin tieteellisiin suhteisiin toisen maailmansodan aikana. Teoksessa Hietala, Marjatta (toim.), Tutkijat ja sota. Suomalaisten tutkijoiden kontakteja ja kohtaloita toisen maailmansodan aikana, 229-345. Jyväskylä 2006.

Ruotsalo, Ritva, Naturlandschaft und Siedlung in der Gegend der Stadt Kuopio auf der Finnischen Seenplatte. Annales Academiae Scientiarum Fennicae A III: 91/1967, 1-118.

Ruotsalo-Aario, Ritva, Räumliche Gliederung im Gebiet westlich von Kuopio. Terra 89/1969, 220-228.

Rönккӧ, PaAvo, Eetu Isto (1865-1905) ja Hyökkäys (1899). Ars Nordica 2/1990.

SaAlas, Uunio, Muistelmia lapsuuteni ja nuoruuteni ajoilta. Porvoo 1963.

SAARI, JUHA, Evankelisia saarnaajia Siperian suomalaiskylillä. Kevätkukkia 1993, 37-39.

SAAri, Juha, Valoa Siperiaan. Kirkollinen työ Siperian suomalaisten parissa 1863-1921. Julkaisematon pro gradu -työ. Helsingin yliopiston teologisen tiedekunnan kirjasto 1994.

SAlminen, Timo, Suomen tieteelliset voittomaat. Venäjä ja Siperia suomalaisessa arkeologiassa 1870-1935. Suomen muinaismuistoyhdistyksen aikakauskirja 110. Helsinki 2003.

Salokorpi, Asko, Aro ja Sininen Altai. Uutispäivä Demari 21.3.2002.

SAlonen, Ville, Eläinmaantiede - näkökulmia ihmisen ja eläimen vuorovaikutussuhteeseen. Terra 116/2004:4, 227-240.

Sandvik, Martin, Sex år i Siberien. Vasabladet 11.2.1975.

_ bladet 22.5.1986.
SaUer, Carl, The morphology of landscape. Teoksessa Leighly, J. (ed.), Land and life, a selection from the writings of Carl Ortwin Sauer. Berkley 1925.

Sauramo, Matti, Erkki Mikkola kuollut. Terra 52/1940, 99-100.

Sauramo, Matti \& Pentti Eskola, J. G. Granö kuollut. Geologi 8/1956, 22.

Saxén, Lauri, Tieteen vuosisata. Teoksessa Suomen tieteen historia 4 . Tieteen ja tutkimuksen yleinen historia 1880-luvulta lähtien, 14-27. Porvoo 2002.

Schmithüsen, Josef, Allgemeine Geosynergetic. Grundlagen der Landschaftskunde. Berlin 1976.

Schough, Katarina, Hyperboré. Föreställningen om Sveriges plats $i$ världen. Falun 2008.

Schramke, W. Zur Paradigmengeschichte der Geographie und ihrer Didaktik. Eine Untersuchung über Geltungsanspruch und Identitätskrise eines Faches. Geographische Hochschulmanuskripte 2. Göttingen 1975.

Schrepfer, H., Handbuch der Geographischen Wissenschaft VII. Finnland, 521, 534-535, 538, 540, 545. Potsdam 1938.

_- Auvo Heikinheimo, Siedlungsgeographie des Kirchspiels Kustavi in Südwestfinnland; Paavo Niemelä, Die Verteilung der Bevölkerung im Hügelland von Salo in Südwestfinnland unter Berücksichtigung ihrer Ursachen. Petermanns Geographische Mitteilungen 1940, 315-316.

Schulman, H. \& S. Nordenstreng, Finska kadettkårens elever och tjänstemän. Biografiska anteckningar 1812-1912. Helsingfors 1912.

Schultz, Heinz-Dietrich, Die deutschsprachige Geographie von 1800 bis 1970. Ein Beitrag zur Geschichte ihrer Methodologie. Abhandlungen des geographischen Instituts Anthropogeographie 29, 151-161. Berlin 1980. 
Screen, J. E. O., Mannerheim. Keuruu 2001.

Sederholm, J. J., Den vetenskapliga geografins mål och medel. Fennia 32/1912:12, 1-42.

Seppä, Jussi, Lintujen äänet. Taskukirja lintujen lajin määräämiseksi laulusta ja kutsuäänistä tekijän kuvittamana. Porvoo 1922.

—_, Luonnon löytöjä. Lintunäkymiä ja -kuulumia. Porvoo 1928.

—, Linnut ja maisema. Porvoo 1945.

Seppälä, Raimo, Emil Aaltosen Säätiö 1937 1987. Tampere 1987.

Serebrjyannyj, L. E. \& I. P. Gerasimov, J. G. Granë (1882-1956). Izvestija Akademii Nauk SSSR. Serija geograficheskaja 6/1956, 126127.

S(EтÄLÄ), E. N., Tieteellisiä voimia Suomesta Viroon. Uusi Suomi 4.9.1919.

SırpI, Jouko, Pääkaupunkiyhteisö ja sen sosiaalipolitiikka. Teoksessa Helsingin kaupungin historia V:1, 137-380. Helsinki 1962.

Sıмојокı, Aılı, Pappilan ullakolta. Pieksämäki 1983.

Sкyтtё, Seija, Johannes Granö 1850-1913. Julkaisematon pro gradu -työ. Helsingin yliopiston teologisen tiedekunnan kirjasto 1967.

Soikkeli, Martti (toim.), Paavo Kallion sodan ajan (1940-45) kirjeitä opettajalleen, Turun yliopiston maantieteen professori J. G. Granölle. Turun yliopiston maantieteen laitoksen monisteita 21/2000.

Spethmann, Hans, Dynamische Länderkunde. Breslau 1928.

Steiner, Dieter, Geographische Raumgliederung und Mustererkennung. Eidgenössische Technische Hochschule. Geographisches Institut Publikation 55/1975, 19-54.

StrömberG, John, Laajeneva ylioppilaskunta. Teoksessa Klinge, Matti sekä Knapas, Rainer, Leikola, Anto \& John Strömberg, Keisarillinen Aleksanterin Yliopisto 1808-1917. Helsingin Yliopisto 1640-1990. Toinen osa, 766-800. Keuruu 1989.
Suomen Kartasto 1925. Helsinki 1925-28.

Suomen Kartasto 1925. Teksti. Helsinki 1929.

Suomen Kartasto 1960. Helsinki 1960-61.

Suomen Kartasto 1960. Teksti. Helsinki 1961.

Suomi, Juhani, Kuningastie. Urho Kekkonen 1950-1956. Keuruu 1990.

Susiluoto, Paulo, Suomen ajan ihmismaantiedettä Petsamosta. Teoksessa Tanner, Väinö, Ihmismaantieteellisiä tutkimuksia Petsamon seudulta I Kolttalappalaiset. Suomalaisen Kirjallisuuden Seuran Toimituksia 780, 9-31. Vammala 2000.

Suslov, S. P. (1961). Physical geography of Asiatic Russia. San Francisco 1961.

Suutala, Maria, Luonto jota ei enää ole. J. G. Granö ja vuosisadan alun Altai. Kaleva 5.8.1993.

Svendsen, J. I., Alexanderson, H., Astakhov, V. I., Demidov, I., Dowdeswell, J. A., Funder, S., Gataullin, V., Henriksen, M., Hjort, C., Houmark-Nielsen, M., HubBerten, H. W., Ingòlfsson, O., Jakobsson, M., KJær, K. H., Larsen, E., Lokrantz, H., Lunkka, J. P., Lys̊̊, Mangerud, J., Matiouchkov, A., Murray, A., Moller, P., Niessen, F., Nikolskaya, O., Polyak, L., SaArnisto, M., Siegert, C., Siegert, M. J., Spielhagen, R. F. \& R. Stein, Late Quaternary ice sheet history of northern Eurasia. Quaternary Science Reviews 23/2004, 1229-1271.

Syrjö, Veli-Matti, Kielletyt kartat. Teoksessa Kielletyt kartat. Karjala 1928-1944, 9-16. Porvoo 2006.

TAllgren, A. M., Suomalaisia muinaistutkimuksen harrastelijoita Venäjällä. Terra 54/1942, 187-198.

Tammekann, A., J. G. Granö, Puhdas maantiede. Loodusevaatleja I, 150-151. Tartu 1930.

, Iivari Gabriel Leiviskä. Terra 65/1953, 73-80. (Tammekann 1953a)

-, Maantieteellinen aluejako. Terra 65/1953, 117-125. (Tammekann 1953b) 
, Kansleri J. G. Granö. Helsingin Sanomat 21.3.1955. (Tammekann 1955a)

_- Maat ja kansat. Helsingin Sanomat 9.10.1955. (Tammekann 1955b)

Tammekann, Eeva-Maija, August Tammekann ja Irene Tammekann. Teoksessa Terho, Henri \& Maija Mäkikalli (toim.), Alvar Aalto Villa Tammekann, 33-41. Uusikaupunki 2000.

Tarasti, Eero, Maiseman semiotiikasta. Teoksessa Aarre Kinnunen \& Yrjö Sepänmaa, Ympäristöestetiikka. Mänttä 1981.

Tавкка, Peкка, Otavan historia. Toinen osa 1918-1940. Keuruu 1980.

Tarmio, Timo, J. G. Granö - Puhdas maantiede. Teoksessa Päin nousevan Suomen rantaa. Tutkijaprofilleja Turun yliopistosta, 50-73. Loimaa 2000.

Tiainen, Antti, Pehmo rakentaa mukavaa kaupunkia. Helsingin Sanomat 8.2.2011.

Tittta, Allan, Harmaakiven maa. Zacharias Topelius ja Suomen maantiede. Bidrag till kännedom av Finlands natur och folk 147. Tampere 1994.

—, Väinö Auer (1895-1981) Tulimaan ja Patagonian tutkija. Kansallisgalleria. Suuret suomalaiset 4, 72-77. Porvoo 1996.

—, Suomi-kuva tarkentuu. Teoksessa Suomen Kartasto 1999, 18-23. Porvoo 1999.

—, Maantiede. Teoksessa Suomen tieteen historia 3. Luonnontieteet, lääketieteet ja tekniset tieteet, 306-353. Porvoo 2000. (Tiitta 2000a)

—_, Suomen Kartastot. Teoksessa Terra Cognita, 105-109. Helsinki 2000. (Tiitta 2000b)

—, Huippuyksilöitä ja toimikuntia. Suomen Akatemian historia 1 1948-1969. Jyväskylä 2004.

—, J. G. Granö ja nykyvalokuvaajat. Terra 117/2005, 237-238. (Tiitta 2005a)

— Maamme kirja 130 vuotta - voiko 2,5 miljoonaa ihmistä olla väärässä? Teoksessa
Satu Apo \& Märtha Norrback (toim.) Topelius elää - Topelius lever. Topelius-seuran julkaisuja 1/2005, 17-32. (Tiitta 2005b)

_- Porthan Suomen maantieteen tuntemuksen edistäjänä. Teoksessa Henrici Gabrielis Porthan, Opera omnia XIII, IX-LXXV. Turku 2007.

— Tutkimusmatkat Venäjän vallan aikana. Teoksessa Löytönen, Markku (toim.), Uusi matka-arkku, 29-79. Hämeenlinna 2009.

Tiknanen, Matti, Aaro Hellaakoski - runoileva maantieteilijä. Terra 105/1993, 67-82.

Torvonen, Y. H., Suomenkielisestä maisematieteellisestä sanastosta. Terra 36/1924:1, 37-41.

T(olvanen), V(Iljo), J. G. Granö, Altai I. Uusi Suomi. Maantieteellistä kirjallisuutta. Uusi Suomi 30.10.1919.

Tolvanen, Viljo, J. G. Granö, Altai. Terra 32/1920, 107-110.

Tommila, Pärviö, Suomen historiankirjoitus. Tutkimuksen historia. Porvoo 1989.

- Suomalaisen tieteen voimakkaan kasvun kausi. Teoksessa Suomen tieteen historia 4. Tieteen ja tutkimuksen yleinen historia 1880-luvulta lähtien, 28-145. Porvoo 2002.

Tuan, YI-Fu, Topophilia: A study of environmental perception, attitudes and values. Englewood Cliffs 1974.

Tuhranen, Sakari (toim.), J. G. Granön Puhdas Maantiede ja sen uusi tuleminen englanninkielisen käännöksen muodossa. Turun yliopiston maantieteen laitoksen julkaisuja 157/1998.

Tuomi, Ossi, Aluetiede sosiologian ja maantieteen välimaastossa. Teoksessa Littunen, Y., Rautio, P. \& A. Saarinen (toim.), Tieto, tiede, yhteiskunta: keskustelua yhteiskuntatieteistä, 149-166. Tampereen yliopisto. Yhteiskuntatieteiden tutkimuslaitos. Sarja E:6. Tampere 1978.

Tuominen, J. K. V., Das Geschäftscentrum der Stadt Turku. Fennia 54/1930:2. 
Tuominen, Orva, Über die Geographie der Gehöfte im Kirchspiel Yläne. Fennia 61/1939, $1-63$.

—, Suomen maantieteen käsikirja. Uusi Suomi 15.4.1951.

- Suomen maantieteellisistä suuralueista. Terra 68/1956:2, 124-131.

—, Turun Yliopiston maantieteen laitos 1924-1974. Turun Yliopiston Maantieteen laitoksen julkaisuja 83. Turku 1978.

—, J. G. Granö 14.3.1882-1982. Phoenix 1982, 1-11.

, Coincidence and continuity in a Geographer's Life. In Hägerstrand, Torsten \& Anne Buttimer (eds.), Geographers of Norden. Reflections on Career Experiences. Lund Studies in Geography B 52/1988, 130-146.

Turtola, Martti, Risto Ryti. Elämä isänmaan puolesta. Keuruu 1994.

Tuuri, Antti, Suuri viljajuna Siperiasta. Keuruu 2009.

Uimonen, Anu, Tiedemiehestä kuorittiin esiin taiteilija. Helsingin Sanomat 17.3.2002.

_- Kaukomailla ennen ja nyt. Helsingin Sanomat 22.9.2005. (Uimonen 2005a)

Uimonen, Heıkкı, Ääntä kohti. Ääniympäristön kuuntelu, muutos ja merkitys. Acta Universitatis Tamperensis 1110. Tampere 2005. (Uimonen 2005b)

Unwin, Tim, Pure geography. Progress in Human Geography 26/1999, 319-320.

Uola, Miккo, Hackzell, Antti (1881-1946) pääministeri, Suomen Työnantajain Keskusliiton toimitusjohtaja, lähettiläs, kansanedustaja. Suomen kansallisbiografia 3, 454-458. Нämeenlinna 2004.

Waibel, LeO, Was verstehen wir unter Landschaftskunde? Geographischer Anzeiger 1933, 197-207.

Valkonen, Markku, Altain sinessä. Suomen Kuvalehti 19/2002, 50
Vallisaari, Eero, Palmén, Johan Axel (18451919) eläintieteen professori, maantieteen uranuurtaja. Suomen kansallisbiografia 7, 490493. Hämeenlinna 2006.

Van Cleef, E., The Nature and Scope of Geography with illustrations from Finland and Estonia. Geographical Review 20/1930, 171-173.

A philosophy of geography and geographical regions. Geographical Review 22/1932, 495-496.

VAN DER VAART, JACOB H., Granö's pure geography. Monadnock 1975/June, 91-95.

VAres, Mari, Luonnollinen Suomi - käsityksiä Suomen "sijainnista ja suuruudesta 1917-44. Historiallinen Aikakauskirja 2010, 47-59.

Vares, Vesa \& HäKkinen, Kaisa, Sanan valta. E. N. Setälän poliittinen, yhteiskunnallinen ja tieteellinen toiminta. Juva 2001.

Vartiainen, Perttu, Maantieteen yleisiä lähtökohtia. Joensuun korkeakoulu. Historian, maantieteen ja muiden aluetieteiden osaston julkaisuja 7/1980.

Vauras, RittTa, Kultavuoren kartoittaja. Yliopisto $6 / 2002,16-18$.

Wennerholm, Eric, Sven Hedin: en biograf. Stockholm 1978.

Vesikansa, Jyrki, Suomi ja Viro jatkosodan aikana. Uusi Suomi 7.11.1964.

Westermanns Lexikon der Geographie: Granö, Johannes Gabriel; Reine Geographie, 257; 987988. Braunschweig 1969-70.

Vetre, Osmo U., Vihreän talon tarina. Asunto-osakeyhtiö Kotirinne 1909-1976. Helsinki 1976.

Virtala, Pentti, Aluepolitiikka. Teoksessa Suomen Kartasto 1999, 86-89. Porvoo 1999.

Viljanen, T. V., Helsinki sotien jaloissa. Teoksessa Helsingin kaupungin historia IV:1, 181-210. Helsinki 1955.

Wilskman, Atre, Hasselblatt (Fontell). Släktbok 2, 1. Skrifter utgivna av Svenska Litteratursällskapet i Finland 138, 1. Helsingfors 1918. 
Winkler, Ernst (hrsg.), Probleme der allgemeinen Geographie. Darmstadt 1975.

Wisotzki, Emil, Zeitströmungen in der Geographie. Leipzig 1897.

Witting, Rolf, Suomen Maantieteellisen Seuran pöytäkirjat 25.10.1918-21.5.1920. Fennia 42/1921:1, 1-78.

VoIOnMAA, VäINÖ, Suomen uusi asema: maantieteellisiä ja historiallisia peruspiirteitä. Porvoo 1919.

Wrede, Henrik, I Siberien för trettio àr sedan. Stockholm 1918.

von Wright, J. K., Terrae incognitae: the place of the imagination in geography. Annals of the Association of American Geographers 37/1947, $1-15$.

Wärneryd, Olof, Torsten Hägerstrand 11.10.1916-3.5.2004. Kungliga humanistiska vetenskapssamfundet $i$ Lund. Årberättelse 2004-2005, 31-35.

VäÄnÄNEn, Heikki, Suomen maantieteen käsikirja. Helsingin Sanomat 11.4.1951.

Yli-Jokipir, Pentti, J. G. Granön syntymästä on kulunut sata vuotta. Turun Sanomat 3.4.1982. , Centenary bibliography of papers published in the journals of the Geographical Society of Finnland, by topic, 1888-1987. Fennia 166/1988, 193-285.

—, Venäjän dynaaminen aluemaantiede. Tieteessä tapahtuu 76/2003, 74-76.

Ylikangas, Heikкi, Härmän häjyt ja Kauhavan herra. Kuvaus puukkojunkkareitten ja virkavallan välisestä yhteenotosta 1860-luvun lopulla. Keuruu 1974.

Younghusband, F., Natural beauty and geographical science. The Geographical Journal 56/1920:1.

- The Heart of nature. London 1921.

Zetterberg, Seppo, Venäjästä Neuvostoliitoksi. Teoksessa Kirkinen, Heikki (toim.), Venäjän historia, 327-371. Keuruu 2000.
Viron historia. Hämeenlinna 2007.

Österman, Pia, Maisema kaikilla aisteilla. Yliopisto 7/2005, 36-39.

\section{Lehdet}

Aamulehti 1942, 1955

Aftonposten 1926

Arkkitehti 1970

Dagens Nyheter 1956

Göteborgs Morgonpost 1926

Helsingin Sanomat 1922, 1935, 1955, 1956, 2010

Hufvudstadsbladet 1956

Ilta-Sanomat 1956

Lunds Dagblad 1926

Phoenix 1990

Postimees 1920

Stockholms-Tidningen 1926

Suomen Sosiaalidemokraatti 1955

Sydsvenska Dagbladet Snällposten 1926

Terra 1922-29, 1940-42, 1945-47, 1949-52

Turun Sanomat 1932, 1955, 1956

Turun Ylioppilaslehti 1932, 1933

Uusi Aura 1932, 1933, 1943, 1945, 1955, 1956

Uusi Suometar 1910, 1911, 1917

Uusi Suomi 1919, 1929, 1932, 1942, 1945, 1955, 1956

Åbo Underrättelser 1929, 1956

Åland 1932 


\section{Henkilöhakemisto}

\section{A}

Aalto, Alvar 220-221

Aalto, Pentti 89

Aario, Leo 374, 380, 408, 431-433, 442, 454

Abramov, A. N. 458

Adams, Ansel 195

Adamsson, Sylvester 25

Ahlmann, Hans W:son 356-357, 426

Ahonen 69

Ailio, Julius 104-105

Ajo, Reino 456

Aldajeff, Turobai 86-87

Alieva, Alla 191

Allardt, Anders 339

Allix, André 94, 462

Aminoff, Anna 45

Anhava, Tuomas 192

Appelgren, O. H. 70

Appelgren-Kivalo, Hjalmar 19, 32-33

Arminen, Viljo 439

Askyroff, Semjon 80

Aspelin, J. R. 33, 70

Auer, Väinö 262, 264, 278, 335, 351, 355, 381, 406-408, 411, 430-431, 436-437, 442, 453-454, 456, 462

\section{B}

Backlund, Helge 320

Baer, Karl Ernst von 152, 204

Banse, Ewald 211, 287, 342, 351

Beck, Hanno 354

Berg, L. S. 52, 211-212, 254, 369, 421

Birger Jaarli 64

Blomstedt, Kaarlo 413

Blumberg, N. 43

Blücher, Wipert von 416
Boesch, Hans 462

Boldt, Karl 140

Boldt, Robert 232

Boman, Arthur 61

Bomansson, Johan Oskar 17

Bomansson, Johanna (Jeanette) 17

Bomansson, Karl August 17

Bonpland, Aimé 161

Bonsdorff, Johanna Charlotta 39

Bonsdorff, Wäinö 248

Bonsdorffit 39

Borovitinov, Mihail 142

Broek, J. O. M. 355

Bruncrona, Eva Charlotta ks. Rosberg, Eva Charlotta

Brückner, Eduard 53-54, 80, 92-93

Bucher, A. L. 340

Bunge, Alexander von 92

Bunge, William 461

Buttimer, Anne 160

C

Cajander, A. K. 301, 398

Candolin, Einar 385

Capt, A. 462

Carol, Hans 462

Castrén, Gunnar 252-253

Castrén, M. A. 24, 32-33, 75, 92

Cederberg, A. R. 199, 413

Christaller, Walter 224, 330, 438, 460-461

Cressey, George B. 426, 457

Curtis, Edward S. 195

D

Danielson-Kalmari, J. R. 296, 300, 303, 411

Danielson-Kalmari, Jenny 390
Darwin, Charles 39, 161

Davis, W. M. 53, 57, 102-103, 108, $110,129,132,138,211-212,422$, 427

De Geer, Sten 223, 277, 355-357, 459

Donner, Anders 155, 252-253

Donner, Otto 63, 70-72, 81, 85-86

Dostojevski, Feodor 27

\section{E}

Ekholm, Aleksis 295

Ekholm, Hilma ks. Granö, Hilma

Ekholm, Isak 295

Elfving, Fredrik 55, 140, 247, 301

Engel, Carl Ludvig 261

Enkola, Kurt 330

Erich, Rafael 411

Eriksson, Petter Alfred 43

Eskola, Pentti 133-134, 265, 278, 303, $317,408,432-433,472$

Eskola, Taneli 168, 172, 192, 194-195, 378

$\mathbf{F}$

Federley, Harry 252, 254

Feijo, Mariano 441

Fels, E. 463

Feodor 83

Fleege, Uno A. 56

Fontell, A. G. 16

Fontell, Alma Jakobina ks. Granö, Alma Jakobina

Fontell, Elisabet 26, 50

Fontell, Johan Wilhelm 19

Fontell, Josef 17-19

Fontell, Karl Oskar 19

Forsgren, Gustaf 146

Forsman, Väinö 472 
Forssander-Granö, Anders 17

Frödin, John 356

\section{G}

Gebler, Friedrich von 80, 92

Gegenbaur, Carl 39

Geresimov, I. P. 458

Gmelin, Johan Georg 92

Golledge, Reginald G. 379

Goltz, Rüdiger von der 145

Gould, Peter 461

Gradmann, Robert 342, 348, 369

Granö (Fontell), Alma Jakobina 16-17, 19, 26, 42, 44-45, 50, 69, 90, 126 165, 200, 202, 208, 250, 306, 391, 474

Granö, Anders (Antti) 26, 30, 66

Granö, Aune 126, 128, 141, 146, 208, 272, 387, 434

Granö, Edla 17

Granö, Eeva (J. G. Granön tytär) 145146, 201, 208, 272, 342, 387, 434

Granö (Kaleva), Eeva (J. G. Granön miniä) 272, 433

Granö, Elin 106, 206

Granö, Erik 106

Granö, Gabriel 18

Granö, Greta 65

Granö (Ekholm), Hilma 17, 105, 107 108, 123-124, 126, 128, 141, 146, $151,165,179,204,250,269,272$ 295, 310, 386-387, 396, 398-399, $403,433,445,463,472,480$

Granö, Jenny 18

Granö, Johannes 16-22, 26-35, 38, 41-46, 48-51, 69, 72, 102, 105$106,160-161,312,474$

Granö, Matti 106

Granö, Olavi 190, 192, 254, 267, 272, $307,311,379,387,396,433-434$, 440-441, 454
Granö, Paavo (J. G. Granön serkku) 66, 110-112, 114, 126, 344

Granö, Paavo (Paul) (J. G. Granön veli) 19, 26, 35, 41-42, 44-45, 48-50, 63-66, 68-69, 105-106, 125, 205-207, 306, 317, 391, 420

Granö, Petter 18

Granö, Siine Taiga ks. Schauman, Siine Taiga

Granö, Teodor 18

Greta 45

Grotenfelt, Kustavi 411

Grünthal, Wilhelm 202

Gummerus, Herman 104-105

Gutersohn, Heinrich 462

$\mathbf{H}$

Haataja, Kyösti 301

Hackzell, Antti 412

Hakkila, Väinö 398

Hakulinen, Lauri 408

Halén, Harry 84

Haltenberger, Mihály 254

Hannula, Uuno 267, 398-399

Hartshorne, Richard 354-355

Harva, Uno 384

Harvey, David 376

Hasselblattit 16

Hassinger, Hugo 353

Hausen, Hans 320

Hedberg, F. G. 20-21, 35

Hedin, Sven 72, 356

Hedman, K. S. 35

Heikel, A. O. 70

Heikel, Ivar August 252

Heikinheimo, Anneli 439

Heikinheimo, Auvo 331

Heiskanen, V. A. 413

Helaakoski, Antti Rietrikki 37, 333, 397

Helander, Niilo 48

Hellaakoski, Aaro 37, 191, 333, 351,
396-397, 431

Hellbach, Willy 342

Helmersen, Gregor von 92, 204

Hettner, Alfred 211, 255, 288, $342-$ $343,354-355$

Hicks, Malcolm 379

Hildén, Kaarlo 110-113, 115, 126, 133, $179,248,351,372,403,437,439$, $442,470,472$

Hintilla, T. J. 190

Hitler, Adolf 368, 412-413, 416, 463

Hohenthal, Otto Mauritz 20

Holsti, Rudolf 398

Homén, Theodor 94, 144, 406

Honkanen, Ilmari 333

Huhtamäki, Heikki 307

Hult, Ragnar 17, 37, 54, 58-59, 61, $100,165,243,245$

Humboldt, Alexander von 58, 68, 92, 160-161, 173, 175, 203, 211-212, 355,398

Huntington, E. 108

Hustich, Ilmari 457

Hägerstrand, Torsten 378-379, 460461

Hägglund, Aadolf 20, 30

Hällström 57

Häyrén, Ernst 97, 262, 278

Ignatius, K. E. F. 67

Iisakkila, Leena 376

Ikola, Niilo 388, 391

Ilvessalo, Yrjö 453

Inha, I. K. 100, 194

Isard, Walter 378

Isotalo, Antti 20

Isto, Eetu 48-50, 68, 312

J

Jaakkola, Jalmari 407

Jaatinen, Martti I. 376

HENKILÖHAKEMISTO 
Jacobi, Moritz Hermann 152

Jaeger, Fritz 353

Jakolev, S. A. 93

Jansson, Tove 339

Japšyr 173

Jonasson, Felix 167

Jonasson, Lyyli 439

Judenitšs, Nikolai 198

Juntunen, Paavo 43, 206

Juntunen, Wilhelm 30, 44, 50

Jurva, Risto 452

Jutikkala, Eino 407, 453

Juva (Juvelius), Einar W. 380, 391-393, 433, 444, 446-447, 467

Juvelius, Einar W. ks. Juva, Einar W.

Jäntti, Jalmari 149, 163, 178

Jäntti, Yrjö A. 190

Järnefelt, K. 453

Järvi, Osmo 446-447, 467

\section{K}

Kaikko, Johannes 326, 330

Kaila, Eino, 352

Kairamo, A. O. ks. Kihlman, A. O.

Kalaja, Pentti 452

Kaleva, Eeva ks. Granö, Eeva

Kalinin 69

Kaljunen, Heikki 206

Kallio, Kyösti 252-253, 386, 398

Kallio, Paavo 315, 331, 419-420, 438

Kalliola, Reino 191, 331, 339, 408, 453

Kanervo, Erkki 452

Kant, Edgar 215, 219, 222-225, 236, $238, \quad 240-241,352,405,440$, 459-461, 470

Kant, Immanuel 101, 212, 255

Karsten, Rafael 104, 133, 194, 433

Karttunen, Liisi 105

Keinänen, Timo 376

Kekkonen, Urho 457, 472

Keränen, Jaakko 452

Kestilä, Heikki 465-466
Ketonen, Arvo 423

Kettunen, Lauri 64, 198-200, 213, 413

Kihlman (Kairamo), A. O. 59-60

Kilpi, Eino 452

Kilpi, Sulo 105

Kilpi, Volter 312

Kissinger, Henry 460

Kivinen, Olli 376

Kjéllen, Rudolf 406

Klossner, A. R. 467

Kogutowicz, Károly 266

Koldajeff, Sultanbai 119

Koltšak, Aleksandr 206

Komppa, Gustaf 392-393, 411, 444

Koppel, Heinrich 240-241

Koskenniemi, A. E. 295

Koskenniemi, V. A. 300-301, 312, 383-386, 447-448

Kotéljnikov, Ilja 117-118

Krause, Johann Wilhelm 197

Krebs, Norbert 369

Krep, Endel 224

Krohn, Kaarle 163

Kropotkin, Pjotr 80

Kruus, Hans 237

Kubarev, V. D. 91

Kuismanen, Antti 43

Kujala, Viljo 452

Kukk, Juhan 237

Kustaa II Aadolf 152

Kustaa VI Aadolf 320, 385, 464

Kyngrak 184

\section{L}

Laasimer, Liivia 229

Lagerspetz, Kari 440

Laitakari, Aarne 452-453

Lallukka, Juho 86

Larin-Kyösti ks. Larsson, Karl Gustav

Larsson, Karl Gustav (Larin-Kyösti) 312
Lautensach, Hermann 351, 376, 463

Laxman, Eric 92

Ledebour, Carl Friedrich von 92, 203204

Lehtikunnas, Toivo 391

Lehto, Ananias 43

Lehtola, Erkka 192

Lehtonen, Katri 390

Leiviskä, Iivari Gabriel 37, 94-95, 9798, 133, 153-154, 247, 252, 262, 265-266, 278, 280, 290-293, 296-297, 299, 316, 320, 330, 352, 364-366, 382, 397, 411, 431

Lenin, V. I. 143, 205

Liakka, Niilo 252

Lignell, Hanna 45, 64, 98, 107

Lilius, Aleko 163

Lindberg, Carolus 411

Lindberg, Sextus Otto 55

Lindelöf, Ernst 156

Lindholm, P. E. 26, 31

Linkola, Kaarlo 277, 381, 399, 408, 411

Linkomies, Edwin 433, 448, 467

Linnaniemi, Walter M. 298-299, 380

Linnilä, Kai 376

Louise 385, 464

Lundell, J. A. 392

Luther, Alexander 104

Långfors, Arthur 104-105, 252, 268, 444

Löffler, E. 211

Lönnrot, Elias 57, 160

Lönnroth, Erik 445

M

Mannerheim, C. G. E. 72, 143, 398399, 403, 407, 410, 421, 433, 464

Manninen, Otto 411

Markus, Eduard 254

Matai 184-185

Mattila, Jorma 436, 439 
Merisuo, A. K. 396, 402-403, 419

Meud, W. R. 456

Meurman, Otto-Iivari 376, 456-457

Mieler, August 204

Mikkola, Erkki 168, 335, 362, 366, 415,418

Morrill, Richard 461

Munsala 69

Myrberg, P. J. 446, 467

Möller 69

\section{$\mathrm{N}$}

Neef, F. 342

Nelson, Helge 277

Nevanlinna, Rolf 431, 444

Niemelä, Paavo 331

Niemi, A. R. 160

Nikolai I 23

Nordberg, Otto 48

Nordenskiöld, A. E. 40, 194, 356

Nordenskiöld, Otto 320

Nordqvist, O. 67

Nordström, J. G. 465-466

Norrlin, J. P. 39, 52, 58

Nurmela, Tauno 467

Nyblin, Daniel 70

Nyström, Usko 139

\section{0}

Obrutšev, V. A. 129, 426, 459

Obst, Erich 462

Ohlson, Birger 377

Oikarinen, Iida 439

Ojansuu, Heikki 154

Ojansuu, Ilta 390

Okko, Veikko 440

Olin, Toivo E. 446-447, 467

Olsoni, Börje 155

Osmonsalo, Erkki K. 408

Ostwald, Wilhelm 152

Ottelin, Fredrik Napoleon 20
Paasi, Antti 378-379

Paasikivi, Annikki 468

Paasikivi, J. K. 207, 391, 411, 443, 448, 464, 468

Paasilinna, Erno 474

Paats, Vello 229

Paffen, Karlheinz 376

Pallas, Peter Simon 92

Palmén, A. J. 394

Palmén, E. G. 38, 394

Palmén, Johan Axel 38-41, 52, 57-58, 60-61, 63, 67-68, 85, 101, 133, $161,210,242-243,245,476$

Palmén, Johan Philip 39

Palomaa, M. H. 299, 310, 315, 380

Palomaa, Nanna 310

Palomaat 315

Palomäki, Mauri 461

Passarge, Siegfried 132, 211, 226, 256, 291, 342, 344, 350-351, 358-359

Pável 119, 123

Penck, Albrecht 53-54, 80, 92-93, 95, $102,237,353,356,369,422$

Penck, Walther 422-423, 427, 453

Penckit 422

Pesonen, Uuno 452

Pietilä, Reima 374-376

Piiper, Johannes 154

Plathan, Alexander E. 50

Platt, Raye R. 453

Ponkala, E. W. 48

Porkka, Osmo H. 276, 418

Porre 31

Porthan, Henrik Gabriel 58, 229, 373

Post, Lennart von 442

Potanin, G. N. 80, 126

Pred, Allan 461

Ptolemaios 101, 398

Pumpelly, R. 108

Puranen, Jorma 194

Pälsi, Sakari 86, 89-90
Päts, Konstantin 236

Päätalo, Kalle 187

Pöld, Peeter 153

Pöllu, Peeter 154

\section{R}

Radloff, Wilhelm 32, 73, 82

Ramsay, Henrik 416

Ramsay, Wilhelm 37, 70, 80, 84, 104 , 133-134, 247, 265, 280, 303, 317

Ramstedt, G. J. 86, 89-90

Rannanjärvi, Antti 20

Rapola, Martti 411, 413

Rautala, Emil 465-466

Rautanen, Martti 194

Ravenau, Louis 94

Ravila, Paavo 444, 467

Regel, Konstantin 203

Rehn, Rafael E. 275-276

Relander, Lauri Kr. 294

Renier, Stefano 369

Renvall, Essi 465-466

Reuter, Enzio 247

Ribbentrop, Joachim von 416

Richthofen, Ferdinand von 58, 210

Rickert, Heinrich 342-343

Ritter, Carl 376, 398

Rosberg (Bruncrona), Eva Charlotta 54

Rosberg, Johan Evert 37, 53-57, 59$62,66,80,84,94-95,97-98,103$, 107-109, 146, 149, 155-156, 160, 165, 167, 190-191, 243, 246-248, 262, 265-266, 301-302, 320, 331, 351, 371, 382, 471

Rosberg, Sigvald 331

Rosberg, Victor 54

Roschier, Herman 25-26

Rosenqvist, A. S. 467

Rosenthal, Elmar 153

Rumma, Jaan 219, 236, 238

Runeberg, J. L. 373

Ruotsalo-Aario, Ritva 440-441

HENKILÖHAKEMISTO 
Ryti, Risto 386, 406-408

Römer, Marta 423

Saalas, Uunio 62, 320

Saari, Elias 73, 76

Saari, Johannes 179

Salmi, Toivo 467

Salminen, Arvo 452

Salminen, Väinö 31, 413

Salomaa, J. E. 384

Sammallahti, Pentti 194

Sapožnikov, Vasili Vasiljevitš 93-94, 184-185

Sapper, Karl 342, 348

Sarkia, Kaarlo 312

Sauer, Carl 287, 350, 355

Sauramo, Matti 168, 278, 320, 323, $335,362,408,411,430-433,453$

Savonenkov, G. M. 458

Schaffer, Werner 462

Schalin, Teodor 312

Schauman, Henrik 433

Schauman (Granö), Siine Taiga 140$141,146,208,342,387,433$

Schlücking, Heinrich 339

Schlückingit 339

Schlüter, Otto 211, 288, 350, 376

Schmidt, Alexander 152

Schmithüsen, Josef 376

Schrepfer, Hans 277, 354, 369

Sédeljnikov, Aleksandr 117

Sederholm, J. J. 242, 245, 301

Seiro, Väinö 394, 468-469

Semjon 83

Semjonov Tjan-Shanski, P. P. 369

Seppä, Jussi 346

Serebrjyannyj, L. G. 470

Sergejeff, Feodor 86

Setälä, E. N. 155-156, 326, 382-394, 411

Seyn, Frans Albert 142
Simelius, Josef 34, 43

Simons, Tom 376

Sirelius, U. T. 278

Sjögren, A. J. 92

Sjöström, Wilho 105, 143, 262

Smeds, Helmer 436-438, 441

Snellman, Paavo ks. Virkkunen, Paavo

Soli, Edvard 312

Spethmann, Hans 344, 374

Stalin, Josif 86, 417

Strabon 101, 398

Stenman, Emilia 42

Ståhlberg, K. J. 254, 411, 439, 453

Ståhlberg-Kovero, Kyllikki ks. Tuominen, Kyllikki

Subbótin, Kyprián Mihailovitš 119, 174, 184

Sudarhanoff, Kosbatai 87

Suits, Gustav 202

Sundwall, Johannes 104

Suolahti, Hugo 252, 392

Suosalmi, Kerttu-Kaarina 191

Supan, Alexander 94

Suslov, S. P. 421

Svento, Elvi 439

Svento, Igor 436, 439

Sverdrup, Harald 357

Svinhufvud, P. E. 143

T

Tallgren, Aarne Michaël 199, 209, 234, 408, 413

Tallqvist, Hjalmar 247

Tammekann, August 218-219, 221, 227, 236, 238, 269, 330, 352, 409, $431,442,459$

Tammekannit 221

Tanner, Väinö 144, 381-382, 430-431, 453

Tarkiainen, Viljo 433

Teleki, Pál 266-267, 415

Teräsvuori, Kaarlo 199, 250, 253
Thomsen, Vilhelm 33, 81

Toikka, Pietari 43, 69

Toivonen, Y. H. 278

Tokoi, Oskari 205

Tolvanen, Viljo 190

Topelius, Zacharias 58, 149, 232, 256, 373

Troll, Carl 376, 462

Trotski, Lev 198

Tseveendorj, D. 91

Tuglas, Friedebert 202

Tulenheimo, Antti 392, 445

Tungerek, Iljá 124, 184

Tuominen, J. K. V. 37, 98, 106, $124-$ $125,127,147-148,185-186,203$, 246-247, 250, 266, 268, 295-298, $312,314,316,318-320,322-323$, 330-331, 334, 394-396, 409, 417, $421,433,438,441,461,472$

Tuominen (Ståhlberg-Kovero), Kyllikki 439-440

Tuominen, Oiva 326, 330, 417, 419, $422,438-442,456,461$

Tutuk, Alp Urungu 84

Tömen 184

U

Udelius, Georg Leonard 21-22

Uimonen, Annikki 439

Uimonen, Heikki 377

Unkuri, Matti 46, 86

Unkuri, Tapani (Stepan) 85-86, 8990, 107, 121

\section{V, W}

Wagner, Hermann 342

Wainio, E. A. 142

Vainio, Toini 439

Wallin, Georg August 194

Wallin, Väinö ks. Voionmaa, Väinö

Vals 46

Van Cleef, Eugene 354 
Waren, Harry ks. Waris, Harry

Waris (Waren), Harry 314, 380, 446

Vasari, Yrjö 440

Weissmuller, Johnny 315

Veski, J. V. 238

Westermarck, Edvard 288, 300

Vidal de la Blache, Paul 211

Wiedemann, Ferdinand Johann 92

Vikman, Niilo 325

Vikstedt, Toivo (Topi) 173-174, 179180

Wilhelmi, D. 340

Vilkuna, Kustaa 453

Winkler, Ernst 376, 462

Virkkunen, Helmi 390

Virkkunen (Snellman), Paavo 64

Virtanen, Rauli 194, 475

Wisotzki, Emil 340

Witting, Rolf 274, 320

Voionmaa (Wallin), Väinö 62, 406, 411

Vokk, Karl (Kalle) 74, 82-84, 206

Wright, Georg Henrik von 352

Wright, Johan von 352

Wright, Magnus von 39

Vuori, A. K. 394

Wuorio, Salomo 48

Wüllner, Adolph 148

Väisälä, Kalle 156, 199, 213, 301, 380, 385

Väisälä, Marja 387

Väisälä, Yrjö 380, 387, 389, 447-448, 466

Välikangas, Ilmari 327

Välivuori, Annikki 439

Y

Younghusband, Francis 287

Yrjö-Koskinen, Yrjö-Sakari 26

\section{Å, $\ddot{A}, 0 ̈$}

Åkesson, Otto 253

Äyräpää, Aarne 453

Öhmann, Emil 385 


\section{Paikkahakemisto}

A

Aasia 68, 72, 89, 95, 97, 102, 104, 203, 403, 408, 421, 466, 473, 476

Aasian mannerlaatta 427

Abá 179

Afganistan 322

Afrikka 226

Agassiz 427

Ahvenanmaa 16-17, 321

Akaban 115

Alanko-Viro 219

Alatornio 33-35, 42-43, 48, 64, 312, 398,441

Alpit 53, 80, 93-94, 462

Altai 28, 33, 49, 52, 68-71, 78-79, 81, $83,86-87,92-95,98,102-105$, 107-110, 113, 116-118, 120, 123, 128-129, 132-135, 140, 143, 149, $156,162-163,165,167-168,170-$ 171, 173-174, 176-184, 186, 189191, 194, 200, 203, 212-213, 228, 252, 280, 319, 339, 344, 353-354, 359, 368, 399, 402, 412, 421-423, 426-427, 453, 459, 462-463, 466, 470, 473, 476-477, 479

Altaiskaja-stanitsa 68, 86

Altun Tardai 114

Altyn-köl ks. Telétskojejärvi

Amerikka ks. Yhdysvallat

Amsterdam 368

Amurinmaa 102

Amyl 74

Appalakit 53

Argentiina 436, 462

Argut 123-124

Argutin rotkolaakso 123

Artybaš 117

Aštšegul 24
Aulanko 192

Aunuksen Karjala 406

Aura ks. Aurajoki

Aurajoki (Aura) 247, 295, 306, 308, $311,327,386,473$

B

Baikaljärvi 91

Baku 109

Baltia 16, 143, 216

Baltoskandia 223-224

Baškaus 115

Baškausin laakso 115, 125

Bei-kemin laakso 75

Belúha (Katunin pylväät, Kultainen vuori) 123

Belyi-Berelin laakso 123

Bengalinlahti 68

Berel 68

Berelskoje 68, 175

Berliini 102, 108, 358, 413, 417, 463

Bija 68, 107, 110-111, 113, 117, 129, 423

Bijan laakso 116

Bijisk 83, 110-111, 113, 115-118, 124126

Bobyrganin vuori 116, 344

Bordeaux 463

Buhtarma 86

Bojarka 24

Borojoen laakso 169

Botogonjoki 405

Brest-Litovsk 152

Budapest 382

Bugene 24, 31, 45-46, 86, 206

Buhtarmájoki 68, 86, 123

Burjatia 194

\section{C, D, E}

Cambridge 276

Dnepr 109

Dnipropetrovsk 109

Dzungaria 79

Edjigan 124

Eesti ks. Viro

Elva 231

Emäjoki 202-203, 258

Englanti (Iso-Britannia) 276, 354-456, 460

Espoo 194, 250-251, 375

Etelä-Amerikka 133

Etelä-Pohjanmaa 363

Etelä-Ruotsi 463

Etelä-Siperia 15, 68, 75, 94, 109, 464

Etelä-Suomi 335

Etelä-Venäjä 71

Etelä-Viro 228

Euraasia 408, 427

Euroopan Venäjä 404

Eurooppa 40, 57, 84, 104, 108, 224, 267, 322, 326, 350, 358, 373, 407-409, 413, 440, 462

F

Fennoskandia 134, 217, 262, 408

Ferganan laakso 109

Forssa 40, 242

Fuji 102

G

Geblerin jäätikkö ks. Katunin jäätikkö Georgia ks. Gruusia

Grano 466

Granö (Målas) 16, 18

Granön jäätikkö 466, 475

Greifswald 359 
Gruusia (Georgia) 109

Göteborg 356

\section{$\mathrm{H}$}

Haaparanta 48

Hakem 76

Hamina 54

Hapuri 358-359

Hangaivuoristo $85,88-90,121,162$, 405

Hankoniemi 40

Heidelberg 39

Heinola 247

Heinäveden reitti 266

Helsingin kylä 24, 30-31, 44, 206

Helsinki 22, 26, 33, 37, 39-40, 53, 55, $57,64-65,72-73,78,81-82,84$, $86,94,99,106-107,110,133-$ 134, 138-146, 148, 153, 155-156, 177, 192, 194, 200-201, 213, 219, $234,245-252,259,261-262,265$, 267, 270, 276-277, 294-303, 306, 309-310, 316, 320, 322-325, 327 $330-331,334,339$, 346, 351-352, $374,380-382,386,388,390-392$, 394, 396-397, 399, 409, 416, 422, 429-434, 436-440, 442-444, 446, 448, 454, 456, 462, 464, $466,468,472,477-480$

Hietaniemi 472

Himalaija ks. Himalaja

Himalaja (Himalaija) 403, 427

Häme 373

I

Iisalmi 266

Inarijärvi 441

Intian mannerlaatta 427

Irtyšjoen laakso 178

Irtyšjoki 22, 25, 68, 86, 104

Iso-Britannia ks. Englanti

Italia 470
Ity-kölin allas 115

Ity-kölin järvi 166

Itä-Altai 115, 124-125

Itä-Karjala 55, 133-134, 144-145, 406-409, 412, 431

Itämeri 207, 223, 225

Itä-Siperia 24, 67, 102

Itä-Turkestan 404

Itä-Venäjä 257

Itä-Viro 228

\section{J}

Japani 45, 102-103, 312

Jekaterinburg 27

Jekaterinoslav 109

Jenisei 67-68, 74, 76, 78, 83-84, 91, 120

Jyväskylä 141

Järvenpää 393

Järvi-Suomi 338, 368, 373, 468

Jäämeri 68, 406

K

Kaakkois-Viro 228-229, 236

Kaarepere 202

Kabinan kartano 176, 202

Kaivopuisto 458

Kajaani 266

Kajaanin-Kuusamon vaaramaat 373

Kajaaninlinna 373

Kajir 124

Kakola 22, 50, 318

Kaliningrad ks. Königsberg

Kalmukia 194

Kanada 194

Kara-sun 120

Kara-sunin laakso 184

Karjala 373, 468, 470

Karjalan kannas 95, 418

Karjalan vaaramaat 373

Karjalohja 141, 146, 150-151, 420
Karvala 363

Kaspianmeri 68, 109

Katajanokka 48, 97-98

Katrineholm 35

Katun 68-69, 107, 110, 112, 116-117, $124,186,423,426$

Katunin alpit 123

Katunin laakso 123, 186

Katunin jätikkö (Geblerin jäätikkö) 123

Katunin pylväät ks. Belúha

Kauhava 20

Kaukasus 107, 109, 125

Kaukoitä 102

Kaunas 358

Kebezen 113

Keltainenmeri 68

Kemiö 19-21

Kesk-Harjumaa lausmaa 228

Keski-Aasia 70, 72, 80, 94, 129, 190, 399, 403, 465, 467

Keski-Altai 110, 125

Keski-Altain vuoristo 178

Keski-Eurooppa 53-54, 58-59, 353, 362, 412

Keski-Mongolia 88-89

Keski-Pohjanmaa 16

Keski-Siperia 95, 203

Keski-Suomi 445

Keski-Viro 228

Kiina 61, 73, 75, 82, 86, 110, 404

Kilpinen 150

Kiova 108

Kirgiisiaro 107

Kirkkonummi 54, 56

Kjahta 91, 169

Knaapila 107

Kobdo 78-79, 88, 162

Kobdojärvet 87

Koillis-Altai ks. Venäjän Altai

Koillis-Viro 219

Kokemäenjoen laakso 95 
Kokkola 18

Kok-sun 123

Koli 468

Kolonia 45, 47

Korppolaismäki 330

Koš-agatš 123, 125

Kotandá 118, 123

Krasnojarsk 67, 84

Krasnovodsk (Türkmenbaš) 109

Krim 107, 109

Kuhmoinen 141, 143, 163

Kultainen vuori ks. Belúha

Kultajärven seutu ks. Telétskojejärven seutu

Kultajärvi ks. Telétskojejärvi

Kulttuuri-Suomi (Viljely-Suomi) 362, 372-373, 456

Kuman 124

Kuola ks. Kuolan niemimaa

Kuolan Lappi 144, 406

Kuolan niemimaa (Kuola) 40, 144, 406-408, 415, 470

Kuopio 54, 266, 441, 468

Kurain vuoristo 115,125

Kustavi 331

Kužebar 74

Kygýn laakso 114

Kälviä 19

Königsberg (Kaliningrad) 101, 225, 413

Kööpenhamina 358, 382, 462-463

\section{L}

Laatokka 330, 362, 372

Lahemaa 229

Lappajärvi 363

Lappi 36, 39, 55, 110, 194, 216, 338, $373,417-418,430,441$

Lapua 16, 20

Latinalainen Amerikka 68, 161

Latvia 207

Lebedj 113
Leipzig 102

Lemland 16

Liettua 203

Lissabon 457, 462-463

Lohja 95

Lohtaja 19

Lounais-Häme 372

Lounais-Suomi 322, 330, 438, 456

Lund 440, 460-461

Luonnon-Suomi 362, 372-373, 456457

Luoteis-Altai 117

Luoteis-Mongolia 71, 74, 86, 94, 135

Luuan kartano 202, 208

Länsi-Australia 325

Länsi-Berliini 463

Länsi-Mongolia 89

Länsi-Siperia 22, 24, 27, 32, 44, 45, 51, 68, 91, 103-104, 162, 206, 257

Länsi-Viro 228

Läänemaa 238

M

Madeira 463

Malo-Krasnojarsk 86

Meilahti 192

Meri-Viro 228

Metsä-Altai 178, 180

Mikkeli 269, 279, 468

Minneapolis 194

Minnesota 194

Minusinsk 31-32, 67, 73, 84

Minusinskin piirikunta 24

Mongolia 61, 68, 71-73, 83-86, 88, $91-92,102-103,110,115,120-$ $121,125,162,166-168,173,176$, 178, 194, 277, 403-405, 464-466, 475-476

Mongolian Altai 87

Moora 230

Moskova 24, 27, 86, 108, 207, 409, 411, 417, 430, 454
Musta Altai 178, 180, 189

Musta-metsä 113, 186

Målas ks. Granö

N

Namangaan 109

Narvajoki 198

Narymjoki 68

Nertšinsk 102

Neuvostoliitto (Neuvosto-Venäjä) 145, 152, 198, 206-207, 219, 221, 223-225, 229, 254, 409, 411, 413, 416-417, 426-427, 436, 452, 455, $458,463,465,470$

Neuvosto-Venäjä ks. Neuvostoliitto

Nižni Novgorod 27

Norja 55, 266, 319, 407

Novgorod 335

Novo-Nikolajevsk 83

Novorossijsk 109

Novosibirsk 83, 206

0

Ob $68,83,104,110,113$

Obin laakso 118

Objoki 423

Ohio 354

Om 24, 30, 45, 50

Omjoki 22, 25, 28, 44, 49, 65-66

Omsk 22, 24-25, 27-29, 42-45, 4850, 64-65, 73, 79, 85-86, 91-92, 105-107, 109, 116-118, 125-128, 133-134, 138, 165, 200, 205-207, 317

Ongudai 112

Oranienbaum 73

Orhonjoki 89

Otepää suurkuplite 228

Oulu 35-38, 54, 64, 194, 266, 310, $312,374,376$

Oulunkylä 306, 391

Oulujoki 266 
Oulujärvi 372

P

Paimio 221

Palamuse 202, 208, 235

Palamuse-Aksi suurvortte 228

Pallastunturi 36, 441, 452

Palmsen kartano 229

Palumaa 229

Palytkty-köl 123

Parasniemi 34

Pariisi 58, 108, 463

Pasi 141

Patagonia 436

Peipsimaa 229

Peking 83

Pelé 117

Pelkosenniemi 366

Pellinki 272, 360, 472

Perm 27

Persia 322

Perttula 19

Perä-Pohjola 35, 373

Pestšána 125

Petrograd ks. Pietari

Petsamo 56, 266, 415

Petser 235-236

Pielinen 372

Pietari (Petrograd) 26-27, 72-73, 82, $84,86,92,107-108,142,194$, $198,203,207,420$

Pietarin kuvernementti 216

Pihkovan kuvernementti 216

Pipola 420

Pohjanlahti 362, 372

Pohjanmaa 17-18, 20-21, 42, 373

Pohjois-Amerikka 104, 195, 354, 427

Pohjoismaat 298

Pohjois-Mongolia 88, 90, 169, 402

Pohjois-Pohjanmaa 35

Pohjois-Ruotsi 430

Pohjois-Saksa 201
Pohjois-Suomi 95, 335, 457

Pohjois-Viro 228

Pohjola 470

Pommern 359

Portugali 463

Porvoo 270, 272, 339, 360, 387

Pultava 23

Puujärvi 146, 150-151

Puula 397

Puuskansaari 279

Pyhäjärvi 366

Pyhätunturi 366

Pyreneitten niemimaa 463

Pähkinäsaari 335

Pärnumaa 238

Pääsiäissaaret 396

Pöltsamaa 229

\section{R}

Raadin kartano 250-251, 253

Rahmanovin-lähteet 68

Raiso 360

Rannikko-Suomi 372

Ranska 463, 470

Rautalammi 373

Renko 105

Riika 358

Ristinummi 392

Rohnu 229

Rotala 229

Rovaniemi 266, 372

Ruotsi 16, 23, 33, 48, 55, 144, 152-153, $225,319-320,335,355-356,385$, $426,430-431,440,442,459$, 460-461, 464, 470

Rymättylä 107

Ryžkova (Vanha paikka) 22, 24, 32, 167

$\mathrm{S}$

Saaremaa 238

Saaristomeri 321
Saaristo-Suomi 338

Saari-Viro 228

Sadran laakso 113

Saimaa 266, 279

Sajanin vuoristo $15,24,43,68,70,73$, $75,81,84,104$

Sakala 229

Saksa 57, 100, 108, 129, 143, 152-153, 210-211, 237, 249, 254, 267, 339, $351 ， 353 ， 368 ， 394 ， 406-407$, 412-413, 416-417, 419, 430, 455, 458,463

Salmijärvi 266

Salo 331

Salpausselkä 247

Samppalinnanmäki 306

Santa Claran laakso 355

Sarymsakty 86

Satakunta 373

Satulamäki 15, 69

Savo 373

Seattle 194

Sēman vuorimaa 118

Semey ks. Semipalatinsk

Semipalatinsk (Semey) 68, 79, 86, 109

Setumaa 238

Sevastopol 109

Sininen Altai 178, 189, 192

Siperia 14, 21-31, 33, 40-45, 47, 49-52, $61,64-68,71-74,82,84-87,91-$ $92,94,97,102-103,105,107,110$, 126-127, 133, 141, 145, 154-155, $160,163,167-168,171-173,176$, 178, 192, 194-195, 201, 205-206, 212-213, 317, 399, 401, 411, 421, $436,459,474,476$

Sipoo 43

Sisä-Aasia 156, 464

Sisä-Mongolia 404

Sisä-Suomi 321, 372

Skandinavia 320, 391

Sodankylä 266 
Sortavala 337

Suomenlahti 198, 229, 232, 246, 248, 259

Suomi 14, 16-17, 21, 23-25, 27-31, $33,39-40,42-43,45,48-49,54$, 56-62, 67-68, 71, 79-81, 84, 95, 99-103, 110, 115, 127, 134, 137, 139-140, 142-143, 145, 149, 151$156,163,168,184,190,194,196$, 201, 205-207, 210, 216, 219, 221, 229, 232, 234, 240, 242, 245-246, 248-252, 256, 258-259, 266-267, 269, 274, 277, 293, 295, 297-298, $301,310,314,319,321-322,325$, 330-331, 333-335, 337-339, 347, $352, \quad 354, \quad 358-362, \quad 364-367$, 369-370, 372-374, 376-378, 382-383, 386, 388, 390-391, 394, 397-399, 405-413, 416-418, 421, $426,430,432,436,438,440$ $442,445,448-449,452-454$, $456-459, \quad 461, \quad 464-465,468$, 470-471, 473-478, 480

Suur-Suomi 64, 144, 406, 409-410, 475

Suvikumpu 375

Sveitsi 455, 462

Syväri 409

Sääksmäki 56

\section{$\mathrm{T}$}

Taalainmaa 16

Tabun-Bodgo-uula 86, 94, 475

Taipaleenjoki 418

Tallinna 207, 229, 236

Talménjejärvi 123, 183

Tamirjoki 88-89

Tampere 143, 364, 377, 456

Tanska 58, 319

Tartto 92, 136, 152-157, 177, 191, 194, 197-204, 206-211, 213, 215-219, 221, 223-226, 228, 232, 236,
238-241, 246, 249-251, 253-255, 257-259, 267, 277, 284, 294-295, 299, 301, 316, 319, 322, 324-325, 330-331, 338, 399, 406, 409, 411, 413, 422, 436, 460-461, 468, $476-478$

Tartumaa 235-236, 238-240

Tarvaspää 194

Tbilisi 109

Teerijärvi 16, 18-19, 33, 36, 63-64

Telétskojejärven seutu (Kultajärven seutu) 178

Telétskojejärvi (Altyn-köl, Kultajärvi) 107-108, 113-115, 117, 123, 132, 176, 180, 182, 187, 191, 193

Tenojoki 441

Terijoki 206

Tibet ks. Tiibet

Tienšan 68, 107, 109

Tiibet (Tibet) 404

Tirmo 270, 339, 387, 389, 412, 417, $420,426,468-469,472$

Tiusala 365

Tjukalinskin piirikunta 24

Tjumen 27

Tobolskin kuvernementti 24

Toimela 392

Tomsk 126

Tomskin kuvernementti 83

Tornio 33, 35, 48, 99

Tornionjoki 33, 48, 441

Toronto 194

Tšaa-köl 84

Tšaptyjakjoki 180

Tšaryš 117

Tšaryšin laakso 118

Tšujajoki 83, 123

Tšujan aro 426

Tšujan laakso 115

Tšujan laaksotasanko 427

Tšujan vuoristo 119,123

Tšulyšman 107, 115, 124
Tšulyšmanin jäätikkö 132

Tšulyšmanin laakso 115

Tšulyšmanin luostari 117

Tšöltšy 115

Tukholma 411, 462-463, 480

Turkki 322

Turkmenistan 109

Turku 21, 26, 28, 55, 194, 213, 221, $247,259,276,294-300,301$, $303-312, \quad 315-327, \quad 330-334$, 339, 352, 358, 379-396, 399, 403, $420-421,423,426,432-434$, $436,438-440,443-447,454$, 464-469, 472, 477-480

Tuva ks. Urjanhai

Tvärminne 40, 242

Türkmenbaš ks. Krasnovodsk

Tähtvere 221

Töölö 472-473

U

Ubsajärvi 78, 83

Uimonin aro 124

Ulaanbaatar ks. Urga

Ulan Bator ks. Urga

Uljasutai 88

Ulko-Mongolia 110, 404, 421

Ullava 19

Unkari 249, 266-267

Ural 27

Urga (Ulaanbaatar, Ulan Bator) 88, 90-91, 169, 473

Urjanhai (Tuva) 71, 75, 80-81, 83, 115, 135, 194, 402, 412, 470

Ustj-Kamenogorsk 68, 79

Uusi-Guinea 57

Uusimaa 137, 149, 373, 468, 471

V

Vahemaa 229

Valgamaa 237-238

Valkeasaari 72 
Valkoinen Altai 178, 189, 423

Valosaari 168, 195, 268-270, 273, 279-283, 338, 341, 346, 350, 355-356, 361, 365, 468, 478

Vanha paikka ks. Ryžkova

Varsinais-Suomi 373, 420

Varsova 153, 367-368, 399, 479

Venäjä $21,23,25,30,45,48-49,52$, $68,72,79,84,86-88,91,125$, 128, 137, 142-144, 152-153, 166, 202, 205-207, 212, 216, 277, 322, 410-412, 421, 458, 475

Venäjän Altai (Koillis-Altai) 86, 110 $111,118-119,123,129,175,179$, 183,422

Venäjän Karjala 406

Verhne Suetuk 15, 24-26, 29, 31, 43, 69, 74

Verhne-Udinsk 91

Vesilinnanmäki ks. Yliopistonmäki

Vienan Karjala 194, 406

Viipuri 266

Viljandi ügorgunde 228

Viljandimaa 237-238

Viljely-Suomi ks. Kulttuuri-Suomi

Viro (Eesti) 16, 85, 152-156, 196, 198, 200, 202, 204-207, 210, 212-213, 215-216, 219, 221, 223-226, 228229, 231-235, 237-238, 240, 246, 250-251, 254, 256, 259, 278-279, $316,319,335,338-339,347,350$, $352,399,405,409,413,436,459$, 461, 470, 473, 477

Vladikavkaz 109

Vladivostok 44, 102

Volga 27, 412

Vähä-Pellinki 270, 272

Välimeren maat 56, 262

Vôru 235-236

Vōrumaa 238

Vöyri 18
Y, Z

Yellowstone 408

Yhdysvallat (Amerikka) 21, 45, 53, 194-195, 254, 350, 379, 426, 458, 460-461

Ylihärmä 86

Yliopistonmäki (Vesilinnanmäki) 305, 447

Ülkön-Oigurin laakso 87

Ylä-Kainuu 373

Yläne 330

Ylänkö-Viro 219

Yosemite 195

Ytš-mongolin laakso 123

Zaisan 79

Zürich 442, 462 